University of Nebraska - Lincoln

DigitalCommons@University of Nebraska - Lincoln

\title{
GEOLOGY AND GROUND-WATER RESOURCES OF SOUTH- CENTRAL NEBRASKA. With Special Reference to the Platte River Valley between Chapman and Gothenburg
}

\author{
Alvin Leonard Lugn \\ University of Nebraska-Lincoln \\ L. K. Wenzel
}

Follow this and additional works at: https://digitalcommons.unl.edu/geosciencefacpub

Part of the Earth Sciences Commons

Lugn, Alvin Leonard and Wenzel, L. K., "GEOLOGY AND GROUND-WATER RESOURCES OF SOUTHCENTRAL NEBRASKA. With Special Reference to the Platte River Valley between Chapman and Gothenburg" (1938). Papers in the Earth and Atmospheric Sciences. 367.

https://digitalcommons.unl.edu/geosciencefacpub/367

This Article is brought to you for free and open access by the Earth and Atmospheric Sciences, Department of at DigitalCommons@University of Nebraska - Lincoln. It has been accepted for inclusion in Papers in the Earth and Atmospheric Sciences by an authorized administrator of DigitalCommons@University of Nebraska - Lincoln. 


\section{UNITED STATES DEPARTMENT OF THE INTERIOR}

Harold L. Ickes, Secretary

GEOLOGICAL SURVEY

W. C. Mendenhall, Director

Water-Supply Paper 779

\section{GE0LOGY AND GROUND-WATER RESOURCES OF SOUTH-CENTRAL NEBRASKA}

\section{WITH SPECIAL REFERENCE TO THE PLATTE RIVER VALLEY BETWEEN C GAPMAN AND GOTHENBDS

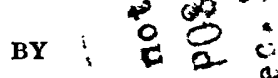

A. L. LUGN AND L. K. REEZEL

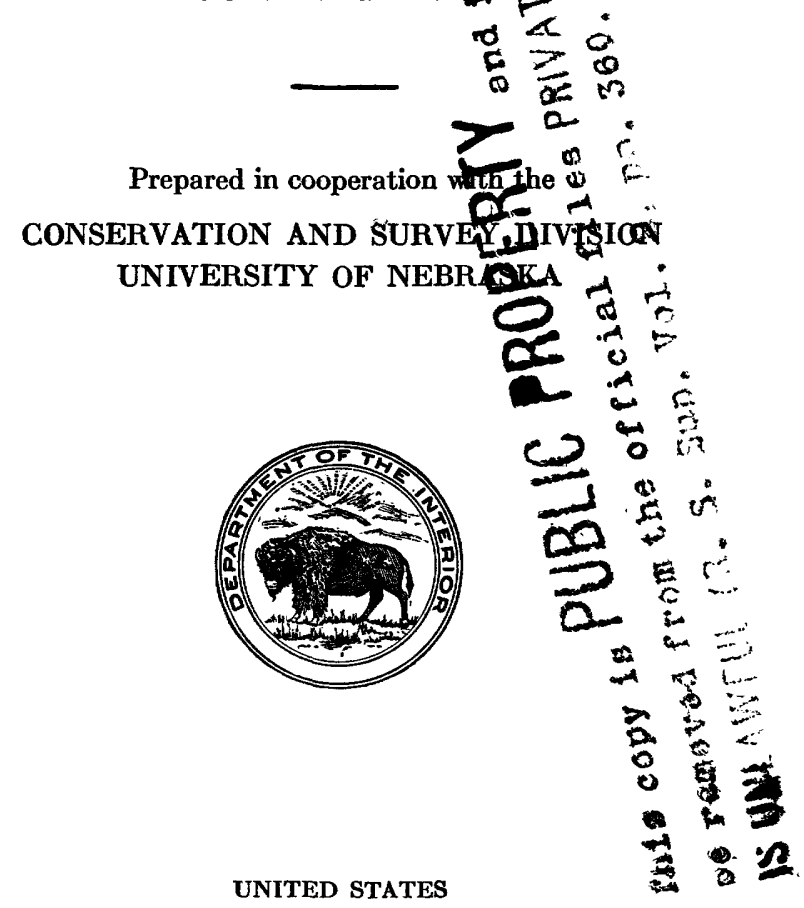

GOVERNMENT PRINTING OFFICE

WASHINGTON : 1938 
\%

$-\because$ 


\section{CONTENTS}

Abstract
Introduction, by A. L. Lugn and $\mathrm{L}$. K. Wenzel
Purpose and need of the investigation
History of the investigation
Previous geologic and hydrologic work
Acknowledgments
Geography, by A. L. Lugn and $\mathrm{L}$. K. Wenzel
Location and topography
$\quad$ General topography of Nebraska
Topography and drainage of south-central Nebraska.
Population.
Transportation
Agriculture and industry
Climate.

Earlier work

Pleistocene deposits...

Glacial and interglacial deposits of eastern Nebraska...........

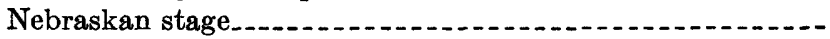

Basal sand and gravel.

Till

Gumbotil

Aftonian stage...........

Aftonian or early Kansan intertill silt, sand, and gravel.-..-

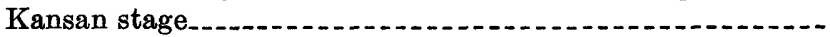

Till

Gumbotil__.

Yarmouth stage.........

Late Yarmouth or later pre-Loveland erosion................

Ground water in the glacial and associated deposits of eastern

Nebraska

General features...

Holdrege formation.

Fullerton formation

Grand Island formation. 44

Upland formation

Post-Yarmouth formations, chiefly wind-blown sand and loess_.. $\quad 53$

Loveland loess . . . . . . . . . . .

Pre-Peorian erosion...... 56

Peorian and younger loess.

Relation of the sand-hill area to the area under investigation...- $\quad 59$

Relation of the Platte River Valley to the plain to the south.... $\quad 60$ 
General ground-water conditions in south-central Nebraska, by A. L. Lugn and L. K. Wenzel.

Quantity of ground water.

Movement of ground water.

Types of wells

Depth to the water table

Blowing wells ..........

Ground-water irrigation on the plains

Character and thickness of the Pleistocene water-bearing materials in the

Platte Valley, by A. L. Lugn.

Ground-water resources of the Platte River Valley, by L. K. Wenzel...-

Irrigation in the Platte Valley ...

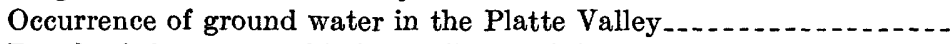

Depth of the water table in the Platte Valley . . .

Hydrologic properties of the water-bearing materials ..........

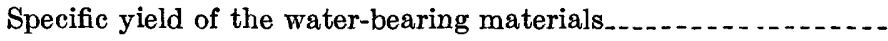

Methods used to determine specific yield..............

Laboratory determinations........

Loess . . . . . .

Ogallala formation

Pleistocene sand and gravel

Soil

Determination by the pumping method

Permeability of the water-bearing materials_._.

Methods used to determine permeability

Laboratory determinations._...

Loess. _. . . .

Ogallala formation

Pleistocene sand and gravel...... 97

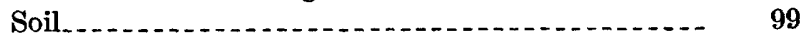

Ground-water velocity method. 99

Pumping-test method ........ 100

Test near Grand Island . . . . . . . .

Test near Kearney

Test near Gothenburg

Summary

Ground-water levels . . .

Method of investigation.......... 105

Division of the Platte Valley into ground-water areas ........ 108

Fluctuations of the water table...

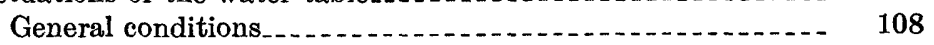

Fluctuations caused by pumping 110

Fluctuations caused by stream flow and surface-water irri-

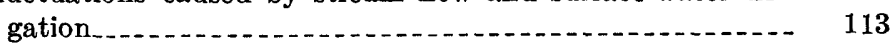

Fluctuations caused by transpiration..... 117

Fluctuations caused by precipitation................ 119

Fluctuations caused by changes in atmospheric pressure...- 123

Net rise or decline of the water table...... 125

Movement of the ground water. 128

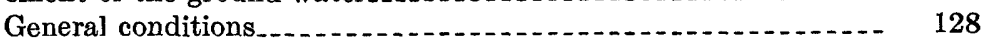

Methods of showing the direction of movement of the ground water 
Ground-water resources of the Platte River Valley, by L. K. Wenzel-Con. Movement of the ground water-Continued.

Movement of the ground water near Lexington

Movement of the ground water near Kearney .............

Movement of the ground water near Grand Island..........

Ground-water discharge ...

Discharge from wells

Domestic and industrial supplies.

Irrigation supplies......

Yield of irrigation wells. . . . .

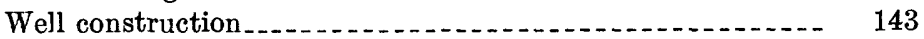

Types of irrigation pumps . . . .

Irrigation-pump power.....

Depth and diameter of irrigation wells................ 145

Municipal water supplies.

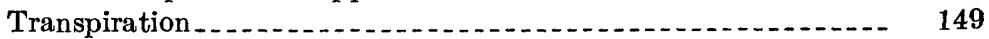

Evaporation . .

Seepage into streams

Percolation . .

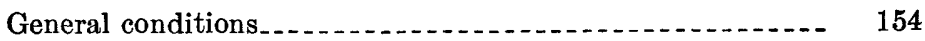

Discharge through tributaries to the Republican River..... 156

Flow of tributaries between Superior and Red Cloud... 161

Flow of tributaries between Red Cloud and Franklin _. 167

Flow of tributaries between Franklin and Alma..... 170

Flow of tributaries between Alma and Arapahoe...... 173

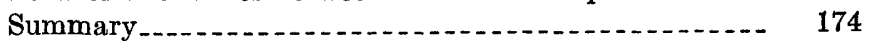

Flow of the Big Blue and Little Blue Rivers and tributaries.- $\quad 175$

Big Blue River and tributaries..................... 176

Little Blue River and tributaries.

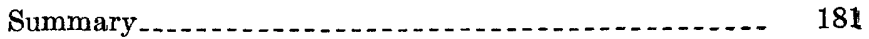

Computation of percolation of ground water from the Platte River Valley ........................................ 181

Comparison of computed rate of percolation with the measured ground-water flow of streams................. 182

Ground-water recharge.............. 183

Precipitation

Seepage from streams

Irrigation water..... 187

Percolation

Net change in ground-water storage in the Platte River Valley..... 188

Well records ............. 191

Index .... 


\section{ILLUSTRATIONS}

Plate 1. A, Fossil red-cedar tree from gravel pit at Central City; $B$, Lovers Leap, west of Fullerton.

2. Geologic section from Dannebrog, in southern Howard County, to Lincoln, in Lancaster County.

3. $A$, The Thompson sand and gravel pit at Cowles; $B$, Sand and gravel of the Grand Island formation exposed in gravel pit south of Hastings

4. Type exposure of the Upland formation west of Upland.......

5. $A$, Loveland and Peorian loess east of Greeley; $B$, Sand and gravel exposed in the dry bed of Thompson Creek...........

6. North-south geologic profile section from Elm Creek to Alma - -

7. North-south geologic profile section from Gibbon to Riverton.-

8. Map showing contours on the water table for south-central Nebraska _........... In pocket

9. Map of the Platte Valley in central Nebraska showing location of test holes.

10. Map showing the location of irrigation and domestic wells and river pumping plants in the Platte Valley, Nebraska, with lines indicating depths to water level......... In pocket

11. Hydrographs showing fluctuations of the water levels in a line of wells across the Platte Valley near Lexington

12. Hydrographs showing fluctuations of the water levels in wells in the Platte Valley between Grand Island and Kearney -.....-

13. Hydrographs showing fluctuations of the water levels in wells in the Platte Valley between Kearney and Gothenburg .........

14. Map showing tributaries of the Republican River between Superior and Arapahoe.

15. Map showing a part of the area in south-central Nebraska drained by the Big Blue and Little Blue Rivers and their tributaries.

16. Cumulative change in ground-water storage, cumulative departure from normal flow of the Platte River, and cumulative departure from normal precipitation in the Platte Valley....

Figdre 1. Map of Nebraska showing area covered by this report.........

2. Map showing major topographic areas of Nebraska and the area covered by this report.

3. Geologic map of Nebraska

4. Stratigraphic relations in Nebraska and Iowa. . .

5. Map of Nebraska showing distribution of Pleistocene sand and gravel deposits.

6. Pleistocene deposits at Lovers Leap, west of Fullerton, and correlation with logs of wells at Grand Island, Aurora, and Holdrege . . . . . . . . . . . . . . . . . . .

7. Geologic section from Farnam, in southwestern Dawson County to Arlington, in Washington County 
Fravre 8. Hydrographs showing fluctuation of the water levels in wells in the Platte Valley about 5 miles from Kearney.

9. Profiles of the water table in the vicinity of a pumped well

10. Hydrographs showing the average weekly water levels in 10 wells in the west shallow-water area and the weekly stages of the Platte River

11. Hydrographs of two wells in the bed of the Platte River near Lexington, showing the effect of the wind on the water level of the stream

12. Hydrographs showing the fluctuations of the water levels in an irrigation canal and in a nearby well

13. Graph produced by an automatic water-stage recorder showing water-level fluctuations caused by transpiration...........-

14. Graph produced by an automatic water-stage recorder showing the rise of the water level in a well after a rain..........

15. Graph produced by an automatic water-stage recorder showing fluctuations of the water level in well 219 caused by changes in atmospheric pressure

16. Graph produced by an automatic water-stage recorder showing fluctuations of the water levels in wells 219 and 541 caused by changes in atmospheric pressure.

17. Map showing contours on the water table for the vicinity of

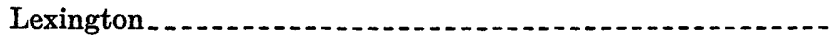

18. Map showing contours on the water table for a part of the Platte Valley near Kearney

19. Map showing contours on the water table for the vicinity of

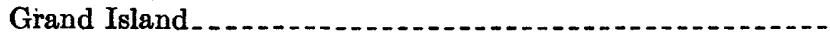

20. Diagrammatic section across the channel of a creek 2 miles west of Superior, showing geologic and ground-water conditions

21. Diagrammatic section along the channel of a creek near Bostwick, showing the conditions that produce an interrupted stream 
. 


\title{
GEOLOGY AND GROUND-WATER RESOURCES OF SOUTH-CENTRAL NEBRASKA
}

\author{
WITH SPECIAL REFERENCE TO THE PLATTE RIVER VALLEY \\ BETWEEN CHAPMAN AND GOTHENBURG
}

By A. I. Lugiv and L. K. WenzeL

\begin{abstract}
The investigation here reported, which covered a period of about 5 years, 1929 to 1933 , was made for the purpose of determining the available supply of ground water in south-central Nebraska, the origin and discharge of the ground water, and the relation of the geologic and ground-water conditions in the Platte River Valley to the conditions occurring under the plains to the south.

The area was found to be underlain by permeable Pleistocene and Tertiary sand and gravel, much of which is saturated and yields relatively large quantities of water to wells. Except in a few isolated places the ground-water supply is abundant. The Pleistocene and Tertiary formations were found in many places to be continuous across the area, but they thin out and disappear near the southern and southeastern boundary of the area. A part of the ground water occurring in south-central Nebraska percolates into the area from the sand-hill region of north-central Nebraska through the permeable water-bearing formations. Ground water is also derived from precipitation on the area and from seepage from streams entering the area from the west and northwest. Some of the ground water of the area is discharged into streams, especially in the southern and eastern parts of the area, and some ground water is used by plants, chiefly in the valleys of the streams. Almost all the public, domestic, industrial, and stock water supplies of the area are derived from wells, and in the Platte River Valley about 800 wells are used for irrigation. There are also irrigation wells in the valleys of other streams, and a few irrigation wells have been drilled on the plains.

The investigation leads to the conclusion that for most parts of the area the ground-water supply is ample to furnish the present needs. Evidence indicates that further development of irrigation with water pumped from wells can be made in the Platte Valley and in some of the valleys of the smaller streams. Additional irrigation wells can be drilled on the plains to the south, but because the ground-water supply in that area is limited chiefly to percolation from the Platte Valley, the development of large irrigation projects depending on wells is not feasible.
\end{abstract}

\section{INTRODUCTION}

By A. L. Lugn and L. K. Wenzer

PURPOSE AND NEED OF THE INVESTIGATION

This report embodies the results of several years of investigation of the water resources of an area of about 10,000 square miles in southcentral Nebraska, with special reference to the part of the Platte 
River Valley between Chapman and Gothenburg, comprising about 1,300 square miles. (See fig. 1.)

The almost universal use of ground water for domestic, municipal, and industrial supplies in the area and the increasing development of irrigation with water pumped from wells in the part of the Platte River Valley under consideration made it imperative that a better understanding of the geology and hydrology of the valley and adjoining areas, as they affect replenishment, loss, and storage of ground water, should be obtained without further delay. Moreover, there is a possibility that irrigation with water pumped from deep wells on the upland plains of south-central Nebraska may become feasible in the future, and for this reason a detailed knowledge of the water-bearing sand and gravel deposits under these plains is needed.

More nearly complete utilization of the surface waters of the State, including both normal flow and flood discharge, has been under way for many years under the administration of the State Bureau of Irrigation, Water Power, and Drainage. Expansion of this work and even fuller utilization of all surface water is now in prospect. It has therefore become increasingly necessary to understand the relations between the surface waters and the ground waters in the Platte River Valley and adjoining areas.

The effect of present and proposed diversions of surface water above North Platte on the ground-water replenishment in the valley below North Platte has become a problem of great practical significance. If further diversions are to be made-especially to areas from which a return underflow to the Platte River Valley cannot be expected-it is necessary to determine the effects that such diversions will have on the ground-water supply and the need for allowing surface water to flow past North Platte, in the natural channel of the river, in order to maintain the natural ground-water level in the valley. This problem is complicated by the percolation of water from the Platte River Valley through strata of sand and gravel that underlie the upland plains into the drainage systems of the Republican, Big Blue, and Little Blue Rivers. It is hoped that the data presented in this report will aid in the solution of these important problems relating to the water resources of the State.

\section{HISTORY OF THE INVESTIGATION}

The investigation on which this report is based was begun by the Nebraska State Geological Survey, G. E. Condra, State geologist, in 1929, and A. L. Lugn was assigned to the project. During the field season of that year attention was devoted mainly to the Platte River Valley and the northern part of the upland plain to the south. Geologic sections were measured, water-level altitudes determined, and well logs tabulated. Field work was continued along the same 


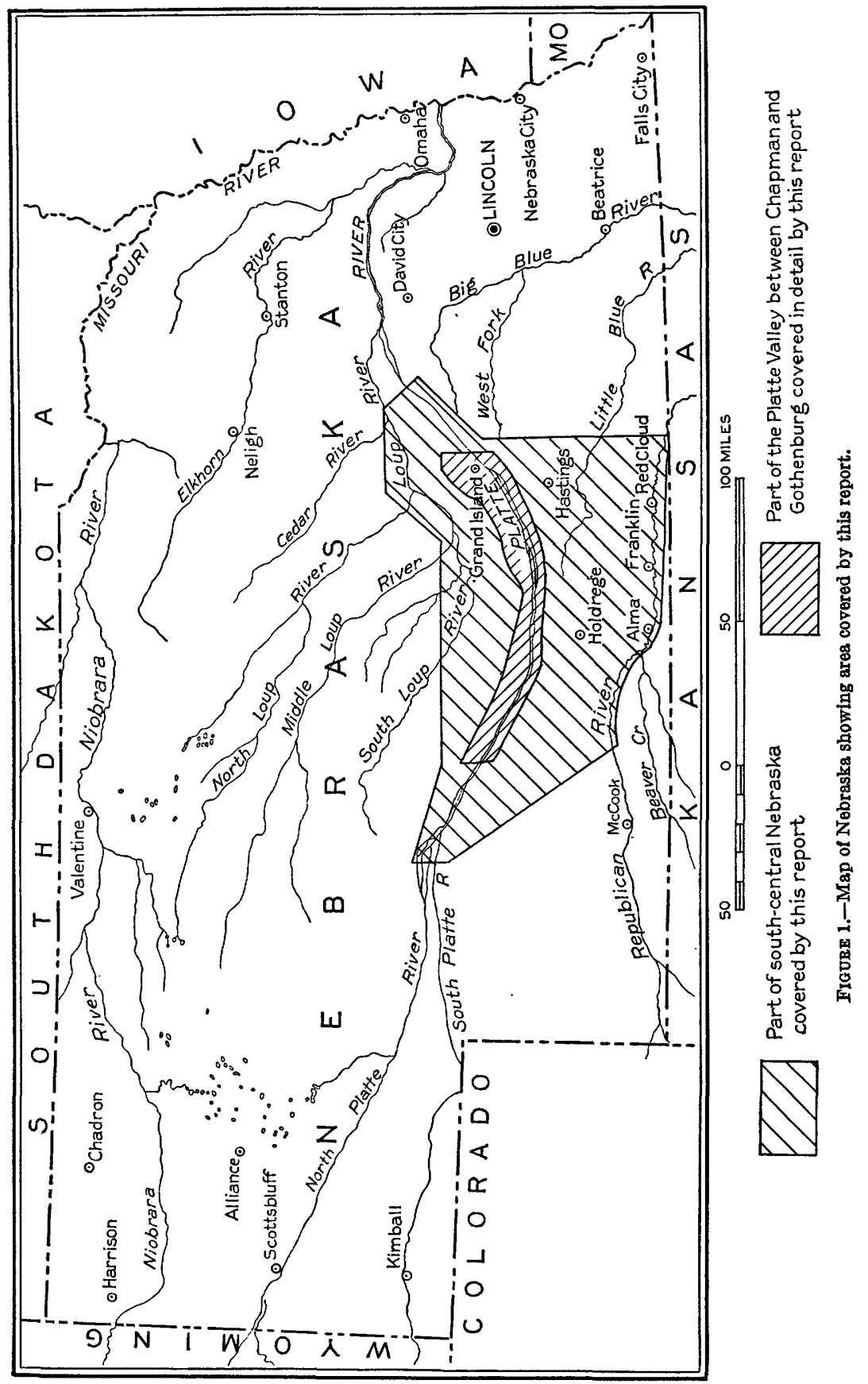


lines during the early part of the field season of 1930, when attention was focused on the soutliern part of the area slıown in figure 1.

Since July 1930 the investigation lias been conducted as a cooperative project between the conservation and survey division, University of Nebraska, and the Federal Geological Survey, under the direction of Mr. Condra and O. E. Meinzer, geologist in cliarge of the division of ground water in the Federal Survey. Mr. Lugn continued the study of the geology and general hydrology of the area, and L. K. Wenzel, of the Federal Survey, was assigned to study especially the hydrologic problems of the valley.

A small hydraulic rotary rig was used in 1931, 1932, and 1933 as an aid in making a detailed study of the part of the Platte Valley under investigation. Lines of test holes were drilled across the valley to determine the character and thickness of the water-bearing materials. Several of the lines of test holes were extended southward on the upland plains, and several holes were drilled in the drainage basin of Elm Creek, a tributary of the Republican River, to ascertain the thickness of the gravel there. This work was carried on under the supervision of Mr. Lugn, and the drilling was done by Keith Miller, Harry P. Burleigh, Howard Haworth, and Edwin Selk.

Observation wells were selected throughout the Platte Valley between Chapman and Gothenburg, and periodic measurements were made on the water levels in them during the course of the investigation. An inventory of existing irrigation wells in the valley was taken, and the altitudes of the water levels in many of the wells were determined by instrumental levels. This work was done by Herbert A. Waite and Howard Haworth under the direction of Mr. Wenzel.

Several pumping tests were made in the valley to determine the permeability of the water-bearing materials. The State and Federal personnel was aided on this work by the agricultural engineering department of the University of Nebraska, which supplied a party of about eight men for the tests near Grand Island.

In the fall of 1933, Messrs. Wenzel and Waite made measurements of the spring and seepage water being discharged in the tributaries of the Republican, Big Blue, and Little Blue Rivers in an attempt to determine the amount of seepage loss from the Platte River Valley. Many of these streams were again measured in 1934 by the State Bureau of Irrigation, Water Power, and Drainage.

During the course of the investigation the area was visited by R. M. Leggette and A. G. Fiedler, of the division of ground water of the Federal Geological Survey. W. C. Alden, geologist in charge of the section of glacial geology of the Federal Geological Survey, spent about a month in the field with members of the State Geological Survey reviewing the geologic work. Mr. Meinzer visited the area several times, and Mr. Condra made frequent trips to the area during the course of the investigation. 


\section{PREVIOUS GEOLOGIC AND HYDROLOGIC WORK}

Very little literature is available on either the geology or the hydrology of the area investigated. Early papers by Aughey ${ }^{1}$ and Darton ${ }^{2}$ have been drawn on to some extent. A bulletin by Condra ${ }^{3}$ contains information on the geology of the area. A later bulletin ${ }^{4}$ contains the records of some deep wells in the area. Other publications of direct or indirect value that have been used in connection with this work are noted at appropriate places in this report.

\section{ACKNOWLEDGMENTS}

Credit is due to the residents of the area for their interest and helpful cooperation in supplying geologic and hydrologic information and for permitting test drilling to be done on their farms, sometimes at an inconvenience to themselves. Special acknowledgment should be given to the fine cooperation of the well drillers of the State and of the Nebraska Well Drillers Association. Several deep wells were drilled in the area as tests for oil and gas during the course of the investigation, and the operators kindly made their data available for inspection and study. The Kelly Well Co., of Grand Island, cooperated by furnishing well logs and other data and loaning items of equipment for the work done in connection with the permeability tests near Grand Island. The county agricultural extension agents and many municipal officials also provided helpful data. The Dempster Mill Manufacturing Co., of Beatrice, furnished aid and advice concerning the mechanical operation of the rig during the test drilling. The writers are especially grateful to E. E. Brackett and Chauncy Smith, of the agricultural engineering department of the University of Nebraska, for aiding in the pumping tests near Grand Island, and to Fred Meyer, Albert Anderson, and J. H. Teed for allowing the tests to be made on their farms.

\section{GEOGRAPHY \\ LOCATION AND TOPOGRAPHY}

\section{GENERAI TOPOGRAPHY OF NEBRASKA}

Nebraska has an area of about 76,808 square miles. About onehalf of the State is of the dissected-plain type, and the remainder is made up of constructional plains as yet undissected by drainage. The surface as a whole slopes southeastward. The altitude ranges from 840 feet in the southeast corner of Richardson County to 5,340 feet in the western part of Banner County.

\footnotetext{
1 Aughey, Samuel, The physical geography and geology of Nebraska, Omaha, 1880.

2 Darton, N. H., Underground waters of a portion of southeastern Nebraska: Geol. Survey WaterSupply Paper 12, pp. 1-56, 1898.

'Condra, G. E., The sand and gravel resources and industries of Nebraska: Nebraska Geol. Survey, [1st ser.], vol. 3, pt. 1, 1908.

4 Condra, G. E., Schramm, E. F., and Lugn, A. L., The deep wells of Nebraska: Nebraska Geol. Survey, 2d ser., Bull. 4, 1931.
} 
The major topographic areas into which the surface of Nebraska is divided are shown in figure 2. About 42,000 square miles of the surface is underlain by thick loess deposits. Of this area about 14,000 square miles still remains nearly flat upland plains. The largest single area of little-dissected plajn is the Nebraska Plain of the southcentral part of the State, part of which is included in the area covered by this report. The eastern part of the State, which is underlain by loess-covered deposits of two glacial till sheets, is maturely dissected, and south of the Platte River the majn streams have cut entirely through the loess and drift deposits into the underlying bedrock. This area is indicated in figure 2 east of the heavy dotted line. The remainder of the areas covered by loess are made up of small remnant loess plains, small maturely eroded loess-hill areas, and loess plains deeply incised by canyons. Such canyon areas are to be seen in parts of Lincoln, Dawson, Custer, Hayes, Frontier, Hitchcock, and Gosper Counties.

The sand-hill region, in the north-central and central-western part of the State (fig. 2), is the most clearly defined topographic subdivision and occupies about 20,000 square miles, which includes some small outlying areas of sand hills. The surface is a rolling plain of windblown sand and sand dunes, which are now largely stationary, as prajrie grasses and some other kinds of vegetation have become firmly rooted and prevent the dunes from migrating. The western margin of the sand-hill region is clearly defined. In many places an abrupt eastwardfacing escarpment defines the margin of the high bedrock (Tertiary) plains that rise to the west. The eastern margin of the sand hills is not so clearly marked, inasmuch as there are tracts of low hills of wind-blown sand east of the main sand-hill area, and these hills rest on loess.

The small isolated areas of sand hills in the Platte Valley have probably come into existence recently by wind action reworking the upper part of the exposed sand and gravel of the Grand Island formation and by piling up fine sand carried in to the Platte Valley by the Loup River. A similar explanation is thought to account for the sandy areas south of the Platte River at Kearney and some other places.

The remainder of the State, a little over 15,000 square miles, is made up of undissected high bedrock plains or tables, rough broken areas, and valley plains and terraces.

TOPOGRAPHY AND DRAINAGE OF SOUTH-CENTRAL NEBRASKA

The area especially under consideration lies west of the till border, between the Platte and Republican River Valleys. The glaciated eastern part of the State is described to some extent in showing the relations of the till sheets and associated deposits to the fluviatile 


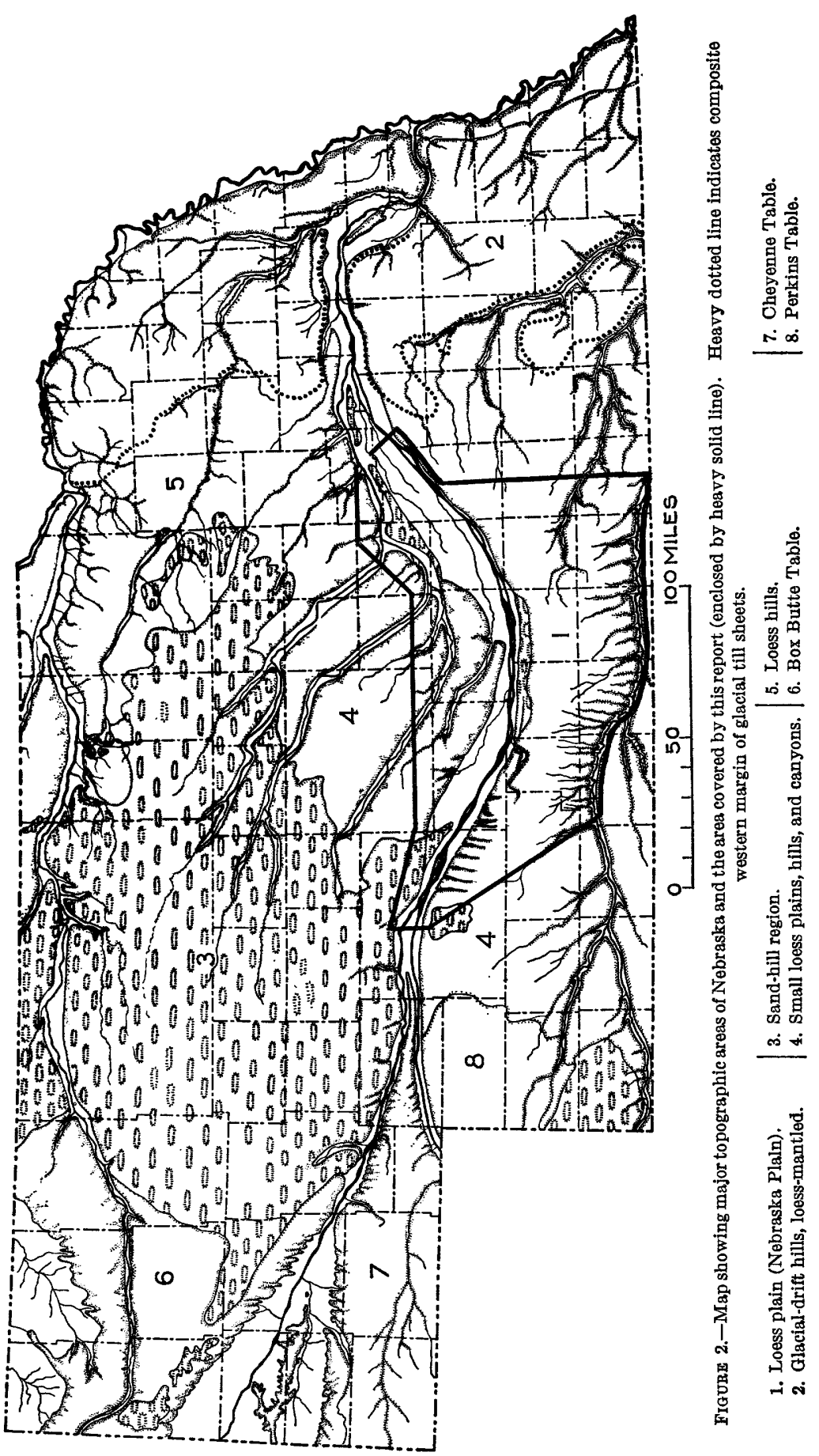


and fluvioglacial formations in the Platte River Valley and under the upland plain between the Platte and the Republican.

The upland plain between the Platte and Republican Valleys is a partly dissected loess plain, large areas of which are almost entirely unmodified by surface drainage. The largest undissected areas are in northeastern Gosper, Phelps, Kearney, Adams, southeastern Hall, Hamilton, and Clay Counties. A small part of northeastern Harlan County and a larger part of northwestern Franklin County are also very little dissected. Large parts of the original plain still remain in the counties east and northeast of the area treated in this report. The plain has a fairly uniform slope to the east and southeast of 5 . to 8 feet to the mile. The western part of the plain rises toward the High Plains somewhat more steeply, in places as much as 20 feet to the mile.

The only noticeable relief features on the upland plain are hummocks of loess and marshy depressions, in some places several hundred acres in extent. The depressions sometimes contain shallow water throughout the summer, but most of them usually dry up during the warm season.

The southern margin of the plain is rather intricately dissected by many streams that drain into the Republican River, about 25 of which are perennial. This strip of territory is from 10 to 15 miles wide.

The Republican River flows along the southern border of the area under discussion. Its altitude above sea level is about 2,150 feet at Arapahoe, about 1,740 feet at Riverton, and about 1,535 feet at Superior. It flows at altitudes that are about 300 feet lower than the Platte River at points directly north. For example, the Platte River at Cozad is about 2,480 feet above sea level, and the Republican River at Arapahoe, directly south of Cozad, is 2,150 feet-330 feet lower. South of Gibbon the Platte flows at about 2,060 feet above sea level, and at Riverton the Republican River is about 1,740 feet above sea level. The altitude of the Platte River near Grand Island is about 1,833 feet, and that of the Republican River at Superior is about 1,535 feet.

The depth of the Republican River Valley ranges from 200 to 400 feet below the undissected remnants of the upland plain on its north side. Throughout most of its course the river has cut its valley entirely through the thick loess and gravel deposits, which underlie the plain north of it, and is flowing on the relatively impervious Cretaceous bedrocks. These several factors combine to enable the Republican River to receive a perennial discharge of water from under the plains to the north.

A fertile flood plain and one or two well-defined terraces border the Republican River. The width of the flood plain and terrace 
areas in the valley is fairly uniform and exceeds 2 miles in only a few places.

The main branch of the Big Blue River and several other feeding tributaries, such as Beaver Creek and Lincoln Creek, head in the vicinity of Hastings and in the eastern part of the area between Hastings and Aurora. The Big Blue Valley, within this area, is for the most part relatively wide and shallow, being incised only 50 to 100 feet below the general plain level. The Little Blue River heads in the vicinity of Minden and follows a rather irregular course eastward for about 50 miles across part of Kearney County, all of Adams County, and part of Clay County and leaves the area near the Clay-Nuckolls County line. The valley of the Little Blue is similar to that of the Big Blue River. The Little Blue River is fed somewhat by underflow from the Platte Valley from a point near Ayr southeastward. The Big Blue River is similarly supplied by seeps and springs along its course from a point a few miles east of the area covered by this report.

A part of the loess-covered area north of the Platte River Valley is included in this report because it is closely related, both geologically and hydrologically, to the Platte Valley and to the plain on the south. It is made up of small remnants of the original loess plain, rounded loess hills, and canyons. Its erosional topography is in middle maturity, and the relief ranges from 100 to 200 feet. Drainage of the area is effected in part by the Loup River and its tributaries and in part by the Wood River and a few large creeks.

The Platte River flows from west to east across the area covered by this report. The river has entrenched itself from 50 to 150 feet below the plains, remnants of which are seen on both sides of the valley as flat tops to the dissected uplands. The north and south limits of the valley are usually well defined by an abrupt rise of 20 to 100 feet, and in some places this rise is rather precipitous. However, the southern limit of the valley for a few miles west of Kearney and the northern limit north of Grand Island are composed of sand hills of hummocky appearance, and in these localities the valley edge is less conspicuous.

The valley floor is nearly flat and contains the flood plains and terraces of the Platte River. The flood plains occupy the topographically lowest parts of the valley close to the river and range in width from a few hundred feet to 3 or 4 miles. These bottom lands are crossed by old river channels of the Platte and contain many poorly drained depressions. In places sand from the river bed has been blown onto the flood plains and has formed small sand dunes a few feet in height. The terraces lie farther back from the river and are more extensive on the north side because the river in most places flows close to the southern uplands. The transition from the flood plains to the terraces is usually marked by a gradual slope, but the 121343-38-2 
slope from the terraces to the uplands is usually steep. In some localities the terraces are distinct and there is an abrupt rise between different levels, but in most places the terraces have been eroded and the surface rises gently from the bottom lands to the valley limits.

\section{POPULATION}

The population of the area investigated is about 205,000 and is largely rural, as only about 39 percent of the people live in towns of 1,000 or more. About 30 percent live in the portion of the Platte River Valley which has been given detailed attention in this report. This includes both rural and town population but does not include any part of the valley below Chapman or above the west line of Dawson County.

The largest cities in the area and their population in 1930 are Grand Island, 18,041; Hastings, 15,490; and North Platte, 12,061.

\section{TRANSPORTATION}

Railroad facilities are good. Several main-line railroads cross the area, and numerous minor branches serve other parts of it. The main line of the Union Pacific Railroad follows the Platte River and serves the valley, and branch lines of the Union Pacific extend into the area north of the Platte River. The Chicago, Burlington \& Quincy Railroad serves almost all parts of the area except the Platte River Valley itself. One branch extends northwest into the loess hills from Central City, and the Alliance branch traverses the loess hills northwest from Grand Island. Another line of the Burlington traverses the Republican Valley, and the main line from Chicago and Omaha to Denver extends through the middle of the Nebraska Plain, passing through Hastings, Minden, and Holdrege. The Curtis branch of the same railroad extends across northern Webster and Franklin Counties and passes northwestward through Holdrege, Bertrand, Elwood, Eustis, Farnam, Moorfield, and points west. A branch of the Missouri Pacific Railroad extends into the area from the southeast and connects Superior, Lawrence, Hastings, and Prosser. The St. Joseph \& Grand Island Railroad also extends into the area from the southeast.

Several important national and State highways cross the area both east and west and north and south. There are many secondary highways maintained by the State, and most of the county roads are good. Nearly all the State or national designated highways are graveled or paved. The Lincoln Highway follows the Platte River and more or less parallels the Union Pacific Railroad. It is now all paved, and there are also many miles of paving on some of the other highways. The country dirt roads are for the most part graded and are usually good except in rainy weather. 


\section{AGRICULTORE AND INDUSTRY}

The main industry of the area is agriculture. The raising of grain, especially wheat, and corn and to a somewhat less extent livestock and general farming prevail. Irrigation is practiced chiefly in the Platte River Valley, although a few deep wells have been used for irrigation on the upland plain and in the valleys of some of the other large streams.

The soils of the entire area are for the most part fertile and tillable. Loess soils prevail over all other types. Both loess and sandy soils occur in the Platte River Valley. United States Department of Agriculture soil-survey reports have been published for most of the counties in south-central Nebraska, and maps are procurable from the Superintendent of Documents, Washington, D. C., or from the conservation and survey division of the University of Nebraska, Lincoln, Nebr.

The cities and towns of the area are the trade and business centers for the surrounding farming districts. Livestock and grain are shipped from hundreds of points. There is some manufacturing in the larger towns, such as Grand Island and Hastings, and considerable milling is done at a number of places.

\section{CIIMATE}

The mean annual precipitation in the area ranges from about 20 inches at the west to about 26 or 27 inches at the east. The absolute minimum annual precipitation so far on record is about 12 inches at the west and about 15 inches at the east. The absolute maximum annual recorded precipitation ranges from about 34 to 44 inches at places in the western part of the area and from 38 to 48 inches at places in the eastern part. The January mean precipitation ranges from 0.40 to 0.60 inch for the whole area. The June mean precipitation ranges from 3.20 inches in the west to 4.40 inches in the east. The annual mean precipitation for several stations is given in the table below.

The area receives most of its precipitation in the form of local thunderstorms during the summer, about 65 percent of the rainfall occurring in the growing season of May, June, July, August, and September. In May and June the rainfall is usually well distributed, in July the distribution is less favorable, and during August and September long periods of drought are not infrequent. Little precipitation is received in months when the prevailing wind is from the north or northwest, but most of the precipitation occurs in months with prevailing south or southeast winds. The average annual snowfall in the area is about 30 inches.

The prevailing wind direction changes from north or northwest in winter to south or southeast in summer. 
The average date of the last killing frost in the spring is about. May 1. The average growing season in the Platte Valley ranges from 161 days at Grand Island to 148 days at Gothenburg. Killing frosts occur about the first of October. Thunder and hailstorms accompanied by brisk winds are not infrequent. The mean annual wind velocity is about 9 miles an hour. During storms winds of 30 to 50 miles an hour are likely to occur, and velocities as high as 80 miles. an hour have been recorded for short periods of time. The proportion of clear and sunshiny days is relatively high.

The mean annual temperature of the area ranges from $49^{\circ}$ at the north to $52^{\circ}$ in the Republican River Valley at the south. The January mean temperature ranges from about $23^{\circ}$ at the north to about $26^{\circ}$ at the south. The July mean temperature ranges from $73^{\circ}$ or $74^{\circ}$ at the north to about $77^{\circ}$ at the south. Much higher temperatures normally occur in the area during the summer. Temperatures of more than $100^{\circ}$ are not uncommon, and the summers are usually regarded as hot. The winters are usually rather cold, with extreme temperatures of more than $30^{\circ}$ below zero on record in some localities. The mean annual temperature for several stations is given in the following table:

Summary of climatic data for stations in south-central Nebraska

[From U. S. Weather Bureau]

\begin{tabular}{|c|c|c|c|c|c|}
\hline & \multirow{2}{*}{$\begin{array}{c}\text { Altitude } \\
\text { above sea } \\
\text { level } \\
\text { (feet) }\end{array}$} & \multicolumn{2}{|c|}{ Precipitation } & \multicolumn{2}{|c|}{ Temperature } \\
\hline & & $\begin{array}{l}\text { Length of } \\
\text { record } \\
\text { (years) }\end{array}$ & $\begin{array}{c}\text { Mean } \\
\text { annual } \\
\text { (inches) }\end{array}$ & $\begin{array}{l}\text { Length of } \\
\text { record } \\
\text { (years) }\end{array}$ & $\underset{\text { Mean }}{\text { annual }}$ \\
\hline $\begin{array}{l}\text { Red Cloud. } \\
\text { Central City } \\
\text { St. Paull } \\
\text { Franklin } \\
\text { Grand Isiand } \\
\text { Hastings... } \\
\text { Alma } \\
\text { Kearney } \\
\text { Minden } \\
\text { Holdrege } \\
\text { Lexington } \\
\text { Gothenburg }\end{array}$ & $\begin{array}{l}1,687 \\
1,699 \\
1,796 \\
1,820 \\
1,860 \\
1,932 \\
1,939 \\
2,146 \\
2,169 \\
2,324 \\
2,385 \\
2,557\end{array}$ & $\begin{array}{l}42 \\
44 \\
40 \\
43 \\
43 \\
43 \\
38 \\
60 \\
57 \\
43 \\
45 \\
40\end{array}$ & $\begin{array}{l}23.99 \\
26.08 \\
25.30 \\
23.49 \\
27.35 \\
25.71 \\
22.58 \\
24.97 \\
27.72 \\
23.24 \\
22.58 \\
22.29\end{array}$ & $\begin{array}{l}38 \\
19 \\
39 \\
43 \\
43 \\
41 \\
37 \\
40 \\
51 \\
40 \\
44 \\
40\end{array}$ & $\begin{array}{l}52.1 \\
51.0 \\
50.6 \\
51.5 \\
50.4 \\
50.2 \\
51.7 \\
50.5 \\
50.2 \\
51.3 \\
49.9 \\
50.3\end{array}$ \\
\hline
\end{tabular}

\section{GEOLOGY}

By A. L. LugN

Most of the ground water used in the area under investigation: occurs in sand and gravel formations of Pleistocene age. Several. formations of the Tertiary system yield water at places in the State. Of these, only the Ogallala formation occurs extensively in the area under investigation (fig. 3). The Brule clay and Chadron formation extend into the area for a few miles east of the city of North Plattebut are here of little importance in yielding ground water. Formations older than the Tertiary are relatively unimportant as aquifers and. are not utilized for water supply in this area. 


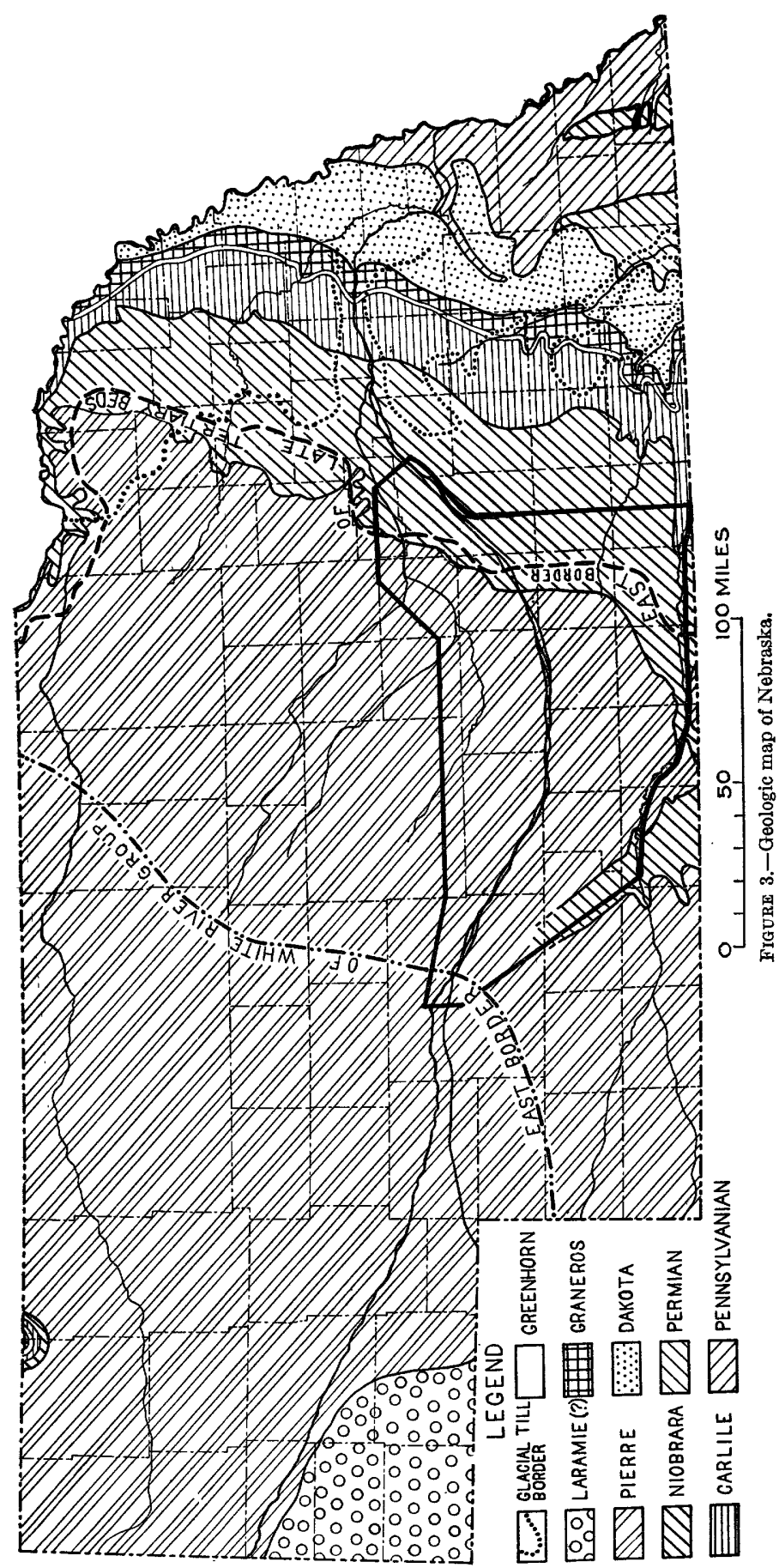


The Pleistocene formations which occur in south-central Nebraska and from which most of the ground water in the area is derived have not heretofore been definitely correlated with the Pleistocene formations in eastern Nebraska or with the Pleistocene formations in other States. As a result of this investigation data have been collected which appear to indicate that the Pleistocene formations in southcentral Nebraska can be correlated with the Pleistocene of eastern Nebraska and Iowa. A brief section on the glacial and interglacial deposits in eastern Nebraska is included in this report to show the relation of these deposits to those occurring in south-central Nebraska. The relation between the Pleistocene classifications of the Federal Geological Survey, of G. F. Kay (1931) for Iowa, of A. L. Lugn (1932) for Nebraska, and of this report are shown in the table on pages 18-19. The stratigraphic relations in Nebraska and Iowa are shown in figure 4.

\section{EARLIER WORK}

The glacial-drift or till deposits of eastern Nebraska were never very closely studied until comparatively recently, and there has been much difference of opinion as to what was drift and what was not. drift and also as to the amount of drift or till present. In 1880 Aughey ${ }^{5}$ discussed the glacial period and gave especial attention to the loess deposits. He noted evidence to indicate two glacial advances separated by a retreat during which soil and forest beds were developed at many places. He also called attention to the occurrence of a calcareous and in part siliceous clay and sandy clay of a darker reddish brown than ordinary loess, which he recognized as distinct from other materials. This is what is now known as the Loveland loess. He called attention to its great similarity to the overlying loess.

Darton $^{B}$ in discussing the earlier Pleistocene deposits states: "These deposits comprise a mass of glacial drift in Lancaster and eastern Seward Counties and a thin sheet of gravelly sand, which extends far westward under the loess mantle of the plains region and appears to be contemporaneous with the glacial drift. ${ }^{*} *{ }^{*}$ No order of succession has yet been determined for the glacial deposits." He understood the general character and relations of these deposits but evidently felt it unnecessary to his purpose at the time or for other reasons did not attempt to work out detailed relations.

An extensive report on the Pleistocene deposits of South Dakota and Nebraska by Todd ${ }^{7}$ was published in 1899. He described a number of measured sections, mainly in northeastern Nebraska north of the Platte River.

\footnotetext{
Aughey, Samuel, Physical geography and geology of Nebraska, pp. 252-309, Omaha, 1880.

- Darton, N. H., Underground waters of a portion of southeastern Nebraska: Geol. Survey WaterBupply Paper 12, pp. 21-23, 1898.

ITodd, J. E., The moraines of South Dakota and their attendant deposits: Geol. Survey Bull. 158, pp. 56-81, etc., 1899.
} 


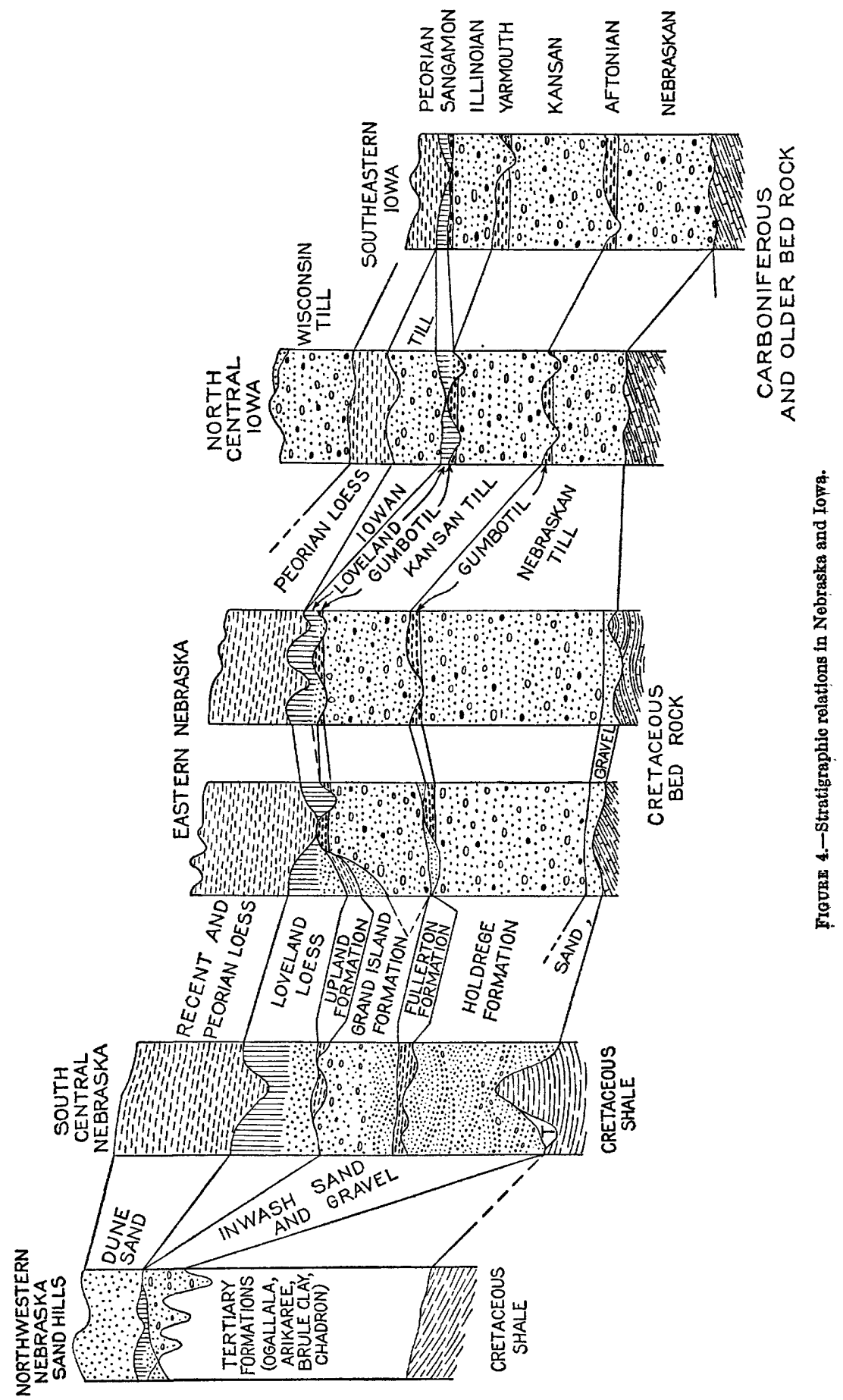


In 1903 Barbour $^{8}$ discussed the glacial drift of Nebraska in a general way. In $1914^{\circ}$ he called attention to the fact that the term "glacial drift" was used in "an unfortunately restricted and local sense in Nebraska" but that Pleistocene materials of several different ages had been recognized in the State. It seems that until very recently the drifts were not satisfactorily recognized and separated, either from each other or from the Loveland ("Red drift") or the overlying loess.

Many of G. E. Condra's observations on the Pleistocene of Nebraska have not been reported in print. At least 30 years ago he pointed out to Frank Leverett the existence of materials that pretty definitely established that Nebraska had experienced glaciation at least twice. He regarded the "sand plain" under the younger till of eastern Nebraska as of Aftonian age and considered that the younger till was the Kansan. He believed that the Kansan was the State's major glaciation, and stated that "it is thought by some that the Iowan and Wisconsin invasions reached northeastern Nebraska", ${ }^{10}$ a supposition not supported by later studies. In 1908 Condra emphasized the importance of the Kansan till sheet and "sand bodies, sand beds, and sand plains" within the till-covered area. He also recognized a large "glaciofluival sand plain" which, he stated, "extends westward under the loess an unknown distance. *** This sheet of sand and gravel is 100 feet thick at some places." Condra also called attention to an old channel of the Platte " and to the deposits of Todd Valley. Recently he has briefly outlined the main events of the Pleistocene of Nebraska in accordance with the latest known facts. ${ }^{12}$

The writer ${ }^{13}$ has published several short notes and abstracts concerning the Pleistocene of this State. He also has recently published an outline of Pleistocene geology ${ }^{14}$ in which many of the data and conclusions contained in this report are given. A more comprehensive paper ${ }^{15}$ was published in 1935.

\footnotetext{
8 Barbour, E. H. (State geologist), Nebraska Geol. Survey, vol. 1, pp. 165-169, 1903.

- Barbour, E. H., A phenomenon of the Kansan drift in Nebraska: Jour. Geology, vol. 22, no. 8, pp. 807-810, 1914.

10 Condra, G. E., The sand and gravel resources and industries of Nebraska: Nebraska Geol. Survey [1st ser.], vol. 3, pt. 1, pp. 52-59, 1908.

it Condra, G. E., An old Platte channel: Am. Geologist, vol. 31, pp. 361-369, June 1903.

12 Condra, G. E., Geological phases of soil-erosion investigation and control in Nebraska: Nebraska Geol. Survey Paper 6, pp. 1-22, December 1934.

13 Lugn, A. L., Ground-water hydrology and Pleistocene geology of the Platte River Valley and adjacent areas in Nebraska: , เm. Geophys. Union Trans. 12th Ann. Meeting, pp. 224-226, June 1931; also abstract, Geol. Soc. America ] iull., vol. 41, no. 1, pp. 171-172, March 1930; Pleistocene formations of southern Nebraska [abstract]: Geol. So :. America Preliminary List of Titles and Abstracts, 44th Ann. Meeting, Dec. 29-31, 1931; Geol. Soc. Am эrice Bull., vol. 43, no. 1, p. 190, 1932; Geologic evidence bearing on Pleistocene man in Nebraska [abstract]: Geol. Soc. America Preliminary List of Titles and Abstracts, 47th Ann. Meeting, Dec. 27-29, 1934.

" Lugn, A. L., Outline of Pleistocene geology of Nebraska: Nebraska State Mus. Bull. 41, pp. 321-356, October 1934.

1s Lugn, A. L., The Pleistocene geology of Nebraska: Nebraska Geol. Survey, 2d ser., Bull. 10, 1933.
} 
Other geologists, including W. C. Alden and Frank Leverett, of the Federal Geological Survey, and G. F. Kay and B. Shimek, of Iowa, have studied outcrops of the glacial formations in eastern Nebraska. These men have used data from Nebraska in some of their publications but have not published specifically on this area.

\section{PLEISTOCENE DEPOSITS}

GLACIAL AND INTERGLACIAL DEPOSITS OF EASTERN NEBRASKA

The glacial and associated fluvioglacial materials of the glaciated area of eastern Nebraska (see fig. 2) consist of a lower till sheet, the Nebraskan, an upper till sheet, the Kansan, and associated bodies of sand and gravel. Sand and gravel deposits occur under the Nebraskan till and between the two till sheets, and a considerable accumulation of more or less locally reworked sand and gravel occurs on top of Kansan till. (See accompanying table and fig. 4.) 


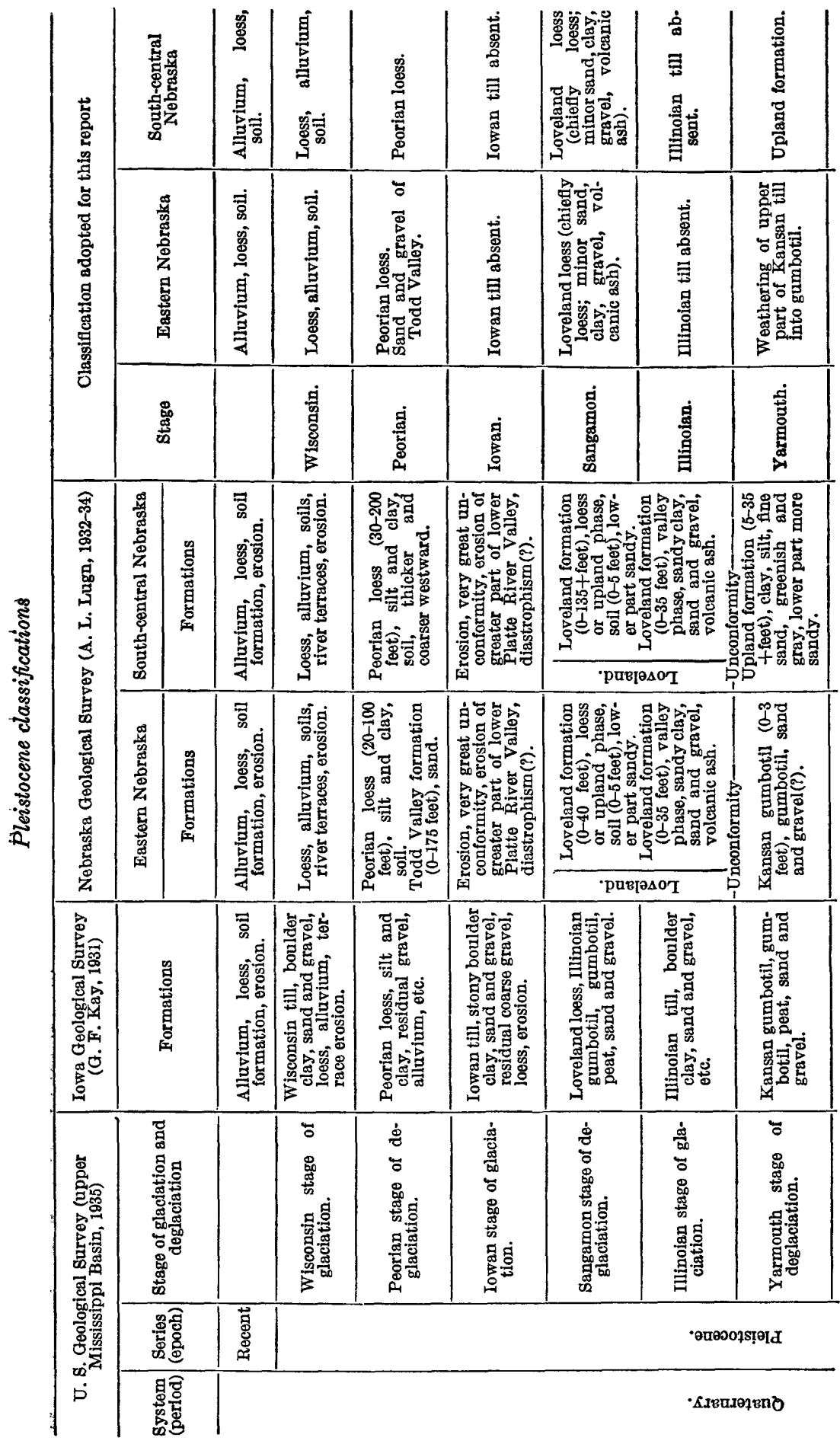




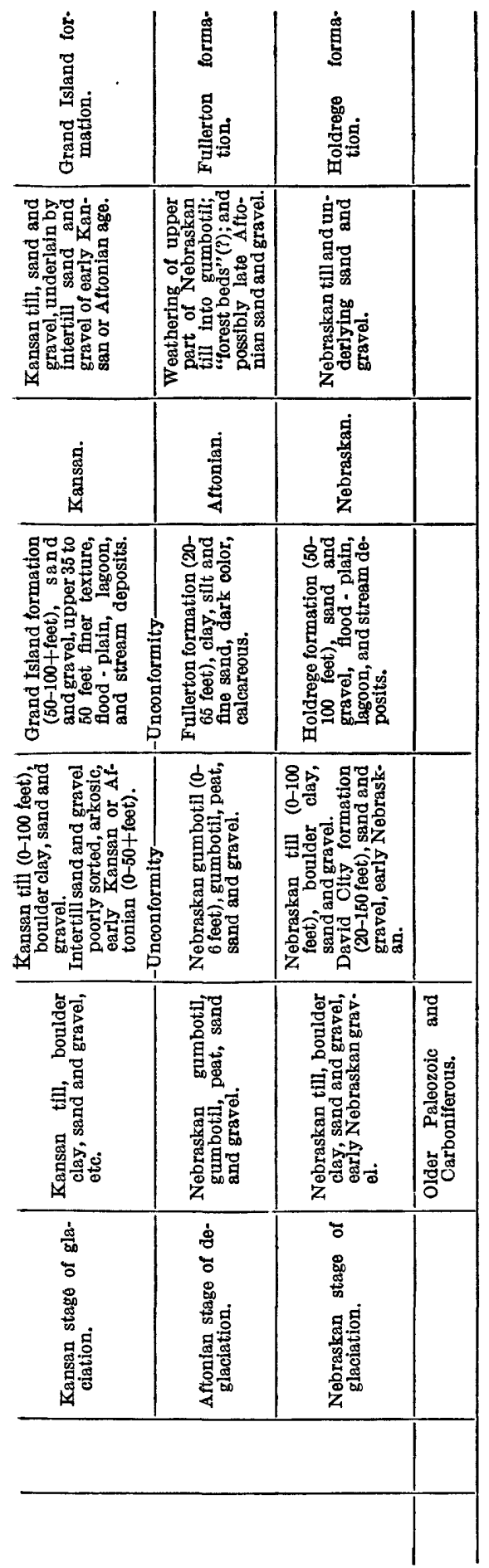




\section{NEBRASKAN STAGE}

BASAL SAND AND GRAVEL

The sand and gravel under the Nebraskan till in the David City well and elsewhere in eastern Nebraska are believed to be of early Nebraskan age. They are thought to consist of the outwash fluvioglacial material carried into old pre-Pleistocene valleys and other depressions on the bedrock in front of the Nebraskan glacier and the inwash sediment carried from other directions by streams whose valleys were dammed by the ice itself or by debris washed from the melting ice sheet. The quantity of this material is large in eastern Nebraska, even though it is exposed at only a very few places and known mainly from well logs. The deposit is widespread but is not a. continuous sheet, because of the irregularities on the bedrock floor on which it was deposited. It fills old buried pre-Pleistocene valleys and ranges from a few feet to 150 feet in thickness. It is said to be 150 feet thick east of David City, where it has been penetrated in deep test wells.

The following log indicates the character and relations of these early Pleistocene deposits:

Log of farm well 2 miles west and 2 miles south from Bellwood, Nebr., in NW $1 / 4$ sec. 1, T. $15 \mathrm{~N}$., R. $1 \mathrm{E}$.

[In a deep gully in bluffi on south side of Platte River Valley. Altitude 1,490 feet]

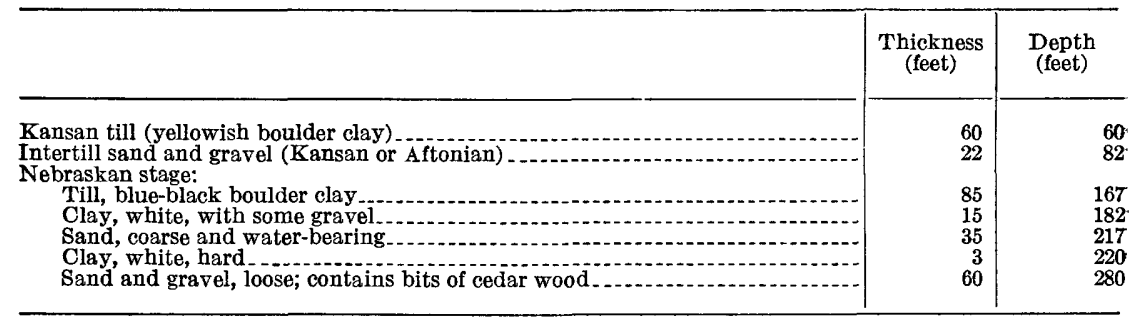

Four feet more of Kansan till was exposed in the bank above the well portal, and rather thick loess formations occur over the Kansan till in the high banks of the gully.

Sand and gravel that correspond to the basal Pleistocene deposit of the David City and other wells are exposed at several places near Hartington, in Cedar County. Here the deposit consists of fine- to medium-textured gray sand, from 5 to 20 feet thick, underlying the Nebraskan till. It is quite unlike the much more heterogeneous sand and gravel that occur in this area between the Nebraskan and Kansan tills. It is conspicuous where the gullies have been eroded entirely through the Nebraskan till. This formation is a source of well water at many places in the eastern part of the State. 
TILL

The till to which the name "Nebraskan till" was applied by Shimek ${ }^{16}$ in 1909 is well developed in eastern Nebraska and extends farther west than the Kansan till. It is thicker than the Kansan till in most places.

The lithologic character of the Nebraskan till in this area is similar to that in other areas, except that it may contain a greater admixture of Sioux quartzite and naturally a large content of the local overlying bedrocks. This fact is well illustrated in the northeastern part of the State, where the till contains great quantities of Pierre and Niobrara shale and, because of this, relatively fewer boulders and pebbles than the higher and younger Kansan till. In general, it is made up of a heterogeneous mixture of granitic, metamorphic, and sedimentary rock materials of nearly all kinds, ranging in size from colloidal particles to large boulders. Where it is preserved in its entirety, it has a few feet of gumbotil at the top, below which usually occurs several feet of oxidized and leached till, underlain by a zone of oxidized but unleached boulder clay, and beneath this the unaltered dark-gray to black till.

Late Aftonian erosion greatly dissected this till sheet, and because of the nearness of most places in the glaciated area of the State to the till margin, less gumbotil had time to form here than over the wide Nebraskan till plain of Iowa. Because of this, the Nebraskan till is poorly preserved, and there are few sections where all the above-mentioned zones can be seen. The Kansan till or even younger formations may rest on the eroded Nebraskan till, in contact with any of its zones, from the uneroded gumbotil down to the fresh unaltered boulder clay.

It is often impossible, because of the lithologic similarity of the two tills, to distinguish Nebraskan from Kansan unless the gumbotil is still preserved at the contact between them in the section. The degree of leaching or oxidation may be of little value in differentiating the two till sheets where, in the absence of more or less of the upper part of the Nebraskan, the Kansan till rests on the oxidized and unleached zone or even on the unaltered lower till.

One of the best exposures of the two tills, where their relations are clearly revealed, occurs in the south bluff of the Platte River Valley southwest of Fremont.

\footnotetext{
$16 \mathrm{~S}$
1909.
} 
Section about $21 \frac{1}{2}$ miles west and three-quarters of a mile south from Fremont, Nebr., in sec. $19, T .17$ N., R. $8 \mathrm{E}$.

[Top of section at edge of bluff is 1,330 feet above sea level, the general level of the upland plain in this vicinity]

Peorian loess (yellow clay); mantles the slopes of tributary Feet gullies as well as caps the bluff itself and lies on and in contact with every formation below

Loveland loess (red loess clay). Only remnants of this formation are exposed. It is sharply eroded at the edge of the bluff under the Peorian, and is in uneven erosional contact with both the Kansan till below and the Peorian loess above

Kansan till (gray, unleached, and, except for the upper few feet at some places, unoxidized typical boulder clay). Basal contact is nearly horizontal on the underlying gumbotil, but elsewhere it is uneven and plainly unconformable on the lower eroded till)

Nebraskan glacial stage:

Gumbotil (dark-brownish clay, with quartz pebbles and quartz sand grains; leached of soluble original limestone but contains some secondary carbonate). The weathering of this Nebraskan till into gumbotil occurred during the Aftonian stage . . . . . . . ......

Till (10 feet of dark-gray till well exposed; 35 feet of till poorly exposed, mostly under covered slope to the water level in the Platte River at the base of the section)

The entire Nebraskan of this section is well exposed at other points nearby along the bluff above the water level. The till probably extends 18 to 20 feet below the Platte River level at this point, as 18 feet of till was penetrated in a shallow well put down at the base of the bluff about half a mile east of the section. Coarse gravel was encountered below the till in this well. The thickness of the gravel at this point. is unknown, but it is about 20 feet thick in water wells that reach it from the upland level south of the river. These Pleistocene formations lie on the Dakota sandstone and the Graneros shale in this part. of Nebraska. (See fig. 3.)

The Nebraskan till is known from many other exposures, especially in the northeastern part of the State, and some occurrences have been noted in the southeastern counties. It is clearly present in the vicinity of David City, where it appears from a study of well logs to have attained its maximum thickness of about 80 to 100 feet. It is as much as 75 feet thick in Cedar County near Hartington but is generally thin or absent (by erosion) in the southeastern part of the State. It will be noted in some of the sections given in the following pages.

\section{GUMBOTIL}

As defined by Kay gumbotil results from the almost ultimate weathering and leaching of glacial till or boulder clay after long expo- 
sure on a poorly drained till plain. ${ }^{17}$ It is always a tough dark-gray to black impervious clay, usually containing only quartz or quartzite pebbles, and grades downward into oxidized and leached till, the parent material. All soluble mineral matter has been leached out, and all granitic minerals and pebbles or boulders are usually thoroughly disintegrated by weathering. This till was laid down in the Nebraskan glacial stage, but the process of weathering of the till into gumbotil occurred during the succeeding Aftonian interglacial stage.

Erosion and dissection of a till plain terminates gumbotil formation and removes much and in places all of the gumbotil previously formed. Only remnants of gumbotil weathered from the Nebraskan and Kansan tills remain on the till sheets of eastern Nebraska. A small remnant of gumbotil at the top of the Nebraskan till, somewhat changed in color and altered by superficial weathering, has been noted in the section southwest of Fremont. Exposures of similar remnants, with till above and below, are known to occur in Saunders, Butler, and Colfax Counties and also possibly in Dodge and Lancaster Counties.

\section{AFTONIAN STAGE}

The Aftonian interglacial stage is represented in eastern Nebraska by the weathering of the upper part of the Nebraskan till into gumbotil, probably by vegetal deposits ("forest beds"), possibly by beds of silt, sand, and gravel occurring between the Nebraskan and Kansan till sheets-which may be of either early Kansan or Aftonian ageand by erosion.

AFTONIAN OR EARLY KANSAN INTERTILL SILT, SAND, AND GRAVET

An old soil, 6 to 8 inches thick, not a gumbotil, is known to lie between layers of till in the vicinity of Valparaiso. Fine-textured beds of dark clay and silt, with very few if any of sand or pebbles, occur between deposits of typical boulder clay in northern Lancaster, southern Saunders, and northeastern Seward Counties. This material lies between the Nebraskan and Kansan tills and may be of Aftonian age. W. C. Alden, ${ }^{18}$ of the United States Geological Survey, has suggested that this material may represent a local accumulation of silt and clay that was reworked from the earlier deposit of Nebraskan till by relatively gentle erosive action during the Aftonian interglacial stage.

Local lenses of intertill sand and gravel as much as 30 or 40 feet thick, some of them of considerable extent, are known at many places in the drift-covered area of eastern Nebraska. This material ranges in texture from coarse gravel to fine sand, and many of the deposits are extensive enough to store sufficient water for farm and village supplies.

17 Kay, G. F., Gumbotil, a new term in Pleistocene geology: Science, new ser., vol. 44, pp. 637-638, Nov. 3, 1916. Kay, G. F., and Pierce, J. N., The origin of gumbotil: Jour. Geology, vol. 28, pp. 89-105, 1920.

1s Personal communication. 
The material seems to be a filling in old valleys, which were eroded into and in places through the Nebraskan till, prior to the deposition of the gravel but later than the formation and subsequent erosion of the gumbotil. The intertill sand and gravel must then have been deposited very late in Aftonian time or early in Kansan time. It seems more probable that the intertill materials were carried out in front of the advancing Kansan ice by glaciofluvial waters from the melting ice sheet and transported by streams from the west and northwest, and that they choked and filled the pre-Kansan valleys that were then more or less dammed up by the ice itself. The deposits thus formed were subsequently overridden by the Kansan glacier, and the fluvial accumulation went on, during the remainder of the Kansan stage, west of the terminal moraine, to build up the Grand Island formation. This explanation is identical with the explanation previously mentioned for the early Nebraskan sand and gravel.

A description of one of the best exposures in southeastern Nebraska containing both the Nebraskan and Kansan tills and the intertill beds is given below:

Section about 81/2 miles south of Tecumseh, Nebr., in the NW1/4 sec. 9, T. 3 N., R. 11 E.

Soil and Peorian loess (clay)

Feet

Loveland loess (red sandy loose clay containing some pebbles); thinly mantles slope over lower beds. The lower 3 to 4 feet consists of medium to fine sand where the Loveland rests directly on the eroded boulder clay .............

Kansan till (yellowish and gray boulder clay). Lower part does not contain many pebbles, but upper part is more typical, with more pebbles and cobbles. The lower contact horizontal, but contains small masses of the underlying brownish sand; the till pinches out to a thin edge against the eroded slope to the north................

Intertill deposits (Aftonian?):

Sand, brownish and gray, medium to fine texture; lower 10 feet badly covered; may be transitional to clay below

Clay, laminated, slightly sandy, grayish to dark buff and yellowish

Sand, very fine, whitish, silty, with much secondary calcium carbonate concentrated in upper 2 feet......-

Nebraskan till (typical boulder clay, pebbles, cobbles, etc., grayish, unoxidized and unleached; lower 8 feet is covered slope to drainage level, upper 10 feet exposed) ...........

Many other occurrences of the intertill materials 10 to 40 feet or more thick, as noted in the foregoing section, are present in the southeastern part of the State. Some of the exposures are small and inconspicuous, others are larger, and many have remnants of Kansan till still in place over the sand and gravel. At some places the formerly overlying Kansan till has been completely broken down and dis- 
integrated, leaving only a heavy gravel, cobble, and boulder residual concentrate over the somewhat cleaner and better-sorted finer sand and gravel. Here and there such residual concentrates can be traced into boulder clay. Gravel pits of considerable local importance have been opened in the intertill deposits in Johnson, Pawnee, Richardson, and Nemaha Counties. At most places small remnants of Kansan till or accumulations of the residual debris occur over the gravel outcrops. Remnants of Nebraskan till are known to occur under the intertill sand and gravel at a few places. Locally the intertill deposits have yielded vertebrate fossil remains, usually dated as Aftonian or early Kansan.

Occurrences almost identical with those noted above can be seen in the northeastern part of the State. The intertill sand and gravel are well developed and well exposed in Cedar, Knox, and Dixon Counties, and there are many occurrences in other counties. Some of the best exposures of the Pleistocene formations in northeastern Nebraska are found at or near Waterbury, Coleridge, Hartington, Randolph, Bloomfield, Crofton, Bazile Mills, Pierce, and Norfolk.

The thickness of Nebraskan till ranges from a knife edge at some places to 75 feet or more northeast of Hartington. The till is more or less overlain by intertill gravel deposits which reach a maximum thickness of 40 feet or more and which are generally confined to old Aftonian channels or valleys, as they are in the southeastern part of the State.

The Kansan till, except in a few places, occurs only as small thin remnants of boulder clay over the intertill deposits, or it may be represented only by a residual accumulation of gravel, cobbles, and boulders, as is well shown at the old gravel pit about 1 mile west of Bazile Mills. Nebraskan boulder clay also occurs a short distance southeast of Bazile Mills under a thick capping of gravel.

A fairly typical section for this part of the State is given below.

Section near Tiptop School, about 21/2 miles north of Hartington, in the SW1/4 sec. 18, T. 31 N., R. $1 \mathrm{E}$.

Loess, yellow silty clay under covered slope

Peorian yellow loess, exposed under soil in roadside bank... 2

Kansan till, much disintegrated and weathered, but some small areas are typical oxidized boulder clay ...........

Intertill sand and gravel, mostly brownish and gray sand; upper 6 to 8 feet, oxidized to a brownish color, normally contains no large cobbles or boulders here. Where the Kansan till has completely disintegrated over it a gravel and cobble concentrate has been let down on the intertill sand . . . 2 - 15-25

Nebraskan till, gray boulder clay with many small pebbles _. 10-12

Covered slope for about 30 feet. The Niobrara formation cannot be far below the base of the slope, and the lower or Nebraskan till may be as much as 30 to 40 feet thick at this point. 
The intertill sand and gravel in this vicinity have also yielded some vertebrate fossil remains, mostly of Aftonian or early Kansan age.

\section{KANSAN STAGE}

The Kansan glacial stage is represented in eastern Nebraska by remnants of a once extensive sheet of till, possibly by the intertill deposits described above as belonging to either the Aftonian or the Kansan stage, and by remnants of the gumbotil into which the upper part of the Kansan till was weathered during the Yarmouth interglacial stage.

TILL

The maximum thickness of the Kansan till, so far known, seems to be about 100 feet at some points in Butler County. It may be even thicker in western Saunders County and eastern Seward County and possibly at other places. The till is lithologically almost exactly like the Nebraskan boulder clay, except that it may contain a higher percentage of Sioux quartzite fragments and certainly less of the underlying shale or limestone bedrocks. Because of its remnant character and thinness, and because it usually occurs relatively high topographically, it is very likely to be more oxidized and even discolored reddish from the overlying Loveland loess than the lower and more protected Nebraskan boulder clay. This has led to a generally accepted misconception about the two till sheets in this State-namely, that the Kansan is red and that the Nebraskan is dark gray or black. Where enough Kansan till is present it has the same weathering zones as the Nebraskan till-that is, gumbotil at the top, an oxidized and leached zone, an oxidized but unleached zone, and at the bottom unaltered, unoxidized, and unleached gray or black boulder clay.

The Kansan till has been differentiated from the underlying Nebraskan till with greater certainty in the Platte River Valley bluff southwest of Fremont than anywhere else in the State. It has been reported in several of the sections previously given, in which its thickness ranges from a few feet to at least 100 feet. In many places it has at its upper surface a lag concentrate or residuum of pebbles and boulders which contains a large amount of Sioux quartzite fragments, and at some places a lag concentrate is all that remains of the Kansan till. This concentrate of coarse fragments was formerly considered to be the Kansan drift.

The distribution of the Kansan till is thought to have been almost coextensive and nearly coterminal with the Nebraskan, except that the earlier Nebraskan glacier is believed to have extended 15 to 20 miles farther west beyond the Kansan terminus in Butler and Polk Counties. North of the Platte River in Platte, Madison, Pierce, and Knox Counties the two till sheets are apparently about coextensive. 
The thin edge of the Kansan till sheet and some of its thicker morainal development across Butler County and in Seward County are so deeply buried under loess formations (Loveland and Peorian) that there is no topographic evidence of their presence.

Neither the Kansan nor the Nebraskan till is believed to extend west of the Big Blue River between Seward and Crete. However, south of Crete the Kansan till is thought to extend beyond the Nebraskan till border to rest on relatively high bedrocks in Saline and Gage Counties and to extend a short distance into Fillmore County at Milligan. In Jefferson County the Kansan till overlies a fine-textured phase of the Holdrege formation (of Nebraskan age), which rests on an uneven bedrock floor.

The Kansan till is generally thick in the counties bordering the Platte River Valley and southward into eastern Seward and Lancaster Counties. In the southeastern part of the State it is rarely more than 10 to 15 feet thick. In Johnson and Pawnee Counties it occurs topographically high and usually is covered by only a thin mantle of Loveland and Peorian loess.

The Kansan till is fairly well developed north of the Platte River Valley and also occurs topographically high under the prairie plain in Stanton, Cuming, Wayne, Pierce, Cedar, and eastern Knox Counties. It seems to attain its thickest development, for this part of the State, at a point 6 to 7 miles west of Crofton, where it rests unconformably directly on the Nebraskan boulder clay without any intervening intertill gravel. The materials at this point were well exposed by new road grading in the summer of 1933 . The section is given below:

\section{Section about 6 miles west of Crofton, near the intersection of the Crofton-Niobrara road and the Bloomfield road}

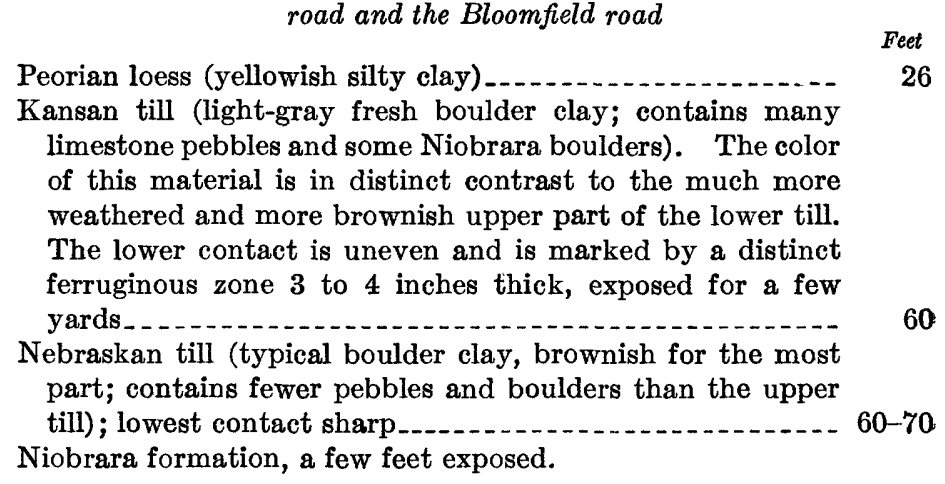

Farther east the Kansan usually occurs only as remnants on more or less thick intertill deposits and has been largely removed by erosion nearer the larger drainage courses, especially near the Missouri River. 
GUMBOTIL

The gumbotil that was weathered from the upper part of the Kansan till during the Yarmouth stage has been found at only a few places. These occurrences are mostly in western Saunders and eastern Butler Counties and a few doubtful outcrops in Lancaster County and possibly in eastern Seward County. Most of the remnants of this material are much weathered and are usually discolored from the generally overlying red Loveland loess. The gumbotil at most places contains secondary calcium carbonate, leached from the overlying loess deposits.

One of the most typical and unmistakable occurrences of gumbotil at the top of Kansan till is seen in an exposure near Pleasantdale, in southeastern Seward County.

Section about 11/2 miles south of Pleasantdale, in sec. 1, T. 9 N., R. 4 E.

Peorian yellow loess (at level of upland plain)
Loveland loess (sandy red clay)
Kansan stage:
Gumbotil (tough, sticky gray clay, with no large pebbles
$\quad$ and only quartz or quartzite sand grains and small
pebbles, somewhat superficially weathered)
Till, upper part oxidized and leached, but poorly ex-
posed down to drainage level...

YARMOUTH STAGE

The only certain record of the Yarmouth interglacial stage in eastern Nebraska is the gumbotil formed by the weathering of the upper part of the Kansan till. The weathering occurred during the Yarmouth stage, but the till was laid down during the Kansan stage.

LATE YARMOUTH OR LATER PRE-LOVELAND EROSION

The explanation for the general absence of gumbotil at the top of the Kansan till is simple. Late Yarmouth or later pre-Loveland erosion so thoroughly and extensively dissected the Kansan till plain that nearly all of the gumbotil and, except in a few counties, most of the Kansan boulder clay were removed. The erosion and dissection at that time seem to have been much greater and more thorough than the earlier erosion in late Aftonian or pre-Kansan time. Perhaps the region had been rejuvenated to a somewhat higher level. The relief developed before Loveland deposition began seems to have been nearly as great as at present. The Loveland, in general, mantled the slopes of the late Yarmouth surface, except along the Platte River Valley, where it occurs only at a higher level than the Kansan till and was sharply eroded at the edge of the bluff prior to Peorian deposition.

There is fairly conclusive evidence that the valleys of the Republican, Big Blue, Little Blue, and Missouri Rivers were opened up again in late Yarmouth or later pre-Loveland time. Many other drainage 
systems in eastern Nebraska were reestablished along pre-Kansan or earlier drainage lines during this epoch.

GROUND WATER IN THE GLACIAL AND ASSOCIATED DEPOSITS OF EASTERN NEBRASKA

Most of the ground water in the glaciated area of the eastern part of Nebraska, about 13,000 square miles in extent, is drawn from the sand and gravel that underlie the Nebraskan till, the intertill sand and gravel, and to a less extent from small bodies of sand and gravel of Loveland age. The quantity of water available from these lenses, sheets, and channel deposits is generally small. There is usually sufficient water to supply farm wells and at some places enough for small village supplies. The occurrence of these irregular and somewhat erratic aquifers is generally quite unpredictable, except by local well drillers, who through long experience have been able to learn of the locations of buried channels and some of the larger lenses. Local drillers usually become familiar with the depths at which the sands may be expected in their areas.

A few dug wells are still in use in eastern Nebraska. They depend on shallow seepage water from loess or till. Dug and bored wells usually range from 30 to 80 feet in depth. Some shallow wells are located in valleys and draw some water from alluvium. However, erosion and gully development have largely ruined these shallow water supplies, and it has been necessary to seek for deeper sources, which are not everywhere available. Thus it has come about that, more and more, farmers in the southeastern part of the State are taking steps to prevent drainage and gully washing and are constructing small reservoirs and cisterns. Villages and towns are more dependent on deeper and more permanent supplies, which are not always easy to find.

\section{FLUVIATILE PLEISTOCENE FORMATIONS WEST OF THE TILL BORDER}

GENERAL FEATURES

The fluviatile Pleistocene deposits west of the till border in $\mathrm{Ne}-$ braska comprise two formations of sand and gravel and two of sandy clay and silt. They are believed to be the correlatives of the glacial formations of eastern Nebraska, Iowa, and other areas, from the $\mathrm{Ne}$ braskan stage to the Yarmouth stage, inclusive. The composite distribution of the two sand and gravel formations (Holdrege and Grand Island) is indicated on figure 5. In a general way, the closeness and number of dots and their size on the map indicate the composite thickness and texture of the fluviatile sand and gravel. The lighter areas indicate the ridges and hills of high but buried bedrock. The "outlet valleys" along the Republican River Valley are also conspicuously shown. The stratigraphic relations and correlation of these beds are shown graphically in figure 4. 


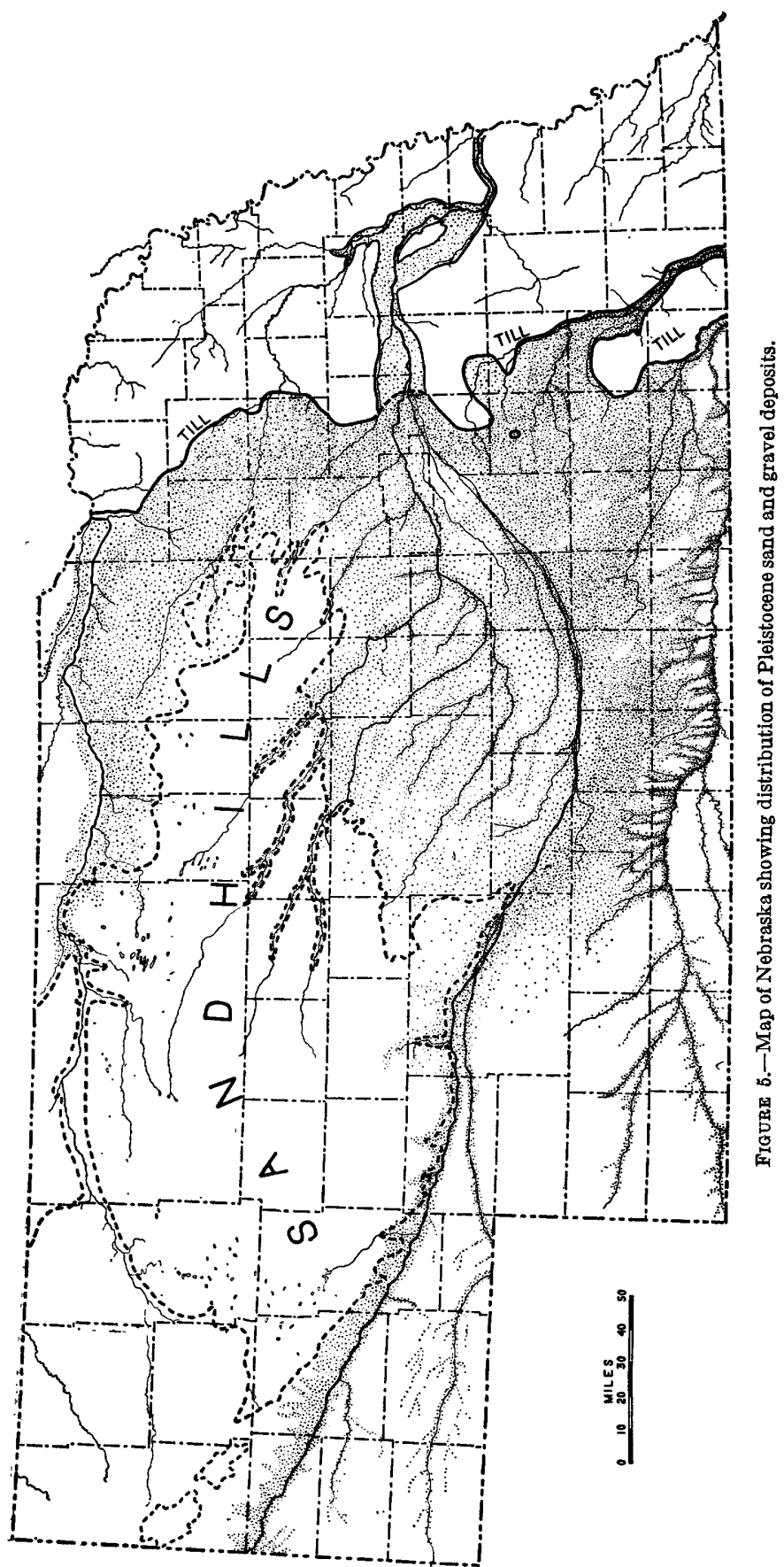


The materials of these formations were recognized by Darton, ${ }^{19}$ and he called attention to " $a$ thin sheet of gravelly sand, which extends far westward under the loess mantle of the plains region and appears to be contemporary with the glacial drift." Condra ${ }^{20}$ also recognized the extent and the thickness of the fluviatile Pleistocene deposits and called them a "glaciofluvial sand plain." He states:

This sheet of sand and gravel is $\mathbf{1 0 0}$ feet thick at some places. It lies below at least a part of the till plain and extends westward under the loess an unknown distance.

The most completely exposed section of these formations is at Lovers Leap, near the south bluff of Cedar Creek, about a mile northwest of Fullerton, in Nance County (pl. 1, B). The section is described below and is shown graphically in connection with well logs from other places in figure 6 .

\section{Pleistocene deposits at Lovers Leap, west of Fullerton}

\begin{tabular}{|c|c|}
\hline \multicolumn{2}{|c|}{$\begin{array}{l}\text { Peorian loess (buff clay, silty, somewhat whitish) } \ldots \ldots \text { Feet } \\
\text { Erosional unconformity. }\end{array}$} \\
\hline Loveland loess $(0-37$ feet $)$ : & \\
\hline ky, dark gray to black & $11 / 4$ \\
\hline h, silty & $23 \% 4$ \\
\hline Clay & 5 \\
\hline 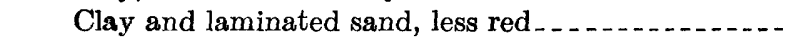 & 5 \\
\hline 1 feet): & \\
\hline 8_. & 2 \\
\hline h gray _........... & $1 \frac{1}{2}$ \\
\hline reenish & \\
\hline Clay, greenish, sandy hard & $1 \frac{1}{2}$ \\
\hline Sand, fine, some clay, gray and greenish & 4 \\
\hline rayish & 1 \\
\hline rand Island formation. & 33 \\
\hline
\end{tabular}

Fullerton formation (20 feet):

Silt, gray, soft, fine and uniform in texture, minutely laminated

Clay, dark gray, hard, silty; some very fine sand; contains many hard calcareous concretions, some 1 foot in diameter. This is the base of the exposure at the flood-plain level of Cedar Creek, 1,616 feet

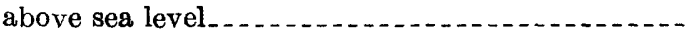

Holdrege formation (sand and gravel similar to the Grand Island). Known from wells but not exposed....

All the beds in the section are in place and fully exposed in one continuous outcrop, except the Holdrege formation. This is the type exposure of the Fullerton formation and is its only known outcrop except in the northern part of the State; elsewhere it is generally recognized in wells.

\footnotetext{
10 Darton, N.H., Underground waters of a portion of southeastern Nebraska: Geol. Survey Water-Supply Paper 12, pp. 21-23, 1898.

${ }^{20}$ Condra, G. E., The sand and gravel resources and industries of Nebraska: Nebraska Geol. Survey [1st ser.], vol. 3, pt. 1, pp. 54-56, 1908.
} 
A deep well was drilled on the upland a few yards south of the crest of the bluff at the location of the foregoing section. It penetrated the same beds as occur in the exposure. A brief log follows and is shown graphically in figure 6.

Log of well near Lovers Leap, west of Fullerton

\begin{tabular}{l|r|r}
\hline & $\begin{array}{r}\text { Thickness } \\
\text { (feet) }\end{array}$ & $\begin{array}{r}\text { Depth } \\
\text { (feet) }\end{array}$ \\
\hline Peorian loess (buff clay) & 67 & 67 \\
Loveland loess (red clay and sand) & 37 & 104 \\
Upland and Grand Island formations (sand and gravel-first water sand, dry). The & 39 & 143 \\
Fulland was not differentiated by the driller & 20 & 163 \\
Foldrege formation (silt and clay, dark and hard) & 40 & 203 \\
sand) & & 480 \\
\hline
\end{tabular}

The stratigraphic relations of the fluviatile formations to the till sheets and to the overlying loess formations are shown in figure 7. This geologic section, about 240 miles long, is based on many outcrops and on many logs from water wells and test wells. It parallels the Platte River closely except where it crosses the valley at Fremont. Three valley basins buried under Holdrege, Hastings, and Aurora and the relatively high bedrock divides under Minden and between Hastings and Aurora are shown as accurately as data at present in hand permit. A similar geologic section extending from Dannebrog, in the Loup River Valley, through the city of Grand Island near the Platte River and eastward to Lincoln, based on detailed well $\log _{s}$, is shown in plate 2. This section extends practically across the buried Aurora basin and reveals the relation of the Platte River to the plains and the continuity of the fluviatile formations under both the plains and the Platte River Valley.

The areal distribution of the fluviatile formations south of the Platte River is known in considerable detail, but much less is known of the distribution of these formations north of the river. There are three principal reasons for this lack of knowledge. First, in the loesshill area and north of the river these formations are more or less confined to deep buried valley fills separated by ridges and divides of bedrock. These early Pleistocene valleys trend from northwest to southeast and were feeder channels to the alluviated areas in southern and southeastern Nebraska. Second, there are very few outcrops, as the entire area, except at the extreme north in Knox and Holt Counties, is deeply buried under thick deposits of Loveland and later loess and sand hills. Third, north of the Platte River very few accurate well $\operatorname{logs}$ seem to be available on which to base conclusions, and very little test drilling has been done. 


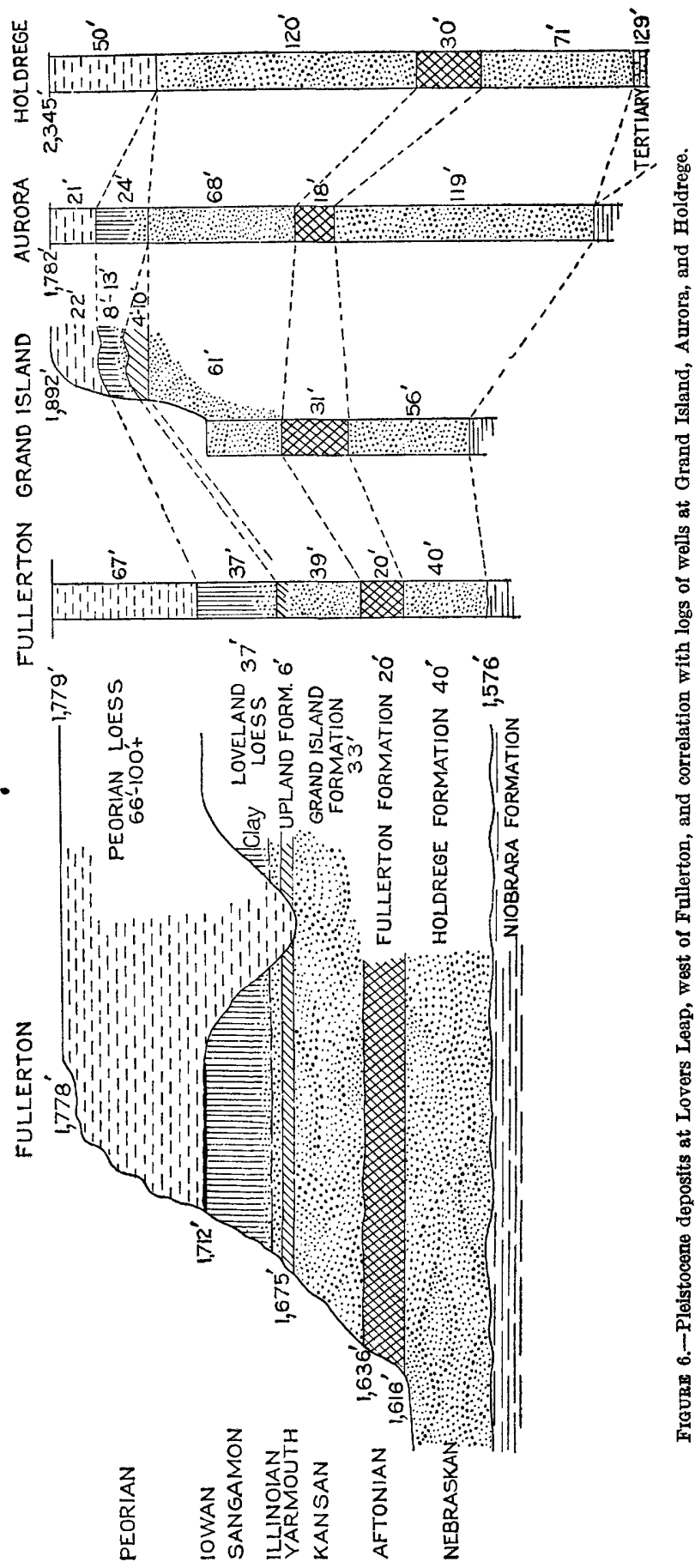




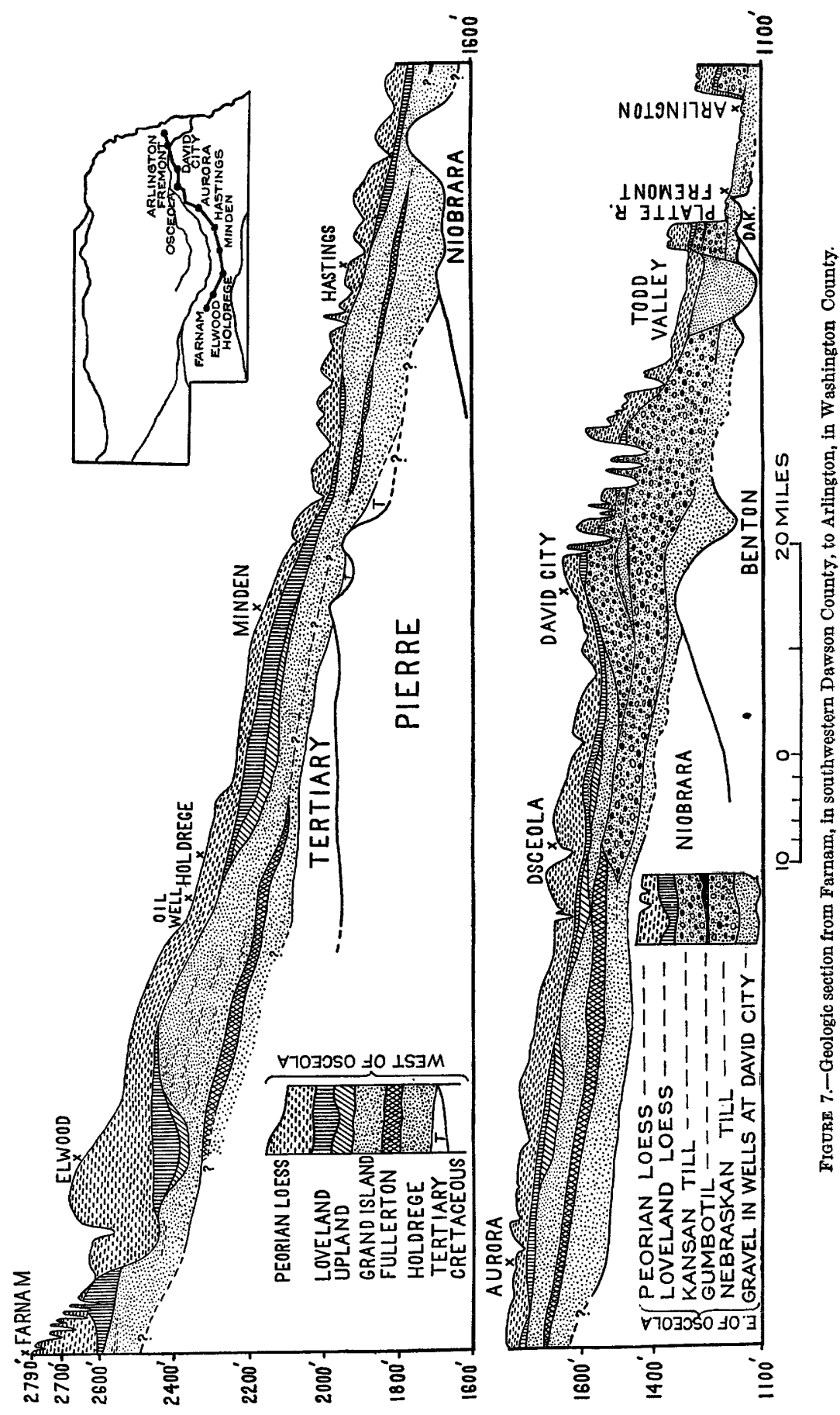


Outcrops in Holt and other northern counties, however, reveal almost everywhere a lower and an upper bed of sand and gravel separated by a bed of clay and silt. A few good well logs are also available to show that these formations are also present in areas covered by thick loess deposits. The individual units vary greatly in thickness, largely because of the irregularities of the bedrock surface on which they were deposited. In general, the Holdrege sand and gravel are more or less confined to the deeper parts of the buried early Pleistocene drainage valleys. The Fullerton and Grand Island formations overlap against the bedrock slopes, and the upper sand and gravel may even extend beyond the limits of the old valleys and spread widely over old buried terraces and peneplains. This is true especially in Brown, Rock, Holt, and Knox Counties.

The thickest fluviatile deposits occur in the counties immediately west of the till border, where the Missouri-Niobrara drainage flowed southward along the ice margins. (See fig. 5.) The greater part of the fluviatile debris in this area is glacial outwash from the ice and till sheets. Apparently the thickest known occurrence of fluviatile materials is in Boone County about $4 \frac{1}{2}$ miles east and $1 \frac{1}{2}$ miles south from Albion (middle of the south side of sec. 29, T. 20 N., R. 5 W.). Here a well 509 feet deep penetrated the deposits shown in the following log:

\begin{tabular}{|c|c|c|}
\hline & $\begin{array}{c}\text { Thick- } \\
\text { ness } \\
\text { (feet) }\end{array}$ & $\begin{array}{l}\text { Depth } \\
\text { (feet) }\end{array}$ \\
\hline $\begin{array}{l}\text { Loess (Peorian and Loveland) } \\
\text { Clay, gray, sticky, hard, jointed (Upland) } \\
\text { Fine sand, some clay, layered, "sticky and gummy" } \\
\text { Sand and gravel, fne- and coarse-layered. } \\
\text { Sand, finer; some silt and thin clay layers; a well-defined thick silt layer (Fullerton?) } \\
\text { somewhere in this bed. } \\
\text { Gravel, uniform and like "cornmeal" } \\
\text { Sand, silt, and clay. } \\
\text { Clay, sandy, very hard; probably reworked shale } \\
\text { Shale (Cretaceous, Pierre) }\end{array}$ & $\begin{array}{r}80 \\
10 \\
100 \\
125 \\
160 \\
10 \\
10 \\
8 \\
6\end{array}$ & $\begin{array}{l}475 \\
405 \\
495 \\
503 \\
509\end{array}$ \\
\hline
\end{tabular}

Only thicknesses of a few feet (or none at all) of the Grand Island sand and gravel, the Upland formation, or the Loveland and Peorian loesses are found south of the Republican River.

The fluviatile formations are exposed in and near the Platte River Valley and have significant relations to the nature and history of the river and its valley. In addition to this, these formations have direct genetic relations to the Nebraskan and Kansan glaciations in Nebraska. They are distributed over 15,000 to 20,000 square miles or more of the State and they occur under both the plains and the Platte River Valley, as shown in figure 7 and plate 2. 
Most geologists have regarded the Platte River as a classic example of an anastomosing or braided aggrading stream, with normal relations to the valley sides. The valley was believed to have been cut at first in bedrock in the normal way, and later, as the drainage area increased, to have been more or less filled with alluvium (at least in part during Pleistocene time). A few geologists have thought that the alluvium or valley fill of the Platte Valley, assumed to have accumulated in the manner stated above, rested in contact with fluvioglacial "sheets" or "channels" of gravel and sand that underlie the plains south of the Platte River. It is now evident that, as stated above, these formations extend under the Platte River Valley and under the plains both to the north and to the south, except, of course, that the upper formations may have been more or less thoroughly cut out by erosion during the excavation of the present valley. However, erosional unconformities occur above the Fullerton and above the Upland, and therefore these formations are absent in some outcrops and missing in some well logs. The Fullerton and in a few places the Upland beds can be traced from the valley back under the bluffs, indicating that these formations are continuous from the valley under the plains. The continuity of the Holdrege sand and gravel has also been established by detailed test drilling. The Grand Island formation of sand and gravel, into which the Platte River has cut rather deeply, can be traced from under the present flood plain and terraces, along continuous outcrops under the loess, along tributary drainage lines, and in deep road cuts in the valley sides. This is especially true of the upper fine sand of the Grand Island formation. The continuity and areal extent of these fluviatile formations, as shown in figure 5, have been established by the study of outcrops, of information from well drillers, and of many test drillings made for that purpose under the writer's direction.

The sand and gravel exposed along the Platte River contain the same kinds of vertebrate fossils, in the same state of preservation, as the fluvioglacial and fluviatile sand and gravel deposits under the loess plain between the Platte and Republican Rivers and elsewhere. These fossil bones, teeth, etc., from sand and gravel pits both in and outside of the Platte River Valley are regarded by paleontologists as early Pleistocene-that is, Kansan or older.

If the sand and gravel in the valley were alluvium and later than early Pleistocene, the early Pleistocene specimens would probably show some evidence of rehandling and wear beyond that of similar specimens from pits and other exposures elsewhere outside of the valley. Also, the later alluvium should contain recent fossils, which have not been found except where they are known to have been "intruded" froin the present surface. The early Pleistocene fossils bear evidence of having been deposited in place and having remained undisturbed, 
except of course very near the present surface. Recent alluvium of the Platte River is apparently limited to a few feet of reworked surface material.

Topographic evidence, from exposed sections along or in the bluffs of the Platte Valley, indicates that the Platte River Valley is of postLoveland but pre-Peorian age. The Loveland loess is always found in place in the bluffs, lying in the east on the eroded gumbotil at the top of the Kansas till and west of the till border on the eroded Upland formation. The Loveland, unlike the younger Peorian loess, nowhere mantles the eroded side slopes of the valley. It is also in place even where it is thicker than the depth of the valley itself, as south of Gothenburg, or where its base extends below the flood-plain level, as west of Kearney, and it is clearly older than the valley.

Peorian and later loess is widely distributed over the plains, resting on the eroded Loveland, and it also mantles the bluff slopes and occurs on the terraces and, in places, on the river flood plain itself. The Peorian and younger loess covers and obscures the eroded edges of the horizontal Loveland loess and the Kansan and Nebraskan tills in the east; west of the till margin it similarly obscures the Loveland and Upland formations and rests on the eroded upper part of the Grand Island formation. It has apparently been deposited since the erosion of the Platte River Valley.

The main cause of confusion in the correct understanding of the sand and gravel along the Platte River is the fact that these sheetlike layered fluviatile deposits are unconsolidated and look like alluvium, which in fact they were at the time and under the conditions existing when they were deposited. The lithology of the unconsolidated sand and gravel under the plain south of the Platte River, as south of Hastings, along Thompson Creek, and at scores of other places, is identical with that of the sand and gravel along the Platte River. However, the material was spread far and wide, probably by many streams draining from the mountains and High Plains, and a great alluvial plain was built up in front of the glaciers and terminal moraines of till. The deposits of all the southeastward-flowing streams first filled the valleys and then spread over the low divides and coalesced, eventually covering an area of many thousand square miles. (See fig. 5.) The finer-grained Fullerton and Upland formations were formed during interglacial stages, when there was less vigorous erosion and sedimentation and possibly more transportation by wind, in strong contrast with the vigorous sedimentation of the glacial stages with which the Holdrege and Grand Island formations are correlated. This rather long epoch of alluvial deposition of these fluviatile formations was followed by the eolian deposition of the Loveland loess. The erosion of the Platte River Valley took place next, and this valley cutting eventually reached the sheets of sand and gravel that now retard further down-cutting by the river. 
The Platte River has cut through the Loveland and Upland formations by being competent to carry such material away. It has also been competent to transport the fine sand that forms the upper part of the Grand Island formation. However, as the river continued to deepen its valley and cut farther down into the Grand Island formation, the material in general became coarser and more difficult to transport.

The Platte is now able to transport clay, silt, and fine sand but can only slightly rework the coarser material, which it has now reached in the process of valley cutting. It seems to have been an eroding stream until recently, and probably it was never in recent times an aggrading stream to any extent.

\section{HOLDREGE FORMATION}

The Holdrege formation consists of sand and gravel, generally coarse near the base and finer toward the top, quartz and other granitic and metamorphic crystalline minerals, and rock fragments. This material is thought to have been transported by rivers from the west and northwest. The formation contains some outwash material from the Nebraskan glacier near the margin of that ice sheet. It may therefore be described as an inwash-outwash fluvioglacial deposit, which was built up, during the Nebraskan stage, as an alluvial plain, mainly in south-central Nebraska. Part of the material was carried into the State by the Missouri-Niobrara drainage system and deposited in front of the Nebraskan glacier. Other streams from the west and northwest, principally the Pleistocene North Platte River, also contributed much material, largely reworked from the Tertiary formations of the High Plains. The Holdrege formation is considered to be equivalent to the Nebraskan till and the underlying sand and gravel of eastern Nebraska.

The Holdrege formation appears to be rather homogeneous as a whole but is intricate in its detailed make-up. It is a more or less continuous sheetlike alluvial-plain deposit, but it is interrupted by buried ridges and hills of bedrock. It is very irregular in thickness, as it was deposited on a somewhat uneven bedrock surface. Its thickness ranges from perhaps 120 feet or more down to the vanishing point and probably averages about 70 feet. It extends more or less continuously under an area of about 15,000 square miles, and contemporaneous valley deposits, which were feeders from the west and northwest, extend over a large additional area.

The formation is not known to crop out at any point along the Platte River Valley or elsewhere in south-central Nebraska. However, it may be exposed at some points along the Republican Valley and is exposed at several places in the Niobrara Valley. Because it is almost completely covered, it has not furnished many mammalian fossils. It 
is known almost entirely from well logs and was named for Holdrege, in Phelps County, near which it was found in the Trees deep-test well for oil and gas, a partial log of which is given below.

Log of Trees test boring, near middle of $S W 1 / 4$ sec. 23, T. 6 N., R. 19 W., 2 miles north and \& miles west from Holdrege

[Curb 2,345 feet above sea level]

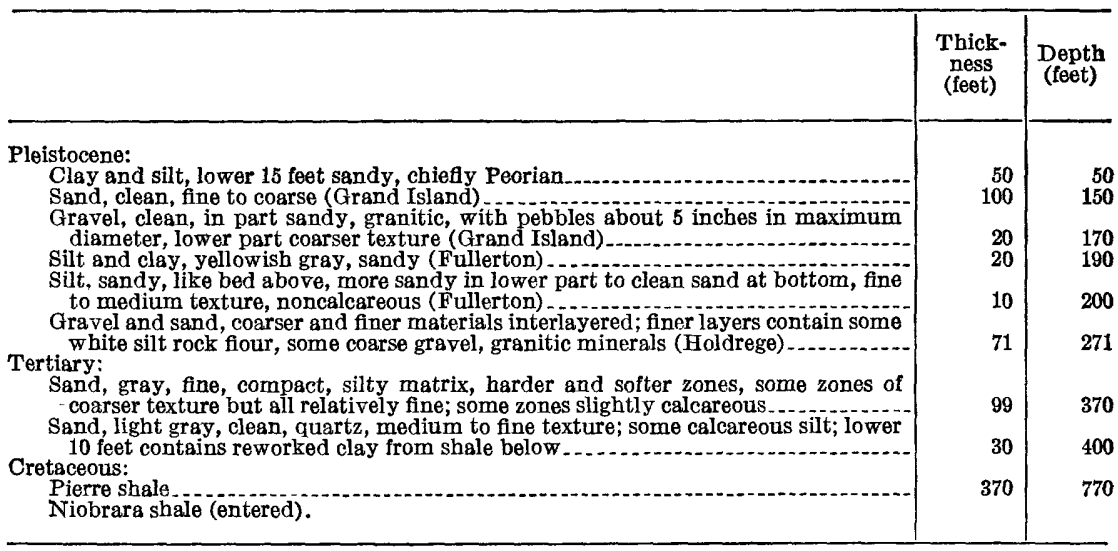

The beds recorded in this $\log$ are essentially duplicated under the city of Holdrege, except that the Holdrege formation is somewhat thinner. The Fullerton formation has not been reported by most drillers in the buried Holdrege basin, and so in many well logs the Grand Island sand and gravel seem to lie on Holdrege sand and gravel and no exact differentiation is possible. A typical log that illustrates these points is given below:

Log of well at Ragan, in northeastern Harlan County

\begin{tabular}{|c|c|c|}
\hline & $\begin{array}{l}\text { Thick } \\
\text { ness } \\
\text { (feet) }\end{array}$ & $\begin{array}{l}\text { Depth } \\
\text { (feet) }\end{array}$ \\
\hline $\begin{array}{l}\text { Clay; grades downward into sandy clay with thin streak of gravel at the bottom } \\
\text { (Peorian and Loveland) } \\
\text { Clay, gray to black, tough, sticky (Üpland?) }\end{array}$ & $\begin{array}{l}70 \\
15\end{array}$ & $\begin{array}{l}70 \\
85\end{array}$ \\
\hline $\begin{array}{l}\text { Upper } 140 \text { feet mostly fine sand, some clay; lower } 40 \text { feet coarse gravel; total thickness } \\
\text { unknown (Grand Island and Fullerton?) }\end{array}$ & & 265 \\
\hline
\end{tabular}

In the immediate vicinity of Hastings the depth to Niobrara shale is said to be from 240 to 260 feet. The Fullerton formation has been rather poorly differentiated between depths of 98 to 130 feet. It seems to have been nearly all removed by erosion prior to the Grand Island sedimentation. At least it has not been reported in many of the wells. 
Log of one of the Hastings city wells

[Surface altitude 1,937 feet; water level at a depth of 100 to 110 feet]

Soil and clay

Yellow clay (Peorian)

Sand, fine (probably upper part of Grand Island)

Sand, mostly fine but coarser downord, with

at the bottom (Grand Island and probably Fullerton in the lower part)

Gravel and coarse sand, from pea size to $1 / 2$ inches (Holdrege?)

Two wells were sunk in 1929 by the Kelly Well Co., of Grand Island, near Kearney. The log of one of these wells is as follows:

Log of well near Kearney

\begin{tabular}{|c|c|c|}
\hline & $\begin{array}{c}\text { Thick- } \\
\text { ness } \\
\text { (feet) }\end{array}$ & $\begin{array}{l}\text { Depth } \\
\text { (feet) }\end{array}$ \\
\hline $\begin{array}{l}\text { Clay (soil and Peorian) } \\
\text { Red-brown clay (Loveland) } \\
\text { Sand and clay (probably Loveland) } \\
\text { Clay, yellowish, hard (Upland?) } \\
\text { Sand, yellow and fine, } 4 \text { feet (Grand Island) } \\
\text { Sand, coarse, } 21 \text { feet (Grand Island) } \\
\text { Sand, coarse, and clay balls (Fullerton) } \\
\text { Sand and gravel, coarse to fine sand; some thin silt and clay partings near the middie } \\
\text { (Holdrege) }\end{array}$ & $\begin{array}{r}17 \\
7 \\
32 \\
17 \\
25 \\
11 \\
71\end{array}$ & $\begin{array}{r}17 \\
24 \\
56 \\
73 \\
- \\
-98 \\
109\end{array}$ \\
\hline
\end{tabular}

Darton ${ }^{21}$ reported a log of a deep test for oil and gas at Hastings, which gives "alluvial soil and clay" 100 feet thick, an upper "gravel and sand, full of water", 60 feet thick, and a lower "gravel and sand, full of water", 60 feet thick. The two layers of sand and gravel are said to be separated by a 4-foot bed of "clay with boulders; very hard." Pierre shale was encountered below the lower sand and gravel. The 4-foot clay bed is probably the Fullerton.

Clay Center, in Clay County, is near the northeast side of the buried Hastings basin, but it is underlain by a fairly complete section. A composite section from several wells and test holes in and near Clay Center is given below:

\section{Pleistocene deposits near Clay Center}

Yellowish clay (Peorian)

Clay and quicksand (Loveland and in part may be Grand

Island)

Sand and gravel (Grand Island)

Clay, yellowish and bluish (Fullerton)

Sand and gravel, in part "rice" gravel, coarser toward

bottom (Holdrege) .... _. . . . $40-60$

21 Darton, N. H., Underground waters of a portion of southeastern Nebraska: Geol. Survey WaterSupply Paper 12, p. 38, 1898. 


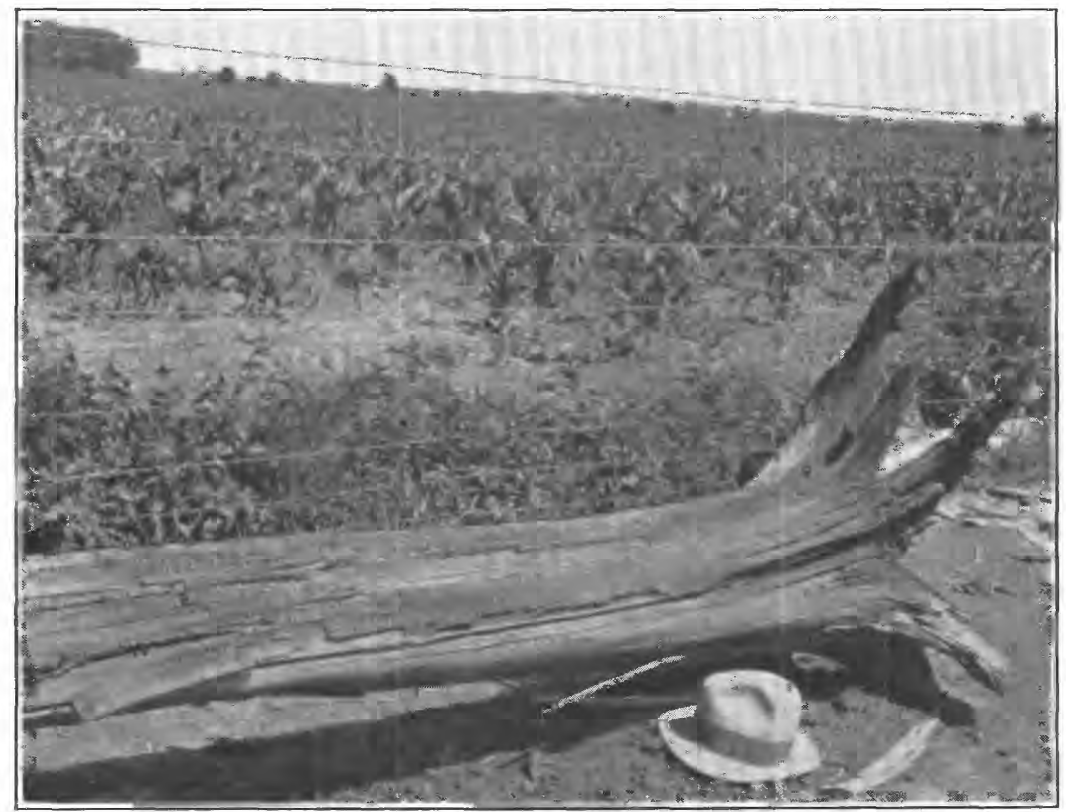

A. FOSSIL RED CEDAR TREE FROM GRAVEL PIT AT CENTRAL CITY, NEBR.

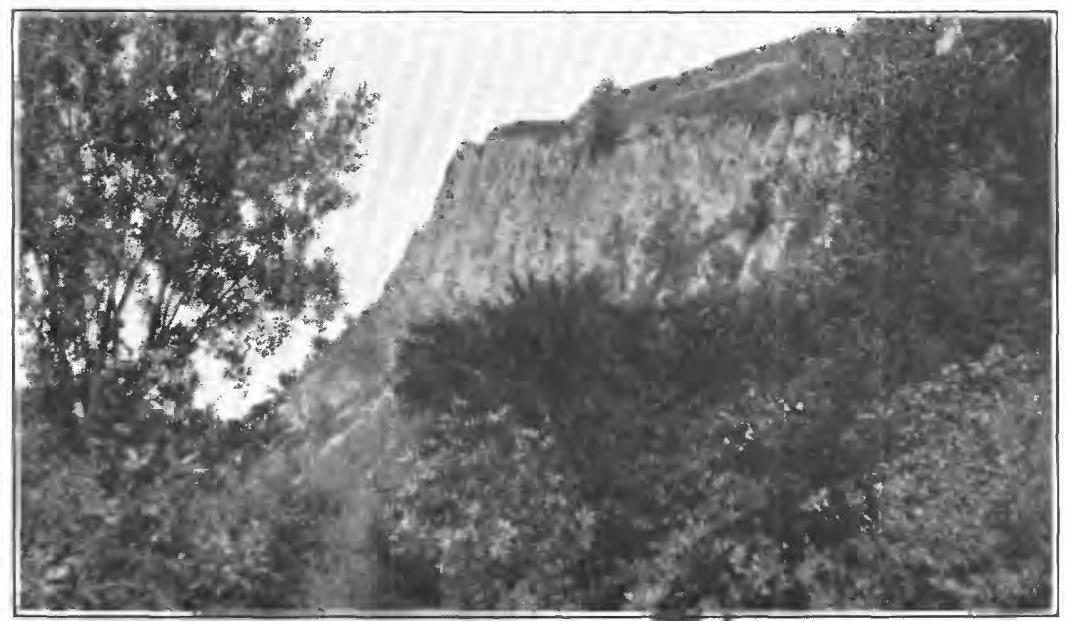

B. LOVERS LEAP, WEST OF FULLERTON, NEBR.

Photographs by A. L. Lugn. 



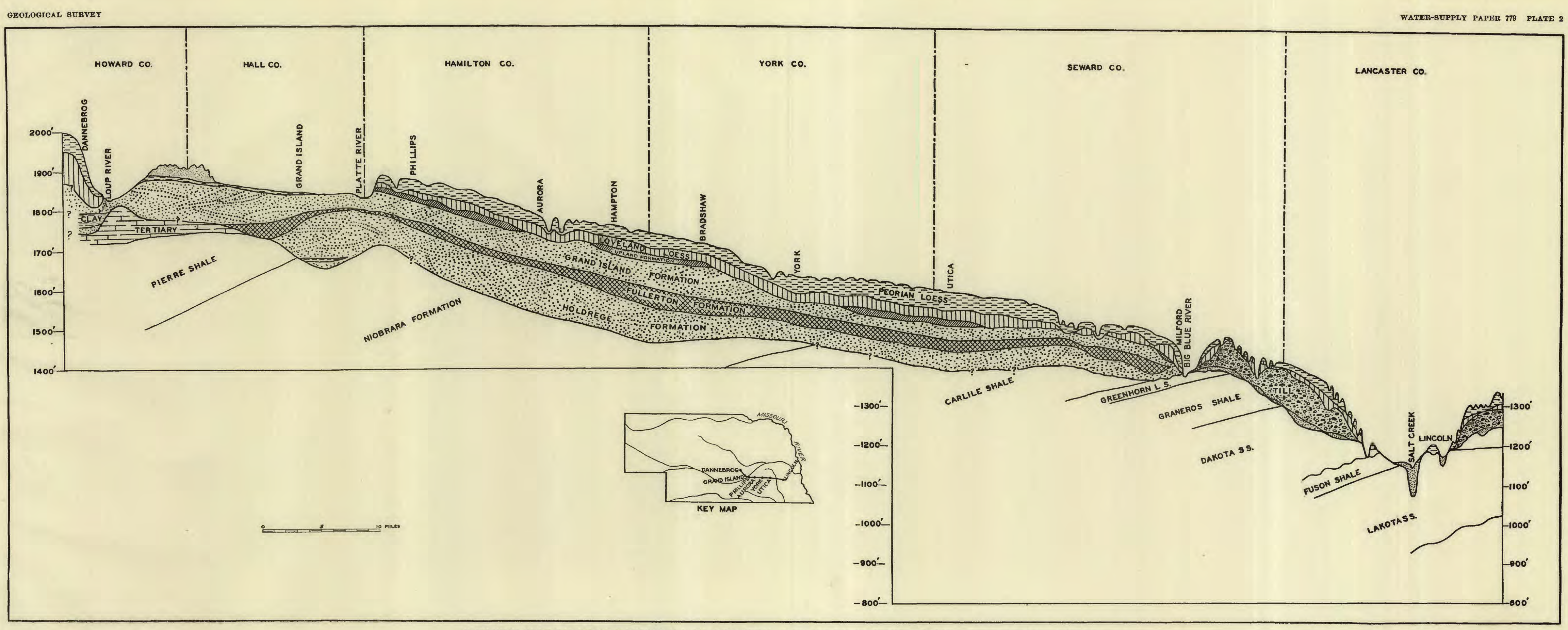

GEOLOGIC SECTION FROM DANNEBROG, IN SOUTHERN HOWARD COUNTY, TO LINCOLN, IN LANCASTER COUNTY. 
The lower gravel may be thicker than 60 feet, but the section is known only to depths of 165 to 180 feet. Water stands at depths of 60 to 70 feet, and the surface altitude is 1,760 to 1,780 feet above sea level.

The town of Blue Hill, in northern Webster County, is near the southwest side of the Hastings basin. Shale of the Niobrara formation has been encountered in the southern part of the town at a depth of less than 100 feet, with little or no water-bearing gravel or sand between the loess and the shale. The following is a $\log$ of a well 196 feet deep drilled at the north edge of the town:

Log of well at Blue Hill, Webster County

\begin{tabular}{l|r|r}
\hline & $\begin{array}{r}\text { Thickness } \\
\text { (feet) }\end{array}$ & \multicolumn{1}{c}{$\begin{array}{c}\text { Depth } \\
\text { (feet) }\end{array}$} \\
\hline Soil and clay (Peorian, Loveland, Upland) & 100 & 100 \\
Sand and gravel, water-bearing (Grand Island) & 12 \\
Clay, silty, some fine sand (Fullerton) & 112 \\
Gravel, coarse, some sand (Holdrege) & 172 \\
Shale. & 24 & 196 \\
\hline
\end{tabular}

The town of Carleton, in northern Thayer County, stands over a buried outlet valley which has determined the trend of the present Little Blue River. This valley is filled with materials of the fluviatile formations, which appear to be connected with the deposits in both the Hastings and Aurora buried basins. Peorian loess, Loveland loess, and 15 to 20 feet of the upper part of the Grand Island formation crop out at numerous places in the Little Blue River Valley near Carleton.

Log of well at Carleton, Thayer County

\begin{tabular}{l|r|r}
\hline & $\begin{array}{c}\text { Thiek- } \\
\text { ness } \\
\text { (feet) }\end{array}$ & $\begin{array}{l}\text { Depth } \\
\text { (feet) }\end{array}$ \\
\hline Soil and clay, Peorian & 30 & 30 \\
bearing gravel, upper 9 feet fine to medium texture, lower 15 feet coarse and water- & 24 & 54 \\
bean (Fullerton) \\
Sand and gravel, upper 8 feet fine to medium sand, lower part coarse (Holdrege)
\end{tabular}

The drill did not go entirely through the lower sand and gravel, so it may be much thicker. It is known to be at least 42 feet thick at Davenport, about 7 miles west of Carleton.

The Holdrege formation is more distinctly separated from the Grand Island formation by Fullerton clay in the buried Aurora basin than it is anywhere else, so far as known. (See fig. 7.) The separating. Fullerton formation has been more generally recognized in this area than elsewhere, probably because it is here a purer, harder, and 
darker clay. This may be in part due to the proximity of the Nebraskan till exposed during the deposition of the Fullerton formation.

Log of one of the city wells in Aurora, Hamilton County

[Surface altitude 1,782 feet; water level at depth of 54 feet]

\begin{tabular}{|c|c|c|}
\hline & $\begin{array}{c}\text { Thick- } \\
\text { ness } \\
\text { (feet) }\end{array}$ & $\begin{array}{c}\text { Depth } \\
\text { (feet) }\end{array}$ \\
\hline $\begin{array}{l}\text { Soil, black. } \\
\text { Clay, yellow (Peorian) } \\
\text { Clay, brownish to reddish (Loveland) } \\
\text { Clay and fine sand (Loveland; may be Grand Island in part) } \\
\text { Sand, white (Grand Island) } \\
\text { Gravel and fine sand (Grand Island) } \\
\text { Sand and gravel, fine to coarse (Grand Island) } \\
\text { Clay, bluish and tough (Fullerton) } \\
\text { Gravel and sand (Holdrege) }\end{array}$ & $\begin{array}{l}4 \\
17 \\
10 \\
14 \\
17 \\
10 \\
41 \\
18 \\
44\end{array}$ & $\begin{array}{r}4 \\
21 \\
31 \\
45 \\
62 \\
72 \\
113 \\
131 \\
175\end{array}$ \\
\hline
\end{tabular}

The lower gravel is known to be as much as 119 feet thick, and the bedrock has been encountered at a depth of about 250 feet.

The town well at Phillips, about 11 miles west of Aurora, penetrated a similar section, but the Grand Island and Holdrege formations were both found to be much thinner than shown above. Impervious clay or hardpan (Fullerton) 15 to 20 . feet thick was noted by the driller. The Holdrege and Fullerton and the lower part of the Grand Island underlie the tableland at and near Phillips and extend thence continuously under the Platte River southeast of Grand Island. (See figs. 6 and 7.) At York, east of Aurora, the town water supply is obtained from an upper and a lower bed of sand and gravel, separated by a clay bed (Fullerton).

West of the Big Blue River at Seward, just west of the till border, the Holdrege sand and gravel are reported to be 55 feet thick, the Fullerton bed of clean bluish clay is 15 feet thick, and the Grand Island sand and gravel are 20 feet or more thick. The overlying loess material is 40 feet thick.

A test well for oil and gas, drilled near Polk, in Polk County, in the NE 14 sec. 32 , T. 13 N., R. 4 W., penetrated the following beds:

Log of well near Polk

\begin{tabular}{|c|c|c|}
\hline & $\begin{array}{c}\text { Thick- } \\
\text { ness } \\
\text { (feet) }\end{array}$ & $\underset{\text { (feet) }}{\text { Depth }}$ \\
\hline $\begin{array}{l}\text { Loess, clay; some very fine sand with clay in lower part (includes Loveland and Up- } \\
\text { land formations) } \\
\text { fand, mostly fine (Grand Island) } \\
\text { Clay, with some very fine sand (Fullerton) } \\
\text { Sand, fine (Holdrege) } \\
\text { Bedrock shale. }\end{array}$ & $\begin{array}{r}66 \\
80 \\
50 \\
75 \\
829\end{array}$ & $\begin{array}{r}66 \\
146 \\
196 \\
271 \\
1,100\end{array}$ \\
\hline
\end{tabular}


The artesian water in the Beaver Crossing area, in southwestern Seward County, is believed to come from the Holdrege formation, the lower water-bearing sand and gravel, which here lie on impervious Cretaceous shale (Carlile). C. A. Aldrich, well driller at Fullerton, drilled a number of artesian wells in the Beaver Crossing area about 1900. He became very much interested in the lower gravel and the overlying clay of the Fullerton formation. Later Mr. Aldrich had opportunity to drill many wells in the Aurora basin area and fully satisfied himself that the lower gravel and the confining Fullerton bed were continuous formations, and that he had succeeded in tracing these formations as well as the overlying "upper water sand" throughout the basin to and across the Platte Valley between Silver Creek and Central City.

\section{FULLERTON FORMATION}

The Fullerton formation is described in the type section at Lovers Leap, near Fullerton (p. 31). It is a widespread and more or less continuous sheetlike deposit of dark calcareous silt and clay, in places rather sandy, which ranges in thickness from a knife edge to about 65 feet. The average thickness is between 20 and 35 feet. The discontinuity of the Fullerton formation is largely due to general erosion after its deposition. It extends over about the same area as the Holdrege formation and is known to be exposed at the surface only in the northern part of the State and at Fullerton. (See pl. 1, $B$, and fig. 6.)

The Fullerton formation is thought to have been formed during the Aftonian interglacial stage, when sedimentation was limited to fine material. It may be in part an old loess with some eolian sand. It separates the Holdrege gravel and sand from the upper or Grand Island gravel and sand. It evidently represents a time when the competency of the streams carrying sediments from the west and northwest was low, in contrast to the competency required for the transportation of the material of the Holdrege and Grand Island formations. It may represent a quiescent time between the two glaciations, when gumbotil was slowly forming at the top of the Nebraskan till plain, to the east. It is apparently conformable on the Holdrege formation but is unconformable under the Grand Island formation.

The greatest thicknesses of this formation occur at points near which exposures of bedrock shale or of glacial boulder clay were important local sources of material during the accumulation of the formation and where conditions may otherwise have been favorable for the accumulation of great thicknesses of this material. This is the case at many points in the Aurora basin, as at Polk, in Polk County (see p. 42), and in eastern Fillmore County. (See also log of Chapman test for oil, p. 69.) 
The Fullerton formation is known to have buried peat beds and trees on its upper surface at some places. Several red-cedar trees and other logs were found in a deep gravel pit a short distance east of Central City (pl. 1, A). Two red-cedar trees, one 23 feet tall and 3 feet 7 inches in circumference above the base, were found still standing vertically and rooted in Fullerton clay, only about 5 feet thick, and buried in more than 35 feet of the sand and gravel of the overlying Grand Island formation. The several deposits are believed to be in place, with only a thin mantle of recent reworked alluvium over the sand and gravel exposed in the pit. A test drilling established the sequence of the formations, and Holdrege gravel 25 feet thick was encountered below Fullerton clay. The gravel rests on the Niobrara. formation at a depth of 65 feet. A log of this test hole (35) is given on page 68 . In general, the wood of the fossil trees is well preserved but very hard when dry. The outer portions are usually deeply checked and blackened from decomposition. An elm log appeared to be slightly mineralized; at least there is some hard mineral matter in the wood to a depth of 2 or 3 inches from the outer surface.

Peat deposits have also been found on Fullerton clay in gravel pits northwest of Central City. At a place 3 miles north and $1 \frac{1 / 2}{2}$ miles east from Archer, in the SW1/4 sec. 3, T. 14 N., R. 7 W., a 10-foot bed of peat was encountered lying on the Fullerton formation under about 30 feet of the sand and gravel of the Grand Island formation. Fossil snail shells are said to have been collected from Fullerton clay in a well on a nearby farm, but they were not preserved for study.

The ball joint, a portion of the femur, and fragments of other bones. of mastodon or mammoth, highly mineralized, were collected from the gravel in which the trees described above were buried. The fragments had probably been broken in the gravel pump. Mammoth and mastodon teeth and bones are commonly found in the gravel pits in the Grand Island formation here and elsewhere in the Platte River Valley. The species have not been determined, but they are of the same general types as have been found in the sand and gravel pits near the Republican River, on the plain between the Platte and Republican Rivers, and in correlated deposits in the northern and northeastern parts of the State.

\section{GRAND ISLAND FORMATION}

The upper sheet of alluvial sand and gravel, the Grand Island formation, is believed to be similar in origin and mode of formation to the Holdrege. It is the inwash-outwash equivalent of the Kansan till and the early Kansan or late Aftonian intertill sand and gravel of eastern Nebraska. It has a maximum thickness of perhaps 150 feet and averages about 75 feet. The upper 30 to 50 feet is usually fine sand that may have been deposited in part by the wind. The 
lower part of the formation contains coarser sand and gravel and is clearly a stream deposit.

The Grand Island formation has about the same areal distribution as the Holdrege but is more continuous. It extends apparently unbrokenly under the plains of southern Nebraska to the Platte River Valley, and the lower part of the formation apparently extends under the valley. The formation is exposed along the Platte River Valley, the Republican River Valley, and other valleys and in scores of gravel pits. (See fig. 5.) It crops out in the bluff of the Platte Valley and in tributary valleys and gullies on the south side almost continuously from the city of Grand Island to Columbus. West of Grand Island it is more or less obscured by the Peorian loess, but on the south side of the valley from a point south of Shelton, west to a point south of Elm Creek, the outcrop belt of the Grand Island formation is wide, and the fine sand of the upper 20 to 40 feet of the formation has been reworked by Recent wind action into sand hills or small dunes. These Recent dunes cover an area of about 90 square miles and form a conspicuous feature of the landscape. (See fig. 2.) Likewise, the sand of the conspicuous sand hills between the Platte River and the Loup River in Hall, Howard, Merrick, Nance, and Platte Counties (see fig. 2) has largely been derived from the upper part of the Grand Island formation.

There is another small area of sand hills in the Platte River Valley along the south bluff and northeast of Osceola in Polk County. From 50 to 60 feet of the Grand Island formation, here mostly fine sand, is more or less continuously exposed under the clay and loess formations in the bluff down to the present flood plain of the river. The small dunes are on the outcrop area of the Grand Island formation, and the relationship of the dunes to the sand in place is more evident here than at any other point.

The Grand Island formation is described in sections recorded in preceding parts of this report. The type section for the formation is in the Platte River bluff east of the Hamilton Bridge, southeast of Grand Island. This formation, like the underlying Fullerton and Holdrege formations, extends continuously from the valley eastward and southward under the loess plains. A composite section for the vicinity southeast of Grand Island is given below. The upper part is exposed in the bluff along the east-west highway east of the Hamilton Bridge, and the lower part is taken from logs of test wells in the valley. (See fig. 6.) 


\section{Pleistocene deposits southeast of Grand Island}

Loess, yellow silty clay (Peorian)

Feet

Red loess clay and sandy clay, with old soil at the top in some places (Loveland) ..............................

A few inches of dark soil at the top; otherwise gray or grayish-green sandy clay, bentonitic, lower part sandier; contains an abundance of small fossil gastropods (Upland).

Fine sand, buff to pinkish gray; lower 10 feet contains some scattered pebbles (Grand Island)

Nore.-This point is at the flood-plain level. The remainder of the log is from test wells.

Sand, buff, fine and coarse, with some gravel (Grand Island)

Sand and gravel, gray, coarse; many pebbles half an inch in diameter (Grand Island)

Sand and gravel, coarse and fine; some clay balls of pebble size (Grand Island) .............................

Sand, coarse to fine, and a little gravel, coarser in lower pari (Grand Island)

Clay and quicksand; upper 3 feet very tough, gray (Fullerton)

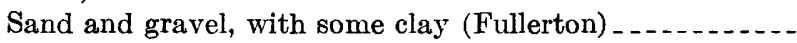

Clay and quicksand, gray and hard (Fullerton) ......... -

Sand and gravel, layered granitic material, contains palegreenish and light-buff grains, some fine sand, and rock flour, lower 14 feet somewhat finer (Holdrege) ..........

Sand, medium to fine (Holdrege) . . . . .

Gravel, coarse (Holdrege) ............

Clay and silt, fine, gray (Holdrege)

Gravel, very coarse, much coarse and medium clear quartz sand, bluish in bulk (Holdrege) .....................

Sand, buff gray, greenish grains and also much clear quartz, fine sand and silt (Holdrege) ..........................

Clay, greenish gray, with thin layers of sand and gravel; clay reworked Niobrara shale (Holdrege)

Gravel and sand, coarse, with some medium and fine sand and much clay reworked from the Niobrara shale (Holdrege)

Shale; upper 1 foot weathered yellowish brown, hard, and soft bluish-gray shale (Niobrara) ................

An exposure in the bluff in the NW/4 sec. $13, T$, 12 N., R. 7 W., about $3 \frac{1}{4}$ miles west and a quarter of a mile north from Marquette, is typical: 


\section{Pleistocene deposits west of Marquette, Hamilton County}

Loess (Peorian)

Feet

$20-40$

Soil, black to brownish (Loveland)

4

Red sandy clay (Loveland) . .

Grayish-green sandy clay (Upland) . .

Sand and gravel, fine yellowish and gray sand (somewhat reworked into very small dunes at the base of the bluff)

A section essentially the same as the type section at Grand Island has been studied in the bluff and in the valley southeast of Central City. The exposures are more or less covered, but the beds can be identified with ease. A composite section is as follows:

\section{Pleistocene deposits near and southeast of Central City}

Loess, yellowish-gray silt and clay (Peorian) _._.

Loess, 3 to 4 feet of dark soil at the top, red sandy clay

(Loveland) part sandy; upper 1 foot darker, suggestive of old soil

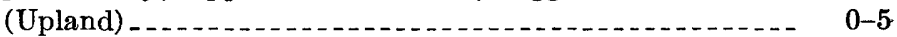

Sand, fine, yellowish gray, partly exposed (Grand Island) ... 30-40

Note.-The beds described above occur in the bluff; the data below are from test wells near Central City.

Sand and gravel, coarse and fine, layered; good water gravel below 4 feet of flood plain . .

Clay, bluish, soft, silty, sticky, carbonaceous with peat and logs in places (Fullerton) ....... 4-10

Sand and gravel ) Holdrege) ............ 20-25

Cretaceous shale at bottom (Niobrara).

A typical exposure of the Grand Island occurs in a sand and gravel pit about 8 miles south of Hastings, Adams County, along the east side of the highway in the SW $1 / 4$ sec. 24, T. 6 N., R. 10 W. (pl. $3, B$ ).

\section{Pleistocene deposits south of Hastings}

Sandy red loess clay (Loveland)
Clay, greenish gray; weathers to a buff-brown tint; uneven
contact with the Loveland above, but even contact with
the gravel below (Upland)
Sand and gravel, cross-bedded and stratified, coarse and fine;
this is the first water sand of the drillers of this part of the
State; water at the base of the exposure (Grand Island) -

The thickness of the Grand Island formation exposed in the Tanner pit, across the road to the west, ranges from 25 to 30 feet. There Grand Island gravel rests on a bluish-gray tough clay (Fullerton?) 
2 to 6 feet thick, and this clay bed is underlain by at least 15 feet of coarse sand and gravel (Holdrege?).

The Grand Island and overlying formations are typically exposed in the bluff and banks of the Little Blue River near the northwest corner of sec. 35, T. 6 N., R. $10 \mathrm{~W}$., on the grounds of the Knights of Pythias Golf Club, about 13: miles southwest of the pit described above. This section is almost identical with the sections, previously described, along the southeast bluff of the Platte Valley between Grand Island and Columbus. The Little Blue River Valley section is as follows:

Pleistocene deposits on the Little Blue River south of Hastings

Buff loess (Peorian)
Soil, dark brownish (Loveland)
Loess clay; lower half very sandy with some gravel; uneven
erosional contacts with both the Peorian and the Loveland.
Clay, typical, gray green; weathers yellowish; only erosional
remnants exposed here.
Sand and gravel, fine above with more gravel in the lower
part, the same as along the Platte Valley; a strong flow
of spring water is discharged from the formation in this
vicinity at the base of the section, the water level in the
Little Blue River (Grand Island)

There are many similar exposures along the Little Blue River and its tributaries in this part of the State. One exposure, about $8 \frac{1}{4}$ miles west of Fairfield, in the NE $1 / 4$ sec. 6 , T. 5 N., R. 8 W., in southern Clay County, shows 3 to 12 feet of Loveland, 1 to $6 \frac{1}{2}$ feet of Upland clay, and 2 feet of black gravelly, sandy, "mucky" soil (?) on the Grand Island sand and gravel. This is the only place so far known in Nebraska where anything like an old soil or swamp muck occurs between the Grand Island and Upland formations.

There is a good exposure about 1 mile north of Cowles, Webster County, where 15 to 20 feet of Peorian loess rests unconformably on 28 feet of Loveland loess clay. The upper 3 feet is an old black Loveland soil. From 27 to 30 feet of typical Grand Island sand and gravel is exposed in the bank under the Loveland and above the water level in EIm Creek. The lower contact of the Loveland is uneven on the Grand Island, with the Upland formation absent. The Upland is usually not present in exposures near the Republican River, as it appears to have been removed by erosion prior to Loveland time.

A large exposure at the Thompson gravel pit, just south of Cowles (pl. 3, $A$ ), supplements the exposure described above. Here the Peorian loess is as much as 10 feet thick, and the Loveland about 14 feet thick, over about 65 feet of sand and gravel, exposed above the water level. The gravel contains well-worn and rounded pebbles 2 


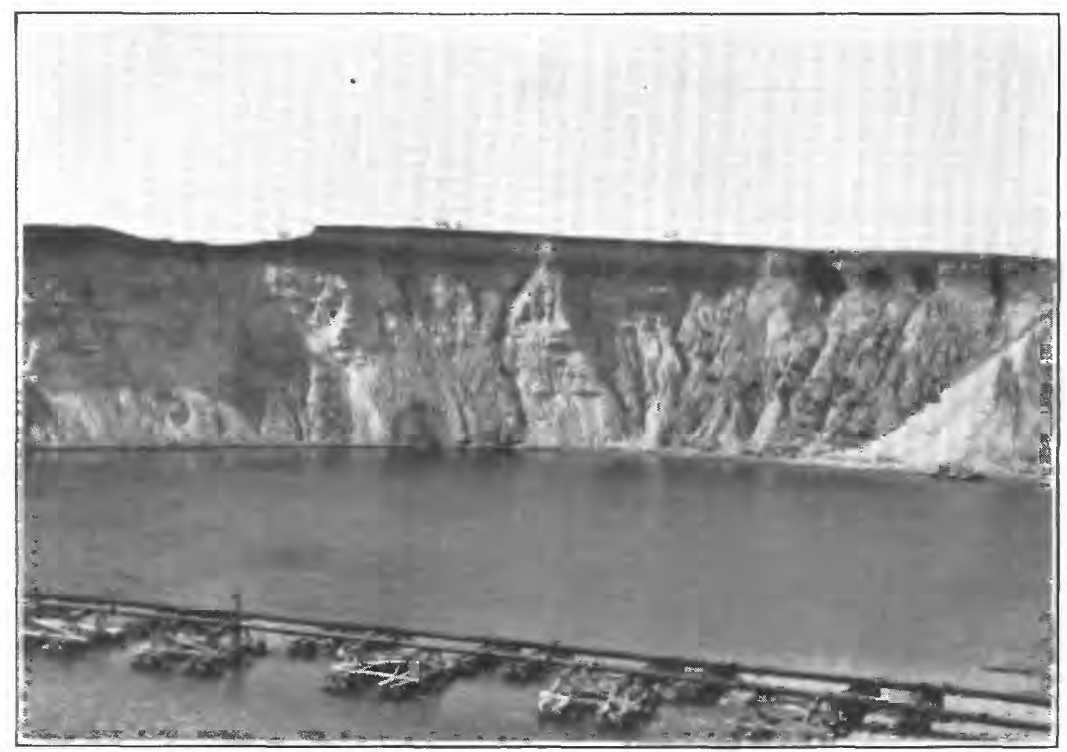

A. THOMPSON SAND AND GRAVEL PIT, COWLES, NEBR.

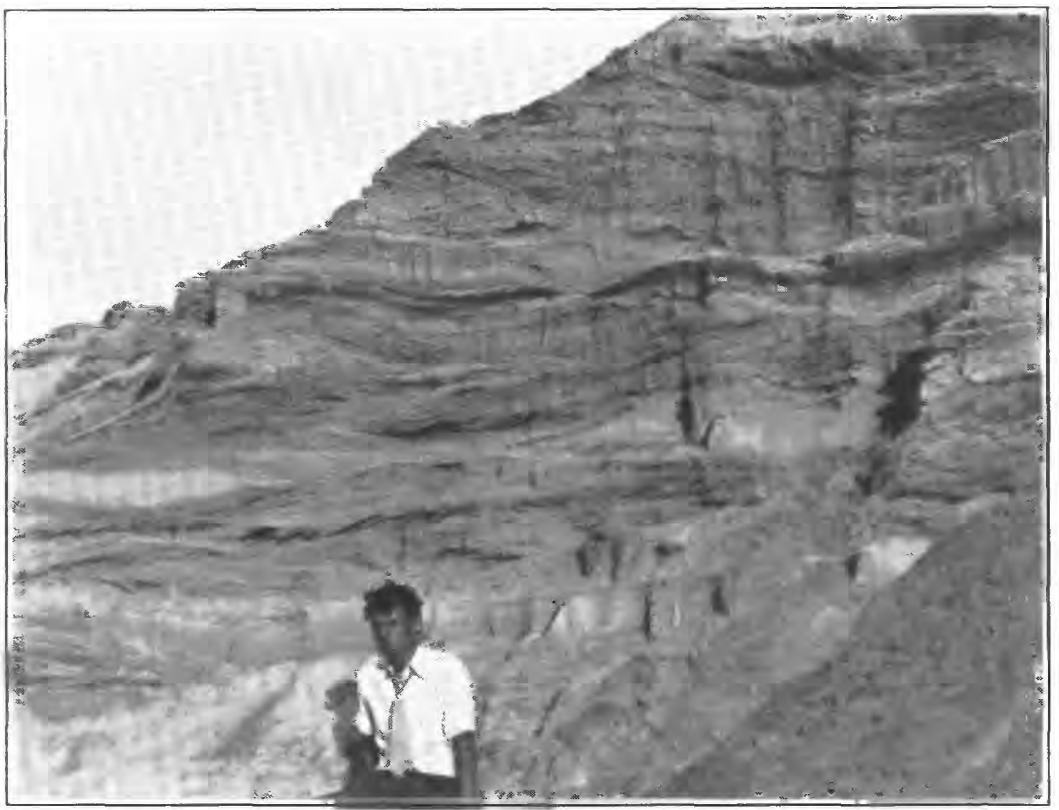

B. SAND AND GRAVEL OF THE GRAND ISLAND FORMATION EXPOSED IN GRAVEL PIT SOUTH OF HASTINGS, NEBR.

Photographs by A. L. Lugn. 


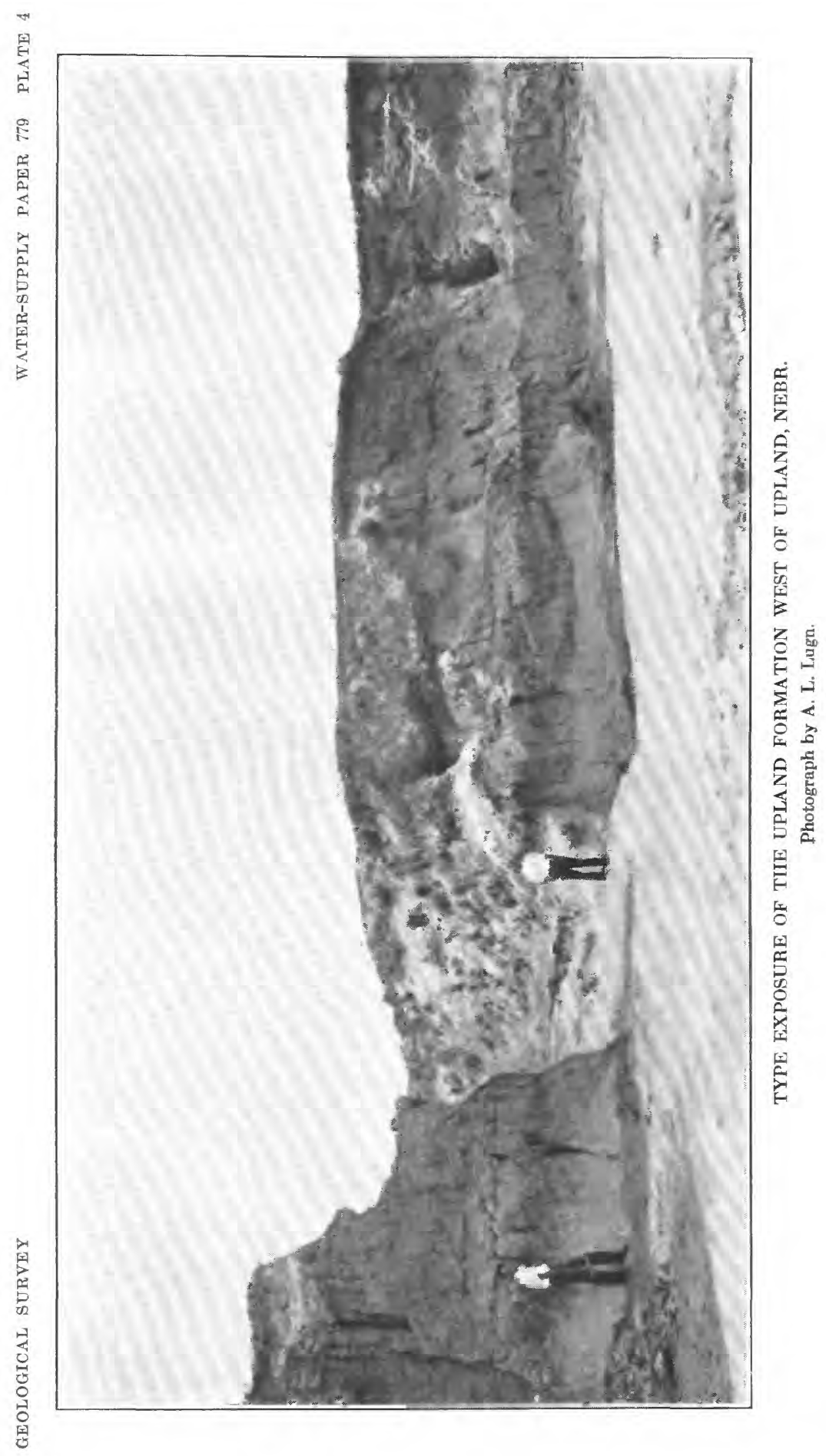




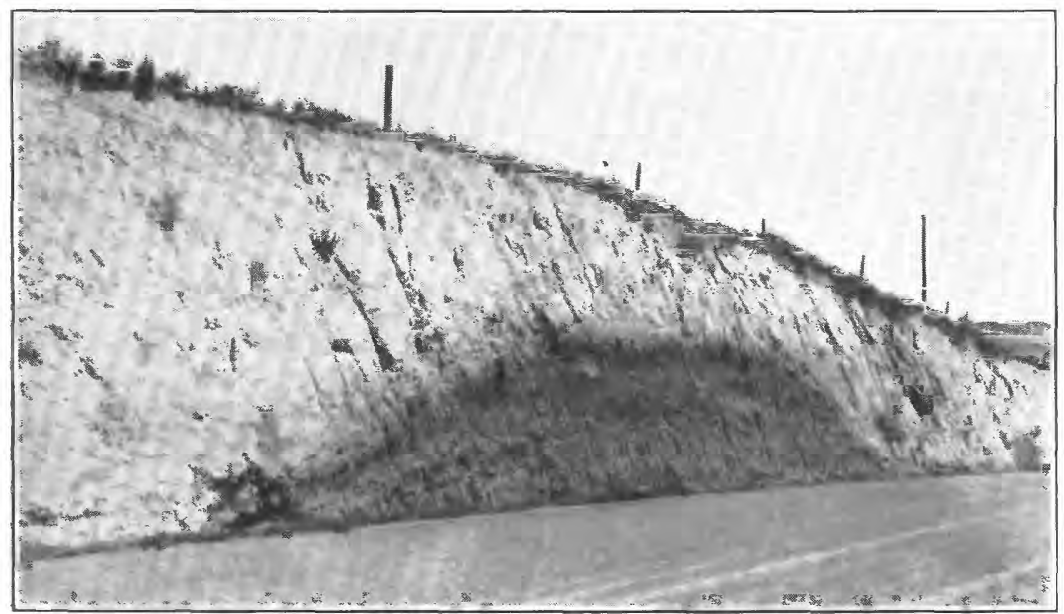

A. LOVELAND AND PEORIAN LOESS EAST OF GREELY, NEBR.

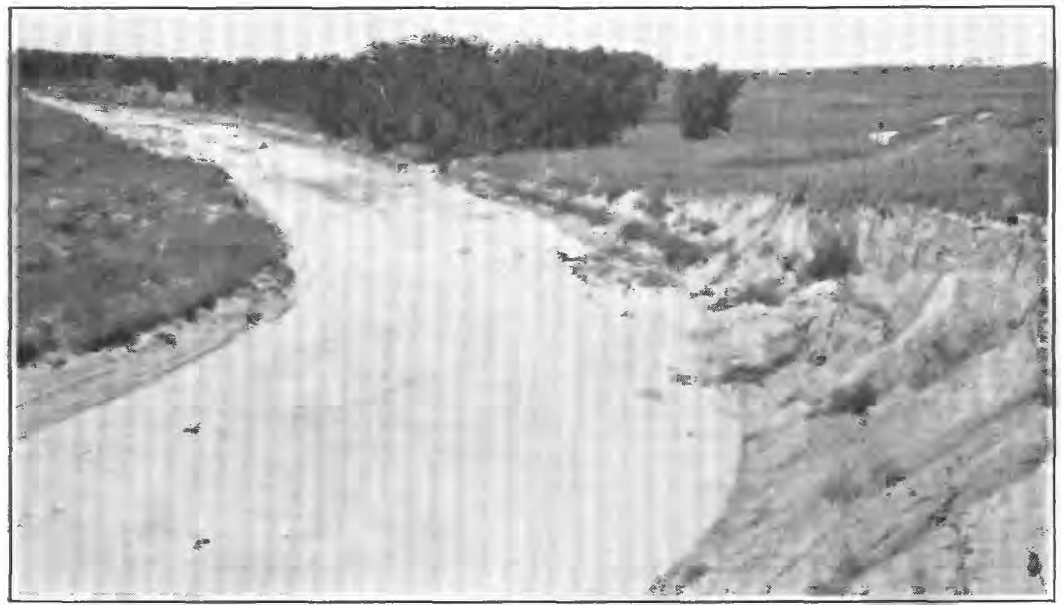

B. SAND AND GRAVEL EXPOSED IN THE DRY BED OF THOMPSON CREEK. Photographs by A. L. Lugn. 

to 3 inches in diameter and clay balls 4 to 5 inches in diameter. The gravel and sand are known to extend down to at least 55 feet below the water level in the pit, making a total thickness of 120 feet of sand and gravel, and at this depth bedrock had not been reached. No Fullerton has so far been noted here, and that formation, like the Upland, seems to be absent near the Republican Valley.

A gravel pit about 7 miles north and 2 miles west from Riverton, in southeastern Franklin County, in the NE1/4 sec. 32, T. 3 N., R. $13 \mathrm{~W}$., has exposed thick sand and gravel, apparently of the Grand Island formation. A section is given below:

\section{Pleistocene deposits northwest of Riverton}

Loess occurs in the vicinity but none at the exposure (Peorian).

Red loess clay and sandy clay (Loveland)

Grayish-green sandy clay; has 6-inch ferruginous zone below at the contact with the sand and gravel (Upland) .........

Fine sand; grades downward into coarser materials (Grand Island)

Feet

\section{(1)} 8-10

Sand and gravel, coarse and fine; 35 feet exposed in the pit, but the thickness is known to be at least 65 feet from a well at the pit.

This locality is near the southeast end of the buried Holdrege basin and is in the line of major ground-water movement from the Platte River to the Republican River. (See fig. 5.) Nearer the Republican River in this part of the State, between Franklin and points as far east as Superior, in southern Nuckolls County, the sheetlike fluviatile sand and gravel formations break up into buried valley fills that descend into the Republican River Valley between narrow ridges of bedrock. These are the outlet valleys referred to on page 29 . Similar outlet valleys from the Holdrege basin occur west of Franklin to Medicine Creek near Cambridge, in northwestern Furnas County, but are mostly of less importance.

The upper 10 to 20 feet of the Grand Island formation crops out generally in many of the creek valleys in this part of the State, especially along the West Branch of Thompson Creek in Franklin County (pl. $5, B$ ). The exposed material is fine sand at most places and grades downward into coarser sand and gravel, as in outcrops along the Little Blue and Platte Rivers. A log of a well at Campbell, in northeastern Franklin County, is given below. It appears that the bedrock here is relatively high, and the Grand Island sand and gravel seem to rest directly on the Pierre shale. The well is in the valley of the Little Blue River at 1,997 feet above sea level, and the water level is at a depth of 70 feet. 


\begin{tabular}{|c|c|c|}
\hline & $\begin{array}{c}\text { Thick- } \\
\text { ness } \\
\text { (foet) }\end{array}$ & $\begin{array}{c}\text { Depth } \\
\text { (feet) }\end{array}$ \\
\hline $\begin{array}{l}\text { Soll and dirt fll } \\
\text { Buff loess, in place (Peorian) } \\
\text { Clay, pinkish, with secondary calcareous concretions (Loveland) } \\
\text { Clay, grayish, hard, silty and sandy (Upland) } \\
\text { Sand, fine gray, much clay, some pebbles (Grand İsland) } \\
\text { Sand and gravel, medium coarse (Grand Island), } \\
\text { Sand and gravel, coarse with much "pea gravel", some pebbles } 1 \text { to } 2 \text { inches diameter } \\
\text { (Grand Island). }\end{array}$ & $\begin{array}{r}4 \\
47 \\
36 \\
25 \\
6 \\
6 \\
27\end{array}$ & $\begin{array}{r}4 \\
51 \\
87 \\
112 \\
118 \\
124\end{array}$ \\
\hline
\end{tabular}

A log of a well at Prosser, in northern Adams County, about 27 miles northeast of Campbell and about 3 miles southeast of the Platte Valley bluff, at the northwest end of the buried Hastings Basin, illustrates the fine texture of much of the Grand Island formation.

Log of well at Prosser, Adams County

\begin{tabular}{|c|c|c|}
\hline & $\begin{array}{c}\text { Thick- } \\
\text { ness (feet) }\end{array}$ & $\underset{\text { (feet) }}{\text { Depth }}$ \\
\hline $\begin{array}{l}\text { Loess clay, very silty and in part sand (Peorian) } \\
\text { Clay with black gumbo soil at the top; lower } 42 \text { feet very sandy clay (Loveland) } \\
\text { Clay, with coneretions (Upland?) } \\
\text { Sand, "quicksand" (Grand Island); this also crops out along the Platte River Valley and } \\
\text { at many other places } \\
\text { Gravel, pink to reddish (Grand Island) } \\
\text { Sand and gravel (Grand Island) }\end{array}$ & $\begin{array}{r}30 \\
60 \\
3 \\
40 \\
6 \\
6 \\
24\end{array}$ & $\begin{array}{r}30 \\
90 \\
93 \\
133 \\
139 \\
163\end{array}$ \\
\hline
\end{tabular}

Test wells farther north and also in the Platte River Valley indicate that the Fullerton formation, about 20 to 30 feet thick, probably lies below the lowest gravel of the Prosser log, also that the Holdrege formation, probably about 30 to 35 feet thick, is below the Fullerton.

The logs of two test wells are given below. They are located over the buried Holdrege basin, and the upper parts of these logs are very similar to the log at Prosser, just given. However, the lower formations, Fullerton and Holdrege, do not seem to be present. This is in contrast with the log of the Trees deep test for oil and gas (p. 39), which is only a few miles to the west. The Tertiary in the wells reported below was encountered at nearly the same depth (180 to 190 feet) as the Fullerton (170 feet) in the Trees test. These logs appear accurate, and all the materials were examined by the writer. These facts indicate a relief on the buried Tertiary surface of about 100 feet in a distance of only about 10 or 12 miles. The first location is 3 miles west and 2 miles south from Axtell, in western Kearney County, in sec. 31 , T. 6 N., R. 16 W., where the surface altitude is about 2,250 feet. 


\begin{tabular}{|c|c|c|}
\hline & $\begin{array}{c}\text { Thick- } \\
\text { ness (feet) }\end{array}$ & $\underset{\text { (feet) }}{\text { Depth }}$ \\
\hline $\begin{array}{l}\text { Loess, buff clay (Peorian) } \\
\text { Sand, fine and dry, some clay (Loveland and Upland? formations) } \\
\text { Sand, fine, brownish, some hard clay (Upland?) } \\
\text { Sand and gravel, mostly sand (Grand Island). } \\
\text { Sand and gravel; grades downward into coarse gravel (Grand Island) } \\
\text { Fine sand and calcareous grit, whitish and "mortarlike" (Tertiary) } \\
\text { Cretaceous shale, weathered (Pierre). }\end{array}$ & $\begin{array}{l}21 \\
63 \\
32 \\
11 \\
63 \\
90\end{array}$ & $\begin{array}{r}21 \\
84 \\
116 \\
127 \\
190 \\
280\end{array}$ \\
\hline
\end{tabular}

The second location is 1 mile east of Sacramento, in southeastern Phelps County, in the northeast corner of sec. 17, T. 5 N., R. 17 W., where the surface altitude is 2,268 feet.

Log of well east of Sacramento

\begin{tabular}{|c|c|c|}
\hline & $\begin{array}{c}\text { Thick- } \\
\text { ness } \\
\text { (feet) }\end{array}$ & $\underset{\text { (feet) }}{\text { Depth }}$ \\
\hline $\begin{array}{l}\text { Loess, buff clay (Peorian) } \\
\text { Clay, reddish, silty (Loveland) } \\
\text { Sand and clay, reddish; some coarse sand near bottom (Loveland) } \\
\text { Clay with much silt and some fine sand, greenish gray (Upland) } \\
\text { Sand, dark gray, fine and silty (Grand Island) } \\
\text { Gravel and sand, coarse to fine, buff pinkish (Grand Island) } \\
\text { Gravel and sand, like bed above but contains white calcareous "gritty" material re- } \\
\text { worked from the Tertiary below (Grand Island) } \\
\text { Grit, Tertiary; fine sand cemented with calcium carbonate. }\end{array}$ & $\begin{array}{l}20 \\
40 \\
20 \\
18 \\
22 \\
50 \\
10 \\
40\end{array}$ & $\begin{array}{r}20 \\
60 \\
80 \\
88 \\
110 \\
160\end{array}$ \\
\hline
\end{tabular}

The west or southwest limit of the buried Holdrege basin would apparently be marked by a straight line extending from the vicinity of Cambridge, in the Republican Valley, to the North Platte River, in the Platte Valley. The fine sand of the Grand Island formation lies in contact with the Tertiary bedrock by overlap along the southwest side of the basin, and the overlying loesses, principally the Loveland and Peorian, increase greatly in thickness in this part of the State and westward for some distance, where the Tertiary formations crop out high enough to form hard high plains and tablelands.

The fine sand of the upper part of the Grand Island formation and of the Upland formation also extends eastward over the edge of the Kansan till. The continuity of the lower part of the Grand Island formation with the intertill deposits (early Kansan or Aftonian) of the glaciated area is described on pages 23-24.

The Grand Island formation is probably the thickest and the most widespread of all the fluviatile formations. Because it crops out at so many places, it is the best known, has yielded the most vertebrate fossils, and has furnished the greatest amount of sand and gravel for road building and construction.

\section{UPLAND FORMATION}

The Upland formation consists of greenish-gray clay and fine greenish sand. It is believed to have had about the same mode of origin as the Fullerton formation. It was deposited during the 
quiescent interglacial stage that followed the Kansan glaciation. The Upland formation is believed to be of Yarmouth age and contemporaneous with the weathering of the upper part of the Kansan till into gumbotil. It ranges in thickness from a knife edge to probably 35 feet but is generally not thicker than 5 to 12 feet. It is rather widely distributed throughout southern and southeastern Nebraska, west of the till border. The Upland seems to be conformable on the Grand Island sand and gravel, but it was greatly eroded prior to Loveland time. It is discontinuous and more or less patchy as a result of this late Yarmouth or later pre-Loveland erosion. There are many outcrops of this formation, but superficial weathering in 2 or 3 years changes its characteristic greenish-gray color to buffyellowish. In this way it quickly becomes indistinguishable in roadside banks.

For example, an exposure of the Upland formation 4 miles north and $3 \frac{1}{2}$ miles west from Superior, in Nuckolls County, was fresh and greenish gray when first seen in 1930, but shortly afterward it had been weathered to grayish yellow. The Upland is very limy or calcareous, almost a marl or "limy grit", at a few places, as 6 miles west of Riverton, Franklin County. Here it contains knobby masses of very sandy calcareous concretions, almost exactly like similar bodies in certain parts of the Ogallala (late Tertiary) formation. This marly development is a result of weathering and ground-water action. Remnants of an old black soil 6 to 8 inches thick are found at the top of the bed in many outcrops, and the old soil, thin as it is, has been identified in test drillings.

The formation takes its name from one of its finest outcrops along the West Branch of Thompson Creek, about $2 \frac{1}{2}$ miles west of the town of Upland, in Franklin County. (See pl. 4.) The section is as follows:

\section{Pleistocene deposits west of Upland, Frankiin County}

Buff dense sand, with uneven contact on the Loveland (Peorian loess occurs between the Loveland and the dune sand in nearby outcrops)

Red, very sandy loess clay and silt (Loveland). Irregular erosional contact with the underlying Upland formation.......

Greenish silty sandy clay; 8-inch dark soil zone at top; below the soil $1 \frac{1 / 2}{2}$ feet of tough greenish-gray sandy clay; lower 3 feet more sandy but hard (Upland). Apparently conformable on sand below. Eastward ialong the exposure the formation becomes thicker and more uniformly compact, hard,

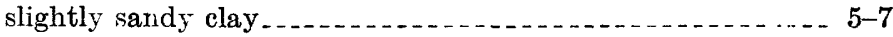

Fine to medium sand, clean, buff to gray, cross-bedded; few pebbles; only the top exposed (Grand Island) . . . . . . . 2-5

The Upland formation is described in several sections in foregoing parts of this report. It has been found in outcrops and wells in many 
places on the plain between the Platte and Republican Rivers in the area under investigation, in an almost equally large area extending eastward to the till border, and in the loess-hill area north of the Platte River and west of the till margin. It has also been observed to lie on probable Tertiary materials in the loess-hill area, west of the buried Hastings Basin, and south of the Republican River in Furnas County.

The clay of this formation contains an abundance of small gastropod shells in some places, but it is not everywhere fossiliferous. One of the best fossiliferous outcrops is east of Hamilton Bridge, near Grand Island. Apparently the fossiliferous outcrops represent the locations of perennial fresh-water ponds or lakes in which the material accumulated. The clay is very fossiliferous in an area north of the Loup River, north and northeast of St. Paul, in Howard County. At a point about $6 \frac{1}{2}$ miles north of St. Paul, on the main highway, the Loveland lies unconformably on 3 to 5 feet of typical greenishgray sandy clay of the Upland formation, which grades downward into gray and greenish-yellow fine sand, probably the upper part of the Grand Island formation. The clay contains an abundance of fossil gastropods like those at Grand Island, with a few additional species.

POST-YARMOUTH FORMATIONS, CHIEFLY WIND-BLOWN SAND AND LOESS

The earlier Pleistocene formations that are described in the preceding pages are chiefly of fluviatile origin, whereas the later Pleistocene formations consist chiefly of wind-blown sand and loess. These eolian deposits extend over more than 62,000 square miles in Nebraska and attain great thicknesses in much of the area. They are separated from the fluviatile formations by a great and widespread unconformity.

\section{LOVELAND LOESS}

The Loveland loess consists of two fairly distinct but intergrading phases. The lower and older part, constituting the so-called valley phase, consists chiefly of poorly sorted sand and gravel with much clay and some volcanic ash. The overlying upland phase consists more largely of wind-blown loess.

The first recognition of the Loveland loess as a distinct material, different from the overlying Peorian loess, was reported by Aughey ${ }^{22}$ in 1880. Udden ${ }^{23}$ also recognized the Loveland as a distinct material and referred to it as "gumbo or red clay." Shimek ${ }^{24}$ described the formation in detail and applied the name "Loveland" in 1909. He said:

22 Aughey, Samuel, Physical geography and geology of Nebraska, pp. 260-263, Omaha, 1880.

${ }_{23}$ Udden, J. A., Geology of Pottawattomie County: Iowa Geol. Survey, vol. 11, pp. 255-258, 1901.

.24 Shimek, B., Geology of Harrison and Monona Counties: Iowa Geol. Survey, vol. 20, pp. 371-375, 1910. 
The name "Loveland" was proposed by the writer for a formation consisting of heavy clay resembling the drift joint-clays. It was named from Loveland (Iowa), a station on the Chicago \& Northwestern Railway located a short distance south of the Harrison County line, where the type section well displays the formation.

The deposition of the Pleistocene fluviatile formations of the Platte River Valley was followed by extensive erosion and deep dissection. Many valleys, like those of the Republican River and perhaps the Big Blue and Little Blue Rivers, which had been more or less filled, were again partly cleaned out. The Loveland was then deposited in the valleys, on the stream terraces.

At first the pre-Loveland valleys were partly filled with the sediments of their own streams and sediments derived locally from the valley slopes. The valley phase of the Loveland in the glaciated part of eastern Nebraska contains a heterogeneous mixture of sand, gravel, and clay, mostly thought to have been reworked from more or less local materials. It generally has the characteristic reddish color of the Loveland, and it attains a thickness of at least 35 feet.

The valley phase of the Loveland west of the glaciated area is usually made up of sand and clay. The sand is of fine to medium texture and was to a large extent derived from the upper part of the Grand Island formation. The very sandy valley phase of the Loveland is typically represented in the exposure west of Upland described on pace 52 .

Calcareous concretions, locally called "boulders" by well drillers, occur in the basal part of the Loveland formation in some places. They are especially abundant and unusually hard in an area north and northeast of St. Paul, east of Cushing, north of the Loup River, and north of Palmer, in Nance County. Some of the concretions. seen are more than 1 foot long and 6 to 8 inches in other dimensions, and test drilling seems to incicate that some may be much larger. They are nearly pure calcium carbonate. Many concretions have also been observed in the Loveland exposed in the small canyons south of the Platte River in Gosper, Dawson, and Lincoln Counties.

Volcanic ash or pumicite occurs at the base of the loess phase of the Loveland very generally in Nebraska. At most places it is only 5 to. 8 feet thick, but southwest of Eustis, in northeastern Frontier County, the ash is locally at least 50 feet thick and of singular purity. The volcanic ash in the Loveland formation seems to have been deposited in small ponds or lakes, or perhaps in bayous along early Loveland valleys. Very pure volcanic ash occurs near the base of the Loveland within a mile of this section. "Pumicite" or "silica" was formerly quarried or mined at several localities about 4 miles west and $1 \frac{1}{2}$ miles north from Orleans. 
The valley phase of the Loveland seems everywhere to grade imperceptibly upward into the upland phase of the formation. The material grows less and less sandy until it is typical loess, consisting of clay and silt in mechanical composition. The entire formation is red. The upland phase of the Loveland differs from the younger buff Peorian loess mainly in its reddish color, greater compactness, and less permeability.

The upland phase of the Loveland is about as widely distributed over the State as the younger buff Peorian loess, covering about 42,000 square miles. Its thickness in eastern Nebraska, where it is fully preserved, ranges in general from about 6 to 30 feet. It is 15 to 40 feet or more thick under the plains of the south-central part of the State and is 135 feet thick at one point west of Kearney. It is thought to be at least 100 feet thick in the vicinity of Ord, in Valley County, and it is more than 100 feet thick south of Gothenburg, Dawson County, and may be more than 150 feet thick in the area north of the Loup River north of Palmer, in Nance County, but is again much thinner a few miles west of this, north of St. Paul, Howard County.

In ceneral the present rolling topography of the loess-hill area, north of the Flatte River Valley, reflects the pre-Peorian topography. The excavation of deep road cuts through the present loess hills and ridges has revealed buried tops of old hills of Loveland loess, with remnants of Loveland soil near the center of some of the present hills. (See pl. 5, A.) These old hilltops are in places very pointed, and the slopes are steeper than present surface slopes. Some of the old hilltops project through the more recent loess on the present hillsides over considerable areas, where the contact of the red Loveland with the overlying buff Peorian loess can be distinctly seen and easily traced through plowed fields. This feature is especially striking in the hills north of the Loup River in northeastern Howard County and in Nance County.

A dark-gray to black soil as much as $4 \frac{1}{2}$ feet thick, with a mature soil profile, according to F. A. Hayes, of the United States Bureau of Chemistry and Soils, was developed on the Loveland loess and is still preserved intact over large areas in the State, especially west of theglaciated area, and there are also many remnants where the formation has been maturely dissected. The soil is noted in many of the sections. recorded in preceding parts of this report. One of the best exposures. of this old soil is in the southeast wall of the Platte River Valley southeast of Chapman, Merrick County. Here the overlying Peorian is about 30 feet thick. The soil of the Loveland is black and 3 to 4 feet thick, and at one place it is exposed continuously for at least half a mile. It is underlain by 8 to 10 feet of sandy Loveland loess clay, below which is 4 to 5 feet of greenish-gray clay of the Upland formation. 
resting on about 30 feet of exposed sand of the Grand Island formation. About 65 feet of the Loveland is exposed in the Medicine Creek Valley

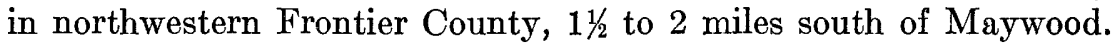
This exposure has $2 \frac{1}{2}$ feet of old black soil still preserved on it, and the soil is overlain by 90 to 100 feet of Peorian loess. Tertiary bedrock is a few feet below the base of the Loveland exposure.

Kay ${ }^{25}$ has shown that the Loveland loess (upland phase), or at least the upper part of it, is younger than the formation of the Illinoian gumbotil and definitely older than the Iowan till sheet. This is a significant fact, for the Loveland, because of its characteristic color, great thickness, and widespread continuity in this State, affords the best datum horizon or time marker in the entire Pleistocene section of Nebraska.

\section{PRE-PEORIAN EROSION}

The erosion that followed the formation of the thick Loveland soil seems to have been the most vigorous so far noted and resulted in fully as mature a topography and as deep dissection as now exists. It is significant that the valleys formed at that time were generally not alluviated prior to the deposition of the Peorian loess, as were the valleys cut prior to the deposition of the Loveland loess. It seems probable that general uplift had taken place, giving the streams greater vigor than they had in the pre-Loveland erosion interval.

The writer knows of no evidence to show that the Platte River had flowed across the glacial-till area, in its present course east of Columbus, before post-Loveland time, unless the extensive sand and gravel deposits in its valley from Columbus to the mouth are regarded as belonging to the early Pleistocene fluviatile formations. Prior to this erosion interval the Platte River had apparently drained away toward the southeast through the now buried Holdrege or Hastings basins or even through the Aurora basin (pp. 32-34).

The Loveland loess is found in place high in the Platte River Valley bluffs resting on glacial till, from the vicinity of Columbus east to the Missouri River. Its eroded edge is or has been covered with a thin mantle of Peorian loess, which extends in most places from the upland level down over the valley slope on to the flood plain. This condition would seem to indicate that the lower part of the Platte River Valley is of post-Loveland but pre-Peorian age. The cause of the postulated diversion of the Platte River is not fully known. After the lower part of the valley was excavated it was filled to a considerable depth with alluvial deposits, including much sand and gravel.

The Loveland loess with its thick old soil seems to have formed in Sangamon time. Subsequently the Loveland constructional plain was dissected to a mature or early mature topography, with a relief

${ }^{25}$ Kay, G. F., The relative ages of the Iowan and Ilinoian drift sheets: Am. Jour. Sci., 5th ser., vol. 16, pp. 497-518, December 1928; Loveland loess; post-Illinoian, pre-Iowan in age: Science, new ser., $\nabla 01.68$, pp. 482-483, Nov. 16, 1928. 
at some places in eastern Nebraska of 150 feet. It is inferred that this erosion occurred before the Peorian loess was deposited, because this later loess now mantles the erosional slopes in many places. If the Peorian loess is post-Iowan and the Loveland loess is of Sangamon age, then it apparently follows that the Iowan glacial stage is represented in Nebraska by a long period of erosion.

The facts that the thin mantle of Peorian and later loess deposits has not been removed or even deeply dissected and that recent erosion has not cut deeply into the underlying formations, except in very favorable places, as near the larger rivers, give evidence of the slowness of erosion and of the relative brevity of the time since the melting of the last glacier of the Wisconsin stage. They also, by contrast, indicate the vigor and longer duration of the erosion epoch preceding the Peorian stage. The geology and problems of the Loveland loess are treated at much greater length by the writer in another paper. ${ }^{26}$

\section{PEORIAN AND YOUNGER LOESS}

The Peorian loess is so well known and so widely distributed over the upper Mississippi Valley States that it does not require a detailed description here. The loess has been described or noted in nearly every section given in preceding parts of this report. It forms an almost unbroken mantle of buff to yellowish silt and clay over about 42,000 square miles in Nebraska. (See fig. 2.) It is now generally accepted that this loess was deposited by the wind. In some places the lower few feet of the loess is sandy and slightly bedded, suggesting that some of the wind-blown material settled in ponds or small lakes.

The plain on the Loveland loess was deeply and maturely dissected nearly everywhere, especially in the glaciated area of eastern Nebraska and in the loess-hill area, as previously explained, before the Peorian loess was deposited. In many places the Loveland was entirely removed, and now the Peorian loess rests on the eroded surface of till. In some places even the tills (Kansan and Nebraskan) were removed and Peorian loess rests on the eroded bedrock. The Peorian loess, being wind-blown, did not greatly affect the courses of earlier streams but was spread like a blanket over the dissected surface, mantling and obscuring all previously exposed formations. It filled many small valleys but not the larger valleys. It spread over the slopes of the Platte Valley, and some of the loess in the valley is believed by the writer to be of Peorian age.

The Peorian loess is from 30 to 50 feet or more thick under the plains of the south-central part of the State and reaches a thickness of 200 feet in places south of Gothenburg. It ranges from 30 to 250 feet in thickness in the loess-hill area north of the Platte River.

Two well logs, which are given below, illustrate its great thickness in the northwestern part of the area under investigation. The Elwood

${ }^{26}$ Lugn, A. L., The Pleistocene geology of Nebraska: Nebraska Geol. Survey Bull. 10, pp. 128-155, 1935. $121343-38-5$ 
well was drilled from a surface altitude of 2,659 feet above sea level, and the water level in the well was reported 312 feet below the surface. The well at Farnam was drilled from a surface altitude of 2,728 feet, and the water level in the well was reported 200 feet below the surface.

Log of well at Elwood, Gosper County

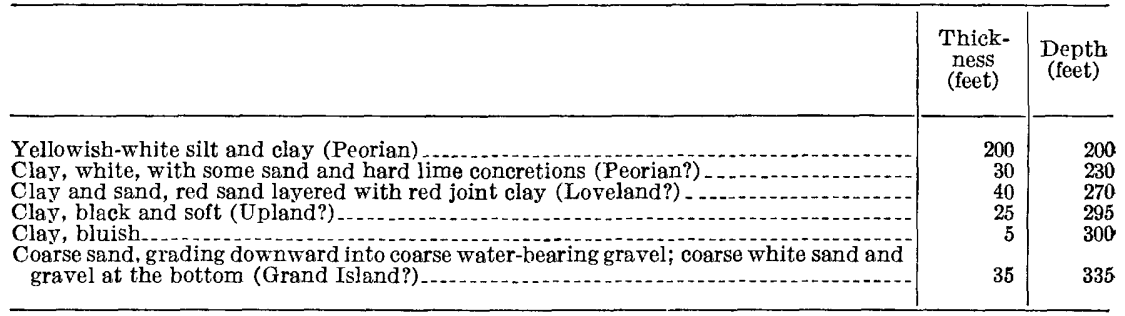

Log of well at Farnam, Dawson County

\begin{tabular}{|c|c|c|}
\hline & $\begin{array}{l}\text { Thick- } \\
\text { ness } \\
\text { (feet) }\end{array}$ & $\begin{array}{l}\text { Depth } \\
\text { (feet) }\end{array}$ \\
\hline $\begin{array}{l}\text { Yellowish-white silt and clay (Peorian) } \\
\text { Clay, whitish with "limy" concretions }\end{array}$ & $\begin{array}{r}185 \\
10\end{array}$ & $\frac{185}{195}$ \\
\hline $\begin{array}{l}\text { Clay, with some sand } \\
\text { Gravel, loose and fairly uniform, the size of corn grains or smaller; rests on clay at the } \\
\text { bottom of the well }\end{array}$ & $\begin{array}{r}5 \\
20\end{array}$ & 200 \\
\hline
\end{tabular}

The younger (post-Loveland) buff loess of Nebraska has always been correlated with the Peorian loess of Iowa and Illinois, but it has long been recognized that loess of later age-Wisconsin and even Recent-is probably included with the Peorian. Deposition of loess and dune sand is believed to have been more or less continuous from Peorian time to the present. Dust storms were particularly bad in the spring of 1935 in parts of Nebraska and adjacent States. At least one fairly thick dark soil is now known within the so-called Peorian loess, and a distinctly younger, looser, and grayer silty loess that may be of Wisconsin age is recognized over a large area around North Platte. Traces of old soils, or at least carbonaceous streaks, have been noted in the loess of eastern Nebraska, and what may prove to be a younger loess has also been noted at some places in the loess-hill area. This younger loess is illustrated by an exposure in a road cut about 5 miles west of Merna:

\section{Pleistocene deposits near Merna, Custer County}

Loess, gray, silty, not very compact; irregular erosional contact with buff loess below

Compact buff silty clay, typical of the Peorian loess of eastern Nebraska; erosional contact below (Peorian) ....-

Loess, bright yellowish red, and ferruginous sandy clay (Loveland) 
West of this locality, in western Custer County, southern Logan County, and northern Lincoln County, the younger gray or postPeorian loess appears to reach the rather surprising maximum thickness of about 250 feet. The younger loess, more yellowish white than gray, has been observed at several points south of the Platte River in the bluffs southeast of North Platte and south of Cozad. The postPeorian (?) loess is 50 to 100 feet thick south of Cozad, and it rests on a black soil with a true soil profile 3 feet thick. The old soil has been developed on a yellowish-white (Peorian?) loess, of which about 100 feet is exposed at some places, above the red Loveland loess.

In general the Peorian formation becomes thicker and the loess composing it becomes lighter in color and coarser in texture from east to west. In some places north and northwest of the loess-covered area is an extensive area of sand dunes. This sand-hill area is almost entirely outside of the area under investigation. The loess grades into the dune sand of the sand hills. The origin and history of the Peorian and later loess deposits and the sources of the loess are discussed in greater detail by the writer in another paper. ${ }^{27}$

RELATION OF THE SAND-HILL AREA TO THE AREA UNDER INVESTIGATION:

In many places dune sand of the sand-hill area mantles older Pleistocene deposits, which are more or less confined to Pleistocene valleys. These valleys trended east or southeast. Like the North Platte River Valley, they were feeders through which sand, gravel, and finer material were transported from the High Plains to the south-central and southeastern parts of Nebraska. The dune sand rests upon Tertiary materials on the divides between the Pleistocene valleys. The valley deposits appear to be more or less correlative with the Pleistocene formations of the south-central part of the State. Such correlation is suggested especially by outcrops along the Middle Loup River in southern Cherry County and in Hooker and Thomas Counties and along the Dismal River in southern Hooker and Thomas Counties.

The dune sand and other Pleistocene deposits of the sand-hill area. are underlain by Tertiary beds-mostly the Brule, Arikaree, and Ogallala formations. The Tertiary deposits attain thicknesses of 50 to 200 feet in the eastern part of the area and 500 feet or more to the west. The Ogallala and Arikaree materials are porous and permeable, and great quantities of ground water are stored in them, both in areas where they are overlain by Pleistocene deposits and in areas where they are exposed.

The dune sand readily absorbs large quantities of rain water, which: in many parts of the sand-hill area is stored in the permeable Pleistocene and Tertiary formations. Much of this ground water percolates to the southwest, following the general slope of the land until

" Lugn, A. L., The Pleistocene geology of Nebraska: Nebraska Geol. Survey Bull. 10, pp. 158-168, 1935. 
it is intercepted and is added to the flow of streams. The three Loup Rivers and numerous creeks that discharge into the Platte River Valley as far west as Garden County are fed by seepage from this great ground-water reservoir.

The Tertiary formations west of the vicinity of Grand Island are continuous beneath the area under investigation, and doubtless ground water percolates through them from the sand-hill area and is discharged into the Platte River Valley and under it southward and southeastward as far even as the Republican River and its tributaries, where the formations thin out and disappear. There is also groundwater percolation through the overlying Pleistocene deposits in the same general direction, but in the area north of the Platte River this percolation is probably confined chiefly to buried Pleistocene valleys.

The total amount of ground-water percolation into the Platte Valley and away from it has not been determined, but it is believed that the amount of percolation through the Pleistocene deposits south of the Platte River greatly exceeds that through the Tertiary materials, because the Pleistocene deposits are in general considerably more permeable than the older formations. On page 182 is given an estimate of the amount of water that percolates southeastward out of the Platte River Valley through the Pleistocene sand and gravel. There is, of course, additional percolation through the underlying Tertiary deposits.

The most abundant supplies of ground water in south-central Nebraska are obtained from the Pleistocene sand and gravel deposits, and only a few domestic wells draw water from the Tertiary formations. However, it is probable that some of the ground water recovered from the Pleistocene sand and gravel is derived from the Tertiary formations, because the water in the deposits is free to move from one formation to another.

The degree to which the ground-water level in the Platte Valley and in the rest of south-central Nebraska is sustained by underflow from the sand-hill area is not known, but the geologic and hydrologic conditions are such that this contribution by underflow must be appreciable.

\section{RELATION OF THE PLATTE RIVER VALLEY TO THE PLANN TO THE SOUTH}

The continuity and identity of the sand and gravel in the Platte River Valley with the sand and gravel sheets under the plain to the south is noted on page 36. Two geologic profile sections (pls. 6, 7), based on well logs, show this relation in more detail.

A north-south geologic profile section across the buried Holdrege basin from Elm Creek, in the Platte River Valley, to Alma, in the Republican River Valley, is shown in plate 6. The section crosses the northwestward-trending buried Holdrege basin diagonally. The 
Holdrege and Grand Island formations are both present and are separated in some places by the Fullerton formation. The part of the section in and adjacent to the Platte River Valley is based on test-well logs, but the part extending southward across the plain is less accurate, being based chiefly on logs supplied by well drillers. The approximate position of the water table as obtained from reports by farmers is shown on the section. Throughout most of the section the water table stands near the base of the Grand Island formation, and there is considerable unsaturated sand and gravel above it.

A north-south geologic profile section between Gibbon, in the Platte River Valley, and Riverton, in the Republican River Valley, is shown in plate 7. This section crosses the north end of the buried Hastings basin and a part of the buried Holdrege basin. The bedrock divide near the middle of the section is an erosion remnant ridge between the Holdrege and Hastings basins. This ridge trends northwest and intersects the section diagonally. (See fig. 5.) The ridge is not a barrier to the percolation of ground water through the water-bearing formations in the basins. The approximate position of the water table as obtained by reports from farmers is shown on the section.

\title{
GENERAL GROUND-WATER CONDITIONS IN SOUTH- CENTRAL NEBRASKA
}

\author{
By A. L. LugN and L. K. WenzeL
}

A detailed study of the ground-water conditions in the whole of south-central Nebraska was not attempted as a part of this investigation. The detailed study was confined to the Platte River Valley between Chapman and Gothenburg, where irrigation with water pumped from wells is extensively practiced. However, records were collected for about 1,000 wells on the upland plain of south-central Nebraska, and considerable information on the ground-water conditions of the area was obtained from them.

Abundant supplies of potable ground water are obtained in most places in south-central Nebraska from the Pleistocene Grand Island and Holdrege formations, which furnish almost all the municipal and domestic wells of the area. Although in the central part of the area the Pleistocene deposits are underlain by water-bearing Tertiary formations, it is not necessary in most places for wells to penetrate to the Tertiary beds to obtain plentiful supplies. In the western part of the area, however, where the Pleistocene sand and gravel are thin, wells end in the Tertiary formations and obtain satisfactory supplies. In a few isolated areas in south-central Nebraska the Cretaceous shales are relatively high, and the water-bearing Pleistocene and Tertiary formations are thin or absent. In such places, as near Nelson, in Nuckolls County, only small and rather unreliable supplies of water are obtained from wells. 


\section{QUANTITY OF GROUND WATER}

Large quantities of ground water occur in the Pleistocene sand and gravel in the buried Holdrege, Hastings, and Aurora basins, and hence abundant supplies are derived from wells in these areas. The sand and gravel are more nearly filled with water in the buried Aurora basin than in the Hastings and Holdrege basins. The sand and gravel in the Holdrege basin are the least fully saturated, and at many places from 50 to 100 feet of the upper part, largely in the Grand Island formation, lies above the water table. For example, at Holdrege at least 50 feet of the sand and gravel of the Grand Island formation is above the water table, but there is more than 150 feet of saturated material below. This does not include about 130 feet of saturated Tertiary deposits at greater depth. From 100 to 140 feet of saturated sand and gravel lies beneath Hastings, in Adams County, and at some places in the buried Aurora basin the saturated thickness of sand and gravel may be as great as 125 to 150 feet.

The amount of ground water stored in the Pleistocene sand and gravel under the plain in the area under investigation is computed to be about 77,000,000 acre-feet, on the assumption that 4,000 square miles of the area is underlain by an average of about 100 feet of saturated sand and gravel with a porosity of 30 percent. An additional quantity of ground water occurs under an area about equally large south and east of the Platte Valley and east of the area under investigation.

\section{MOVEMENT OF GROUND WATER}

A map showing contours on the water table for south-central Nebraska is given in plate 8 (in pocket). This map is believed to show the general direction of movement of the ground water, because of the large contour interval chosen, although it is known that the contours are not precise, inasmuch as the map was prepared from depths to water reported by the farmers and from altitudes determined by means of an altimeter. The contours indicate that the general direction of movement of the ground water in the area is from northwest to southeast, although in certain places the direction of movement is to the east or northeast. The interception of the underflow by streams in the area, especially by the Little Blue River, is shown by the depressions in the water table along the stream valleys.

The map also shows the building up of the water table in front of local impervious areas, such as Fillmore County, where there is high relatively impervious bedrock of Cretaceous shale. The water table is also built up in front of a lobe of Nebraskan till in western Polk County. In both these localities the water table slopes away on both sides of the impervious area, where the movement of ground water is less obstructed. The effect of high bedrock (Niobrara shale) under 
Nelson, in central Nuckolls County, and under Blue Hill, in northern Webster County, is evident but less apparent. The rate of movement of the ground water of the Platte River Valley has been computed to range from about 8 inches to 4 feet a day under the hydrologic conditions that exist there (pp. 130-136). It is probable that the rates of flow through the sand and gravel under the plain are of similar magnitude, because the hydrologic conditions in the two areas are similar.

\section{TYPES OF WELLS}

Most of the wells drilled in south-central Nebraska for domestic and stock purposes are only 2 or 3 inches in diameter and are of the tubular type, which are jetted into place. The wells are usually equipped with lift pumps, because on the plains the water level stands from 50 to 200 feet or more below the land surface. Most of the wells are equipped with windmills, which operated efficiently in the area because of the relatively high velocity of the prevailing winds.

In the southeastern part of the area under investigation, as in some parts of Clay and Nuckolls Counties, the Pleistocene water-bearing materials are composed chiefly of fine sand, and here wells ranging in diameter from 4 to 10 inches are drilled. Considerable difficulty is experienced in screening wells so as to keep out the sand. Gravel treatment is coming into more general use now than formerly. In the western part of the area, where the Pleistocene water-bearing formations are thin or absent, as in parts of Lincoln, Frontier, and Redwillow Counties, most wells are 4 inches in diameter.

\section{DEPTH TO THE WATER TABLE}

The depth to the water table below the land surface in south-central Nebraska ranges from about 1 foot to more than 200 feet. In the valleys of most of the larger streams, such as the Platte, Republican, and Blue, the water table is relatively shallow, ranging from 1 foot to 35 feet below the land surface. On the divides between the streams and on the plains the water table stands much deeper. In general, the water table decreases in depth below the land surface from west to east across the plains of south-central Nebraska. South of Curtis, in Frontier County, the depth to water in a well on the plains in the NW/4/4SW1/4 sec. 3, T. 7 N., R. 28 W., was 192.7 feet on November 23, 1934. North of Bertrand, in Phelps County, the water table stands about 173 feet below the land surface; near Axtell, in Kearney County, about 101 feet; near Hastings, in Adams County, about 100 feet; near Edgar, in Clay County, about 73 feet; in a well near Farnam, in southwestern Dawson County, about 193 feet; in a well in the valley of the Wood River near Sumner, in Dawson County, 
about 33 feet; in a well in the valley of the Wood River near Amherst, in Buffalo County, about 32 feet; in a well at Holdrege, in Phelps County, about 152 feet; near Lawrence, in Nuckolls County, about 79 feet; near Ruskin, in Nuckolls County, about 115 feet; near Cowles, in Webster County, about 36 feet; and near Upland, in Franklin County, about 167 feet.

\section{BLOWING WELLS}

There is in most places some unsaturated Pleistocene sand and gravel above the water table and below the loess. This material is filled with air, which is more or less confined between the water table and the base of the loess and is therefore subject to compression and expansion with changes in atmospheric pressure. Changes in atmospheric pressure in some wells cause a flow of air into or out of the formation through the well casings and thus give rise to the so-called blowing and sucking wells of the area.

\section{GROUND-WATER IRRIGATION ON THE PLAINS}

In recent years several wells have been drilled on the plains to furnish water for irrigation, and most of the wells have yielded relatively large supplies of watel from the Pleistocene sand and gravel. However, because the water table lies relatively deep, the cost of lifting the water to the surface has been rather great, and some of the wells have been abandoned.

About six irrigation wells are now being operated near Hastings, where the depth to water is about 100 feet. Recently an irrigation well was drilled near Upland, in Franklin County, where the depth to water is about 167 feet. Several wells are used for irrigation near Aurora, in Hamilton County, where the water table is about 90 feet below the land surface. There are other irrigation wells south of the Platte Valley in the valleys of the Big Blue and Little Blue Rivers and their tributaries and in the Republican River Valley.

The number of irrigation wells that can be operated on the plains without excessively lowering the water table is limited by the quantity of underground percolation from the Platte River Valley and the sand-hill region, because there is apparently little if any recharge to the zone of saturation from the precipitation that falls on the plains. The amount of ground water that percolates out of the Platte Valley between Chapman and Gothenburg through the Pleistocene sand and gravel has been estimated at about 50,000 acre-feet a year, hence the total amount of water pumped on the plains should not exceed this figure. There is, of course, some underground percolation under the central and western part of the area through the Tertiary deposits, 


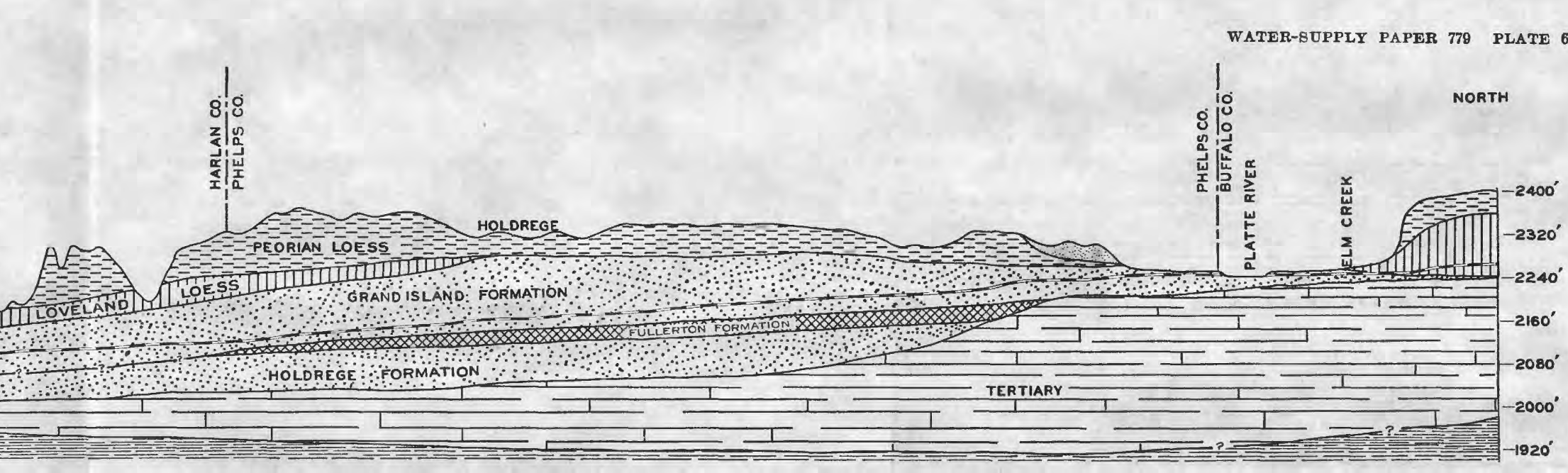

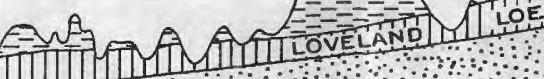
11 1 III IIIII 11111 1 -1

-2000- A

NIOBRARA Formation

APPROXIMATE POSITION OF
WATER TABLE

․․이, $\quad 2,4,6,8$ MILES

NORTH-SOUTH GEOLOGIC PROFILE SECTION FROM ELM CREEK TO ALMA, NEBR. 


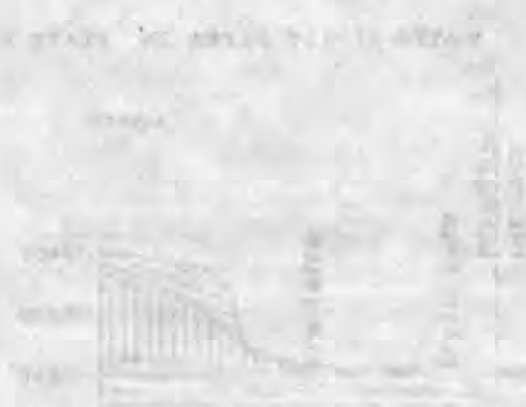




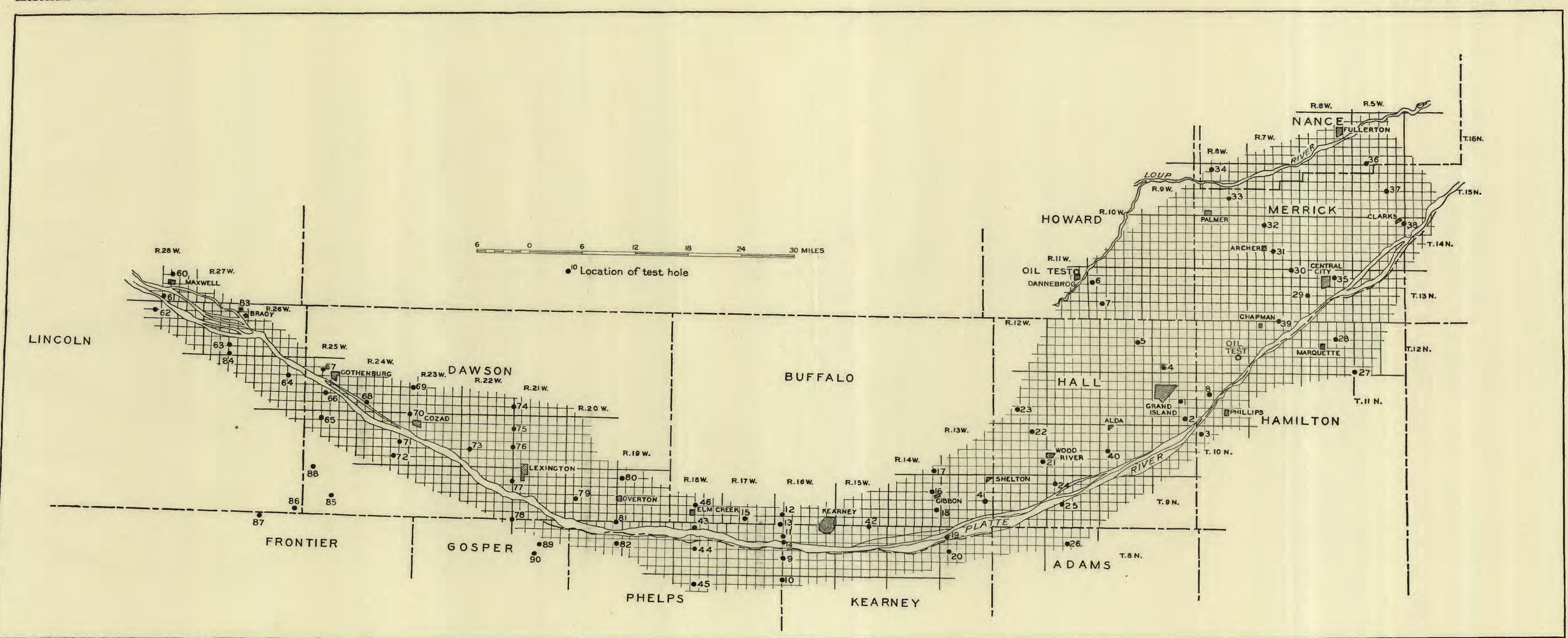

MAP OFJTHE PLATTE RIVER VALLEY IN CENTRAL NEBRASKA, SHOWING LOCATION OF TEST HOLES. 


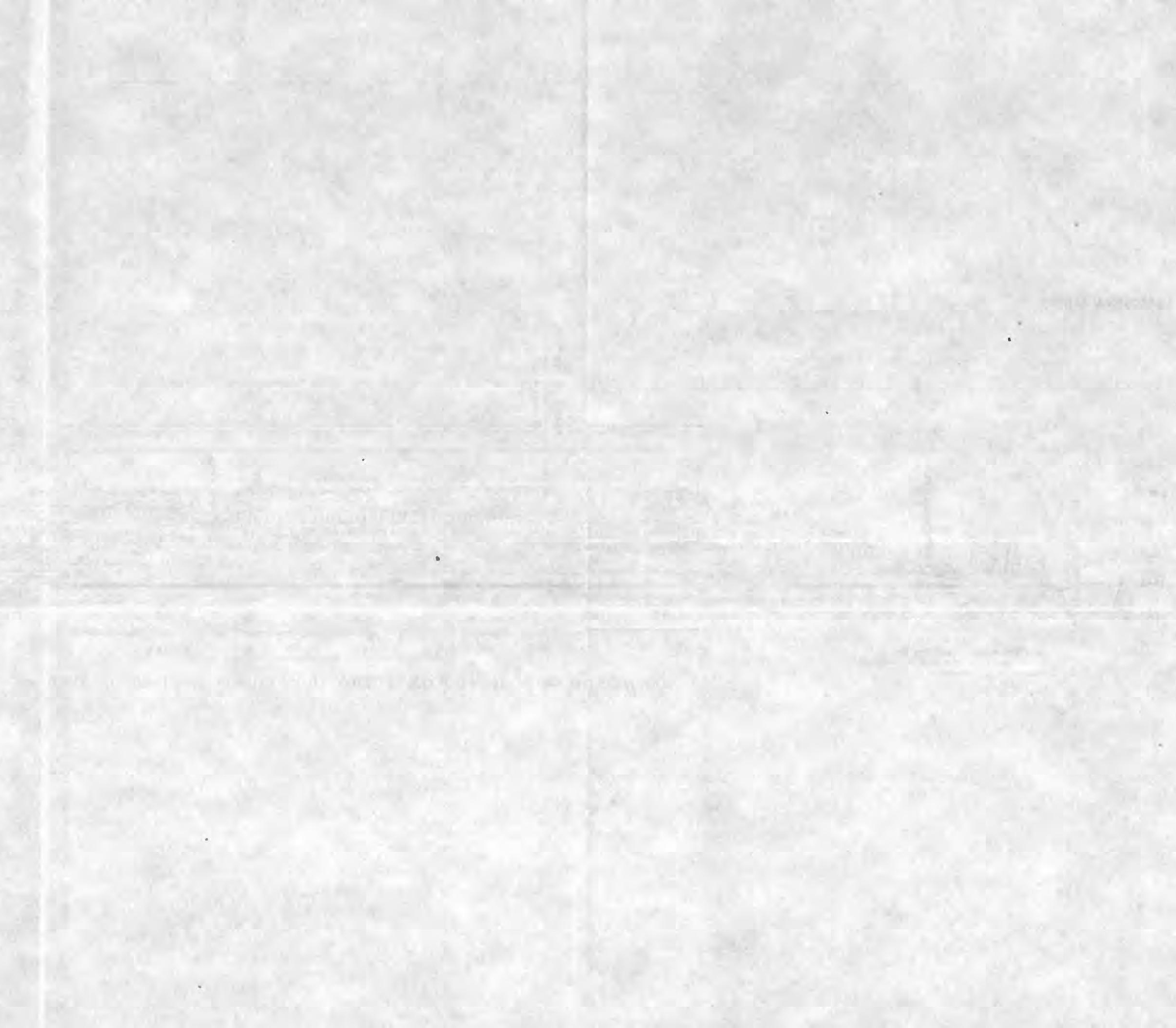


but it is believed that this amount of water would be no more than a factor of safety. The area on the plain where irrigation is feasible by water pumped from wells amounts to about 4,000 square miles, which indicates that by recovering the entire 50,000 acre-feet of ground-water percolation, about 12 acres of land in each square mile could be irrigated, on the assumption that the supplemental water requirement for crops in south-central Nebraska is 12 inches a year (p. 140). If each pumping plant supplied water for 60 acres of crops, an average of one irrigation well could be operated for each 5 square miles of plain. However, such complete utilization of the ground water would probably produce certain detrimental effects at other places in the area. The flows of the Big Blue and Little Blue Rivers and the tributaries of the Republican River would doubtless decrease, inasmuch as the seepage flows of these streams are composed in part of overflow from the ground-water reservoir under the plain. The general water table under the plain would probably be somewhat lowered, and the resulting increase in lift would be apparent at the irrigation pumping plants and also at municipal pumping plants in the area. Moreover, the effect of pumping would probably be transmitted slowly to the Platte River Valley, where also the water table would be lowered. These forecasts of possible effects are based on the best distribution of pumping plants on the plains. It is more likely that the plants would be located closely in groups, and if they were the detrimental effects of pumpage would be greater.

Although a certain amount of water can be pumped for irrigation on the plain and this amount is many times that which is being pumped at present, the safe yield of the ground-water reservoir is so low that pump irrigation on a large scale would cause a serious lowering of the water level and other detrimental effects.

\section{CHARACTER AND THICKNESS OF THE PLEISTOCENE WATER-BEARING MATERIALS IN THE PLATTE VALLEY}

\section{By A. L. LUGN}

In connection with the investigation test holes were drilled in the Platte Valley to determine the character and thickness of the underlying water-bearing materials. In all, about 75 holes were drilled for this purpose, as shown in plate 9 . The logs of these test holes and of two test holes drilled by commercial concerns for oil and gas are given on the following pages.

From the logs of these test holes, many of which were drilled in lines across the Platte Valley, the cross-sectional area of sand and gravel was determined in the valley at 12 localities, and the volume of sand and gravel occurring in the segments between the successive cross-sectional areas was computed. 
Cross-sectional area of Pleistocene sand and gravel in the Platte Valley

\begin{tabular}{|c|c|c|c|}
\hline \multicolumn{3}{|c|}{ Square feet } & \\
\hline 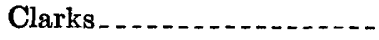 & $2,400,000$ & Elm Creek & 760 \\
\hline Central City & $2,800,000$ & Overton & 1,100 \\
\hline Grand Island & $10,900,000$ & Lexington & $1,400,00$ \\
\hline Wood River $\ldots \ldots$ & $3,300,000$ & Cozad_. & 800 \\
\hline Gibbon.... & $3,600,000$ & Gothenburg & 400,0 \\
\hline Kearney & $1,000,000$ & Maxwell _............ & 500 \\
\hline
\end{tabular}

Volume of Pleistocene sand and gravel between successive cross sections in the Platte Valley

\begin{tabular}{|c|c|c|c|}
\hline Clarks-Central City & $\begin{array}{r}\text { Acre-feet } \\
4.300,000\end{array}$ & Overton-Lexington & $\begin{array}{r}\text { Acre-feet } \\
1,800,000\end{array}$ \\
\hline Central City-Grand Island. & $15,000,000$ & Lexington-Cozad & $1,700,000$ \\
\hline Grand Island-Wood River_- & $14,500,000$ & Cozad-Gothenburg & 600,000 \\
\hline Wood River-Gibbon $\ldots$ & $5,400,000$ & Gothenburg-Maxwell $\ldots$ & $1,100,000$ \\
\hline Gibbon-Kearney _........ & $5,200,000$ & & \\
\hline Kearney-EIm Creek & $1,100,000$ & Total_... & $1,700,000$ \\
\hline Elm Creek-Overton & $1,000,000$ & & \\
\hline
\end{tabular}

If it is assumed that the sand and gravel has an average porosity of 30 percent (see pp. 91-93), and if allowance is made for the quantity of sand and gravel that lies above the water table, the total quantity of water in storage in the sand and gravel is computed to be about. $15,000,000$ acre-feet. However, only a part of this water can be recovered by wells. At a specific yield of 22 percent (see p. 96) the volume of water that could be recovered from sand and gravel if all of the material were unwatered is computed to be about $11,000,000$ acre-feet. Additional water is stored below the Pleistocene sand and gravel in the Tertiary materials.

\section{Logs of test holes near Clarks}

Test hole 36

[Southeast corner of sec. 32 , T. 16 N., R. 5 W.; altitude, 1,640 feet above mean sea level]

\begin{tabular}{|c|c|c|}
\hline & $\begin{array}{c}\text { Thick- } \\
\text { ness } \\
\text { (feet) }\end{array}$ & $\begin{array}{c}\text { Depth } \\
\text { (feet) }\end{array}$ \\
\hline Soil, black silty loam. & 2 & \\
\hline Clay, soft, sticky, gray, silty and sandy & 3 & 5 \\
\hline Sand and silt, gray, loose, very little coarse material & 8 & 13. \\
\hline Gravel, coarse, dirty, pea size or larger & 1 & 14 \\
\hline $\begin{array}{l}\text { Sand, fine, dirty, gray, contains much silt; grains well rounded } \\
\text { Chalky clay, compact, light greenish gray, very calcareous (Niobrara formation) }\end{array}$ & $\begin{array}{l}15 \\
12\end{array}$ & $\begin{array}{l}29 \\
41\end{array}$ \\
\hline Cnalky clay, compact, light greenish gray, very calcareous (N1obrara rormation) & & \\
\hline
\end{tabular}

Test hole 37

[Southeast corner of sec. 15, T. 15 N., R. 5 W.; altitude, 1,635 feet above mean sea level; depth to water, 8 feet]

Soil, black silty loam, loose... gray.
Clay, hard and tough, compact, gray
Gravel and sand, reddish, coarse and fine, grains subangular; lower part contains clay
balls, and lower 1 foot very coarse.
Clay, soft, silty and sandy, light grayish to brownish
Gravel, coarse and fine interlayered, reddish and pinkish
Gravel and sand, reddish.
Shale, chalky, tough, compact, calcareous, bluish gray




\section{Logs of test holes near Clarks-Continued}

\section{Test hole 38}

[Southwest corner of sec. 15, T. 15 N., R. 5 W.; altitude, 1,635 feet above mean sea level; depth to water, 5 feet]

\begin{tabular}{|c|c|c|}
\hline & $\begin{array}{l}\text { Thick- } \\
\text { ness } \\
\text { (feet) }\end{array}$ & $\begin{array}{l}\text { Depth } \\
\text { (feet) }\end{array}$ \\
\hline $\begin{array}{l}\text { Soil, black sandy loam } \\
\text { Clay, hard, compact, silty, bluish-gray }\end{array}$ & $\stackrel{2}{3}$ & $\mathbf{2}$ \\
\hline Sand and gravel, coarse and fine interbedded, coarser at depth from 8 to 20 feet, reddish & & \\
\hline $\begin{array}{l}\text { or pentask chalky, whitish color (Niobrara) } \\
\text { Clay, chalky, bluish gray, consolidated (Niobrara) }\end{array}$ & $\begin{array}{r}22 \\
3 \\
11\end{array}$ & $\begin{array}{l}27 \\
30 \\
41\end{array}$ \\
\hline
\end{tabular}

\section{Logs of test holes near Central City}

Test hole 97

[SW1/4NW1/4SW1/4 sec. 31, T. 12 N., R. 5 W.; altitude, 1,795 feet above mean sea level]

\begin{tabular}{|c|c|c|}
\hline $\begin{array}{l}\text { Soil, gray, silty, unconsolidated. } \\
\text { Loess, yellowish, soft. } \\
\text { Loess, red, hard and compact } \\
\text { Clay, blue and greenish, silty, tough and compact } \\
\text { Clay and silt, greenish, compact, lower part somewhat sandy } \\
\text { Sand and gravel, bluish gray, coarse and fine interbedded, much coarser near bottom. }\end{array}$ & $\begin{array}{r}2 \\
38 \\
37 \\
7 \\
5 \\
16\end{array}$ & $\begin{array}{r}2 \\
40 \\
77 \\
84 \\
89 \\
105\end{array}$ \\
\hline
\end{tabular}

\section{Test hole 28}

[Northeast corner of sec. 15, T. 12 N., R. 6 W.; altitude, 1,805 feet above mean sea level]

\begin{tabular}{|c|c|c|}
\hline $\begin{array}{l}\text { Soil, dark brown, silty, loosely consolidated. } \\
\text { Loess, yellow, silty, fairly soft. } \\
\text { Soil, dark brown and black, compact } \\
\text { Loess, reddish, compact, hard and tough, silty, lower } 4 \text { feet sandy } \\
\text { Sand and gravel. } \\
\text { Clay and silt. } \\
\text { Sand and gravel } \\
\text { Shale, bluish gray, and whitish chalk (Niobrara) }\end{array}$ & $\begin{array}{r}2 \\
25 \\
2 \\
19 \\
45 \\
40 \\
25 \\
42\end{array}$ & $\begin{array}{r}2 \\
27 \\
29 \\
48 \\
93 \\
133 \\
158 \\
200\end{array}$ \\
\hline
\end{tabular}

\section{Test hole 29}

[Southeast corner of sec. 18, T. 13 N., R. 6 W.; altitude, 1,713 feet above mean lea level]

Soil, dark brownish to black, sandy silt

Sand and gravel, coarse and fine interlayered.

Clay, soft, sticky, bluish, some fine sand.

Gravel and sand, coarse and fine interlayered

(N)

Shale, tough, compact, very calcareous, bluish gray and chalky (Niobrara)

$\begin{array}{r}2 \\ 40 \\ 7 \\ 84 \\ 89 \\ \hline 05\end{array}$




\section{Logs of test holes near Central City-Continued}

\section{Test hole 32}

[Southwest corner of sec. 4, T. 14 N., R. 7 W.; altitude, 1,737 feet above mean sea level]

\begin{tabular}{|c|c|c|}
\hline & $\begin{array}{l}\text { Thick- } \\
\text { ness } \\
\text { (feet) }\end{array}$ & $\begin{array}{l}\text { Depth } \\
\text { (feot) }\end{array}$ \\
\hline $\begin{array}{l}\text { Sand, fine, eolian, well-rounded quartz grains, } \\
\text { Clay, brownish to black, hard, silty, alkaline, "hardpan" } \\
\text { Clay, soft, bluish gray } \\
\text { Clay, hard, black, silty } \\
\text { Clay, soft, bluish gray } \\
\text { Gravel, coarse and fine interbedded, and sand; lower gravel is bluish gray } \\
\text { Shale, hard, chalky, grayish (Niobrara) }\end{array}$ & $\begin{array}{r}1 \\
8 \\
6 \\
2 \\
2 \\
18 \\
3\end{array}$ & $\begin{array}{r}1 \\
9 \\
15 \\
17 \\
19 \\
37 \\
40\end{array}$ \\
\hline
\end{tabular}

Test hole 33

[Northeast corner of sec. 27, T. 15 N., R. 8 W.; altitude, 1,733 feet above mean sea level]

Soil, black silty loam.

Clay, soft, bluish gray

Sand and gravel, reddish and pinkish, little sand

Shale, compact, tough, calcareous, bluish gray (Niobrara)

Test hole 34

[SE $1 / 4$ SE1/4 sec. 5 , T. 15 N., R. 8 W.; altitude, 1,813 feet above mean sea level]

Clay, red loess, hard, silty

Clay, red loess, very hard

Clay and limestone concretions; clay is soft, silty, gray and brownish; contains hard calcareous concreticns 6 inches to 2 feet thick

Clay, brownish red, very silty, soft; much fine sand.-.

Concretion or limestone layer, light gray, very hard; breaks in to conchoidal chips

Clay, brownish, soft, silty, much fine sand; hard limestone layer or concretion 1 foot thick near the middle.

Clay, compact, hard, gray, silty

Calcareous grit, gray, silty, consolidated, hard and soft layers (Ogallala)

\begin{tabular}{r|r}
32 & 32 \\
30 & 62 \\
& \\
6 & 68 \\
23 & 91 \\
2 & 93 \\
17 & 110 \\
8 & 118 \\
37 & 155 \\
\hline
\end{tabular}

\section{Test hole 35}

[Southeast corner of sec. 3, T. 13 N., R. 6 W.; altitude, 1,689 feet above mean sea level; depth to water, 5 feet]

Soil, hard black gummy loam

Sand, coarse and fine interbedded, red dish and pinkish

Clay, silty, sandy, loosely consolidated, gray (this bed has well-preserved trees and

stumps roted in it)

\begin{tabular}{r|r}
8 & 8 \\
3 & 11 \\
8 & 19 \\
6 & 25
\end{tabular}

\begin{tabular}{l|l|l} 
& 25 & 65 \\
\hline
\end{tabular}

\section{Test hole 39}

[SE1/4 sec. 34, T. 13 N., R. 7 W.; altitude, 1,744 feet above mean sea level; depth to water, 5 feet]

Silt and fine sand, compact, silty, gray-

Sand and gravel, coarse and fine interbedded; pea-size or larger gravel, reddish or pink-

ish, silty near bottom
Clay, tough, compact, brownish in upper 12 feet, grayish and softer in lower part.

Shale, compact, tough, gummy (Niobrara?)

Clay or shale, as above but softer (Niobrara?)

Clay, hard, compact, whitish. calcareous (Niobrara)

Clay, fairly soft, silty, brown (Niobrara?)

Clay, light brown, silty, calcareous (Niobrara?).

Clay, very soft, light brown (Niobrara?)

Clay, compact, hard, calcareous, brownish tan (Niobrara?)

Shale, compact, calcareous, chalky, bright ocher yellow (Niobrara?)

Chalk, hard, white (Niobrara?)

Shale, ocher yellow (Niobrara?)

\begin{tabular}{r|r}
8 & 8 \\
28 & 36 \\
16 & 52 \\
7 & 59 \\
10 & 69 \\
4 & 73 \\
9 & 83 \\
3 & 85 \\
6 & 91 \\
24 & 115 \\
21 & 136 \\
1 & 137 \\
39 & 176 \\
\hline
\end{tabular}




\section{Logs of test holes near Central City-Continued}

\section{Chapman test for oil 1}

[Northeast corner of sec. 26, T. 12 N., R. 8 W.; driller, Nieswanger, Jayhawk Producing \& Refining Co., 1928-29; cable tool drill used]

\begin{tabular}{|c|c|c|}
\hline & $\begin{array}{c}\text { Thick- } \\
\text { ness } \\
\text { (feet) }\end{array}$ & $\begin{array}{l}\text { Depth } \\
\text { (feet) }\end{array}$ \\
\hline $\begin{array}{l}\text { Soil } \\
\text { Sand and gravel, coarse and fine light gray, coarse sand and interlayered gravel } \\
\text { Sand and gravel, } \\
\text { Niobrara, Carlile, Greenhorn, Graneros, and Dakota. }\end{array}$ & $\begin{array}{r}4 \\
58 \\
56 \\
12 \\
1,310\end{array}$ & $\begin{array}{r}4 \\
62 \\
118 \\
130 \\
1,440\end{array}$ \\
\hline
\end{tabular}

1 For a complete $\log$ of this well, see Condra, G. E., Schramm, E. F., and Lugn, A. L., Deep wells of Nebraska: Nebraska Geol. Survey, 2d ser., Bull. 4, pp. 255-257, 1931.

\section{Logs of test holes near Grand Island}

Test hole 3

[SW $1 / 4$ SE1/4 sec. 6, T. 10 N., R. 8 W.; altitude, 1,899 feet above mean sea level; depth to water, 67 feet]

Loess, yellowish silt, and clay; has 8-inch zone of soil at top, brown silt loam.

Soil, dark-brown to neariy black silt and clay

Loess, red silt, and clay.

Clay, compact, grayish green, and silt

Sand, silt, and

and, silt, and some clay, mostly very fine sand and silt; certain thin zones consist of greenish sandy clay, very compact.

Sand and gravel, mostly coarse sand and fine gravel, somewhat layered, pinkish to reddish.

Sand and gravel, similar to bed above but coarser, somewhat layered coarse and fine; lower part contains less sand and more gravel of pea size or larger.

Sand and gravel. somewhat finer-textured at the top, becoming coarser lower down, coarser and finer material interlayered; the lower 7 to 10 feet contains a large admixture of pebbles as much as half an inch in diameter

Coarse gravel, some sand.

Sand and gravel, coarse and fine, like beds above, lower

Shale, bluish gray, harder and softer layers, calcareous, some hard chalk or limestone (Niobrara)

\begin{tabular}{r|r}
18 & 18 \\
2 & 20 \\
11 & 31 \\
1 & 32 \\
9 & 41. \\
& \\
37 & 78 \\
13 & 91 \\
& \\
24 & 115 \\
& \\
29 & 144 \\
2 & 146 \\
31 & 177 \\
38 & 225 \\
\hline
\end{tabular}

\section{Test hole 2}

[NEt/4NEt/4 Sec. 34, T. 11 N., R. 9 W.; altitude, 1,843 feet above mean sea level; depth to water, 6.8 feet]

Soil and alluvium, silt and fine sand.

Sand and gravel, coarse and fine, granitic sand and gravel, layered

Clay, 6-inch hard yellow clay at top, 6 inches of gravel and sand in the middle, and 2 feet of yellowish gummy clay at the bottom.

Sand and gravel, granitic, pinkish to reddish, coarse and fine, some zones very coarse others fine.

Sand and gravel, coarse and fine, similar to bed above, but some zones contain the coarsest

gravel encountered, the lower 10 to 15 feet more greenish and contains some clay

Shale, upper 2 feet weathered, but for the most part bluish gray or mouse-colored and calcareous (Niobrara)

\begin{tabular}{r|r}
\multicolumn{1}{l|}{3} & 3 \\
34 & 37 \\
3 & 40 \\
38 & 78 \\
87 & 165 \\
22 & 187
\end{tabular}

\section{Test hole 1}

[NW $1 / 4$ NW1/4 sec. 22, T. 11 N., R. 9 W.; altitude, 1,840 feet above mean sea leve]; depth to water, 7.5 feet]

\begin{tabular}{|c|c|c|}
\hline Soil and alluvium, black argillaceous loam and yellow silty clay. & 2 & 2 \\
\hline Sand, light gray, fine. & $\overline{4}$ & 6 . \\
\hline Sand and gravel, fine and coarse, granitic, layered, some thin fine-texturea layers, a little & 32 & 38 \\
\hline Clay, silt, and fine sand, grayish; may contain some coarse sand. & 7 & \\
\hline Sand and gravel, coarse and fine; some clay. & 38 & \\
\hline Sand and silt, coarse sand and rock flour & 13 & \\
\hline Sand and gravel, dark-colored, with much smoky quartz, coarse and fine & 13 & 109 \\
\hline Sand and gravel, lighter in color than bed above, coarse and fine, large quartz content.. & 28 & 137 \\
\hline $\begin{array}{l}\text { Clay, greenish gray, silty, some fine sand } \\
\text { Sand and gravel, coarse and fine, clean; lower part greenish in mass, finer texture near }\end{array}$ & 9 & $14 f$ \\
\hline $\begin{array}{l}\text { sand and gravel, coarse and nne, clean; lower part greenish in mass, nner texure near } \\
\text { bottom. }\end{array}$ & 40 & \\
\hline Shale, grayish, calcareous, massive (Niobrara) & 42 & 228 \\
\hline
\end{tabular}




\section{Logs of test holes near Grand Island-Continued}

\section{Test hole 4}

[NW1/4 sec. 33, T. 12 N., R. 9 W.; altitude, 1,851 feet above mean sea level; depth to water, 5.5 feet]

\begin{tabular}{l|r|r}
\hline & $\begin{array}{c}\text { Thick- } \\
\text { ness } \\
\text { (feet) }\end{array}$ & $\begin{array}{r}\text { Depth } \\
\text { (feet) }\end{array}$ \\
\hline $\begin{array}{l}\text { Soil and alluvial fine sand, silt, and clay, black loam, and sandy clay } \\
\text { Sand and gravel, coarse and fne, granitic minerals; upper part contains more fine sand } \\
\text { than lower part; some very fine zones and some coarse }\end{array}$ & 9 \\
clay, for the most part grayish brown, hard and very tough; contains thin streaks or \\
$\begin{array}{l}\text { zones of sand and gravel. } \\
\text { Shale, weathered brownish. somewhat calcareous (Pierre) }\end{array}$ & 74 \\
\hline
\end{tabular}

Test hole 5

[NW 14 sec. 14, T. 12 N., R. 10 W.; altitude, 1,872 feet above mean sea level; depth to water, 7.5 feet]

\begin{tabular}{|c|c|c|}
\hline $\begin{array}{l}\text { Sand, fine, uniform (dune sand) } \\
\text { Loess, yellowish, silty } \\
\text { Sand, mostly medium to fine, a few coarser lavers } \\
\text { Sand and gravel, granitic, mostly sand; gravel is fine-textured }\end{array}$ & $\begin{array}{r}3 \\
8 \\
89 \\
3\end{array}$ & $\begin{array}{r}3 \\
11 \\
100 \\
103\end{array}$ \\
\hline $\begin{array}{l}\text { Sand, fine, calcareous, buff brown and grayish white, more or less indurated, hard and } \\
\text { soft layers (Ogallala) }\end{array}$ & 20 & 123 \\
\hline $\begin{array}{l}\text { Shale, greenish gray, soapy when wet, noncalcareous, some gypsum (Pierre) } \\
\text { Shale, black, noncalcareous, soft, soapy; lower part contains yellowish and whitish } \\
\text { "curds" of soaplike material; some masses of soft ocherous yellow material; lower } 1 \text { foot }\end{array}$ & 3 & 126 \\
\hline $\begin{array}{l}\text { is brown (Pierre) } \\
\text { Shale, gray, sornewhat calcareous, hard (Pierre) }\end{array}$ & $\begin{array}{r}16 \\
5\end{array}$ & $\begin{array}{l}142 \\
147\end{array}$ \\
\hline
\end{tabular}

Test hole 7

[ Northwest corner of sec. 29, T. 13 N., R. 10 W.; altitude, 1,890 feet above mean sea level; depth to water, 12.3 feet]

Sand and soil; 8 inehes of dark sandy loam at top; remainder is fine quartz sand except a

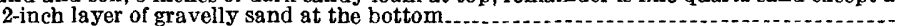
Clay, yellowish at the top and gray lower down; looks much like loess clay; friable, somewhat sandy
Sand. gray, medium to fine texture: lower part contains admixture of coarser sand and fine gravel Sand, gray, fine to coarse; fine gravel, coarser-and finer-layered; lower 2 feet somewhat Sreenish; thin clay layer at the bottom

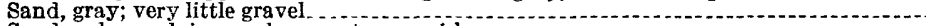
Sand and gravel, in equal amounts, greenish gray.

Gravel, coarse; some sand.

Sand and gravel, coarse granitic gravel; lower 11 feet coarse gravel

Sand, fine, greenish gray and whitish, indurated with calcium carbonate in a "limy grit", hard and soft layers. much silt and some clay (Ogallala) Shale, whitish to dark bluish gray, sticky, tough; some parts ocherous yellow, somewhat calcarerus (Pierre)

\begin{tabular}{r|r}
2 & 2 \\
7 & 9 \\
19 & 28 \\
27 & 55 \\
12 & 67 \\
7 & 74 \\
11 & 85 \\
11 & 96 \\
16 & 112 \\
45 & 157 \\
10 & 167 \\
\hline
\end{tabular}

\section{Test hole 6}

[SW1/4 SW1/4 sec. 7, T. 13 N., R. 10 W.; altitude, 1,837 feet above mean sea level; depth to water, 4.8 feet]

\begin{tabular}{l|r|r}
\hline Soil and fine sand; 8 inches of black sandy loam; remainder fine quartz sand & $\mathbf{7}$ \\
Sand and gravel, coarse and fine, grayish & 7 \\
Sand, silt, and clay, coarser and finer, hard and soft; some layers indurated, gray or gray- & 15 & 22 \\
ish white (Ogallala) & 97 & 129 \\
Shale, hard, soapy when wet, light yellowish to ocherous (Pierre) & 5 & 134 \\
\hline
\end{tabular}

\section{Dannebrog oil well 1}

[Center of south side of sec. 2, T. 13 N., R. 11 W.; altitude, 1,852 feet above mean sea level; drilled with standard equipment in 1899]

Loess clay; lower 4 feet sandy-
Clay, sandy, red
Sand and gravel
Clay, yellow and darker.
Sand and gravel
'Limerock", sandy, "sandstone", and sand, hard and soft (Ogallala)
Shale (Pierre)
Niobrara formation.
Carlile formation.

${ }^{1}$ See Condra, G. E., Schramm, E. F., and Lugn, A. L., Deep wells of Nebraska: Nebraska Geol. Survey, 2d ser., Bull. 4, pp. 259-260 (location incorrectly given), 1931: also Geol. Survey Prof. Paper 32, pp. 278279, 1905. 
Logs of test holes near Grand Island-Continued

\author{
Test hole 8
}

[SE1/4 NW1/4 sec. 17, T. 11 N., R. 8 W .; altitude, 1,820.(?) feet above mean sea level; depth to water, 4.5 feet]

\begin{tabular}{|c|c|c|}
\hline & $\begin{array}{c}\text { Thick- } \\
\text { ness } \\
\text { (feet) }\end{array}$ & $\begin{array}{l}\text { Depth } \\
\text { (feet) }\end{array}$ \\
\hline 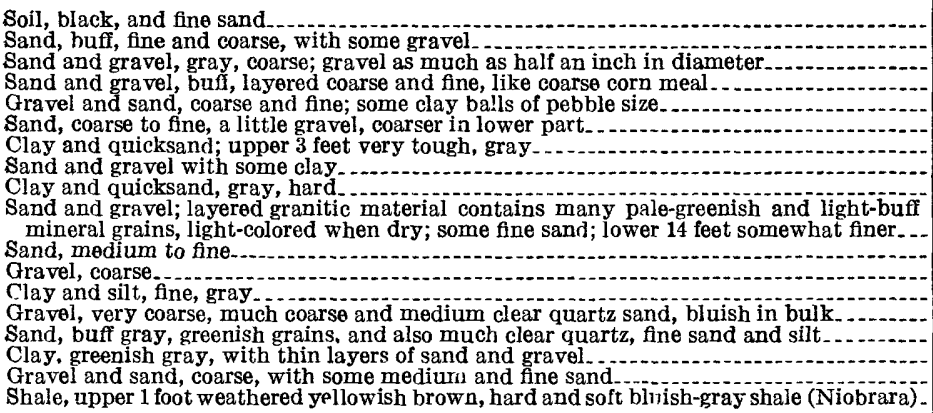 & $\begin{array}{r}1 \\
9 \\
6 \\
16 \\
2 \\
5 \\
22 \\
4 \\
5 \\
\\
29 \\
1 \\
4 \\
1 \\
5 \\
2 \\
5 \\
9 \\
17\end{array}$ & $\begin{array}{r}1 \\
10 \\
16 \\
32 \\
34 \\
39 \\
61 \\
65 \\
70 \\
99 \\
100 \\
104 \\
105 \\
110 \\
112 \\
117 \\
126 \\
143\end{array}$ \\
\hline
\end{tabular}

\title{
Test hole 40
}

[NE1/4 sec. 19, T. 10 N., R. 10 W.; altitude, 1,904 feet above mean sea-level; depth to water, 6 feet]

Soil, loose, silty, sandy, light brown.

Gravel and sand, coarse and fine interbedded, mostly cornmeal size, much sand, pink-

ish red.

Clay, soft, silty, sandy, gummy, dark brown.

Sand and gravel, containing much fine sand

rlay, soft, silty, sandy, gray

Sand and gravel, fine gravel with much sand, very compact

Shale, bright ocher yellow, hard, calcareous, darker below (Pierre)

\section{Logs of test holes near Wood River}

\section{Test hole 26}

[SE1/4 SW1/4 sec. 9, T. 8 N., R. 11 W.; altitude, 2,039 feet above mean sea level; depth to water, about 120 feet]

Clay, yellow sandy loess (Peorian)
Clay and sand, mixed.
Clay, yellow and slightly sandy
Clay, yellow and grayish
Clay, yellow, sandy, and soft

\section{Test hole 25}

[NW1/4NE1/4 sec. 20, T. 9 N., R. 11 W.; altitude, 1,955 feet above mean sea level; depth to water, 2 feet

Soil, light-brown friable sandy loam

Clay, grayish and brown, very silty, slightly calcareous; some fine sand; lower part more sandy, soft.

Sand and fine gravel.

Clay, light gray, uniform, soft; some silt and fine sand

Gravel, light-colored, fairly coarse, granitic, fairly clean and fresh

Clay, dark brown, sandy.-

Gravel and sand, very coarse

Silt and fine sand. This bed is reworked material and consists of silt with clay; upper 5 feet contains some sand and gravel; color mostly brow uish or gray; some of the sand grains have frosted surfaces; lower part cemented with calcium carbonate (Ogallala)-

Fine sand and grit, hard calcareous grit and softer sandy-silt layers; some of the hard

layers are pure white and very hard, almost limestone (Ogallala).

\begin{tabular}{r|r}
2 & 2 \\
23 & 25 \\
20 & 45 \\
2 & 47 \\
1 & 48 \\
12 & 60 \\
2 & 62 \\
18 & 80 \\
& \\
30 & 110 \\
43 & 153 \\
\hline
\end{tabular}




\section{Logs of test holes near Wood River-Continued}

\section{Test hole 24}

[SW 1/4SW1/4 sec. 5, T. 9 N., R. 11 W.; altitude, 1,959 feet above mean sea level; depth to water, 75 feet]

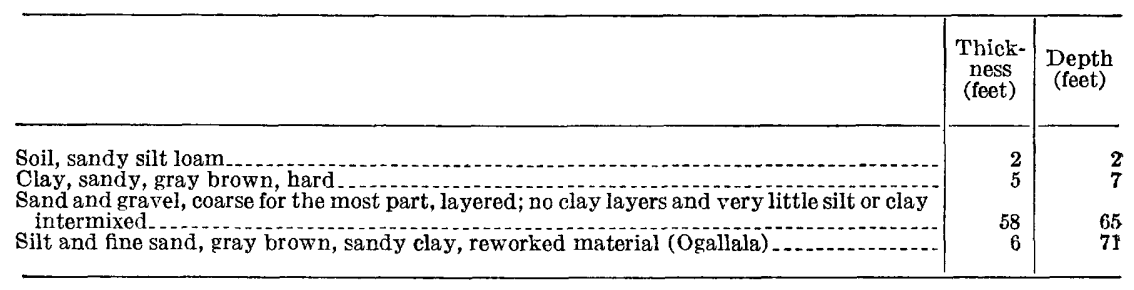

Test hole 21

[NW1/4NE1/4 ser, 25, T. 10 N., R. 12 W.; altitude, 1,968 feet above mean sea level; depth to water, about 12 feet]

Soil, dark sandy silty loam

Clay, brown, compact.

Gravel, coarse; some interbedded coarse sand

Gravel, coarse; some interbedded coarse sand

Gravel and clay, similar to bed above, but contains much clay -

Gravel and sand, coarse

Clay, dark brown, sandy, silty, slightly calcareous, reworked material (Ogallala) ......

\section{i'est hole 22}

[SW $1 / 4$ SW $1 / 4$ sec. 22 , T. 10 N., R. 12 W.; altitude, 1,975 feet above mean sea level; depth to water, 25 to 30 feet]

Soil, light gray-brown sandy clay loam

Loess, light-yellowish silty clay-

Sand and gravel undifferentiated, for the

Calcareous sandy silt, with some clay: soft silty part coarse, pinkish

lower part; the upper 25 to 30 feet softer, browner, and reworked (Ogallala).

\section{Test hole 23}

[SE $1 / 4 \mathrm{NE} / 4$ sec. 23, T. 11 N., R. 12 W.; altitude, 1,975 feet above mean sea level; depth to water, 30 feet]

Soil, brown sandy silt loam

Clay, hard, brown, silty, probably alluvium

Clay, bluish green, slightly calcareous, silty, hard

Sand and gravel, coarse gravel and some sand.

(1)

Silt, fine sand, and some clay; reworked material (Ogallala)

Silt, fine sand, some clay, calcareous, transitional (Ogallala)

Silt, sand, calcareous grit, soft and hard layers, in place (Ogallala)

\section{Test hole 41}

[Southeast corner of sec. 14, T. 9 N., R. 13 W.; altitude, 2,008 feet above mean sea level; depth to water, 4 feet]

Soil, black silty alkaline "hardpan".

Clay, gray brown, silty, compact.-

Sand and gravel, coarse gravel, little intermixed sand

Clay, compact and tenacious, silty and slightly sandy, gray

Gravel, coarse and fine interlavered, some sand

Clay, silty, calcareous, yellowish to gray brown (Ogallala)

\begin{tabular}{r|r|r}
3 & 3 \\
2 & 5 \\
16 & 51 \\
5 & 26 \\
16 & 42 \\
23 & 65
\end{tabular}

\section{Logs of test holes near Gibbon}

\section{Test hole 20}

[SW1/4SW1/4 sec. 17, T. 8 N., R. 13 W.; altitude, 2,052 feet above mean sea level]

Soil and alluvium, light-brown sandy loam.

Sand and gravel, fairly coarse; some intermixed clay; lower 10 feet somewhat finer in texture with more sand.-

Clay, brownish, fairly soft-

Sand and gravel.

Sand and gravel

Clay and silt, soft, gray, reworked material (Ogallala)

Grit, hard and soft, calcareous, fine sand, silt, and some clay (Ogallala)

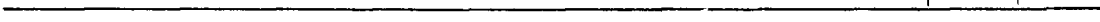




\section{Logs of test holes near Gibbon-Continued}

\section{Test hole 19}

[NE1/4 sec. 7, T. 8 N., R. 13 W.; altitude, 2,049 feet above mean sea level; depth to water, 5.4 feet]

\begin{tabular}{|c|c|c|}
\hline & $\begin{array}{c}\text { Thick- } \\
\text { ness } \\
\text { (feet) }\end{array}$ & $\begin{array}{c}\text { Depth } \\
\text { (feet) }\end{array}$ \\
\hline 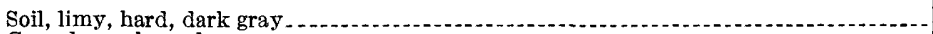 & 4 & \\
\hline Gravel, much sand. & 12 & 16 \\
\hline Gravel, coarse & 4 & 20 \\
\hline Gravel, medium coarse & 19 & 39 \\
\hline Gravel and sand & 12 & 51 \\
\hline Gravel, very coarse & 2 & 53 \\
\hline Gravel, medium coarse & 4 & 57 \\
\hline Gravel, some intermixed clay & 3 & 60 \\
\hline Gravel, coarse. & 8 & 68 \\
\hline Gravel and fine sand. & 4 & \\
\hline Gravel, coarse. & 2 & \\
\hline Sand, fine. & 10 & 84 \\
\hline Sand, very fine "quicksand", quartz & 51 & 135 \\
\hline Calcareous grit, hard and soft layers (Ogallala) & 22 & 157 \\
\hline
\end{tabular}

\section{Test hole 18}

[NE1/4NW1/4 sec. 25, T. 9 N., R. 14 W.; altitude, 2,055 feet above mean sea level]

Soil, black silty loam

Clay, brown, tough, hard

Gravel and sand, coarse, mostly gravel.

Sand, uniform medium sand.

Gravel and sand, mostly fine gravel.

Gravel, very coarse

Silt, sandy, light brown, hard, reworkd material (O)aila)

Clay and sandy grit, grayish to brownish soft layers and hard whitish beds of calcareous sandy grit (Ögallala)

\begin{tabular}{r|r}
1 & 1 \\
2 & 3 \\
13 & 16 \\
9 & 25 \\
22 & 47 \\
1 & 48 \\
10 & 58 \\
37 & 95 \\
78 & 173 \\
\hline
\end{tabular}

\section{Test hole 16}

[NE1/4NE1/4 sec. 14, T. 9 N., R. 14 W.; altitude, 2,063 feet above mean sea level]

Soil and clay, grayish-yellow loesslike clay, 6 inches of brown loam soil .

Sand, fine, well rounded.

Sand and fine gravel.

Gravel, very coarse, much sand

Gravel, fine, much sand.

Gravel and sand, layers of coarse and fine

Gravel and sand, layers of coarse and fine.........................

Clay and silt, brown, compact, sandy, reworked material (Ogallala)

Clay, silt, and whitish-gray and white calcareous grit (Ogallala).

\begin{tabular}{r|r}
8 & 8 \\
9 & 17 \\
8 & 25 \\
13 & 38 \\
2 & 40 \\
27 & 67 \\
6 & 73 \\
32 & 105 \\
\hline
\end{tabular}

\section{Test hole 17}

[NW1/4SW1/4 sec. 36, T. 10 N., R. 14 W.; altitude, 2,082 feet above mean sea level]

Soil, black loam

Loess, light yellowish gray, soft; may be in part reworked from the bigher slopes

Clay, dark bluish green, very hard, somewhat calcareous; much silt.

Gravel, gray green.

Gravel, fairly coarse, pinkish

Gravel, coarse, very little sand

Silt, fine sand, calcareous grit, hard and soft layers, gray to white (Ogallala)

\section{Test hole 42}

[Northwest corner of sec. 2, T. 8 N., R. 15 W.; altitude, 2,110 feet above mean sea level]

Soil, fine, silty, buff

Unusually coarse, clean gravel.

Calcareous grit, hard and soft, silty, sandy, light gray or whitish (Ogallala)

\begin{tabular}{r|r}
3 & 3 \\
55 & 58 \\
22 & 80 \\
\hline
\end{tabular}




\section{Logs of test holes near Kearney}

\section{Test hole 10}

[NE1/4SE1/4 sec. 1, T. 7 N., R. 17 W.; altitude, 2,183 feet above mean sea level; depth to water, 19.4 feet]

\begin{tabular}{|c|c|c|}
\hline & $\begin{array}{c}\text { Thick- } \\
\text { ness } \\
\text { (feet) }\end{array}$ & $\begin{array}{l}\text { Depth } \\
\text { (feet) }\end{array}$ \\
\hline $\begin{array}{l}\text { Sand, very fine dune sand, gray, well rounded, frosted surfaces, mostly quartz } \\
\text { Sand and gravel, granitic minerals, coarse and fine, bedded; some gravel but mostly } \\
\text { medium-textured sand } \\
\text { Gravel, clean, fine to fairly coarse. } \\
\text { Gravel, clean, fine; contains some sand and fragments of "limy grit" } \\
\text { Sand, gray, rounded, quartz..... } \\
\text { Clay, greenish gray; contains much silt and fine sand, limy grit fragments and slightly } \\
\text { calcareous, soft (reworked Ogallala) } \\
\text { Grit, calcareous, grayish green, friable, silty and sandy, leached of most of its calcium } \\
\text { carbonate (Ogallala) }\end{array}$ & $\begin{array}{r}19 \\
31 \\
23 \\
7 \\
5 \\
20 \\
17\end{array}$ & $\begin{array}{r}19 \\
50 \\
73 \\
80 \\
85 \\
105 \\
122\end{array}$ \\
\hline
\end{tabular}

Test hole 9

[Northeast corner of sec. 25, T. 8. N., R. 17 W.; altitude, 2,177 feet above mean sea level; depth to water, 7.9 feet]

Sand, medium and coarse

Sand and clay

Gravel, fine sand.

Sand, coarse and fine, some gravel

Clay, brownish, very soft, friable, silty, sandy, slightly calcareous (reworked ogallala)

Grit, calcareous, sandy, silty, hard and soft layers, greenish gray to white, crumbly and upper part much leached; some very hard "limestone" layers; some zones contain much clay (Ogallala).

Test hole 141

[Southeast corner of sec. 12, T. 8 N., R. 17 W. altitude, 2,174 feet above mean sea level; depth to water, 5 feet]

Soil and alluvium, sandy, silty black loam

Sand and gravel, coarse and fine...

Calcareous, sandy, brown silt (reworked Ogallala?)

1 Determinations of permeability and specific yield were made on the material taken from this hole (p. 92).

\section{Test hole 11}

[NW1/4SW1/4 sec. 8, T. 8 N., R. 16 W.; altitude, 2,173 feet above mean sea level; depth to water, 4 feet]

Soil and fine sand.

Sand and gravel, coarse and fine

Grit, calcareous, light gray, soft and hard; lala)

\section{Test hole 13}

[NW1/4NE1/4 sec. 6 , T. 8 N., R. 16 W.; altitude, 2,212 feet above mean sea level; depth to water, about 17 feet]

Soil, black sandy loam.

Clay, reddish brown, hard; lower part more or less calcareous

Grit, hard and soft calcareous layers, sandy, silty, grayish green to white (Ogallaia)

\begin{tabular}{ll|l|r} 
& 42 & 90 \\
\hline
\end{tabular}

\section{Test hole 12}

[SE1/4SE1/4 sec. 25, T. 9 N., R. 17 W.; altitude, 2,260 feet above mean sea level; depth to water about 80 feet]

Clay, red; some fine sand and silt

Clay, reddish but lighter than bed above, somewhat calcareous and coneretionary

Clay, light brownish, calcareous, sandy

Gravel, medium-texture, sandy; some clay and somewhat calcareous

Grit, light brownish gray, greenish, and white, hard and soft, fine and coarse sandy grit layers, and many thin beds of hard white "limestone", all calcareous (Ogallala)

\begin{tabular}{r|r}
3 & 3 \\
35 & 38 \\
10 & 48 \\
42 & 90 \\
\hline
\end{tabular}




\section{Logs of test holes near Kearney-Continued}

Test hole 15

[NE1/4 sec. 33, T. 9 N., R. 17 W.; altitude, 2,237 feet above mean sea level; depth to water, about 20 feet]

Clay, reddish brown; lower 10 feet hard and calcareous

Gravel, medium coarse.

Gravel, very coarse.

Gravel, medium

Clay, brown, calcareous (Ögaliala)

Grit, calcareous; clay at base (Ogallala)

Grit and limestone, harder and softer layers; some clay (Ogallala).

\begin{tabular}{|r|r}
$\begin{array}{c}\text { Thick- } \\
\text { ness } \\
\text { (feet) }\end{array}$ & $\begin{array}{r}\text { Depth } \\
\text { (feet) }\end{array}$ \\
\hline & \\
38 & 38 \\
2 & 40 \\
2 & 42 \\
6 & 48 \\
25 & 73 \\
36 & 109 \\
22 & 131 \\
\hline
\end{tabular}

\section{Logs of test holes near Elm Creek}

Test hole 45

[NE $1 / 4$ NW1/4 sec. 9, T. 7 N., R. 18 W.; altitude 2,350 feet above mean sea level]

\begin{tabular}{|c|c|c|}
\hline $\begin{array}{l}\text { Soil. } \\
\text { Loess, red; } 3 \text { feet of soil at top. } \\
\text { Clay, gray, silty } \\
\text { Fine sand with } 2 \text { feet of coarse gravel at the base brownish. } \\
\text { Gravel. }\end{array}$ & $\begin{array}{r}2 \\
30 \\
15 \\
15 \\
32 \\
8 \\
6\end{array}$ & $\begin{array}{r}2 \\
32 \\
47 \\
62 \\
94 \\
102 \\
108\end{array}$ \\
\hline
\end{tabular}

Test hole 44

[NE1/4NW1/4 sec. 21, T. 8 N., R. 18 W.; altitude, 2,245 feet above mean sea level]

Soil.

Clay, dark grayish brown, sticky and gummy, silty.

Sand and gravel, very coarse; reddish-pink gravel, some sand; bed of cobujestones at

to 47 feet. very calcareous, hard, silty (Ogallala)

\section{Test hole 43}

[Southeast corner of NW1/4 sec. 4, T. 8 N., R. 18 W.; altitude, 2,246 feet above mean sea level]

Soil, silty, sandy, light buff.

Clay, mouse gray, silty, compact

-

gravel, very coarse, reddish pink _.

Grit and clay (Ogallala)

\begin{tabular}{r|r|r}
-- & 2 & 2 \\
-- & 5 & 7 \\
18 & 25 \\
7 & 32 \\
\hline
\end{tabular}

\section{Test hole 46}

[Northwest corner of sec. 27 , T. 9 N., R. 18 W.; altitude, 2,263 feet above mean sea level]

Soil, soit, coherent, silty, sandy brownish loam.

Clay, soft but compact, uniform, grayish brown, silty; clay may be in part reworked; lower 2 feet gray and harder

Gravel, coarse, and sand.

Grit, calcareous, silty, sandy (Ogallala)

\begin{tabular}{r|r|r}
\hline$;$ & 2 & 2 \\
- & 23 & 25 \\
10 & 35 \\
35 & 70 \\
\hline
\end{tabular}

\section{Logs of test holes near Overton}

Test hole 82

[Southeast corner of NW1/4 sec. 13, T. 8 N., R. 20 W.; altitude, 2,302 feet above mean sea level]

Soil, tough, black, silty and sandy, alkaline.
Clay, sticky, silty, light yellowish,
Gravel and clay, fine gravel embedded in silty clay,
Gravel, coarse, reddish pink, and sand
Clay and grit, gray to white, calcareous, silty, sandy, hard and soft (Ogallala)




\section{Logs of test holes near Overton-Continued}

\section{Test hole 81}

[Southeast corner of sec. 36, T. 9 N., R. 20 W.; altitude, 2,309 feet above mean sea level]

\begin{tabular}{|c|c|c|}
\hline & $\begin{array}{c}\text { Thick- } \\
\text { ness } \\
\text { (feet) }\end{array}$ & $\begin{array}{c}\text { Depth } \\
\text { (feet) }\end{array}$ \\
\hline $\begin{array}{l}\text { Soil and alluvium, black, silty, gummy, alkaline } \\
\text { Clay, light yellowish, silty, soft, sticky } \\
\text { Clay, gray, tough, gummy } \\
\text { Sand and gravel, fine gravel with much sand, well rounded } \\
\text { Clay and grit, light gray, soft, calcareous, silty, and much fine sand (Ogallala) }\end{array}$ & $\begin{array}{r}9 \\
3 \\
1 \\
26 \\
11\end{array}$ & $\begin{array}{r}9 \\
12 \\
13 \\
39 \\
50\end{array}$ \\
\hline
\end{tabular}

\section{Test hole 80}

[Southeast corner of SW1/4 sec. 6, T. 9 N., R. 19 W.; altitude, 2,321 feet above mean sea level]

\begin{tabular}{|c|c|c|}
\hline $\begin{array}{l}\text { Soil and alluvium, gray, silty, soft } \\
\text { Loess, yellowish-grav silt and clay } \\
\text { Gravel, coarse and fine, reddish pink }\end{array}$ & $\stackrel{4}{4}$ & $\begin{array}{r}4 \\
8 \\
30\end{array}$ \\
\hline $\begin{array}{l}\text { Clay and silt, some fine sand, hard and soft, brownish to gray; lower } 6 \text { feet compact, } \\
\text { hard, gray, and very calcareons (Ogallala) }\end{array}$ & 12 & 42 \\
\hline
\end{tabular}

\section{Test hole 79}

[NW1/4NW1/4 sec. 20, T. 9 N., R. 20 W.; altitude, 2,349 feet above mean sea level]

Soil and allnvium, dark-brown to grayish sandy loam

Clay, gray, compact, sticky, smooth...

Gravel, coarse, reddish pink, some sand

Clay and grit, soft and hard, brownish to gray, silty, sandy, more or less calcareous

(Ogallala)

\section{Logs of test holes near Lexington}

\section{Test hole 89}

[SE $1 / 4$ sec. 16, T. 8 N., R. 21 W.; altitude, about 2,400 feet above mean sea level]

Loess, compact, tough yellowish silty clay $\ldots \ldots \ldots \ldots \ldots \ldots \ldots \ldots \ldots$
Gravel, coarse and fine.

Test hole 90

[SW1/4 sec. 21, T. 8 N., R. 21 W., in Plum Creek Valley; altitude, about 2,415 feet above mean sea level]

Loess, yellowish compact silty clay

Gravel, coarse and fine; some sand.

Clay and grit, compact, gray, silty, calcareous (Ogallala)

Test hole 78

[Southwest corner of sec. 31, T. 9 N., R. 21 W.; altitude, 2,440 feet above mean sea level]

Soil, gray, silty

Loess, light yellowish, silty, compact.

Soil, brow nish black, silty, carbonaceous.

Sand and gravel, coarse, reddish pink

\begin{tabular}{r|r}
7 & 7 \\
7 & 14 \\
22 & 36 \\
16 & 52 \\
\hline
\end{tabular}

ב_.

\section{Test hole 77}

[Southeast corner of NE1/4 sec. 12, T. 9 N., R. 22 W.; altitude, 2,408 feet above mean sea level]

Soil and alluvium, sticky silty alkaline clay.

Sand and gravel, coarse for the most part, reddish pink

Clay, silt, and grit, hard and soft, calcareous (Ogallala)

\begin{tabular}{r|r}
9 & 9 \\
21 & 30 \\
15 & 45
\end{tabular}




\section{Logs of test holes near Lexington-Continued}

\section{Test hole 76}

[NE1/4SE1/4 sec. 24, T. 10 N., R. 22 W.; altitude, 2,423 feet above mean sea level]

\begin{tabular}{|c|c|c|}
\hline & $\begin{array}{l}\text { Thick- } \\
\text { ness } \\
\text { (feet) }\end{array}$ & $\begin{array}{l}\text { Depth } \\
\text { (feet) }\end{array}$ \\
\hline $\begin{array}{l}\text { Soil, gray, silty } \\
\text { Clay, mouse gray, sticky, compact, alkaline. } \\
\text { Sand and gravel. } \\
\text { Clay and grit, hard and soft, calcareous (Ogallala) }\end{array}$ & $\begin{array}{r}2 \\
12 \\
23 \\
16\end{array}$ & $\begin{array}{r}2 \\
14 \\
37 \\
53\end{array}$ \\
\hline
\end{tabular}

\section{Test hole 75}

[Northeast corner of SE1/4 sec. 12, T. 10 N., R. 22 W.; altitude, 2,441 feet above mean sea level]

Soil, black silty loam.

Loess, yellowish gray, silty

Sand and gravel, reddish pink, much sand, granitic minerals

Clay and grit, gray, calcareous, hard and soft, silty (Ogallala)

\begin{tabular}{r|r}
2 & 2 \\
23 & 25 \\
19 & 44 \\
16 & 60 \\
\hline
\end{tabular}

\section{Test hole 74}

[Southwest corner of sec. 25 , T. 11 N., R. 22 W.; altitude 2,478 feet above mean sea level]

Soil, gray, silty

Loess, yellowish silty clay

Clay, greenish gray, compact, silty

Sand and gravel, coarse and fine, granitic minerals.

Clay, grayish, and gravel, sandy (Ogallala?)

Clay and grit, hard and soft, gray to white, calcareous, sandy (Ogallala)

\section{Test hole 73}

Southwest corner of sec. 20 , T. 10 N., R. 22 W.; altitude, 2,444 feet above mean sea level]

Soil and alluvium, grayish brown, silty

Silt, brown, compact, sandy

Clay and grit, soft and hard, brownish to light-gray calcareous silty sand (ögailaia) ......

\begin{tabular}{r|r}
2 & 2 \\
43 & 45 \\
10 & 55 \\
10 & 65 \\
10 & 75 \\
7 & 82 \\
\hline
\end{tabular}

Clate

\section{Logs of test holes near Cozad}

Test hole 72

[Southeast corner of SW1/4 sec. 26, T. 10 N., R. 24 W.; altitude, 2,538 feet above mean sea level]

Soil, gray, silty, loose

Clay and silt, reworked silty loess clay

Loess, yellowish silty clay

Sand and gravel

ay, grayish brown, compact, silty; some fine sand

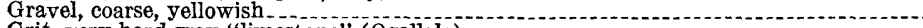

Grit, very hard gray "limestone" (OgallaIa)

\section{Test hole 71}

[SW1/4NW1/4 sec. 24, T. 10 N., R. 24 W.; altitude, 2,496 feet above mean sea level]

Soil, black, sandy

Loess, yellowish gray, silty

Gravel and sand, medium texture

Chalky

\begin{tabular}{r|r}
10 & 10 \\
3 & 33 \\
28 & 41 \\
15 & 56 \\
\hline
\end{tabular}




\section{Logs of test holes near Cozad-Continued}

Test hole 70

[Southeast corner of sec. 36, T. 11 N., R. 24 W.; altitude, 2,492 feet above mean sea level]

\begin{tabular}{l|r|r}
\hline & $\begin{array}{c}\text { Thick- } \\
\text { ness } \\
\text { (feet) }\end{array}$ & $\begin{array}{c}\text { Depth } \\
\text { (feet) }\end{array}$ \\
\hline Soil, black, sticky, alkaline. & & 4 \\
Clay, mouse gray, sticky. .10 & 4 \\
Sand and gravel & 19 \\
Clay and grit, silty "magnesia rock" (Ogallala) & 13 \\
\hline
\end{tabular}

Test hole 69

[Northwest corner of NE14 sec. 19, T. 11 N., R. 23 W.; altitude, 2,535 feet above mean sea level]

Soil, gray, silty

Loess, yellowish-gray silty clay

Clay, very compact, sticky, dark bluish gray, soar greenish

Gravel.

Clay, grit, silty, sandy (Ogallala)

a)

Clay, pink, compact and hard, silty (Brule)

\section{Test hole 68}

[Southwest corner of sec. 29 , T. 11 N., R. 24 W.; altitude, 2,525 feet above mean sea level]

Soil and alluvium, brownish-black sandy silt

Sand and gravel, coarse and fine

Grit, hard calcareous fine sand, and "magnesia rock" (Ogalog)

Clay, hard,

lay, hard, pinkish red, silty; some fine sand (Brule)

Test holes 85-88 were drilled from tableland levels on the loess plain southwest of Cozad and Gothenburg.

\section{Logs of test holes near Gothenburg \\ Test hole 87}

[Northwest corner of sec. 5, T. 8 N., R. 26 W., about 41/2 miles west of Farnam; altitude, about 2,640 feet above mean sea level]

Loess, yellowish-gray silty clay

Soil, an old black alkaline soil zone

Loess, yellowish-gray silty clay.

Clay, silt, and calcareous grit (Ogallala)

Clay, pink, hard, silty (Brule)...

\begin{tabular}{r|r}
2 & 2 \\
40 & 42 \\
5 & 47 \\
17 & 64 \\
14 & 78 \\
2 & 80 \\
\hline
\end{tabular}

\begin{tabular}{l|l|} 
& 85 \\
\hline
\end{tabular}

Test hole 86

[Southwest corner of NW1/4 sec. 36, T. 9 N., R. 26 W., about 11/2 miles west of Farnam; altitude. ahnit 2,740 feet above mean sea level]

Soil, black, tough, silty

Loess, yellowish-gray silty clay

Clay, silty, sandy, and calcareous grit, hard and soft (Ogallala)

Test hole 85

[SW $1 / 4$ SW $1 / 4$ sec. 22, T. 9 N., R. 25 W., $2 \frac{1}{2}$ miles east and 2 miles north from Farnam; altitude, 2,720 feet above mean sea level]

Loess, yellowish-gray silty clay

Loess, hard red silty clay

Calcareous grit and silty clay, conglomeratic at the base, hard and soft layers (Ogailala)

Clay, compact, silty, pink (Brule). 


\section{Logs of test holes near Gothenburg-Continued}

\section{Test hole 88}

[Northwest corner of SW1/4 sec. 5, T. 9 N., R. 25 W., about 51/2 miles north of Farnam; altitude, 2,820 feet above mean sea level]

\begin{tabular}{l|c|c|c|c|c}
\hline & $\begin{array}{c}\text { Thick- } \\
\text { ness } \\
\text { (feet) }\end{array}$ \\
\hline Loess, yellowish -gray silty clay \\
(feet)
\end{tabular}

\section{Test hole 65}

[Southeast corner of NW1/4 SE1/4 sec. 5, T. 10 N., R. 25 W.; altitude, 2,635 feet above mean sea level]

Soil and reworked alluvial loess and slope wash

Loess, yellowish silty soft clay, slightly sandy in some zones

Soil, black, silty, compact, alkaline, hard.

Clay and silt, grayish green, compact, hard, slightly sandy

Gravel and sand, with much silt and clay.

Silty, sandy grit and silty clay, hard and soft layers (Ogallala)

Test hole 66

[Southwest corner of $\mathrm{SE} 1 / 4 \mathrm{SW} 1 / 4$ sec. $21, T .11 \mathrm{~N} ., \mathrm{R} .25 \mathrm{~W}$; altitude, 2,565 feet above mean sea level]

\begin{tabular}{|c|c|c|}
\hline Soil, grayish-brown silty, sandy loam & 3 & \\
\hline Clay, gray, compact, tough, silty ..... & 13 & 16 \\
\hline Sand and gravel & 13 & 29 \\
\hline Silty, sandy calcareous grit (Ogallala) & 8 & 37 \\
\hline Clay, pinkish red and grayish green, hard, slightly calcareous, silty (Brule) & 10 & 47 \\
\hline Chalky shale, compact, massive, grayish green (Niobrara) & 14 & 61 \\
\hline
\end{tabular}

\section{Test hole 67}

[Southwest corner of NW1/4NW1/4 sec. 9, T. 11 N., R. 25 W.; altitude, 2,568 feet above mean sea level]

Soil, sandy

Clay, bluish gray to greenish, tough, sticky, silty, alkaline

Sand and gravel

Calcareous grit and sandy silt, hard and soft layers (Ogallaia)

\section{Test hole 64}

[Southeast corner of sec. 10, T. 11 N., R. 26 W.; altitude, 2,588 feet above mean sea level]

Soil, black sticky "gumbo", alkaline

Loess clay, reworked

Gravel and sand, pinkish, very coarse.

Clay, reddish and brown, hard, silty; some fine sand (Brule)

Gravel and sand in silt (Brule?, Chadron?)

Chalky shale white, light gray, and brownish; hardina

chalk zones and softer calcareous

shale beds (Niobrara)

\begin{tabular}{r|r}
2 & 2 \\
10 & 12 \\
17 & 29 \\
13 & 42 \\
\hline
\end{tabular}
. 


\section{Logs of test holes near Brady Island-Continued}

\section{Test hole 63}

[Southeast corner of sec. 28, T. 12 N., R. 27 W.; altitude, 2,656 feet above mean sea level]

Soil, dark gray, compact

Loess, yellowish gray compact silty clay

Clay, greenish, compact, very silty, and some fine sand; has thick black gummy, silty, sandy soil at top.

Gravel and much sand.

Sandy, silty clay, calcareous (Ogallaia)

Clay, hard, reddish brown, silty (Brule)

Fine gravel and sand in matrix of silt and fine sand; much clay, mostly brownish and red

Shale, chalky and calcareous (Niobrara or Pierre?)

\begin{tabular}{|r|r}
$\begin{array}{c}\text { Thick- } \\
\text { ness } \\
\text { (feet) }\end{array}$ & $\begin{array}{c}\text { Depth } \\
\text { (feet) }\end{array}$ \\
\hline & 3 \\
3 & 18 \\
15 & 23 \\
5 & 33 \\
10 & 36 \\
3 & 56 \\
20 & \\
24 & 80 \\
40 & 120 \\
\hline
\end{tabular}

\section{Test hole 83}

[Southwest corner of sec. 2, T. 12 N., R. 27 W.]

Fine dune sand, gray

Gravel, coarse and fine

Silty, sandy clay and calcareous grit (Ogallaia)

\begin{tabular}{l|l}
12 & 12 \\
15 & 27 \\
33 & 60 \\
\hline
\end{tabular}

\section{Logs of test holes near Maxwell}

\section{Test hole 62}

[Southeast corner of SW1/4 sec. 6, T. 12 N., R. 28 W.; altitude, 2,754 feet above mean sea level]

\begin{tabular}{l|l|l}
\hline Loess, yellowish-gray silty clay, & 42 & 42 \\
Gravel, coarse, with much sand. & 58 \\
Silty sand, somewhat calcareous, harder and softer beds (Ogallala) & 16 & 50 \\
\hline
\end{tabular}

\section{Test hole 61}

[SW1/4NW1/4 sec. 33, T. 13 N., R. 28 W.; altitude, 2,710 feet above mean sea level; depth to water, 4 feet]

Soil, black silty, sandy "gumbo", alkaline

Sand and gravel, coarse and fine, granitic minerals

Clay, tough, dark brown, silty.

Fine gravel and much sand

Light-gray compact silty sandy clay and calcareous grit (Ogallala)

Clay, reddish, hard, silty; some layers grayish and brownish, somewhat calcareous (Brule)

Coarse reddish gravel and sand in silty calcareous matrix; hard silty clay in Iower 1 foot

(Chadron?)

(n)

\begin{tabular}{r|r}
4 & 4 \\
13 & 17 \\
1 & 18 \\
14 & 32 \\
3 & 35 \\
15 & 50 \\
11 & 61 \\
\hline
\end{tabular}

\section{Test hole 60}

[Southwest corner of sec. 15, T. 13 N., R. 28 W.; altitude, 2,731 feet above mean sea level]

Dune sand, fine, gray

Loess, soft grayish silty clay

Sand and gravel, granitic minerals

Silty, sandy clay and calcareous grit, soft and hard layers, white to gray (Ogallaia)

Clay, reddish to whitish and gray; some layers are calcareous; not very sandy, but some

silt zones (Brule)

Sandstone and shale or clay, gray, greenish gray, or white; interbedded sandstone and

chalk and shale, interbedded limestone and silty calcareous shale, gray and whitish

(Niobrara?, Pierre?)

\begin{tabular}{r|r}
7 & 7 \\
8 & 15 \\
8 & 23 \\
35 & 58 \\
27 & 85 \\
55 & 140 \\
40 & 180
\end{tabular}




\section{GROUND-WATER RESOURCES OF THE PLATTE RIVER VALLEY}

By L. K. WenzeL

\section{IRRIGATION IN THE PLATTE VALLEY}

In the part of the Platte River Valley covered by this reportfrom the vicinity of Chapman to the vicinity of Gothenburg-irrigation is practiced to some extent to supplement the rainfall, which in most years is inadequate for raising crops satisfactorily. In the part of the valley lying east of Kearney almost all of the irrigation water is pumped from wells, but in the part farther west water is largely obtained from the Platte River. On a few farms east of Kearney water is diverted from the Wood River, and on several farms west of Kearney wells are used for irrigation.

When Nebraska was rapidly settled in the eighties, it was thought that the precipitation was ample for crop requirements, and irrigation was discouraged. In conjunction with efforts to induce the farmers to raise sugar beets comparisons were made with the precipitation, and the conclusion was reached that irrigation in Nebraska was not required to insure regular production of crops. Many Nebraskans asserted that the agricultural reputation of the State would be ruined if it were found that irrigation is necessary. Many of the farmers had migrated from areas farther east, and in their minds irrigation was associated with desert regions, where people struggled along on a few acres of land to produce a scant living. Large farms were symbols of success, but large farms could not be readily irrigated. However, several periods of drought that occurred in the early nineties finally brought the farmers to the realization that, at least in such years, irrigation was a necessity, and as a result diversions from the Platte River were first made at that time. The yields of crops were so much increased by irrigation that sentiment was completely reversed, and many canals were constructed to lead the water out of the Platte River to the farms in the valley. In Dawson County alone during the 3 years 1894-96 nine canals were constructed with a total length of 219 miles to serve about 157,000 acres of land. ${ }^{28}$

It soon became apparent that during some years the Platte River does not carry enough water to supply the requirements of all irrigators. Irrigation has greatly increased in western Nebraska and in Wyoming and Colorado, and large quantities of water are diverted in these areas from the North and South Platte Rivers. During dry years, when snowfall in the mountains is light, the discharges of the North and South Platte Rivers are comparatively small and diversions from these rivers take most of their flow. Consequently, at

\footnotetext{
${ }^{28}$ Smith, H. O., History of irrigation in Dawson County: Nebraska State Board of Irrigation Rept., $1895-97$, p. 37, 1897.
} 
such times little water reaches the confluence of these streams, and even a part of that is lost by transpiration, evaporation, diversions, or seepage before it reaches the part of the valley described in this report. Several large reservoirs have been constructed on the headwaters of the North and South Platte Rivers to store a part of the flood flows of the streams and to distribute the flow better throughout the summer months. Even with this better distribution and some increase in flow derived from return flow from irrigated areas the amount of water in the Platte River during most years is considerably less than is required by irrigators in the Platte Valley.

Soon after irrigation with surface water was begun some farmers in the area began to use windmills to pump water for irrigation. According to Barbour ${ }^{29}$ many windmills were erected in the valley prior to 1900 and some of the water pumped by them was used for irrigation, from 1 to 50 acres being irrigated with the water from one mill. Most of the windmills used at that time were constructed locally and were of various shapes and sizes. Numerous schemes of irrigating were utilized, but the total acreage supplied with water pumped by windmills was small, and it became less as modern methods of well drilling were employed and efficient pumps and engines were introduced. At the present time there are many modern windmills in the valley, but these are used mostly for domestic purposes and stock and for irrigating small gardens.

With the advent of modern well-drilling methods and machinery more and more farmers in the valley turned to irrigation with water pumped from wells. In order to compute the total quantities of ground water withdrawn by pumping from wells, a canvass of pumping plants was made during this investigation. The number of irrigation wells completed each year is shown in the following table:

Irrigation wells in the Platte Valley

\begin{tabular}{|c|c|c|c|c|c|c|}
\hline $1893 \ldots \ldots$ & 1 & $1915 \ldots \ldots$ & 14 & 1921 & 14 & $1927 \ldots$ \\
\hline $1910 \ldots$ & 2 & $1916 \ldots$ & 7 & $1922 \ldots$ & 10 & 1928. \\
\hline $1911 \ldots \ldots$ & 3 & 1917 & 14 & $1923 \ldots \ldots$ & 10 & 1929 \\
\hline $1912 \ldots \ldots$ & 24 & $1918 \ldots \ldots$ & 21 & $1924 \ldots \ldots$ & 18 & 140 \\
\hline $1913 \ldots \ldots$ & 17 & $1919 \ldots \ldots$ & 9 & $1925 \ldots \ldots$ & 26 & $1931-32^{1} \ldots$ \\
\hline $1914 \ldots \ldots$ & 21 & $1920 \ldots$ & 16 & 1926 & 47 & Total_- \\
\hline
\end{tabular}

The number of wells completed has steadily increased, especially since 1926. The figure showing the number of wells completed in 1931 and 1932 is incomplete because the canvass was made during those years. Most of the wells drilled prior to about 1915 were located in the valley west of Kearney, but because during some years

${ }^{29}$ Barbour, E. H., Wells and windmills in Nebraska: Geol. Survey Water-Supply Paper 29, p. 31, 1899. 
surface water is available for irrigation in this area, the increase in pumping plants has not been rapid. East of Kearney, however, the amount of surface water available for irrigation is small and there has been a rapid increase in pumping plants. According to the census of 1930 about 75 percent of all irrigation pumping plants in Nebraska are in the Platte Valley between Chapman and Gothenburg.

The progress of irrigation with both surface and ground water has been erratic, because of the great variation in precipitation from year to year. In some years there has been ample rainfall to supply crop requirements, and irrigation ditches and pumping plants have been neglected. In recurring dry years many farmers have been unable to obtain sufficient water for crops because of the neglect of their irrigation facilities in previous years. The seasonal precipitation is often poorly distributed, and even in years of average rainfall there are periods of drought. Thus in 1930 the average of the precipitation at Grand Island, Kearney, Lexington, and Gothenburg was 140 percent of normal, but the distribution throughout the year was very poor, and little rain fell during the hot months of July and August. Smith ${ }^{30}$ recently compared the yield of corn on unirrigated land in Phelps and Kearney Counties with the annual precipitation and with the approximate rainfall during the growing season, as indicated in the following table:

Average precipitation at Minden and Holdredge and average yield of corn in Phelps and Kearney Counties, 1904-22

[Compiled by F. F. Smith]

\begin{tabular}{|c|c|c|c|c|c|c|c|}
\hline Year & $\begin{array}{l}\text { Annual } \\
\text { precipi- } \\
\text { tation } \\
\text { (inches) }\end{array}$ & $\begin{array}{l}\text { Approxi- } \\
\text { mate pre- } \\
\text { cipitation } \\
\text { in grow- } \\
\text { ing season } \\
\text { (inches) }\end{array}$ & $\begin{array}{l}\text { A verage } \\
\text { yield of } \\
\text { corn } \\
\text { (bushels } \\
\text { to the } \\
\text { acre) }\end{array}$ & Year & $\begin{array}{l}\text { Annual } \\
\text { precipi- } \\
\text { tation } \\
\text { (inches) }\end{array}$ & $\begin{array}{c}\text { Approxi- } \\
\text { mate pre- } \\
\text { cipitation } \\
\text { in grow- } \\
\text { ing season } \\
\text { (inches) }\end{array}$ & $\begin{array}{l}\text { Average } \\
\text { yield of } \\
\text { corn } \\
\text { (bushels } \\
\text { to the } \\
\text { acre) }\end{array}$ \\
\hline $\begin{array}{l}1904 \\
1905 \\
1906 \\
1907 \\
1908 \\
1910 \\
1911 \\
1912\end{array}$ & $\begin{array}{l}24.3 \\
37.5 \\
26.9 \\
20.9 \\
29.2 \\
23.6 \\
18.6 \\
21.3 \\
18.4 \\
20.4\end{array}$ & $\begin{array}{r}16 \\
24 \\
10 \\
14 \\
21 \\
10 \\
12 \\
13 \\
9 \\
5\end{array}$ & $\begin{array}{r}39 \\
41 \\
39 \\
14 \\
25 \\
15 \\
19 \\
14 \\
14 \\
4\end{array}$ & $\begin{array}{l}1914 \\
1915 \\
1916 \\
1917 \\
1918 \\
1919 \\
1920 \\
1921\end{array}$ & $\begin{array}{l}17.2 \\
40.4 \\
23.6 \\
18.5 \\
20.8 \\
29.2 \\
19.7 \\
18.6 \\
18.7\end{array}$ & $\begin{array}{r}11 \\
28 \\
17 \\
9 \\
10 \\
14 \\
9 \\
11 \\
11\end{array}$ & $\begin{array}{l}16 \\
35 \\
23 \\
18 \\
14 \\
34 \\
26 \\
11 \\
15\end{array}$ \\
\hline
\end{tabular}

According to this table the yield of corn varies approximately with the annual precipitation and more closely with the rainfall during the growing season. The relation shown in the table probably holds generally for the yields of unirrigated corn throughout most of the Platte Valley. The estimated average yield of corn from irrigated lands in Hall County in 1929, as obtained by the county agricul-

so Smith, F. F., unpublished report on tri-county project, Nebraska, Bur. Reclamation, ms. vol. 1, p. 93,1924 . 
tural extension agent, ${ }^{31}$ was about 43 bushels to the acre-a yield higher than any shown for unirrigated corn in the table, although the precipitation during 1929 at Grand Island, the county seat of Hall County, was 6.56 inches below normal. The inference to be drawn is that the yields of corn in most years could be considerably increased by the use of supplemental water.

\section{OCCURRENCE OF GROUND WATER IN THE PLATTE VALLEY}

In most regions there is a zone-called the zone of saturation ${ }^{32}$ below the surface of the earth where the pores, cracks, and crevices in the rocks are filled with water under hydrostatic pressure. The water in the zone of saturation is called ground water, and the upper surface of the zone of saturation is known as the water table. The depth of the water table below the land surface and the thickness of the zone of saturation differ greatly in different localities. In some areas the zone of saturation is overlain by a relatively impervious formation that confines the ground water under pressure, and in other areas water is suspended above the main water table because of a relatively impervious bed that hinders the downward movement of the water to such an extent that it forms an upper zone of saturation. Water that is confined under pressure is called artesian water, and an upper zone of saturation is known as perched ground water.

In the Platte Valley water occurs relatively near the surface in the loess, the Pleistocene sand and gravel, and the Ogallala formation. These formations, which are described on preceding pages, differ greatly in character and therefore in water-bearing properties.

Ground water occurs in the loess only where the underlying sand and gravel are completely saturated. Near Lexington the water table in many places stands 5 to 10 feet above the base of the loess. Ground water occurs in the loess mostly west of Kearney, where there has been considerable irrigation with surface water, seepage from which has produced a rise of the water table. Loess is so fine-grained that it yields little water to wells, and hence the water that occurs in it cannot be readily recovered and is of little value as a water supply. Several ditches have been constructed in Dawson County to drain water out of the loess into the Platte River.

At most places in the valley abundant supplies of water are found in the Pleistocene sand and gravel, which usually lie directly beneath the loess. Near the Platte River the loess has been eroded, and the sand and gravel are exposed. In other places the loess forms a cover that increases in thickness toward the valley limits. The thickness of the sand and gravel varies greatly in the area, because the surface of

\footnotetext{
${ }^{81}$ Ulrich, Irwin, unpublished report on irrigation in Hall County.

32 Meinzer, O. E., Outline of ground-water hydrology, with definitions: Geol. Survey Water-Supply Paper 494 , p. 21, fig. 2, 1923 .
} 
the underlying bedrock is irregular and the upper surface of the sediments is fairly smooth. There is, however, a general increase in the thickness of the sand and gravel from west to east, as shown by the test holes drilled in the valley (pp. 65-80). Near Gothenburg the thickness of the sand and gravel is about 20 feet, and near Grand Island it is more than 100 feet.

In a few places in the valley, especially close to the valley limits, little water can be obtained from the sand and gravel. One such area exists north of Gibbon and another southwest of Grand Island, on the south side of the Platte River. Irrigation wells drilled in these localities have been abandoned, but the sand and gravel yield sufficient water to supply domestic demands.

The Ogallala formation is relatively unimportant as a water-bearing formation in the valley. The sand and gravel found in it are more or less thoroughly cemented together by carbonate of lime and have a rather low permeability and specific yield. The Ogallala underlies the Pleistocene sand and gravel only from Gothenburg to a point between Gibbon and Grand Island. Farther east the Ogallala is eroded and the Pleistocene sand and gravel rest on relatively impermeable Cretaceous formations. Few wells in the valley obtain water from the Ogallala, principally because the overlying sand and gravel provide a more abundant supply. However, where the Pleistocene sand and gravel are absent or supply only small quantities of water some domestic wells obtain water from the Ogallala formation.

There are no indications in the Platte Valley that artesian conditions or perched water tables exist. The loess is relatively impermeable and little flow takes place in it, but it readily transmits changes in water pressure. In the test wells that were sunk through saturated loess the water encountered in the loess stood at about the same level as the water that was encountered later in the underlying sand and gravel. In some localities in the valley the Pleistocene sand and gravel are divided by a clayey stratum (Fullerton formation) that separates the sediments into upper and lower deposits of sand and gravel, the Grand Island and Holdrege formations (pp. 38-51). The Fullerton formation is absent in many places, although small clay lenses are often encountered throughout both the sand and gravel formations. The clay lenses do not appear to cause artesian or perchea water conditions-probably because they are not extensive. The separating clayey Fullerton formation, although found in many localities, does not appear to confine the water in the underlying Holdrege formation under pressure or to hinder the water in the overlying Grand Island formation from percolating to the lower sand and gravel. The water level in the well drilled through the Fullerton into the Holdrege formation in connection with tests to determine the permeability of the formations (p. 101) corresponded with the water- 
level in wells that ended in the Grand Island formation, thus indicating that the water pressures in the two formations were the same.

\section{DEPTH OF THE WATER TABLE IN THE PLATTE VALLEY}

The depth of the water table below the land surface in the Platte Valley in general increases with the distance from the Platte River. From the measured depths to the water table in about 1,000 wells in the valley, a map was prepared showing the depth of the water table below the prevailing land surface (pl. 10, in pocket). The lines on the map represent only the approximate depth of the water table at any particular locality, because there are minor depressions and elevations of a few feet in the land surface that were disregarded in the preparation of the map. Moreover, the water table fluctuates constantly, and therefore its depth below the land surface changes from time to time. The lines are probably accurate within 2 or 3 feet.

The water table between Gothenburg and Kearney is in most localities more shallow than the water table between Kearney and Chapman. Irrigation since about 1890 west of Kearney with water diverted from the Platte River has produced a rise of the water table in that area. East of Kearney the water table has been lowered in many places by the withdrawal of ground water from wells. Thus the present difference in level of the water table in the two areas has been caused chiefly by the difference in sources of the water used for irrigation.

There are only a few wells between Gothenburg and Cozad in which the depth to water could be measured, hence few data are available on the ground-water level in that locality. North of Gothenburg, where there is little irrigation, the water table lies more than 50 feet below the land surface. The depth of the water table increases rapidly on the south side of the Platte River as the valley limit is approached.

In the vicinity of Lexington and eastward to the vicinity of Kearney the water table lies less than 15 feet below the ground surface except close to the north valley limit. South of the river the water table lies rather deep. There are several river terraces on the north side of the river between Lexington and Kearney that cause the depth of the water table to vary considerably within short distances. The water table on each terrace lies deepest near the front of the terrace and shallowest near the back. Southwest of Kearney on the south side of the river there is a group of sand hills. In the depressions between the hills the water table stands close to the land surface, but wells drilled on the hills must go deep for water. No attempt was made to show the depth of the water table in this locality.

From Kearney to and beyond the town of Wood River the depth of the water table ranges from less than 5 feet to more than 25 feet. 
Except close to the river the water table in most of the area lies more than 15 feet below the land surface. On the south side of the Platte River the depth of the water table increases rapidly except in the vicinity of Lowell, where the valley limit is not well defined. North of the town of Wood River there is a depressional area of about 12 square miles where the water table lies at a depth greater than 25 feet. This may have been caused by heavy pumping, because a large part of this area is irrigated by water pumped from wells. The Wood River does not appear to have any great effect on the depth of the water table in the area. The stream flows at about the level of the water table, and there is probably little seepage into or out of the stream, because throughout most of its course the stream bed is composed of loess.

The Platte Valley widens east of the town of Wood River and the lines showing depth to water follow in general the north valley limit. The shallow-water area is greatly increased by this broadening of the valley. A local depression in the vicinity of the city of Grand Island, where the water table stands more than 20 feet below the land surface, is probably caused by heavy pumping of water for municipal use. North of Grand Island the depth of the water table in a large area is less than 10 feet, probably because of plentiful recharge from precipitation and seepage from Prairie and Silver Creeks. The Platte River south of Grand Island flows close to the valley limit, and the depth of the water table increases rapidly to the south. At Doniphan, about 2 miles south of the river, the water table lies about 70 feet below the land surface.

\section{HYDROLOGIC PROPERTIES OF THE WATER-BEARING MATERIALS}

The quantity of ground water that a water-bearing material will yield to wells or other recovery devices depends principally upon the hydrologic properties of the material. These properties vary greatly, even where differences in the texture of the material are apparently only slight, hence ordinary geologic descriptions are quite inadequate for hydrologic purposes, and quantitative descriptions based on laboratory or field determinations have become essential.

The two hydrologic properties of greatest significance are permeability and specific yield. Mechanical analyses and determinations of porosity and moisture equivalent are useful chiefly as indirect means of determining these two essential hydrologic properties.

The specific yield of a water-bearing formation is defined by Meinzer as the ratio of (1) the volume of water which, after being saturated, it will yield by gravity to (2) its own volume ${ }^{33}$ It is a measure of the quantity of water that a formation will yield when it is drained by a

\footnotetext{
${ }^{33}$ Meinzer, O. E., Outline of ground-water hydrology, with definitions: Geol. Survey Water-Supply Paper 494, p. 28, 1923.
} 
lowering of the water table. Thus if 100 cubic feet of saturated water-bearing material when drained will supply 20 cubic feet of water the specific yield of the material is said to be 20 percent.

The practical use of the specific yield is obvious. The quantity of water that a saturated material will furnish from storage depends upon its specific yield. To estimate the water supply obtainable from a deposit for each foot that the water table is lowered, or to estimate the available water supply represented by each foot of rise of the water table during periods of recharge, it is necessary to determine the specific yield.

The permeability of a water-bearing formation is usually expressed as a coefficient of permeability, which is defined, according to the present usage of the United States Geological Survey, as the rate of flow, in gallons a day, through a square foot of its cross section, under a hydraulic gradient of 100 percent, at a temperature of $60^{\circ} \mathrm{F}^{34}$ In field terms the coefficient of permeability may be expressed as the number of gallons a day, at $60^{\circ} \mathrm{F}$., that is conducted laterally through each mile of water-bearing bed under investigation (measured at right angles to the direction of flow), for each foot of thickness of the bed and for each foot per mile of hydraulic gradient. ${ }^{34}$ The quantity of water that will percolate through a given cross section of waterbearing material under a known hydraulic gradient is directly proportional to the coefficient of permeability of the material. It is necessary to determine this important hydrologic property in order to compute the quantity of ground water that percolates into or out of a ground-water basin or reservoir or a specific well or well field.

Coefficients of permeability vary widely. Fine sand is in general less permeable than coarse sand and therefore transmits less water through equal cross-sectional areas under the same hydraulic gradient. Clay may contain more water per unit volume than sand or gravel, but its permeability is generally low, and therefore the quantity of water transmitted through it is usually much less than is transmitted through sand and gravel. Coefficients of permeability of less than 100 are said to be low, coefficients between 100 and 1,000 are said to be medium, and coefficients above 1,000 are said to be high. Most materials that yield sufficient water to be utilized by wells have coefficients ranging between 10 and 1,000, and most villages and cities that utilize ground water for their supply obtain water from formations having coefficients greater than about $100 .^{35}$ Coefficients of permeability ranging from about 0.001 for clay to more than 90,000 for sand and gravel have been determined in the hydrologic laboratory of the United States Geological Survey.

\footnotetext{
${ }^{34}$ Stearns, N. D., Laboratory tests on physical properties of water-bearing materials: Geol. Survey Water-Supply Paper 596, p. 148, 1928.

ss Meinzer, O. E., Movements of ground water (address at 19th annual meeting of Am. Assoc. Petroleum Geologists, Dallas, Tex., March 23, 1934).
} 
Meinzer ${ }^{36}$ gives seven more or less distinct methods of determining specific yield-namely, (1) saturating samples in the laboratory and allowing them to drain; (2) saturating in the field a considerable body of material situated above the water table and above the capillary fringe and allowing it to drain downward naturally; (3) collecting samples immediately above the capillary fringe after the water table has gone down an appreciable distance, as it commonly does in summer and autumn; (4) ascertaining the volume of sediments drained by heavy pumping, a record being kept of the quantity of water that is pumped; (5) ascertaining the volume of sediments saturated by a measured amount of seepage from one or more streams; (6) making indirect determinations in the laboratory with small samples by the application of centrifugal force; and (7) making mechanical analyses and determinations of porosity and estimating therefrom the specific yield. The specific yield of the water-bearing materials in the Platte Valley was determined by the use of the fourth and sixth of these methods. Samples of the materials were analyzed in the hydrologic laboratory of the United States Geological Survey, and a pumping test was made near Grand Island.

\section{LABORATORY DETERMINATIONS}

In the laboratory the samples of water-bearing material are saturated and subjected to a centrifugal force approximately 1,000 times the force of gravity. The samples are weighed, then dried and reweighed. The difference in weight represents the weight of the moisture that is retained after centrifuging. The moisture equivalent by weight is computed by dividing the weight of the moisture retained after centrifuging by the weight of the dry soil, and the moisture equivalent by volume is computed by multiplying the moisture equivalent by weight by the apparent specific gravity of the material.

The moisture-equivalent determinations are made to ascertain the specific retention ${ }^{37}$ - that is, the quantity of water that a soil or rock will retain against the pull of gravity if it is drained after having been saturated, expressed as the ratio of the retained water to the total volume of material. The specific yield of a material is equal to the porosity minus the specific retention. It has sometimes been assumed that the moisture equivalent and the specific retention of a water-bearing material are approximately equal. However, several investigators have found that this relation holds most nearly when

${ }^{36}$ Meinzer, O. E., Outline of methods for estimating ground-water supplies: Geol. Survey WaterSupply Paper 638, p. 113, 1932.

${ }^{37}$ Meinzer, O. E., The occurrence of ground water in the United States, with a discussion of principles: Geol. Survey Water-Supply Paper 489, pp. 55 et seq., 1923.

121343-38-7 
the moisture equivalent is comparatively large. Piper ${ }^{38}$ prepared a graph showing the relation between these properties, using the results obtained by him in the Mokelumne area, California, and the results obtained elsewhere by others. Where the moisture equivalent ranged between 3 and 5 percent the specific retention was found to range between about 5 and 7 percent. Moisture equivalents greater than 15 percent agreed more closely with specific retention.

Samples of loess, Ogallala formation, Plejstocene sand and gravel, and soil were analyzed in the hydrologic laboratory of the Geological Survey. A mechanical analysis was made to determine the general size and assorting of the grains, the porosity and moisture equivalent were determined so that specific yield could be computed, and the permeability was determined so that the rate of flow of water through the material could be approximated.

Loess.-Tests for moisture equivalent were made on four samples of loess obtained in the Platte Valley near Lexington. The results are shown below.

\section{Physical properties of loess from the Platte Valley}

[Collected by L. K. Wenzel; analyzed by V. C. Fishel]

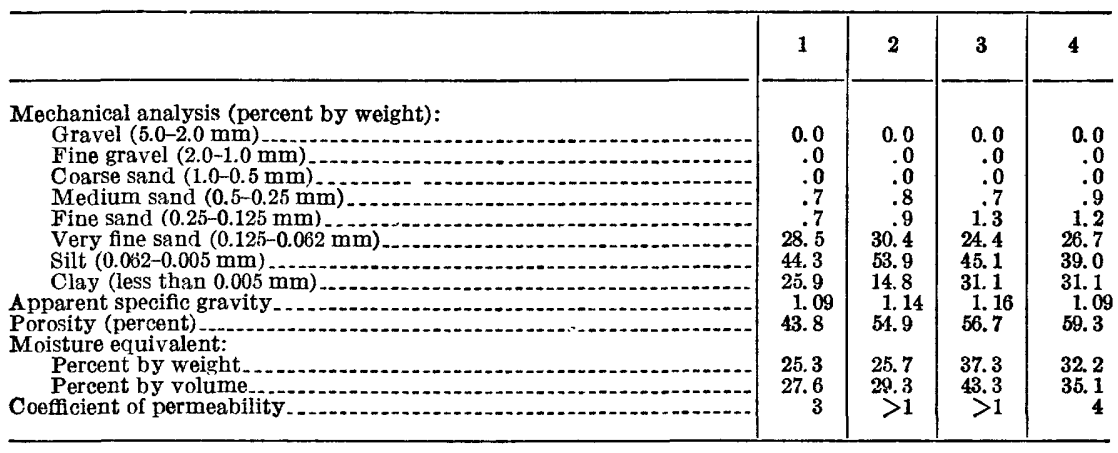

1. Unsaturated loess, 5 feet below surface, $2 \frac{1}{2}$ miles northwest of Lexington.

2. Saturated loess, 7 feet below surface, same location as sample 1 .

3. Unsaturated loess, 6 feet below surface, 1 mile north of Lexington.

4. Saturated loess, 7 feet below surface, same location as sample 3.

The average moisture equivalent by volume was 33.8 , and the average porosity was 53.7. If the average moisture equivalent is taken to represent the average specific retention, the average specific yield of the four samples of loess is about 20 .

Ogallala formation.-The moisture equivalent of one sample of the Ogallala formation was determined in the laboratory. (See table on p. 92.) The sample was obtained about 55 feet below the surface during the drilling of a 6 -inch test well in connection with the present investigation in the $\mathrm{SE}_{4} / \mathrm{SE}^{1 / 4}$ sec. 12 , T. 8 N., R. 17 W., about 5 miles

\footnotetext{
${ }_{37}$ Piper, A. M. Notes on the relation between the moisture equivalent and the specific retention of water-
} bearing materials: Am. Geophysical Union Trans. 14th Ann. Meeting, pp. 481-487, 1933. 
west of Kearney. The moisture equivalent is 13.9 , the porosity 34.3 , and the computed specific yield of the sample 20.4.

Pleistocene sand and gravel.-The moisture equivalent of samples of the Pleistocene sand and gravel obtained near Grand Island, Kearney, and Lexington was also determined in the laboratory. During the drilling of a test well on the farm of Fred Meyer, about 4 miles east of Grand Island, in the NW1/4 sec. 17, T. 11 N., R. 8 W., 19 samples of material were collected and the moisture equivalent was determined for 18 of them. One sample was composed principally of clay, and its moisture equivalent was 27.1, and the specific yield 13.2. The remaining 17 samples consisted of mixtures of sand and gravel, as shown by the mechanical analyses listed in the following table:

Physical properties of water-bearing materials from a well near Grand Island, in the NW $1 / 4$ sec. $17, T .11$ N., R. $8 \mathrm{~W}$.

[Collected by L. K. Wenzel; analyzed by V. C. Fishel]

\begin{tabular}{|c|c|c|c|c|c|c|c|c|c|c|c|c|c|}
\hline \multirow{2}{*}{$\begin{array}{c}\text { Depth } \\
\text { of } \\
\text { sample } \\
\text { (feet) }\end{array}$} & \multicolumn{8}{|c|}{ Mechanical analysis (percent by weight) } & \multirow{2}{*}{$\begin{array}{c}\text { Appar- } \\
\text { ont } \\
\text { spe- } \\
\text { cific } \\
\text { gravity }\end{array}$} & \multirow{2}{*}{$\begin{array}{l}\text { Por- } \\
\text { osity } \\
\text { (per- } \\
\text { cent) }\end{array}$} & \multicolumn{2}{|c|}{$\begin{array}{l}\text { Moisture } \\
\text { equivalent }\end{array}$} & \multirow{2}{*}{$\begin{array}{c}\text { Coeff- } \\
\text { cient- } \\
\text { of per- } \\
\text { meabil- } \\
\text { ity }\end{array}$} \\
\hline & $\begin{array}{c}\text { Larger } \\
\text { than } \\
2.0 \\
\text { mm }\end{array}$ & $\begin{array}{c}2.0- \\
1.0 \\
\mathrm{~mm}\end{array}$ & $\begin{array}{l}1.00- \\
0.50 \\
\mathrm{~mm}\end{array}$ & $\begin{array}{l}0.50- \\
0.25 \\
\mathrm{~mm}\end{array}$ & $\begin{array}{l}0.25- \\
0.125 \\
\mathrm{~mm}\end{array}$ & $\begin{array}{c}0.125 \\
0.062 \\
\mathrm{~mm}\end{array}$ & $\begin{array}{l}0.062 \\
0.005 \\
\mathrm{~mm}\end{array}$ & $\begin{array}{l}\text { Less } \\
\text { than } \\
0.005 \\
\mathrm{~mm}\end{array}$ & & & $\begin{array}{c}\text { Per- } \\
\text { cent by } \\
\text { weight }\end{array}$ & $\begin{array}{c}\text { Per- } \\
\text { cent by } \\
\text { vol- } \\
\text { ume }\end{array}$ & \\
\hline $\begin{array}{l}6-10 \\
10-16 \\
16-20 \\
20-25 \\
25-30 \\
30-39 \\
39-40 \\
40-42 \\
42-46 \\
46-51 \\
51-55 \\
55-61 \\
61-66 \\
66-71 \\
71-78 \\
78-86 \\
86-92 \\
92-99 \\
99-105\end{array}$ & $\begin{array}{r}29.7 \\
14.1 \\
16.8 \\
18.6 \\
7.5 \\
36.4 \\
3.4 \\
15.9 \\
15.4 \\
17.3 \\
39.6 \\
27.4 \\
20.6 \\
18.1 \\
179.3 \\
14.3 \\
36.2 \\
15.1 \\
25.8\end{array}$ & $\begin{array}{r}16.9 \\
17.9 \\
15.2 \\
18.8 \\
17.2 \\
20.8 \\
3.6 \\
11.0 \\
15.2 \\
10.7 \\
12.8 \\
14.9 \\
19.6 \\
18.0 \\
3.5 \\
11.9 \\
10.3 \\
10.4 \\
13.3\end{array}$ & $\begin{array}{r}18.9 \\
31.2 \\
25.8 \\
21.3 \\
25.0 \\
21.4 \\
1.8 \\
20.1 \\
20.2 \\
13.1 \\
9.5 \\
16.3 \\
19.7 \\
17.7 \\
3.9 \\
18.2 \\
14.6 \\
22.8 \\
13.7\end{array}$ & $\begin{array}{r}17.1 \\
30.4 \\
29.4 \\
24.8 \\
30.0 \\
15.0 \\
4.7 \\
33.4 \\
19.5 \\
29.4 \\
15.7 \\
22.4 \\
19.1 \\
23.7 \\
6.3 \\
25.1 \\
17.1 \\
31.1 \\
21.9\end{array}$ & $\begin{array}{r}15.4 \\
5.5 \\
10.5 \\
13.8 \\
16.0 \\
4.7 \\
26.0 \\
15.4 \\
16.4 \\
24.4 \\
13.5 \\
11.8 \\
9.7 \\
14.0 \\
4.0 \\
18.7 \\
11.6 \\
13.9 \\
14.3\end{array}$ & $\begin{array}{r}1.3 \\
.3 \\
1.6 \\
1.9 \\
3.4 \\
.8 \\
14.0 \\
2.6 \\
7.0 \\
3.2 \\
4.7 \\
3.7 \\
4.3 \\
3.3 \\
1.5 \\
6.5 \\
4.3 \\
3.0 \\
5.2\end{array}$ & $\begin{array}{r}0.4 \\
.2 \\
.5 \\
.6 \\
.8 \\
.5 \\
31.5 \\
.4 \\
4.5 \\
1.0 \\
2.5 \\
2.1 \\
4.4 \\
3.0 \\
1.0 \\
3.0 \\
3.4 \\
2.5 \\
3.5\end{array}$ & $\begin{array}{r}0.2 \\
.1 \\
.1 \\
.2 \\
.3 \\
.1 \\
13.6 \\
.2 \\
1.5 \\
.4 \\
1.0 \\
1.0 \\
1.9 \\
1.9 \\
.3 \\
1.7 \\
2.3 \\
1.0 \\
2.0\end{array}$ & $\begin{array}{l}1.90 \\
1.84 \\
1.80 \\
1.89 \\
1.83 \\
1.81 \\
1.56 \\
1.83 \\
1.92 \\
1.84 \\
1.94 \\
1.92 \\
1.92 \\
1.94 \\
2.02 \\
1.88 \\
1.97 \\
1.86 \\
1.90\end{array}$ & $\begin{array}{l}27.1 \\
30.9 \\
32.3 \\
28.5 \\
31.0 \\
30.6 \\
40.3 \\
31.2 \\
26.3 \\
30.2 \\
26.2 \\
25.6 \\
25.0 \\
26.3 \\
22.8 \\
41.8 \\
21.5 \\
29.9 \\
27.6\end{array}$ & \begin{tabular}{r}
1.4 \\
1.5 \\
1.1 \\
1.4 \\
1.4 \\
1.0 \\
17.4 \\
1.5 \\
1.6 \\
1.6 \\
1.7 \\
1.6 \\
1.4 \\
1.6 \\
\hdashline-1.6 \\
1.9 \\
1.2 \\
1.5
\end{tabular} & $\begin{array}{r}2.6 \\
2.7 \\
2.0 \\
2.6 \\
2.6 \\
1.9 \\
27.1 \\
2.7 \\
3.0 \\
3.0 \\
3.3 \\
3.0 \\
2.8 \\
3.0 \\
-3.1 \\
3.1 \\
3.9 \\
2.1 \\
2.9\end{array}$ & $\begin{array}{r}480 \\
1,685 \\
1,460 \\
1,095 \\
1,095 \\
4,350 \\
2 \\
925 \\
150 \\
350 \\
780 \\
730 \\
2,095 \\
1,050 \\
2,185 \\
220 \\
495 \\
430 \\
285\end{array}$ \\
\hline
\end{tabular}

176.0 percent larger than $5 \mathrm{~mm}$.

The moisture equivalents of these 17 samples ranged from 1.9 to 3.9 and averaged 2.8. This average falls into the range where Piper found that the moisture equivalent was considerably less than the specific retention. By using his diagram, the specific retention corresponding to a moisture equivalent of 2.6 is found to be about 5 . The porosity of the 17 samples of sand and gravel ranged from 21.5 to 41.8 and averaged about 29 . The average specific yield is therefore computed to be 29 minus 5 , or 24 .

Seven samples of water-bearing sand and gravel were taken during the drilling of the test well west of Kearney from which the Ogallala sample mentioned above was obtained. The properties of these 8 samples are shown in the following table: 
Physical properties of water-bearing materials from a well near Kearney, in the SE 34 $S E 1 / 4$ sec. $12, T .8 \mathrm{~N}$., R. $17 \mathrm{~W}$.

[Collected by Keith Miller; analyzed by V. C. Fishel]

\begin{tabular}{|c|c|c|c|c|c|c|c|c|c|c|c|c|c|}
\hline \multirow[b]{2}{*}{ Material } & \multicolumn{8}{|c|}{ Mechanical analysis (percent by weight) } & \multirow[b]{2}{*}{ 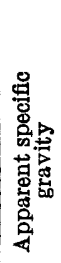 } & \multirow[b]{2}{*}{ 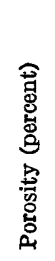 } & \multicolumn{2}{|c|}{$\begin{array}{l}\text { Moisture } \\
\text { equivalent }\end{array}$} & \multirow[b]{2}{*}{ 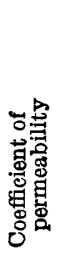 } \\
\hline & 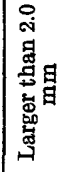 & $\begin{array}{l}\text { 日 } \\
\text { 日 } \\
0 \\
\dot{j} \\
\text { d } \\
\text { i }\end{array}$ & 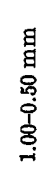 & $\begin{array}{l}\text { 日 } \\
\text { 日 } \\
\text { sุ } \\
0 \\
0 \\
0 \\
0\end{array}$ & 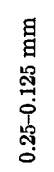 & 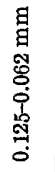 & 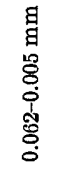 & 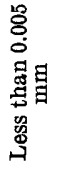 & & & 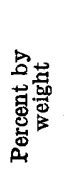 & 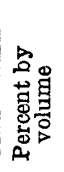 & \\
\hline 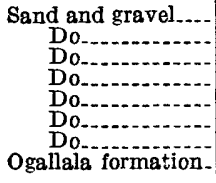 & \begin{tabular}{|r|}
40.4 \\
27.4 \\
122.4 \\
31.3 \\
16.9 \\
46.9 \\
8.5 \\
21.1 \\
16.3
\end{tabular} & $\begin{array}{r}15.5 \\
11.9 \\
9.5 \\
21.0 \\
14.5 \\
16.5 \\
8.3 \\
4.7\end{array}$ & $\begin{array}{r}22.8 \\
19.2 \\
16.2 \\
19.6 \\
17.1 \\
28.2 \\
14.5 \\
6.8\end{array}$ & $\begin{array}{l}16.5 \\
27.7 \\
41.7 \\
19.6 \\
16.6 \\
36.6 \\
34.9 \\
15.4\end{array}$ & $\begin{array}{r}3.9 \\
11.1 \\
9.0 \\
6.5 \\
4.1 \\
8.9 \\
18.0 \\
9.0\end{array}$ & $\begin{array}{r}0.4 \\
1.9 \\
.7 \\
1.2 \\
.4 \\
.7 \\
2.0 \\
6.5\end{array}$ & $\begin{array}{r}0.3 \\
.5 \\
.4 \\
.5 \\
.2 \\
.3 \\
.7 \\
35.2\end{array}$ & $\begin{array}{r}0.1 \\
.2 \\
.1 \\
.1 \\
.1 \\
.1 \\
.1 \\
4.3\end{array}$ & $\begin{array}{l}1.87 \\
1.88 \\
1.87 \\
1.95 \\
1.91 \\
1.84 \\
1.83 \\
1.74\end{array}$ & $\begin{array}{l}27.2 \\
27.0 \\
27.2 \\
26.1 \\
27.5 \\
29.7 \\
30.7 \\
34.3\end{array}$ & $\begin{array}{l}1.4 \\
1.2 \\
1.3 \\
1.2\end{array}$ & $\begin{array}{l}2.6 \\
2.3 \\
2.3 \\
2.3\end{array}$ & $\begin{array}{r}2,600 \\
815 \\
1,145 \\
1,370 \\
2,515 \\
1,820 \\
770 \\
15\end{array}$ \\
\hline
\end{tabular}

1 One rock $41 / 2$ by 11 centimeters removed; weight 328 grams.

34.1 percent larger than $5 \mathrm{~mm}$.

The moisture equivalents were determined for 6 of the samples of sand and gravel, and the average value was 2.25. The specific retention, according to Piper's diagram, for a moisture equivalent of 2.25 is about 4.1. The average porosity of these 6 samples was about 28; hence the average specific yield of the 6 samples is about 24 .

Three samples of sand and gravel (nos. 7-9 in the following table) were taken from an auger hole about 25 feet from the Platte River, southwest of Kearney, in the $\mathrm{NE}_{1 / 4}^{1} \mathrm{NE} / 4 / 4$ sec. 21 , T. 8 N., R. $16 \mathrm{~W}$. The average moisture equivalent of these samples is 2.4 , and the average porosity is 34.5. Piper's diagram shows that the specific retention is about 4.5 percent. Hence the average specific yield of these samples is about 30 .

Samples of sand and gravel were collected at two localities near Lexington. One of these samples (no. 4) from the SW 1/4 SW $1 / 4$ sec. 17, T. 9 N., R. 21 W., was found to have a moisture equivalent of 1.8 and a porosity of 37.5. As a moisture equivalent of 1.8 is taken to indicate a specific retention of about 4 , the specific yield is about 33.5. The moisture equivalent of a sample of sand and gravel obtained from an auger hole about a mile north of Lexington (no. 10) was found to be 5.6 , and the porosity was 25.5 percent. By Piper's diagram the specific retention corresponding to a moisture equivalent of 5.6 is about 7.8; hence the specific yield of this sample is about 17.7.

Soil.- The moisture equivalent was determined also for several samples of soil in the vicinity of Lexington. Most of the soil is developed from loess and therefore may be expected to possess similar hydrologic properties. The samples collected in the $\mathrm{SW}^{1 / 4} \mathrm{SW} 1 / 4$ sec. 17, T. 9 N., R. 21 W., northwest of Lexington (nos. 1, 2) show a rather high moisture equivalent -47.4 for the top soil and 22.4 for the soil 


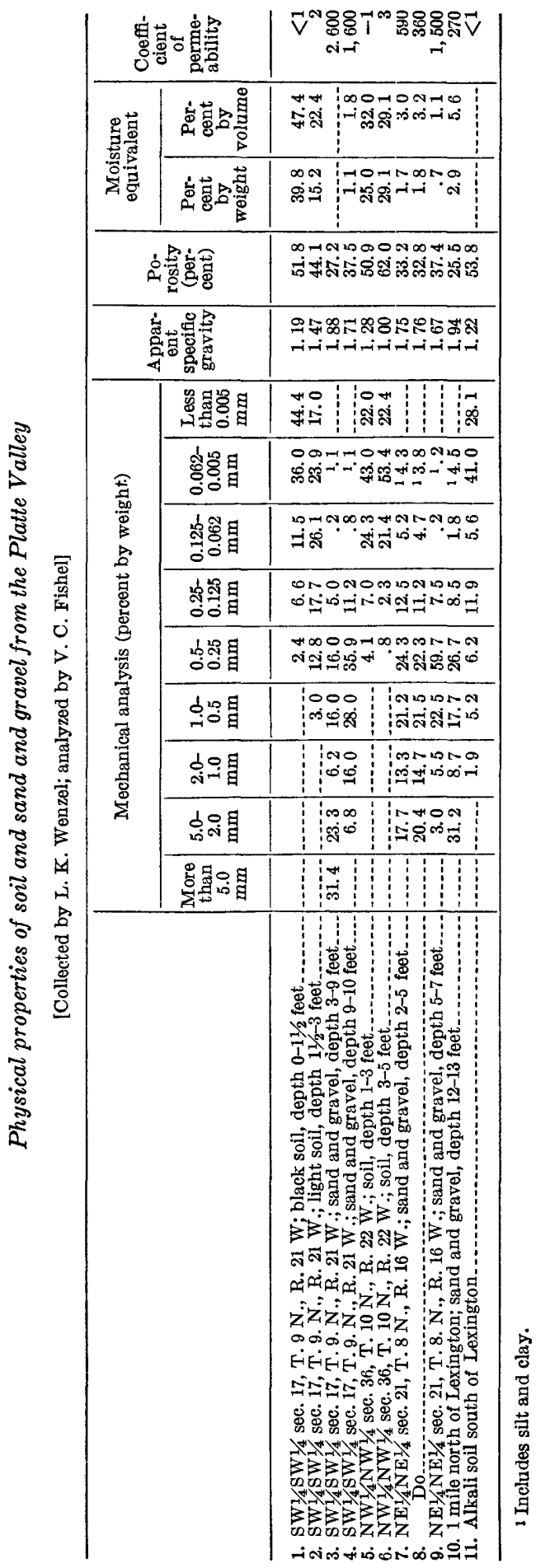


below. The specific yields of these samples are 4.4 and 21.7 respectively. The moisture equivalents of samples of soil collected in the NW $1 / 4 \mathrm{NW}^{1} / 4$ sec. 36, T. 10 N., R. 22 W. (nos. 5, 6) are 32.0 and 29.1. The porosities of the samples are high (50.9 and 62.0), and the specific yields are 18.9 and 32.9 respectively.

\section{DETERMINATION BY THE PUMPING METHOD}

A pumping test was made on the farm of Fred Meyer, about 4 miles west of Grand Island, in the NW1/4 sec. 17, T. 11 N., R. 8 W., and the specific yield of the water-bearing sand and gravel was determined in place. The method was suggested by Meinzer ${ }^{39}$ and consists of determining the ratio of (1) the quantities of ground water which in a given time are taken from storage between concentric cylindrical sections around the pumped well to (2) the volume of sediments between the cylinders that are unwatered in that time. A complete description and summary of the results of this test was recently published. ${ }^{40}$

The pumping-test method is based on the law of flow of water through sand as propounded by Darcy. ${ }^{41}$ Darcy's law may be written $Q=P I A$, in which $Q$ is the quantity of water that percolates through a cross section of water-bearing material, $P$ is the coefficient of permeability, $I$ is the hydraulic gradient, and $A$ is the cross-sectional area of the material. When a well is pumped some water is inevitably taken out of storage from the well and the material surrounding it. This reduces the pressure, creates a hydraulic gradient toward the well, and causes ground water to flow into the well. If the waterbearing formation has a water table, considerable ground water may have to be removed from storage before a gradient will be developed that is steep enough to make water flow toward the well at the rate that it is pumped and to establish equilibrium.

During the period of pumping water percolates toward the pumped well through an indefinite series of concentric cylindrical sections around the pumped well. The flow through these cylinders at first is unequal, because some water is being taken out of storage from between the cylinders, but after approximate equilibrium has been established the flow through each of the cylinders is the same. Thus for a time the flow through a large cylinder will be less than the flow through a small cylinder by the amount equal to the quantity of water withdrawn from storage between the cylinders. The volume of material between any two cylinders unwatered in a given time can be

${ }^{39}$ Meinzer, O. E., Outline of methods for estimating ground-water supplies: Geol. Survey Water-Supply Paper 638, p. 136, 1932.

10 Wenzel, L. K., Specific yield determined from a Thiem's pumping test: Am. Geophys. Union Trans. 14th Ann. Meeting, pp. 457-477, 1933; The Thiem method for determining permeability of water-bearing materials and its application to the determination of specific yield: Geol. Survey Water-Supply Paper 679-A, 1936.

" Darcy, H., Les fontaines publiques de la ville de Dijon, Paris, 1856. 
computed from the draw-down of the water table as shown by successive measurements of the depth to water in observation wells. The average hydraulic gradient that causes the water to percolate toward the pumped well can be determined from the same records of depth to water, provided the altitude of the tops of the observation wells is known. The total quantity of water that percolates through each of the two cylinders in a given time is computed by Darcy's formula. As the quantity of water that is taken from storage is determined by ascertaining the difference in the quantities of water that percolate through the cylinders in a given time, the specific yield may be expressed by the equation

$$
y=\frac{100\left(Y_{1}-Y\right)}{V}
$$

in which $y$ is the specific yield, $Y_{1}$ the quantity of ground water that percolates through the smaller cylinder, $Y$ the quantity of ground water that percolates through the larger cylinder, and $V$ the volume of water-bearing material that is unwatered between the cylinders. Ordinarily, the volume of unwatered material and the quantities of ground water that percolate through the cylinders are expressed in cubic feet.

The volumes of water-bearing material that were unwatered between concentric cylindrical sections around the pumped well during certain periods of pumping were computed by the formula

$$
V=\pi\left(a^{2}-a_{1}^{2}\right) \frac{s+s_{1}}{2}
$$

in which $V$ is the volume of unwatered material, in cubic feet, $a$ is the radius of the large cylinder, in feet, $a_{1}$ is the radius of the small cylinder, in feet, and $s$ and $s_{1}$ represent the draw-down of the water table, in feet, at the distances $a$ and $a_{1}$, respectively, from the pumped well.

The quantities of water that were taken from storage between the concentric cylindrical sections were determined by computing the quantity of water that percolated through the smaller cylinder and subtracting from the figure thus obtained the quantity of water that percolated through the larger cylinders. The quantities of water that percolated through each cylinder were computed by the formula

$$
Y=\frac{2 \pi P i a h T}{7.48 \times 24}
$$

in which $Y$ is the quantity of ground water, in cubic feet, $P$ is the coefficient of permeability, $i$ is the average hydraulic gradient in feet per foot, at the distance $a$ from the pumped well, $h$ is the average thickness, in feet, of the saturated water-bearing material at the distance $a$, and $T$ is the period of pumping, in hours. 
The specific yield was determined by this method for several periods of pumping and by using several cylindrical cross sections, as shown in the following table:

Specific yield as computed for several concentric cylindrical sections and for several periods of pumping

\begin{tabular}{|c|c|c|c|c|c|}
\hline \multirow{2}{*}{ Radii of cylinders (feet) } & \multicolumn{5}{|c|}{ Specific yield during different periods of pumping } \\
\hline & $\begin{array}{c}0-6 \\
\text { hours }\end{array}$ & $\begin{array}{c}0-12 \\
\text { hours }\end{array}$ & $\begin{array}{c}0-24 \\
\text { hours }\end{array}$ & $\begin{array}{c}0-36 \\
\text { hours }\end{array}$ & $\begin{array}{c}0-48 \\
\text { hours }\end{array}$ \\
\hline $\begin{array}{l}50 \text { and } 280 \\
50 \text { and } 3200 \text { and } 360 \\
50 \text { and } 400 \\
50 \text { and } 500 \text { and } 600 \\
50 \text { and } 700 \text { and } 800 \\
50 \text { and } 900 \\
50\end{array}$ & $\begin{array}{r}9.8 \\
9.2 \\
9.2 \\
9.1 \\
9.3 \\
9.0 \\
8.7 \\
8.8\end{array}$ & $\begin{array}{l}12.8 \\
11.9 \\
12.0 \\
11.9 \\
11.8 \\
11.4 \\
11.1 \\
11.1 \\
11.2\end{array}$ & $\begin{array}{l}16.7 \\
16.0 \\
16.3 \\
16.3 \\
16.4 \\
15.9 \\
15.9 \\
15.7 \\
15.5\end{array}$ & $\begin{array}{l}18.7 \\
18.2 \\
18.5 \\
18.5 \\
18.5 \\
18.6 \\
18.8 \\
18.4 \\
18.2\end{array}$ & $\begin{array}{l}20.0 \\
19.8 \\
19.9 \\
19.9 \\
19.9 \\
20.0 \\
20.8 \\
20.5 \\
20.3\end{array}$ \\
\hline Average & 9.2 & 11.7 & 16.1 & 18.5 & 20.1 \\
\hline
\end{tabular}

The computed specific yield became larger as the pumping increased, for the reason that all the water in the material does not drain out of it immediately. When pumping starts, a comparatively large volume of material is unwatered, partly because only a small percentage of the water contained in the interstices of the sediments immediately drains down to the water table. As pumping is continued, more water gradually drains out of the unwatered sediments, and hence the specific yield computed from the first few hours of pumping is relatively small. The specific yield computed from the volume of water-bearing material unwatered in the last few hours of pumping would be too large because of the addition of water that percolated down from the material previously unwatered. The average results for specific yield given in the table, plotted against the periods of pumping, fall on a smooth curve. By extending this curve the conclusion is reached that the true specific yield lies between 22 and 23.

The specific yield determined by this test applies only to the upper few feet of water-bearing material that was unwatered during the period of pumping. A sample of water-bearing material from the well drilled at the location of this test was obtained close to the water table. (See first sample in table on p. 91.) The porosity was found to be 27.1 and the moisture equivalent 2.6 in the hydrologic laboratory. Piper's relation between moisture equivalent and specific retention gave a specific retention of about 5 , from which the specific yield is computed to be about 22 .

\section{PERMEABILTY OF THE WATHR-BEARING MATERIALS}

METHODS USED TO DETERMINE PERMEABIITYY

The permeability of water-bearing materials may be determined by laboratory tests of samples of the materials, by determinations of ground-water velocity in the field, and by pumping tests made on 
wells that withdraw water from the materials. All these methods were used in the Platte Valley.

Hazen ${ }^{42}$ and Slichter ${ }^{43}$ have studied the rate of flow of water through sands and have developed formulas that essentially include the determination of the permeabilities of the sands. King ${ }^{44}$ has reviewed the results of the investigators on the flow of water through porous media and also has described an apparatus for measuring the flow in the laboratory. ${ }^{45}$ In the Geological Survey laboratory the permeability of water-bearing materials is now determined by means of an apparatus devised by Meinzer. ${ }^{46}$ The coefficient of permeability is determined directly by measuring the rates of flow of water through a sample of material with known cross section and thickness under observed differences of head. Recently a more accurate apparatus, based on the same principles, has been installed in the laboratory to measure the rates of flow of water under very small differences of head. ${ }^{47}$

\section{LABORATORY DETERMINATIONS}

Loess.-Determinations of the coefficients of permeability were made in the laboratory on the four samples of loess collected near Lexington. (See table on p. 90.) The coefficients range from less than 1 to about 4 and average about 2 . These coefficients are very low and indicate that little water percolates laterally through the saturated loess at the gradients that exist in the Platte Valley. Moreover, the low permeability of loess accounts for the low yield of wells from the loess. The specific yield of the loess is almost equal to the specific yield of the sand and gravel, but because the permeability of the loess is low, water can flow through it toward wells only very slowly-usually at a rate so slow that the wells become dry soon after pumping is begun.

Ogallala formation.-The sample of the Ogallala formation obtained from the test well west of Kearney had a coefficient of permeability of 15. The permeability of this material is likewise low, though greater than that of loess. In some areas, especially in western Nebraska, abundant supplies of water are obtained from the base of the Ogallala, and in these areas the coefficient of permeability of the material is doubtless greater than it is near Kearney.

Pleistocene sand and gravel.-Coefficients of permeability were determined in the laboratory for 19 samples of material that were

4 Hazen, Allen, Some physical properties of sands and gravels: Massachusetts State Board of Health, 24th Ann. Rept., p. 553, 1892.

13 Slichter, C. S., Motions of underground waters: Geol. Survey Water-Supply Paper 67, p. 26, 1902.

4 King, F. H., Principles and conditions of the movements of ground water: Geol. Survey 19th Ann. Rept., pt. 2, pp. 178-204, 1899.

is Idem, p. 228.

is Stearns, N. D., Laboratory tests on physical properties of water-bearing materials: Geol. Survey WaterSupply Paper 596, p. 144, 1928.

7 Meinzer, O. E., and Fishel, V. C., Tests of permeability with low hydraulic gradients: Am. Geophys. Union Trans. 15th Ann. Meeting, pt. 2, p. 405, 1934. 
obtained during the drilling of the well on the farm of Fred Meyer, east of Grand Island. (See table on p. 91.) One of the samples consisted of clay and had a coefficient of permeability of 2 . The other 18 samples consisted of mixtures of sand and gravel, and their coefficients of permeability ranged from 150 to 4,350. The permeabilities of these samples can all be classified as medium or high. The average coefficient of permeability of the water-bearing material taken from the well, weighted as to the thickness of material represented by each sample, is about 1,200 .

The coefficients of permeability of 7 samples of water-bearing sand and gravel penetrated in the test well west of Kearney, as determined in the laboratory (see table, p. 92), range from 770 to 2,600 , and the weighted average is about 1,434 .

The coefficient of permeability of the samples of sand and gravel from the SW $1 / 4$ sec. 17, T. 9 N., R. 21 W., south of Lexington, averaged 2,100 , and that of the samples collected in the NE1/4 sec. $21, \mathrm{~T} .8 \mathrm{~N}$., R. $16 \mathrm{~W}$., averaged 817. (See table on p. 93.) The samples were obtained from the upper few feet of water-bearing material and therefore do not represent the average permeability of the entire thickness of the formation.

During the course of the investigation samples of sand and gravel were taken from a gravel pit south of Cowles (see pl. $3, A$ ), within the drainage basin of Elm Creek, a stream that apparently receives underflow from the Platte Valley. (For a description of this stream see p. 165.) The samples were collected from the side of the pit above the water level-which probably represented the ground-water level-at vertical intervals of about 6 feet. The material was very heterogeneous, and layers of sand and gravel were interspersed with clay lenses and clay balls. The coefficients of permeability, as determined in the hydrologic laboratory, ranged from 250 to 8,350 , and the average was 2,650 . This figure corresponds well with the permeability of the sand and gravel in the Platte Valley.

Physical properties of sand and gravel materials from a gravel pit south of Cowles

[Collected by L. K. Wenzel and H. A. Waite; analyzed by V. C. Fishel]

\begin{tabular}{|c|c|c|c|c|c|c|c|c|c|c|}
\hline \multirow{2}{*}{$\begin{array}{l}\text { Distance } \\
\text { above water } \\
\text { Ievel (feet) }\end{array}$} & \multicolumn{7}{|c|}{ Mechanical analysis (percent by weight) } & \multirow[b]{2}{*}{$\begin{array}{l}\text { Apparent } \\
\text { specific } \\
\text { gravity }\end{array}$} & \multirow[b]{2}{*}{$\begin{array}{l}\text { Porosity } \\
\text { (percent) }\end{array}$} & \multirow{2}{*}{$\begin{array}{l}\text { Coeff- } \\
\text { cient of } \\
\text { perme- } \\
\text { ability }\end{array}$} \\
\hline & $\begin{array}{c}\text { Larger } \\
\text { than } \\
2.0 \\
\text { mm }\end{array}$ & $\begin{array}{l}2.0- \\
1.0 \\
\mathrm{~mm}\end{array}$ & $\begin{array}{l}1.0- \\
0.50 \\
\mathrm{~mm}\end{array}$ & $\begin{array}{l}0.50- \\
0.25 \\
\mathrm{~mm}\end{array}$ & $\begin{array}{l}0.25- \\
0.125 \\
\mathrm{~mm}\end{array}$ & $\begin{array}{l}0.125- \\
0.062 \\
\mathrm{~mm}\end{array}$ & $\begin{array}{l}\text { Less } \\
\text { than } \\
0.062 \\
\text { mm }\end{array}$ & & & \\
\hline \multirow[t]{2}{*}{$\begin{array}{l}6 \\
12 \\
18 \\
30\end{array}$} & \multirow[t]{2}{*}{$\begin{array}{r}31.3 \\
25.5 \\
17.9 \\
23.4\end{array}$} & \multirow[t]{2}{*}{$\begin{array}{r}14.8 \\
4.9 \\
4.4 \\
7.5\end{array}$} & \multirow[t]{2}{*}{$\begin{array}{r}0.1 \\
32.8 \\
32.7 \\
25.1 \\
26.9\end{array}$} & \multirow[t]{2}{*}{$\begin{array}{r}3.3 \\
15.2 \\
28.1 \\
38.6 \\
31.8\end{array}$} & \multirow[t]{2}{*}{$\begin{array}{r}64.1 \\
2.0 \\
7.6 \\
10.7 \\
5.9\end{array}$} & \multirow[t]{2}{*}{$\begin{array}{r}30.5 \\
3.3 \\
.8 \\
2.4 \\
3.6\end{array}$} & \multirow[t]{2}{*}{$\begin{array}{r}2.1 \\
.5 \\
.3 \\
.9 \\
.4\end{array}$} & \multirow[t]{2}{*}{$\begin{array}{l}1.53 \\
1.77 \\
1.86 \\
1.74 \\
1.79\end{array}$} & \multirow[t]{2}{*}{$\begin{array}{l}43.3 \\
33.3 \\
29.1 \\
33.3 \\
33.3\end{array}$} & $\begin{array}{r}250 \\
3,450 \\
750 \\
450 \\
8,350\end{array}$ \\
\hline & & & & & & & & & & Av, 2, 650 \\
\hline
\end{tabular}


Soil.-The coefficients of permeability of the samples of soil collected near Lexington ranged from less than 1 to about 3, which corresponds closely to the permeability of the loess. A sample of alkali soil south of Lexington had a permeability of less than 1.

\section{GROUND-WATER VELOCITT METHOD}

A method of determining permeability by tests made in the field for the natural velocities of ground water, patterned after the method of the German hydrologist A. Thiem, was developed by Slichter. ${ }^{48}$ Several small wells are driven into the water-bearing materials in such a manner that the movement of water is from one well toward one or more of the other wells. A salt is introduced into the up-gradient well and is allowed to move down-gradient with the ground water to the other wells, where its arrival is detected electrically. The rate of movement of the salt and hence the rate of movement of the ground water is computed from the elapsed time between the introduction of the salt in the central well and its detection in a well located downgradient. The quantity of water flowing through a given cross-sectional area of the water-bearing material is computed by the formula $Q=p A v$, in which $Q$ is the quantity of water, $p$ is the porosity of the water-bearing material, $A$ is the cross-sectional area, and $v$ is the average velocity of the ground water.

Slichter did not compute permeability after determining the natural velocity of the ground water. However, permeability can be computed by equating the formula given above and Darcy's equation. The resulting equation for determining the coefficient of permeability is $P=\frac{p v}{I}$, in which $P$ is the coefficient of permeability, $p$ is the porosity of the water-bearing material, $v$ is the velocity of the ground water, and $I$ is the hydraulic gradient.

Tests were made by this method at three localities in the Platte Valley -2 miles south of Lexington, in the SW $1 / 4 \mathrm{SW} 1 / 4$ sec. 17, T. 9 N., R. $21 \mathrm{~W} . ; 2 \frac{1}{2}$ miles northwest of Lexington, in the NW1/4 NW $1 / 4$ sec. 36 , T. 10 N., R. 22 W.; and southwest of Kearney, in the NE1/4 NE $1 / 4$ sec. 21, T. 8 N., R. 16 W.49 The tests were not successful in detecting normal ground-water velocities in the Platte Valley, apparently because the velocities are low. The salt solution introduced into the wells had a higher specific gravity than natural water. Thus it sank rather rapidly and in time percolated below the down-gradient wells

48 Slichter, C. S., The motions of underground waters: Geol. Survey Water-Supply Paper 67, pp 46-51, 1902; Description of underflow meter used in measuring the velocity and direction of underground water: Geol. Survey Water-Supply Paper 110, pp. 17-31, 1905; Field measurements of the rate of movement of underground waters: Geol. Survey Water-Supply Paper 140, pp. 16-28, 1905. Hamlin, Homer, Underflow tests in the drainage basin of Los Angeles River: Geol. Survey Water-Supply Paper 112, pp. 11-32, 1905. Veatch, A. O., Slichter, C. S., Bowman, Isaiah, Crosby, W. O., and Horton, R. E., Underground water resources of Long Island, N. Y.: Geol. Survey Prof. Paper 44, pp. 88-99, 1906.

- Wenzel, L. K., Report on field work of 1930 on ground-water investigations in the Platte River Valley near Lexington, Nebr., Geol. Survey manuscript files, 1931. 
instead of passing almost horizontally between the up-gradient and down-gradient wells. Slichter found by experiments made in a vertical tank that even when the ground-water velocities were rather high, the electrolyte sank considerably below the level at which it was introduced.50

If a coefficient of permeability of 2,100 is used (the average coefficient of permeability obtained by laboratory tests on samples of the sand and gravel collected at the location of the velocity test south of Lexington), the average velocity of the ground water computed by the formula $v=\frac{P I}{p}$ at a porosity of 32 and a hydraulic gradient of 6 feet to the mile is 0.99 foot a day, or about 361 feet a year.

\section{PUMPING-TEST METHOD}

The pumping-test method of determining permeability is simple in principle. It consists of pumping a well that penetrates waterbearing material whose permeability is to be determined and observing the decline of the water table around the pumped well. The method is based on the consideration that in localities where the normal water table is horizontal, after approximate equilibrium is established around a pumped well, equal quantities of water move toward the well in a given unit of time through a successive series of concentric cylindrical cross sections around the well. Because the areas of the large cylinders through which the water percolates are greater than the areas of the smaller cylinders, the velocity of the ground water passing through them is proportionally less and the hydraulic gradients are proportionally smaller.

According to Darcy's equation, the discharge through any of the concentric cylindrical sections of water-bearing material, $Q$, is equal to $P I A$, and the permeability of the material, $P$, equals $\frac{Q}{I A}$. The hydraulic gradient at a given distance from the pumped well can be determined from the slope of the water table or piezometric surface. ${ }^{51}$ For artesian conditions the area of the cylindrical section through which the ground water percolates at that distance from the pumped well is equal to $2 \pi x m$, if $x$ is the distance from the pumped well and $m$ is the thickness of the water-bearing material. For water-table conditions the area is equal to $2 \pi x(m-s)$, where $s$ is the draw-down at the

\footnotetext{
so Slichter, C. S., Field measurements of the rate of movement of underground waters: Geol. Survey Water-Supply Paper 140, pp. 41-49, 1905.

51 The upper surface of the zone of saturation in ordinary soll or rock is called the water table. If a well is sunk it remains empty until it enters a saturated permeable bed-that is, until it enters the zone of saturation. Then water flows into the well. If the rock through which the well passes is all permeable the first water that is struck will stand in the well at about the level of the top of the zone of saturation-that is, at about the level of the water table. If the rock overlying the bed in which water is struck is impermeable the water is generally under pressure that will raise it in the well to some point above the level at which it was struck. In such a place there is no water table, and the imaginary surface to which the water rises under its full head is called the piezometric surface.
} 
distance $x$ from the pumped well. Thus the permeability of the water-bearing formation can be computed by substituting these values in the equation $P=\frac{Q}{I A}$.

The method was first used by G. Thiem, ${ }^{62}$ son of the German hydrologist A. Thiem, in 1906 in connection with an investigation to determine additional water supply for the city of Prague and its suburbs. A formula was developed for computing permeability by using the draw-down as measured in two observation wells and the discharge of the pumped well rather than determining the flow through concentric cylindrical sections directly by Darcy's equation. Thiem's formula, modified for convenient use in the United States, is

$$
P=\frac{527.7 q \log \frac{a_{1}}{a}}{m\left(s-s_{1}\right)}
$$

in which $P=$ the coefficient of permeability defined on page 88 .

$q=$ rate of pumping, in gallons a minute.

$a$ and $a_{1}=$ respective distances of two observation wells from the pumped well, in feet.

$m$ for artesian conditions $=$ thickness of water-bearing bed, in feet.

$m$ for water-table conditions $=$ average thickness (at $a$ and $a_{1}$ ) of the saturated part of the water-bearing bed, in feet.

$s$ and $s_{1}=$ draw-downs at the two observation wells, in feet.

Test near Grand Island.-Thiem's formula is based on several theoretical hydrologic and geologic conditions that are rarely found in nature. Of these, the assumptions that the water table or piezometric surface is horizontal and that a condition of equilibrium has been established around the pumped well are the most widely variant from the conditions observed in the field. In an endeavor to determine the applicability of Thiem's method to field conditions two rather intensive pumping tests were made on the farm of Fred Meyer, 4 miles east of Grand Island, in the NW $1 / 4$ sec. 17 , T. 11 N., R. 8 W. ${ }^{53}$ The pumped wells used in these tests are designated in the table on page 193 by nos. 38 and 39 . About 80 observation wells were sunk on lines radiating from the pumped wells, at distances as great as 1,200 feet. A test hole and a test well were drilled to determine the thickness of the sand and gravel and to obtain samples of the material for laboratory determinations of permeability. The well was pumped continuously for 48 hours, and during that time and for about 24

\footnotetext{
39 Thiem, G., Hydrologische Methoden, Leipzig, 1906.

ss Wenzel, L. K., Recent investigations of Thiem's method for determining permeability of water-bearing materials: Am. Geophys. Union Trans. 13th Ann. Meeting, pp. 313-317, 1932; The Thiem method for determining permeability of water-bearing materials and its application to the determination of specific yield: Geol. Survey Water-Supply Paper 679-A, 1936.
} 
hours after pumping was discontinued measurements were made on the water level in the observation wells. The data collected during this test were carefully studied, and a method of procedure was determined whereby the difference between theoretical and observed conditions could be minimized.

It was found that satisfactory results could be obtained only by substituting in Thiem's formula the draw-down of the water table in that part of the cone of depression where approximate equilibrium had been established. The water table after 48 hours of pumping had not reached equilibrium, but for distances out to 200 feet from the pumped well an approximate equilibrium had been established. Thus the difference in draw-down $s-s_{1}$ as substituted in Thiem's formula did not change appreciably after 12 to 24 hours of pumping, although the absolute draw-down of the water table increased.

For distances less than 50 feet from the pumped well the draw-down of the water table was found to be affected by changes in the permeability of the material resulting from the development of the well and by the failure of the well to penetrate the entire thickness of the waterbearing material.

Coefficients of permeability as computed in 48-hour pumping test near Grand Island

[Pumping rate 540 gallons a minute]

\begin{tabular}{|c|c|c|c|c|c|c|c|c|c|}
\hline \multicolumn{2}{|c|}{$\begin{array}{l}\text { Distance from } \\
\text { pumped well } \\
\text { (feet) }\end{array}$} & \multirow{2}{*}{$\begin{array}{l}\text { Thickness } \\
\text { of water- } \\
\text { bearing } \\
\text { bed (feet) } \\
(m)\end{array}$} & \multirow{2}{*}{$\begin{array}{c}\text { Difference } \\
\text { in draw- } \\
\text { down } \\
(\text { feet) } \\
\left(s \rightarrow s_{1}\right)\end{array}$} & \multirow{2}{*}{$\begin{array}{c}\text { Coefficient } \\
\text { of perme- } \\
\text { ability } \\
(P)\end{array}$} & \multicolumn{2}{|c|}{$\begin{array}{l}\text { Distance from } \\
\text { pumped well } \\
\text { (feet) }\end{array}$} & \multirow{2}{*}{$\begin{array}{c}\text { Thickness } \\
\text { of water- } \\
\text { bearing } \\
\text { bed (feet) } \\
(m)\end{array}$} & \multirow{2}{*}{$\begin{array}{c}\text { Difference } \\
\text { in draw- } \\
\text { down } \\
\text { (feet) } \\
\left(s-s_{1}\right)\end{array}$} & \multirow{2}{*}{$\begin{array}{l}\text { Coefficient } \\
\text { of perme- } \\
\text { ability } \\
(P)\end{array}$} \\
\hline $\begin{array}{c}\text { Distant } \\
\text { well } \\
\left(a_{1}\right)\end{array}$ & $\begin{array}{c}\text { Near } \\
\text { well } \\
(a)\end{array}$ & & & & $\begin{array}{c}\text { Distant } \\
\text { well } \\
\left(a_{1}\right)\end{array}$ & $\begin{array}{c}\text { Near } \\
\text { well } \\
(a)\end{array}$ & & & \\
\hline $\begin{array}{r}60 \\
80 \\
100 \\
120 \\
140 \\
160 \\
180 \\
200 \\
80 \\
100 \\
120 \\
140 \\
160 \\
180 \\
200 \\
100 \\
120 \\
140\end{array}$ & $\begin{array}{l}40 \\
40 \\
40 \\
40 \\
40 \\
40 \\
40 \\
40 \\
60 \\
60 \\
60 \\
60 \\
60 \\
60 \\
60 \\
80 \\
80 \\
80\end{array}$ & $\begin{array}{l}96.94 \\
97.14 \\
97.28 \\
97.40 \\
97.50 \\
97.58 \\
97.65 \\
97.71 \\
97.40 \\
97.54 \\
97.67 \\
97.76 \\
97.84 \\
97.91 \\
97.98 \\
97.73 \\
97.85 \\
97.95\end{array}$ & $\begin{array}{r}0.53 \\
.91 \\
1.19 \\
1.44 \\
1.63 \\
1.79 \\
1.93 \\
2.07 \\
.38 \\
.66 \\
.91 \\
1.10 \\
1.26 \\
1.40 \\
1.53 \\
.28 \\
.53 \\
.72\end{array}$ & $\begin{array}{r}976 \\
970 \\
980 \\
969 \\
975 \\
982 \\
987 \\
985 \\
962 \\
983 \\
965 \\
975 \\
985 \\
992 \\
994 \\
1,010 \\
967 \\
982\end{array}$ & $\begin{array}{l}160 \\
180 \\
200 \\
120 \\
140 \\
160 \\
180 \\
200 \\
140 \\
160 \\
180 \\
200 \\
160 \\
180 \\
200 \\
180 \\
200 \\
200\end{array}$ & $\begin{array}{r}80 \\
80 \\
80 \\
100 \\
100 \\
100 \\
100 \\
100 \\
120 \\
120 \\
120 \\
120 \\
140 \\
140 \\
140 \\
160 \\
160 \\
180\end{array}$ & $\begin{array}{l}98.03 \\
98.10 \\
98.16 \\
98.00 \\
98.09 \\
98.17 \\
98.24 \\
98.30 \\
98.22 \\
98.30 \\
98.37 \\
98.43 \\
98.39 \\
98.46 \\
98.52 \\
98.54 \\
98.60 \\
98.68\end{array}$ & $\begin{array}{r}.88 \\
1.02 \\
1.15 \\
.25 \\
.44 \\
.60 \\
.74 \\
.87 \\
.19 \\
.35 \\
.49 \\
.62 \\
.16 \\
.30 \\
.43 \\
.14 \\
.27 \\
.13\end{array}$ & $\begin{array}{r}994 \\
1,002 \\
1,005 \\
919 \\
964 \\
987 \\
1,000 \\
1,003 \\
1,023 \\
1,035 \\
1,040 \\
1,043 \\
1,050 \\
1,071 \\
1,043 \\
1,053 \\
1,038 \\
1,000\end{array}$ \\
\hline
\end{tabular}

The draw-down of the water table at equal distances in different directions from the pumped well was found to be unequal, probably because the normal water table had an original slope. Thus coeffcients of permeability that varied widely were computed by substituting these draw-downs in Thiem's formula. However, this condition was minimized by averaging the draw-down of the water table at equal distances and in opposite directions from the pumped well. 
The coefficients of permeability computed by using only the drawdown of the water table where the cone of depression had reached approximate equilibrium and by averaging the draw-downs at equal distances from the pumped well are given in the table on page 102 . The average coefficient of permeability is about 997 , and the maximum deviation from the average is 7.8 percent. It should be noted that the most irregular results accompany small differences in the draw-down of the water table. Such results are to be expected, because small errors in the measurements cause large differences in the computed permeability. Moreover, the part of the cone farthest from the pumped well had not approached complete equilibrium as nearly as the part of the cone nearer the well.

The average coefficient of permeability, as determined in the hydrologic laboratory, of 19 samples of the water-bearing material obtained during the drilling of a well at the location of this test is 1,200 , and the average determined by the test is 997 . Because the samples were unconsolidated and the material was rearranged before the laboratory tests were made, it seems probable that the coefficient of permeability determined by the Thiem test is the more accurate.

Test near Kearney. - Two other pumping tests were made in the Platte Valley to determine the permeability of the sand and gravel in the vicinity of Kearney and Gothenburg. One test was made about 8 miles east of Kearney, in the NW1/4 sec. 27 , T. 9 N., R. 14 W. The well pumped for this test is designated in the table on page 217 by no. 576. Only 10 observation wells were used in this test, and they were located on a line that was approximately parallel to the maximum slope of the water table. Five wells were driven on each side of the pumped well at distances of 50,100,150,200, and 250 feet, in accordance with the results of the more elaborate test made near Grand Island. A test hole was drilled near the existing irrigation well, and the saturated thickness of the sand and gravel above the Ogallala formation was found to be about 48 feet. The pumped well was operated continuously at a rate of about 1,100 gallons a minute for 24 hours, and measurements of water level were made in the observation wells about once an hour. From these data coefficients of permeability were computed by Thiem's formula for all possible combinations of observed draw-downs. The average coefficient was 4,140 , and the maximum deviation from the average only 3.6 percent. The high permeability determined was expected, in view of the relatively high yields of the irrigation wells in this locality. 
Coefficients of permeability as computed in 24-hour pumping test near Kearney

[Pumping rate 1,100 gallons a minute]

\begin{tabular}{|c|c|c|c|c|c|c|c|c|c|}
\hline \multicolumn{2}{|c|}{$\begin{array}{l}\text { Distance from } \\
\text { pumped well } \\
\text { (feet) }\end{array}$} & \multirow{2}{*}{$\begin{array}{c}\text { Thickness } \\
\text { of water- } \\
\text { bearing } \\
\text { bed (feet) } \\
(m)\end{array}$} & \multirow{2}{*}{$\begin{array}{l}\text { Difference } \\
\text { in draw- } \\
\text { down } \\
\text { (feet) } \\
\left(s-s_{1}\right)\end{array}$} & \multirow{2}{*}{$\begin{array}{l}\text { Coeffi- } \\
\text { cient of } \\
\text { permea- } \\
\text { bility } \\
(P)\end{array}$} & \multicolumn{2}{|c|}{$\begin{array}{l}\text { Distance from } \\
\text { pumped well } \\
\text { (feet) }\end{array}$} & \multirow{2}{*}{$\begin{array}{c}\text { Thickness } \\
\text { of water- } \\
\text { bearing } \\
\text { bed (feet) } \\
(m)\end{array}$} & \multirow{2}{*}{$\begin{array}{c}\text { Difference } \\
\text { in draw- } \\
\text { down } \\
\text { (feet) } \\
\left(s-s_{1}\right)\end{array}$} & \multirow{2}{*}{$\begin{array}{l}\text { Coeffi- } \\
\text { cient of } \\
\text { permea- } \\
\text { bility } \\
(P)\end{array}$} \\
\hline $\begin{array}{l}\text { Dis- } \\
\text { tant } \\
\text { well } \\
\left(a_{1}\right)\end{array}$ & $\begin{array}{c}\text { Near } \\
\text { well } \\
(a)\end{array}$ & & & & $\begin{array}{l}\text { Dis- } \\
\text { tant } \\
\text { well } \\
\left(a_{1}\right)\end{array}$ & $\begin{array}{c}\text { Near } \\
\text { well } \\
(a)\end{array}$ & & & \\
\hline $\begin{array}{l}100 \\
150 \\
200 \\
250 \\
150\end{array}$ & $\begin{array}{r}50 \\
50 \\
50 \\
50 \\
100\end{array}$ & $\begin{array}{l}44.6 \\
44.8 \\
45.0 \\
45.2 \\
4.3\end{array}$ & $\begin{array}{l}0.975 \\
1.50 \\
1.88 \\
2.185 \\
.525\end{array}$ & $\begin{array}{l}4,030 \\
4,130 \\
4,150 \\
4,110 \\
4,290\end{array}$ & $\begin{array}{l}200 \\
250 \\
200 \\
250 \\
250\end{array}$ & $\begin{array}{l}100 \\
100 \\
150 \\
120 \\
200\end{array}$ & $\begin{array}{l}45.5 \\
45.7 \\
45.8 \\
45.9 \\
46.1\end{array}$ & $\begin{array}{r}.905 \\
1.21 \\
.38 \\
.685 \\
.305\end{array}$ & $\begin{array}{l}4,240 \\
4,180 \\
4,160 \\
4,100 \\
4,010\end{array}$ \\
\hline
\end{tabular}

Test near Gothenburg.-The other pumping test to determine permeability was made about 2 miles east of Gothenburg, in the SW $1 / 4$ NW $1 / 4$ sec. 19, T. 11 N., R. 24 W. The irrigation well used for the test is no. 978 in the table on page 236 . Ten observation wells were again located on a straight line through the pumped well, in a direction that approximated the maximum slope of the water table. Five of the wells were driven on each side of the pumped well at distances of $50,100,150,190$, and 250 feet. A test hole was drilled near the pumped well, and the saturated thickness of sand and gravel was found to be only 17 feet. In this locality, however, the zone of saturation extended up into the loess for about 5 feet. The pumped well was operated continuously at a rate of about 532 gallons a minute for 24 hours, and measurements were made in the observation wells about once an hour. From these data coefficients of permeability were computed by Thiem's formula for all combinations of observed draw-downs. The average coefficient of permeability was 3,842 , and the maximum deviation from the average only 2.4 percent.

Coefficients of permeability as computed in 24-hour pumping test near Gothenburg

[Pumping rate 532 gallons a minute]

\begin{tabular}{|c|c|c|c|c|c|c|c|c|c|}
\hline \multicolumn{2}{|c|}{$\begin{array}{l}\text { Distance from } \\
\text { pumped well } \\
\text { (feet) }\end{array}$} & \multirow{2}{*}{$\begin{array}{c}\text { Thickness } \\
\text { of watter- } \\
\text { bearing } \\
\text { bed (feet) } \\
(m)\end{array}$} & \multirow{2}{*}{$\begin{array}{l}\text { Difference } \\
\text { in draw- } \\
\text { down } \\
\text { (feet) } \\
\left(s-s_{1}\right)\end{array}$} & \multirow{2}{*}{$\begin{array}{l}\text { Coeffi- } \\
\text { cient of } \\
\text { permea- } \\
\text { bility } \\
(P)\end{array}$} & \multicolumn{2}{|c|}{$\begin{array}{l}\text { Distance from } \\
\text { pumped well } \\
\text { (feet) }\end{array}$} & \multirow{2}{*}{$\begin{array}{l}\text { Thickness } \\
\text { of water- } \\
\text { bearing } \\
\text { bed (feet) } \\
(m)\end{array}$} & \multirow{2}{*}{$\begin{array}{c}\text { Difference } \\
\text { in draw- } \\
\text { down } \\
\text { (feet) } \\
\left(s-s_{1}\right)\end{array}$} & \multirow{2}{*}{$\begin{array}{l}\text { Coeffi- } \\
\text { cient of } \\
\text { permea- } \\
\text { bility } \\
(P)\end{array}$} \\
\hline $\begin{array}{l}\text { Dis- } \\
\text { tant } \\
\text { well } \\
\left(a_{1}\right)\end{array}$ & $\begin{array}{l}\text { Near } \\
\text { well } \\
(a)\end{array}$ & & & & $\begin{array}{l}\text { Dis- } \\
\text { tant } \\
\text { well } \\
\left(a_{1}\right)\end{array}$ & $\begin{array}{l}\text { Near } \\
\text { well } \\
(a)\end{array}$ & & & \\
\hline $\begin{array}{l}100 \\
150 \\
190 \\
250 \\
150\end{array}$ & $\begin{array}{r}50 \\
50 \\
50 \\
50 \\
100\end{array}$ & $\begin{array}{l}17 \\
17 \\
17 \\
17 \\
17\end{array}$ & $\begin{array}{l}1.28 \\
2.02 \\
2.47 \\
2.99 \\
0.74\end{array}$ & $\begin{array}{l}3,880 \\
3,890 \\
3,870 \\
3,860 \\
3,920\end{array}$ & $\begin{array}{l}190 \\
250 \\
190 \\
250 \\
250\end{array}$ & $\begin{array}{l}100 \\
i 00 \\
150 \\
150 \\
190\end{array}$ & $\begin{array}{l}17 \\
17 \\
17 \\
17 \\
17\end{array}$ & $\begin{array}{l}1.19 \\
1.71 \\
.45 \\
.97 \\
.52\end{array}$ & $\begin{array}{l}3,870 \\
3,840 \\
3,750 \\
3,800 \\
3,770\end{array}$ \\
\hline
\end{tabular}

Thiem's formula for artesian conditions was used in computing the results of this test-that is, the thickness of the saturated waterbearing material was taken as 17 feet, although the zone of saturation 
included a part of the overlying loess. The ground water in the area was not confined under pressure, hence artesian conditions did not exist. However, the permeability of the sand and gravel is so much greater than the permeability of the loess-in about the ratio of 3,840 to 2-that comparatively little water moved through the loess to the well. Thus it was possible-and in all such circumstances it is necessary--to use the artesian formula for computing permeability.

Summary.-The pumping-test method probably gives a more accurate result for the average permeability of the formation than can be obtained by miscellaneous determinations of permeability of samples of the material in the laboratory. The three pumping tests in the Platte Valley indicate that the coefficient of permeability of the sand and gravel near Gothenburg is about 3,850, near Kearney about 4,150, and near Grand Island about 1,000.

\section{GROUND-WATER IEVELS}

\section{METHOD OF INVESTIGATION}

Periodic measurements of the depth to the water table were made in about 100 wells in the segment of the Platte Yalley between Gothenburg and Grand Island. The wells were selected so that fluctuations of the water table could be observed in all parts of the area. During the early part of the investigation measurements were made on only 60 wells, but other wells were added later as it became desirable to study the fluctuation of the water table in more detail. Periodic measurements were also made on the altitude of the water surface in canals, creeks, and rivers in localities where their flow might influence the water levels in observation wells.

As a result of increased interest in ground-water levels a State-wide program of water-level measurements was begun in $1934,{ }^{54}$ and about 60 of the wells in the Platte Valley on which measurements were begun in 1930 and 1931 were included in this program. The measurements of water levels in wells in the Platte Valley and in wells located throughout the State are given to January 1, 1937, in a recent publication. ${ }^{55}$ The following table gives the numbers assigned to the Platte Valley observation wells in the State-wide program and the corresponding numbers that are used in this report. In WaterSupply Paper 817 the State-wide program numbers are used. The location and description of each well appears in the table of well records at the end of this report.

\footnotetext{
54 Wenzel, L. K., A State-wide program of periodic measurements of ground-water level in Nebraska: Am. Geophys. Union Trans. 16th Ann. Meeting, vol. 2, pp. 495-498, 1935. Waite, H. A., Ground-water level survey in Nebraska: Nebraska Geol. Survey Paper 7, 14 pp., 1935.

${ }^{65}$ Water levels and artesian pressure in observation wells in the United States in 1936: Geol. Survey WaterSupply Paper 817, pp. 89-167, 1937.
}

$121343-38-8$ 
Observation well numbers used in this report and corresponding numbers used in State-wide observation well program

\begin{tabular}{|c|c|c|c|}
\hline $\begin{array}{l}\text { Well } \\
\text { nn. in } \\
\text { this } \\
\text { report }\end{array}$ & Well no. in State-wide program & $\begin{array}{l}\text { Well } \\
\text { no. in } \\
\text { this } \\
\text { report }\end{array}$ & Well no. in State-wide program \\
\hline 104 & Hall County.. & 865 & Dawson County \\
\hline 130 & ................ & 856 & do................. \\
\hline 166 & ..... do & 867 & -287 \\
\hline 215 & .....do-.. & 868 & -.. 288 \\
\hline${ }_{246}^{219}$ & 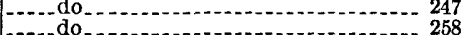 & $\begin{array}{l}871 \\
872\end{array}$ & -289 \\
\hline 315 & (....do..... & 873 & do.. \\
\hline 339 & - & 874 & do. \\
\hline 349 & do & 877 & do. \\
\hline 381 & Buffalo County & 878 & -.do \\
\hline 410 & - do & 879 & ...do_ \\
\hline 418 & - do & 880 & -.....do-. \\
\hline $\begin{array}{l}458 \\
509\end{array}$ & do & $\begin{array}{l}883 \\
885\end{array}$ & do \\
\hline 529 & do 267 & 887 & 298 \\
\hline & do & 889 & - ndon- \\
\hline & do & 890 & -...-. do.. \\
\hline 614 & Kearney County & 896 & do \\
\hline 632 & Buffalo County............ & 897 & 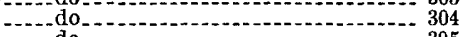 \\
\hline & - do & & ....do-.... \\
\hline 767 & do- & 907 & Gosper County \\
\hline 772 & do & 937 & 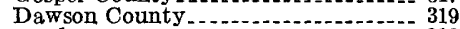 \\
\hline 774 & Phelps County & 951 & 318 \\
\hline 775 & 275 & 964 & 308 \\
\hline 787 & 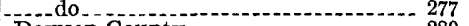 & 979 & do \\
\hline 863 & Dawson County-_. & 988 & do \\
\hline 864 & do & & \\
\hline
\end{tabular}

The depth to the water table in the observation wells was measured with a steel tape to the nearest hundredth of a foot. The tape was coated with blue or white carpenter's chalk before it was lowered into the water so that a definite water mark could be obtained. A lead or brass swiveled weight was attached to the tape to prevent it from becoming slack. It was thus not difficult to ascertain if the loaded tape was obstructed by irregularities of the casing or was coiling up on the bottom of the well.

All measurements were made from definitely established reference points. On most wells the top of the pipe or casing was used, but on some a permanent point on the pump base or wood curb was selected. Each reference point was plainly marked with keel, and the number of the well was posted in a conspicuous place near the well. A description of the reference point, its distance above or below the general land surface, and the location of the well in reference to cultural and topographic features were recorded. Benchrnarks were set in nearby permanent objects, and the differences in altitude between these benchmarks and the measuring points on the wells were determined by instrumental leveling. Thus the present water levels can be compared with future water levels, even though the present wells are destroyed, by constructing new wells on the same sites and determining the altitudes of the new measuring points from the benchmarks. 
The water-table measurements were made weekly on some wells and monthly on others. Two automatic water-stage recorders were maintained on wells in the area for a part of the period of the investigation, thus affording an opportunity to study the daily fluctuations of the water table.

The measurements were plotted as hydrographs showing the fluctuation of the water table, and many of the hydrographs are here reproduced (pls. 11, 12, and 13 and fig. 8). The measurements of the depth to the water table were used also to obtain an average figure for the fluctuation of the water table in the valley.

The observation wells were segregated according to their location, and the average fluctuation computed for each area. Thus a more representative result was obtained than if the arithmetic average of all the water levels in the wells had been used. The average fluctuation of the water table in each area was compared with the average fluctuation of the water table in other areas, the precipitation at nearby stations of the United States Weather Bureau, and the flow of the Platte River. This comparison

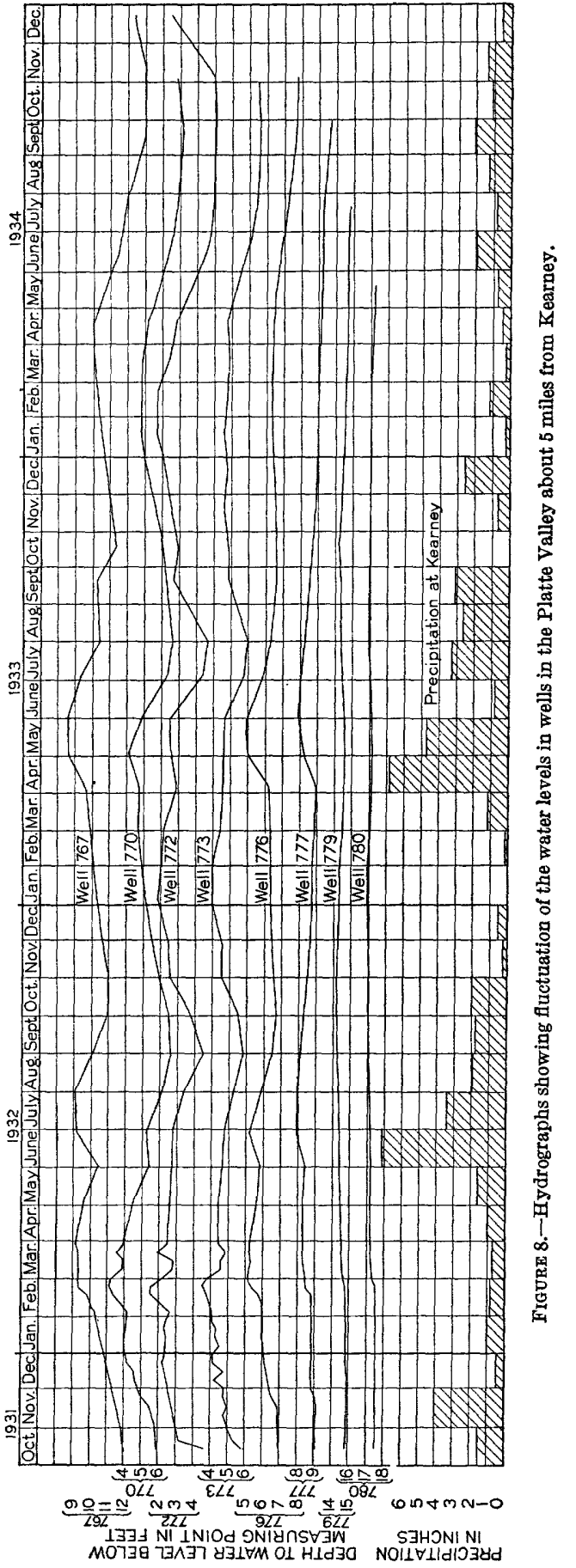


served as a basis for determining the present status of the depth of the water table in the valley with reference to predictions of its future depth.

\section{DIVISION OF THE PLATTE VALLEY INTO GROUND-WATER AREAS}

For the purpose of studying the fluctuation of the ground-water levels in detail, the Platte Valley between Chapman and Gothenburg was divided somewhat arbitrarily into four areas-the pumping area, the surface-water irrigation area, the east shallow-water area, and the west shallow-water area. The pumping area includes the part of the valley between Kearney and Chapman, where the water table is more than 10 feet below the land surface; the surface-water irrigation area includes the part of the valley between Gothenburg. and Kearney, where the water table is more than 10 feet below the land surface; and the shallow-water areas include the parts of the valley where the water table is less than 10 feet below the ground surface - the east area extending from Chapman to Kearney and the west area extending from Kearney to Gothenburg.

The boundaries between the shallow-water areas and the other areas are represented by the contour lines showing 10-foot depth to water. The lines are very irregular, and hence the areas themselves are irregular. In some places in the valley there are isolated areas at considerable distances from the Platte River where the depth to water table is less than 10 feet below the surface, and these areas have been included in the shallow-water areas. Conversely, there are places. close to the Platte River where the depth to the water table is more than 10 feet, and these areas have been included in either the pumping area or the area of surface-water irrigation. Thus part of the east shallow-water area lies within the pumping area north of Grand Island, and part of the west shallow-water area lies within the surfacewater irrigation area north of Lexington. North of Overton a part. of the surface-water irrigation area is entirely surrounded by the west. shallow-water area. The shallow-water areas mainly include and border the Platte River. On the south side of the river their areal extent is very slight, but on the north side they extend several miles north of the stream.

The Platte River Valley between Gothenburg and Chapman covers. about 800,000 acres, or 1,250 square miles, of which the pumping area covers 240,000 acres, the east shallow-water irrigation area 201,600 acres, the west shallow-water area 185,600 acres, and the surfacewater irrigation area 172,800 acres.

\section{FLUCTUATIONS OF THE WATER TABLE} GENERAI CONDITIONS

The water table of the ground-water reservoir in the Platte Valley fluctuates much like the water surface of any surface reservoir. The: 
water table rises when the inflow exceeds the draft and falls when the draft exceeds the inflow. The water table, however, fluctuates more with addition or depletion of a given quantity of water than the water in a surface reservoir, because only a part of the material that contains ground water is porous. The Pleistocene sand and gravel have a specific yield of about 24 , and the loess has a specific yield of about 20. Thus the addition of 1 foot of water to the sand and gravel will raise the water table in that material about 4 feet, and the addition of 1 foot of water to the loess will raise the water table in that material about 5 feet. Changes of the water levels in wells record the fluctuation of the water table and hence the recharge and discharge of the ground-water reservoir, somewhat as the fluctuation of the water level in a surface reservoir indicates the changes in storage. Therefore the safe yield of the ground-water reservoir can to some extent be estimated by observing the fluctuation of the water levels in wells. Measurements of depth to water in irrigation wells made soon after they have been pumped may not indicate the regional ground-water level, because the water table may not have fully recovered from the local disturbance caused by the pumping. However, measurements made after the water table has recovered indicate the actual regional water level. The rate of fluctuation of the water table depends upon the rate at which the ground-water reservoir is replenished or depleted.

The principal factors controlling the rise of the water table (groundwater recharge) in the Platte Valley are the amount of rainfall penetration, the amount of seepage from the Platte and other streams in the valley, and the amount of water added to the valley by underflow. The principal factors controlling the decline of the water table (groundwater discharge) are the amount of water lost from the valley by underflow, the amount of water pumped from wells, the amount of water transpired directly from the water table, and the amount of water lost from the ground-water reservoir by evaporation. If the quantity of ground water withdrawn from the valley during a certain year is greater than the recharge the water table will suffer a net decline. During a period of dry years the water table may register successive declines, but during a subsequent period of wet years the water table may return to its previous maximum level. Therefore, decline of the water table during a dry year does not necessarily mean an excessive withdrawal of water from the ground-water reservoir. Ground-water reservoirs usually contain large quantities of water in storage and hence they constitute important sources of water in dry years. During dry years the amount of water supplied to the ground-water reservoir by rainfall penetration and the discharge of streams is decreased, and the amount of water withdrawn through greater evaporation, larger demands by the vegetation, and heavier 
pumpage for irrigation is increased. During wet years, on the other hand, the amount of water supplied by rainfall and the discharge of the streams is increased, while the water withdrawn by evaporation, pumping, and transpiration is decreased.

In general, wells in the shallow-water areas, where the water table is less than 10 feet below the land surface, show greater fluctuations, both in magnitude and in rate, than wells in the areas where the depth to the water table is more than 10 feet. Most wells in the surfacewater irrigation area show greater fluctuations than the wells in the pumping area.

The water table in the Platte Valley usually reaches its highest stage in the spring and its lowest stage in the fall. During some years an additional peak occurs about December and another low point is reached about February or March. If there is alternate freezing and thawing throughout the winter recharge may occur intermittently, and the water may rise more or less continuously until June. On the other hand, if the winter is severe and the ground frozen for several months, although recharge may occur from the later part of September until the ground freezes, the water table may then decline until the ground thaws out in the spring, when the zone of saturation may receive recharge from the melting snow and spring rains. Under such conditions there may be two high and two low stages of the water table during the year.

The fluctuations of the water level in about 80 observation wells in the valley are plotted in plates 11,12 , and 13 and figure 8 . The fall low-water levels and the spring high-water levels are apparent for most of the wells. Several of the wells near Lexington show two low and two bigh stages during 1931-32. The first low stage was reached about October 1. This was followed by a high stage about March 1, another low stage about May 24, and a final high stage about June 7 to 21. During 1932-33 there was only one low stage, which occurred about April 18, followed by one high stage, about May 16.

The annual high-water levels in the wells in the pumping area usually occur later than those in the wells in the shallow-water areas. In 1931 the high-water level in the pumping area was reached in most wells about May 19, and in most wells in the west shallow-water area about April 1. In 1932 the high-water level occurred in most wells in the pumping area about July 1 and in the west shallow-water area about June 1. In 1933 the high-water level in wells in the pumping area occurred about June 1 and in the west shallow-water area about May 1. (See pls. 11, 12, and 13.)

\section{FLUCTUATIONS CAUSED BY PUMPING}

When wells are pumped the water table declines around each of the pumped wells and takes a form similar to an inverted cone. When pumping stops this cone of depression gradually fills up with water 
withdrawn from the area beyond the limits of the cone, and the regional water table in the vicinity of the pumped well declines slightly until it is once more practically smooth. Most wells are pumped intermittently, and while a cone is being formed in one part of the area another cone is being filled up in some other part of the area. After the end of the pumping season the regional water level of the ground-water reservoir gradually assumes a form similar to the form it had before the pumping season began, but the regional level of the water table is lower than it would be if there had been no pumping.

The pumping season in the Platte Valley usually extends from June through September, but its length varies from year to year, depending upon the distribution of the precipitation. The fluctuations of the water levels in 13 wells in the pumping area are plotted in plate 12, and the length of the pumping season is apparent from the comparatively rapid decline of the water levels in the summer. Some of the wells were pumped during the period of measurement, and these periods of pumping are indicated on the graphs by broken lines. The water table around some of the wells was drawn down below the regional water level, and after the pumping season a short period of recovery occurred. This is illustrated by the hydrographs of well 235 in 1931, well 246 in 1932, and well 410 in 1932.

The low water levels are usually reached at the end of the pumping season, and as that time varies for almost every well the low water levels occur on dates ranging from August to October. The regional water level is lower after the end of the pumping season than before pumping starts.

The fluctuations of the water table caused by local pumping were observed during the pumping test made in connection with the determination of the permeability and specific yield of the water-bearing materials near Grand Island (pp. 101-103). Profiles of the water table were drawn showing the water level in the vicinity of the pumped well before pumping started, after 12 hours of pumping, after 48 hours of pumping, and 24 hours after pumping stopped (fig. 9). The section was taken almost parallel to the maximum slope of the water table. The profiles show that close to the pumped well the water table declined more during the first 12 hours of pumping than during the next 36 hours. Farther from the pumped well the reverse is true. After 12 hours of pumping a ground-water divide was formed about 440 feet down-gradient from the pumped well. After 36 hours of additional pumping the divide had shifted down-gradient to about 600 feet from the pumped well. This was caused by the removal of water from storage and the consequent decline of the water table down-gradient from the divide. The profile of the water table 24 hours after pumping had stopped shows a rapid recovery near the pumped well and a 
112 GEOLOGY AND GROUND WATER, SOUTH-CENTRAL NEBRASKA

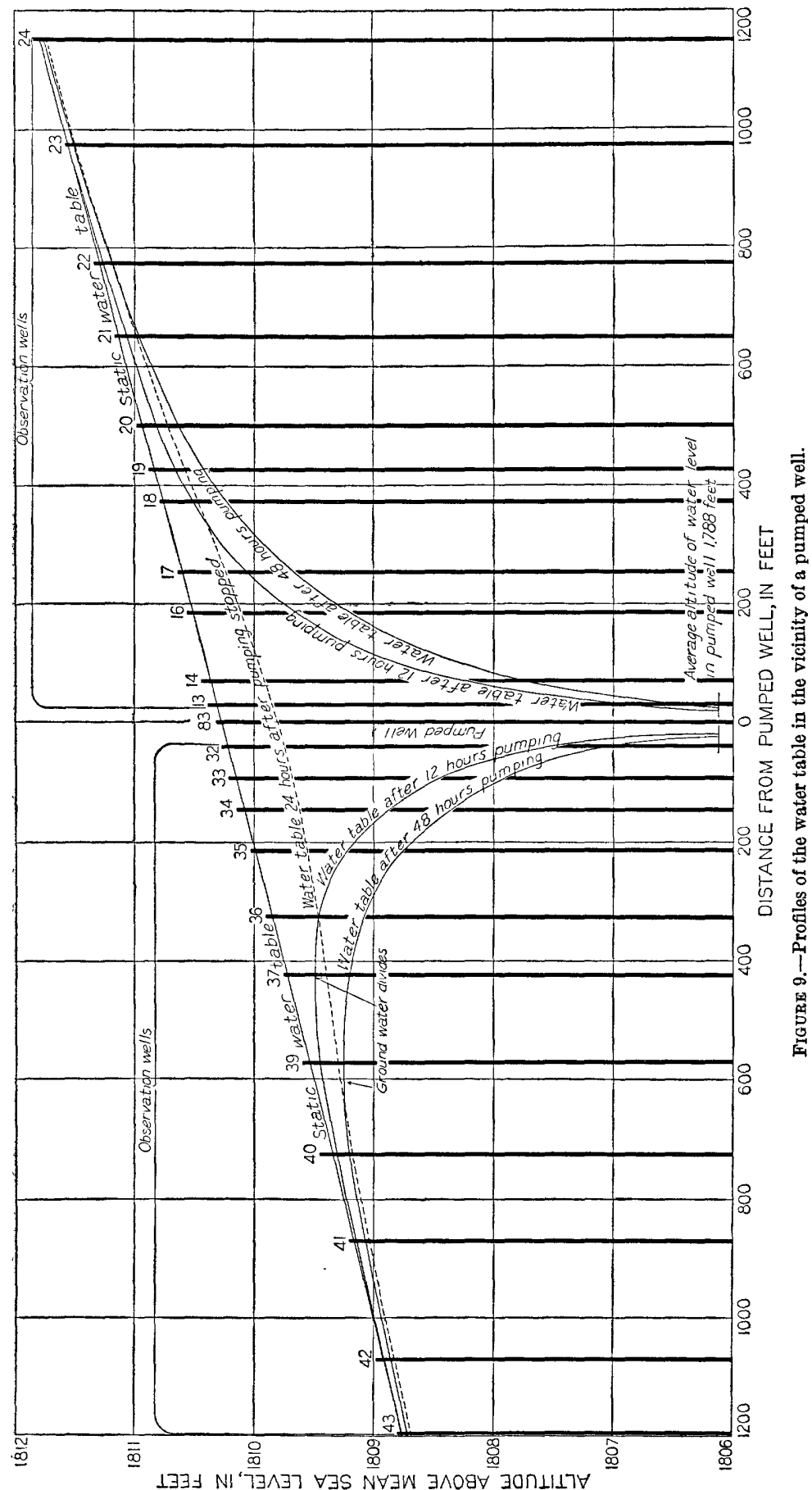


GEOLOGICAL SURVET 1931 1932

WATEB-SUPPIT PAPEB 779 PLATE 15 1934

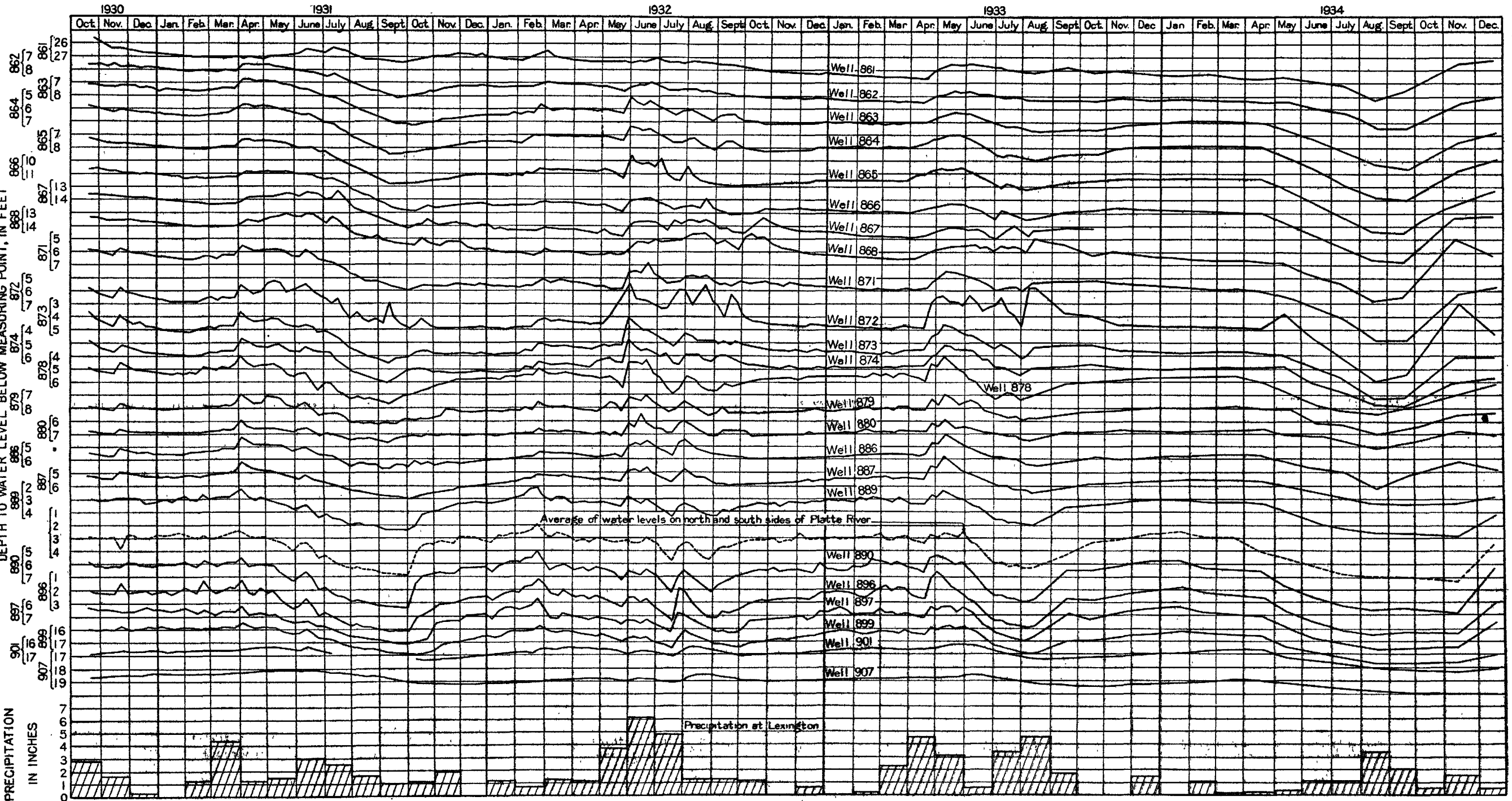
HYDROGRAPHS SHOWING FLUCTUATIONS OF THE WATER LEVEIS IN A LINE OF WELLS ACROSS THE PLATTE VALLEY NEAR LEXINGTON. 

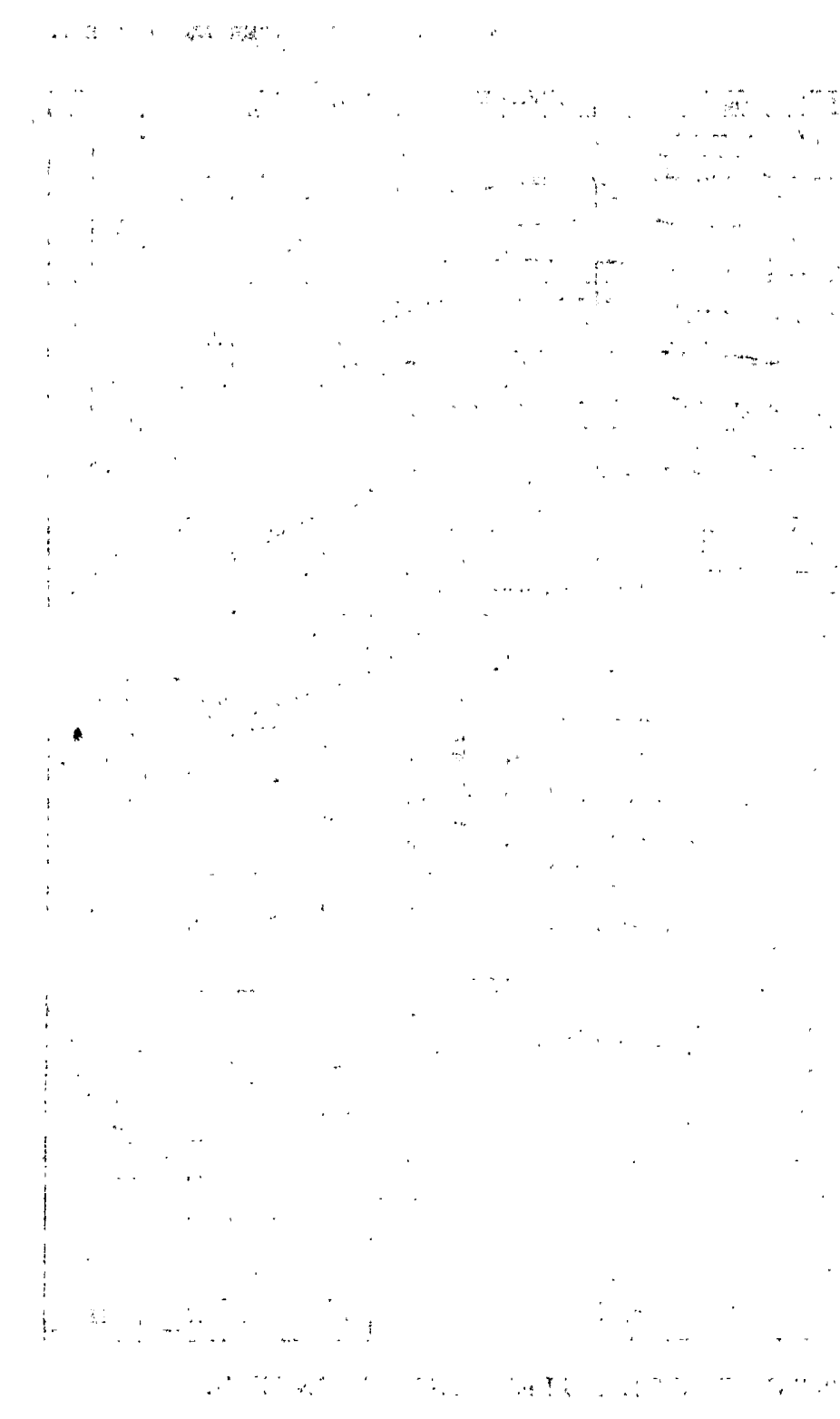
GEOLOGICAI SURVET

1930

1931

1932

1933

WATER-SUPPLY PAPER 770 PLATE 12

1934

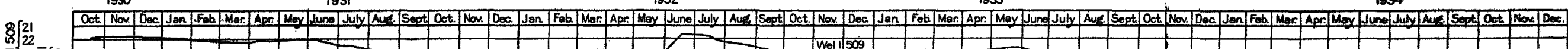

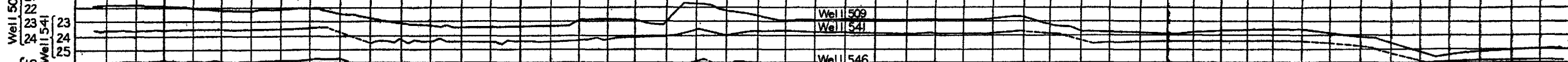

.

竞 of

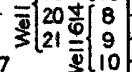

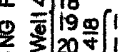

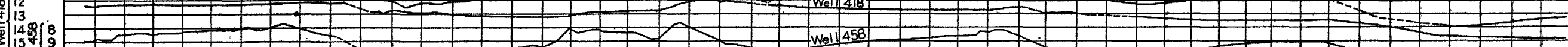

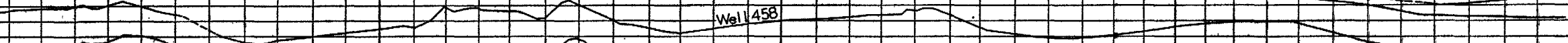

.

$\sum 21 \frac{20}{m}[24$

$\frac{8}{19}=\frac{25}{20}=$

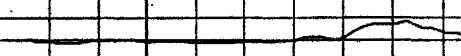

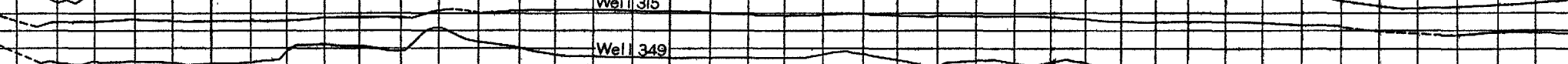

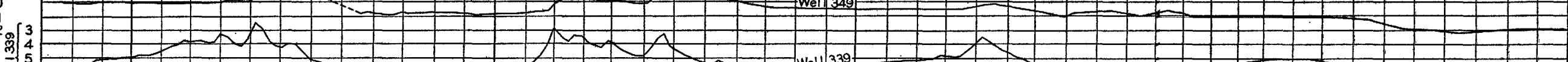
$=5$

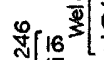

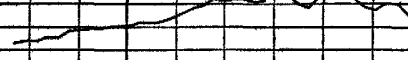

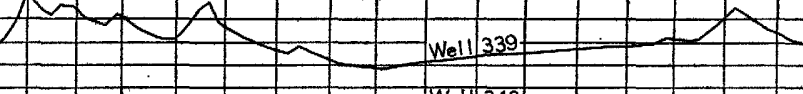

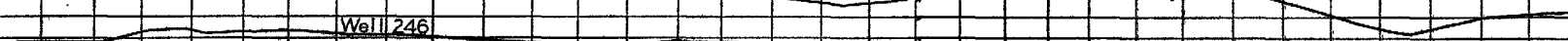

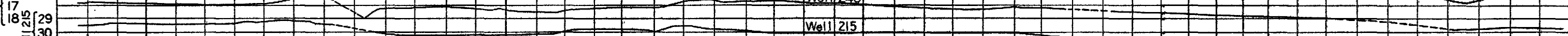

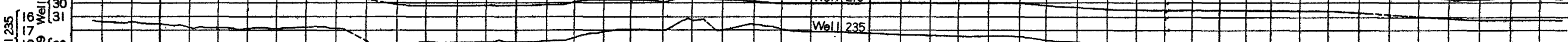

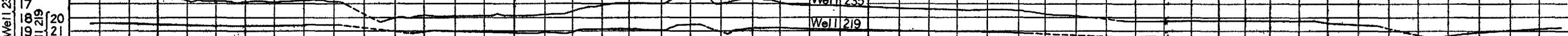

$\frac{5}{=}=\begin{aligned} & 4 \\ & 5 \\ & 6 \\ & 7\end{aligned}$

$\frac{3}{3}\left[\begin{array}{l}6 \\ 7 \\ 8 \\ 9 \\ 9\end{array}\right.$

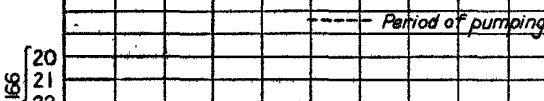

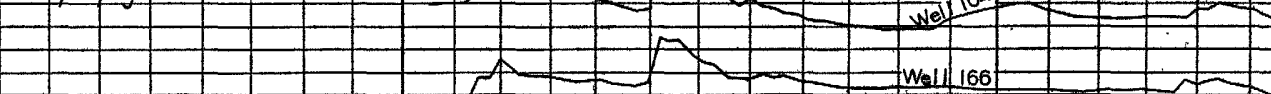

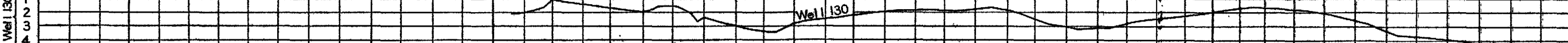

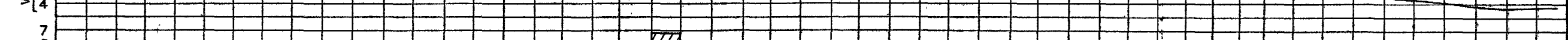

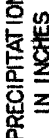

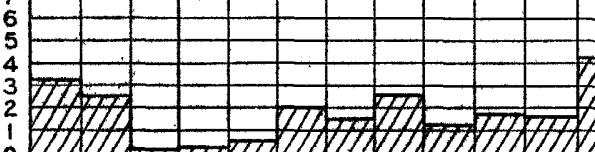

7

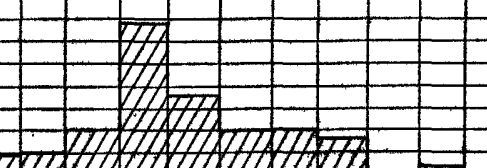

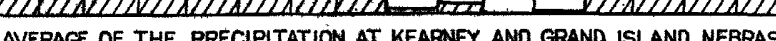

HYDROGRAPHS SHOWING FLUCTUATIONS OF THE WATER LEVELS IN WELIS IN THE PLATTE VALLEY BETWEEN GRAND ISLAND AND KEARNEY. 


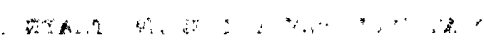

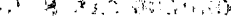

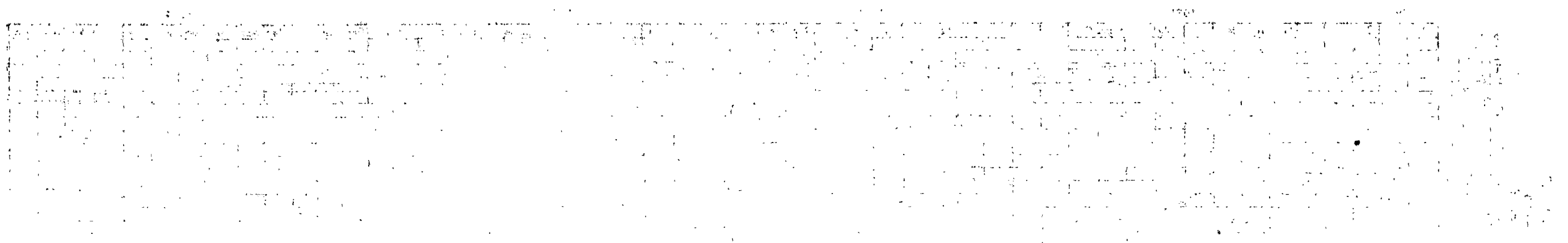




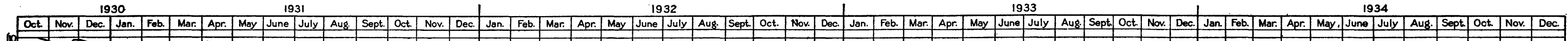

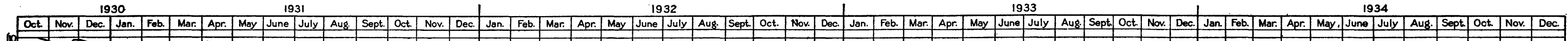

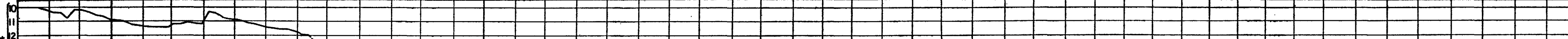

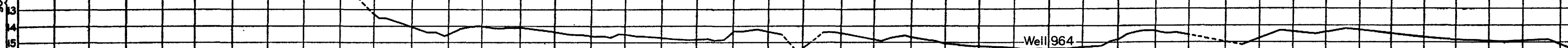

(1)

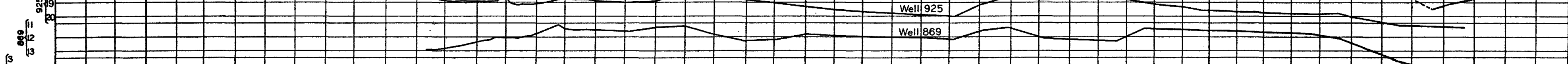

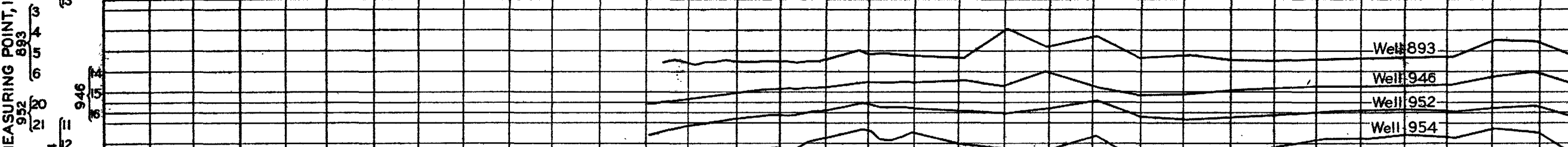

W W

W

_ _ _ _ (2)

m.

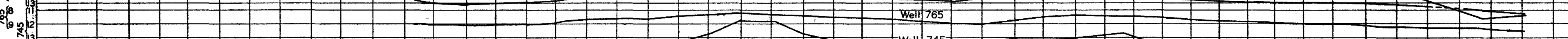

(2) (1) 
decline of the water table at distances of over 650 feet up-gradient and 800 feet down-gradient from the pumped well. This is significant, because it illustrates the gradual decline of the regional water table when water percolates into the cone of depression to take the place of the water that has been withdrawn from the formation by pumping. Measurements made in these 23 wells 1 month later showed that the water table then was parallel to the static water table shown in figure 9 , but about 0.3 foot lower.

\section{FLUCTUATIONS CAUSED BY STREAM FLOW AND SURFACE-WATER IRRIGATION}

When the discharge of the Platte River increases, the water surface of the stream rises above the ground-water level at its banks. Consequently water percolates out of the river into the ground until the adjacent water table is raised to a level corresponding to about the level of the stream. Conversely, when the discharge of the river decreases the water surface declines below the ground-water level, and water flows back into the stream until the water table declines to a position corresponding to the stage of the stream. These fluctuations of stage probably affect the ground-water levels at greater distances from the river in the Platte Valley than in most other valleys, because the water table for several miles adjacent to the Platte River has practically the same rate and direction of slope as the river, and a small rise or fall in the stage of the stream produces a change of gradient over an area extending several miles from the river. A stream that receives ground water from the zone of saturation is said to be a gaining stream, and a stream that contributes water to the zone of saturation is said to be a losing stream. The Platte River is at times a gaining stream and at times a losing stream. There is a lag between the fluctuations of the river and the fluctuations of the adjacent water table, because water is transmitted slowly through the ground. The longer the river maintains its new stage the farther back from the river will the water table be affected.

The average weekly water levels in 10 wells in the west shallowwater area are plotted in comparison with the weekly stage of the Platte River in figure 10. The hydrographs are very similar, but the wells in the shallow-water area are also affected by rainfall, and therefore the two hydrographs are not always alike. For instance, the discharge of the Platte declined from November 17 to 24,1930 , but the average water levels in the 10 wells rose sharply as a result of a. heavy rain on November 19. The Platte River was dry from the last. part of June until the middle of October 1931, and the hydrograph of the river between these dates shows the ground-water level below the river bed. The rises of the water table in the weeks ending July 6 and August 10,1931, were caused by rains on July 2 and 4 and on August 7, 8, and 9 . 


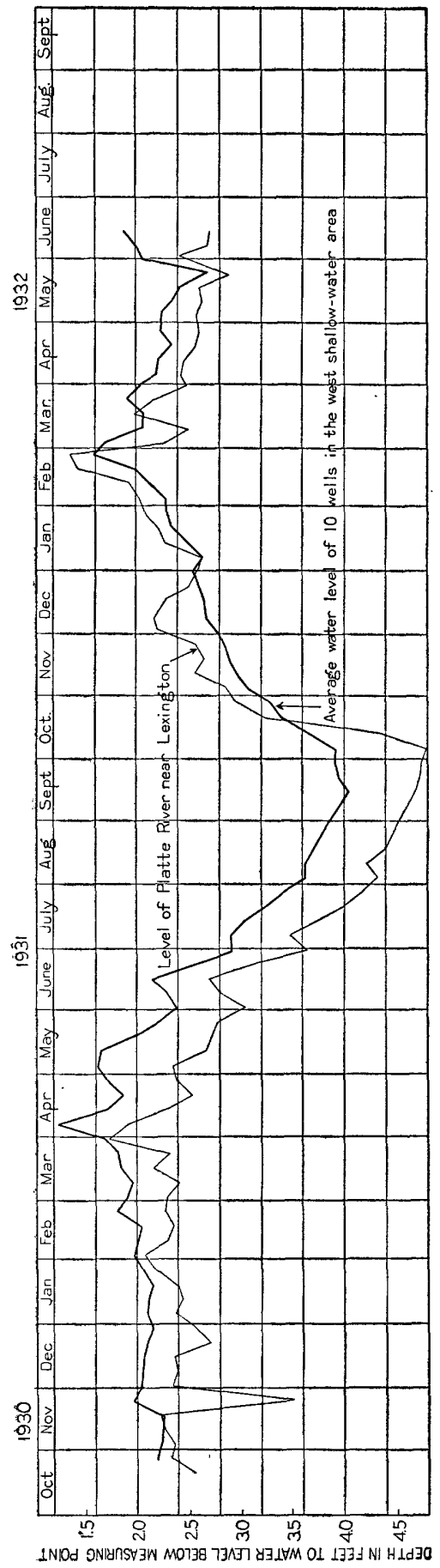

The average stage of the Platte River near Lexington is plotted in plate 11 as the average of the water levels as observed in two wells in the bed of the stream near its north and south banks. The general similarity in form between the average water level in these wells and the water levels in the wells on both sides of the river is readily seen.

The flow of the river is affected by the strong winds that occur frequently in the valley. When there is little wind movement the Platte usually meanders over its wide bed in small rivulets, but when there is a brisk wind the water is piled up on the leeward side of the river and the windward side is sometimes almost dry. This is a rather common occurrence on the Platte River. The water levels in the wells in the bed of the river indicate the stage of the stream when it is flowing and the stage of the water table when the stream is dry. Weekly measurements of depth to water were made in these wells, and the hydrographs were plotted (fig. 11). A close inspection of the two hydrographs shows that the water surface on the north side of the Platte River fluctuates differently from the water surface on the south side of the river, although the major fluctuations are similar. A comparison of the fluctuations for a part of 1930 and 1931 is given in the table on page 115 .

In the 32 weeks included in this tabulation the fluctuation of the 
river near its north bank in 14 weeks was reverse to the fluctuation near its south bank. In other weeks when the fluctuations on both sides of the river were accordant in trend, they differed greatly in magnitude. These differences were probably caused by changes of wind movement and changes in the channel through which the river flowed.

Comparison of the fluctuations of the Platte River by measurements of wells in the bed of the river near its north bank and near its south bank

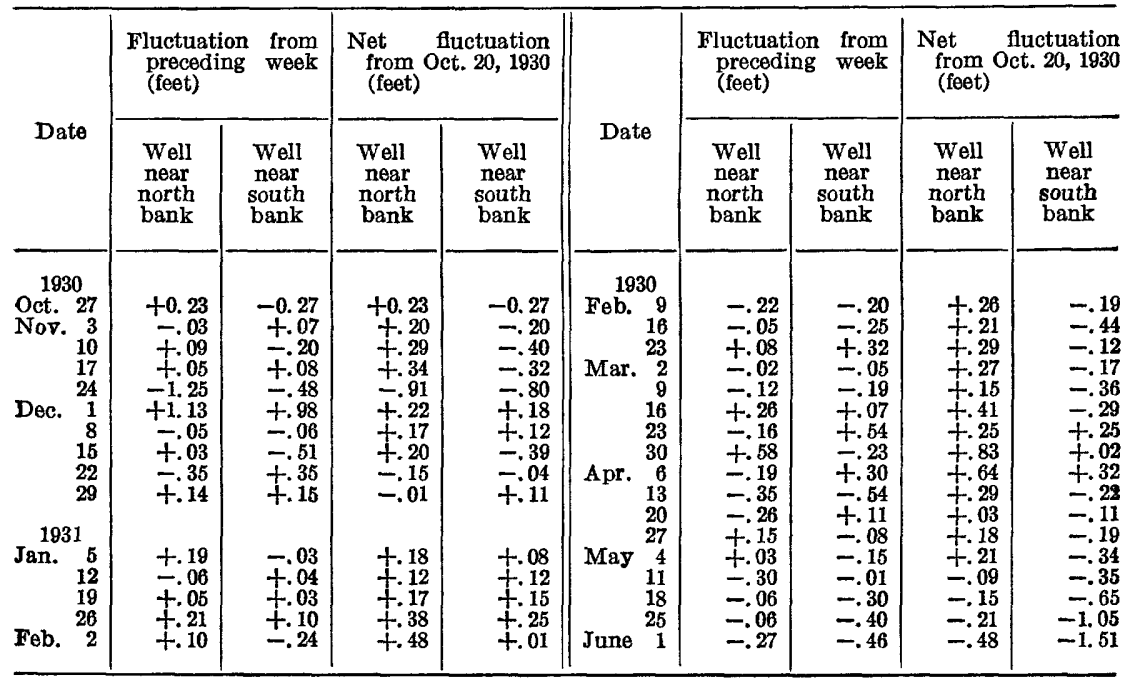

Fluctuations of the water surface of the Platte River usually cause corresponding fluctuations of the water table along its banks. When the water surface on one side of the river fluctuates differently from that on the other side, the water table along the banks of the river also fluctuates differently. When the water on the north side of the river is raised by wind, the water table along the north bank rises and the water table along the south bank declines.

Tests were made in 1930 by Slichter's electrolytic method to determine the velocity of ground water on the south side of the Platte River near Kearney. A contour map of the water table was made for a small area along the bank of the stream, and the direction of movement was found to be parallel to the river. Salt was introduced into a well about 5 feet from the river bank and was detected in wells spaced radially about $2 \frac{1}{2}$ feet from the salt well. It was expected that the movement of water would be parallel to the river, as indicated by the contour map of the water table, but the actual movement was found to be away from and at right angles to the river. When the test was started, at 8:15 a. m. September 24 , a brisk wind had blown most of the water flowing in the Platte River to the north side of the river. The direction of the wind changed abruptly after the 


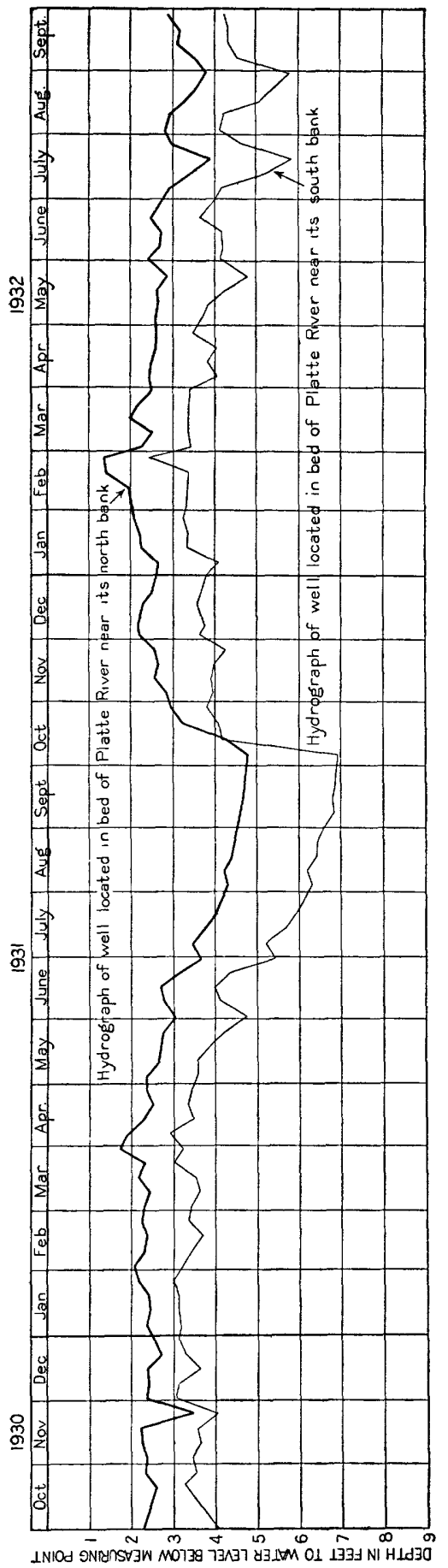

salt had been introduced into the well, and the water in the river was blown to the south side. This created a temporary gradient at about right angles to the river and caused the ground water to move southward, away from the river and about at right angles to the general gradient of the water table in the area, with a velocity of about 18 feet a day.

The water table may be inHuenced also by the stages of streams whose beds lie so far above the water table that ground water percolates only from the streams and never back in to them. Such is the case with most of the irrigation canals in the surfacewater irrigation area between Kearney and Gothenburg. During the winter these canals are dry, and no water seeps from them except that collected from rains and melting snow. The canals are filled with water from the Platte River about May 1, and except when water in the Platte is scarce they are usually maintained with some water in them until October. The altitude of the water surfaces in these canals varies throughout the summer with the draft on the canals and the inflow into them. The effective head and therefore the rate of percolation to the water table varies with the altitude of the water surfaces in the canals. When the water surface in a canal is high more water seeps to the water table than when the water surface is lower, and the water table fluctuates not be- 
cause water is added to it intermittently but because of the changes in the rate at which it is added. During years when the Platte River is dry, as in 1931, the canals may become dry also, and then the fluctuations of the water table are accentuated. Hydrographs of the water surface in an irrigation canal and in a well nearby show the relation between fluctuations of the water surface in the canal and fluctuations of the water table (fig. 12). During the winter, when the canal is dry, there are fluctuations caused by rainfall penetration, but during the summer each major change of water level in the canal is reflected by a corresponding fluctuation of the water table. The general decline of the water table from May until October 1931, even though percolation from the canal produced rises of the water table at times, shows that the transpiration, evaporation, and underflow losses from the zone of saturation around the well were greater than the average rate of seepage loss from the canal.

FLUCTUATIONS CAUSED BY TRANSPIRATION

Vegetal discharge of ground water is discharge through physiologic functioning of plants. The water may be taken into the roots of the plants directly from the zone of saturation or from the capillary fringe, which in turn is supplied from the zone of saturation. It is discharged from plants by the process of transpiration. .56

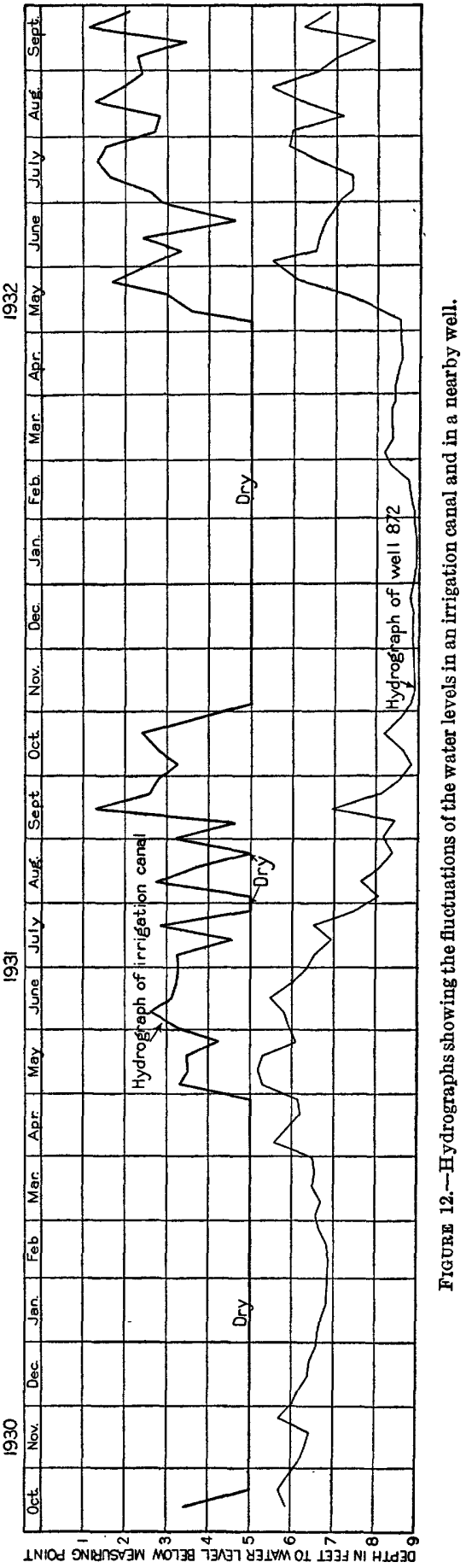

${ }^{60}$ Meinzer, O. E., Outline of ground-water hydrology, with definitions: Geol. Survey Water-Supply Paper 494, p. 48, 1923. 
Growing plants absorb most of the water they require from the soil. Where the water table lies but a few feet below the ground surface, as it does in the shallow-water area in the Platte Valley, the roots of plants draw water directly from the capillary fringe or from the zone of saturation, and the water table fluctuates in response to this vegetal discharge. The roots of some plants penetrate to great depths in order to draw water from the zone of saturation, especially in desert regions where rainfall is insufficient for their growth. Even in more humid regions the roots of some plants, such as alfalfa, penetrate 20 to 30 feet below the land surface to the water table.

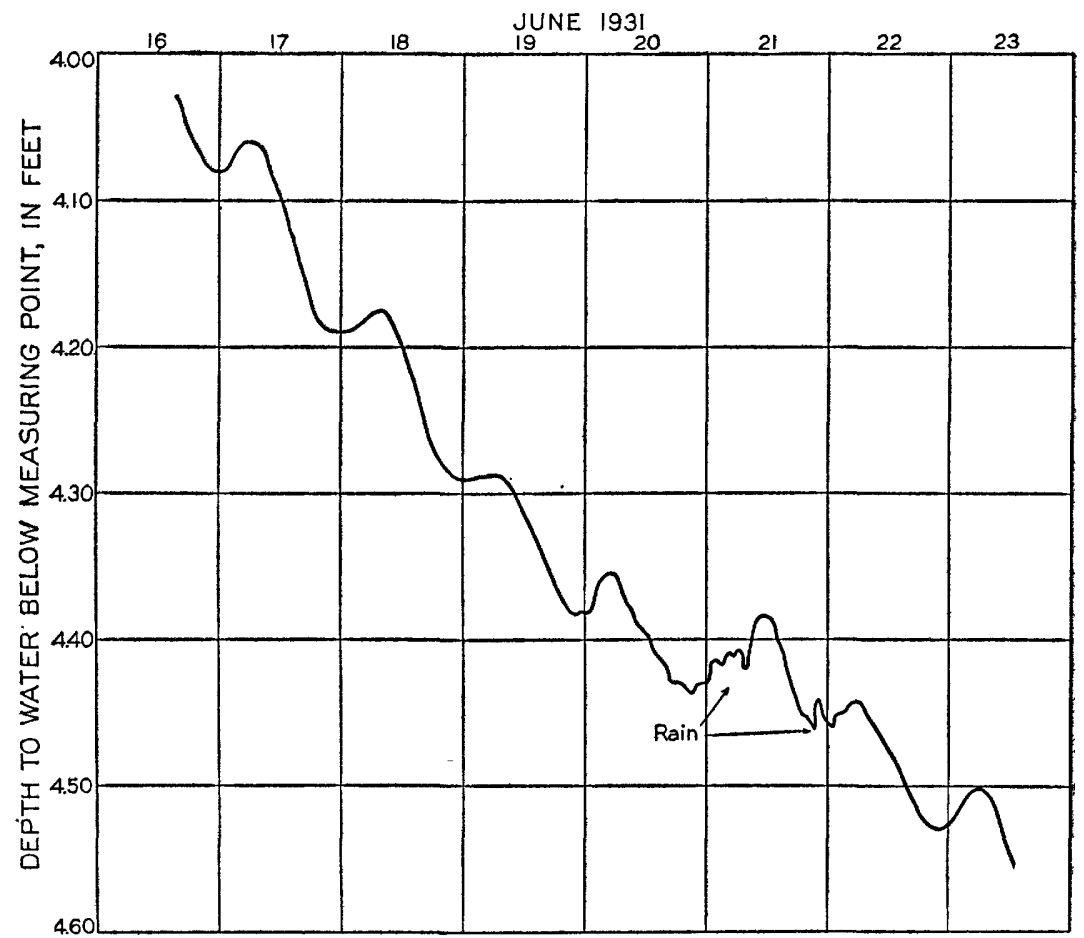

FrgURE 13.-Graph produced by an automatic water-stage recorder showing water-level fluctuations caused by transpiration.

The amount of transpiration by plants varies somewhat with the amount of sunlight. On cloudy days plants do not use as much water as on sunshiny days. Plants use little water during the night. The fluctuation of the water table as recorded by an automatic water-stage recorder on well 339 shows fluctuations caused by transpiration (fig. 13). This well is in a field of corn 75 feet from 40 acres of alfalfa and 25 feet from a field of barley. On most days the water level declined from 8 or 10 a.m. to about $10 \mathrm{p} . \mathrm{m}$. and then rose until 8 or 10 a $\mathrm{m}$. the next morning. The total rise each day was less than the previous loss, so that the water table suffered net daily declines. The 
transpiration draft on the ground water depressed the water table in this area and caused water to flow into the depression from surrounding areas where the draft was less. As soon as transpiration decreased the discharge from the zone of saturation decreased and the decline of the water table was retarded. The amount of water flowing into the depression from nearby areas was then great enough to cause a small rise of the water table. When transpiration increased once more the rate soon became greater than the rate of recharge and the water table again declined. If the water table had been lowered the same amount over the entire valley there would have been no daily rise of the water level as shown in well 339 , hence the amount of water transpired by the plants in the vicinity of the well must have been comparatively large. The rise and minor fluctuations of the water table on June 21 were caused by rainfall penetration.

\section{FLUCTUATIONS CAUSED BY PRECIPITATION}

Under favorable conditions of soil moisture a part of the precipitation seeps down through the interstices of the soil and is added to the zone of saturation. The amount and frequency of this recharge depend in part upon the depth of the water table below the surface. A discussion of soil-moisture conditions governing recharge by precipitation is given on pages 149-150. In general, recharge from precipitation occurs more frequently where the water table is shallow than where the water table is at a greater distance below the surface. In the Platte Valley the fluctuations of the water table caused by precipitation occur more often near the Platte River than near the valley limits, because the water table near the river is shallow. Wells 861 and 862 are close to the north valley limit, and wells 901 and 907 are close to the south valley limit. The range of fluctuation of the water levels in wells 901 and 907 is less than the range in the two wells that are nearer to the river (pl. 11).

The amount of water that reaches the zone of saturation after a rain varies greatly in the same locality. Tests of rainfall penetration indicate that water does not seep into the soil in equal amount everywhere but varies considerably within distances of a few feet. This variation is probably caused by differences in the arrangement of the soil particles and differences in the moisture-holding capacity of the soils. Because of the unequal downward movement of moisture after a rain, more water is added to the zone of saturation in some areas than in others. The water table then resembles surface topography, with small knolls and intervening valleys. Water at once starts to move from higher to lower altitudes, and the water table gradually smooths out. This process of unequal recharge from precipitation is reflected in the fluctuation of water levels in wells. An automatic water-stage recorder was maintained on well 787, south of Elm Creek, 


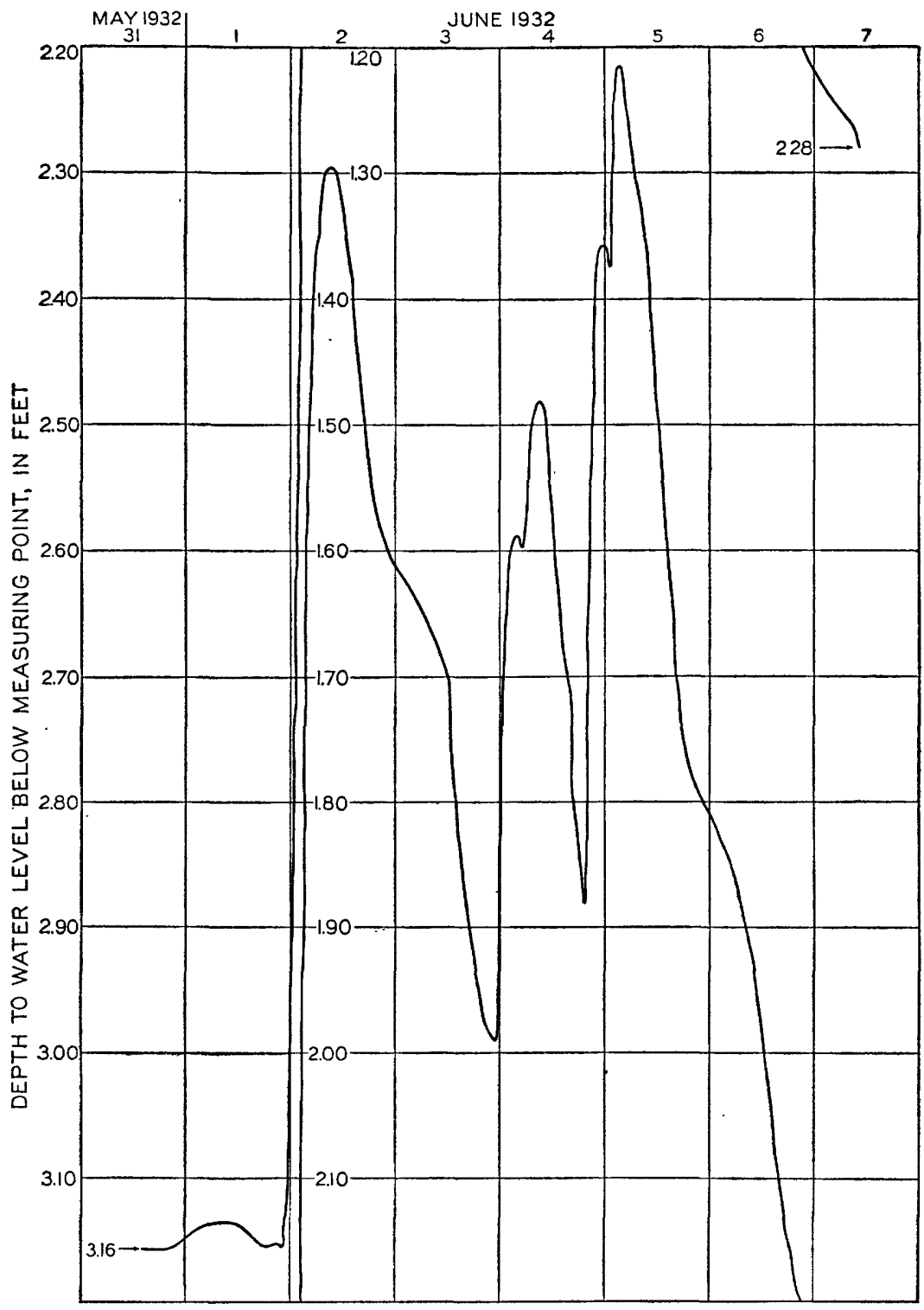

FIGURE 14.-Graph produced by an automatic water-stage recorder showing the rise of the water level in a well after a rain.

in the SW1/4 $\mathrm{SE}^{1 / 4}$ sec. 9 , T. 8 N., R. $18 \mathrm{~W}$. The water table in the vicinity of the well ranged from 1 to 4 feet below the surface. There was heavy precipitation on June 1, 1932, and the water table, as indicated by the automatic recorder, rose 1.86 feet in about 11 hours (fig. 14). The water level in the well then declined rapidly, probably because the areas where recharge had been less began to receive water by underflow from areas of large recharge. Evidently the area in 
the vicinity of the well received a plentiful recharge, while adjoining areas did not receive as much. Water near the well then percolated to adjoining areas where the water table was lower in altitude, thus tending to equalize the recharge. Similar fluctuations due to additional precipitation were observed later in the week. Fluctuations of this kind have been observed in many wells in the Platte Valley at places where the water table is comparatively shallow and where recharge from precipitation is relatively large. Some wells in the same areas show small immediate effects from recharge, but later rises of water levels are caused by percolation from local areas of greater recharge. Wells 877 and 878 are within the city limits of Lexington about half a mile apart. On May 24, 1932, the water levels in both wells stood 6.41 feet below their respective measuring points. By June 1 the water level in well 878 had risen 1.98 feet, or to a level 4.43 feet below its measuring point. By June 2 the water level in well 877 had risen 2.34 feet, or to a level 4.07 feet below its measuring point. By June 7 the water level in well 877 had declined 1.07 feet, but the water level in well 878 remained constant. The water level in well 877 , which received the largest recharge from precipitation, also declined the most. The water table around well 877 had apparently been built up temporarily, by recharge, to an altitude higher than the water table in adjoining areas. Therefore, a large part of the rise in the water table near that well was lost as water percolated from the vicinity of the well to nearby areas. On the other hand, the water table around well 878 had not been built up more than the water table in adjoining areas and therefore did not decline.

Where the water table stands comparatively far below the surface, recharge from precipitation occurs less frequently and the water table fluctuates less in response to precipitation than where the water table is comparatively shallow. A deep water table fluctuates little from rainfall during the growing season, because plants usually absorb the water supplied by the rain about as fast as it occurs. However, when heavy rainfall occurs during the summer some recharge may occur, with consequent rise of the water table. There is usually a lag between the time of precipitation and the time when the rain water reaches the zone of saturation, because the soil above the water table must first be filled with water in excess of its water-holding capacity. Moreover, water percolates downward at a rather slow rate, and therefore a considerable period is required before it reaches the zone of saturation. Recharge to the zone of saturation that occurs a considerable period after the precipitation may be called delayed recharge, and recharge that occurs soon after the precipitation may be called immediate recharge. A comparison of the fluctuation of water levels in wells 339 and 246 for several months in 1931 shows the effects of delayed and immediate recharge, as given in the following table: 
Comparison of water-table fuctuations in wells 399 and 246 and precipitation at Grand Island, 1931

\begin{tabular}{|c|c|c|c|c|c|c|c|}
\hline \multirow[b]{2}{*}{ Date } & \multirow{2}{*}{$\begin{array}{l}\text { Precipita- } \\
\text { tion during } \\
\text { preceding } \\
\text { week } \\
\text { at Grand } \\
\text { Island } \\
\text { (inches) }\end{array}$} & \multicolumn{3}{|c|}{ Well 339} & \multicolumn{3}{|c|}{ Well 246} \\
\hline & & $\begin{array}{l}\text { Depth to } \\
\text { water } \\
\text { (feet) }\end{array}$ & $\begin{array}{c}\text { Weekly } \\
\text { fluctuation } \\
\text { (feet) }\end{array}$ & $\begin{array}{l}\text { Net flue- } \\
\text { tuation } \\
\text { (feet) }\end{array}$ & $\begin{array}{l}\text { Depth to } \\
\text { water } \\
\text { (feet) }\end{array}$ & $\begin{array}{l}\text { Weekly } \\
\text { fluctuation } \\
\text { (feet) }\end{array}$ & $\begin{array}{l}\text { Net fluc- } \\
\text { tuation } \\
\text { (feet) }\end{array}$ \\
\hline $\begin{array}{l}\text { Mar. } 4 \\
\text { Mar. } 11 \\
\text { Mar. } 18 \\
\text { Mar. 25 } \\
\text { Apr. } 1 \\
\text { Apr. } 8 \\
\text { Apr. } 15 \\
\text { Apr. } 22 \\
\text { Apr. } 29 \\
\text { May } 6 \\
\text { May } 13 \\
\text { May } 20 \\
\text { May } 27 \\
\text { June } 2 \\
\text { June } 9 \\
\text { June } 16 \\
\text { June } 23 \\
\text { June } 30 \\
\text { July } 7\end{array}$ & $\begin{array}{r}0.02 \\
.75 \\
.00 \\
.75 \\
1.14 \\
.24 \\
.01 \\
.35 \\
.75 \\
1.08 \\
1.13 \\
.24 \\
.00 \\
.34 \\
.81 \\
.46 \\
.66 \\
.00 \\
.56\end{array}$ & $\begin{array}{l}3.88 \\
3.71 \\
3.86 \\
3.89 \\
3.27 \\
3.47 \\
3.98 \\
4.10 \\
3.67 \\
2.47 \\
2.80 \\
3.71 \\
4.08 \\
4.22 \\
4.04 \\
4.03 \\
4.59 \\
5.09 \\
5.25\end{array}$ & $\begin{array}{r}+0.17 \\
-.15 \\
-.03 \\
+.62 \\
-.20 \\
-.51 \\
-.12 \\
+.43 \\
+1.20 \\
-.33 \\
-.91 \\
-.37 \\
-.14 \\
+.18 \\
+.01 \\
-.56 \\
-.50 \\
-.16\end{array}$ & $\begin{array}{r}+0.17 \\
+.02 \\
+.01 \\
+.61 \\
+.41 \\
-.10 \\
-.22 \\
+.21 \\
+1.41 \\
+1.08 \\
+.17 \\
-.20 \\
-.34 \\
=.16 \\
-.15 \\
-. .71 \\
-1.21 \\
-1.37\end{array}$ & $\begin{array}{l}16.92 \\
16.96 \\
16.96 \\
16.97 \\
16.97 \\
16.94 \\
16.95 \\
16.95 \\
16.92 \\
16.90 \\
16.79 \\
16.68 \\
16.60 \\
16.54 \\
16.50 \\
16.48 \\
16.47 \\
16.47 \\
16.51\end{array}$ & $\begin{array}{r}-0.04 \\
.00 \\
-.01 \\
.00 \\
+.03 \\
-.01 \\
.00 \\
+.03 \\
+.02 \\
+.11 \\
+.11 \\
+.08 \\
+.06 \\
+.04 \\
+.02 \\
+.01 \\
.00 \\
-.04\end{array}$ & $\begin{array}{r}-0.04 \\
-.04 \\
-.05 \\
-.05 \\
-.02 \\
-.03 \\
-.03 \\
.00 \\
+.02 \\
+.13 \\
+.24 \\
+.32 \\
+.38 \\
+.42 \\
+.44 \\
+.45 \\
+.45 \\
+.41\end{array}$ \\
\hline
\end{tabular}

The water table at well 339 averaged about 4 feet below the surface, and the water table at well 246 averaged about 16.75 feet below the surface. Well 246 is about $2 \frac{1}{2}$ miles northeast of well 339 . The water level in well 339 fluctuated rather closely with the weekly precipitation, in contrast to the level in well 246 , which did not. There was little fluctuation in well 246 until about April 29. The soil at that time had been supplied with sufficient moisture, and water began to percolate down to the zone of saturation. Because the deficit in soil moisture was not supplied until late in the spring, the total recharge was small. Probably all the water reaching the zone of saturation between May 20 and June 30 had been added to the subsoil some time before May 20. Slow draining of the soil accounted for the rise of 0.17 foot in the water table after May 20, as indicated by the weekly decrease in the amount of water added to the zone of saturation.

The monthly precipitation at nearby stations of the United States Weather Bureau is plotted in plates 11, 12, and 13 and figure 8 below the hydrographs of the water levels in the observation wells. The effect of the precipitation is apparent by an immediate rise of the water table in most of the wells in areas where the water table is shallow. Where the water table is comparatively deep the effect of the precipitation is usually delayed, and a rise of the water table occurs after an accumulation of precipitation. During the first few months in 1932 the precipitation on the pumping area was considerably less than normal. The water level in several wells, however, rose slightly about the first of March and then declined as the growth of plants depleted the zone of soil moisture (pl. 12). With normal precipitation the water 
levels would probably have declined continuously through the summer, but rather heavy precipitation during the first weeks of June satisfied the moisture deficit in the zone of soil moisture and allowed water to percolate to the zone of saturation. The water levels rose abruptly in most of the wells, thus producing an unseasonable high level in the later part of June. Continued plant growth soon caused the zone of soil moisture to become depleted, and moderate rains in July, August, and September had no effect on the water level.

\section{FLUCTUATIONS CAUSED BY CHANGES OF ATMOSPHERIC PRESSURE}

Where there is an impervious confining bed above the zone of saturation the water levels in wells that penetrate the water-bearing formation may fluctuate in response to changes of atmospheric pressure. The pressure on the water surface in a well increases with an increase of atmospheric pressure. If this increase in pressure is transmitted freely through the interstices of the soil above the zone of saturation to the ground water, the pressure is applied equally to the water around the well and in the well, and there will be no barometric fluctuation. However, if the pressure is not transmitted to all of the ground-water surface but acts only on the exposed water surface in the well, the water level in the well fluctuates according to change in pressure.

At times the soil above a water table acts as a confining bed and the water level in wells fluctuates with changes of barometric pressure. When the interstices of the soil are saturated with water and when the ground is frozen changes in atmospheric pressure are not transmitted readily through the soil to the water table. Hydrographs of wells 219 and 541 plotted with the barograph at Lincoln show a general correlation between changes of barometric pressure and fluctuations of the water levels in those wells (figs. 15 and 16). The barograph is inverted, because an increase in barometric pressure causes the water levels in wells to decline, and inversely a decrease of barometric pressure causes a rise in the water levels. The wells showed fluctuations in water level caused by changes in atmospheric pressure that were in magnitude about one-thirtieth of the fluctuations recorded by the barometer.

As the wells are more than 100 miles from the barometer station at Lincoln, small changes of atmospheric pressure there do not necessarily mean the same changes at the wells, and the fluctuations of the water levels correspond only to the general changes of pressure. However, unusual changes of barometric pressure that occur over extensive areas, as on November 19, 1930 (fig. 15), affect the water level in wells.

It is probable that the water level in most wells fluctuates to a small extent in response to changes in atmospheric pressure. The fluctuations in the Platte Valley are only a few bundredths of a foot, and the 
effect is negligible on weekly measurements of depths to water. Only with water-stage recorders of high precision were the fluctuations observable. Both wells were first equipped with 7 -inch floats, and no fluctuations were observed. Later well 541 was equipped witl a 14-

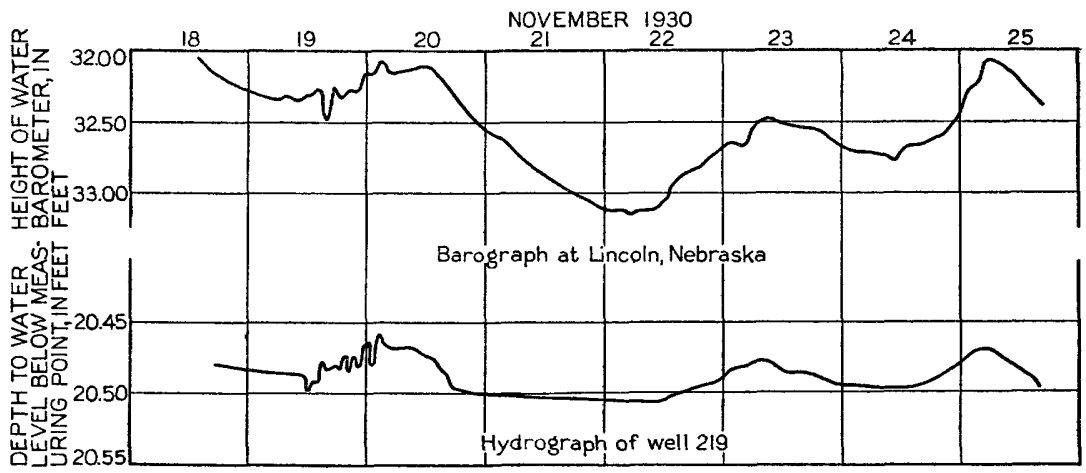

FIGURE 15.-Graph produced by an automatic water-stage recorder showing fluctuations of the water level in well 219 caused by changes in atmospheric pressure.

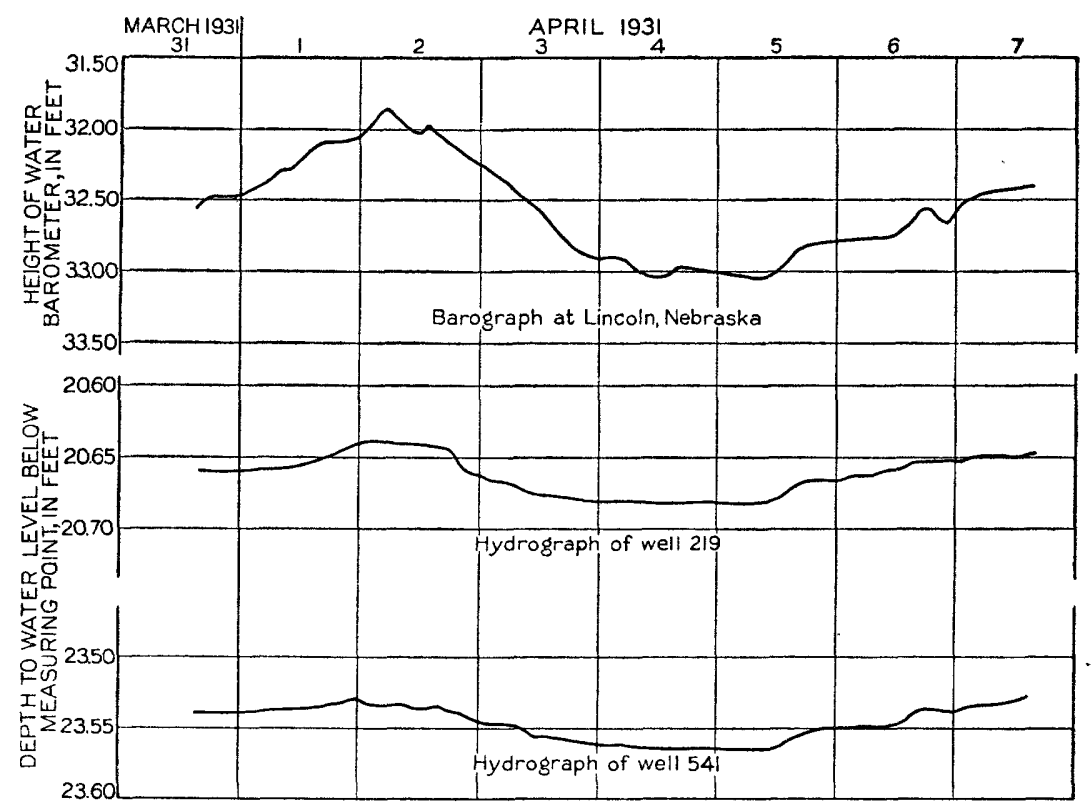

Figure 16.-Graph produced by an automatic water-stage recorder showing fluctuations of the water levels in wells 219 and 541 caused by changes in atmospheric pressure.

inch float and well 219 with a 22 -inch float. The hydrographs shown in figures 15 and 16 were then obtained. In some localities in the United States where the ground water is confined under pressure the water levels in wells have been observed to fluctuate several feet as a result of changes in atmospheric pressure. 


\section{NET RISE OR DECLINE OF THE WATER TABLE}

The graphs showing the fluctuations of the water levels in the observation wells indicate that in most wells there has been a net decline in water level in the period January 1, 1931, to January 1, 1935. The decline has been somewhat of the same magnitude through-

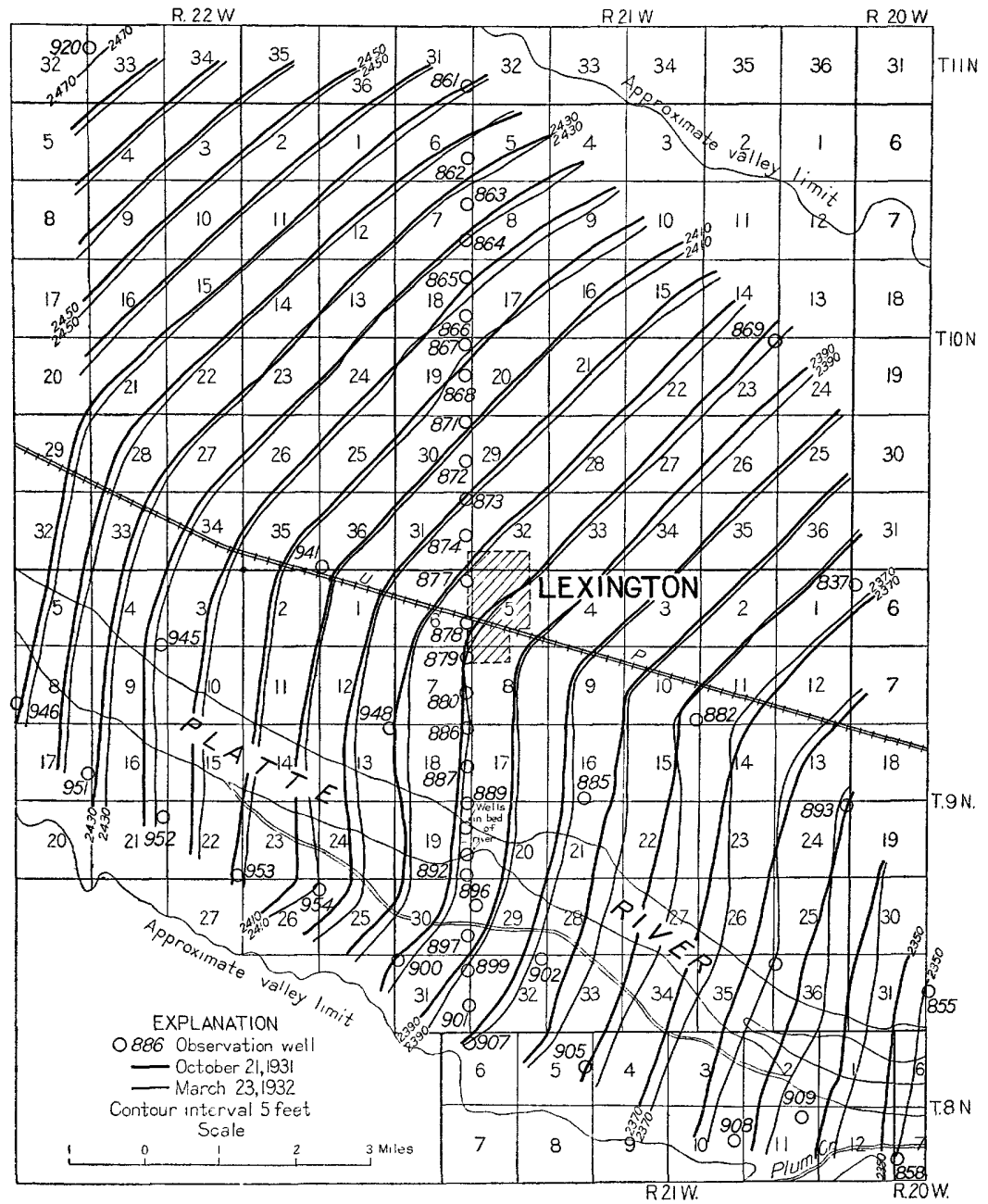

Frgure 17.-Map showing contours on the water table for the vicinity of Lexington. Heavy lines show contours on October 21, 1931; light lines show contours on March 23, 1932.

out the valley, although the particular years in which the major declines have been registered have differed in different parts of the area. The largest net decline of the water levels in the surface-water irrigation area occurred in the summers of 1931 and 1934, when only a little water in the Platte River was available for irrigation. The water table in this area has been built up in many places during the 
last 30 years to an abnormal level by the irrigation with surface water, and in years when little water is available for irrigation the water table shows a net decline. This is shown by the hydrographs of the wells near Lexington (pl. 11) and by the hydrograph of well 964, between Lexington and Cozad, and well 842, near Overton (pl. 13). The hydrograph of well 861, north of the area where intensive irrigation is carried on, shows a somewhat more continuous decline during the period of investigation (pl. 11). According to the contour map of the water table in the vicinity of Lexington (fig. 17), the water moves from the area near this well southeastward to the area where in 1931 and 1934 the largest declines of the water table occurred. Hence the gradual decline of the water level in this well was probably caused by the increased rate of percolation of the water from the vicinity of the well in those years. The recovery of the water level in this well in the last quarter of 1934 was probably caused by seepage from a nearby creek that is normally dry.

The water levels in most of the wells in the pumping area have fluctuated within a relatively small range, but most of them show net declines of about 1 or 2 feet. The fluctuations of the water levels in such wells as 215 and 315 are practically negligible except for a few weeks during which the wells are pumped.

In several of the wells eqst of Kearney the water levels rose gradually in most years from the low stages in September and October to the time when rapid recharge from precipitation occurred (pl. 12). This was especially apparent in wells 614,458 , and 339 , in the east shallowwater area, and wells 410 and 381 , in the pumping area. These gradual rises were probably caused by underflow into the area around the wells. The underflow into the shallow-water area occurs in the fall and winter, when the stage of the Platte River is higher than in the summer and a hydraulic gradient away from the river is produced. The underflow into certain localities in the pumping area is probably caused by local depressions of the water table formed during the summer by pumping. The gradual rise of the water level in wells is rather general over most of the east shallow-water area, but in the pumping area this rise occurs in only a few wells and is strictly limited in areal extent.

The 3-month fluctuations of the average of 14 wells in the pumping area, 12 wells in the surface-water irrigation area, 6 wells in the east shallow-water area, and 10 wells in the west shallow-water area are tabulated on page 127 .

The average water level of January 1, 1931, was selected as the datum from which the cumulative fluctuations were computed. At the end of 4 years, January 1, 1935, the average water level in all areas had declined over 2 feet. The decline amounts to 3.46 feet in the east shallow-water area, 2.36 feet in the west shallow-water 
area, 2.32 feet in the pumping area, and 2.29 feet in the surface-water irrigation area. The largest 3-month change occurred in the surfacewater irrigation area during the period July ! to October 1, 1931, when the water table declined an average of 1.83 feet. The next largest 3-month change occurred in the east shallow-water area during the period July 1 to October 1, 1932, when the water table declined an average of 1.75 feet. The largest change in the west shallow-water area was 1.62 feet, and the largest change in the pumping area was 1.06 feet.

Fluctuation, in feet, of the average water levels in wells in the four ground-wrter areas

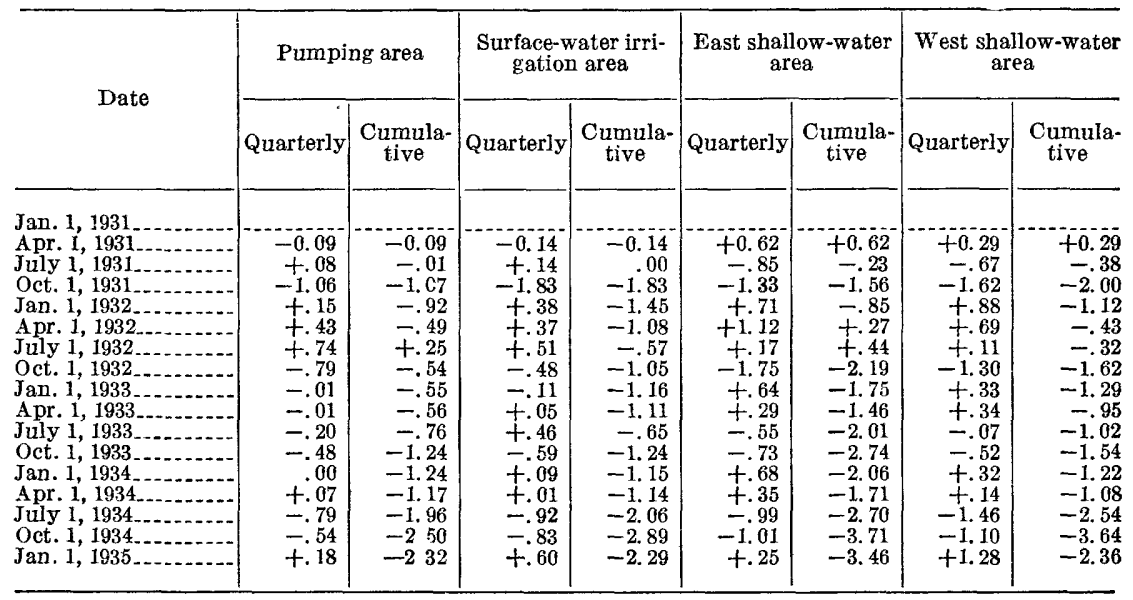

In the west shallow-water area and in the surface-water irrigation area the largest part of the 4-year decline of the water levels occured in 1931 and 1934. The decline of the water table in the west shallowwater area was 1.12 feet in 1931 and only 0.10 foot in the next 2 years. In the surface-water irrigation area the water table declined 1.45 feet in 1931 and rose 0.30 foot in the next 2 years. However, the water table suffered a net decline of 1.14 feet in 1934. In the east shallowwater area the average water level declined 0.85 foot in 1931 and 1.34 feet in 1932, rose 0.13 foot in 1933, and declined 1.40 feet in 1934 . In the pumping area the average water level declined 0.92 foot in 1931, rose 0.37 foot in 1932, and declined 0.69 foot in 1933 and 1.08 feet in 1934.

The net declines of the average water levels in the ground-water areas do not indicate that the long-time trend of the water table in the Platte Valley is downward, but only that from 1931 to 1935 the water levels were following a minor fluctuation that, in general, was downward in comparison to the average water levels on January 1, 1931. There is good reason to believe that on January 1, 1931, the water levels in the Platte Valley were abnormally high, because the precipitation during 1930 averaged about 140 percent of normal at Grand 
Island, Kearney, Lexington, and Gothenburg. This unusual amount of precipitation probably caused more than normal recharge to the zone of saturation and a more than normal rise of the water table. Hence a decline from these abnormal levels would be expected in subsequent years, even though precipitation during those years was normal. However, the annual precipitation in the Platte Valley during 1931, 1932, 1933, and 1934 was considerably less than normal, and presumably ground-water recharge was also greatly less than normal. The cumulative departure from normal precipitation at stations of the United States Weather Bureau in the Platte Valley averaged a loss of more than 21 inches during the 4 years 1931 to 1934 , and in only 2 out of 16 of the 3-month periods shown in the table on page 127 was the precipitation greater than normal. The 4-year deficiencies of precipitation were 31.16 inches at Grand Island, 18.32 inches at Kearney, 12.91 inches at Lexington, and 21.67 inches at Gothenburg. It may be reasonably expected that the water levels in the Platte Valley will rise with recurring years of normal or greater than normal precipitation.

\section{MOVEMENT OF THE GROUND WATER}

\section{GENERAL CONDITIONS}

The movement of ground water depends upon two factors. First, the interstices in the rocks must be connected so that water can percolate from one interstice to another; second, there must be a difference in pressure from one interstice to the next to provide a force that will cause the water to move. Obviously, where the interstices of the rocks are not connected or where there is no force to cause the water to move, the ground water that saturates the interstices must be stagnant.

The sizes, shapes, and interconnections of the interstices (permeability of the rock) and the difference in pressure (hydraulic gradient) determine the rate of movement of the ground water. According to Darcy the velocity of the ground water is directly proportional to the permeability of the rock and to the hydraulic gradient, and hence the rate of movement differs greatly in different aquifers. For instance, the rate of movement of water in the loess is comparatively slow, whereas in the Pleistocene sand and gravel, which are more permeable, it is comparatively rapid. The rate of movement of water in the Pleistocene sand and gravel-a few feet a day-is relatively slow, however, when compared to the movement of water in highly permeable aquifers, such as cavernous limestone.

The general direction of the movement of the ground water is toward points of discharge, such as springs, wells, streams, or areas of ground-water transpiration, and is shown, of course, by the direction of the hydraulic gradient. The natural points of discharge are ordi- 
narily determined by the relation of the land surface to the water table. In low places where the land surface intersects the water table, ground water is discharged at the surface along the line of intersection, as along streams that have cut their channels below the water table or along lakes whose bottoms lie below the water table.

The quantity of ground water that moves through an aquifer depends upon the rate of movement of the water and the cross-sectional area through which the water percolates. In many places the thickness and areal extent of aquifers are great, and hence the quantities of wa ter that percolate through them may be relatively large, even though the rate of movement of the water is slow. Most ground-water investigations are concerned with the quantities of water that are available for use, and an attempt is usually made to determine the quantities of water that move through the aquifers in a given time. The permeability of the water-bearing material is determined by one or more of the methods outlined above, the hydraulic gradient is ascertained by instrumentally determining the altitudes of the water levels in wells, and the cross-sectional area of the aquifer is found from test drillings or from logs of existing wells. These data are substituted in the Darcy formula $Q=P I A$. When the permeability, $P$, is used as defined in this report (p. 88), the hydraulic gradient, $I$, is expressed in feet to the mile, and the cross-sectional area, $A$, is taken to be the product of the thickness of the aquifer in feet times the width of the aquifer in miles, the quantity of water that moves through the aquifers, $Q$, will be given in gallons a day.

\section{METHODS OF SHOWING THE DIRECTION OF MOVEMENT OF THE GROUND WATER}

The direction of movement of the ground water is usually shown by contour maps of the water table or profiles of the water table. A contour on the water table is a line all points along which have the same altitude, and a profile of the water table is a vertical section of the water table. Maps showing contours on the water table are similar to maps showing topographic contours, but generally there is less relief to the water table and the contours are more regular. A profile of the water table simply shows a line that represents the slope of the water table along the section selected.

Because all points on a contour line have the same altitude, there is no difference in pressure along the line and no movement of water in the direction of the line. The maximum difference of pressure occurs at right angles to the contours, hence the water moves at right angles to the lines, and the slope or hydraulic gradient of the water table is measured along this direction of maximum difference in pressure. A profile of the water table does not necessarily indicate the direction of movement of the ground water, because the section can be taken at 
any angle to the contour lines and hence at any angle to the hydraulic gradient. Only when the profile shows the maximum slope of the water table does it represent the direction of movement of the water. Profiles are prepared from straight-line sections, and as the direction of movement of the ground water may change within short distances only parts of the profiles may show the true direction. Because of the difficulty in interpreting profiles, maps showing contours on the water table are usually considered the best means of indicating the direction of movement of the ground water.

\section{MOVEMENT OF THE GROUND WATER NEAR LEXINGTON}

A map was prepared showing contours on the water table for an area of about 110 square miles in the vicinity of Lexington (fig. 17). Two sets of contours were drawn by using the altitudes of the water levels in 52 wells, one set showing contours on October 21, 1931, and the other set showing contours on March 23, 1932. The direction of movement of the ground water and the rate of slope of the water table were practically the same on both dates, although the water table stood higher on March 23.

The water table in the northern part of the area covered by the contour map slopes rather uniformly southeastward with a gradient of about $8 \frac{1}{2}$ feet to the mile. The movement of the ground water near the north valley limit is slightly toward the Platte River, and the general trend of the valley is followed rather closely. This indicates that there is comparatively little ground water moving into the valley in this area from the north, and that most of the water is derived from recharge in the valley proper. The direction of slope of the water table changes rather abruptly about 2 miles north of the Platte River to almost due east, and the rate of slope is decreased to the general slope of the land in the valley, about 7 feet to the mile. The direction of movement of the ground water is somewhat away from the Platte River into the valley to the east, hence the area a few miles north of the river is an area of ground-water discharge that receives underflow both from the river and from the area nearer the valley limit. In this area considerable ground water is used by plants and discharged by drainage ditches and creeks. These discharge processes probably maintain the water table relatively low north of the river. The slope of the water table west of Lexington and south of the river is obviously toward the river from the west. South and southeast of Lexington the slope of the water table is more nearly parallel to the river on the south side of the stream. This indicates that very little water seeps out of the river to the south. Close to the south valley limit there is a tendency for the water to slope more toward the southeast. There is probably some ground-water percolation out of the valley in this area to the south through the 
Pleistocene sand and gravel that extend beneath the loess upland, but most of this underflow must be derived from recharge on the land south of the Platte River, because the contours do not indicate that the movement is away from the river in that direction.

It is probable that the direction of movement of the ground water in the vicinity of Lexington has changed somewhat since 1900, because the water table in places has been built up by seepage water from irrigation. In 1896 Darton ${ }^{57}$ made a survey of the undergroundwater conditions in Dawson County and found that the water table around Lexington stood about 21 to 22 feet below the land surface. At the present time the water table around Lexington stands less than 10 feet below the surface (pl. 10). If the contour lines in the vicinity of Lexington were rearranged to show altitudes about 10 feet lower and the water level at the river were kept the same the indicated movement of the ground water would be changed from the general eastward direction that now exists for a few miles north of the Platte River to a northeastward direction. Thus, before irrigation with water diverted from the Platte River became prevalent, probably more water was lost from the river to the valley north of the river than there is at the present time.

The flow of ground water down the valley varies from place to place with changes in the permeability of the water-bearing material, with changes in the hydraulic gradient, and with changes in the thickness of the formation. If the average permeability of the material is taken as 3,950 throughout this part of the valley, the quantities of water that percolate through different sections of the valley can be determined from the hydraulic gradient and the thickness of the formation at each section. The hydraulic gradient is ascertained from the contour map (fig. 17) and the thickness of the sand and gravel is taken from the logs of the test holes drilled in the vicinity (pp. 76-77). North of Lexington the discharge of ground water through a section of material 1 mile in width is computed to be about 670,000 gallons a day, or 465 gallons a minute. South of Lexington, where the hydraulic gradient is less, the discharge through a similar section is about 420 gallons a minute. The total discharge of ground water through the 12-mile width of valley at Lexington is computed to be about $6,850,000$ gallons a day, or about 4,750 gallons a minute.

The velocity of the ground water south of Lexington has been computed to be about 0.99 foot a day (p. 100). However, this computation was based on laboratory determinations of the permeability of samples of Pleistocene sand and gravel collected from the upper few feet of the formation. The average permeability of the entire thickness of material can probably be ascertained more accurately from the Thiem tests. If the permeability is assumed to vary

${ }^{57}$ Darton, N. H., Underground waters of southeastern Nebraska: Geol. Survey Water-Supply Paper 12, p. 43, 1898. 
uniformly between Gothenburg and Kearney, the locations of two of the Thiem tests, the average permeability of the material near Lexington is computed by direct interpolation to be about 3,950 . The effective porosity is taken as 28 percent. The average velocity

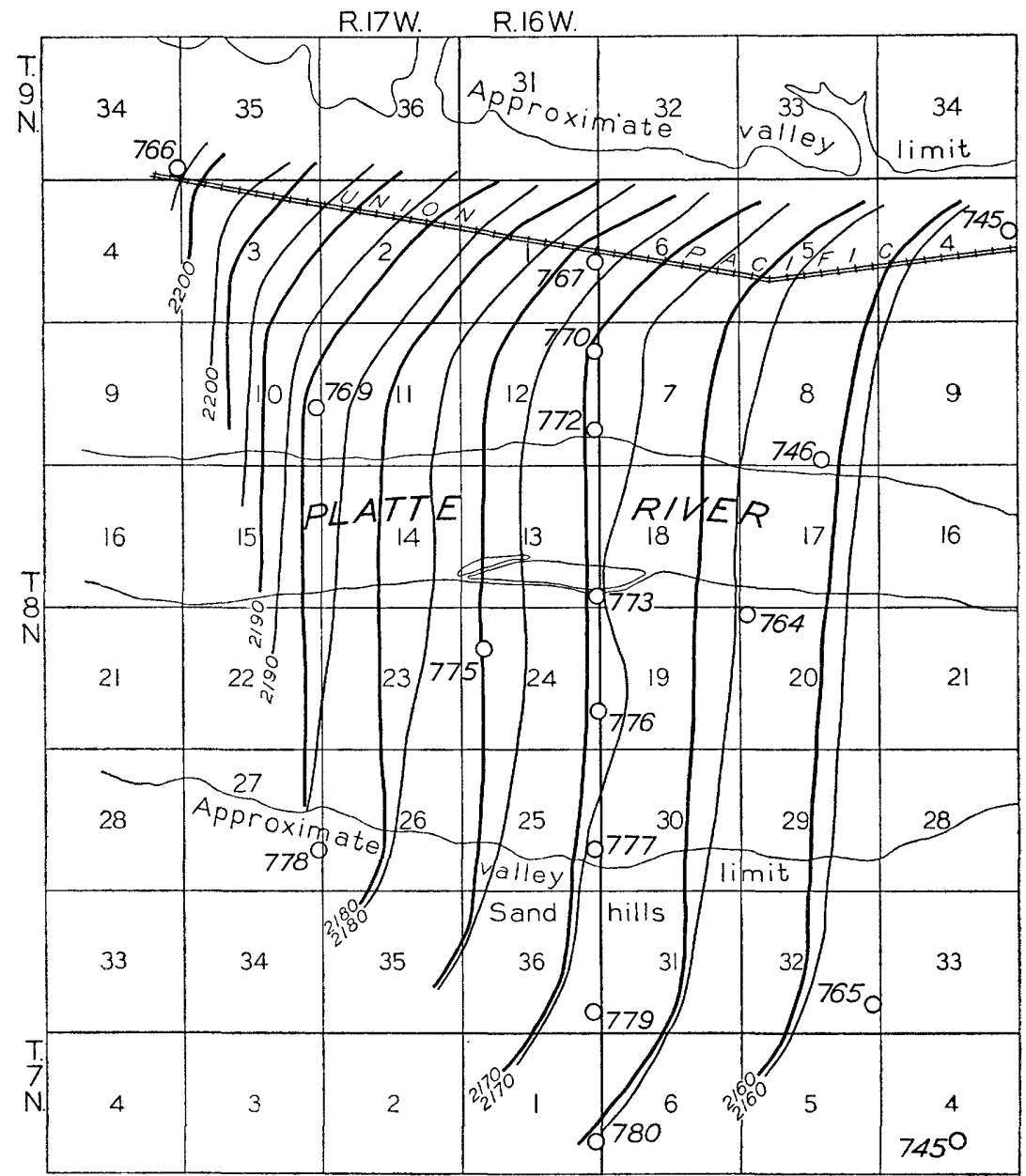

R.17W.

R.16W.

EXPLANATION

O745 Observation well $\underbrace{1}_{\text {Contour interval } 5 \text { feet }}$ October 12,1931 Mile

Figure 18.-Map showing contours on the water table for a part of the Platte Valley near Kearney. Heavy lines show contours on October 12, 1931; light lines show contours on March 22, 1932.

of the ground water in the sand and gravel near Lexington is then computed to be about 2.7 feet a day. It is probable that the upper few feet of the water-bearing material is less permeable than the lower part of the formation. 


\section{MOVEMENT OF THE GROUND WATER NEAR KEARNEY}

A map was prepared showing contours on the water table for an area of about 30 square miles in the valley between Kearney and Odessa (fig. 18). The valley floor north of the river is composed of loess in this locality, and the zone of saturation in most places includes the base of the loess. The area south of the river is composed of sand hills, and there is very little loess exposed except close to the river. Two sets of contours were drawn by using the altitudes of the water levels in 16 wells, one set showing contours on October 12, 1931, and the other set showing contours on March 22, 1932. The direction of movement of the ground water was somewhat different on the two dates, because the water table in the northern part of the area covered by the map rose more during the period than the water table in the southern part of the area. The rate of slope of the water table, however, changed very little.

The direction of slope of the water table near the Union Pacific Railroad is to the southeast, at an angle of about $45^{\circ}$ with the river. The contours north of the railroad indicate that the direction of movement of the ground water is more from the valley limit than is shown by the contour map of the vicinity of Lexington. This difference in direction is probably caused by the seepage from a large irrigation canal that is only a few hundred feet south of and approximately parallel to the valley limit. The slope of the water table near the valley limit ranges from 10 to 11 feet to the mile. Near the Platte River the movement of the ground water changes to an eastward direction and follows the general course of the river and the valley. The transition from a southeastward to an eastward direction north of the river is mole uniform than near Lexington, probably because there is a more uniform discharge of ground water in the area west of Kearney. The slope of the water table near the river averages about 7 feet to the mile. South of the river the direction of movement of the ground water appears to change as the water table fluctuates. On October 12, 1931, the water table was comparatively low, and the direction of movement of the ground water for several miles south of the river was approximately parallel to the river. However, near the southern limit of the area covered by this map the movement of water was to the southeast, away from the valley. On March 22, 1932, the water table north of the river and for several miles south of the river was comparatively high, but the southernmost wells showed only moderate rises, and the movement of ground water was gently away from the river. Thus the inference may be drawn that in this segment of the valley the Platte River loses water during part of the year to the area south of the river but loses little water to the north. During some months the water lost from the 
river percolates directly out of the valley through the sand and gravel that underlie the plains south of the sand hills. During other months there is little loss of water from the river, and most of the underflow is supplied by recharge, mainly precipitation in the valley south of the river, as is the case south of the river near Lexington.

In 1896 a line of wells was driven across the Platte Valley about 2 miles east of the area covered in figure 18. ${ }^{58}$ The line of wells extended from a point $2 \frac{1}{2}$ miles south of the bridge across the Platte River at Kearney to a point about the same distance north of the river. A profile of the water table was drawn showing the altitudes of the water levels in the wells on October 4, 1896. The slope of the profile was toward the Platte River on the south side of the river and away from the river on the north side.

The flow of the ground water down the valley west of Kearney is less than at Lexington. North of the river, where the gradient averages about $10 \frac{1}{2}$ feet to the mile and the thickness of the sand and gravel is about 10 feet, the quantity of water moving through a cross section of material a mile in width is about 410,000 gallons a day, or about 285 gallons a minute. The direction of movement of the ground water is to the southeast, obliquely toward the river. Close to the river the gradient averages about 7 feet to the mile, and the Pleistocene sand and gravel are about 43 feet thick. Here the discharge through a cross section of the material a mile in width is about $1,230,000$ gallons a day, or 855 gallons a minute. The direction of movement of the ground water in this area is parallel to the river. The total flow down the 5-mile width of valley, considering the variation in the direction of movement of the ground water and the thickness of the water-bearing material, is about $5,300,000$ gallons a day, or 3,700 gallons a minute. This may be compared with a computed flow of 47,750 gallons a minute through the sand and gravel in the valley near Lexington and indicates that there is a loss of ground-water flow amounting to about 1,050 gallons a minute between Lexington and the area covered by figure 18 .

The velocity of the ground water west of Kearney and in the vicinity of Lexington is about the same. The coefficient of permeability of the Pleistocene sand and gravel as obtained by direct interpolation from the locations of the Thiem tests is about 4,100 in the area covered by figure 18. The gradient near the Platte River in this area and near Lexington is about 7 feet to the mile, hence the velocity of the ground water at these two localities, with assumed effective porosities of 28 percent, is approximately the same. Near the north valley limit the gradient is about 10 to 11 feet to the mile, which is about $1 \frac{112}{2}$ to $2 \frac{1}{2}$ feet a mile greater than the gradient at corresponding parts of the

ss Darton, N. H., op. cit. (Water-Supply Paper 12), p. 40. 
valley near Lexington. The average velocity of the ground water near the north valley limit, at a gradient of $10 \frac{1}{2}$ feet to the mile, is computed to be 3.9 feet a day.

\section{MOVEMENT OF THE GROUND WATER NEAR GRAND ISLAND}

A map was prepared showing contours on the water table for an area of about 40 square miles in the vicinity of Grand Island (fig. 19).

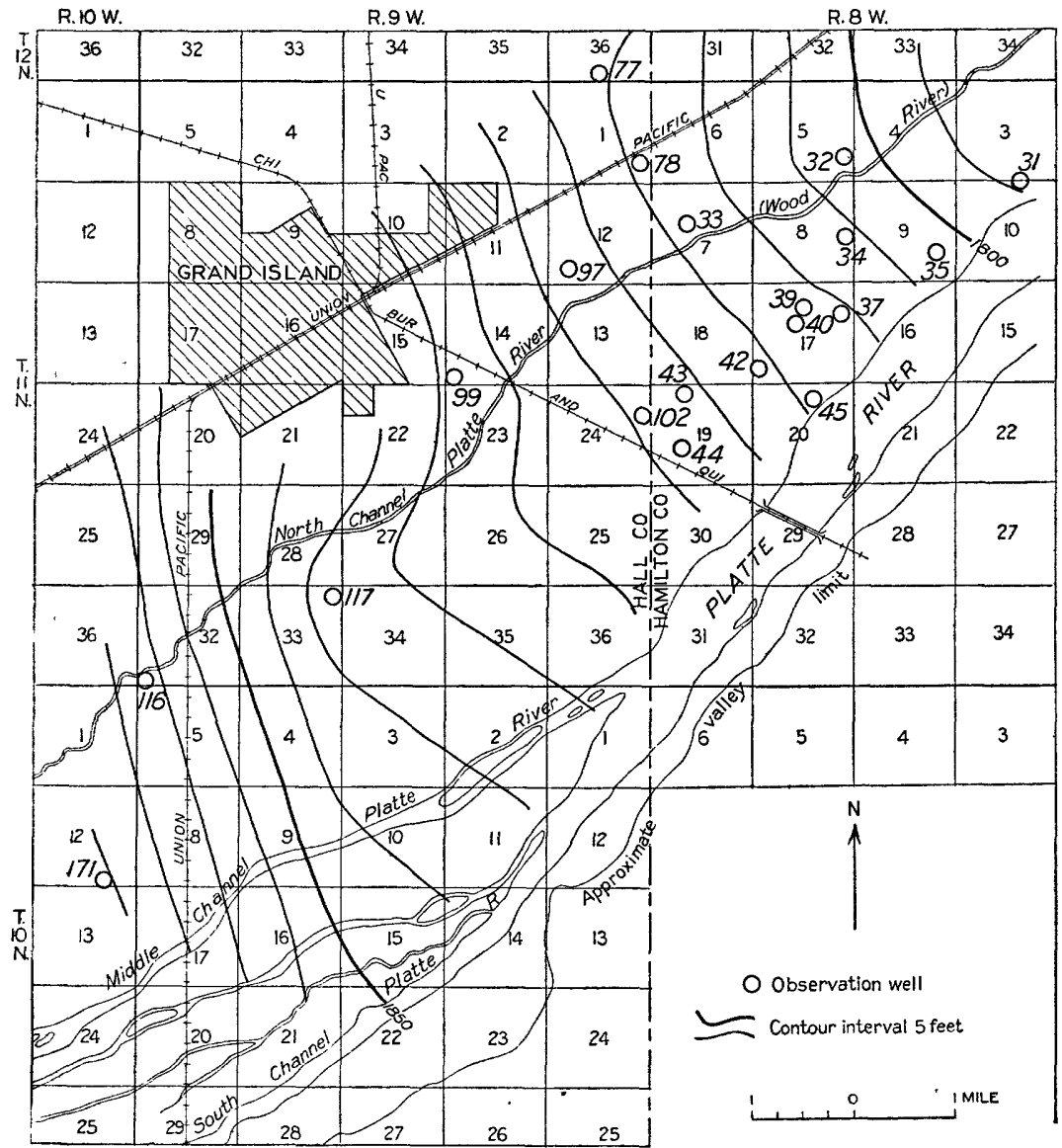

Figure 19.-Map showing contours on the water table for the vicinity of Grand Island.

The contours are based upon measurements of the altitudes of the water levels in 27 wells during the month of July 1931. As measurements of the depth to water in the wells were made over a period of about a month, the contours may be somewhat in error because of changes that may have occurred before the measurements on all the wells were completed. Nevertheless, to judge from the contours on the water table near Kearney and Lexington on dates about 5 months apart, the general form of the water table and hence the direction of 
movement of the ground water are indicated, even though the measurements were not made in a short period of time. This is especially true where the water table is shallow, as it is near Grand Island.

The general movement of the ground water near Grand Island is to the northeast, parallel to the Platte River, with a slope of about 7 feet to the mile. There is little indication of loss of water to the north from the river. The map does not cover the area south of the river, because the valley limit lies close to the south bank of the river and there are no wells on that side in which the water level could be ascertained. Certain irregularities in the contour lines south of Grand Island are probably caused by fluctuations of the water table between measurements. The steeper slope of the water table southwest of Grand Island-about 11 feet to the mile-is probably caused by a dam in the Wood River in sec. 32, T. 11 N., R. 9 E. The dam raises the water level in the Wood River about 4 feet and consequently raises the adjacent water table above the normal level. Grand Island obtains its municipal water supply from the wells in the immediate vicinity of the city. It is probable that the water table is depressed in this locality by pumpage from these wells. The water levels in the municipal wells have declined excessively, and it has been necessary to drill wells in the area around the outskirts of the city, where the decline of the water level has been less severe.

The Platte Valley near Grand Island is about 14 miles wide. The Pleistocene sand and gravel are comparatively thick in this vicinity, averaging about 123 feet, as shown by the test holes drilled (pp. 6971). The flow of ground water down the valley under a gradient of 7 feet to the mile through this thickness of sand and gravel with a coefficient of permeability of 1,000 amounts to about $12,000,000$ gallons a day, or about 8,400 gallons a minute. This represents an increase in ground-water flow between Kearney and Grand Island of about 4,700 gallons a minute.

The velocity of the ground water in the vicinity of Grand Island is less than near Kearney or Lexington. The coefficient of permeability of the sand and gravel determined by a pumping test 4 miles east of Grand Island is about 1,000. If the average gradient of the water table is taken to be 7 feet to the mile and the porosity of the waterbearing material to be 28 percent, the same as at the other two localities, the velocity of the ground water is computed to be about 0.63 foot a day.

\section{GROUND-WATER DISCHARGE}

Ground water is discharged from the Platte Valley by wells, plants, evaporation, streams, and underflow. The rate at which it is withdrawn from the zone of saturation varies with many factors, but especially with the stage of the water table and with the season of the year. Local differences in conditions cause more ground water to be 
discharged in some parts of the valley than in others. For instance, more ground water is removed by pumps in the area east of Kearney than in the area west of Kearney. More water from the zone of saturation is used by plants in the area along the Platte River than in the area along the valley limits. Evaporation of water directly from the zone of saturation is confined almost exclusively to the dry bed of the Platte River and the land immediately adjoining the stream, where the water table is very shallow.

The part of the Platte Valley between Chapman and Gothenburg has been subdivided into four ground-water areas for the purpose of studying the magnitude and types of water-table fluctuations (p. 108). This subdivision also separates the valley into areas of different types of water-table fluctuations and of different types of ground-water discharge. Discharge of ground water from wells occurs principally in the pumping area, transpiration by plants and direct evaporation from the zone of saturation are confined mainly to the east and west shallow-water areas, discharge by seepage into streams takes place mostly in the area of surface-water irrigation, and underflow out of the valley to the south is from the two shallow-water areas.

\section{DISCHARGE FROM WELLS}

\section{DOMESTIC AND INDUSTRIAL SUPPLIES}

Most of the rural residents of the Platte Valley derive their domestic supplies from small wells equipped with pitcher, force, or rotary pumps. Some of the pumps are driven by small gasoline engines, and others are operated by windmills or by hand. Most of these wells yield only a few gallons a minute and are pumped only at intervals when water is needed. The total volume of water pumped for rural use is comparatively small.

Some industrial plants are supplied with water pumped from private wells. No attempt was made to determine the number of such pumping plants that are in use in the valley.

\section{IRRIGATION SUPPIIES}

Many farmers in the valley, especially east of Kearney, pump water from one or more large wells to irrigate crops-principally corn, sugar beets, potatoes, alfalfa, and garden truck. A canvass was made in 1931 and 1932 of the irrigation pumping plants in the Platte Valley between Chapman and Gothenburg, and the crops and number of acres irrigated by these plants were ascertained.

About 90 percent of the irrigated acreage is devoted to corn and the remaining 10 percent to sugar beets, potatoes, alfalfa, garden truck, and miscellaneous crops. There was a gain in irrigated acreage of 
about 7 percent from 1930 to 1931, resulting mostly from increased irrigation of corn. The small amount of garden truck irrigated in 1930 was doubled in 1931.

The canvass shows that ground-water irrigation is practiced mostly east of Kearney and that a large part of the total land irrigated lies between Kearney and the Wood River. There are 32 sections of land east of Kearney in each of which over 200 acres was irrigated by water from wells in 1931 and only one such section west of Kearney.

Summary of acreage irrigated with water from wells in the Platte Valley in 1990

\begin{tabular}{|c|c|c|c|c|c|c|c|c|}
\hline \multicolumn{2}{|c|}{ Location } & \multicolumn{7}{|c|}{ Area irrigated (acres) } \\
\hline T. N. & R. W. & Corn & Sugar beets & Potatoes & Alfalfa & $\begin{array}{c}\text { Garden } \\
\text { truck }\end{array}$ & $\begin{array}{c}\text { Miscella- } \\
\text { neous }\end{array}$ & Total \\
\hline 12 & 7 & & & & & 0.25 & 1.0 & 1.25 \\
\hline 13 & 8 & 125.0 & & - & 16.0 & & & 141. 0 \\
\hline $\begin{array}{l}12 \\
11\end{array}$ & $\begin{array}{l}8 \\
8\end{array}$ & $\begin{array}{l}496.0 \\
157.0\end{array}$ & & & $\begin{array}{l}50.5 \\
10.0\end{array}$ & $\begin{array}{l}1.5 \\
.25\end{array}$ & $\cdots$ & $\begin{array}{l}548.0 \\
167.25\end{array}$ \\
\hline 13 & 9 & 4.0 & & & & i. 0 & & 5. 0 \\
\hline 12 & 9 & $1,016.5$ & & 7.5 & 103.5 & 13. 0 & .5 & $1,141.0$ \\
\hline 11 & $\begin{array}{l}9 \\
9\end{array}$ & 432.0 & $\cdots$ & 36.0 & 81.0 & 34. 25 & -.....- & 583.25 \\
\hline $\begin{array}{l}10 \\
12\end{array}$ & 10 & 30.0 & & $\ldots$ & (n... & 6.0 & & $\begin{array}{r}6.0 \\
30.0\end{array}$ \\
\hline 11 & 10 & 385.0 & 9.0 & 1.5 & & 11.0 & & 406.5 \\
\hline 10 & 10 & 335.0 & 27.0 & 15.0 & ( & 1.0 & 1.0 & 379.0 \\
\hline 9 & 10 & 30.0 & & 7.0 & ...... & 5.0 & & 42.0 \\
\hline 12 & 11 & 140.0 & & 10. 0 & & ...... & & 150.0 \\
\hline 11 & 11 & 843.0 & 132.0 & 2.0 & 40.0 & $\ldots$ & & $1,017.0$ \\
\hline 10 & 11 & $1,148.0$ & 3.5 & 13.0 & 33.0 & 2.5 & - & $1,200.0$ \\
\hline 9 & 11 & 103.0 & & & & .25 & & 103.25 \\
\hline 12 & 12 & 60.0 & & 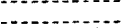 & -... & $\ldots$ & & 60.0 \\
\hline 11 & 12 & 600.0 & & 1.0 & & & & 601.0 \\
\hline 10 & 12 & $2,122.0$ & 29.0 & 10. 75 & 37.0 & 6. 0 & 8.0 & $2,212.75$ \\
\hline 9 & 12 & 570.5 & 37.0 & 13. 0 & $\ldots$ & 1.25 & $\ldots .$. & 621.75 \\
\hline 8 & 12 & 15.0 & & 6.0 & $-\ldots$ & 2.25 & $\ldots$ & 23.25 \\
\hline 10 & 13 & 734.0 & 25.0 & 76.0 & & .5 & & 835.5 \\
\hline 9 & 13 & 1. 934.0 & 191.5 & 128.5 & 51.0 & 5. 25 & & $2,310.25$ \\
\hline 8 & 13 & 187.0 & 50.0 & 12.0 & & 13.25 & & 262.25 \\
\hline 9 & 14 & $5,065.5$ & 386.0 & 172.0 & 24.5 & 1.0 & 10.0 & $\varepsilon, 659.0$ \\
\hline 8 & 14 & 367.0 & 117.0 & 171.0 & & 1.5 & & 656.5 \\
\hline 9 & 15 & $3,330.0$ & 195.0 & 78.5 & 38.0 & 7.0 & 12.0 & $3,660.5$ \\
\hline 8 & 15 & 969.0 & 183.0 & 99.5 & 23.0 & 12.0 & 20.5 & $1,307.0$ \\
\hline $\begin{array}{l}9 \\
8\end{array}$ & $\begin{array}{l}16 \\
16\end{array}$ & $\begin{array}{l}160.0 \\
268.0\end{array}$ & 580 & 40.5 & $-\cdots$ & $\begin{array}{r}3.0 \\
45.5\end{array}$ & 20 & $\begin{array}{l}163.0 \\
414.0\end{array}$ \\
\hline 8 & $\begin{array}{l}10 \\
17\end{array}$ & $\begin{array}{r}80.0 \\
80.0\end{array}$ & 58.0 & $\begin{array}{r}40.0 \\
3.0\end{array}$ & $-\cdots$ & $\begin{array}{r}40.0 \\
3.0\end{array}$ & & $\begin{array}{r}414.0 \\
86.0\end{array}$ \\
\hline 9 & 18 & 20.0 & 100.0 & & $\cdots$ & & & 120.0 \\
\hline 8 & 18 & 202.0 & & 6.5 & $\ldots$ & 12.0 & $-\cdots$ & 220.5 \\
\hline 9 & 19 & $\begin{array}{r}96.0 \\
347.5\end{array}$ & 22.0 & 120 & 50.0 & 125 & $-\cdots$ & 168.0 \\
\hline $\begin{array}{r}8 \\
10\end{array}$ & 19 & 347.5 & 90.0 & 12.0 & & 12.5 & & 462.0 \\
\hline $\begin{array}{r}10 \\
9\end{array}$ & $\begin{array}{l}20 \\
20\end{array}$ & $\begin{array}{r}80.0 \\
150.0\end{array}$ & ....... & . & 40.0 & (..... & & $\begin{array}{r}80.0 \\
190.0\end{array}$ \\
\hline 8 & 20 & 100.0 & & n....... & $\ldots$ & & $\cdots$ & $\begin{array}{r}190.0 \\
0.0\end{array}$ \\
\hline 10 & 21 & 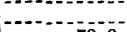 & . & 20-1 & nor & $\cdots$ & & +00 \\
\hline $\begin{array}{l}9 \\
8\end{array}$ & 21 & $\begin{array}{l}70.0 \\
95.0\end{array}$ & $\cdots$ & in & $\ldots \ldots$ & .25 & & 70.25 \\
\hline 11 & $\begin{array}{l}21 \\
22\end{array}$ & $\begin{array}{r}95.0 \\
570.0\end{array}$ & - & 10.0 & -- & & & $\begin{array}{l}105.0 \\
570.0\end{array}$ \\
\hline 10 & 22 & 330.0 &.- & - n & - & 1.0 & & 331.0 \\
\hline 9 & 22 & 257.0 & & & & & & 257.0 \\
\hline 11 & 23 & 21.0 & & - & . & - & $-\ldots$ & 21.0 \\
\hline 10 & 23 & 440.0 & 15. 0 & & ........ & & & 455.0 \\
\hline 12 & 24 & 40.0 & . & . & - & $\ldots . . .$. & 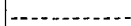 & 40.0 \\
\hline 11 & 24 & 177.0 & ...... & . & $\ldots$ & ....... & - & 177.0 \\
\hline 10 & 24 & 150.0 & -.... & & 20.0 & & & 170.0 \\
\hline \multirow{3}{*}{$\begin{array}{l}12 \\
11\end{array}$} & 25 & 80.0 & 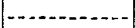 & . & 20.0 & $\ldots$ & $-\ldots$ & 100.0 \\
\hline & 25 & 68.0 & $\cdots$ & - n & $\mid-\ldots, \ldots-1$ & 4.0 & & 72.0 \\
\hline & & $24,900.0$ & $1,670.0$ & 932.25 & 637.5 & 207.25 & 55.0 & $28,402.0$ \\
\hline
\end{tabular}


Summary of acreage irrigated with water from wells in the Platte Valley in 1931

\begin{tabular}{|c|c|c|c|c|c|c|c|c|}
\hline \multicolumn{2}{|c|}{ Location } & \multicolumn{7}{|c|}{ Area irrigated (acres) } \\
\hline T. N. & R. W. & Corn & Sugar beets & Potatoes & Alfalfa & $\underset{\text { truck }}{\text { Garden }}$ & $\begin{array}{c}\text { Miscella- } \\
\text { neous }\end{array}$ & Total \\
\hline \multirow{40}{*}{$\begin{array}{r}12 \\
13 \\
12 \\
11 \\
13 \\
12 \\
11 \\
10 \\
12 \\
11 \\
10 \\
9 \\
12 \\
11 \\
10 \\
9 \\
12 \\
11 \\
10 \\
9 \\
8 \\
10 \\
9 \\
8 \\
9 \\
8 \\
9 \\
8 \\
9 \\
8 \\
8 \\
9 \\
8 \\
9 \\
8 \\
10 \\
9 \\
8 \\
10 \\
9 \\
8 \\
11 \\
10 \\
9 \\
11 \\
10 \\
12 \\
11 \\
10 \\
12 \\
11\end{array}$} & 7 & & & & & 0.5 & 1.0 & 1.5 \\
\hline & 8 & 125.0 & & & 16.0 & & & 141.0 \\
\hline & $\begin{array}{l}8 \\
8\end{array}$ & $\begin{array}{l}496.0 \\
190.0\end{array}$ & (n-...... & $-\cdots+10$ & 50.5 & 17.75 & $-\cdots$ & 564.25 \\
\hline & $\begin{array}{l}8 \\
9\end{array}$ & $\begin{array}{r}190.0 \\
1.0\end{array}$ & (n) & 1.0 & & $\begin{array}{l}5.0 \\
3.0\end{array}$ & 10.0 & $\begin{array}{r}216.0 \\
4.0\end{array}$ \\
\hline & 9 & $1,012.0$ & (n) & 10.75 & 103.5 & 39.0 & .5 & $1,165.75$ \\
\hline & $\begin{array}{l}9 \\
9\end{array}$ & 460.0 & 13.0 & 61.5 & 89.0 & $\begin{array}{r}55.5 \\
6.0\end{array}$ & & $\begin{array}{r}679.0 \\
6.0\end{array}$ \\
\hline & 10 & 65.0 & & 1.5 & & & & 66.5 \\
\hline & 10 & 470.0 & 5. 0 & 6.0 & & 12.0 & & 493.0 \\
\hline & 10 & 322.0 & - & 58.0 & & 9.0 & 1.0 & 390.0 \\
\hline & 10 & 44.0 & (- & 18. 0 & - & 6.5 & .5 & 69.0 \\
\hline & 11 & 154.0 & & 15.0 & & & & 169.0 \\
\hline & 11 & 1. 085.0 & 118.25 & 8. 0 & 70.0 & 1.0 & 2. 0 & $1,284.25$ \\
\hline & 11 & $\begin{array}{r}\text { 1, } 238.0 \\
95.0\end{array}$ & 6.75 & 42.5 & 43.0 & 12. 75 & $\cdots$ & $1,343.0$ \\
\hline & 12 & $\begin{array}{r}95.0 \\
140.0\end{array}$ & -- & $\cdots$ & & 4.25 & 0.0 & $\begin{array}{l}105.20 \\
140.0\end{array}$ \\
\hline & 12 & 735.0 & & 8.0 & & & & 743.0 \\
\hline & 12 & $2,286.0$ & 53.0 & 105 & 37.0 & 20.75 & 14. 0 & $2,421.25$ \\
\hline & 12 & 575.0 & -....... & 78.5 & 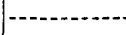 & .25 & 4.0 & 657.75 \\
\hline & $\begin{array}{l}12 \\
13\end{array}$ & $\begin{array}{r}50.0 \\
1.039 .0\end{array}$ & 25.0 & $\begin{array}{r}17.0 \\
118.5\end{array}$ & --- & $\begin{array}{r}5.25 \\
.75\end{array}$ & $\cdots$ & $\begin{array}{r}72.25 \\
198.25\end{array}$ \\
\hline & 13 & $\begin{array}{l}1,008.0 \\
2,440.0\end{array}$ & $\begin{array}{l}2.0 .0 \\
149.0\end{array}$ & $\begin{array}{l}10.0 \\
94.0\end{array}$ & $\begin{array}{l}\text { 15. } \\
61.0\end{array}$ & 5.0 & 6.0 & $\begin{array}{l}1,198.20 \\
2,755.0\end{array}$ \\
\hline & 13 & 170.0 & 70.0 & 18. 0 & & 16. 25 & $-\ldots$ & 274.25 \\
\hline & 14 & $5,011.5$ & $\begin{array}{r}198.0 \\
03.0\end{array}$ & 143.0 & 29.5 & 7.5 & $\ldots$ & $5,389.5$ \\
\hline & $\begin{array}{l}14 \\
15\end{array}$ & $3,533.0$ & $\begin{array}{l}93.0 \\
82.0\end{array}$ & $\begin{array}{r}103.0 \\
56.5\end{array}$ & 66.0 & 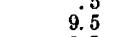 & 15.0 & $\begin{array}{r}415.5 \\
3,762.0\end{array}$ \\
\hline & $\begin{array}{l}15 \\
16\end{array}$ & 824.0 & 128.0 & 76.5 & 23.0 & $\begin{array}{l}6.5 \\
3.0\end{array}$ & 20.5 & $\begin{array}{r}1,078.5 \\
3.0\end{array}$ \\
\hline & 16 & 214.0 & 112.0 & 39.5 & & 54. 5 & 7.0 & 427.0 \\
\hline & $\begin{array}{l}17 \\
18\end{array}$ & 80.0 & 101.0 & 3.0 & & 3.0 & & $\begin{array}{r}86.0 \\
101.0\end{array}$ \\
\hline & 18 & 170.0 & & 4.0 & $\ldots$ & 23.0 & $-\cdots$ & 197.0 \\
\hline & $\begin{array}{l}19 \\
19\end{array}$ & $\begin{array}{l}169.5 \\
382.5\end{array}$ & $\begin{array}{l}65.0 \\
73.0\end{array}$ & $\begin{array}{r}2.0 \\
14.0\end{array}$ & & 13.0 & & $\begin{array}{l}236.5 \\
482.5\end{array}$ \\
\hline & 20 & 75.0 & 52. 0 & & & & & 127.0 \\
\hline & $\begin{array}{l}20 \\
20\end{array}$ & $\begin{array}{r}354.0 \\
35.0\end{array}$ & 130.0 & $\begin{array}{r}5.5 \\
.5\end{array}$ & 13.5 & 66.0 & 10.0 & 579.0 \\
\hline & 21 & $\begin{array}{r}00.0 \\
150.0\end{array}$ & & $\cdots$ & 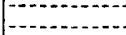 & 1.0 & & $\begin{array}{r}00.0 \\
151.0\end{array}$ \\
\hline & 21 & $\begin{array}{r}75.0 \\
105.0\end{array}$ & 85.0 & $\cdots$ & $\cdots$ & .75 & $\ldots . .$. & 160.75 \\
\hline & 22 & 605.0 & & $\cdots$ & & o & & $\begin{array}{l}105.0 \\
605.0\end{array}$ \\
\hline & 22 & $\begin{array}{l}550.0 \\
180.0\end{array}$ & 30.0 & 16.0 & 14.0 & 2.0 & $\ldots$ & 612.0 \\
\hline & 23 & $\begin{array}{r}180.0 \\
61.0\end{array}$ & 20.0 & & & 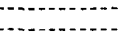 & $\cdots$ & $\begin{array}{r}200.0 \\
61.0\end{array}$ \\
\hline & 23 & 351.0 & 30.0 & 20.0 & 9.0 & 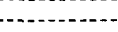 & & 410.0 \\
\hline & $\begin{array}{l}24 \\
24\end{array}$ & $\begin{array}{r}40.0 \\
157.0\end{array}$ & - & - & -- & 30 & $\cdots$ & $\begin{array}{r}40.0 \\
180.0\end{array}$ \\
\hline & 24 & $\begin{array}{l}157.0 \\
100.0\end{array}$ & (n) & $\cdots$ & & 3.0 & - & $\begin{array}{l}160.0 \\
100.0\end{array}$ \\
\hline & 25 & 80.0 & $-\ldots . . .1$ & 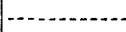 & 20.0 & $\cdots$ & -......... & 100.0 \\
\hline & 25 & 98.0 & & & & 2.0 & & 100.0 \\
\hline & & $26,811.5$ & $1,639.0$ & $1,050.25$ & 670.0 & 415. 75 & 97.5 & $30,684.0$ \\
\hline
\end{tabular}

About 100 domestic and abandoned wells, in areas where there were no irrigation wells in which depths to the water table could be measured, were also recorded in this canvass.

During the canvass 809 irrigation pumping plants were visited. The total reported area on which water was pumped from these plants was 30,684 acres in 1931 , an average of about 38 acres to a plant. Many of the pumping plants are small and irrigate tracts as small as 0.25 acre, but other pumping plants are large and are used to irrigate more than 100 acres. The smallest plants usually pump water for irrigating garden truck or small fields of potatoes, and most of the largest plants pump water only for irrigating corn. 
An estimate of the quantity of water pumped annually by the irrigation plants in the valley can be made by determining the supplemental water requirements of crops in the valley and applying these requirements to the area irrigated in 1931. The quantity of supplemental water required for the proper growth of crops depends on several factors, the most important of which are the precipitation and the moisture-retaining capacity of the soil. The precipitation in the Platte Valley varies considerably from year to year, and the moistureretaining capacity of the soil varies from place to place, hence it is difficult to arrive at an average figure for the water requirements of crops. Some records have been kept on the quantity of water pumped for crops, and investigations have been made in connection with proposed irrigation projects to determine the amount of supplemental water needed. Records obtained by Weakley ${ }^{59}$ at the North Platte Agricultural Experiment Station for the years 1925 to 1930 are given in the following table:

Average quantity of water, in acre-inches per acre, pumped for irrigation of corn, potatoes, and alfalfa at the North Platte Agricultural Experiment Station

\begin{tabular}{|c|c|c|c|c|c|c|c|}
\hline & 1925 & 1926 & 1927 & 1928 & 1929 & 1930 & $\begin{array}{l}\text { A verage, } \\
1925-30\end{array}$ \\
\hline $\begin{array}{l}\text { Corn } \\
\text { Potatoes. }\end{array}$ & $\begin{array}{l}11.20 \\
19.00\end{array}$ & $\begin{array}{l}10.17 \\
26.70\end{array}$ & $\begin{array}{r}9.32 \\
17.11\end{array}$ & $\begin{array}{c}9.8 \\
11.69\end{array}$ & $\begin{array}{l}16.44 \\
16.30\end{array}$ & $\begin{array}{l}18.34 \\
21.42\end{array}$ & $\begin{array}{l}12.55 \\
18.76\end{array}$ \\
\hline Alfalfa & 18. 30 & 14.34 & 9.87 & 9.35 & 7.70 & 5.67 & 10.87 \\
\hline
\end{tabular}

Fellows ${ }^{60}$ after making a study of the irrigation requirements for crops in Gosper, Phelps, Kearney, and Adams Counties concluded that the average annual quantity of water required on lands of the proposed project was 12 inches in depth over the surface irrigated.

Irwin Ulrich, Hall County agricultural extension agent, in 1929 compiled records (unpublished) on 47 pumping plants in the county and on the number of acres of corn irrigated by the plants. He also determined the number of hours that the pumping plants were operated. The average period of pumping during the year to irrigate an acre of corn was 5.57 hours. There is no record to show the rate at which water was pumped from the wells, but a comparable figure can be determined from the results of pumping tests made on wells in Hall and Buffalo Counties by the agricultural engineering department of the University of Nebraska. (See table, p. 142.) The average of the maximum yields of the wells included in these tests was 1,023 gallons a minute. However, under ordinary operating conditions the wells were pumped at lesser rates-probably not exceeding an average of 750 gallons a minute. From this figure the

${ }^{59}$ Weakley, H. E., Pump irrigation, North Platte substation, University of Nebraska, p. 9, 1930.

${ }^{60} \mathrm{Fellows}, \mathrm{A} . \mathrm{L}$., A report on some agricultural and engineering phases of the proposed tri-county irrigation project of central Nebraska, p. vii, U. S. Dept. Agr., 1924. 
average quantity of water pumped for each acre of corn in Hall County in 1929 is found to have been 9.2 acre-inches. This figure is somewhat smaller than the one obtained by Weakley at the North Platte experiment station, but as the normal precipitation in Hall County is greater than the normal precipitation at North Platte the supplemental water requirements of crops in Hall County are presumably less than at North Platte. The conclusion may be tentatively drawn from the foregoing data that the average supplemental water requirementhence the quantity of water pumped from wells-in the Platte Valley is about 10 acre-inches a year for corn, about 15 acre-inches for potatoes, and about 8 acre-inches for alfalfa.

From these figures for supplemental water requirements and the reported number of acres irrigated in 1931, the pumpage in that year is computed to have been 22,400 acre-feet for corn, 1,310 acre-feet for potatoes, 450 acre-feet for alfalfa, and 2,150 acre-feet for sugar beets, garden truck, and miscellaneous crops--a total of 26,310 acrefeet.

The total annual pumpage for irrigation in the Platte Valley varies considerably, but the recent increase in the number of pumping plants operated in the valley suggests that the volume of water pumped probably increased rather steadily for several years up to 1931 or 1932, when the investigation was made. The annual pumpage varies with the effective precipitation in the valley-that is, the precipitation during the growing season. Doubtless more area is irrigated and more water pumped for each acre of crops irrigated during dry years than during wet years. Recently many irrigators have reached the conclusion that irrigation should be carried on regardless of the amount of precipitation, except, of course, when the precipitation is greatly above normal. Several days is usually required to spread water on moderate-sized fields, and occasionally when the fields have not received water for some time the crops that receive water last suffer. Consequently, irrigation is mostly carried on regularly except when precipitation occurs at especially favorable times.

\section{YIELD OF IRRIGATION WELIS}

The yields of irrigation wells in the Platte Valley vary widely. Small driven wells produce only a few gallons a minute, but larger and deeper drilled wells yield as much as 2,500 gallons a minute. The agricultural engineering department of the University of Nebraska recently made tests under the direction of $\mathrm{E}$. E. Brackett of the vields of irrigation wells in Hall County. ${ }^{61}$ A part of the data collected during this investigation appear in the following table, in which the well numbers refer to the corresponding well numbers in the table on pages 192-237.

${ }^{a 1}$ A report on the operation of irrigation wells, Nebraska Univ., Agr. Eng. Dept., 1931. 
Pumping tests of irrigation wells in Hall County

[Made by the agricultural engineering department of the University of Nebraska]

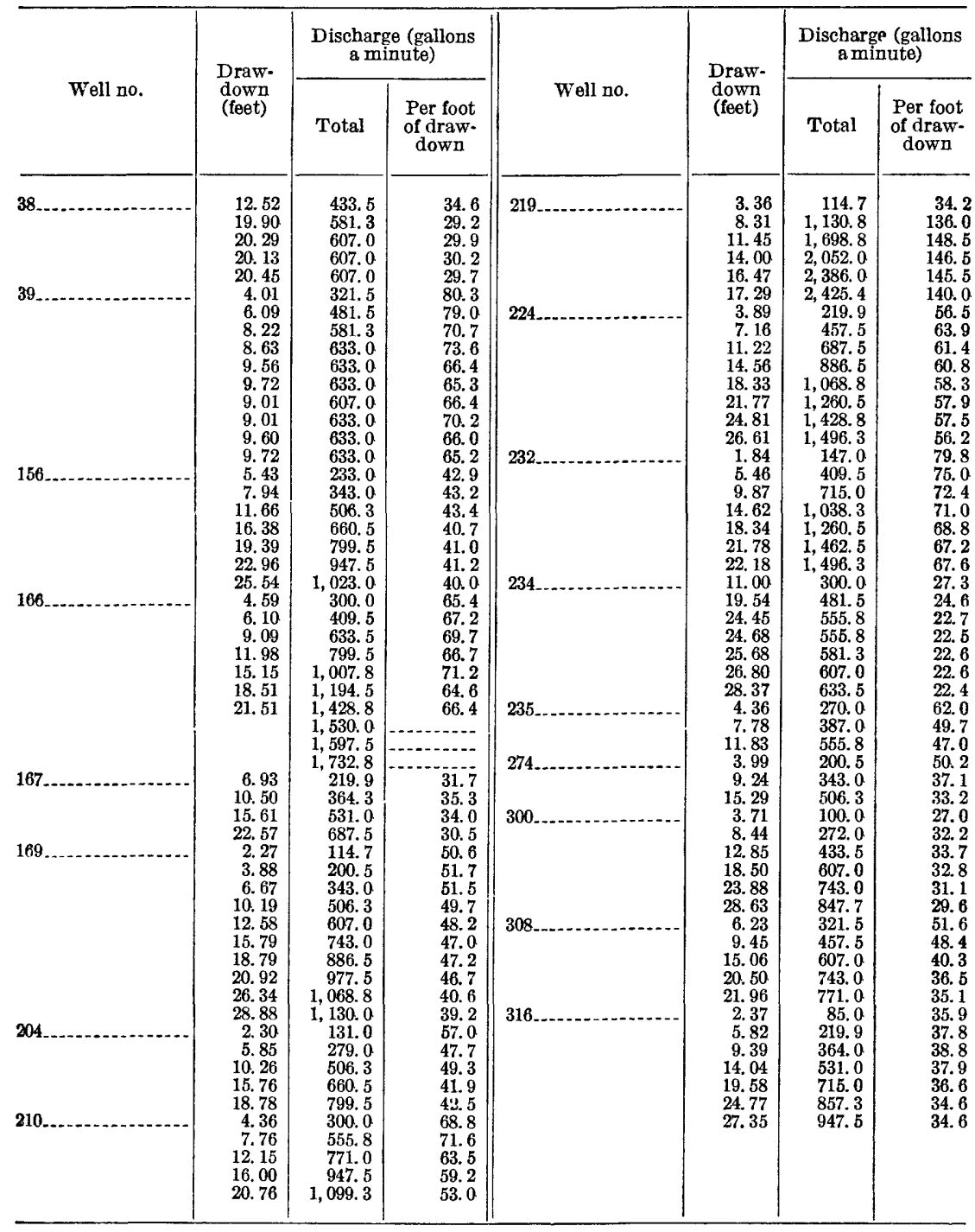

The wells in these tests were pumped to the capacity of the pump or to the capacity of the gasoline engine used to drive the pump. The average maximum yield of the 16 wells given in the table was 1,023 gallons a minute. However, the wells are normally pumped at a smaller discharge rate. The report states: "Observations on the output of the wells as they were being pumped by the farmer showed that most of the wells could supply more water than was 
being drawn from them." ${ }^{62}$ It is probable that the average. discharge of these irrigation wells-which are among the better wells in the valley-does not exceed 750 gallons a minute. The average discharge of all irrigation wells in the Platte Valley is considerably less.

\section{WELL CONSTRUCTION}

Methods of well construction in the Platte Valley are many and diverse. Some irrigation wells are drilled by farmers where the water table is shallow and the drilling of a well is comparatively easy. Other wells are drilled by local drillers who devote part or all of their time to this work. Several drillers in the valley manufacture pumps, well casings, and screens and, of course, use their own equipment to construct wells.

Where the water table stands only a few feet below the land surface, wells are usually drilled and pumps installed over the casings at the surface. The casing is generally of galvanized iron, 24 inches in diameter, and entirely perforated. A few farmers have used wood casings for their wells, and others have used oil barrels. In some localities quicksand is encountered, and several sections of unperforated casing are used to seal it off. Wells are drilled with sand pumps ${ }^{63}$ rather than sand bailers, because the pump seems to be more effective in withdrawing the Pleistocene sand and gravel. The casing is usually weighted with sandbags and forced downward as the sand pump withdraws material. Farmers drilling their own wells erect tripods and use small stationary gasoline engines or horses for power, but ordinarily well drillers use rigs mounted on automobile trailers. One well driller in the valley used an electrically operated rig.

Where the water table is comparatively deep some wells are dug and drilled. Either a pit is dug and the well drilled in the bottom of it or the well is drilled from the surface and a pit is dug after the well is completed. The sides of the pit are usually boarded or concreted, and the pumps are installed over the casing in the pit bottom. Pits are dug within a foot or so of the water table and may become flooded in the spring when the water table is high.

A few irrigation wells are driven. These wells usually consist of one or more pipes of small diameter driven a few feet below the water table. Holes are dug to the water table with post-hole augers, and the pipe strainers, ranging in length from 24 to 60 inches, are

68 A report on the operation of irrigation wells, p. 2, Nebraska Univ., Agr. Eng. Dept., 1931.

o3 Bowman, Isaiah, Well-drilling methods: Geol. Survey Water-Supply Paper 257, p. 40, 1911. 
driven from that depth. Some of these wells are driven from the bottoms of pits, and pumps are then installed in the pits. Large yields are not expected from such wells, for they are intended to irrigate only small areas, usually of garden truck.

There are some irrigation plants that consist of two or more large wells connected to one pump. If the wells are spaced far enough apart the yield from such a system is considerably greater than the yield from one well, but the yield of each well is less than if the other well was not being pumped. In a few localities wells have have been spaced so close together that their combined yield is but little more than the yield of one well.

The relation of the size of the casing perforations to the ultimate yield of a well is not fully appreciated in the Platte Valley. Some well casings have large perforations, and others have small perforations. In some wells the perforations are too small to admit water freely; in others the perforations are so large that quantities of sand are washed into the well, thus necessitating frequent cleaning. Only a few wells in the valley are gravel-packed or otherwise developed properly after drilling. As a result the draw-down in most wells is greater than would be experienced with proper well construction and development. The loss of head of water entering many of the wells in the Platte Valley is great. This is apparent in some wells where the water level in the casing when the pump is running is several feet below the water level on the outside of the casing and the water spurts into the well through the open perforations.

In general, wells of greater capacity and less draw-down than the existing wells can be drilled in most localities in the valley. Many wells are comparatively shallow and do not completely penetrate the sand and gravel. Deeper wells, combined with proper well casings and well development, will be more satisfactory and economical and give higher yields.

\section{TYPES OF IRRIGATION PUMPS}

Most irrigation wells in the Platte Valley are equipped with centrifugal pumps ranging in size from $1 \frac{112}{2}$ to 10 inches. These pumps are of both vertical and horizontal types, but no differentiation was made between them in the canvass. More than 200 turbine pumps are installed on the deeper wells, and about 70 rotary pumps on the shallower wells. A few plunger and force pumps are used for irrigating very small tracts of land. There are in the valley 11 irrigation pumps of the screw type, most of which are of local manufacture. 
Size and kind of irrigation pumps as determined by a canvass of the pumping plants in the Platte Valley

\begin{tabular}{|c|c|c|c|c|c|}
\hline Kind & $\left|\begin{array}{c}\text { Size } \\
\text { (inches) }\end{array}\right|$ & Number & Kind & $\begin{array}{c}\text { Size } \\
\text { (inches) }\end{array}$ & $\underset{\text { ber }}{\text { Num- }}$ \\
\hline Centrifugal_..... & $\begin{array}{c}11 / 2 \\
2 \\
3 \\
4 \\
5 \\
6 \\
7 \\
8 \\
10 \\
12 \\
(1) \\
\end{array}$ & $\begin{array}{r}2 \\
12 \\
22 \\
40 \\
30 \\
309 \\
4 \\
13 \\
1 \\
17 \\
17 \\
\end{array}$ & Rotary & $\begin{array}{c}3 / 4 \\
11 / 4 \\
11 / 2 \\
21 / 2 \\
21 / 2 \\
3 \\
31 / 2 \\
4 \\
5 \\
6 \\
7 \\
8\end{array}$ & $\begin{array}{r}1 \\
6 \\
2 \\
17 \\
2 \\
2 \\
1 \\
12 \\
9 \\
5 \\
8 \\
4\end{array}$ \\
\hline Turbine & $\frac{\ldots+\ldots}{4}$ & $\frac{451}{3}$ & Total_.. & 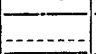 & 69 \\
\hline & $\begin{array}{r}6 \\
7 \\
8 \\
10 \\
(1)\end{array}$ & $\begin{array}{r}159 \\
10 \\
27 \\
3 \\
5\end{array}$ & $\begin{array}{l}\text { Screw } \\
\text { Plunger } \\
\text { Force- } \\
\text { Bucket conveyor }\end{array}$ & 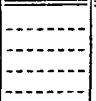 & $\begin{aligned} 11 \\
6 \\
4 \\
2\end{aligned}$ \\
\hline Total... & $\ldots$ & 207 & & . & 750 \\
\hline
\end{tabular}

1 Unknown.

\section{IRRIGATION-POMP POWER}

Most of the farmers in the valley use tractors to furnish the power for operating their pumping plants. Tractors are economical and can be used for other work at times when they are not required for pumping. Moreover, some farms are irrigated by water pumped from two or more wells, and a tractor can be moved from one well to another and so supply the power needed at all the pumping plants.

Kind of power used on irrigation wells in the Platte Valley and number of installations

Tractor

Automobile

Stationary gasoline or oil engine.

Electric

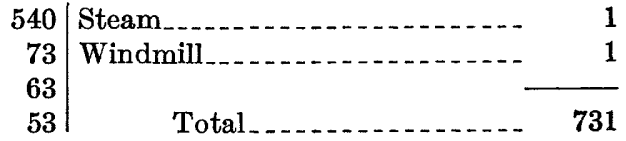

DEPTH AND DIAMETER OF IRRIGATION WELLS

Most irrigation wells in the Platte Valley are comparatively shallow. Only a few exceed 100 feet in depth, and only 14 out of 757 whose depths were ascertained are more than 80 feet deep.

\section{Number of irrigation wells of different depths in the Platte Valley}

10-20 feet. . . . . . . .

20-30 feet....... 62 70-80 feet $\ldots \ldots$

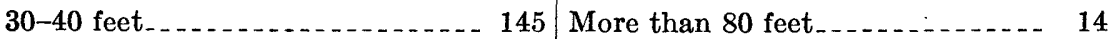

40-50 feet .

50-60 feet ...

Total

757

The average depth of all the irrigation wells is 46.4 feet. but more wells are drilled to depths between 50 and 60 feet than to any other 10 -foot interval.

The diameters of the irrigation wells range from $1 \frac{1 / 4}{4}$ inches for the driven wells to 8 feet for the largest drilled wells. Over 500 of the 800 irrigation wells are 24 inches in diameter. 
Number of irrigation wells in the Platte Valley of different diameters

\begin{tabular}{|c|c|c|c|c|}
\hline Diameter in inches: & & Diameter in inches: & & Diameter in inches: \\
\hline $11 / 4 \ldots$ & 5 & $11 \ldots$ & 1 & $28 \ldots \ldots$ \\
\hline $2 \ldots$ & 18 & 12 & 23 & 29 \\
\hline $21 / 2 \ldots \ldots$ & 1 & $14 \ldots$ & 6 & $30 \ldots$ \\
\hline $3 \ldots$ & 2 & $15 \ldots \ldots$ & 7 & 36 \\
\hline 4 & 1 & $16 \ldots$ & 5 & $46 \ldots$ \\
\hline $5 \ldots$ & 3 & 18 & 91 & $48 \ldots$ \\
\hline 6 & 34 & $20 \ldots$ & 6 & $72 \ldots \ldots$ \\
\hline $7 \ldots$ & 3 & $22 \ldots \ldots$ & 10 & $96 \ldots$ \\
\hline $8 \ldots \ldots$ & 9 & $24 \ldots \ldots \ldots$ & 519 & \\
\hline 9 & 1 & $25 \ldots$ & 22 & Total . . . . . . \\
\hline $10 \ldots$ & 14 & $26 \ldots \ldots \ldots$ & 1 & \\
\hline
\end{tabular}

\section{MONICIPAL WATER SUPPLIES}

All the towns in the area covered by this report obtain their water supplies from wells. Grand Island, Wood River, Shelton, Cairo, Gibbon, Kearney, Elm Creek, Lexington, Cozad, and Gothenburg have public systems, but Chapman, Alda, and Darr obtain water from individual domestic wells. A record of municipal wells is given in the table on page 147 .

\section{GRAND ISLAND}

The water supply of Grand Island is pumped from seven wells. Three of these wells pump directly into the water mains; the other four pump into a 1,000,000-gallon storage reservoir. The water is chlorinated. The water system is capable of supplying $11,520,000$ gallons a day, but the maximum consumption rarely exceeds $7,000,000$ gallons. The average consumption is $1,915,000$ gallons a day, which is equal to about 2,140 acre-feet a year. The average per-capita consumption is 106 gallons a day.

WOOD RIVER

Wood River obtains its water supply from a 24-inch well 58 feet deep. Water is pumped from this well directly into the water mains, as well as into a 50,000-gallon elevated steel storage tank. The daily capacity of the system is about 354,000 gallons, the maximum daily consumption is 295,000 gallons, and the average daily consumption is 70,000 gallons. The average per-capita consumption is 93 gallons a day.

\section{SHELTON}

The water supply of Shelton is obtained trom a 36 -inch well 57 feet deep. Water is pumped from this well directly into the water mains and also to a 65,000-gallon elevated steel storage tank. The daily capacity of the system is about 504,000 gallons, but the maximum consumption is only 295,000 gallons. The average daily consumption is 150,000 gallons, which is equal to about 167 acre-feet of water a year. The average per-capita consumption is 162 gallons a day. 


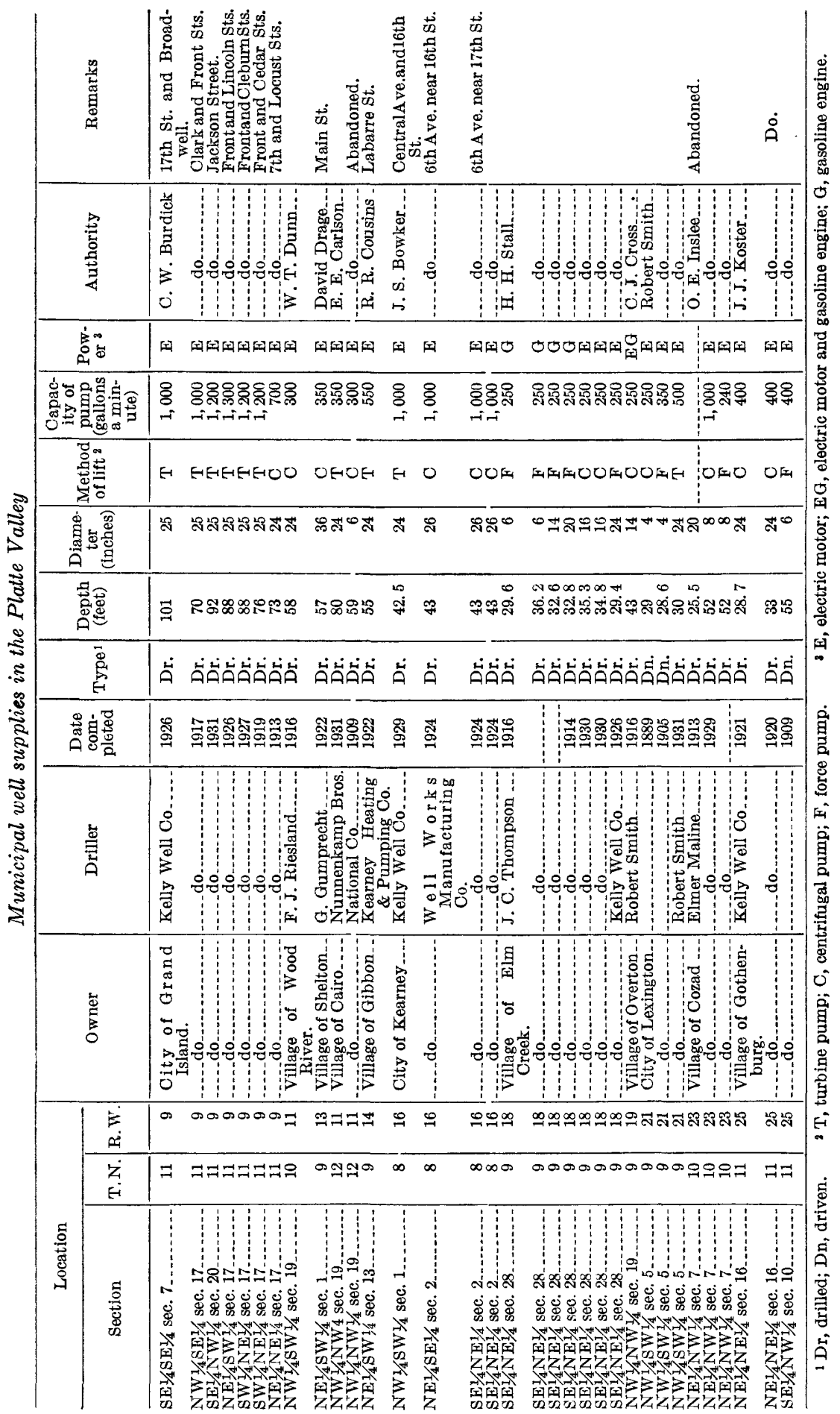


CAIRO

Cairo obtains its water supply from a 24 -inch well 80 feet deep. Water from this well is pumped directly into the water mains and also into a 40,000-gallon elevated storage tank. The capacity of the system is about 504,000 gallons a day, but the maximum daily consumption is only 100,000 gallons. The average daily consumption is 40,000 gallons, which is equal to about 44.7 acre-feet of water a year. The average daily per-capita consumption is 94 gallons.

GIBBON

The water supply of Gibbon is obtained from a 24-inch well about 55 feet deep. Water is pumped into a 65,000-gallon elevated steel tank and also directly into the water mains. Although the capacity of the system is about 792,000 gallons a day, the maximum consumption is only 396,000 gallons. The average daily consumption is 200,000 gallons, which is equal to 224 acre-feet of water a year. The average daily per-capita consumption is 242 gallons.

\section{KEARNEY}

Kearney obtains its water supply from three 26 -inch wells and one 24 -inch well, which average about 43 feet in depth. Water is pumped directly into the water mains and also into a 1,000,000-gallon storage reservoir. The capacity of the system is about $5,000,000$ gallons a day, but the maximum daily consumption is only $3,500,000$ gallons. The average daily consumption is $1,000,000$ gallons, which is equal to about 1,140 acre-feet of water a year. The average per-capita consumption is 114 gallons a day.

\section{ELM CREEK}

The village of Elm Creek obtains its water supply from five 6-inch, one 12-inch, two 16-inch, one 18-inch, and one 24-inch well. The wells average about 33 feet in depth. Water is pumped directly into the water mains and also to an elevated steel storage tank with a capacity of 40,000 gallons. The capacity of the system is 318,000 gallons a day, but the maximum consumption is only 60,000 gallons. The average daily consumption is 40,000 gallons, which is equal to about 44.7 acre-feet of water a year. The per-capita consumption is rather low, 56 gallons a day.

\section{OVERTON}

The water supply of Overton is obtained from a 14-inch well 43 feet deep. Water is pumped directly into the mains and to a 50,000 gallon elevated steel storage tank. The total capacity of the system is 360,000 gallons a day, but the maximum consumption rarely exceeds 285,000 gallons. The average daily consumption is 120,000 gallons, which is equal to about 134 acre-feet of water a year. The arerage daily per-capita consumption is 200 gallons. 


\section{LEXINGTON}

Lexington obtains its water supply from eleven 4 -inch driven wells and a 24-inch drilled well. The depth of the wells averages about 30 feet. Water is pumper directly into the mains and also into a 94,000gallon elevated storage tank. The capacity of the system is about $1,580,000$ gallons a day, but the maximum consumption is only 600,000 gallons. The average daily consumption is 400,000 gallons, which is equal to 447 acre-feet of water a year. The average percapita consumption is 135 gallons a day.

\section{COZAD}

The water supply of Cozad is obtained from eight driven wells averaging about 50 feet in depth. One of the wells is reported to be 187 feet deep. Water is pumped into a 60,000 -gallon elevated steel storage tank. The capacity of the system is about $2,285,000$ gallons a day. As no records have been kept, the maximum consumption is not known. The average daily consumption is estimated to be about 360,000 gallons, which is equal to 402 acre-feet of water a year. The average daily per-capita consumption, based on the estimated average daily consumption, is 198 gallons.

\section{GOTHENBURG}

Gothenburg obtains its water supply from four driven wells averaging about 55 feet in depth and one drilled well 29 feet deep. Water is pumped directly into the water mains and also into a 65,000-gallon elevated steel storage tank. The capacity of the system is $1,500,000$ gallons a day, but the maximum consumption is only 400,000 gallons. The average daily consumption is 200,000 gallons, which is equal to 224 acre-feet of water a year. The average per capita consumption is 86 gallons a day.

SUMMARY

According to the records given in the preceding table, about 5,063 acre-feet of ground water is pumped each year for municipal use by cities and villages in the area that have public waterworks. This amount of water is equal to the quantity that would be discharged by one well pumping continuously at the rate of 3,140 gallons a minute, or by 255 irrigation wells pumping 500 gallons a minute, 12 hours daily, for 3 weeks of 6 days each.

\section{TRANSPIRATION}

When rain falls on the ground or snow melts some water enters the interstices of the soil. This water after penetrating the first few feet of soil may either remain there for some time or percolate downward to the water table, the alternative depending upon the amount of water that is already held in the soil. If the amount of water in the 
belt of soil moisture, perhaps the upper 6 or 7 feet of soil, has been depleted by evaporation and plant growth, water that percolates down from the surface is retained in this belt until the amount of water in the interstices of the soil is greater than can be held by molecular attraction against the pull of gravity. Surplus water will then move down, and most of it will eventually be added to the zone of saturation. For a distance of a few feet above the water table some of the interstices are filled with water that is continuous with the zone of saturation but is held above that zone by capillarity acting against gravity. This belt above the zone of saturation is called the capillary fringe. ${ }^{64}$ Where the water table is close to the land surface the capillary fringe may extend upward into the belt of soil moisture, but where the water table is deeper there is an intermediate belt, ${ }^{64}$ which contains only water held by molecular attraction. The intermediate belt serves only as a passageway for the water from the belt of soil moisture to the water table, and the water in it is not available for plants or wells. The variation in depth of the water table in the Platte Valley produces three types of soil-moisture conditions. Near the Platte River the water table is only a few feet below the land surface and the capillary fringe extends to the surface. Farther back from the river the capillary fringe extends to the belt of soil moisture but not to the surface. Where the water table is about 10 feet or more below the land surface the capillary fringe may not extend upward to the belt of soil moisture and there is an intermediate zone between.

Most ordinary grasses and field crops obtain water for their growth from the upper few feet of soil. ${ }^{65}$ Corn, wheat, and barley probably use water from depths not exceeding 7 feet. Alfalfa is a noteworthy exception, because its roots will penetrate 20 or 30 feet to the water table. Plants growing near the Platte River obtain water for their growth from the zone of saturation when their demands exceed the rainfall contribution, by drawing directly on the capillary fringe. Farther from the river the roots of most plants and crops do not go deep, and they draw water from the belt of soil moisture, which is replenished only by precipitation. Thus transpiration, or the use by plants of the water stored in the ground, affects the ground water in the Platte Valley in two ways. Close to the river it causes the water table to decline because there is a direct draft on the zone of saturation. Farther from the river it depletes the belt of soil moisture, thereby decreasing recharge to the water table.

Discharge of ground water from the zone of saturation by transpiration in the Platte Valley is mostly limited, with the exception of fields of alfalfa, to areas adjacent to the Platte River and its tributaries,

64 Meinzer, O. E., Outline of ground-water hydrology, with definitions: Geol. Survey Water-Supply Paper 494, p. 26, 1923.

${ }^{65}$ Meinzer, O. E., The occurrence of ground water in the United States: Geol. Survey Water-Supply Paper 489, p. 82, 1923. 
where the water table stands comparatively close to the surface. Measurements of deptlı to water in wells in the Platte Valley indicate that the amount of water transpired per acre exceeds the amount of water that is pumped per acre from wells, for the decline of water level in wells near the river exceeds the seasonal decline in wells in the pumping area. A part of the decline of the water table near the river is caused by evaporation and otler processes, but the use of water by plants creates most of the decline. Water levels in wells in the pumping area, where the ground water is comparatively far below the land surface, do not decline greatly until pumping begins, but the water levels in wells along the Platte River declines rapidly as soon as vegetation begins to grow in the spring. The water levels in wells near the river rise soon after vegetation dies, but those in wells in the pumping area do not usually rise until spring.

The amount of ground water used by plants in the Platte Valley from the zone of saturation probably is not fully realized. Water is transpired directly from the zone of saturation where the water table is less than 10 feet below the surface in more than 600 square miles of the 1,250 square miles in the part of the Platte Valley covered in detail by this report. Plants whose roots extend down to the capillary fringe or to the water table have the opportunity to use the maximum amounts of water for their growth. These plants, of course, also derive water from the belt of soil moisture, but usually the amount of water in this belt is insufficient to supply the needs of the plants, and water is then withdrawn from the zone of saturation. The supplemental water requirements for alfalfa, corn, and potatoes, ranging from 8 to 15 inclies a year (p. 141), indicate that these quantities of water are necessary for the best growth of the crops. However, where more water is available, as in areas where the plant roots draw upon the zone of saturation, these crops and also trees, plants, and shrubs probably use more water than is represented by these figures. If an average of 12 inches of supplemental water is used annually by the plants whose roots extend to the zone of saturation, the resulting quantity of water discharged by transpiration in the part of the Platte Valley covered by this report would amount to about 390,000 acre-feet a year, or about 12 times the quantity of water pumped annually from wells.

\section{EVAPORATION}

Where the water table is shallow a certain amount of ground water from the zone of saturation is evaporated directly from the soil. Most of this water is drawn from the zone of saturation and is evaporated from the capillary fringe. In localities where the capillary fringe does not extend upward within a few feet of the land surface, no water from the zone of saturation is lost by evaporation. Water in 
the upper foot or so of soil is evaporated, but this water is derived from rainfall.

It is difficult to determine the amount of water evaporated from the zone of saturation, because of the extreme variations in soil and weather conditions. The factors that influence evaporation of ground water are, with the exception of the character of the soil, about the same as those that influence evaporation from a free water surface. The climatic conditions in the Platte Valley are rather favorable for a high rate of evaporation. The high temperatures during the growing season and the high average wind velocity produce an evaporation rate that is somewhat greater than in many other irrigated areas. The high evaporation loss is indicated by the action of the Platte River during the summer. On cloudy days the stream, if dry, will sometimes start to flow, or, if flowing, will increase its discharge, owing to the difference in evaporation.

The United States Department of Agriculture maintains two evaporation stations at the North Platte experiment station. One evaporation pan is in the Platte Valley and the other on the uplands. Both pans are 6 feet in diameter and 2 feet deep and are so set that their tops are just level with the ground surface. The evaporation for April through September from the upland station for the years 1907-31 averaged 41.305 inches. The evaporation from the valley pan averages about 90 percent of that from the upland pan.

Monthly, seasonal average evaporation, in inches, from U.S. Weather Bureau pan and ratio of evaporation to seasonal precipitation, at the upland station at North Platte, $1907-31$

\begin{tabular}{|c|c|c|c|c|c|c|c|c|}
\hline Year & April & May & June & July & August & $\begin{array}{c}\text { Sep- } \\
\text { tember }\end{array}$ & Total & $\begin{array}{l}\text { Ratio of } \\
\text { evapora- } \\
\text { tion to } \\
\text { precipi- } \\
\text { tation }\end{array}$ \\
\hline $\begin{array}{l}1907 \\
1908 \\
1910 \\
1911\end{array}$ & $\begin{array}{l}\text { 6. } 447 \\
\text { 6. } 001 \\
\text { 4. } 626 \\
\text { 7. } 489 \\
\text { 5. } 699\end{array}$ & $\begin{array}{l}\text { 6. } 226 \\
6.992 \\
7.352 \\
5.976 \\
7.213\end{array}$ & $\begin{array}{r}7.785 \\
6.246 \\
6.123 \\
9.901 \\
12.485\end{array}$ & $\begin{array}{l}7.563 \\
7.513 \\
7.853 \\
9.747 \\
9.858\end{array}$ & $\begin{array}{l}\text { 7. } 703 \\
6.932 \\
8.341 \\
7.603 \\
8.093\end{array}$ & $\begin{array}{l}5.595 \\
8.242 \\
6.128 \\
5.848 \\
6.354\end{array}$ & $\begin{array}{l}41.319 \\
41.936 \\
40.423 \\
46.564 \\
49.702\end{array}$ & $\begin{array}{l}2.859 \\
2.531 \\
2.478 \\
4.756 \\
4.252\end{array}$ \\
\hline $\begin{array}{l}1912 \\
1913 \\
1915 \\
1916\end{array}$ & $\begin{array}{l}4.835 \\
6.662 \\
5.641 \\
6.108 \\
4.552\end{array}$ & $\begin{array}{l}\text { 7. } 536 \\
6.626 \\
6.324 \\
5.886 \\
7.015\end{array}$ & $\begin{array}{l}\text { 7. } 593 \\
9.219 \\
8.984 \\
6.040 \\
6.963\end{array}$ & $\begin{array}{r}8.965 \\
10.386 \\
10.147 \\
6.607 \\
11.028\end{array}$ & $\begin{array}{r}7.455 \\
11.558 \\
9.580 \\
5.981 \\
7.763\end{array}$ & $\begin{array}{l}\text { 5. } 294 \\
7.005 \\
\text { 6. } 765 \\
4.867 \\
6.282\end{array}$ & $\begin{array}{l}41.678 \\
51.456 \\
47.441 \\
35.469 \\
43.603\end{array}$ & $\begin{array}{l}3.596 \\
4.160 \\
3.712 \\
1.232 \\
\text { 3. } 631\end{array}$ \\
\hline $\begin{array}{l}1917 \\
1918 \\
1920 \\
1921\end{array}$ & $\begin{array}{l}4.391 \\
4.304 \\
4.016 \\
\text { 3. } 320 \\
4.570\end{array}$ & $\begin{array}{l}4.886 \\
7.365 \\
6.069 \\
4.556 \\
6.637\end{array}$ & $\begin{array}{l}8.258 \\
8.387 \\
6.976 \\
6.478 \\
7.185\end{array}$ & $\begin{array}{r}10.488 \\
8.883 \\
9.951 \\
8.629 \\
10.873\end{array}$ & $\begin{array}{l}7.676 \\
8.048 \\
7.384 \\
7.511 \\
8.015\end{array}$ & $\begin{array}{l}4.879 \\
4.862 \\
5.730 \\
5.882 \\
5.502\end{array}$ & $\begin{array}{l}40.578 \\
41.849 \\
40.126 \\
36.376 \\
42.782\end{array}$ & $\begin{array}{l}2.866 \\
3.558 \\
2.000 \\
2.062 \\
3.311\end{array}$ \\
\hline 1922 & $\begin{array}{l}\text { 4. } 644 \\
\text { 4. } 669 \\
\text { 5. } 672 \\
\text { 5. } 447 \\
\text { 5. } 312\end{array}$ & $\begin{array}{l}\text { 6. } 684 \\
\text { 5. } 731 \\
\text { 5. } 949 \\
\text { 6. } 256 \\
\text { 7. } 459\end{array}$ & $\begin{array}{l}8.243 \\
6.491 \\
6.281 \\
7.662 \\
7.453\end{array}$ & $\begin{array}{l}7.033 \\
6.863 \\
8.119 \\
9.503 \\
8.797\end{array}$ & $\begin{array}{l}8.057 \\
5.489 \\
7.935 \\
7.579 \\
8.593\end{array}$ & $\begin{array}{l}\text { 6. } 312 \\
\text { 6. } 966 \\
4.749 \\
\text { 5. } 165 \\
\text { 4. } 615\end{array}$ & $\begin{array}{l}40.973 \\
34.209 \\
38.705 \\
41.612 \\
42.229\end{array}$ & $\begin{array}{l}2.570 \\
1.453 \\
3.554 \\
\text { 3. } 334 \\
\text { 3. } 615\end{array}$ \\
\hline $\begin{array}{l}1927 \\
1928 \\
19290 \\
1931\end{array}$ & $\begin{array}{l}\text { 4. } 196 \\
\text { 6. } 139 \\
\text { 4. } 592 \\
\text { 4. } 382 \\
\text { 4. } 277\end{array}$ & $\begin{array}{l}7.218 \\
6.301 \\
5.575 \\
5.685 \\
6.795\end{array}$ & $\begin{array}{l}6.194 \\
4.802 \\
6.626 \\
6.179 \\
8.198\end{array}$ & $\begin{array}{r}7.971 \\
6.730 \\
8.677 \\
8.331 \\
10.268\end{array}$ & $\begin{array}{l}5.349 \\
7.561 \\
8.326 \\
5.980 \\
8.710\end{array}$ & $\begin{array}{l}\text { 5. } 548 \\
\text { 6. } 148 \\
\text { 4. } 384 \\
4.807 \\
\text { 7. } 649\end{array}$ & $\begin{array}{l}36.376 \\
37.681 \\
38.180 \\
35.364 \\
45.897\end{array}$ & $\begin{array}{l}\text { 1. } 934 \\
\text { 2. } 343 \\
2.633 \\
\text { 1. } 899 \\
\text { 6. } 055\end{array}$ \\
\hline Mean & 5. 120 & 6. 412 & 7. 470 & 8.831 & 7. 729 & 5. 743 & 41.305 & 2. 770 \\
\hline
\end{tabular}


The rate of evaporation of ground water is not as rapid as the rate of evaporation from a free water surface, yet the total amount evaporated from the zone of saturation is considerable. Well 786, in the dry bed of the Platte River, showed an average decline of water level of about 0.16 foot a week during rainless weeks. Part of this decline was due to transpiration by vegetation along the banks of the river and on small islands, but the largest part was caused by evaporation. A decline in water level of 0.16 foot a week represents a loss of about 2.3 inches of water a month. If the proportion of ground water transpired by plants in the dry bed of the Platte is assumed as 30 percent, the amount directly evaporated would be equivalent to 1.6 inches a month, or about 26 percent of the average monthly rate of summer evaporation from a free water surface. Estimates based on a strip of the river bed 0.6 mile wide give about 5,600 acre-feet of ground water evaporated monthly between Chapman and Gothenburg when the Platte is dry. The evaporation rate from areas adjacent to the Platte River is less than the evaporation rate from the dry bed of the river. The total yearly evaporation of ground water from the dry bed of the Platte and adjacent lands where the water table is shallow is probably at least 15,000 acre-feet.

\section{SEEPAGE INTO STREAMS}

Ground water is discharged into streams wherever the water table slopes toward the stream. Generally in the Platte Valley both the water surfaces of streams and the adjacent water table fluctuate, so that at times the discharge of the streams is augmented by ground water, and at times water is added to the zone of saturation from surface flow. This condition is largely a result of a subhumid climate. In regions where rainfall is plentiful streams usually receive accessions from ground water, and where rainfall is scanty streams are more likely to contribute to the ground water. The slope of the water table near the Platte River is almost parallel to the stream, thus indicating that fluctuations of the water table or changes in discharge of the river may cause the Platte to become either a losing or a gaining stream.

The tributaries of the Platte River are augmented by ground water most of the year, because their beds have been cut to or below the general water table. The banks of these streams for a foot or so above their water surfaces are usually wet from ground-water seepage. Their flow at low stages is rather constant, thus indicating groundwater gain. The flow of the Wood River on August 11, 1927, was 2.5 cubic feet a second in sec. 7 , T. 10 N., R. 17 W., 3.6 cubic feet a second in sec. 5 , T. 9 N., R. 16 W., and 4.8 cubic feet a second in sec. 12, T. 9 N., R. $16 \mathrm{~W} .{ }^{66}$ These quantities of water are low flows for

${ }^{66}$ Nebraska State Board of Irrigation, Water Power, and Drainage Bienn. Rept., 1927-28, p. 363. $121343-38-11$ 
the Wood River, so they probably were derived from ground water. There was a small but continuous gain of water downstream. It is probable that some stretches of both the Platte River and its tributaries are gaining while other stretches are losing. This condition is illustrated by measurements of the Wood River October 20, 1922, at several places from a point near the head of the stream to its mouth. As shown by these measurements the flow in cubic feet a second at the successive places was $2.0,2.9,2.4,4.1,2.6$, and at its mouth the stream was dry. ${ }^{67}$ The tributaries of the Platte River go dry, but usually for shorter periods than the trunk stream. The tributaries probably lose water to the zone of saturation just before and after such periods.

There are a few drainage ditches near Lexington which discharge ground water. The total flow of these ditches is rather small but nearly constant, because it is derived mainly from ground-water seepage.

The available records are not adequate to serve as a basis for estimating the average annual discharge of ground water by seepage into the streams. The seepage discharge is greater in the part of the valley between Kearney and Gothenburg than in the part between Chapman and Kearney.

\section{PERCOLATION}

\section{GENERAL CONDITIONS}

Several writers have pointed out that the Platte Valley is higher in altitude than the Republican and Blue Rivers and hence that the Platte River probably loses water to these streams. Curley ${ }^{68}$ in 1875 stated: "As the country descends toward the south, it seems to drain the waters of the Platte into the Republican and is therefore a source of water supply all over the country south of the former river." Darton ${ }^{69}$ in 1898 wrote:

As the valley of Platte River is somewhat higher than the adjoining branches of Blue, Republican, and Loup Rivers, th $\bullet$ waters that lie in its bottom flow out laterally through the coarse material underlying the loess and issue as springs or underground seepage in these deeper depressions. In the vicinity of Grand Island the evidence is very clear that the Platte waters pass under the loesscovered divide and emerge in the deep valleys of the headwaters of branches of the Big BJue River, which are considerably lower in altitude than the bottom of the Platte Valley. $* *^{*} *$ There is excellent evidence that under Phelps and Kearney Counties there is underflow from the Platte River toward the Republican River. This underflow is rendered possible by the pervious nature of the great sheet of materials which lies between the loess and the top of the impervious Pierre shales. $*{ }^{*} *$ The rate of this underflow is exceedingly slow, for careful experiments have shown that underground water moving through sands, even if the sands are relatively coarse, does not progress over a mile or two a year.

77 Nebraska State Board of Irrigation, Water Power, and Drainage Bienn. Rept., 1923-24, p. 473.

${ }_{68}$ Curley, E. A., Nebraska, its advantages, resources, and drawbacks, p. 137, American News Co., 1875.

${ }^{60}$ Darton, N. H., Underground waters of southeastern Nebraska: Geol. Survey Water-Supply Paper 12, pp. 24-25, 1898. 
The further intensive investigation by A. L. Lugn, as described in the first part of this report, has substantiated the observations of these writers and has determined in detail the geologic and hydrologic conditions. Test holes drilled near the southern limit of the Platte Valley in connection with the present investigation indicate that the sand and gravel extend beneath the loess uplands to the south of the Platte Valley from the area between Gothenburg and Lexington eastward to and beyond Grand Island. Abundant water supplies have been obtained at most localities on the uplands south and east of the Platte Valley from thick deposits of sand and gravel underlying the loess. The tributaries of the Republican, Big Blue, and Little Blue Rivers receive rather large quantities of ground water in localities where their courses have been cut into the sheetlike sand and gravel. Investigations of the loess that overlies the sand and gravel indicate that the amount of percolation through it is probably negligible. ${ }^{70}$ Hence the great quantity of ground water that occurs in the sand and gravel below the loess cannot be entirely accounted for by recharge from precipitation or by seepage from the small streams that head in the uplands.

The ground water that percolates through the sand and gravel in the region south of the Platte Valley is not confined under artesian pressure south of the segment of the valley covered in this report. but is reported to be under artesian pressure at certain places farther east. The logs of most wells drilled in the loess uplands between the Platte and Republican Rivers show that there is considerable unsaturated sand and gravel above the water table. This is also shown where the deposit of sand and gravel is exposed in pits and in natural outcrops near the courses of some of the tributaries of the Republican River. The fact that the ground water does not completely fill the deposit of sand and gravel shows that this deposit is capable of carrying more water than it contains at the present time.

The channel of the Platte River is several miles from the southern limit of the valley at most localities. The maps showing contours. on the water table near Lexington and Kearney show that the contour lines cross the Platte River nearly at right angles to the course of the river, continue in this direction nearly to the south valley limit, and then bend to the southwest (figs. 17 and 18). This course of the contours indicates that the direction of movement of ground water is nearly parallel to the river in the sand and gravel below the river bed and for a mile or more on each side, but that near the south limit of the valley the direction of movement is toward the southeast. Thus water that seeps into the sand and gravel from the Platte River may percolate for a considerable distance in a direction approximately

${ }^{70}$ Personal communication by J. C. Russell, University of Nebraska, 1932. 
parallel to the river's course and then may gradually approach the south limit of the valley and eventually travel under the loess toward the southeast. However, the contour maps indicate that a large proportion of the water that is in transit in the bed of the river follows the course of the river and is not diverted from the valley.

The volume of water that percolates out of the river depends on the permeability of the water-bearing material, the thickness of the material, and the slope of the water table away from the river. Obviously, in the localities where there is only a slight slope away from the river the percolation loss is slight, and where the water table slopes toward the river the stream is gaining rather than losing water. The reason that in most parts of the valley the water table does not have a greater slope away from the river is apparent from a study of the fluctuation of the water levels in wells in the valley south of the river. The water table in the valley south of the river responds readily to precipitation, generally rising more than the surface of the river. Hence, the direction of movement of water is altered by recharge from precipitation, and at times water percolates back to the stream. Moreover, the decline of the water table takes place slowly, and the effect of a rain may be apparent by the change in the direction of the hydraulic gradient for weeks afterward. The altitude of the water table south of the river is thus maintained relatively high by the precipitation, so that the escape of water from the river is largely prevented. In the vicinity of Grand Island the river flows close to the south edge of the valley, and therefore the ground water that percolates southeastward out of the valley in that vicinity is probably supplied largely by the river.

In an endeavor to determine the amount of water discharged from the Platte Valley by percolation under the upland a careful examination was made of the localities where the underflow is intercepted by the tributaries of the Republican and Blue Rivers, and measurements were made of the flow of these streams at different points on their courses. The investigation was carried on during the dry period of August and September 1933, when the flow of the streams consisted entirely or almost entirely of ground water.

\section{DISCHARGE THROUGH TRIBUTARIES TO THE REPUBLICAN RIVER}

The Republican River flows in a general eastward direction in southern Nebraska and for a short distance south of Kearney approximately parallels the Platte River. Arapahoe, in the Republican Valley, is about 32 miles south of Lexington, in the Platte Valley, but is about 280 feet lower in altitude. The Republican flows about 40 miles south of Kearney and is about 300 feet lower in altitude. The Republican River bends to the south near Superior and enters 
Kansas. The part of south-central Nebraska east of this point is drained by the Little Blue River, hence almost all of the underflow that the Republican River intercepts must percolate into the stream or its tributaries west of Superior. The test holes drilled in the Platte Valley show that the western limit of the sheetlike sand and gravel that extend from the Platte Valley under the loess to the south lies between Gothenburg and Lexington (pp. 76-79). Hence, most of the underflow from the Platte Valley is intercepted by the Republican River and its northern tributaries east of Arapahoe and west of Superior.

The Department of Public Works of Nebraska in biennial reports has published miscellaneous measurements of the flows of the tributaries to the Republican River, and some of these measurements are given in the following table. They include measurements on 19 of the largest tributaries in the area here described, at about the locations where measurements were made by $\mathrm{H}$. A. Waite and the writer. These published measurements are valuable because they show the flow of the streams in other years.

\section{Miscellaneous measurements of the flow of northern tributaries of the Republican River between Superior and Arapahoe}

[Compiled from biennial reports of the Nebraska Department of Public Works, 1898-1932. The numbers given with the names of the tributaries correspond to those shown on pl. 14]

Jost Creek (2)

\begin{tabular}{c|c|c||c|c|c}
\hline Location & Date & $\begin{array}{c}\text { Discharge } \\
\text { (second- } \\
\text { feet) }\end{array}$ & Location & Date & $\begin{array}{c}\text { Discharge } \\
\text { (second- } \\
\text { feet) }\end{array}$ \\
\hline $\begin{array}{l}\text { Sec. 26, T. 1 N., R. 7 W. } \\
\text { Sec. 35, T. 1 N., R. 7 W. }\end{array}$ & $\begin{array}{l}\text { June 23, 1924 } \\
\text { Mar. 18, 1925 }\end{array}$ & $\begin{array}{c}59.0 \\
0\end{array}$ & $\begin{array}{r}\text { Sec. 26, T. 1 N., R. 7 W. } \\
\text { Do... }\end{array}$ & $\begin{array}{l}\text { Oct. 26, 1928 } \\
\text { Dec. 21, 1928 }\end{array}$ & $\begin{array}{r}6.6 \\
4.2\end{array}$ \\
\hline
\end{tabular}

Elm Creek (15)

\begin{tabular}{|c|c|c|c|c|c|}
\hline $\begin{array}{l}\text { Bec. } 3 \text {, T. } 1 \text { N., R. } 10 \text { W. } \\
\text { Do } \\
\text { Do } \\
\text { Do } \\
\text { Do } \\
\text { Do } \\
\text { Do } \\
\text { Do } \\
\text { Do } \\
\text { Do } \\
\text { Do } \\
\text { Do }\end{array}$ & $\begin{array}{lr}\text { Jan. } & 7,1923 \\
\text { Aug. } & 20,1923 \\
\text { June } & 23,1924 \\
\text { Mar. } 18,1925 \\
\text { Oct. } 9,1925 \\
\text { Mar. } 12,1926 \\
\text { Apr. } 2,1926 \\
\text { Apr. } 22,1926 \\
\text { May } 15,1926 \\
\text { June } & 8,1926 \\
\text { July } & 17,1926 \\
\text { Sept. } 23,1926 \\
\text { Oct. } 16,1926\end{array}$ & $\begin{array}{l}15.2 \\
16.4 \\
19.7 \\
13.7 \\
31.6 \\
13.9 \\
15.3 \\
15.7 \\
14.5 \\
12.7 \\
8.0 \\
26.0 \\
23.9\end{array}$ & $\begin{array}{l}\text { Sec. } 34, T .2 \text { N., R. } 10 \text { W. } \\
\text { Do } \\
\text { Do } \\
\text { Do } \\
\text { Do } \\
\text { Do } \\
\text { Do } \\
\text { Do } \\
\text { Do } \\
\text { Do } \\
\text { Do } \\
\text { Do }\end{array}$ & $\begin{array}{l}\text { Oct. } 16,1930 \\
\text { Nov. } 24,1930 \\
\text { Jan. } 27,1931 \\
\text { Apr. } 2,1931 \\
\text { Apr. 21, 1931 } \\
\text { May } 8,1931 \\
\text { May } 30,1931 \\
\text { July 13,1931 } \\
\text { Aug. 10,1931 } \\
\text { Sept. 17, 1931 } \\
\text { Sept. 29, 1931 } \\
\text { Nov. 24, 1931 } \\
\text { Jan. } 19,1932\end{array}$ & $\begin{array}{l}11.8 \\
21.0 \\
19.7 \\
22.0 \\
136.0 \\
0 \\
0 \\
1.0 \\
0 \\
2.0 \\
25.2 \\
25.5\end{array}$ \\
\hline
\end{tabular}

Crooked Creek (17)

\begin{tabular}{|c|c|c|c|c|c|}
\hline $\begin{array}{l}\text { Sec. } 1, \text { T. } 1 \text { N., R. } 11 \text { W. } \\
\text { Do } \\
\text { Do } \\
\text { Do } \\
\text { Do } \\
\text { Do }\end{array}$ & $\begin{array}{lr}\text { July } & 2,1902 \\
\text { Apr. } & 2,1931 \\
\text { Apr. } & 21,1931 \\
\text { May } & 8,1931 \\
\text { May } & 30,1931 \\
\text { June } & 29,1931\end{array}$ & $\begin{array}{r}175 \\
2.3 \\
1.0 \\
36.0 \\
0^{.4}\end{array}$ & $\begin{array}{l}\text { Sec. } 1, \mathrm{~T} .1 \mathrm{~N} ., \mathrm{R} .11 \mathrm{~W}- \\
\text { Do } \\
\text { Do Do } \\
\text { Do }\end{array}$ & $\begin{array}{l}\text { July } 13,1931 \\
\text { Aug. } 10,1931 \\
\text { Sept. } 17,1931 \\
\text { Sept. } 29,1931 \\
\text { Oct. } 14,1931\end{array}$ & $\begin{array}{l}0.5 \\
3.3 \\
0 \\
0 \\
.1\end{array}$ \\
\hline
\end{tabular}

I Flood. 
Miscellaneous measurements of the flow of northern tributaries of the Republican River between Superior and Arapahoe-Continued

Tributary 18

\begin{tabular}{|c|c|c|c|c|c|}
\hline Location & Date & $\begin{array}{l}\text { Discharge } \\
\text { (second- } \\
\text { feet) }\end{array}$ & Location & Date & $\begin{array}{l}\text { Discharge } \\
\text { (second- } \\
\text { feet) }\end{array}$ \\
\hline $\begin{array}{l}\text { Sec. 9. T. } 1 \text { N., R. } 11 \text { W. } \\
\text { Sec. } 23, \text { T. } 2 \text { N., R. } 11 \text { W. } \\
\text { Do., } \\
\text { Do... } \\
\text { Do. } \\
\text { Do } \\
\text { Do } \\
\text { Do } \\
\text { Do } \\
\text { Do }\end{array}$ & $\begin{array}{l}\text { Apr. } 29,1930 \\
\text { Apr. } 21,1931 \\
\text { May } 8,1931 \\
\text { May } 30,1931 \\
\text { June 29,1931 } \\
\text { July 13,1931 } \\
\text { Aug. 10, 1931 } \\
\text { Sept. 17, 1931 } \\
\text { Sept. 29, 1931 } \\
\text { Oct. 10,1931 }\end{array}$ & $\begin{array}{l}13.0 \\
7.7 \\
.2 \\
0.2 \\
.2 \\
5.5 \\
0 \\
0 \\
.2\end{array}$ & $\begin{array}{r}\text { Sec. } 23, \text { T. } 2 \text { N., R. } 11 \text { W } \\
\text { Do. } \\
\text { Do Do } \\
\text { Do } \\
\text { Do } \\
\text { Do } \\
\text { Do } \\
\text { Do }\end{array}$ & $\begin{array}{l}\text { Jan. } 25,1932 \\
\text { Feb. } 25,1932 \\
\text { Mar. } 25,1932 \\
\text { Apr. } 14,1932 \\
\text { May } 31,1932 \\
\text { June } 16,1932 \\
\text { July } 20,1932 \\
\text { Aug. 22, 1932 } \\
\text { Sept. 23, 1932 }\end{array}$ & $\begin{array}{r}0.3 \\
20.4 \\
6.4 \\
1.2 \\
.4 \\
.2 \\
0 \\
0 \\
0\end{array}$ \\
\hline
\end{tabular}

Farmers Creek (23)

\begin{tabular}{|c|c|c|c|c|c|}
\hline $\begin{array}{l}\text { Sec. } 5 \text {, } 1 . \mathrm{N}, \mathrm{R} .12 \mathrm{~W} \\
\text { Do } \\
\text { Do } \\
\text { Do } \\
\text { Do } \\
\text { Do } \\
\text { Do } \\
\text { Do } \\
\text { Do } \\
\text { Do } \\
\text { Do } \\
\text { Do } \\
\text { Do } \\
\text { Do } \\
\text { Do } \\
\text { Do } \\
\text { Do } \\
\text { Do } \\
\text { Do }\end{array}$ & $\begin{array}{lr}\text { Oct. } & 9,1925 \\
\text { Mar. } 12,1926 \\
\text { June } & 8,1926 \\
\text { Oct. } 16,1926 \\
\text { May } 17,1927 \\
\text { June } \quad 6,1927 \\
\text { July } 11,1927 \\
\text { Aug. } 17,1927 \\
\text { Oct. } 25,1927 \\
\text { Dec. } 6,1927 \\
\text { Mar. } 21,1928 \\
\text { May } 17,1928 \\
\text { June } 22,1928 \\
\text { Apr. } 18,1929 \\
\text { July } 12,1929 \\
\text { Oct. } 16.1930 \\
\text { Oct. } 23,1930 \\
\text { Jan. } 27,1931 \\
\text { Mar. } 17,1931\end{array}$ & $\begin{array}{l}1.4 \\
2.8 \\
.3 \\
1.8 \\
2.4 \\
1.7 \\
.6 \\
2.6 \\
2.1 \\
4.2 \\
4.3 \\
3.1 \\
4.7 \\
2.9 \\
.8 \\
.8 \\
5.6 \\
2.0 \\
3.9\end{array}$ & 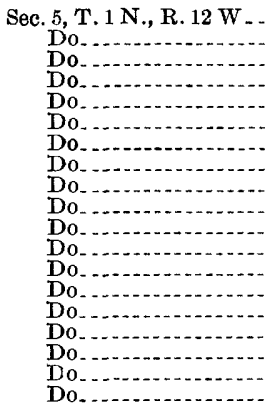 & $\begin{array}{l}\text { Apr. } 21,1931 \\
\text { May } 8,1931 \\
\text { May } 30,1931 \\
\text { June } 29,1931 \\
\text { July } 13,1931 \\
\text { Aug. } 10,1931 \\
\text { Sept. 29, 1931 } \\
\text { Oct. } 14,1931 \\
\text { Nov. } 24,1931 \\
\text { Jan. } 19,1932 \\
\text { Jan. } 25,1932 \\
\text { Feb. } 25,1932 \\
\text { Mar. } 24,1932 \\
\text { Apr. } 14,1932 \\
\text { May } 31,1932 \\
\text { June } 16,1932 \\
\text { July } 20,1932 \\
\text { Aug. } 22,1932 \\
\text { Sept. 23, } 1932\end{array}$ & $\begin{array}{c}2.1 \\
7.2 \\
.7 \\
0 \\
.1 \\
19.0 \\
0 \\
.4 \\
2.8 \\
2.1 \\
1.7 \\
15.6 \\
5.4 \\
2.0 \\
1.0 \\
1.4 \\
0 \\
.2 \\
.2\end{array}$ \\
\hline
\end{tabular}

Thompson Creek (24)

\begin{tabular}{|c|c|c|c|c|c|}
\hline 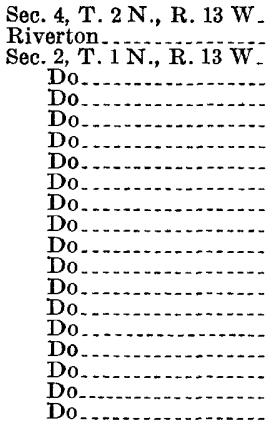 & $\begin{array}{lr}\text { Sept. } & 8,1899 \\
\text { Aug. } 20,1923 \\
\text { June } 23,1924 \\
\text { Mar. } 18,1925 \\
\text { Oct. } 9,1925 \\
\text { Mar. } 12,1926 \\
\text { June } 8,1926 \\
\text { Oct. } 16,1926 \\
\text { May } & 17,1927 \\
\text { June } & 6,1927 \\
\text { July } & 11,1927 \\
\text { Aug. } 17,1927 \\
\text { Oct. } & 25,1927 \\
\text { Dec. } 12,1927 \\
\text { Mar. } 21,1928 \\
\text { May } & 17,1928 \\
\text { June } & 22,1928 \\
\text { Apr. } 18,1929 \\
\text { July } & 12,1929 \\
\text { Mar. } & 6,1930\end{array}$ & $\begin{array}{r}3.4 \\
11.1 \\
11.5 \\
26.4 \\
23.3 \\
17.0 \\
16.0 \\
24.4 \\
24.1 \\
23.6 \\
18.8 \\
36.3 \\
23.7 \\
24.7 \\
22.8 \\
20.7 \\
28.1 \\
25.6 \\
16.3 \\
27.0\end{array}$ & 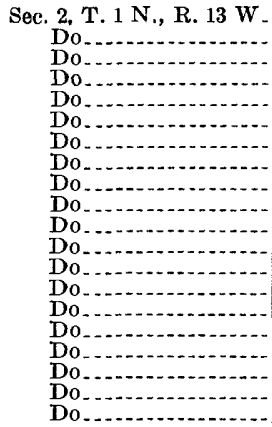 & $\begin{array}{lr}\text { Apr. } & 2,1930 \\
\text { Apr. } 29,1930 \\
\text { June } 20,1930 \\
\text { Sept. } 16,1930 \\
\text { Oct. } 16,1930 \\
\text { Nov. } 24,1930 \\
\text { Jan. } 27,1931 \\
\text { Mar. } 17,1931 \\
\text { Apr. } 2,1931 \\
\text { Apr. } 21,1931 \\
\text { May } 8,1931 \\
\text { May } 30,1931 \\
\text { June } 29,1931 \\
\text { July } 13,1931 \\
\text { Aug. } 10,1931 \\
\text { Sept. } 17,1931 \\
\text { Sept. } 29,1931 \\
\text { Oct. } 14,1931 \\
\text { Nov. } 24,1931 \\
\text { Jan. } 19,1932\end{array}$ & $\begin{array}{r}17.0 \\
33.0 \\
55.0 \\
16.0 \\
18.3 \\
24.0 \\
24.7 \\
27.2 \\
26.5 \\
21.5 \\
27.9 \\
13.1 \\
8.7 \\
14.5 \\
33.6 \\
9.5 \\
8.5 \\
9.6 \\
22.5 \\
19.7\end{array}$ \\
\hline
\end{tabular}

Lovely Creek (27)

\begin{tabular}{|c|c|c|c|c|c|}
\hline $\begin{array}{l}\text { Sec. } 35, \text { T. } 2 \text { N., R. } 14 \text { W. } \\
\text { Do } \\
\text { Do } \\
\text { Do } \\
\text { Do } \\
\text { Do } \\
\text { Do } \\
\text { Do }\end{array}$ & $\begin{array}{lr}\text { Oct. } & 16,1930 \\
\text { Nov. } 24,1930 \\
\text { Jan. } 27,1931 \\
\text { Mar. } 17,1931 \\
\text { Apr. } 2,1931 \\
\text { Apr. } 21,1931 \\
\text { May } 8,1931 \\
\text { May } 30,1931\end{array}$ & $\begin{array}{r}1.7 \\
1.2 \\
2.0 \\
.7 \\
2.9 \\
1.0 \\
.4 \\
.2\end{array}$ & $\begin{array}{l}\text { Sec. } 35, \mathrm{~T} .2 \mathrm{~N} ., \mathrm{R} .14 \mathrm{~W} . \\
\text { Do } \\
\text { Do } \\
\text { Do } \\
\text { Do } \\
\text { Do } \\
\text { Do } \\
\text { Do }\end{array}$ & $\begin{array}{l}\text { June } 29,1931 \\
\text { July } 13,1931 \\
\text { Aug. } 10,1931 \\
\text { Sept. 17, 1931 } \\
\text { Sept. } 29,1931 \\
\text { Oct. } 14,1931 \\
\text { Nov. } 24,1931 \\
\text { Jan. } 19,1932\end{array}$ & $\begin{array}{l}0.2 \\
\vdots 1 \\
0 \\
0 \\
.2 \\
2.5 \\
2.5\end{array}$ \\
\hline
\end{tabular}


Miscellaneous measurements of the flow of northern tributaries of the Republican River between Superior and Arapahoe-Continued

Sand Creek (28)

\begin{tabular}{|c|c|c|c|c|c|}
\hline Location & Date & $\begin{array}{l}\text { Discharge } \\
\text { (second- } \\
\text { feet) }\end{array}$ & Location & Date & $\begin{array}{l}\text { Discharge } \\
\text { (second- } \\
\text { feet) }\end{array}$ \\
\hline $\begin{array}{l}\text { Bec. 33, T. } 2 \text { N., R. } 14 \text { W.. } \\
\text { Do } \\
\text { Do } \\
\text { Do } \\
\text { Do }\end{array}$ & $\begin{array}{lr}\text { Apr. } & 21,1931 \\
\text { May } & 8,1931 \\
\text { May } & 30,1931 \\
\text { June } & 29.1931 \\
\text { July } & 13,1931\end{array}$ & $\begin{array}{r}0.7 \\
1.7 \\
.2 \\
.2 \\
.2\end{array}$ & $\begin{array}{l}\text { Sec. } 33, \mathrm{~T} .2 \mathrm{~N} ., \mathrm{R} .14 \mathrm{~W} \\
\text { Do } \\
\text { Do } \\
\text { Do }\end{array}$ & $\begin{array}{l}\text { Aug. } 10,1931 \\
\text { Sept. } 17,1931 \\
\text { Sept. 29, } 1931 \\
\text { Oct. } 13,1931\end{array}$ & $\begin{array}{l}0.1 \\
0 \\
0 \\
.3\end{array}$ \\
\hline
\end{tabular}

Tributary 29

\begin{tabular}{|c|c|c|c|c|c|}
\hline 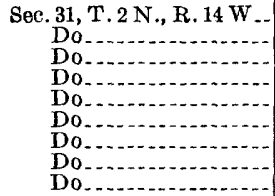 & $\begin{array}{l}\text { Apr. } 30,1930 \\
\text { June } 20,1930 \\
\text { Sept. } 16,1930 \\
\text { Oct. } 16,1930 \\
\text { Nov. } 24,1930 \\
\text { Jan. } 27,1931 \\
\text { Mar. } 17,1931 \\
\text { Apr. } 2,1931 \\
\text { Apr. } 21,1931\end{array}$ & $\begin{array}{r}2.4 \\
.5 \\
.5 \\
1.0 \\
.3 \\
.8 \\
.7 \\
.2\end{array}$ & $\begin{array}{l}\text { Sec. } 31, \mathrm{~T} .2 \mathrm{~N} ., \mathrm{R} .14 \mathrm{~W} \\
\text { Do } \\
\text { Do } \\
\text { Do } \\
\text { Do } \\
\text { Do } \\
\text { Do } \\
\text { Do } \\
\text { Do }\end{array}$ & $\begin{array}{l}\text { May } 18,1931 \\
\text { Apr. } 30,1931 \\
\text { June } 29,1931 \\
\text { July } 13,1931 \\
\text { Aug. 10, 1931 } \\
\text { Sept. } 17,1931 \\
\text { Oct. } 14,1931 \\
\text { Nov. 24, 1931 } \\
\text { Jan. } 19,1932\end{array}$ & $\begin{array}{r}0.2 \\
.1 \\
.2 \\
.1 \\
1.0 \\
0 \\
.3 \\
1.1 \\
.4\end{array}$ \\
\hline
\end{tabular}

Center Creek (30)

\begin{tabular}{|c|c|c|c|c|c|}
\hline 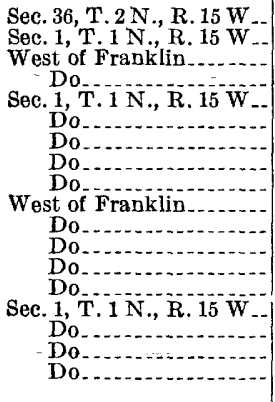 & $\begin{array}{lr}\text { June } & 10,1902 \\
\text { Aug. } & 21,1923 \\
\text { Mar. } 18,1925 \\
\text { Oct. } 9,1925 \\
\text { Oct. } 16,1926 \\
\text { May } 17,1927 \\
\text { June } 8,1927 \\
\text { July } 12,1927 \\
\text { Aug. } 18,1927 \\
\text { Oct. } 25,1927 \\
\text { Dec. } 7,1927 \\
\text { Mar. } 22,1928 \\
\text { May } 17,1928 \\
\text { June } 22,1928 \\
\text { Apr. } 19,1929 \\
\text { July } 12,1929 \\
\text { Mar. } 7,1930 \\
\text { Apr. } \quad 3,1930\end{array}$ & $\begin{array}{r}7.6 \\
2.7 \\
7.4 \\
4.5 \\
4.3 \\
4.7 \\
3.6 \\
3.0 \\
5.0 \\
4.8 \\
4.6 \\
6.9 \\
5.5 \\
5.8 \\
23.8 \\
2.6 \\
4.5 \\
4.7\end{array}$ & $\begin{array}{l}\text { See. } 1 \text { T. } 1 \text { N., R. } 15 \text { W } \\
\text { Do } \\
\text { Do } \\
\text { Do } \\
\text { Do } \\
\text { Do } \\
\text { Do } \\
\text { Do } \\
\text { Do } \\
\text { Do } \\
\text { Do } \\
\text { Do } \\
\text { Do } \\
\text { Do } \\
\text { Do } \\
\text { Do } \\
\text { Do }\end{array}$ & $\begin{array}{l}\text { Apr. } 30,1930 \\
\text { June } 21,1930 \\
\text { Sept. } 17,1930 \\
\text { Oct. } 17,1930 \\
\text { Nov. } 25,1930 \\
\text { Jan. } 27,1931 \\
\text { Mar. } 17,1931 \\
\text { Apr. } 2,1931 \\
\text { Apr. } 21,1931 \\
\text { May } 8,1931 \\
\text { May } 29,1931 \\
\text { June } 28,1931 \\
\text { July } 13,1931 \\
\text { Sept. } 16,1931 \\
\text { Sept. } 29,1931 \\
\text { Oct. } 14,1931 \\
\text { Nov. } 23,1931 \\
\text { Jan. } 18,1932\end{array}$ & $\begin{array}{l}8.7 \\
6.2 \\
2.7 \\
3.1 \\
4.0 \\
1.9 \\
5.9 \\
5.0 \\
8.0 \\
3.0 \\
4.6 \\
0 \\
.8 \\
0 \\
.3 \\
1.3 \\
6.0 \\
6.3\end{array}$ \\
\hline
\end{tabular}

Little Cottonwood Creek (33)

\begin{tabular}{|c|c|c|c|c|c|}
\hline 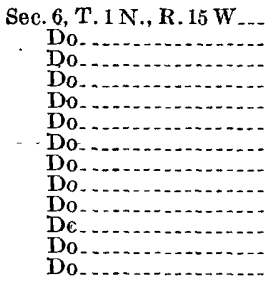 & $\begin{array}{lr}\text { Oct. } 16,1926 \\
\text { Mar. } 22,1928 \\
\text { May } 17,1928 \\
\text { June } 22,1928 \\
\text { Mar. } 7,1930 \\
\text { Apr. } 3,1930 \\
\text { Apr. } 30,1930 \\
\text { June } 21,1930 \\
\text { Sept. } 17,1930 \\
\text { Oct. } 17,1930 \\
\text { Nov. 25, 1930 } \\
\text { Jan. 27, 1931 } \\
\text { Mar. } 17,1931\end{array}$ & $\begin{array}{l}1.2 \\
5.6 \\
4.9 \\
6.1 \\
4.2 \\
4.5 \\
6.7 \\
2.6 \\
1.6 \\
2.2 \\
5.2 \\
5.0 \\
5.5\end{array}$ & $\begin{array}{l}\text { Sec. } 6, \mathrm{~T} .1 \mathrm{~N}, \mathrm{R} .15 \mathrm{~W} \\
\text { Do } \\
\text { Do } \\
\text { Do } \\
\text { Do } \\
\text { Do } \\
\text { Do } \\
\text { Do } \\
\text { Do } \\
\text { Do } \\
\text { Do } \\
\text { Do }\end{array}$ & $\begin{array}{lr}\text { Apr. } & 2,1931 \\
\text { Apr. } 21,1931 \\
\text { May } & 8,1931 \\
\text { May } & 29,1931 \\
\text { June } & 28,1931 \\
\text { July } 13,1931 \\
\text { Aug. } 10,1931 \\
\text { Sept. } 16,1931 \\
\text { Sept. } 29,1931 \\
\text { Oct. } 13,1931 \\
\text { Nov. } 23,1931 \\
\text { Jan. } 18,1932\end{array}$ & $\begin{array}{r}4.1 \\
2.0 \\
1.7 \\
1.4 \\
.1 \\
.3 \\
.6 \\
.2 \\
.3 \\
.8 \\
5.3 \\
5.6\end{array}$ \\
\hline
\end{tabular}

Big Cottonwood Creek (34)

\begin{tabular}{|c|c|c|c|c|c|}
\hline $\begin{array}{l}\text { Sec. } 25, T .2 \text { N., R. } 16 \text { W } \\
\text { Do } \\
\text { Do. } \\
\text { Do } \\
\text { Do } \\
\text { Sec. } 36, \mathrm{~T} .2 \mathrm{~N} ., \mathrm{R} .16 \mathrm{~W} \\
\text { Do } \\
\text { Do } \\
\text { Do } \\
\text { Do } \\
\text { Do }\end{array}$ & $\begin{array}{lr}\text { Oct. } & 16,1926 \\
\text { July } & 12,1927 \\
\text { Aug. } & 18,1927 \\
\text { Oct. } & 25,1927 \\
\text { Dec. } & 7,1927 \\
\text { Apr. } & 21,1931 \\
\text { May } & 8,1931 \\
\text { May } & 29,1931 \\
\text { June } & 28,1931 \\
\text { July } & 13,1931 \\
\text { Aug. } & 10,1931\end{array}$ & $\begin{array}{l}2.3 \\
4.3 \\
5.2 \\
3.1 \\
4.1 \\
5.0 \\
3.6 \\
2.2 \\
1.3 \\
3.5 \\
2.4\end{array}$ & $\begin{array}{l}\text { Sec. } 36, \mathrm{~T} .2 \mathrm{~N}, \mathrm{R} .16 \mathrm{~W} \\
\text { Do } \\
\text { Do } \\
\text { Do } \\
\text { Do } \\
\text { Do } \\
\text { Do } \\
\text { Do } \\
\text { Do } \\
\text { Do } \\
\text { Do }\end{array}$ & $\begin{array}{l}\text { Sept. } 16,1931 \\
\text { Sept. 29, 1931 } \\
\text { Jan. 26, 1932 } \\
\text { Feb. 26, 1932 } \\
\text { Mar. 25, 1932 } \\
\text { Apr. 14, 1932 } \\
\text { May } 31,1932 \\
\text { June 16, 1932 } \\
\text { July 20,1932 } \\
\text { Aug. 22, 1932 } \\
\text { Sept. 24, } 1932\end{array}$ & $\begin{array}{l}1.2 \\
1.1 \\
4.6 \\
6.2 \\
4.0 \\
4.1 \\
3.2 \\
3.4 \\
2.2 \\
3.5 \\
3.1\end{array}$ \\
\hline
\end{tabular}


Miscellaneous measurements of the flow of northern tributaries of the Republican River between Superior and Arapahoe-Continued

Turkey Creek (36)

\begin{tabular}{|c|c|c|c|c|c|}
\hline Location & Date & $\begin{array}{l}\text { Discharge } \\
\text { (second- } \\
\text { feet) }\end{array}$ & Location & Date & $\begin{array}{c}\text { Discharge } \\
\text { (second- } \\
\text { feet) }\end{array}$ \\
\hline 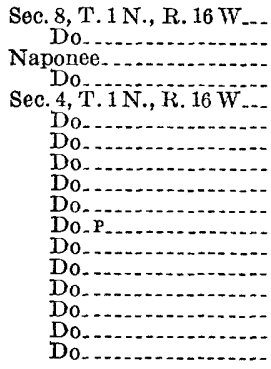 & $\begin{array}{lr}\text { Jan. } & 6,1923 \\
\text { July } & 23,1924 \\
\text { Miar. } & 18,1925 \\
\text { Oct. } & 9,1925 \\
\text { Oct. } & 16,1926 \\
\text { July } & 12,1927 \\
\text { Aug. } & 11,1927 \\
\text { Aug. } 18,1927 \\
\text { Mar. } 22,1928 \\
\text { May } 17,1928 \\
\text { June } 22,1928 \\
\text { Apr. } 19,1929 \\
\text { July } 12,1929 \\
\text { Mar. } 7,1930 \\
\text { Apr. } 3,1930 \\
\text { Apr. } 30,1930 \\
\text { June } 21,1930\end{array}$ & $\begin{array}{l}11.3 \\
16.1 \\
14.9 \\
15.4 \\
18.0 \\
10.0 \\
11.6 \\
16.1 \\
18.9 \\
23.8 \\
16.1 \\
27.1 \\
35.0 \\
17.0 \\
21.0 \\
32.0 \\
45.0\end{array}$ & $\begin{array}{l}\text { Sec. }{ }^{4,} \mathrm{~T} .1 \mathrm{~N}, \mathrm{R} .16 \mathrm{~W} \\
\text { Do } \\
\text { Do } \\
\text { Do } \\
\text { Do } \\
\text { Do } \\
\text { Do } \\
\text { Do } \\
\text { Do } \\
\text { Do } \\
\text { Do } \\
\text { Do } \\
\text { Do } \\
\text { Do } \\
\text { Do } \\
\text { Do } \\
\text { Do }\end{array}$ & $\begin{array}{lr}\text { Sept. } 17,1930 \\
\text { Oct. } 17,1930 \\
\text { Nov. } 25,1930 \\
\text { Jan. } 26,1931 \\
\text { Mar. } 17,1931 \\
\text { Apr. } 2,1931 \\
\text { Apr. } 21,1931 \\
\text { May } 8,1931 \\
\text { May } 29,1931 \\
\text { June } 28,1931 \\
\text { July } 13,1931 \\
\text { Aug. } 10,1931 \\
\text { Sept. } 16,1931 \\
\text { Sept. } 29,1931 \\
\text { Oct. } 14,1931 \\
\text { Nov. 23, } 1931 \\
\text { Jan. } 18,1931\end{array}$ & $\begin{array}{r}10.0 \\
27.1 \\
23.7 \\
21.8 \\
18.4 \\
13.6 \\
12.9 \\
13.5 \\
15.8 \\
9.4 \\
9.8 \\
6.1 \\
3.2 \\
6.9 \\
4.3 \\
9.3 \\
19.1\end{array}$ \\
\hline
\end{tabular}

Rope Creek (39)

Sec. 2, T. 1 N., R. $18 \mathrm{~W} . \mid$ Sept. 24,1901 2.6||$\quad \mid$

Tributary 41

\begin{tabular}{l|l|l|l|}
\hline Sec. 32, T. 2 N., R. 18 W. & Sept. 24,1901 & $0.6 \|$ & \\
\hline
\end{tabular}

Tributary 42

\begin{tabular}{l|l|l|l|l|}
\hline Sec. 25, T. $2 \mathrm{~N}_{.}$, R. $19 \mathrm{~W}-$ & Sept. 24,1901 & 1.4 & \\
\hline
\end{tabular}

Flag Creek (43)

\begin{tabular}{|c|c|c|c|c|c|}
\hline $\begin{array}{l}\text { Sec. } 3 \text {, T. } 2 \text { N., R. } 19 \text { W. } \\
\text { Sec. } 15, \text { T. } 2 \text { N., R. } 19 \text { W- } \\
\text { Orleans. } \\
\text { Do } \\
\text { Do } \\
\text { Do } \\
\text { Do } \\
\text { Do } \\
\text { Do } \\
\text { Do } \\
\text { Do }\end{array}$ & 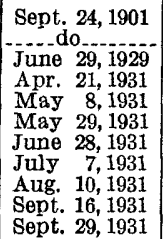 & $\begin{array}{r}1.5 \\
.5 \\
.7 \\
1.5 \\
1.8 \\
7.5 \\
.9 \\
1.1 \\
.8 \\
.4 \\
1.2\end{array}$ & 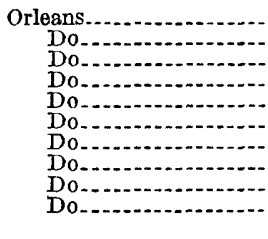 & $\begin{array}{lr}\text { Oct. } & 14,1931 \\
\text { Jan. } 26,1932 \\
\text { Feb. } 26,1932 \\
\text { Mar. } 25,1932 \\
\text { Apr. } 14,1932 \\
\text { June } 1,1932 \\
\text { June } 16,1932 \\
\text { July } 20,1932 \\
\text { Aug. } 22,1932 \\
\text { Sept. } 24,1932\end{array}$ & $\begin{array}{r}0.7 \\
1.4 \\
4.5 \\
1.6 \\
1.7 \\
1.2 \\
.6 \\
.3 \\
1.0 \\
.6\end{array}$ \\
\hline
\end{tabular}

Tributary 48

\begin{tabular}{|c|c|c|c|c|c|}
\hline $\begin{array}{l}\text { Sec. } 30, \text { T. } 4 \text { N., R. } 21 \text { W. } \\
\text { Sec. } 31, \text { T. } 4 \text { N., R. } 21 \text { W. } \\
\text { Do.. } \\
\text { Do } \\
\text { Do. } \\
\text { Do. } \\
\text { Do }\end{array}$ & $\begin{array}{lr}\text { Sept. } & 6,1899 \\
\text { Aug. } & 6,1923 \\
\text { Sept. } 17,1923 \\
\text { Oct. } 15,1923 \\
\text { Nov. } 30,1923 \\
\text { Feb. } 28,1924 \\
\text { Apr. } 1,1924\end{array}$ & $\begin{array}{r}2.3 \\
703.0 \\
407.4 \\
1.4 \\
2.4 \\
3.9 \\
4.9\end{array}$ & 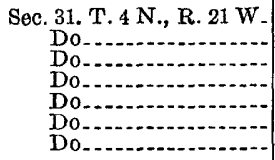 & $\begin{array}{l}\text { Apr. } 26,1924 \\
\text { May } 28,1924 \\
\text { Sept. } 8,1924 \\
\text { Mar. } 19,1925 \\
\text { Apr. } 13,1925 \\
\text { Oct. } 9,1925 \\
\text { Feb. } 16,1926\end{array}$ & $\begin{array}{l}2.8 \\
2.2 \\
1.6 \\
4.6 \\
4.2 \\
2.0 \\
4.3\end{array}$ \\
\hline
\end{tabular}

The present investigation of the discharge of the tributaries of the Republican River is described below according to their location in four segments of the valley-between Superior and Red Cloud, Red Cloud and Franklin, Franklin and Alma, and Alma and Arapahoe. 

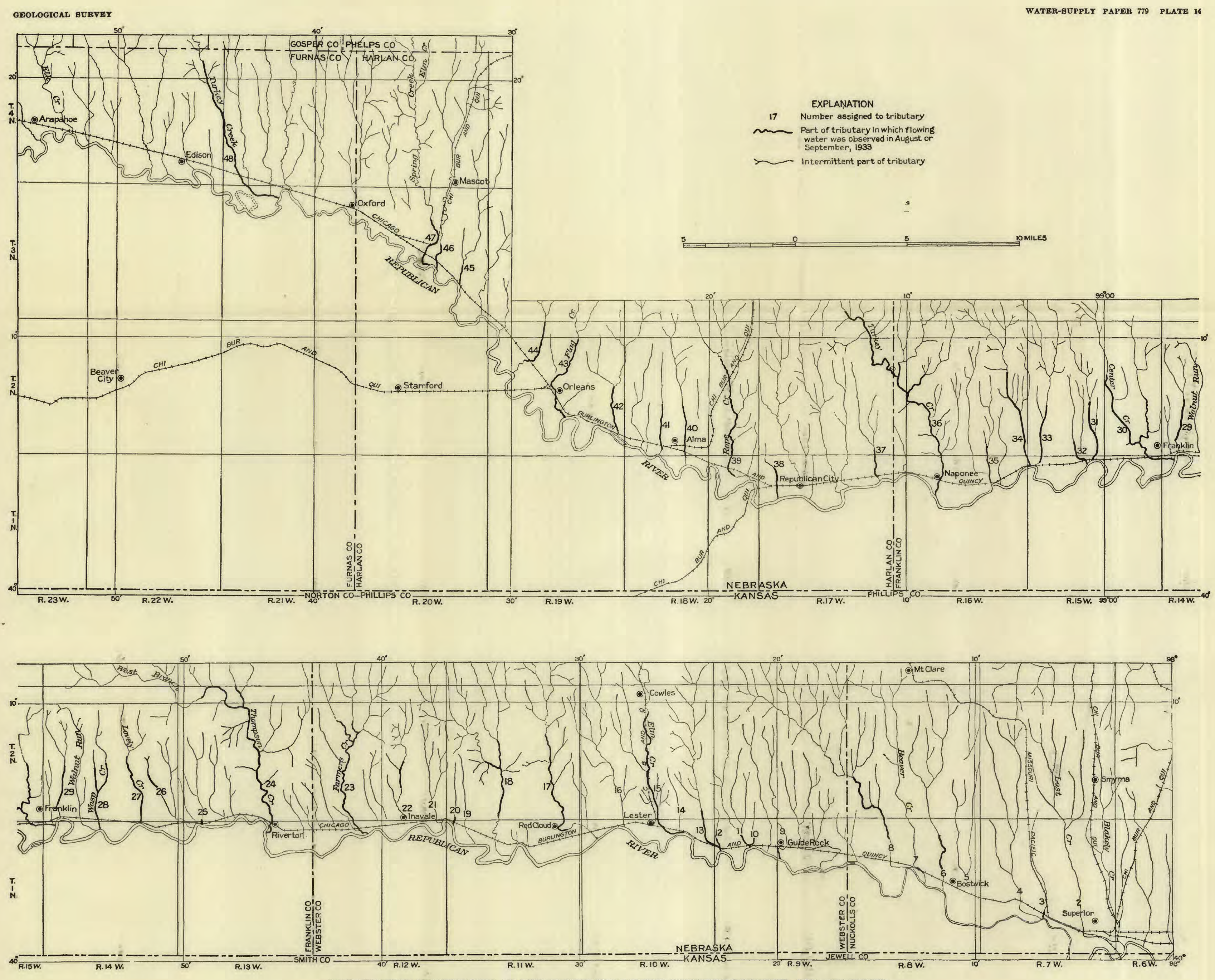

MAP SHOWING TRIBUTARIES OF THE REPUBLICAN RIVER BETWEEN SUPERIOR AND ARAPAHOE. 
FLOW OF TRIBUTARIES BETWEEN SUPERIOR AND RED CLOUD

Blakeley and Lost Creeks, the two streams that empty into the Republican River nearest Superior (nos. 1 and 2, pl. 14) receive no ground-water discharge. These tributaries were examined at 24 locations after a rain and were found to be flowing muddy water that was direct run-off. A measurement was made on the discharge of Lost Creek about 4 miles northwest of Superior, in the NE1/4 sec. 3, T. 1 N., R. 7 W., on August 28, 1933. There had been a rain on August 27 that was recorded in Superior as 0.87 inch. The flow at that point was found to be 375 gallons a minute. The stream had cut into loess

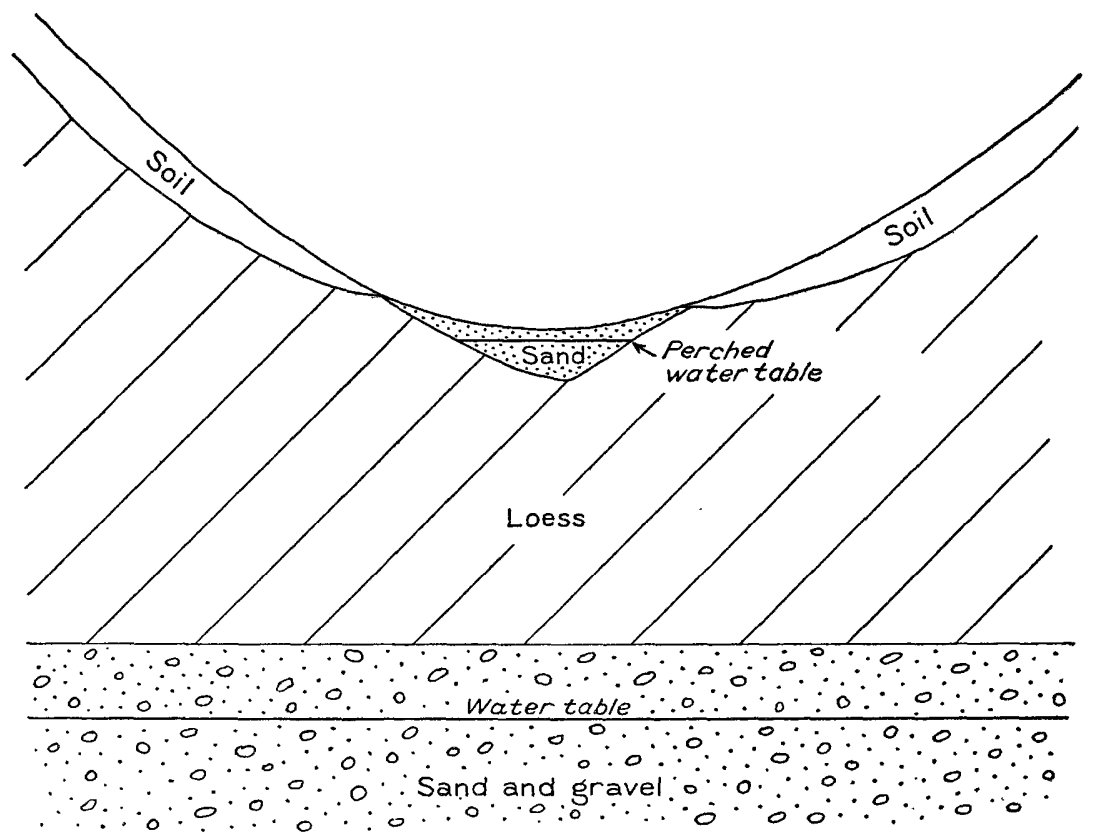

Figure 20.-Diagrammatic section across the channel of a creek 2 miles west of Superior, showing geologic and ground-water conditions.

15 to 20 feet below the prevailing land surface and also somewhat into the underlying Cretaceous shale bedrock, which was exposed on the bank. The bed of the stream, however, was composed of loess. An auger hole was put down, and shale was encountered about 3 feet below the bed of the stream. There was no indication of sand or gravel. The streams were visited on August 31 and were found to be dry at all points. Several previous measurements on the flow of Lost Creek are given in the foregoing table.

There are several large gravel pits in the valley of the small tributary (no. 3) about 2 miles west of Superior. These pits are in secs. 21 and 22, T. 1 N., R. 7 W., and show 25 to 30 feet of sand and gravel below 7 to 8 feet of loess. Both the pits and the stream were dry in August 
1933. About half a mile south of the gravel pits, near the highway in the $\mathrm{NE}_{1 / 4}$ sec. 28 , the bed of the stream was about 10 feet wide and was composed of coarse sand. The stream was dry. Several auger holes put down in the stream bed and along the banks revealed an interesting ground-water relation (fig. 20). The stream at this point had not cut through the loess to the underlying sand and gravel, but it had done so farther upstream. During periods of flow the stream had carried sand down from above and had deposited it on the loess in its bed. After the stream became dry water remained in the sand, thus producing another water-bearing bed and a perched water table. Auger boles showed about 3 feet of sand lying above the loess, of which 2 feet was saturated. There was about 7 feet of loess below the sand in the stream bed and about 2 feet of unsaturated sand and gravel below the loess. The main water table, as shown in figure 20, was about 12 feet below the present stream bed. Pools of water were observed in the bed of the stream a few hundred yards from the Republican River, and at the confluence of the streams there was a small flow in the tributary. The flow was clear and was measured as 23 gallons a minute.

Streams 4 and 5 were dry, and their beds were composed of sand and gravel. The channel of stream 5 disappeared about half a mile north of the Republican River. Evidently in periods of flow the land near the Republican River was flooded by this stream.

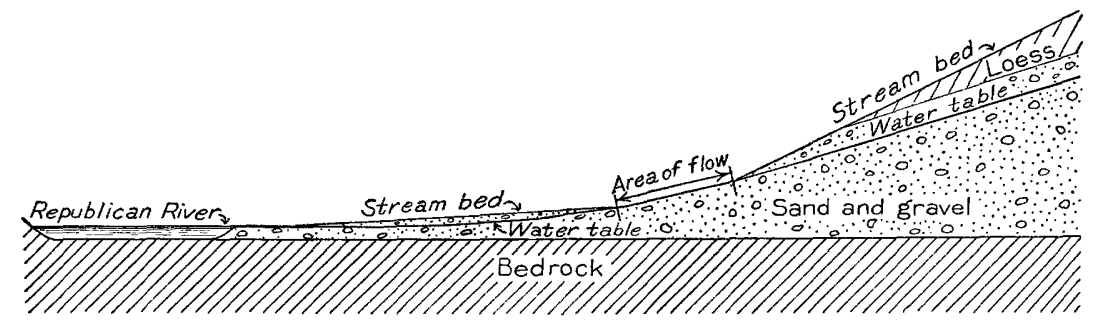

FIGURE 21.-Diagrammatic section along the channel of a creek near Bostwick, showing the conditions that produce an interrupted stream.

Stream 6, about half a mile west of Bostwick, was dry at its mouth. Sand and gravel were present in the channel of the stream as far north as sec. 34, T. 2 N., R. 8 W., about 4 miles from the Republican River, but there was no flow at this point. A mile farther north, in sec. 27, there was considerable water in the channel of the stream, and the flow was estimated at about 20 gallons a minute. The bed of the stream was composed of loess, and the gradient was very small. In the S1/2 sec. 11, about 2 miles north of the Republican River, there was a flow of clear water which was measured north of the highway bridge and found to be 16 gallons a minute. The stream starts to flow in sec. 11, about hălf a mile north of the highway, and becomes dry again about 200 yards south of the highway, in sec. 14 . The conditions that produce this interrupted stream are shown in figure 21 . 
Stream 7, about 2 miles west of Bostwick, is similar to stream 6 . Except in about 100 yards of its course directly north of the Chicago, Burlington \& Quincy Railroad bridge in sec. 15 , the stream had no flow in August 1933. North of the bridge there was a flow of about 1 gallon a minute, which disappeared into the bed of the stream at the bridge. Sand and gravel composed the bed of the stream as far north as sec. 33 , T. 2 N., R. 8 W., about 3 miles from the Republican River. Water was standing in the channel in sec. 27, where the bed of the stream was composed of loess.

Tributary 8 is another interrupted stream. This stream has one of the largest drainage basins of all the tributaries of the Republican between Superior and Red Cloud. Water was standing in the channel in the upper reaches of the stream where it had not cut through the loess. Gravel was first observed in the bed of the stream about 7 miles north of the Republican River, in the N1/2 sec. 10, T. 2 N., R. 9 W., but at this point the stream was dry. Sand and gravel are exposed in the bank of a small tributary in the E $1 / 2$ sec. 23 and on the hills west of the stream, in sec. 24, T. 2 N., R. 9 W., and east of the stream, in sec. 19, T. 2 N., R. 8 W. In the area around the stream and on the nearby hills there is practically no soil, and coarse gravel and boulders can be seen at the land surface. Opportunity for rainfall penetration in this area is great. The stream began to flow in sec. 30, T. 2 N., R. 8 W., and a measurement at the highway bridge between secs. 30 and 31 showed the discharge to be 107 gallons a minute. This flow persisted for about 3 miles (pl. 14) but was lost into the sand and gravel of the stream bed about $1 \frac{11}{2}$ miles from the Republican River, in sec. 8 , T. 1 N., R. 8 W. The stream bed remained dry from this point to its mouth.

Measurements of the flow of the interrupted streams are of little value for determining the seepage to the Republican River, because the flows vary greatly. Residents of the area report that there are times when these streams go entirely dry. This is to be expected, because the stretches of the streams where there is flow are cut only slightly below the normal water table, and when the water table declines below the stream beds, the streams, of course, go dry. The length of the flowing parts of the streams and the volume of flow oscillate with the stage of the water table, reaching a maximum when the water table is relatively high and a minimum when it is relatively low.

The tributaries between stream 8 and the town of Guide Rock carry no ground-water flow. Their beds are composed mostly of loess, although near the Republican River they cut into the sand and gravel but not to the water table. Stream 9 is dry to a point about 400 yards from the Republican River, where a spring on the north bank of the stream furnishes a small flow. The spring is about 
50 feet south of the Chicago, Burlington \& Quincy Railroad tracks, in a small park in Guide Rock. The measured discharge of the spring was 31 gallons a minute.

Tributaries 10 and 11 join about 25 feet north of the Chicago, Burlington \& Quincy Railroad bridge and then flow into the Republican River a few hundred yards to the south. Both of them carry some ground-water flow. Stream 10 was dry at the highway bridge between secs. 5 and 8, T. 1 N., R. 9 W., but at a point about 100 yards below the bridge it picked up a small flow. The discharge of this stream was measured directly above its confluence with tributary 11 , in sec. 8 , and was found to be 23 gallons a minute. Stream 11 began flowing about 250 yards north of the highway bridge in sec. 5 and at the bridge had a measured discharge of 31 gallons a minute. The stream was again measured directly above its confluence with tributary 10, where its discharge was found to have increased to 117 gallons a minute. The total visible ground-water flow into the Republican River from these two tributaries was 130 gallons a minute.

Tributaries 12 and 13 join a few hundred yards north of the Chicago, Burlington \& Quincy Railroad bridge in sec. 7, T. 1 N., R. 9 W. Both of these streams carried ground-water flow. A flow was first observed in stream 13 in sec. 36 , T. 2 N., R. 10 W., about 2 miles north of the Republican River, although sand and gravel were seen in the bed of the stream about 6 miles from the Republican River, in sec. 12. Farther north there was considerable standing water in the bed of the stream where the bed was composed of loess. The discharge of the stream was measured directly above its confluence with tributary 12 and found to be 195 gallons a minute. Stream 12 above the confluence with tributary 13 was discharging 8 gallons a minute. This small seepage flow entered the stream within a few hundred yards of the measuring point, from sand and gravel exposed along the banks of the stream. An auger hole was put down in the bed of the stream where the bed was dry and penetrated about 5 feet of loess and clay before encountering sand and gravel. Water rose in the hole and overflowed the lip, thus indicating that at this point the impermeable nature of the material in the bed of the stream confined the ground water under pressure and allowed it to come to the surface only along the banks of the stream where coarse sediments were exposed. The total ground-water seepage discharge by streams 12 and 13 into the Republican River was 203 gallons a minute.

Tributary 14 was found to be dry throughout its course. The bed of the stream is composed of loess, and probably the underlying sand and gravel are thin, because Niobrara limestone crops out on the east bank of the stream south of the railroad bridge in sec. 2, T. 1 N., R. $10 \mathrm{~W}$. 
Tributary 15, Elm Creek, has the largest ground-water flow of all the tributaries between Superior and Arapahoe. It heads in the loess uplands south of the town of Blue Hill, about 15 miles north of the Republican River. Sand and gravel occur in the bed of the stream for several miles north of Cowles, but the stream was dry above the S 12 sec. 9, T. 2 N., R. 10 W. From this point the stream picked up ground water at a rapid rate. The discharge was measured near the line between secs. 27 and 34, about 3 miles from the point where the stream began to flow, and was found to be 6,320 gallons a minute-an average pick-up of about 2,100 gallons to the mile.

Six test holes were drilled in the drainage basin of Elm Creek to determine the distribution of the underlying sand and gravel. They indicate that Elm Creek flows in a bedrock valley eroded before the sand and gravel were deposited. The sand and gravel-only a part of which is saturated-are comparatively thick north of Cowles but thin out near the Republican River. Three test holes were drilled to obtain a section across the drainage basin of Elm Creek about 9 miles north of the Republican River and about 2 miles north of Cowles. One of the holes, in the northeast corner of the NW1/4 NE1/4 sec. 27, T. 3 N., R. 10 W., penetrated 58 feet of sand and gravel before encountering bedrock. Another hole drilled near the dry bed of the stream in the northwest corner of the NE $1 / 4$ sec. 28 , T. 3 N., R. 10 W., penetrated only 23 feet of sand and gravel above the bedrock. The third hole, in the NE $1 / 4 \mathrm{NE}^{1 / 4}$ sec. 29 , T. 3 N., R. 10 W., found about 72 feet of sand and gravel above the bedrock From the approximate altitudes of the holes as obtained from the United States Geological Survey's topographic map of the area, the altitude of the bedrock surface penetrated in the first and third holes, each about a mile from Elm Creek, was computed to be 1,790 feet The altitude of the bedrock surface near the stream, as shown by a similar calculation from the second test hole, was 1,730 feet. These figures indicate that the bedrock surface has a form similar to the present land surface.

Two test holes were drilled about $1 \frac{1}{2}$ miles south of Cowles. One, in the NW1/4 NW1/4 sec. 15, T. 2 N., R. 10 W., encountered 71 feet of sand and gravel above the bedrock, and the other, in the $\mathrm{NW}_{1 / 4} \mathrm{NW}^{1 / 4}$ sec. 16, encountered 84 feet of sand and gravel above the bedrock. The altitude of the bedrock surface as determined from these holes was about 1,700 feet at the first hole and 1,685 feet at the second hole.

A final test hole was drilled about a mile north of the Republican River, in the NE $1 / 4 \mathrm{NW} 14$ sec. $3, \mathrm{~T} .1 \mathrm{~N}$., R. $10 \mathrm{~W}$., where only 13 feet of sand and gravel was penetrated above the bedrock. The altitude of the bedrock surface was about 1,670 feet. These test holes indicate that the bedrock surface slopes toward the Republican River as well as toward Elm Creek. The bedrock surface in the river has an altitude of about 1,650 feet. 
Previous measurements of the flow of Elm Creek are given in the table on page 157. The stream was dry in sec. 34, T. 2 N., R. 10 W., in 1931, but as these measurements were made below a mill it is not known whether there was water flowing above.

There is no ground-water flow in tributary 16. The bedrock is apparently high under this stream, because it is exposed in the bed and crops out along the banks for several miles north of the Republican River. A few pools of water were observed in sec. $20, T .2$ N., R. $10 \mathrm{~W}$., where the stream bed is composed of sand and gravel. The volume of underflow beneath the bed of this stream is probably so small that it is evaporated and transpired as fast as it is forced to the surface by the high bedrock.

Tributary 17, Crooked Creek, is an interrupted stream. Flow was first observed in the middle of sec. 14, T. 2 N., R. 11 W., about 5 miles north of the Republican River, where the stream made two complete reversals in direction. From a general southern course the stream doubled back north and then returned to the south. By reversing to the north it cut deeper into the general land surface, which slopes to the south, and also cut down through the unsaturated sand and gravel to the water table. Pools of water were observed in the bed of the stream where the course was north, and a small flow started about at the bend where the stream reversed its direction to the south. Thus a flow was seen in the stream at a point north of a dry part. The flow persisted in the stream to and beyond Red Cloud, a distance of about 4 miles. A measurement made at the highway bridge east of Red Cloud, on the line between secs. 36, T. 2 N., R. 11 W., and sec. 1, T. 1 N., R. 11 W., gave a discharge of 94 gallons a minute. The flow was lost into the sand and gravel in the stream bed in sec. 1, and the stream became dry in the middle of the section. The channel of the stream was not discernible in the $S 1 / 2$ sec. 1 ; hence at times of flood the flow of the stream probably spreads out over the bottom lands of the Republican Valley. Several previous measurements of the flow of Crooked Creek are given in the table. Most of the stream courses examined in this area had water standing in their channels in certain places in the upper reaches. The contour maps of the area show that the gradients of the streams are considerably less a few miles north of the Republican Valley than they are in the valley. During periods of flood flow the beds of the streams are eroded into the loess in places below the normal gradient, thus leaving undrained channels in which storm water remains impounded after the stream has stopped flowing. The loess is relatively impermeable, and hence the water stands in these places for long periods.

A summary of the observations on the tributaries between Superior and Red Cloud indicates that the measured discharge of ground-water seepage into the Republican River by the tributaries in August 1933 
was 6,684 gallons a minute, of which 6,320 gallons a minute was discharged by Elm Creek.

FLOW OF TRIBUTARIES BETWEEN RED CLOUD AND FRANKLIN

Tributary 18 is an interrupted stream which has two main branches that meet in sec. 21, T. 2 N., R. 11 W. Sand and gravel were observed in the east branch as far north as sec. 9 and in the west branch as far north as sec. 17. Both branches contribute ground-water flow to the main stream, the flow starting on the west branch in sec. 16 about a mile above the confluence of the branches and on the east branch in sec. 20 about three-quarters of a mile above the confluence. 'The flow was observed as far south as the $\mathrm{N} 1 / 2$ sec. 33 , but below this point the stream was dry. A measurement near the highway bridge on the line in sec. 33 showed a discharge of 65 gallons a minute. North of the second tier of sections the beds of the branches of the stream were composed of loess, and considerable water was standing at places in the channels. Previous measurements on the flow of tributary 18 are given in the table.

Tributaries 19, 20, and 21 contain sand and gravel in their beds, but except in tributary 20 close to the Republican River the streams are dry. Water seeps into the bed of tributary 20 in sec. $30, T .2$ N., R. 11 W., about 100 yards north of the highway bridge, and flows into the Republican River a few hundred yards south of the bridge. The discharge of the stream, measured near the bridge, was 11 gallons a minute.

Tributary 22 is dry except for about a mile of its course north of Inavale, in secs. 22 and 23, T. 2 N., R. 12 W. Here the discharge of the stream was estimated to be only 1 gallon a minute. The bed of the stream is composed of sand and gravel from secs. 22 and 23 to the Republican River, but the small flow of the stream is lost in sec. 27 , and the bed is dry below.

Tributary 23, Farmers Creek, carried some ground-water flow and discharged a part of it into the Republican River. Sand and gravel were observed in the beds of the branches of the stream 6 miles north of the Republican, in secs. 4, 5, and 6, T. 2 N., R. 12 W. The stream started to flow in sec. 8, and a flow persisted to the Republican, a distance of about 5 miles. Sand and gravel are especially noticeable in secs. 7 and 20, where they are exposed on the hills along the course of the stream. The discharge of the stream about 100 yards above the Republican River was found to be 28 gallons a minute. The discharge in sec. 20 was estimated at about 350 gallons a minute; hence it is apparent that the stream loses water in the lower part of its course. Previous measurements on the flow of Farmers Creek are given in the table. The stream was dry at times in 1931 and 1932. 
Tributary 24, Thompson Creek, has the largest drainage basin and the second largest ground-water flow of all the tributaries between Superior and Arapahoe. It discharges into the Republican River at Riverton. The stream has three branches, of which the west branch is the longest. This branch heads in the loess uplands about 25 miles from Riverton. A flow was first observed in the west branch about 7 miles from the Republican River, in sec. 5, T. 2 N., R. 13 W., and in the middle branch in sec. 4 . The east branch was dry. There was a gradual pick-up of water throughout the course of the main stream to Riverton, where a measurement a few hundred yards from the Republican River showed a discharge of 5,050 gallons a minute. Throughout most of the course of the stream the bed is rather wide and is composed of sand and gravel. The west branch has cut into sand and gravel as far northwest as sec. 21, T. 3 N., R. 14 W., about 11 miles from the Republican River. Sand and gravel are exposed on the hills for several miles on each side of the main stream, and in some localities there are dunes. The stream in its middle part has a rather flat valley that ranges from 1 mile to 2 miles in width and is well wooded in localities where the stream is perennial. Along the lower course bedrock crops out at several localities, as east of the stream in sec. 15, T. 2 N., R. 13 W.

Previous measurements of the flow of Thompson Creek are given on page 158. The discharge of the stream appears to be rather constant. The lowest recorded flow was measured on September 29, 1931, when it was 8.5 cubic feet a second, or 3,825 gallons a minute.

Thompson Creek is typical of many of the tributaries of the Republican River in that in its middle course considerable quantities of unsaturated sand and gravel are exposed in its bed and on the neighboring hills. Most of the tributaries head in the loess uplands, cut through the loess into the unsaturated sediments in their middle courses, and penetrate to or nearly to the bedrock near their mouths. These streams may or may not flow near their mouths, but they usually flow if there are considerable exposures of sand and gravel in their middle courses. The geologic and ground-water relations in the drainage basins are such that there is a large amount of rainfall penetration, and hence some of the ground-water flow measured in the streams is the result of local precipitation. Where sand and gravel are exposed on the hills and adjoining areas some water will percolate to the water table and then to the stream. However, the major part of the recharge from precipitation probably occurs directly in the beds of the streams, from surface run-off. A part of the rain water that falls on the drainage basin of a tributary stream follows the general land surface and finds its way into a branch of the tributary and then into the tributary itself. A large part of each drainage 
basin lies on the loess uplands, where there is maximum run-off and practically no seepage. The run-off follows the course of the tributary through the loess and then flows over the unsaturated sand and gravel for varying distances before it reaches the part of the stream that perennially receives ground water. The sand and gravel in the bed of the stream are very permeable, hence a large amount of water percolates into the stream bed and down to the water table. This increases the ground-water storage and provides for a ground-water flow farther downstream in dry periods. The beds of many of the tributaries are composed of sand and gravel for considerable distances above the points where the streams flow perennially. At least 7 miles of such unsaturated material is exposed in the bed of the west branch of Thompson Creek above sec. 5, T. 2 N., R. 13 W., where the first flow was seen in the stream (pl. 5, $B$ ). During the examination of the tributaries flows were observed after rains in the upper courses of many streams where their beds were composed of loess, but at the same time the streams were dry in their middle courses, where their beds were composed of sand and gravel. Evidently the flows were absorbed by the sand and gravel just below the points where the stream beds changed from loess.

The recharge from precipitation on the drainage basins of the tributaries makes a determination of the underflow loss from the Platte Valley by measurements of the ground-water flow of the tributaries extremely difficult if not impossible. In many localities there are opportunities for a maximum recharge of the ground water from precipitation, which might easily furnish all of the ground-water flow of the streams. On the other hand, the ground-water flow of some tributaries is large enough to indicate the possibility of underflow into their drainage basins. A summary of the flows of the principal tributaries is given on pages 174-175.

Tributary 25 cuts into sand and gravel about a mile from the Republican River. The stream was dry to a point about 100 yards above its mouth, where several springs furnished a small flow. The discharge of the stream was found to be 9 gallons a minute by a measurement made directly above the confluence with the Republican River.

Tributary 26 was dry except for about a quarter of a mile in sec. 26 , T. 2 N., R. 14 W., where an estimated discharge of 1 gallon a minute was observed. In most places the bed of the stream is composed of sand and gravel, but in sec. 26 bedrock is exposed about where the flow began. The interrupted character of the stream is probably caused by the high bedrock in that locality.

Sand and gravel were observed in the bed of tributary 27, Lovely Creek, in sec. 15, T. 2 N., R. 14 W., about 3 miles north of the Republican River. Spring discharge from the bed of the stream began in $121343-38-12$ 
the $N \frac{1}{2}$ sec. 22 , and the flow persisted to the Republican. The discharge was measured in the $\mathrm{N} 1 / 2$ sec. 35 and was found to be 80 gallons a minute. Previous measurements shown in the table on page 158 indicate, however, that at times Lovely Creek becomes dry in sec. 35 .

Tributary 28, Sand Creek, has two branches that unite in sec. 28, T. 2 N., R. $14 \mathrm{~W}$. Both of these branches carried ground-water flow, which was measured below their confluence in sec. 33 and found to be 89 gallons a minute. The flow in the west branch started from the sand and gravel in its bed in the $\mathrm{S} 1 / 2$ sec. 21 , and the flow in the east branch began in the N1/2 sec. 21. Like Lovely Creek, Sand Creek goes dry at times, as shown by previous measurements (p. 159).

Tributary 29 is an interrupted stream. In August 1933 it carried a flow from the $\mathrm{S} 1 / 2$ sec. 19, T. 2 N., R. 14 W., to the N $1 \frac{1}{2}$ sec. 31 , a distance of about $1 \frac{11}{2}$ miles. A discharge of 89 gallons a minute was measured near the highway bridge in sec. 30 . Previous measurements are given in the table.

The total visible ground-water flow into the Republican River between Red Cloud and Franklin, as indicated" by measurements of the flow of tributaries entering from the north side of the river, was 5,268 gallons a minute.

FLOW OF TRIBUTARIES BETWEEN FRANKLIN AND ALMA

Center Creek, tributary 30, has the third largest drainage basin of the tributaries between Superior and Arapahoe. The basin is exceeded in area only by those of Thompson Creek, to the east, and Turkey Creek, to the west. The drainage basin of Center Creek is similar to that of Thompson Creek because it contains many hills along the course of the stream where sand and gravel are exposed. The stream bed is wide and is composed of permeable sand and gravel in the middle and lower sections. Water was first observed in the bed of the stream in sec. 15, T. 2 N., R. 15 W., and from this point to the Republican River there was a gradual increase in flow. The length of the flowing part of the stream was about $3 \frac{11}{2}$ miles. A small branch that empties into Center Creek about half a mile west of Franklin carried a flow estimated at about 50 gallons a minute. This branch began to flow in sec. 24, about $1 \frac{1}{2}$ miles north of Franklin. The discharge of Center Creek measured below the confluence of the small branch east of Franklin was 890 gallons a minute. The measurements shown in the table on page 159 indicate, however, that this stream was dry on June 28 and September 16, 1931.

Tributary 31 had a small ground-water flow starting in the $\mathrm{S} 1 / 2$ sec. 21, T. 2 N., R. 15 W., which it discharged into the Republican River. The flow was measured a few hundred yards north of the river and was found to be 37 gallons a minute. 
Tributary 32 has a small drainage basin, which extends only 4 miles north of the Republican River. The stream began to flow at a point about half a mile north of the river and this flow persisted to the river, where it was measured and found to be 9 gallons a minute.

Tributaries 33 and 34, Little and Big Cottonwood Creeks, have elongated drainage basins very similar in shape and differing in area by only 4 square miles. Yet the ground-water discharge per unit of drainage area for tributary 34 was about four times that of tributary 33. Both streams have cut into sand and gravel 4 miles north of the Republican River, but they do not flow for a mile or more below these localities. The bed of tributary 34 is especially wide in the middle course of the stream and in places exceeds 50 feet. The flow in tributary 33 began in the $\mathrm{S} 1 / 2$ sec. 19 , T. 2 N., R. 15 W., and the flow in tributary 34 began about a mile farther north, in sec. 13, T. 2 N., R. $16 \mathrm{~W}$. Bedrock is exposed on the west side of tributary 34 in sec. 25. A discharge measurement was made near the highway bridge in sec. $1, T .1$ N., R. 16 W., where the sand and gravel are absent in the bed and the stream flows directly on the bedrock (Niobrara limestone). The discharge was 1,200 gallons a minute. The discharge of tributary 33 was measured about half a mile to the east, near the highway bridge in sec. 6, T. 1 N., R. 15 W., and was found to be 214 gallons a minute. The bed of the stream was composed of sand and gravel. A comparison of the drainage basins of tributaries 33 and 34 indicates that the relatively high percentage of ground-water discharge in tributary 34 is probably caused by greater rainfall penetration in its drainage basin, greater percolation of water after rains to the zone of saturation through the permeable sand and gravel in the wide bed of the stream, where the bed is normally dry, perhaps a larger volume of underflow from areas beyond the drainage basin to the northwest, and high bedrock north of the Republican River that brings practically all of the ground water to the surface. The low flows of the streams as shown in the table are 45 gallons a minute in Little Cottonwood Creek and 495 gallons a minute in Big Cottonwood Creek.

The discharge of tributary 35 about 300 yards north of the Republican River was 14 gallons a minute. This tributary has two branches that unite about a quarter of a mile from the Republican. The longer one, the west branch, was dry throughout its course, and the total flow of the tributary came from the east branch. This flow percolated from the sand and gravel in the bed of the stream, starting in the $\mathrm{S} 1 / 2$ sec. $35, \mathrm{~T} .2 \mathrm{~N}$., R. $16 \mathrm{~W}$.

Tributary 36, Turkey Creek, heads in the loess uplands a few miles south of Holdrege. Its drainage basin is similar to that of Thompson and Center Creeks-large, containing many hills of sand and gravel, and having abundant vegetation in its lower part. The bed of the stream in its middle course is wide and dry and contains permeable 
sand and gravel. The stream began to flow in sec. 34, T. 3 N., R. 17 W., about 10 miles from the Republican River. Several branches of the stream also picked up ground-water flow but only in small quantities. The discharge of Turkey Creek was found to be 2,950 gallons a minute by a measurement made in Naponee. Although large, the annual ground-water discharge of Turkey Creek is equivalent to only 0.56 inch of rain on the drainage basin of the stream, or about one-half that represented by the discharge of Thompson Creek and only about one-seventh of that represented by the discharge of Elm Creek. The altitude of the stream bed of Turkey Creek in the locality of sec. 34 where the flow starts is about 2,030 feet, and the altitude of the Republican River south of Naponee is about 1,870 feet. Hence the gradient of the stream and of the water table between those points averages about 16 feet to the mile. The average gradient. of the stream bed for the 20 miles above the point where the flow starts is about 15 feet to the mile. The lowest measured flow in Turkey Creek was 1,440 gallons a minute on September 16, 1931.

Of the six small tributary streams between Naponee and Republican all but one, tributary 37, were found to be dry. All the streams cut through the overlying loess into sand and gravel 2 to 3 miles north of the Republican River, but only tributary 37 penetrated to the water table. There was an estimated discharge of about 1 gallon a minute in this stream in sec. 1, T. 1 N., R. 17 W., but this flow disappeared into the bed of the stream a few hundred yards north of the Republican River. Tributary 37, therefore, is an interrupted stream.

Tributary 38 had a ground-water flow that was measured about 25 feet north of the railroad bridge in sec. 18 , T. 1 N., R. 17 W., and found to be 6 gallons a minute. The bed of the stream is composed of sand and gravel. This stream has a drainage basin of only 1.7 square miles.

The ground-water flow in tributary 39, Rope Creek, was observed to begin in sec. 11 , T. 2 N., R. 18 W., about 5 miles from the Republican River. The bed of the stream is composed of sand and gravel in sec. 11, but for several miles in the lower course of the stream the sand and gravel are overspread with loess, and the flow took place on top of the loess. The loess may have been washed into the stream bed from the nearby hills or it may have been in place and the stream may not have eroded through it. In sec. 2 , T. 1 N., R. 18 W., however, the loess has been eroded and the stream flows directly on Niobrara limestone. This suggests that the sand and gravel may be thin or entirely lacking for several miles north of the Republican River. The discharge of Rope Creek was measured near the highway bridge in about the center of sec. 2 and found to be 177 gallons a minute. The discharge on September 24, 1901, was about 1,170 gallons a minute. 
There was a measured discharge of 131 gallons a minute in tributary 40 near the highway bridge in about the center of sec. 33, T. 2 N., R. $18 \mathrm{~W}$. No sand or gravel was seen in the bed of the stream, but probably the stream penetrates the sediments at some localities in its course. Niobrara limestone was exposed in the bed of the stream east of Alma.

The total visible ground-water flow into the Republican River between Franklin and Alma as indicated by measurements on northside tributaries was 5,628 gallons a minute.

FLOW OF TRIBUTARIES BETWEEN ALMA AND ARAPAHOE

There are two tributaries between Alma and Orleans that were not dry. The flow in tributary 41 began in sec. 29 , T. 2 N., R. 18 W., about 2 miles north of the Republican River. The discharge near the highway bridge in the $\mathrm{S} 1 / 2$ sec. 32 was found to be 57 gallons a minute. The measured discharge of tributary 42 near the highway bridge in about the middle of sec. 25 , T. 2 N., R. 19 W., was 11 gallons a minute, less than one-fifth the flow of tributary 41, yet the drainage basin of tributary 42 is more than eight times as large as the drainage basin of tributary 41 . At the point of measurement of tributary 42 Niobrara limestone formed the bed and sides of the stream, but about 15 feet above the stream bed 6 inches of gravel was exposed between the limestone and loess. From this gravel there percolated a small flow of water that amounted to at least half of the measured flow of the stream. A flow of about 270 gallons a minute in tributary 41 and a flow of 638 gallons a minute in tributary 42 were measured on September 24, 1901.

The discharge of tributary 43, Flag Creek, as measured near the highway bridge in the $\mathrm{E} 1 / 2$ sec. $14, \mathrm{~T} .2 \mathrm{~N}$., R. 19 W., was found to be 114 gallons a minute. This flow is lower than any shown in the table of earlier measurements (p. 160). Sand and gravel occur in the bed of the stream, but in places the sediments were obscured by loess that had been washed in from nearby localities.

The discharge of tributary 44 near the railroad bridge in sec. 6 , T. 2 N., R. 19 W., was found to be 28 gallons a minute. The bed of the stream is composed of loess, and the water was rather muddy.

There are 20 tributaries between tributary 42 and Arapahoe, but ground-water flow was observed in only 4 of them. Sand and gravel exposures are rare in this area, and thick deposits of loess mantle the hills. The streams have deep, narrow ravines cut into loess, and only in a few places are sand and gravel present in the stream beds. A discharge of 28 gallons a minute was measured in tributary 45 about 100 yards from the Republican River, in sec. 26 , T. 3 N., R. $20 \mathrm{~W}$. Here sand and gravel were exposed in the bed of the stream, but a mile north of this locality the bed consisted 
of loess and the stream was dry. Tributary 46 had a measured discharge of 91 gallons a minute about a quarter of a mile north of the Republican River, in sec. 22 , T. 3 N., R. 20 W., but was dry about a mile farther north. The discharge of tributary 47 was measured about half a mile north of the Republican River, in sec. 15 , T. 3 N., R. $20 \mathrm{~W}$., and found to be 198 gallons a minute. The water was muddy, and it is probable that a part of this discharge was surface run-off from a rain that occurred a few days earlier. The bed of tributary 48 is composed of loess, and the flow was also very muddy. Probably some of the discharge was surface run-off. The discharge was measured near the railroad bridge in sec. $31, \mathrm{~T}$. 4 N., R. 21 W., and was found to be 445 gallons a minute. Several previous measurements of the flow of tributary 48 are given in the table on page 160 .

The total visible ground-water flow into the Republican River from the north in the stretch between Alma and Arapahoe, as indicated by measurements of the flow of the tributaries, was 972 gallons a minute.

SUMMARY

The aggregate flow of all the tributaries discharging water into the Republican River from the north between Superior and Arapahoe in the period August-September 1933 was 18,552 gallons a minute. This quantity of water is equal to about 41.4 cubic feet of water a second or to about 30,000 acre-feet of water a year. About a third of this quantity was discharged by Elm Creek alone, and 14,320 gallons a minute, or over 77 percent, was discharged by Elm, Thompson, and Turkey Creeks. These three tributaries have drainage basins that are very similar in that considerable exposures of sand and gravel occur near the streams. Moreover, on each stream above the point where it begins to flow there is a long stretch in which permeable sand and gravel constitute its bed. Recharge to the water table from precipitation on the drainage basins of these streams and seepage from run-off in the beds of the streams above the points of first flow evidently furnish a part of the ground-water flow of these streams. Such recharge probably takes place in the basins of most of the other tributaries as well. On the other hand, there is probably invisible seepage to the Republican River through the sand and gravel in the areas between the tributaries; plants draw upon the zone of saturation for water throughout the courses of the tributaries and also in the Republican Valley, where the water table stands close to the Iand surface; and some water is evaporated from the tributaries and from the zone of saturation along the banks of the streams. Thus the flow as measured in the tributaries represents underflow into the valleys of the tributaries, minus transpiration and evaporation losses, minus direct percolation to the Republican River, and plus direct and in- 
direct recharge from precipitation on the drainage basins of the tributaries. It is probable that transpiration and evaporation losses are considerable, that direct percolation to the Republican River is small, and that the amount of rainfall penetration is large. However, these factors can be only approximately evaluated from the data obtained; hence the quantity of water that percolates from the Platte Valley to the Republican Valley cannot be accurately determined.

The flows of the tributaries as measured by the writer were not all the lowest flows observed in these streams. Previous measurements (pp. 157-160) show that at times the flows of the tributaries are considerably less than in 1933. As transpiration and evaporation were near the maximum in August and September 1933, this would indicate that a part of the flow of the tributaries at that time was obtained from ground-water storage derived from earlier recharge in the drainage basins of the streams, and that only a part of the flow came from the Platte Valley. The aggregate of the lowest flow measurements of the tributaries is 11,298 gallons a minute, which may be compared with the 18,552 gallons a minute shown by the measurements made by the writer. Moreover, it is probable that the lowest flows of the tributaries are not on record.

In the fall of 1934 several measurements of the tributaries to the Republican River were made at the locations where measurements were made in 1933 . These measurements were made by the Nebraska Bureau of Irrigation, Water Power, and Drainage under the direction of R. H. Willis. Most of the flows were slightly greater than in 1933, although the precipitation during 1934 was considerably less than normal, thus indicating that the low flows of the streams are probably derived chiefly from ground-water seepage from a large underground reservoir with a large hold-over capacity. A comparison of the flows. in 1933 and 1934 of the three largest tributaries shows for Elm Creek, 6,320 gallons a minute in 1933 and 6,230 gallons a minute in 1934; for Thompson Creek, 5,050 gallons a minute in 1933 and 7,580 gallons a minute in 1934; and for Turkey Creek, 2,950 gallons a minute in 1933 and 3,280 gallons a minute in 1934 . The total flows of all the tributaries were somewhat greater in 1934 than in 1933, but it is not known whether direct run-off was included in the flows in 1934.

FLOW OF THE BIG BLOE AND LITTLE BLUE RIVERS AND TRIB TTARIES

The Big Blue and Little Blue Rivers head in the loess plains south of the Platte River and flow in a general southeasterly direction into Kansas, where the Little Blue empties into the Big Blue. The main stream flows into the Kansas River below the mouth of the Republican River. The drainage basin of the Big Blue extends farther to the north and east than that of the Little Blue, and the Big Blue and its 
tributary Lincoln Creek head close to the Platte River Valley. Lincoln Creek heads southeast of Grand Island, only 2 miles from the Platte River, and the Big Blue rises southeast of Central City, about 4 miles from the Platte Valley. Several of the tributaries of the Little Blue River head 5 or 6 miles south of the Platte Valley, near Gibbon, Shelton, and Wood River.

Periodic measurements of the flows of the Big Blue and Little Blue Rivers have been made at several places east of the area covered by this report. These measurements indicate that the flows are rather constant, even in periods of dry weather. During freshets the rivers have tendencies to shift their channels.

The investigation of the ground-water flows of the Big Blue and Little Blue Rivers has been confined to their upper courses. Each river and tributary was visited at several places west of R. $4 \mathrm{~W}$., and the flow, if any, was measured. The investigation covered these rivers and all their tributaries west of a north-south line passing 9 miles east of Central City, in the Platte Valley, and 13 miles east of Superior, in the Republican Valley, the approximate eastern limit of the area covered by this report. The central part of this area is shown in plate 15 .

\section{BIG BLUE RIVER AND TRIBUTARIES}

The streams that are tributary to the Big Blue River west of $R$. $4 \mathrm{~W}$. are Lincoln Creek, Beaver Creek, the West Fork of the Big Blue, and School Creek.

The Big Blue River heads in T. 12 N., R. 7 W., about 6 miles northeast of Phillips. The course of the stream is irregularly east to $\mathrm{T}$. 11 N., R. 6 W., where it turns north and leaves the area covered by this report in sec. 1, T. 12 N., R. 5 W. Throughout this part of the stream water was observed standing in the stream bed, but there was no flow. The bed was composed of loess; hence the stream had not cut down to the underlying sand and gravel. The altitude of the stream bed in sec. 1, T. 12 N., R. 5 W., is about 1,720 feet, the same as that of the bed of the Platte River about 8 miles to the northwest. A flow of 225 gallons a minute was measured on August 27, 1924, at Stromsburg, about 12 miles east of the area covered in this investigation..$^{71}$

Lincoln Creek heads in T. 10 N., R. 8 W., about 5 miles southwest of Phillips. The stream has a general eastward course except where it makes a south bend near Aurora. It leaves the area here considered in sec. 24, T. 11 N., R. 5 W., where the altitude of the stream bed is about 1,670 feet. Water was observed in the bed of the stream at several places, and an estimated flow of 10 gallons a minute was

71 Nebraska Dept. Public Works Rept., 1923-24, p. 515. 


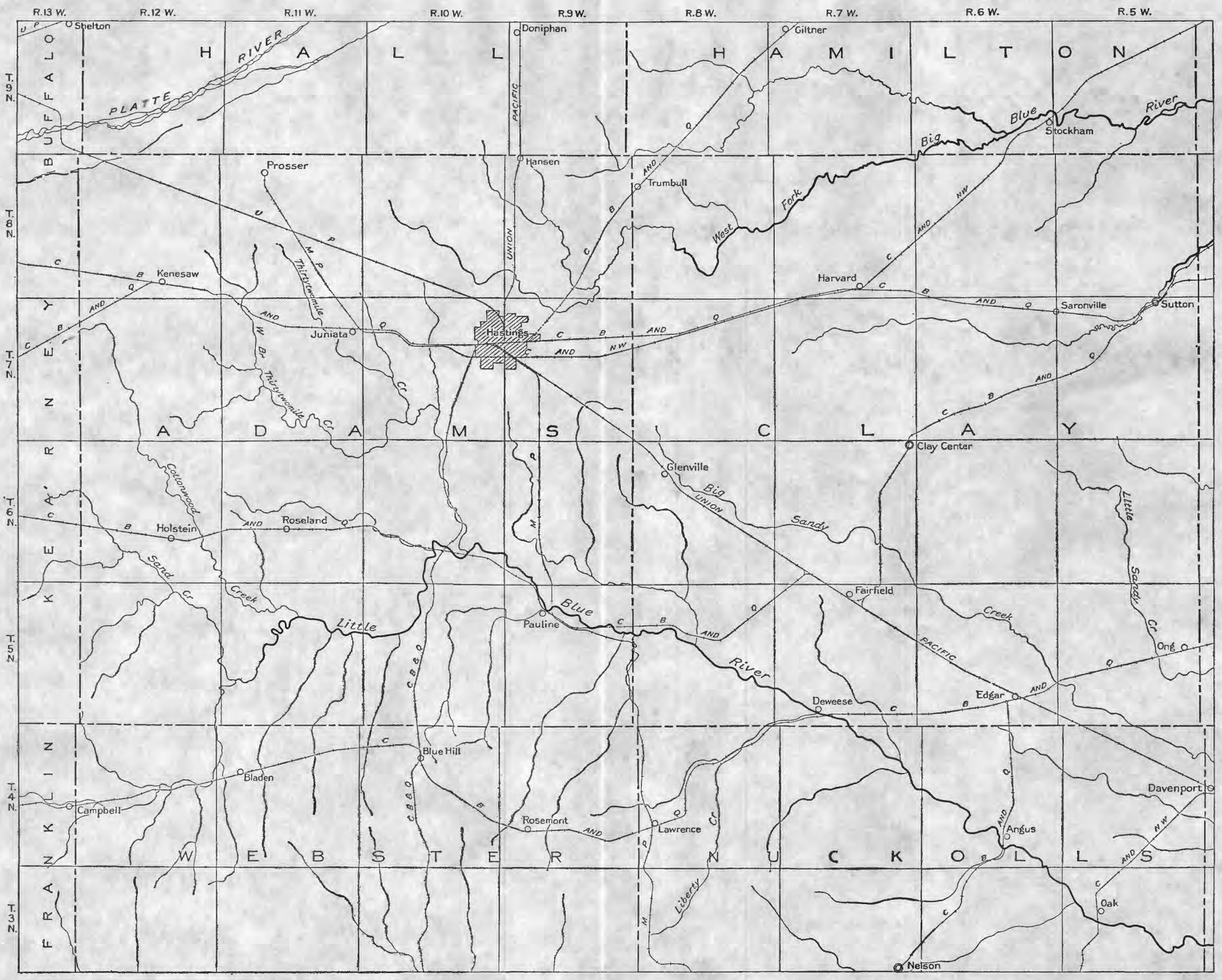

Part of stream in which flowing water
was observed in Septembers 1933 .

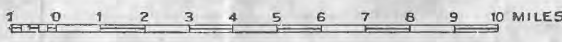



seen about 2 miles east of Aurora. However, the creek was dry at the eastern limit of the area under investigation. The bed of the creek is composed of loess throughout the area.

Beaver Creek heads about 3 miles southwest of the head of Lincoln Creek and flows approximately parallel to Lincoln Creek. About 24 miles of the area under investigation is traversed in an east-west direction by this stream. Water was observed standing at places in the bed of the stream, but it is composed of loess, and there was no flow at the point where the stream leaves the area. The altitude of the stream bed at this point is about 1,660 feet.

The West Fork of the Big Blue River has two main branches that unite about 2 miles west of Stockholm (pl. 15). The south branch is the longer and heads a few miles north of Hastings. The north branch heads north of Trumbull. Both branches have general eastward courses in this area. Water was standing in the south branch in sec. 24 , T. 8 N., R. 9 W., where the bed is composed of loess. This water, as well as the water observed in the stream beds of the other tributaries, probably was the result of recent rains and was left in loess pockets that had been scoured out in times of high water. A flow was seen in the $\mathrm{SW} 1 / 4$ sec. 21, T. $8 \mathrm{~N}$., R. $8 \mathrm{~W}$., where the bed of the stream is composed of loess. The discharge was measured and found to be 425 gallons a minute. About 5 miles lower, in the $\mathrm{SW}^{1 / 1} 4$ sec. $18, \mathrm{~T}$. $8 \mathrm{~N}$., R. $7 \mathrm{~W}$., the flow was found to be 380 gallons a minute. No. sand or gravel was visible in the bed of the stream or in the vicinity. The stream was followed for about 9 miles, and another measurement of its flow was made in the SW1/4 sec. 34 , T. 9 N., R. $6 \mathrm{~W}$. At this point some sand was observed in the bed of the stream. The discharge was 530 gallons a minute. The north and south branches join about a mile below the last measuring point. The flow in the north branch was measured above the junction, in the N1/2 sec. 27 , T. 9 N., R. $6 \mathrm{~W}$., and was found to be 450 gallons a minute. Hence the flow of the West Fork of the Big Blue below the junction was about 980 . gallons a minute. The flow in the north branch started about 3 miles above the junction, in sec. 20 , T. 9 N., R. 6 W., where no sand or gravel was visible in the stream bed. On September 25, 1923, the flow in the north branch in sec. 28, T. 9 N., R. 6 W., was found to be about 40 gallons a minute. ${ }^{72}$ The discharge of the West Fork about 4 miles below the confluence of its branches, in sec. 28 , T. 9 N., R. $5 \mathrm{~W}$., as measured by the writer was 4,400 gallons a minute. Here no sand or gravel was exposed in the stream bed or along the banks. The bed of the stream consisted of soft, mushy loess which probably had been washed into the stream. The gradient of the stream in the area investigated is only about $2 \frac{1}{2}$ feet to the mile, and the flow is very sluggish. During periods of flood flow considerable loess is

79 Nebraska Dept. Public Works Rept., 1923-24, p. 475. 
washed into the stream and deposited in its bed, probably on gravel from which the ground-water flow percolates. The stream is incompetent to move the loess in times of normal flow; hence the sand and gravel in its bed are not exposed. The altitude of the stream bed where the stream leaves the area is about 1,620 feet. Flow was first observed in the south branch at an altitude of about 1,810 feet and in the north branch at about 1,690 feet. It is probable that a'part of the flow in the south branch was surface run-off from previous rains.

School Creek heads in the vicinity of Harvard, has an easterly course to Sutton, and then a northeasterly course to a point near Lushton, where it unites with the West Fork of the Big Blue River. West of Sutton the stream was dry and its bed is composed of loess. In sec. 25 , T. 8 N., R. 5 W., where the creek leaves the area under investigation, there was an estimated flow of 10 gallons a minute. The gradient of the stream, like that of the West Fork, is very small, and the flow was sluggish. The bed and banks of the stream are composed of loess. The altitude of the stream bed in sec. 25 is about 1,660 feet.

Practically all the flow of the Big Blue River derived from the area under investigation came from the West Fork, which discharged about 4,400 gallons a minute. It is probable that some of this flow was direct run-off. The flow in School Creek was negligible, and the Big Blue, Lincoln Creek, and Beaver Creek were dry. The streams had almost no sand or gravel in their beds, in contrast with the tributaries of the Republican River. There is comparatively little groundwater flow in the streams of this area.

\section{LITTLE BLUE RIVER AND TRIBUTARIES}

The run-off of the southeastern part of the area is carried by Little Sandy Creek, Big Sandy Creek, the Little Blue River, and Spring Creek.

Little Sandy Creek heads in the vicinity of Clay Center and has a southeasterly course to the point where it leaves the area. At this point, in sec. 24 , T. 5 N., R. 5 W., the stream was dry and its bed is composed of loess. The altitude of the stream bed in this locality is about 1,620 feet.

Big Sandy Creek heads a few miles southeast of Hastings and has a southeasterly course into Nuckolls County, where it leaves the area. The bed of the stream is composed of loess, and no sand or gravel was visible. The stream was dry throughout the area. The altitude of the bed of the stream in sec. 12 , T. 4 N., R. $5 \mathrm{~W}$., where it leaves the area, is about 1,590 feet.

The Little Blue River has several tributaries in the area under investigation. Sand Creek and Cottonwood Creek head a few miles south of the Platte River near Hartwell and join the Little Blue south 
of Roseland. In sec. 20 , T. 5 N., R. 11 W., about 2 miles below Sand Creek, the Little Blue was dry, but sand and gravel are exposed in its bed. The banks of the stream are composed of loess. This condition continued to sec. 9 , T. 5 N., R. 11 W., where pools of water were observed in the stream. A flow of 50 gallons a minute was measured at the highway bridge between secs. 9 and 10 . The water was clear and flowed over sand and gravel. The altitude at this point is about 1,850 feet. Cottonwood Creek, which joins the Little Blue in sec. 10, was dry. Its bed is composed of loess. Flat Creek, which enters the Little Blue from the south in sec. 14, was dry also. The discharge of the Little Blue was measured near the highway bridge in sec. 18, T. 5 N., R. $10 \mathrm{~W}$., and found to be 885 gallons a minute. This measurement was made about 4 miles below the previous measurement and represented an increase in flow of 835 gallons a minute. The stream from this point turns north for about 4 miles and cuts deeper into the underlying sand and gravel.

Two measurements of the discharge of the Little Blue River were made in this locality in 1900 by Stevens. ${ }^{73}$ The flow at the west line of sec. 18 , T. 5 N., R. $10 \mathrm{~W}$., about at the point where the writer measured 885 gallons a minute, was 720 gallons a minute on August 23, 1900. Another measurement made on the same day at Ayr, 3 miles downstream, gave a discharge of 765 gallons a minute.

Another measurement was made by the writer in sec. 26, T. $6 \mathrm{~N}$., R. $10 \mathrm{~W}$., about 6 miles below the location of the previous measurement. Here the stream was flowing 6,750 gallons a minute, an increase of almost 6,000 gallons a minute. Thirtytwomile Creek enters the Little Blue in sec. 26, but it was dry in loess. A measurement of the discharge of the Little Blue was made east of Pauline, in sec. 11, T. 5 N., R. 9 W., about 6 miles below the location of the previous measurement. Here the flow had increased to 14,750 gallons a minute. One tributary, Ash Creek, supplies a small quantity of ground-water flow between the two measuring points. The flow of Ash Creek in sec. 4, T. 5 N., R. 9 W., a few hundred yards above its mouth, was found to be 80 gallons a minute. The tributary picked up this water about half a mile from the Little Blue. Crooked Creek, which enters the Little Blue River in sec. 12, T. 5 N., R. 9 W., was found to be dry, and its bed is composed of loess. Pawnee Creek was also found to be dry near its entrance to the Little Blue, in sec. 16 , T. 5 N., R. 8 W.

The discharge of the Little Blue River near the Antioch School, in sec. 2 , T. 4 N., R. 7 W., about 14 miles below the location of the previous measurement, was 29,000 gallons a minute, an increase of 14,250 gallons a minute. On January 1,1923 , the flow in sec. 13,

\footnotetext{
i3 Stevens, J. C., Surface water supply of Nebraska: Geol, Survey Water-Supply Paper 230, p. 211, 1909
} 
T. 4 N., R. 7 W., was about 5,980 gallons a minute, ${ }^{74}$ considerably less than the 29,000 gallons measured in 1933. About 7 miles below this point, near Angus, in sec. 35, T. 4 N., R. 6 W., another measurement showed a flow of 27,900 gallons a minute, a loss of 1,100 gallons a minute. A final measurement about 5 miles below this point, near Oak, in sec. 17 , T. 3 N., R. 5 W., showed a flow of 27,500 gallons a minute, a loss of 400 gallons a minute. Elk Creek, which enters the Little Blue west of Oak, in sec. 7 , T. 3 N., R. 5 W., was dry, and its bed is composed of loess.

The measurements of the flow of the Little Blue River at several localities in the area under investigation indicate that the discharge increases rapidly for a few miles and then remains the same or decreases. In about 4 miles below the first flow the average pick-up was about 400 gallons a minute to the mile; in the next 6 miles, about 1,000 gallons a minute; in the next 6 miles, about 1,300 gallons a minute; and in the next 14 miles, about 1,000 gallons a minute. In the final 12 miles there was a small loss that averaged about 100 gallons a minute to the mile. The altitude of the bed of the Little Blue where it leaves the area, in sec. 24, T. 3 N., R. 5 W., is about 1,530 feet.

Spring Creek heads in the vicinity of Nora and flows southeastward to sec. 12 , T. 1 N., R. 5 W., where it leaves the area at an altitude of about 1,570 feet. At this point the stream was dry and its bed is composed of loess.

The Little Blue River is the only stream in the southeastern part of the area that discharges ground-water flow. The tributaries of the Little Blue that enter the stream east of the area under consideration are all dry where they leave the area. . The maximum flow measured in the Little Blue was 29,000 gallons a minute near Antioch School, and this figure represents the total visible percolation of ground water into the streams of the Little Blue drainage basin west of the east lines of Nuckolls County and Clay County. The Little Blue River has a rather wide, flat valley that is in places thickly wooded. The water table probably stands close to the land surface in the valley; hence there is opportunity for rainfall penetration and losses by transpiration and evaporation. These factors influence the quantity of underflow that seeps into the Little Blue and make it impossible to determine the proportion of underflow that is represented by the measured 29,000 gallons a minute. The stream measurement in 1923 was one-fifth of that made in 1933. Hence the ground-water discharge must fluctuate greatly. The opportunity for rainfall penetration in the valley of the Little Blue River appears to be less than in the drainage basins of most of the other tributaries to the Republican River, and the flow of the Little Blue probably represents more nearly the quantity of underflow picked up by the stream.

\footnotetext{
7 Nebraska Dept. Public Works Rept., 1923-24, p. 476.
} 
SUMMARY

The total measured ground-water flow in the Big Blue and Little Blue Rivers and their tributaries in the area under investigation was about 33,400 gallons a minute. This quantity represents about 74.5 cubic feet of water a second, or about 54,000 acre-feet of water a year, which may be compared with the measured ground-water discharge of about 30,000 acre-feet a year in the tributaries of the Republican River. The flows of the streams in this area do not intercept all of the underflow, as there is ground-water pick-up in the beds of the streams farther south and east. However, the problem of determining the proportion of Platte Valley water represented by the measured flows of the streams becomes more complex and difficult as the distance from the source increases, because there is more rainfall penetration on the drainage basins, as well as greater transpiration and evaporation losses.

\section{COMPUTATION OF PERCOLATION OF GROUND WATER FROM THE PLATTE RIVER VALLEY}

It is not possible to determine accurately the quantity of ground water that percolates out of the Platte Valley, because the thickness and permeability of the Pleistocene sand and gravel and the direction and slope of the hydraulic gradient vary considerably from place to place. However, an estimate made from the data obtained in this investigation may show the general order of magnitude of this percolation.

Ground water percolates out of the area under investigation to the southeast, where it largely reappears in the beds of streams as groundwater seepage. Ground water also percolates down the Platte Valley through the Pleistocene sand and gravel in the valley proper. Estimates of the amount of this underflow near Lexington, Kearney, and Grand Island are given on pages 130-136. According to these estimates the quantity of ground water that percolates down the valley and out of the area near Grand Island amounts to about 8,400 gallons a minute, or about 13,500 acre-feet a year, and the quantity of ground water that percolates into the area near Lexington amounts to about 4,750 gallons a minute, or about 7,650 acrefeet a year. The difference between the quantities of ground water that annually percolate into the area and out of the area-about 5,850 acre-feet-represents a net loss of ground water from the area.

The amount of water that percolates southeastward through the Pleistocene sand and gravel that occur beneath the loess uplands may be approximated by dividing the part of the Platte Valley under investigation into segments and computing the percolation of ground water through each of these segments. This part of the valley was accordingly divided into nine segments, the length of each segment being determined by one of the lines of test holes. The area through 
which the ground water percolates out of the valley was then computed by averaging the thickness of saturated sand and gravel as determined by the southernmost test holes in each segment and multiplying this average by the length of the segment. The permeability of the sand and gravel was assumed to vary uniformly throughout the valley, and a coefficient for each valley segment was obtained by direct interpolation of the results of the three Thiem tests. The direction of movement of the ground water at the south valley limit was assumed to be out of the valley at an angle of $30^{\circ}$ with the course of the valley, and the slope of the water table was assumed to be equivalent to the slope of the segment of the valley under consideration. A correction was applied to the cross-sectional area through which the water percolated in order to get a correct measure of the cross-sectional area at right angles to the direction of ground-water movement.

The results of these computations are shown in the subjoined table. The total percolation is computed to be about 50,000 acre-feet a year, exclusive of the net loss by underflow down the valley.

Computation of percolation from the Platte Valley between Gothenburg and Chapman

\begin{tabular}{|c|c|c|c|c|c|c|c|c|}
\hline \multirow[b]{2}{*}{ Segment of the valley } & \multirow{2}{*}{$\begin{array}{l}\text { Length } \\
\text { of seg- } \\
\text { ment } \\
\text { (miles) }\end{array}$} & \multirow{2}{*}{$\begin{array}{c}\text { A verage } \\
\text { thick- } \\
\text { ness of } \\
\text { saturat- } \\
\text { ed sand } \\
\text { and } \\
\text { gravel } \\
\text { (feet) }\end{array}$} & \multirow{2}{*}{$\begin{array}{l}\text { Inter- } \\
\text { polated } \\
\text { coeffi- } \\
\text { cient of } \\
\text { perme- } \\
\text { ability }\end{array}$} & \multirow{2}{*}{$\begin{array}{l}\text { Hy- } \\
\text { draulic } \\
\text { gra- } \\
\text { dient } \\
\text { (feet to } \\
\text { the } \\
\text { mile) }\end{array}$} & \multirow{2}{*}{$\begin{array}{c}\text { Area of } \\
\text { cross sec- } \\
\text { tion } 1 \\
\text { (square } \\
\text { feet) }\end{array}$} & \multicolumn{3}{|c|}{ Discharge through segment } \\
\hline & & & & & & $\underset{\text { day }}{\underset{4 a l l o n s}{a}}$ & $\begin{array}{c}\text { Cubic } \\
\text { feet a } \\
\text { second }\end{array}$ & $\begin{array}{c}\text { Acre- } \\
\text { feet a } \\
\text { year }\end{array}$ \\
\hline $\begin{array}{l}\text { Gothenburg to Cozad } \\
\text { Cozad to Lexington } \\
\text { Lexington to Overton } \\
\text { Overton to Elm Creak } \\
\text { Elm Creek to Odessa. } \\
\text { Odessa to Gibbon } \\
\text { Gibbon to Wood River } \\
\text { Wood River to Grand Island } \\
\text { Grand Isiand to Chapman. }\end{array}$ & $\begin{array}{l}10 \\
16.5 \\
11 \\
9.5 \\
10 \\
20 \\
14.5 \\
16 \\
10\end{array}$ & $\begin{array}{r}5 \\
15 \\
31 \\
22 \\
36 \\
50 \\
45 \\
86 \\
68\end{array}$ & $\begin{array}{l}3,875 \\
3,925 \\
3,975 \\
4,025 \\
4,075 \\
4,150 \\
2,800 \\
1,350 \\
1,000\end{array}$ & $\begin{array}{l}6.1 \\
6.1 \\
6.3 \\
6.5 \\
6.5 \\
6.7 \\
6.7 \\
6.7 \\
7.5\end{array}$ & $\begin{array}{r}132,000 \\
654,000 \\
900,000 \\
552,000 \\
950,000 \\
2,640,000 \\
16,160,000 \\
3,630,000 \\
1,795,000\end{array}$ & $\begin{array}{r}590,000 \\
2,960,000 \\
4,270,000 \\
3,670,000 \\
4,760,000 \\
13,900,000 \\
5,750,000 \\
6,230,000 \\
2,530,000\end{array}$ & $\begin{array}{r}0.9 \\
4.6 \\
6.6 \\
5.7 \\
7.4 \\
21.5 \\
8.9 \\
9.4 \\
3.9\end{array}$ & $\begin{array}{r}650 \\
3,330 \\
4.780 \\
4,120 \\
5,350 \\
15,550 \\
6,450 \\
6,800 \\
2,820\end{array}$ \\
\hline Total. & $-\ldots$ & & & & $\ldots$ & $44,660,000$ & 68.9 & 49,850 \\
\hline
\end{tabular}

1 Corrected for direction of hydraulic gradient (assumed at $30^{\circ}$ with direction of valley).

COMPARISON OF COMPUTED RATE OF PERCOLATION WITH THE MEASURED GROUND-WATER FLOW OF STREAMS

According to the measurements made in August and September 1933, the total flow of the north-side tributaries to the Republican River between Superior and Arapahoe was found to be about 30,000 acre-feet a year, and the total flow of the Big Blue and Little Blue Rivers and their tributaries west of R. $4 \mathrm{~W}$. was found to be about 54,000 acre-feet a year. Part of these measured flows was derived from precipitation on the drainage basins of the streams. The computed rate of percolation from the Platte Valley of about 50,000 acrefeet a year appears to be comparable with the flow of 84,000 acre-feet a year in the streams named when the direct contribution by precipitation on the drainage basins of the streams is taken into considera- 
tion. Therefore it appears that an estimate of 50,000 acre-feet a year for the loss from the Platte Valley by percolation under the uplands may be reasonable.

\section{GROUND-WATER RECHARGE}

Ground water in the Platte Valley is derived from precipitation in the valley, loss from streams, seepage of irrigation water, and underflow. The amount and frequency of recharge vary considerably in the valley, depending principally on the depth to the water table and on the season of the year. Where the water table is shallow recharge from precipitation may take place throughout the year after most rains, but where the water table is relatively deep recharge usually occurs only in the fall and spring, and at such times it is more evenly distributed than in the areas of shallow water. Recharge from rivers and creeks occurs where the water surfaces of the streams rise above the adjacent water table, and in the Platte Valley such recharge probably occurs most frequently in the spring, when the streams are in flood stage, and in the fall, when the water table is low. Recharge from irrigation water is confined mainly to the part of the Platte Valley west of Kearney, where many irrigation canals and ditches traverse the valley. Doubtless there is some percolation into the valley from the north where the sand and gravel extend beyond the valley limit. Also, there is probably some recharge from percolation through the Ogallala formation, which extends northward to the sandhill region.

\section{PRECIPITATION}

The largest amount of water added to the zone of saturation is derived from precipitation in the valley. Rain or snow falling on the valley floor eventually runs off, evaporates, or sinks into the ground. Water that runs off or evaporates is lost to the ground-water reservoir, and only a part of the precipitation that enters the interstices of the soil reaches the zone of saturation. The soil will absorb water until the amount of water in it is greater than can be held against the pull of gravity, and not until that time will water move downward to the zone of saturation. At the end of the growing season in the fall the moisture in the upper 6 or 7 feet of soil, the belt of soil moisture, is usually depleted-that is, evaporation and transpiration by plants have removed most of the available water in this belt, and a moisture deficiency exists. Water that sinks into the ground from fall and winter precipitation goes to supply moisture to the depleted soil belt. As there is little transpiration and evaporation during the fall, winter, and early spring, water that finds its way into the interstices of the soil remains there until the moisture deficiency is satisfied or until the growing season begins. This moisture deficiency is soon satisfied when there is ample precipitation, and recharge to the zone of saturation ordinarily takes place from that time until transpiration and 
evaporation commence. However, when precipitation is small, all the water may be retained in the soil to supply the moisture deficiency, and there will be no ground-water recharge.

The seasonal distribution and intensity of precipitation have important relations to ground-water recharge. Rain that occurs during the fall supplies water to satisfy the deficiency in soil moisture and consequently opens the way for recharge to the zone of saturation from precipitation in winter and early spring. Rain that falls during the growing season tends to do likewise, but transpiration and evaporation dispose of it so rapidly that the moisture deficit is not often satisfied. Hence recharge from precipitation seldom occurs during the summer except in localities where the water table is shallow and the thickness of the belt of soil moisture is small. If the holding capacity of the belt of soil moisture is 6 inches of water, water in excess of 6 inches percolates down and is added to the zone of saturation. At the end of the growing season the moisture in the soil may have been depleted to 1 inch, thus leaving a deficiency of 5 inches of water. If during the fall, winter, and early spring 8 inches of water enters the interstices of the soil, 3 inches may percolate to the water table. During the growing season, however, the amount of water entering the soil may exceed 8 inches but still there may be no groundwater recharge, because rainfall occurs over several months, and evaporation and transpiration have sufficient time between rains to produce deficiencies in moisture that exceed the amount of precipitation of the next storms. Recharge began in well 258 about April 29,1931 . The first killing frost in the preceding autumn occurred on October 15, 1930, and hence the precipitation from that date to April 29 was ample to satisfy the deficiency of soil moisture that existed in the vicinity of the well on October 15. Of course, only a part of the precipitation entered the interstices of the soil. The precipitation between October 15 and April 29 at Grand Island amounted to 7.04 inches; thus it may be said that this quantity of precipitation was required before recharge to the zone of saturation could take place.

Ground-water rechorge occurs during the summer only under favorable conditions of precipitation. Continuous light rains over a considerable period of time reduce transpiration and evaporation losses, and if the total precipitation is large recharge may result. Also, if continuous light precipitation is followed by more intense rains, the moisture deficiency may be satisfied. Heavy precipitation, such as occurs during a cloudburst, often produces ground-water recharge. During the early part of June 1932 intense rains fell over a short period of time, and there was recharge from precipitation even where the water table was more than 20 feet below the land surface (pl. 12).

In localities where the water table is shallow the thickness of the belt of soil moisture may be considerably less than in areas where the 


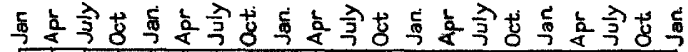
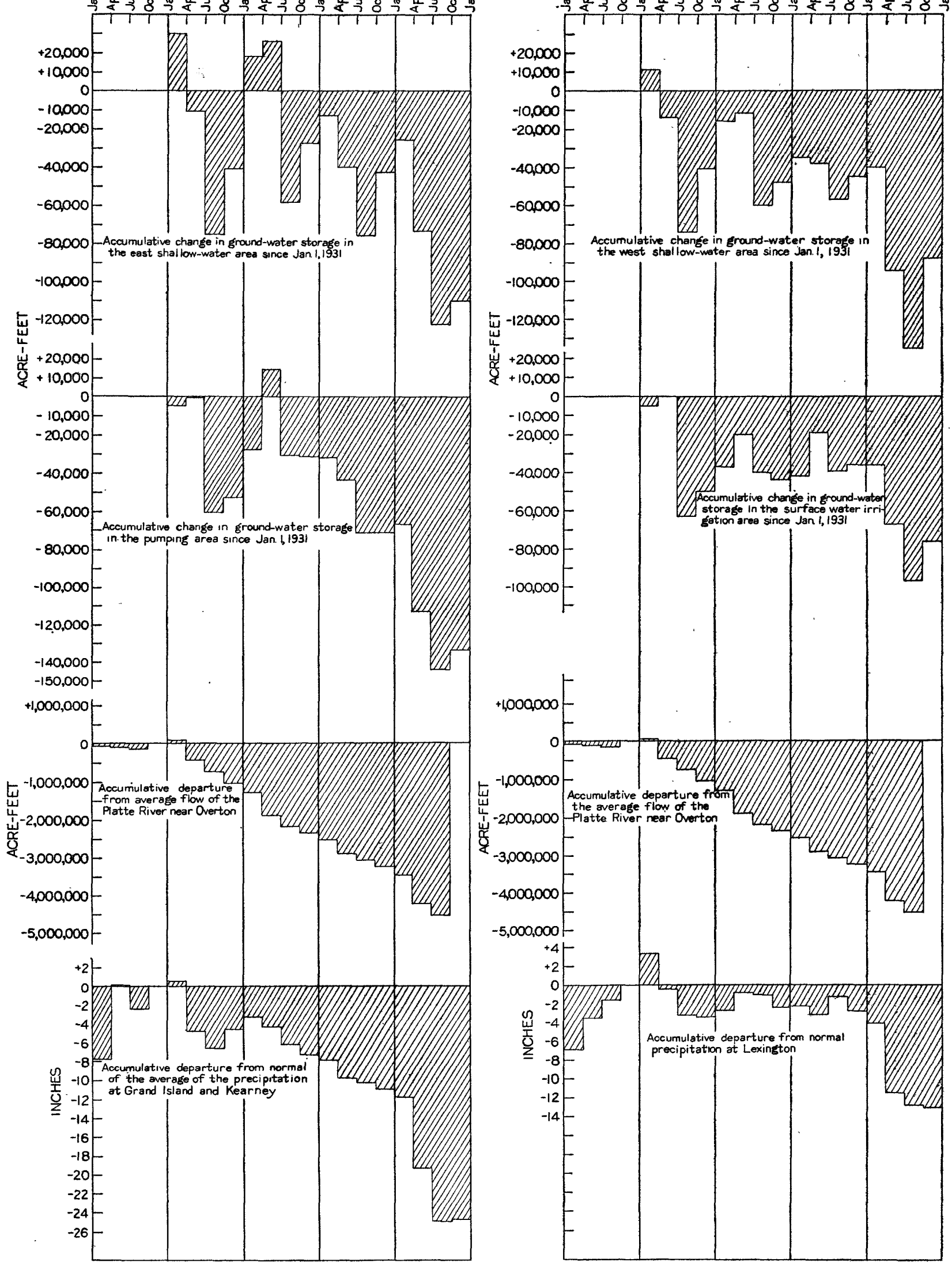

water table occurs at great depths. A belt of soil moisture that is only 4 feet thick of course does not require as much water to supply the moisture deficiency as a 7-foot belt. Accordingly, ground-water recharge normally occurs in localities with shallow water table more quickly and more often, and the total amount of recharge may be greater, than in areas with a deeper water table. In most places in the Platte Valley water-table conditions are favorable for recharge to the zone of saturation. The water table stands only a few feet below the surface of the land along the Platte River and in certain other areas in the valley. In many places the capillary fringe extends to the ground surface. In such places precipitation at most times in the year causes almost immediate recharge. An automatic waterstage recorder was maintained on well 787 , where the water table ranged from 1 to 4 feet below the land surface. A rain of about 3 inches fell during 3 hours, from 10 p. m. June 1 to $1 \mathrm{a}$. m. June 2, 1932. The chart on the recorder indicated the stage of the water table as 3.16 feet below the measuring point at $10 \mathrm{p}$. m. June 1 (fig. 14). The water table started to rise soon after $10 \mathrm{p} . \mathrm{m}$. and rose continuously until about 9 a. m. June 2, when the stage of the water table was recorded as 1.30 feet below the measuring point. The total rise was thus 1.86 feet. The water table then declined, but it rose again later in the week, owing to more precipitation.

Although recharge from precipitation occurs at times nearly everywhere in the Platte Valley, maximum recharge is essentially confined to the areas of shallow water table. In these areas, where the water table is less than 10 feet below the land surface, the water table frequently rises after moderate rains in the summer, thus indicating that the belt of soil moisture is very thin and that moisture deficiencies in this belt are at most times small.

The contour maps of the water table near Lexington, Kearney, and Grand Island show that for several miles north of the Platte River the water table slopes almost parallel to the river. This indicates that recharge in the shallow-water areas north of the river causes ground water to move for short periods toward the river and also toward the north valley limit. However, because the water table near the river is usually rather high and discharge near the valley limits is rather small, the gradient set up in these directions is ordinarily of short duration. So long as the water table in the valley remains near its present stage the principal effect of recharge in the shallow-water areas is to raise the ground-water levels a small amount in and adjacent to those areas. However, should ground-water withdrawal north of the river in the pumping area or the area of surface-water irrigation increase to such an extent that the water table is lowered substantially, a gradient will be set up, and water will move continuously from the shallow-water areas to these areas. 
The amount of ground-water recharge from precipitation is difficult to estimate, because a part of the rise of the water table is caused by recharge from the Platte River and other streams. Moreover, recharge from precipitation occurs in many places in the valley after almost every rain, but, because of the discharge processes that are in operation, the net effect of such recharge sometimes is only to decrease the rate of decline of the water table. Therefore the net changes in water level do not indicate the total recharge or total discharge.

\section{SEEPAGE FROM STREAMS}

Where the water table adjoining the rivers and creeks in the Platte Valley is lower than the water surface in the streams there is a movement of water from the streams into the zone of saturation. Most streams in the Platte Valley lose water to the underground reservoir during certain periods of the year and receive water from the underground reservoir during other periods. Ground-water recharge from stream flow takes place principally in the fall and spring. The greatest amount of recharge from streams comes from the Platte River, especially after the river has been dry for some time. While the Platte is dry the water table beneath its bed and adjoining lands is lowered by evaporation and transpiration. When the river starts to flow, the surface of the stream is considerably higher than the adjacent water table, and water moves out from the river into the zone of saturation. After the water table is once built up to the stage of the stream there is little loss from the river, and when the discharge of the river decreases, ground water moves back into the stream to augment its flow.

The amount of water added to the zone of saturation from stream flow is difficult to determine, because both stream flow and precipitation cause recharge in the same localities and during the same periods of the year. It appears from a study of the fluctuation of the water level in wells that recharge from stream flow is less than recharge from precipitation.

The discharge of the Platte River has an important relation to estimates for future ground-water development. The water table in the recharge area is normally so shallow that recharge from precipitation takes place almost throughout the year. If future ground-water development in the pumping area creates a large draft on the zone of saturation the water table in that area will, of course, be lowered. A significant decline of the water table in the pumping area would also cause the water table to decline in the east shallow-water area, and as a result less recharge from precipitation might occur in the shallowwater area because the thickness of the belt of soil moisture would probably be increased. Such a decline and the consequent decrease in recharge from precipitation might eventually cause the water table 
in the pumping area to decline greatly. However, the Platte River serves as a factor of safety for future ground-water development of this kind. Recharge to the zone of saturation from the river maintains the water table in the shallow-water area at a stage near the ground surface and probably will so maintain it as long as the discharge of the river is undisturbed. Consequently the opportunity for recharge from precipitation in the shallow-water area is high, and a larger draft on the ground water in the pumping area would be supplied from this source.

\section{IRRIGATION WATER}

Ground-water recharge from irrigation water takes place in two ways-by seepage from canals and laterals and by percolation to the zone of saturation after the water has been spread on fields.

In the Platte Valley between Kearney and Gothenburg there is a considerable amount of seepage from irrigation canals and laterals which reaches the zone of saturation. These ditches are almost always above the regional water table, and seepage from them takes place whenever the ditches are filled with water. The water table near irrigation ditches fluctuates with the stage of the water in the ditches. (fig. 12). The water table in most parts of the surface-water irrigation area is maintained above its normal level by the loss of water from the ditches to the zone of saturation. The water table near Lexington is more than 10 feet higher at the present time than in 1896, when Darton made a survey of the ground-water conditions in that locality (p. 131). That the present water table is above its normal altitude is also indicated by the rapid decline of the water levels in wells as soon as the amount of water in irrigation ditches is decreased. Moreover, it has been necessary to construct several ditches in this area to drain lands where the water table was too shallow for farming.

The amount of ground-water recharge from irrigation water after it has been spread is probably small except in localities where the water table is shallow. There is probably little recharge by this process in the pumping area east of Kearney. Where irrigation water collects in depressions or where crops are excessively watered, some seepage to the zone of saturation probably takes place. Moreover, irrigation water may increase recharge from precipitation in some places by supplying a part of the moisture needed to overcome the deficit that usually exists in the belt of soil moisture. A part of the rainfall during the summer may under such conditions percolate to the zone of saturation.

The total amount of ground-water recharge from irrigation water is probably at least 10 percent of the water diverted from the Platte River. This is equivalent to about 20,000 acre-feet a year and probably occurs principally in the area of surface-water irrigation west of Kearney. 


\section{PERCOLATION}

The contour maps of the water table near Lexington and Kearney indicate that the water table slopes away from the northern limits of the valley. It is probable that this slope exists at most places along the valley limit from Chapman to Gothenburg and that some ground water percolates into the valley from the northwest. Logs of wells indicate that the Pleistocene sand and gravel thin out in many localities near the north limit of the valley, and hence it is probable that recharge by percolation through the sand and gravel is relatively small. There is also percolation into the valley from the north and northwest through the Ogallala formation, which occurs below the Pleistocene sand and gravel.

\section{NET CHANGE IN GROUND-WATER STORAGE IN THE PLATTE RIVER VALIEY}

The 3-month fluctuations of the average of 14 wells in the pumping area, 6 wells in the east shallow-water area, 12 wells in the surfacewater irrigation area, and 10 wells in the west shallow-water area have been computed (p. 127).

The average water level of January 1, 1931, was selected as datum, and the 3-month fluctuations were computed from that date. The change in volume of ground-water storage in each of the four groundwater areas can be computed by multiplying the average change in water level in each area by the extent of each ground-water area and multiplying this result by the specific yield of the water-bearing material. The changes in volume of water stored in each ground-water area for 3-month intervals between January 1, 1931, and January 1,1935 , are given in the following table:

Changes in volume of ground water stored in the four ground-water areas in the Platte Valley, in acre-feet

\begin{tabular}{|c|c|c|c|c|}
\hline Date & $\begin{array}{l}\text { Pumping } \\
\text { area ( } 240,000 \\
\text { acres) }\end{array}$ & $\begin{array}{l}\text { East shallow- } \\
\text { water area } \\
(201,600 \\
\text { acres })\end{array}$ & $\begin{array}{c}\text { Area of sur- } \\
\text { face-water } \\
\text { irrigation } \\
(172,800 \text { acres })\end{array}$ & $\begin{array}{l}\text { West shallow- } \\
\text { water area } \\
(185,600 \\
\text { acres })\end{array}$ \\
\hline $\begin{array}{l}\text { Jan. 1-Apr. 1...... } 1931 \\
\text { Apr. 1-July 1- } \\
\text { July 1-Oct. 1- } \\
\text { Oct. 1-Jan. 1 }\end{array}$ & $\begin{array}{r}-5,200 \\
+4,600 \\
-61,000 \\
+8,600\end{array}$ & $\begin{array}{l}+30,000 \\
-41,100 \\
-64,400 \\
+34,400\end{array}$ & $\begin{array}{r}-4,800 \\
+4,800 \\
-63,200 \\
+13,100\end{array}$ & $\begin{array}{l}+10,800 \\
-24,900 \\
-60,100 \\
+32,700\end{array}$ \\
\hline 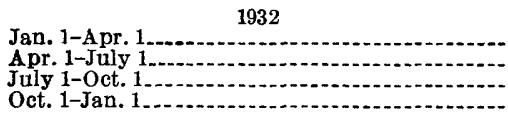 & $\begin{array}{r}+24,800 \\
+42,600 \\
-45,500 \\
-600\end{array}$ & $\begin{array}{r}+59,000 \\
+8,200 \\
-84,700 \\
-\mathbf{3 1}, 000\end{array}$ & $\begin{array}{r}+12,800 \\
+17,600 \\
-20,000 \\
-3,800\end{array}$ & $\begin{array}{r}+25,600 \\
+4,100 \\
-48,300 \\
-12,300\end{array}$ \\
\hline 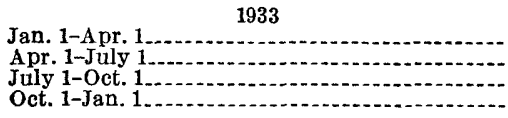 & $\begin{array}{r}-600 \\
-11,500 \\
-27,600 \\
000\end{array}$ & $\begin{array}{l}+14,000 \\
-26,600 \\
-35,300 \\
+32,900\end{array}$ & $\begin{array}{r}+1,700 \\
+22,800 \\
-20,400 \\
+3,100\end{array}$ & $\begin{array}{r}+12,600 \\
-2,600 \\
-19,300 \\
+11,900\end{array}$ \\
\hline 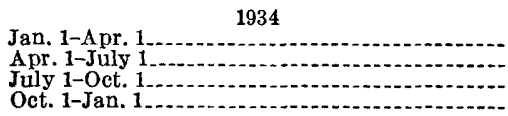 & $\begin{array}{r}+4,000 \\
-45,500 \\
-31,100 \\
+10,400\end{array}$ & $\begin{array}{l}+16,900 \\
-47,900 \\
-48,900 \\
+12,100\end{array}$ & $\begin{array}{r}+300 \\
-31,800 \\
-28,700 \\
+20,800\end{array}$ & $\begin{array}{r}+5,200 \\
-54,200 \\
-40,800 \\
+47,500\end{array}$ \\
\hline
\end{tabular}


The heavy draft on the zone of saturation-mainly transpirationduring the growing seasons included in the periods April 1 to July 1 and July 1 to October 1 is readily apparent from the relatively large loss of ground-water storage in those periods. The net loss of ground water in the east shallow-water area from April 1 to October 1 amounted in 1931 to 105,500 acre-feet, in 1933 to 61,900 acre-feet, and in 1934 to 96,800 acre-feet. The net loss in the other areas in that period was of the same order of magnitude. The net loss in all areas, comprising 800,000 acres, in the period April 1 to October 1 amounted in 1931 to 305,300 acre-feet, in 1932 to 126,000 acre-feet, in 1933 to 120,500 acre-feet, and in 1934 to 328,900 acre-feet. These figures, of course, are net changes in volume and represent only net loss. The actual loss during these periods was undoubtedly much greater, because recharge during these periods added substantial quantities of water to the zone of saturation.

The total annual ground-water discharge can be computed from the estimated figures for ground water discharged by the different discharge processes. According to the estimates previously made the transpiration loss may amount to 390,000 acre-feet, the percolation loss to about 56,000 acre-feet, the evaporation loss to about 15,000 acre-feet, and the pumpage to about 30,000 acre-feet, a total of about 491,000 acre-feet of water. This estimate does not include the ground water that seeps into streams in the Platte River drainage basin, an estimate of which was not made.

The average annual precipitation in the Platte Valley is 24.96 inches, which is equivalent to about 1,670,000 acre-feet of water a year on the part of the valley covered by the four ground-water areas. If all of the 491,000 acre-feet of water lost to the zone of saturation were supplied from precipitation, the resulting recharge would amount to about 30 percent of the average annual precipitation. However, a part of the total recharge is supplied by seepage from streams, irrigation water, and underflow; hence the proportion of precipitation that reaches the zone of saturation is much less than 30 percent.

The cumulative change in ground-water storage in the ground-water areas in 3-month intervals since January 1, 1931, is shown in the following table and is graphically represented in plate 16. All four areas show net losses, which range from 75,700 acre-feet in the area of surface-water irrigation to 133,600 acre-feet in the pumping area. The cumulative departure from normal precipitation and the cumulative departure from the average flow of the Platte River at Overton are also plotted in plate 16. The flow of the Platte since January 1, 1931, has been considerably less than average, and the precipitation, especially east of Kearney, has also been considerably below normal. The cumulative change in volume of ground water stored in the pumping area has closely followed the precipitation as recorded at Grand 
Island and Kearney. There was a large loss of water stored in this area in the period from July 1 to October 1, 1931, but the precipitation that occurred during the next 6-month period was slightly above normal, and the resulting recharge was sufficient to cause an increase in storage that filled the ground-water reservoir by July 1, 1932, to a level above that of January 1, 1931. Since that time the precipitation has been less than normal, and the volume of water stored in the pumping area has decreased accordingly. It is therefore expected that subsequent periods of normal or greater than normal precipitation will again refill the ground-water reservoir. However, the precipitation in 1930 was about 8 inches above normal, and it is likely that the storage represented by the water level on January 1, 1931, was somewhat greater than is usually contained in the reservoir, and hence this amount of storage is not expected normally to remain in the reservoir for long periods.

Cumulative change in ground-water storage in the four ground-water areas in the Platte Valley, in acre-feet

\begin{tabular}{|c|c|c|c|c|}
\hline Date & $\begin{array}{c}\text { Pumping } \\
\text { area }\end{array}$ & $\begin{array}{c}\text { East } \\
\text { shallow- } \\
\text { water area }\end{array}$ & $\begin{array}{l}\text { Area of } \\
\text { surface- } \\
\text { water } \\
\text { irrigation }\end{array}$ & $\begin{array}{c}\text { West } \\
\text { shallow- } \\
\text { water area }\end{array}$ \\
\hline 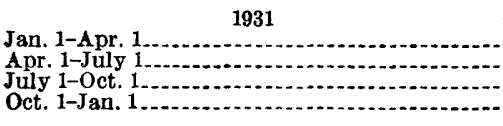 & $\begin{array}{r}-5,200 \\
-600 \\
-61,600 \\
-53,000\end{array}$ & $\begin{array}{l}+30,000 \\
-11,100 \\
-75,500 \\
-41,100\end{array}$ & $\begin{array}{r}-4,800 \\
0 \\
-63,200 \\
-50,100\end{array}$ & $\begin{array}{l}+10,800 \\
-14,100 \\
-74,200 \\
-41,500\end{array}$ \\
\hline $\begin{array}{l}\text { Jan. 1-Apr. 1... } 1932 \\
\text { Apr. 1-July 1.J. } \\
\text { July 1-Oct. 1 } \\
\text { Oct. 1-Jan. 1. }\end{array}$ & $\begin{array}{r}-28,200 \\
+14,400 \\
-31,100 \\
-31,700\end{array}$ & $\begin{array}{l}+17,900 \\
+26,100 \\
-58,600 \\
-27,600\end{array}$ & $\begin{array}{l}-37,300 \\
-19,700 \\
-39,700 \\
-43,500\end{array}$ & $\begin{array}{l}-15,900 \\
-11,800 \\
-60,100 \\
-47,800\end{array}$ \\
\hline $\begin{array}{l}\text { Jan. 1-Apr. 1.. } 1933 \\
\text { Apr. 1-July 1 } \\
\text { July 1-Oct. 1- } \\
\text { Oct. 1-Jan. 1... }\end{array}$ & $\begin{array}{l}-32,300 \\
-43,800 \\
-71,400 \\
-71,400\end{array}$ & $\begin{array}{l}-13,600 \\
-40,200 \\
-75,500 \\
-42,600\end{array}$ & $\begin{array}{l}-41,800 \\
-19,000 \\
-39,400 \\
-36,300\end{array}$ & $\begin{array}{l}-35,200 \\
-37,800 \\
-57,100 \\
-45,200\end{array}$ \\
\hline $\begin{array}{l}\text { Jan. 1-Apr. 1... } 1934 \\
\text { Apr. 1-July 1 } \\
\text { July 1-Oct. 1- } \\
\text { Oct. 1-Jan. 1. }\end{array}$ & $\begin{array}{r}-67,400 \\
-112,900 \\
-144,000 \\
-133,600\end{array}$ & $\begin{array}{r}-25,700 \\
-73,600 \\
-122,500 \\
-110,400\end{array}$ & $\begin{array}{l}-36,000 \\
-67,800 \\
-96,500 \\
-75,700\end{array}$ & $\begin{array}{r}-40,000 \\
-94,200 \\
-135,000 \\
-87,500\end{array}$ \\
\hline
\end{tabular}

The total cumulative loss in ground-water storage from January 1 , 1931 , to January 1, 1935, in the four ground-water areas amounts to about 407,000 acre-feet. In that time there has been a cumulative deficit of precipitation equivalent on the 800,000 acres of valley covered by this investigation to about $1,400,000$ acre-feet and a cumulative deficit in the flow of the Platte River at Overton of about 4,600,000 acre-feet. The relatively small loss in groundwater storage indicates that with normal conditions of precipitation and stream flow the change in storage would probably have been small and also illustrates the importance of the hold-over capacity of the ground-water reservoir in dry years. 
WELL RECORDS 


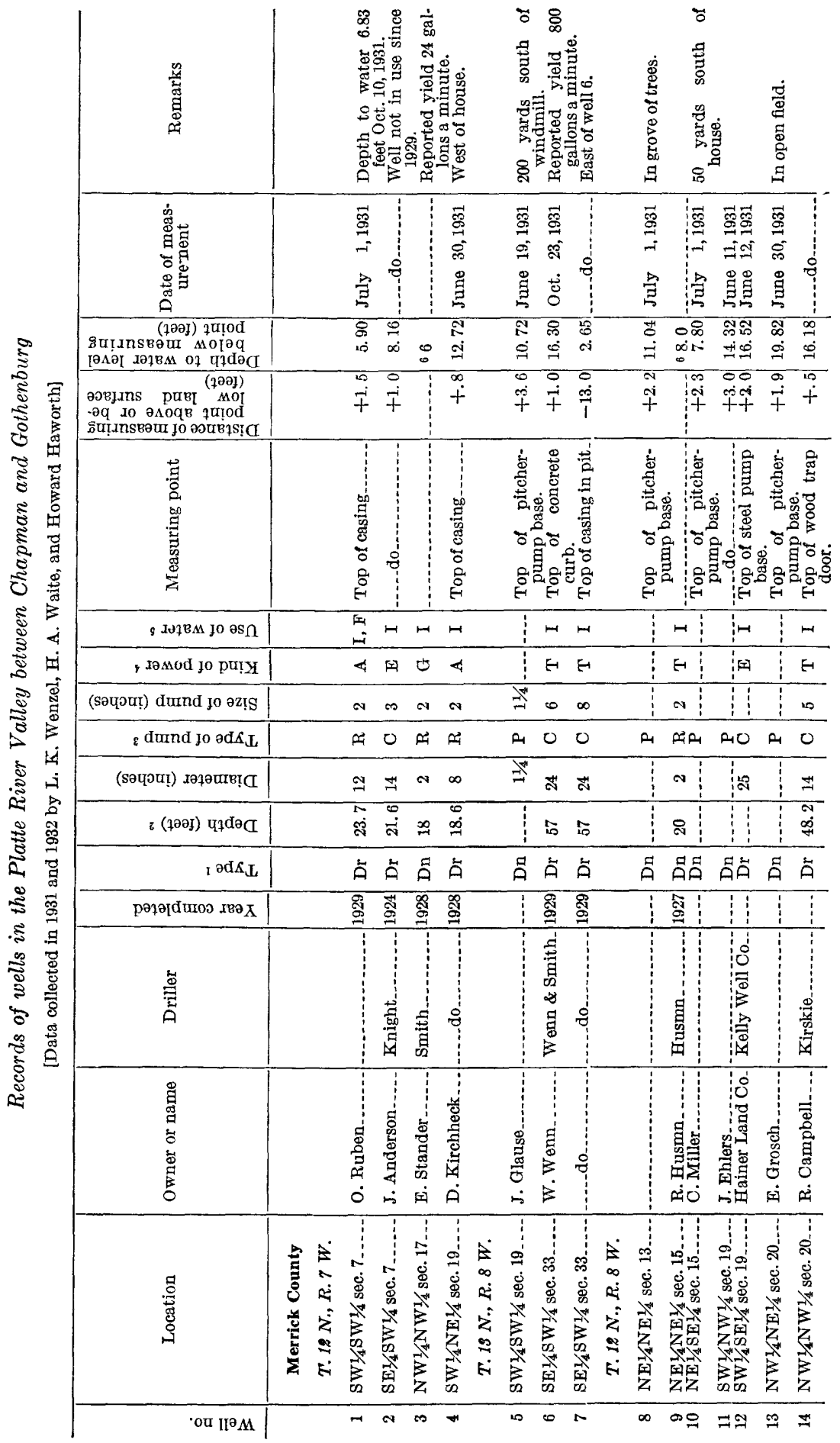




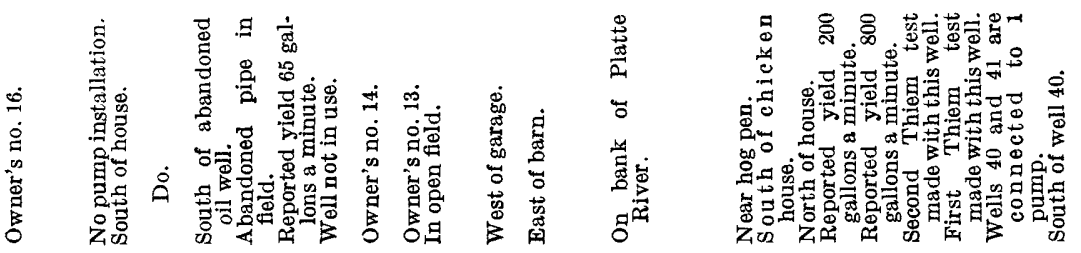

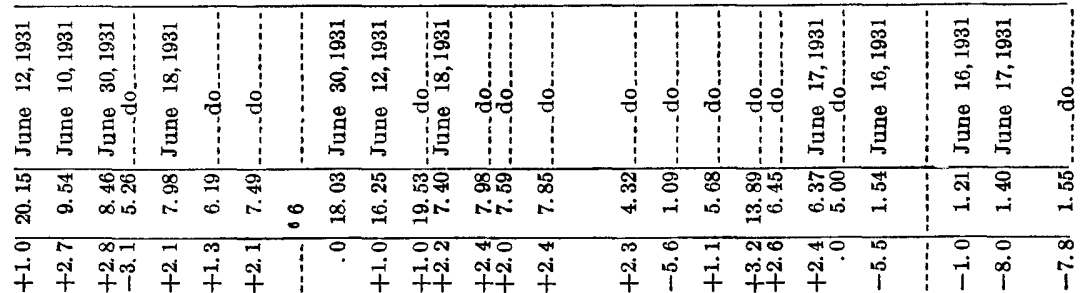

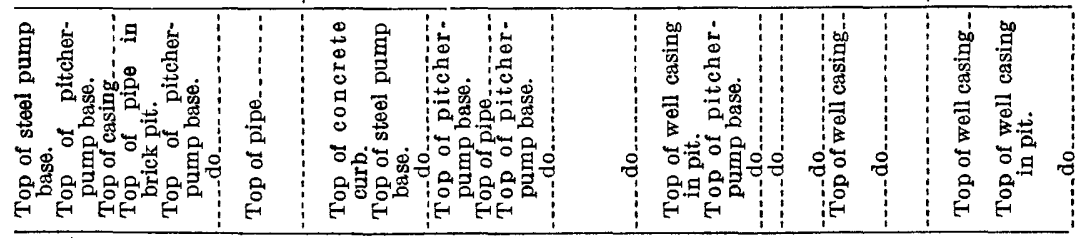

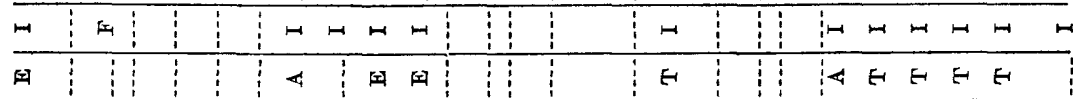

\begin{tabular}{|c|c|c|c|c|c|c|c|c|c|c|c|c|c|c|c|c|c|c|c|c|}
\hline 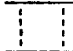 & & & & N & & & 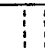 & 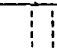 & & & 0 & & 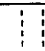 & is & . & & & & $\infty$ & \\
\hline 0 ه & $\vdots$ & or & Pr & 0 & 0 & 0 & $O R$ & $A_{1} \Omega_{1}$ & $n_{1}$ & or & 0 & s & $P_{1} \rho_{1}$ & 20 & 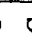 & & & U & 0 & \\
\hline ส & 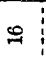 & & \pm & N & & ลి & ฉి & & & 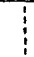 & $\stackrel{\infty}{\sim}$ & & & in & : & & & Z & $\rightarrow$ & ๆ \\
\hline 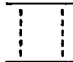 & $\begin{array}{l}\text { N } \\
\text { สิ่ }\end{array}$ & & & สิ & & 今. & $\frac{7}{4}$ & & 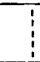 & & ติ & & & $\alpha$ & 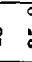 & & ్ㅠㅁ & ڤं & $\stackrel{\infty}{*}$ & $\stackrel{\infty}{+}$ \\
\hline
\end{tabular}

苂

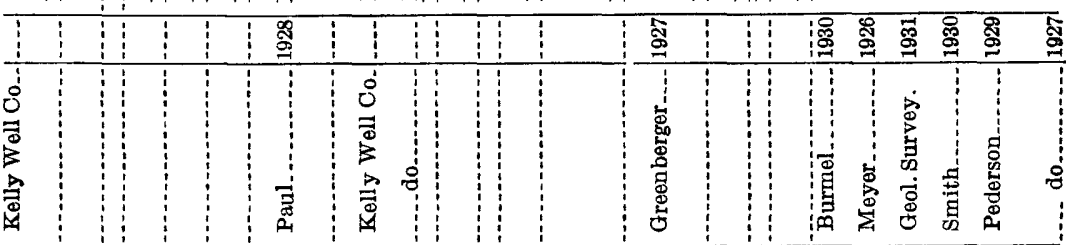

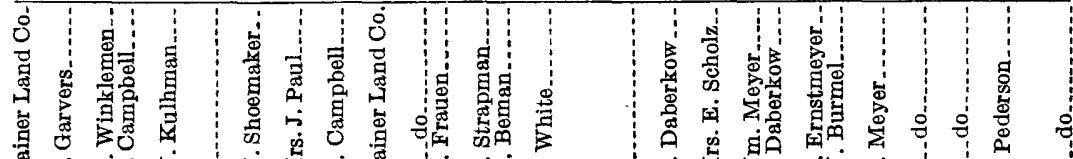

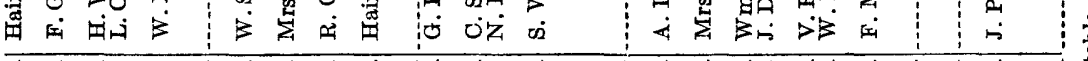

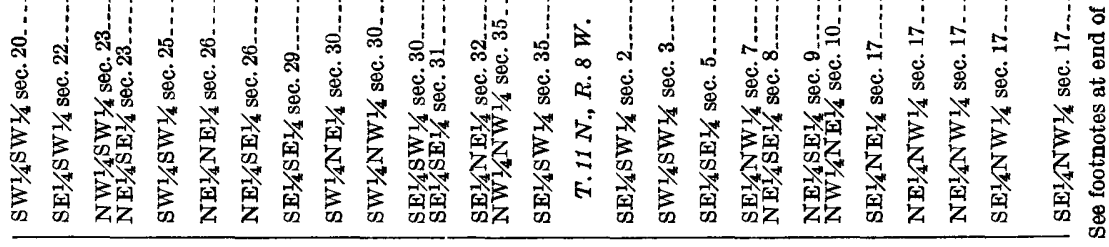

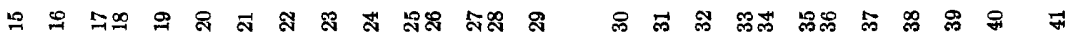


194 GEOLOGY AND GROUND WATER, SOUTH-CENTRAL NEBRASKA

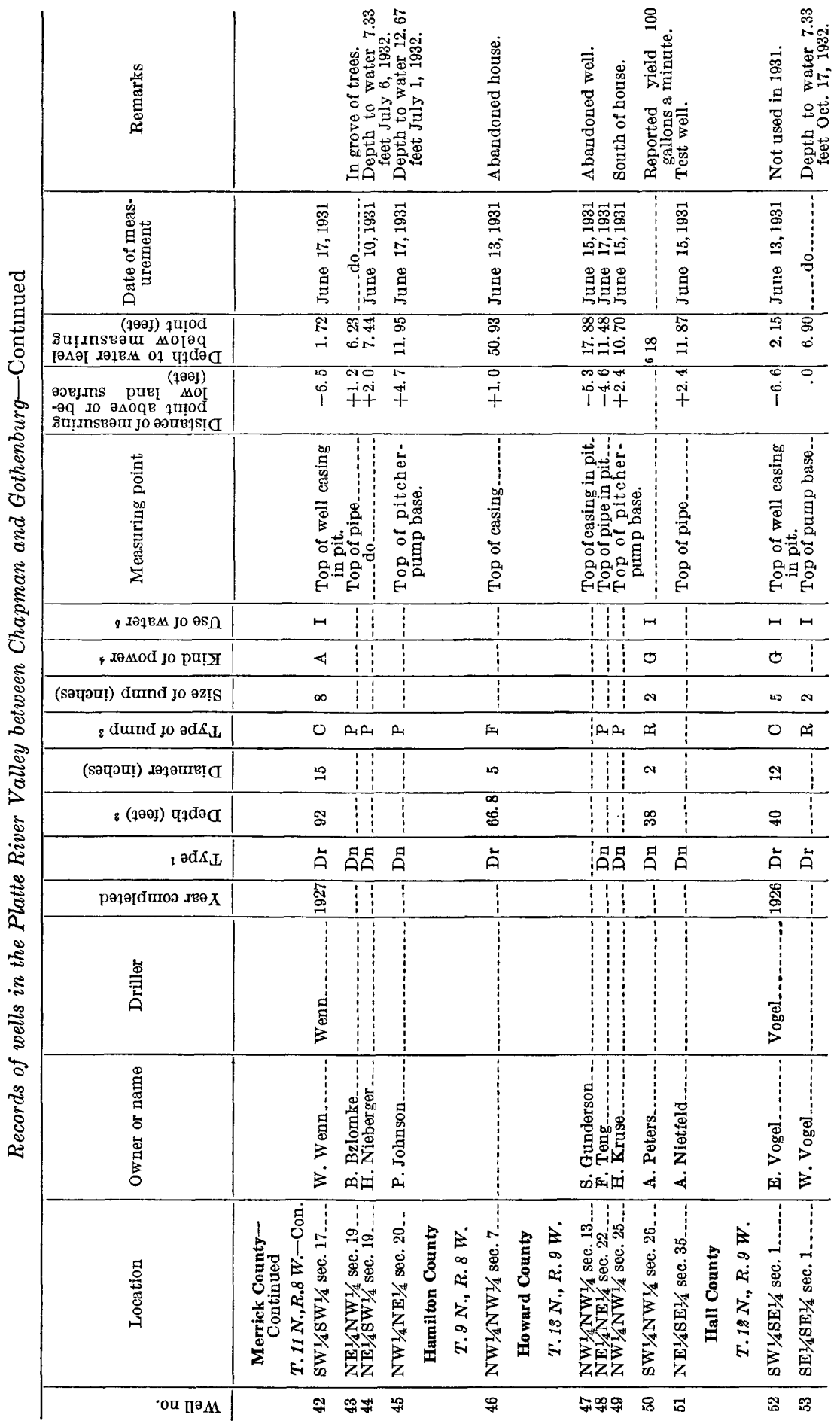




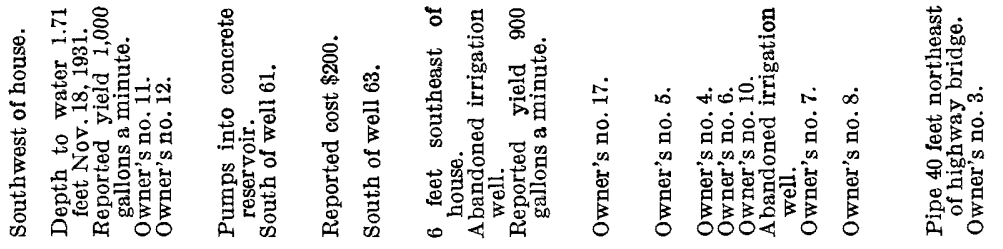

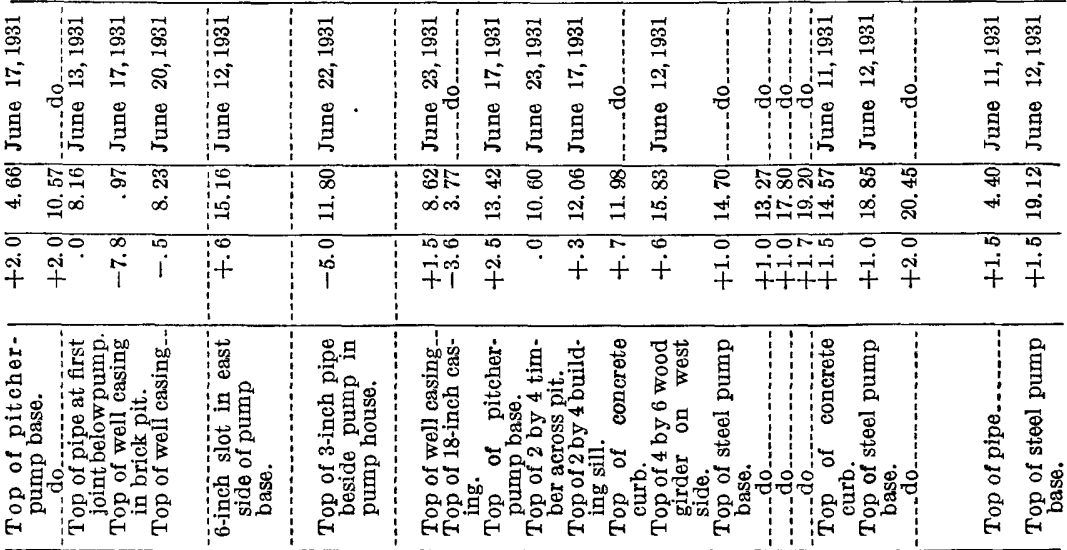

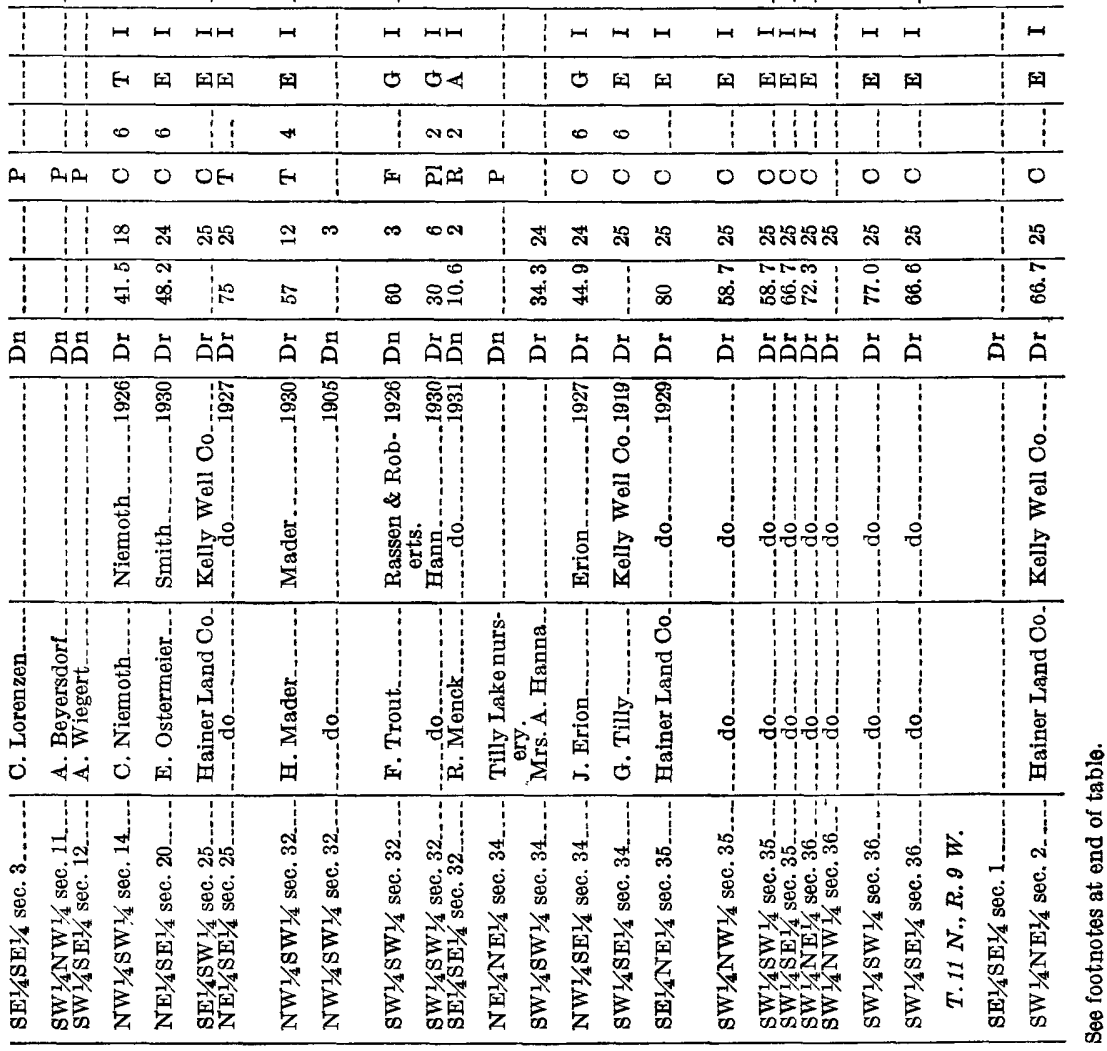

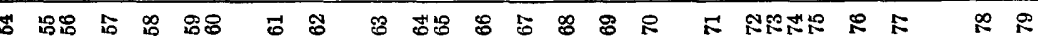


196 GEOLOGY AND GROUND WATER, SOUTH-CENTRAL NEBRASKA

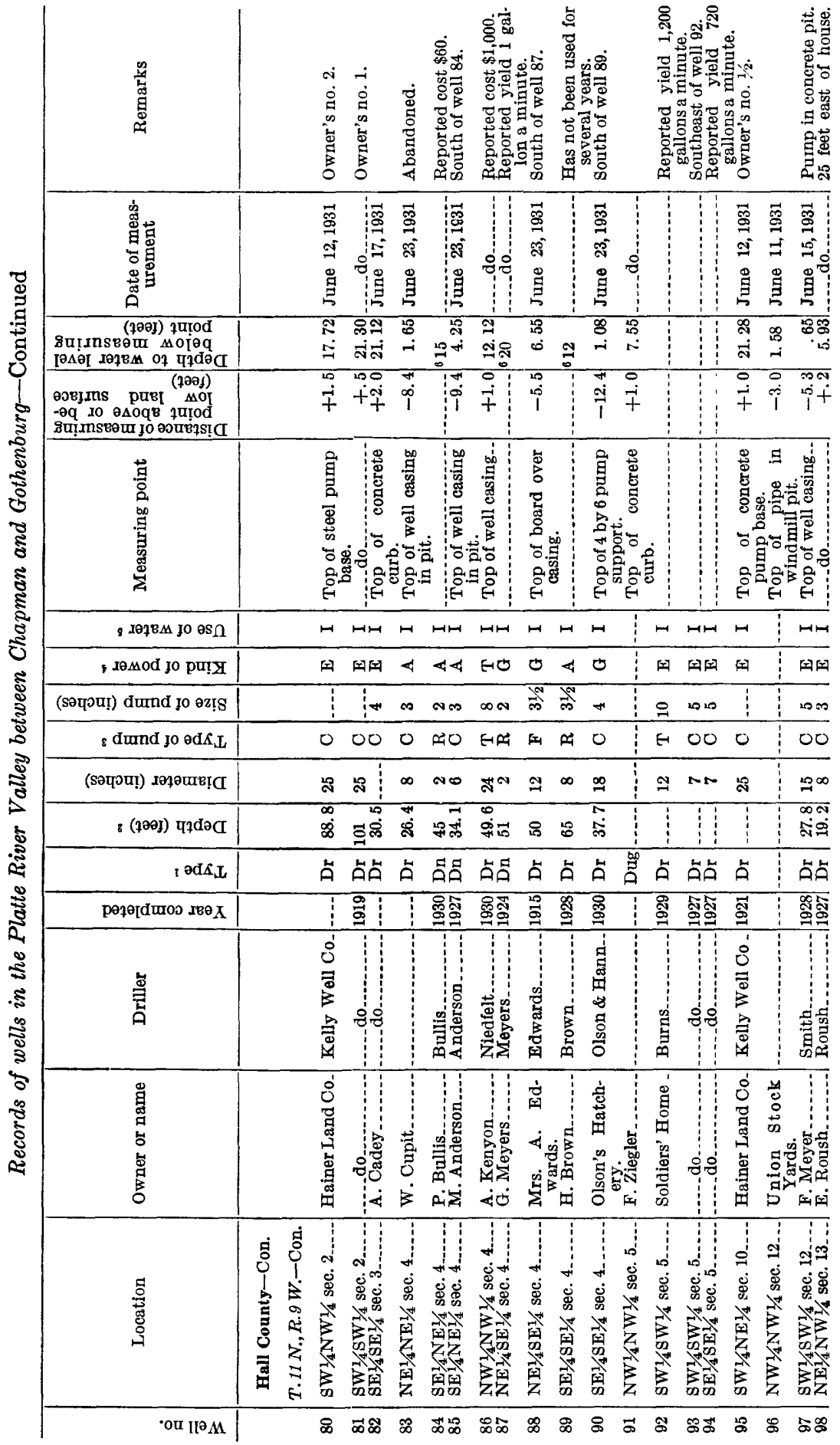




\begin{tabular}{|c|c|c|c|c|}
\hline & 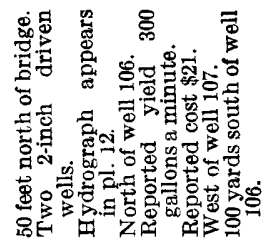 & 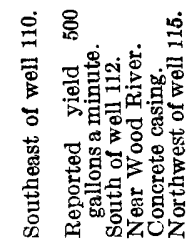 & 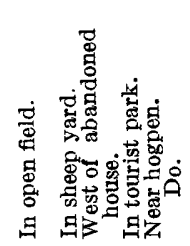 & 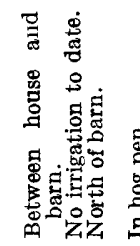 \\
\hline
\end{tabular}

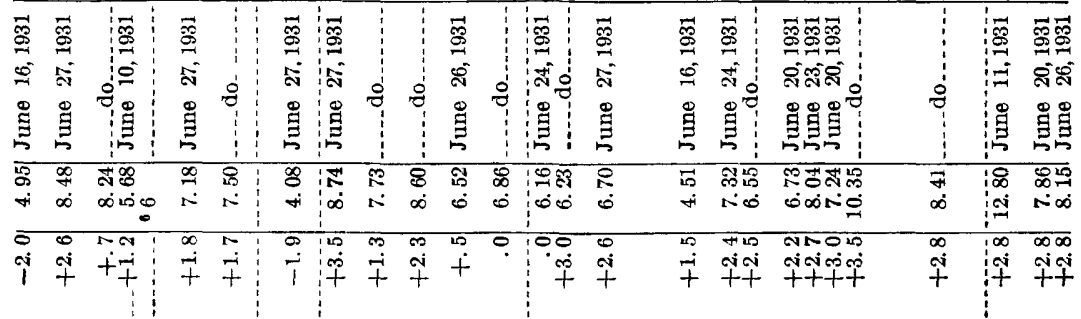

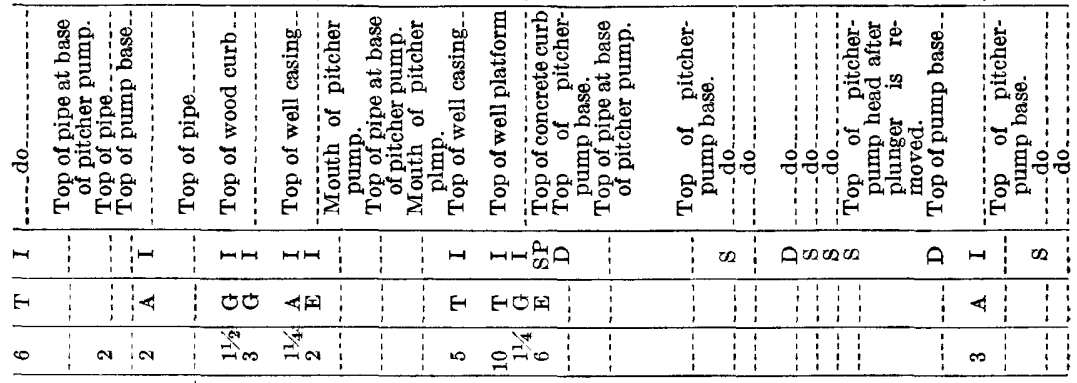

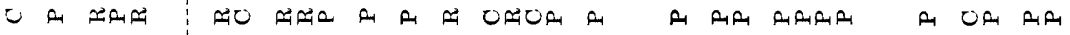

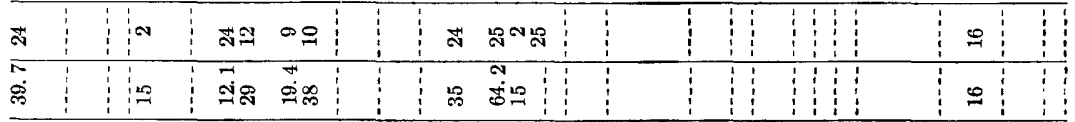

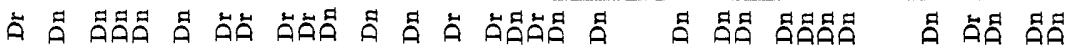

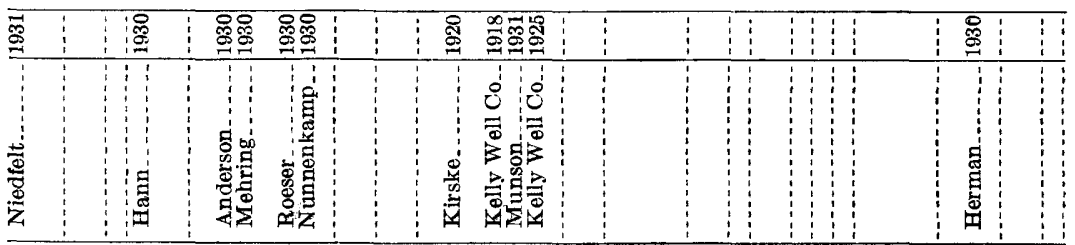

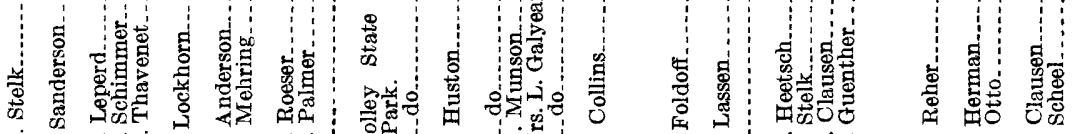

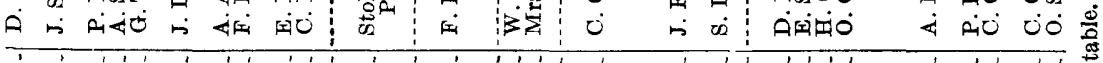

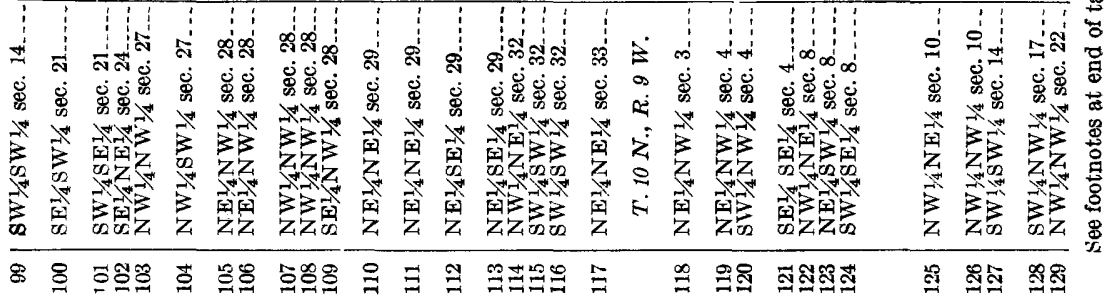


198 GEOLOGY AND GROUND WATER, SOUTH-CENTRAL NEBRASKA

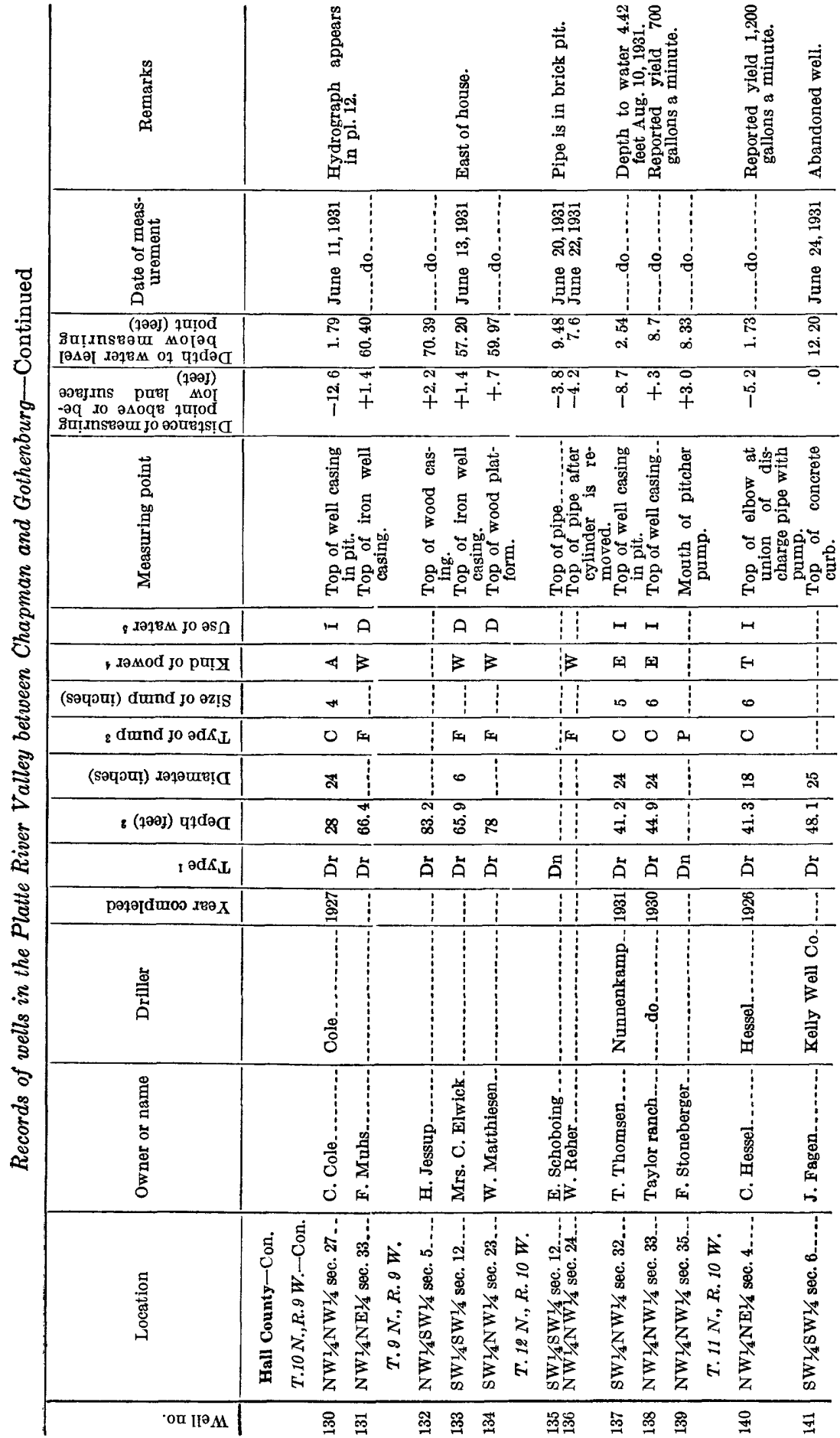




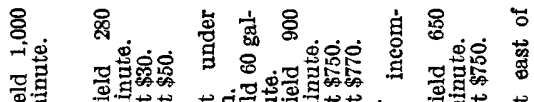

产虽

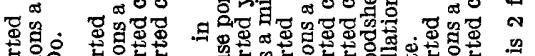

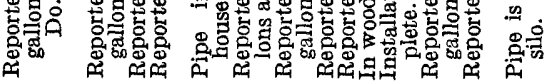

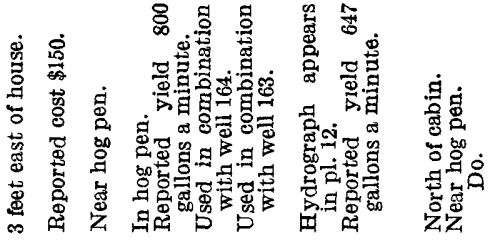

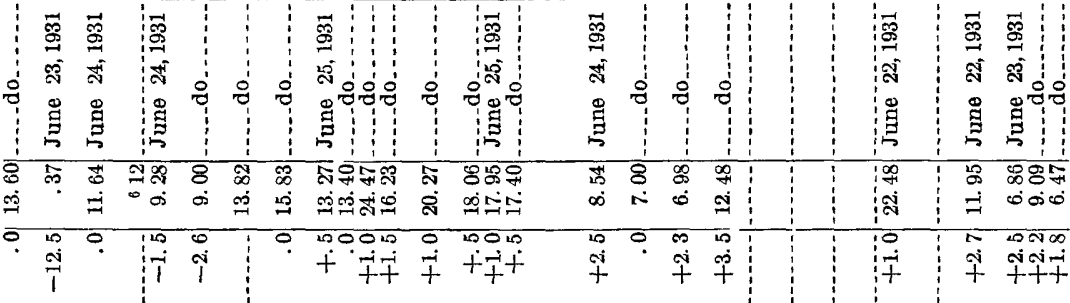

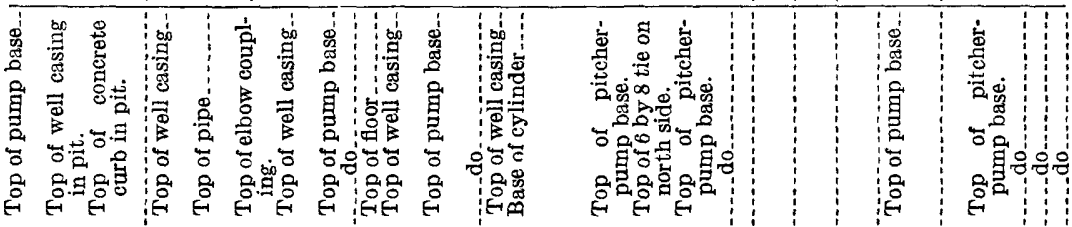

Hम HW

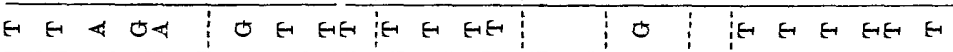

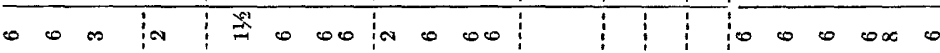

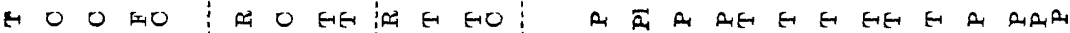

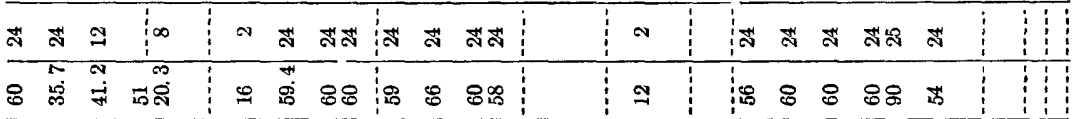

ลั

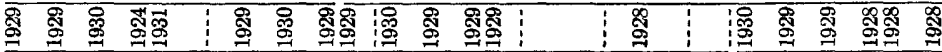

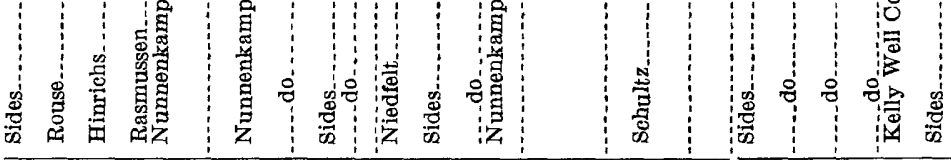

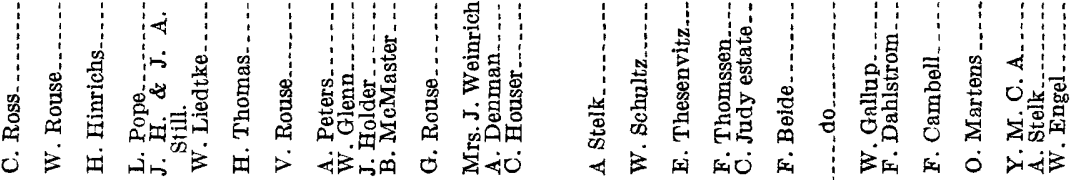

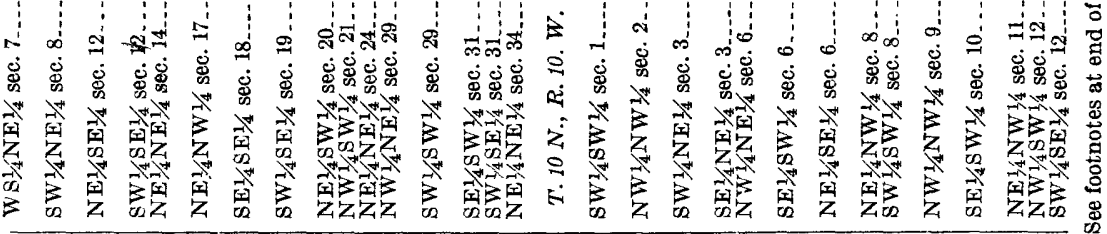

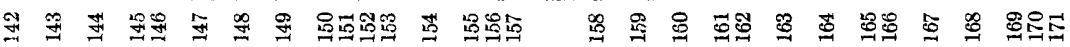




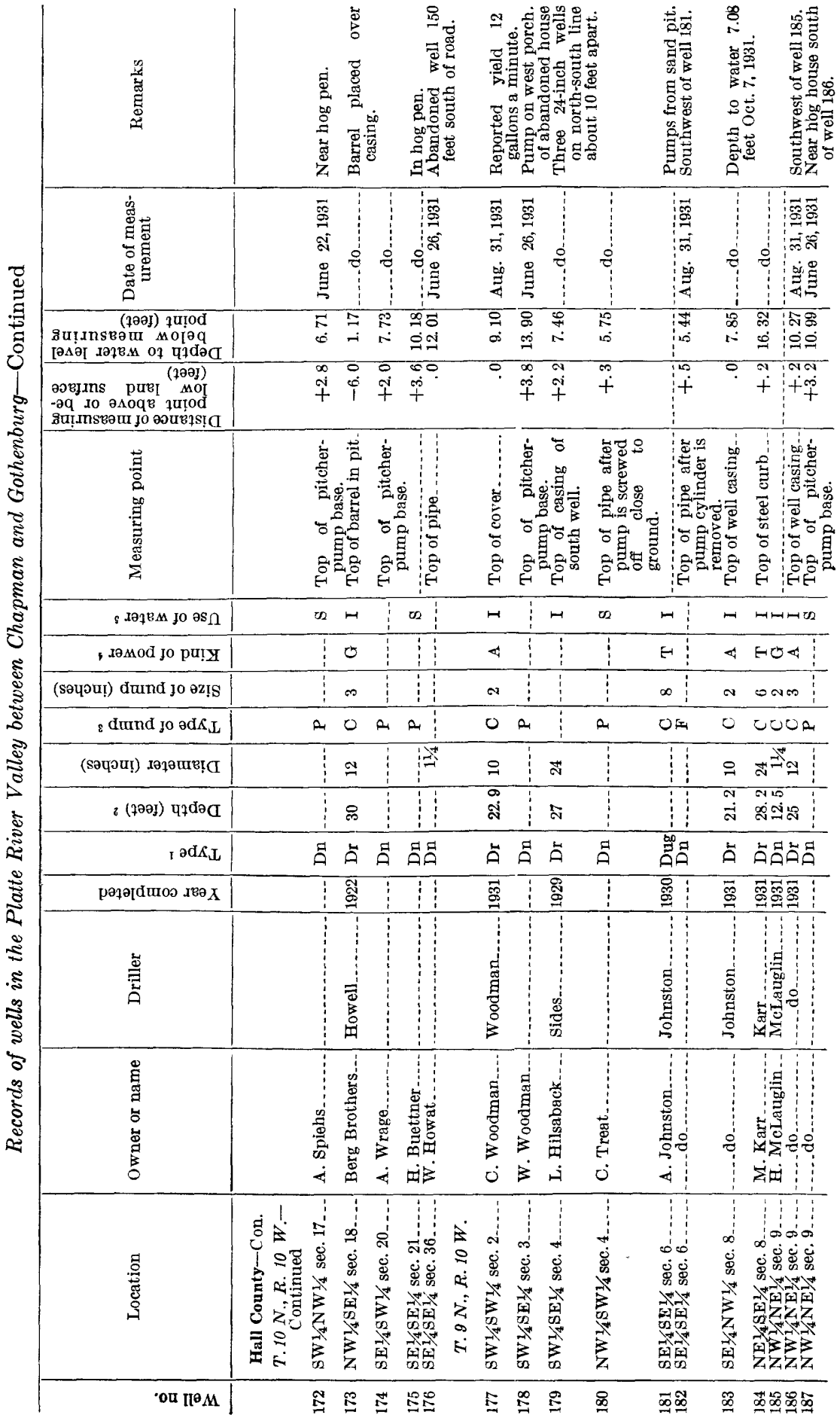




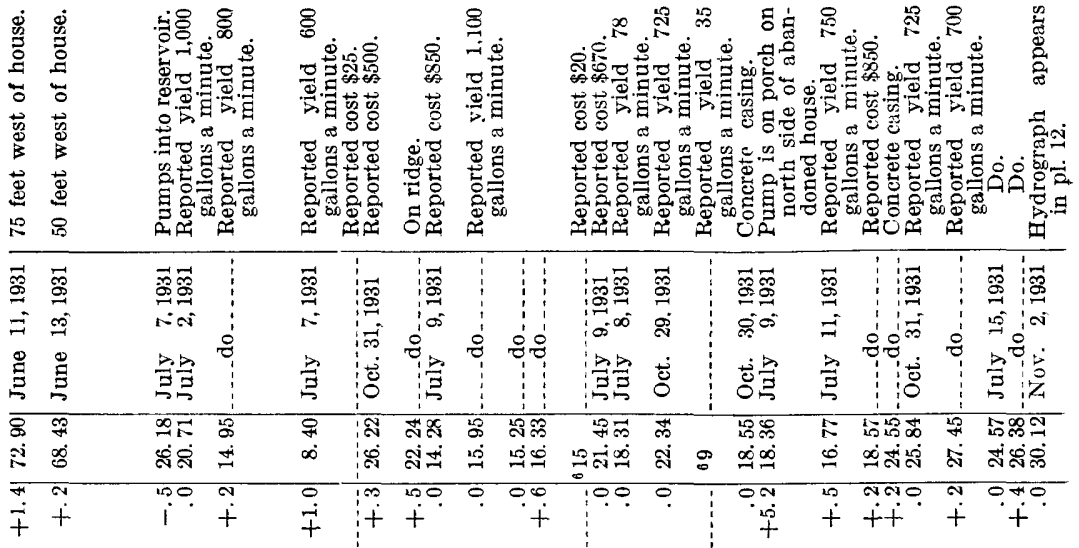

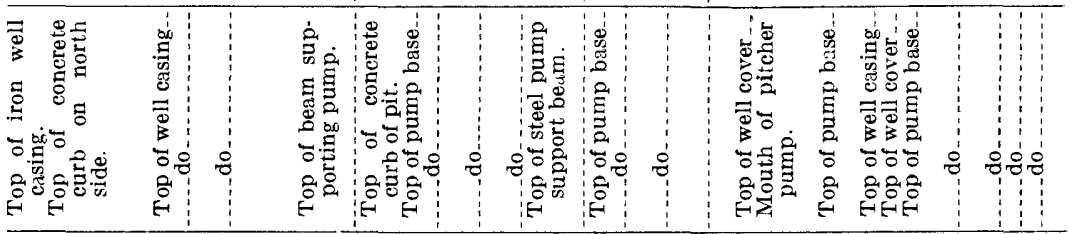

\begin{tabular}{|c|c|c|c|c|c|c|c|c|c|c|c|c|c|c|c|}
\hline$A A$ & trat & r & 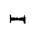 & $\mapsto-11-1$ & ஈル & $\mapsto$ & ルル & ッルル & $\mapsto$ & $n$ & $\mapsto$ & $\mapsto$ & カルカー & $\mapsto$ & カஅー \\
\hline 3 & EF & $H$ & $E$ & OE & सE & E & $4<$ & Oए। & $H$ & $H$ & $E$ & $H$ & ४सE & $H$ & EFE \\
\hline 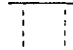 & $\infty 0$ & $\infty$ & 0 & $\approx 0$ & 00 & $\infty$ & $\forall 0$ & $=00$ & 0 & $\Rightarrow$ & $\infty$ & 0 & $\infty \infty 0$ & 0 & 000 \\
\hline
\end{tabular}

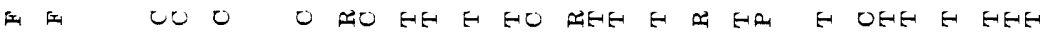

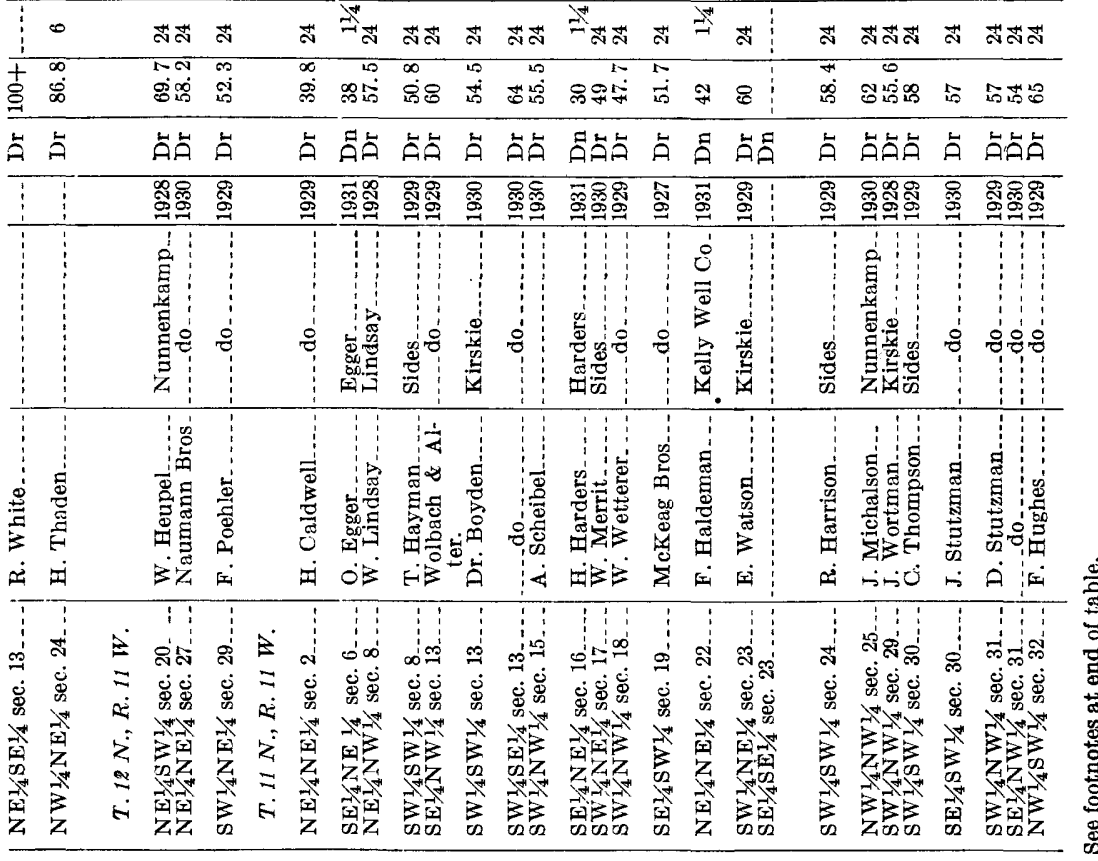

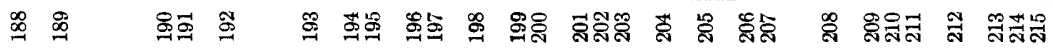
$121343-38-14$ 


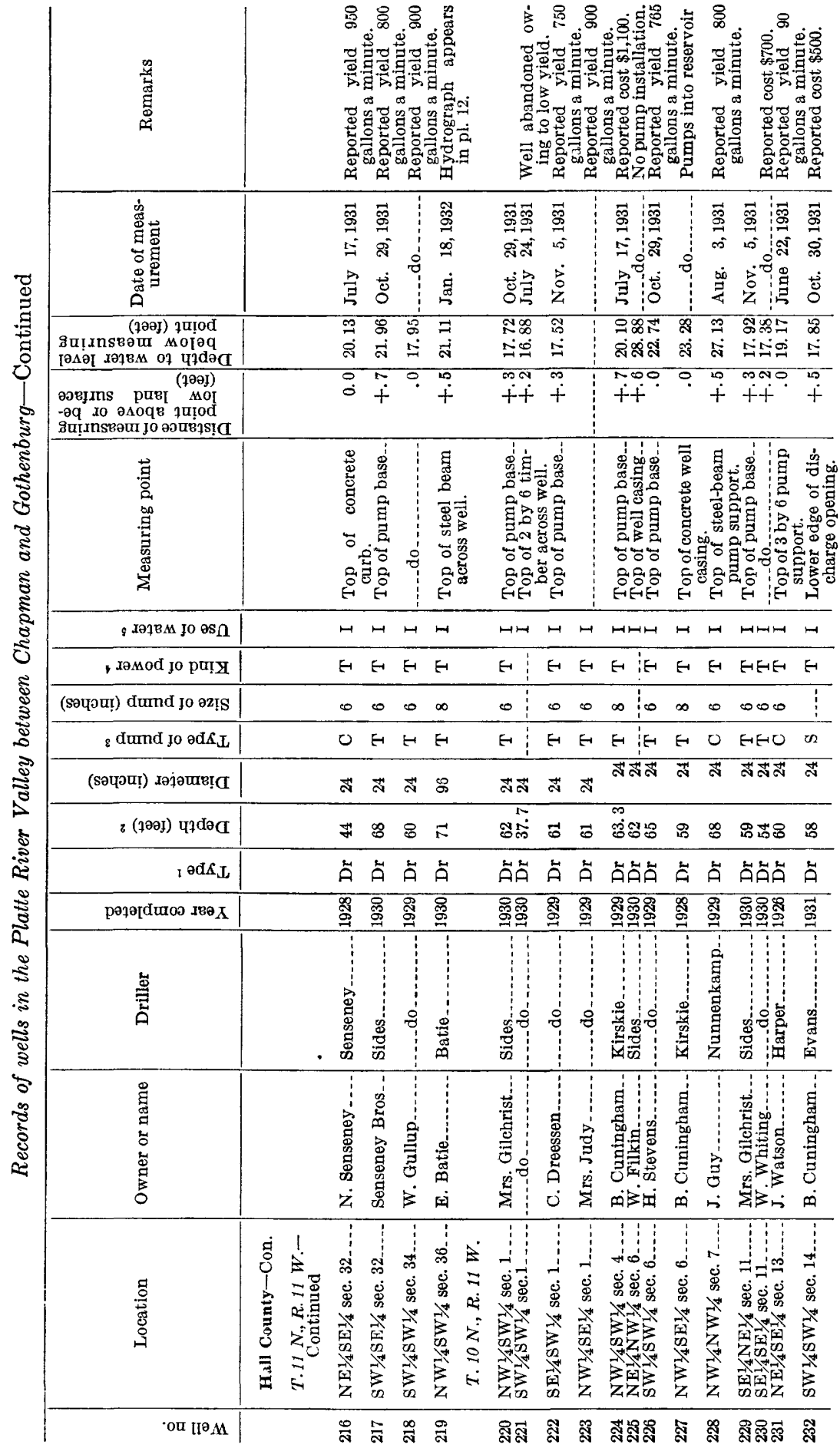




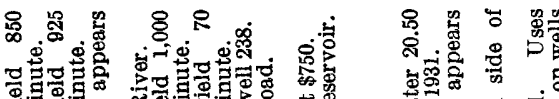

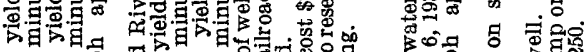
का की

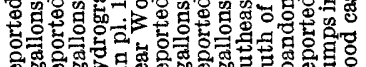

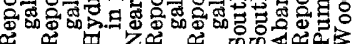
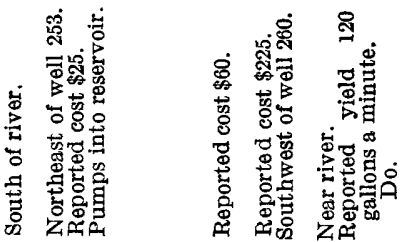

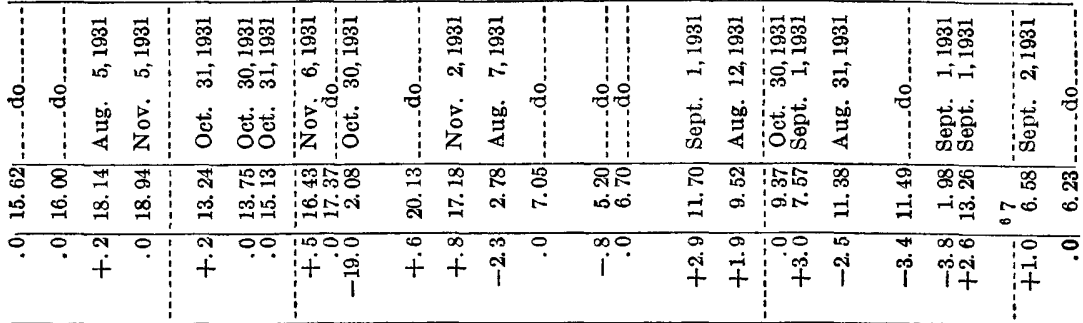

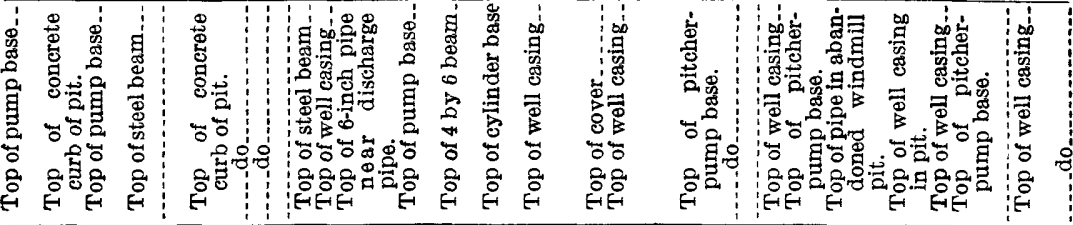

円ー

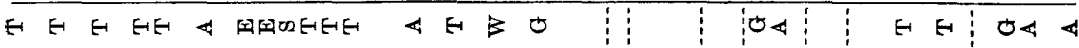

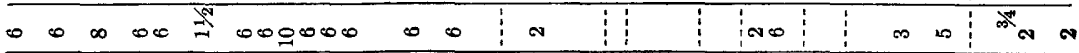

F O F OO O OOFOOO F O A 0 A AROA म

요

ลั

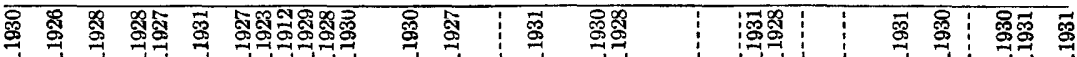

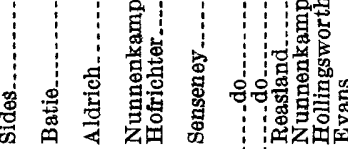
势 青

窎苦 :

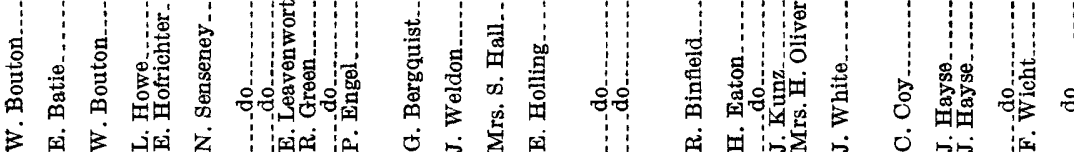

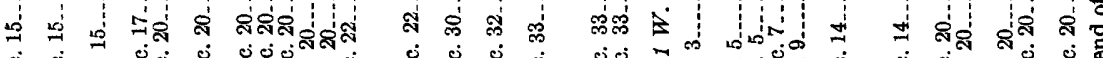

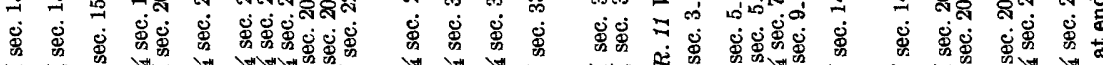
$\vec{l}$

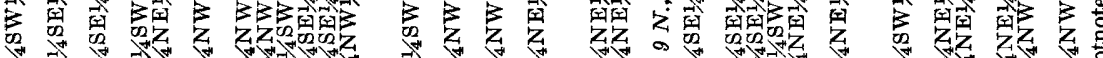
D.

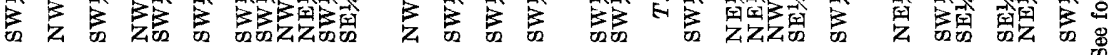

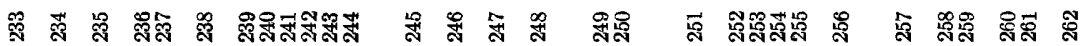




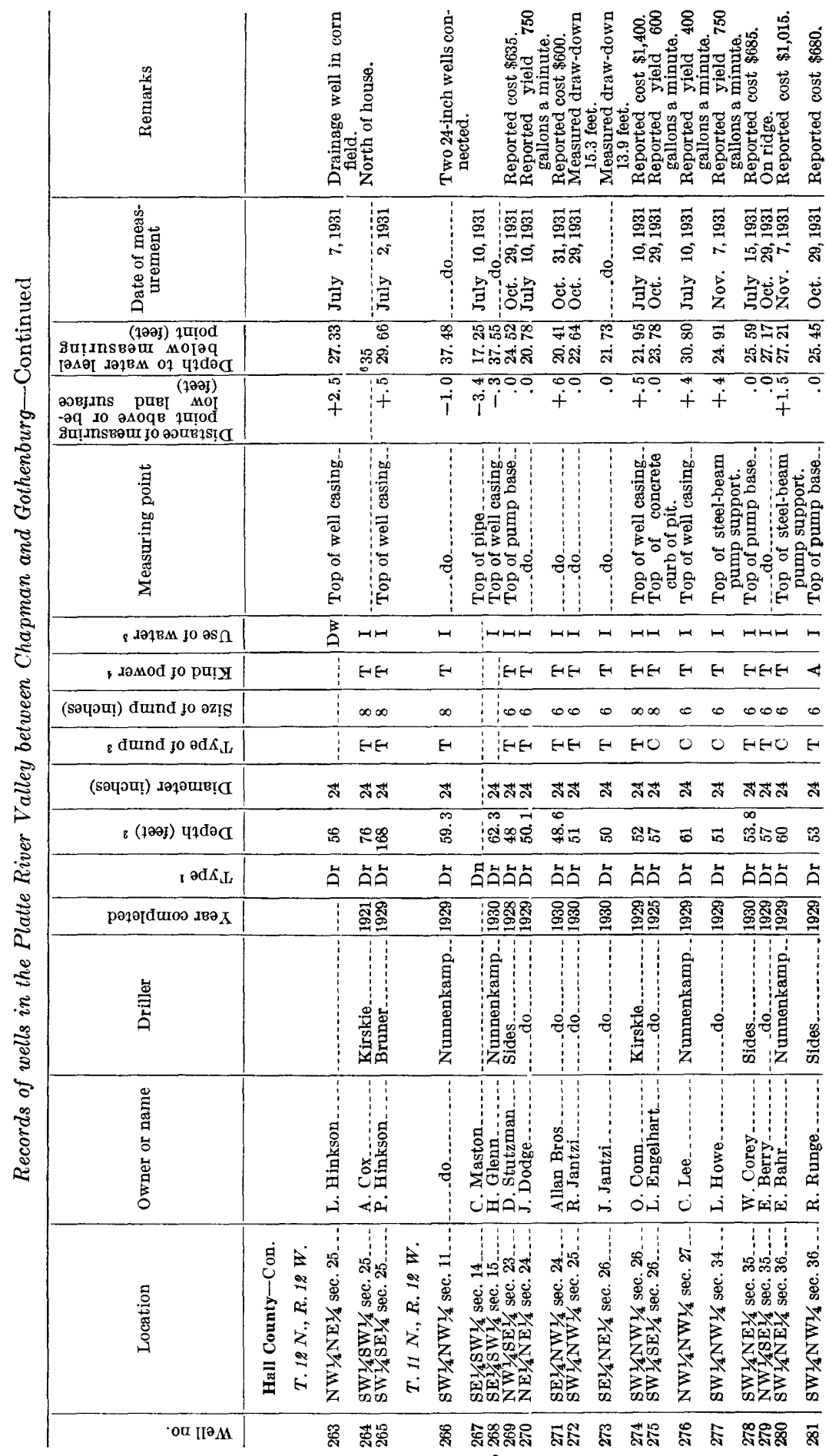




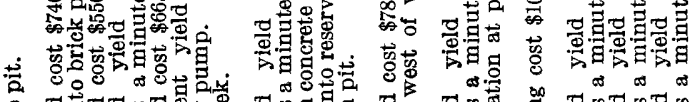

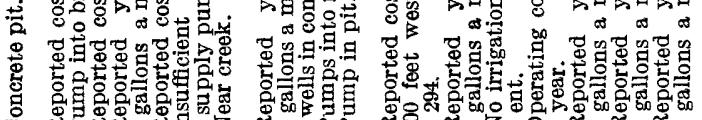

O

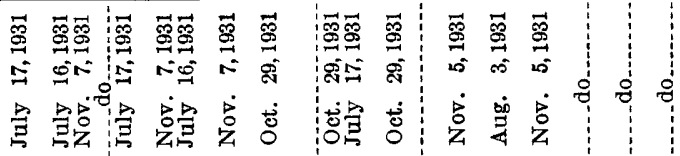

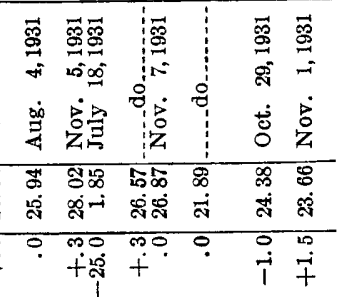

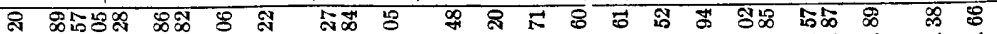

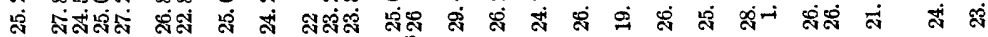

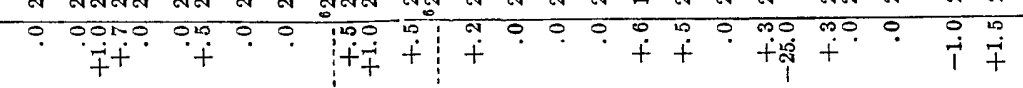

\begin{tabular}{|c|c|c|c|c|}
\hline 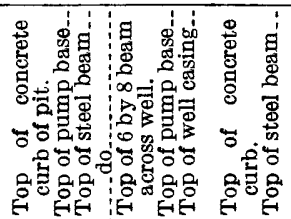 & 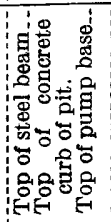 & 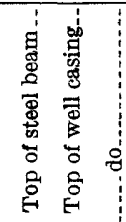 & 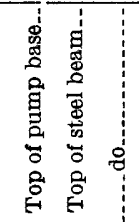 & 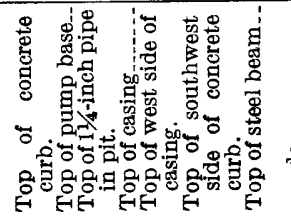 \\
\hline
\end{tabular}

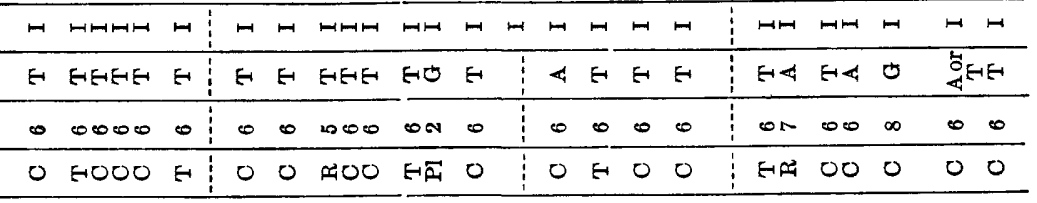

方

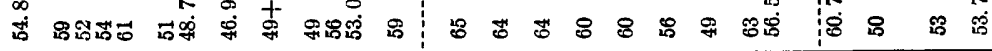

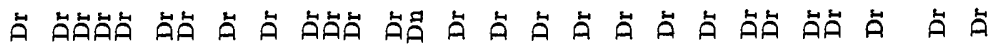

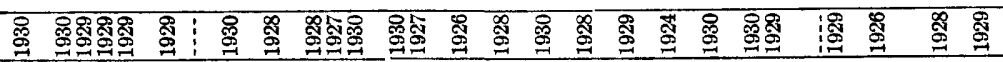

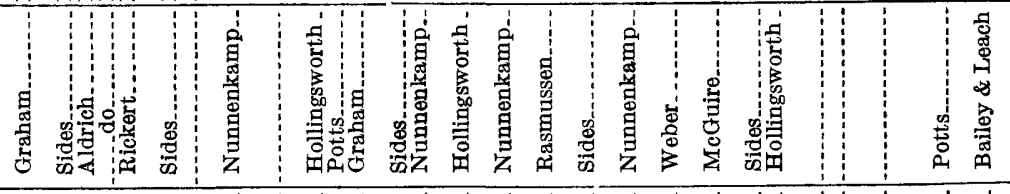

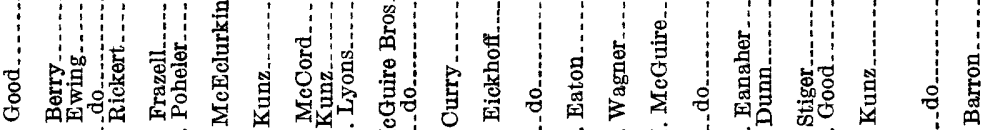

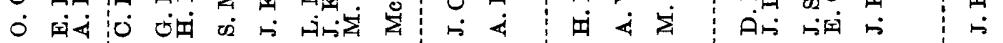

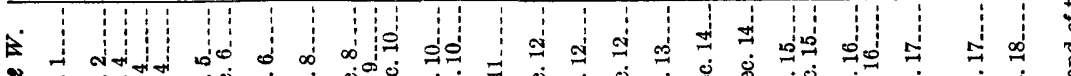

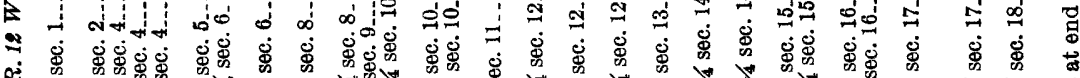

促

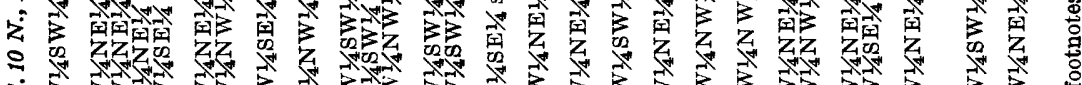

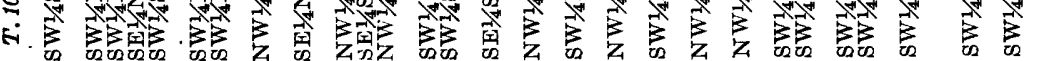

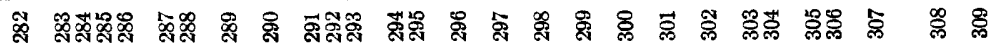




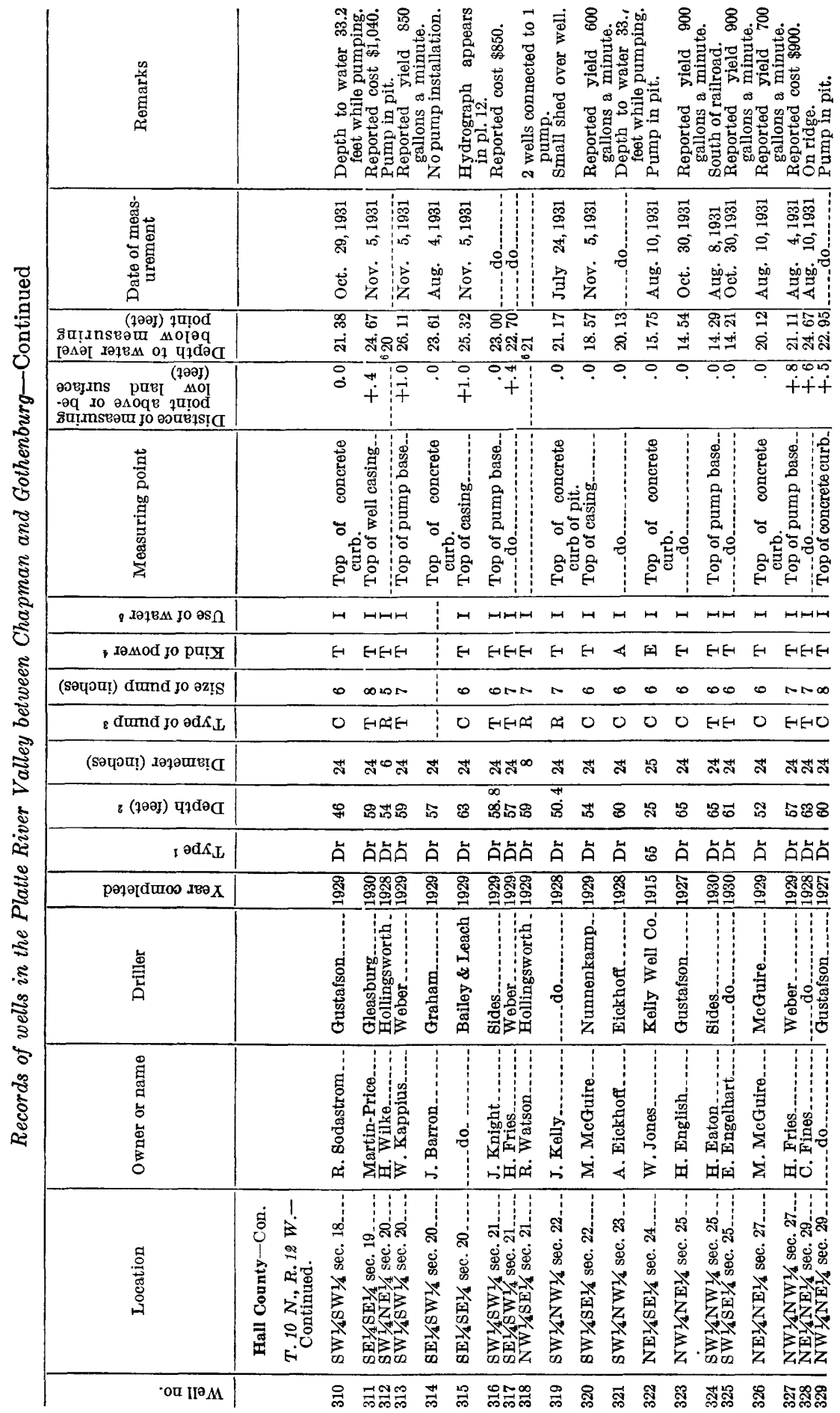




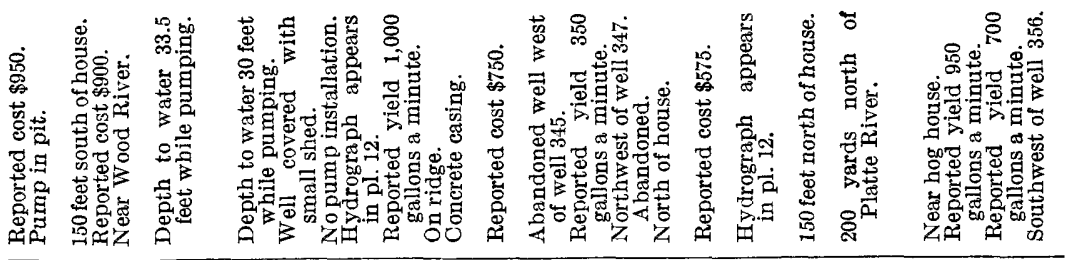

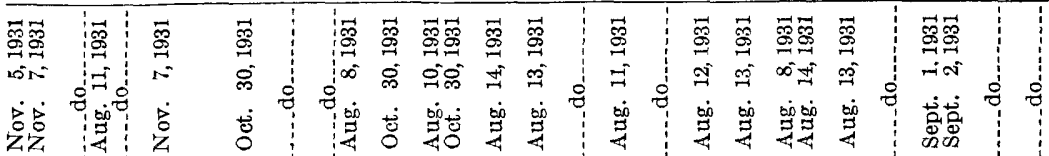

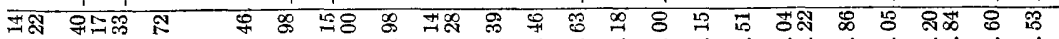

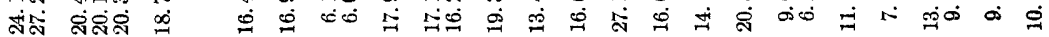

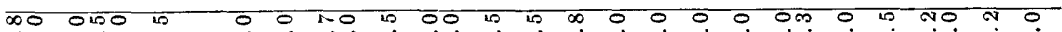

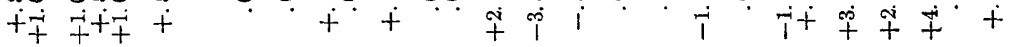

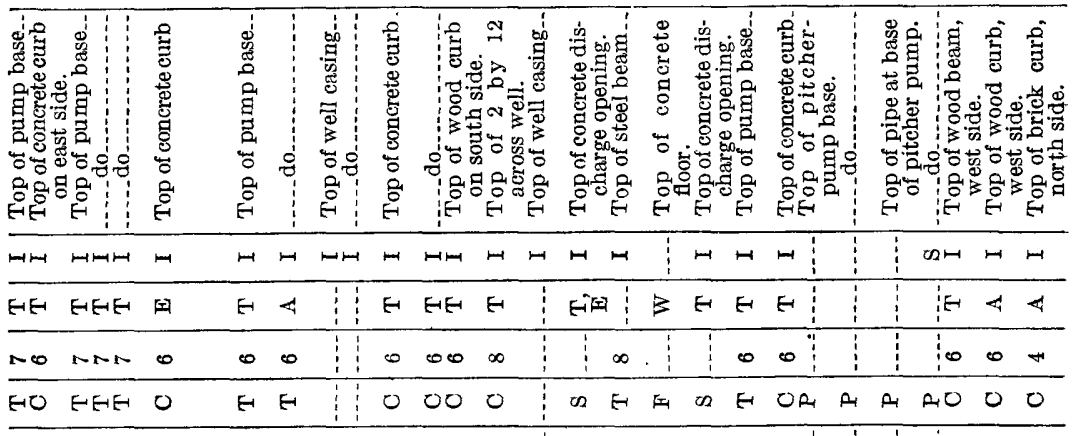

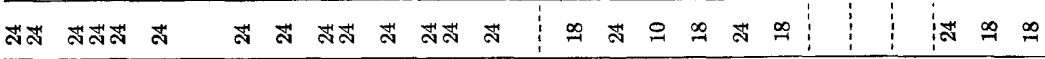

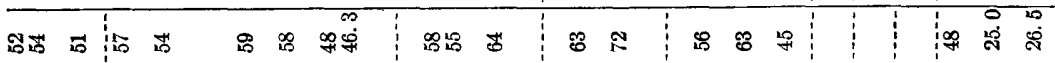

ค̆ล

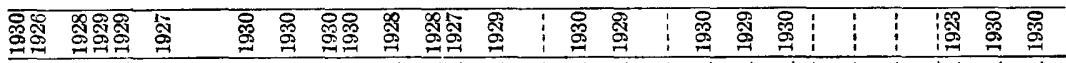

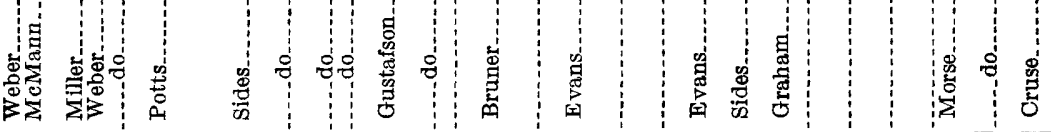

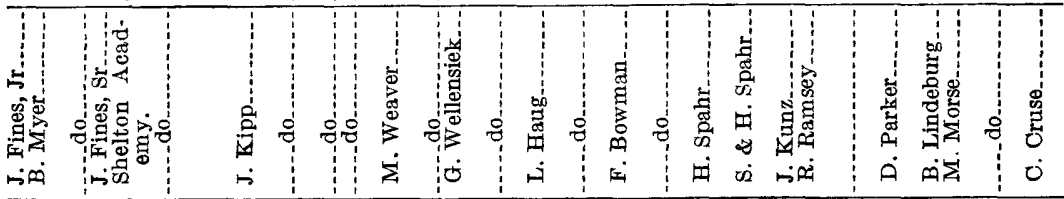

ติธ \% ल

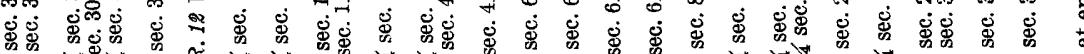

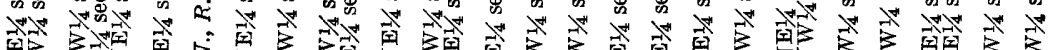

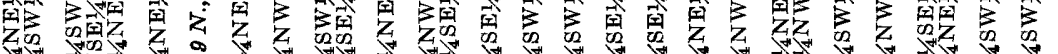
$Z$ क कू

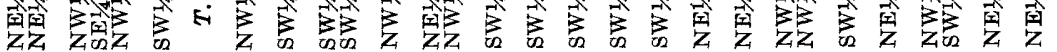

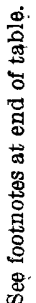

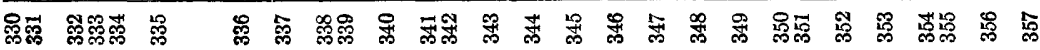




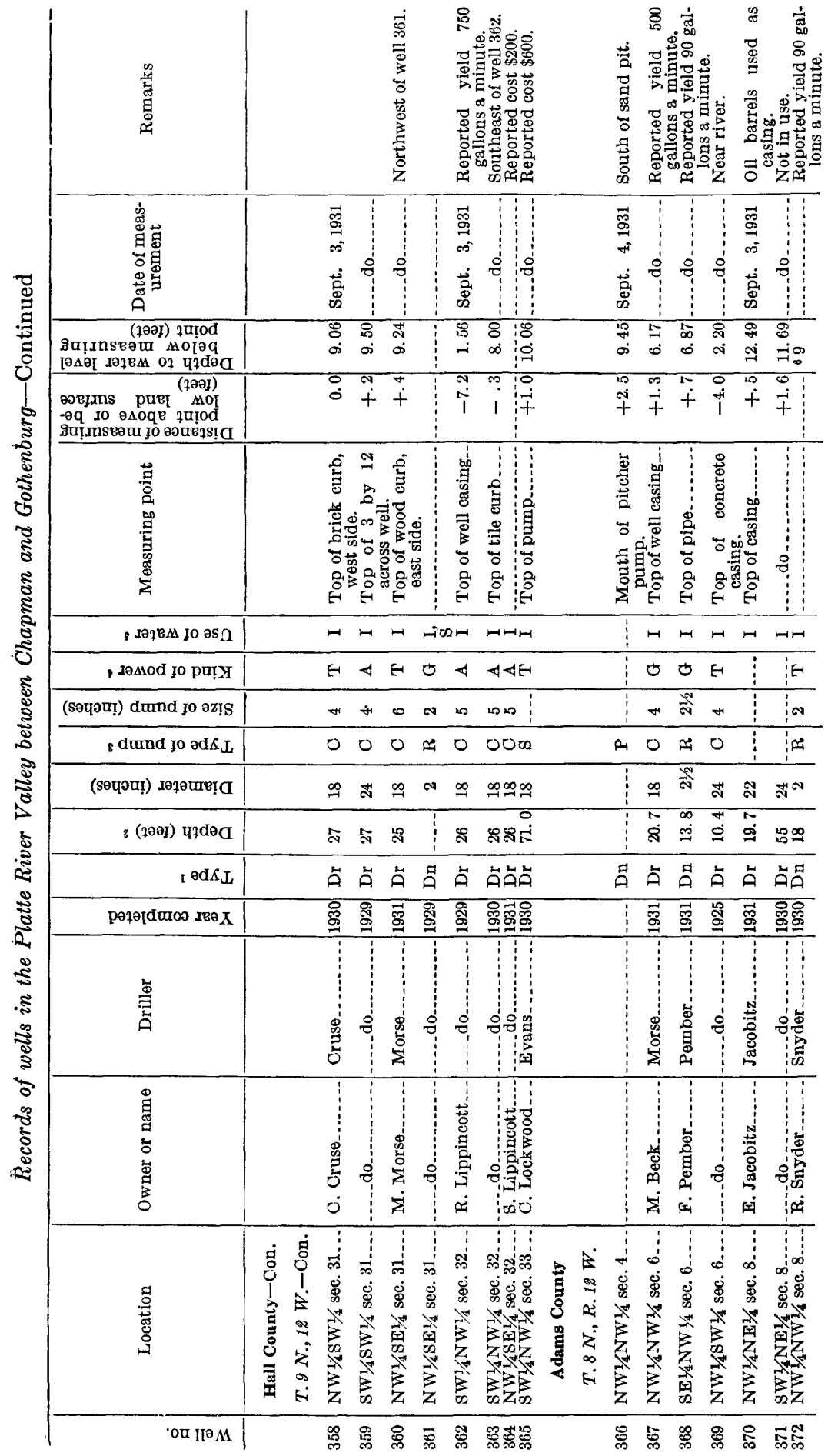




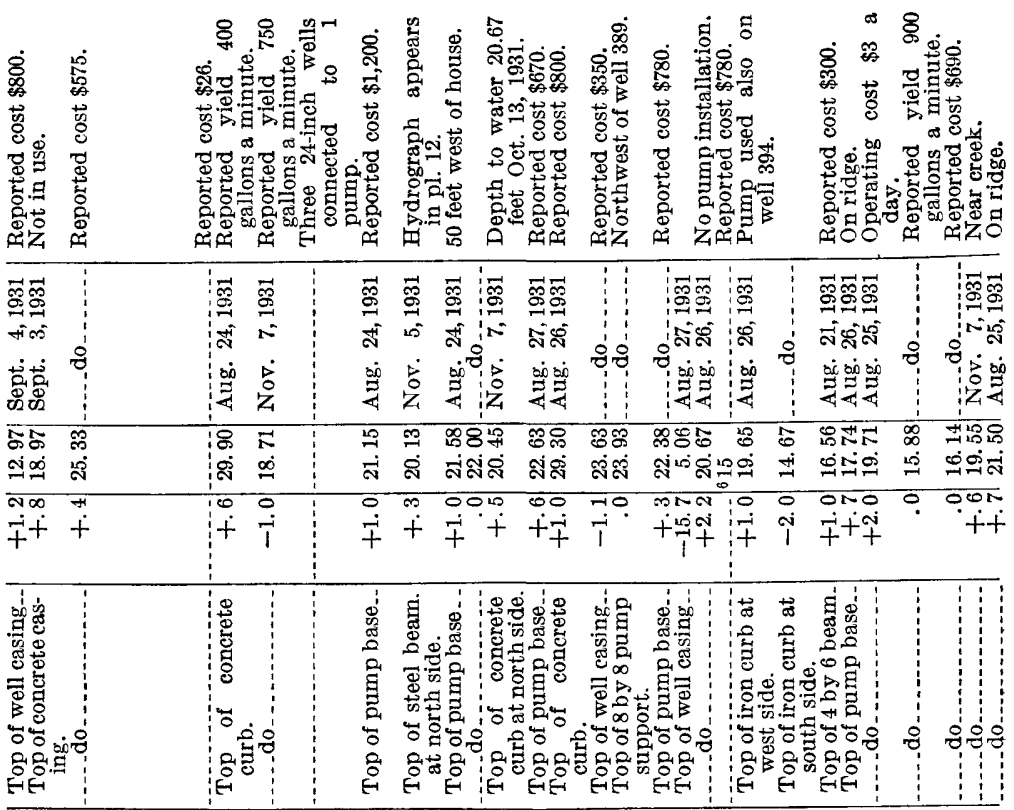

\begin{tabular}{|c|c|c|c|c|c|c|c|c|c|c|c|c|c|c|c|}
\hline मル & $\mapsto$ & मル & $H$ & $\mapsto$ & $\mapsto$ & $\mapsto$ & カサル & அル & ஈル & カルート & पाम & $\mapsto$ & ロルロ & $H$ & •ルル \\
\hline$E$ & $E-1$ & OE & $E$ & $E-$ & E & $E-1$ & EHEE & ERE & $E-4$ & सE & $O E-$ & & EEE & Er & EEE \\
\hline$\infty$ & $\infty$ & $\overbrace{}^{+\infty}$ & $\infty$ & $\sim$ & $\infty$ & 0 & $\infty 0$ & 00 & $\infty \omega$ & 00 & $=0$ & 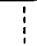 & 000 & $\infty$ & ON \\
\hline$E-1$ & $E-$ & EO & 0 & مُ & E & 0 & Ertion & Fo & EEF & ENo & טגו & 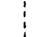 & OEFE- & $E$ & $E-E \in E-1$ \\
\hline
\end{tabular}

ลิส ส ก ก

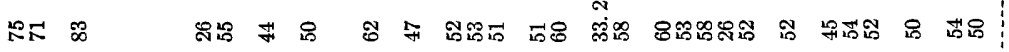

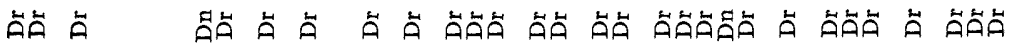

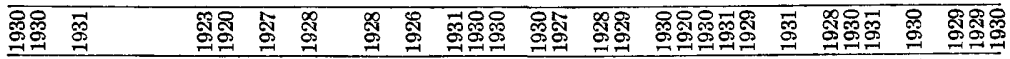

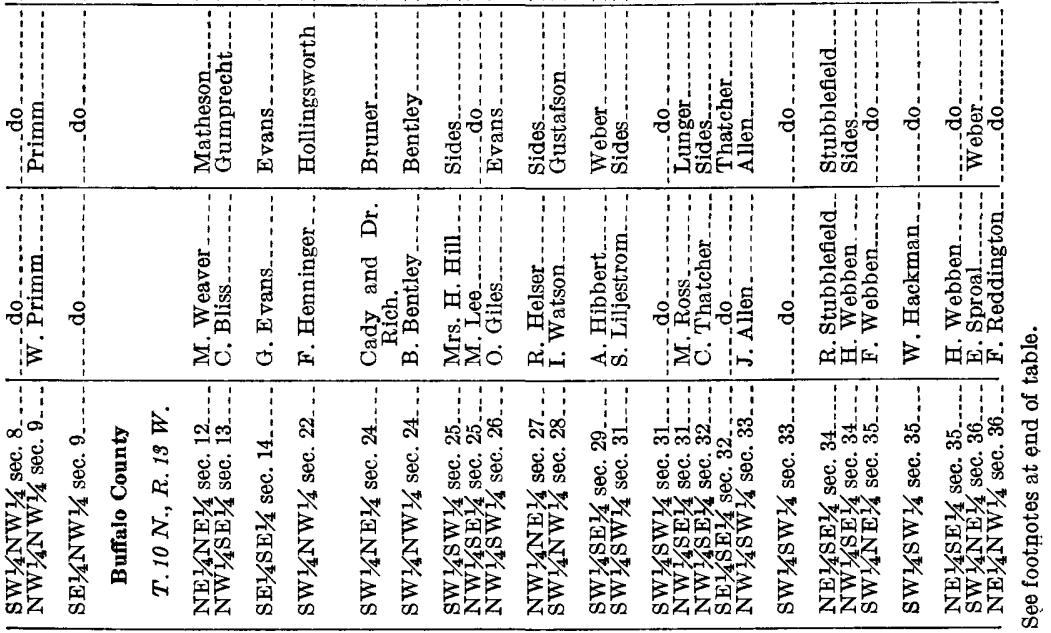

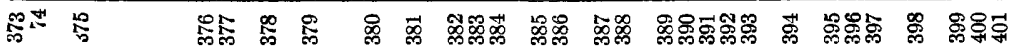




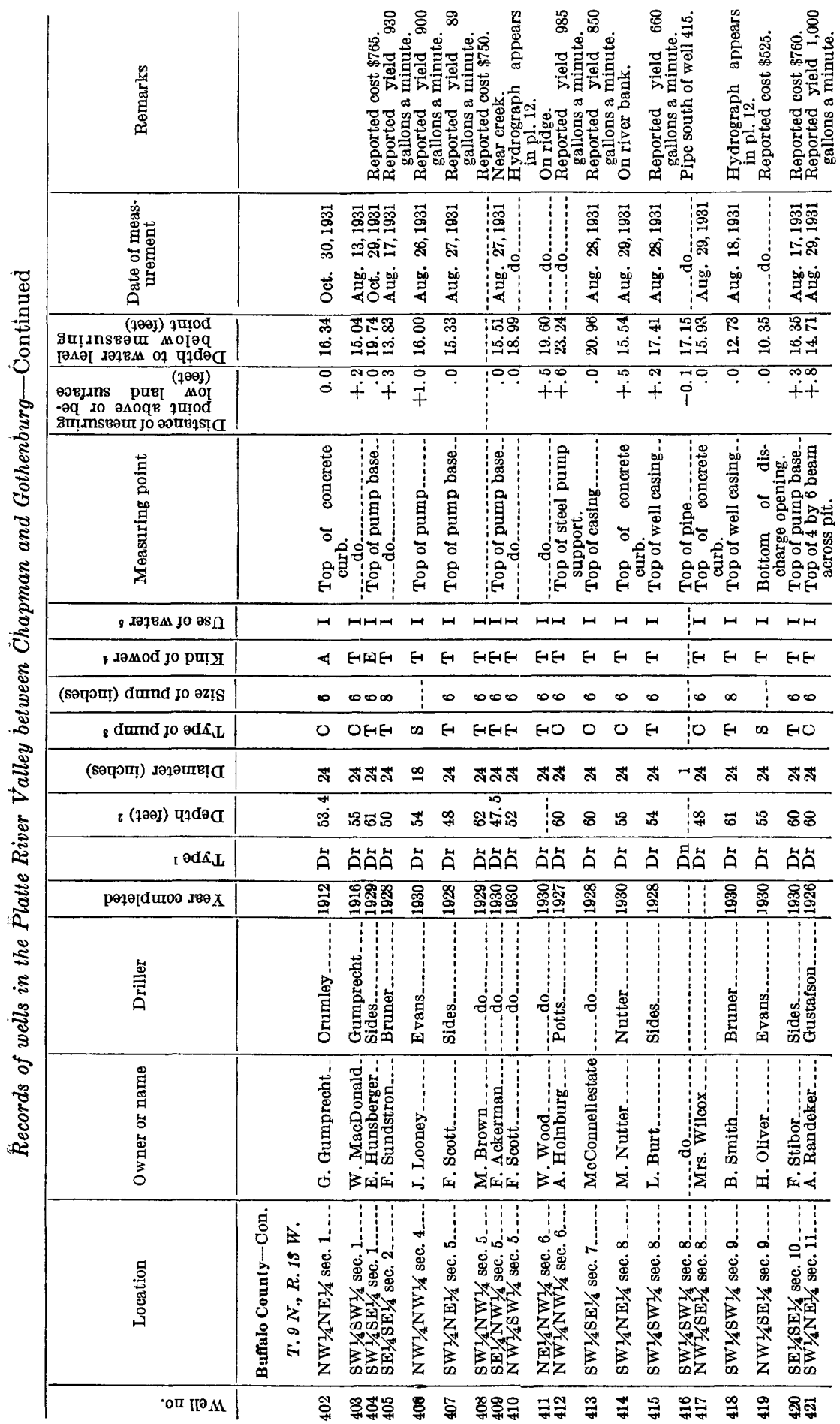




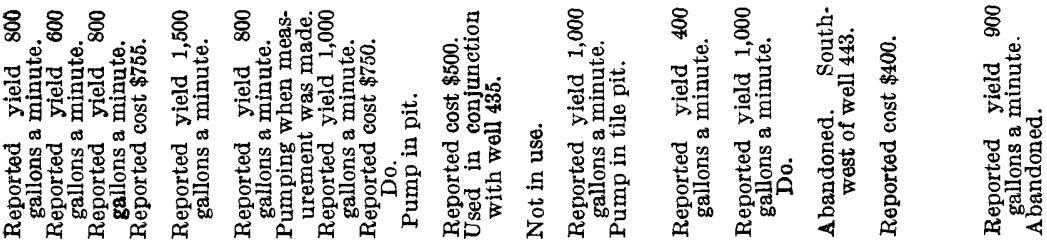

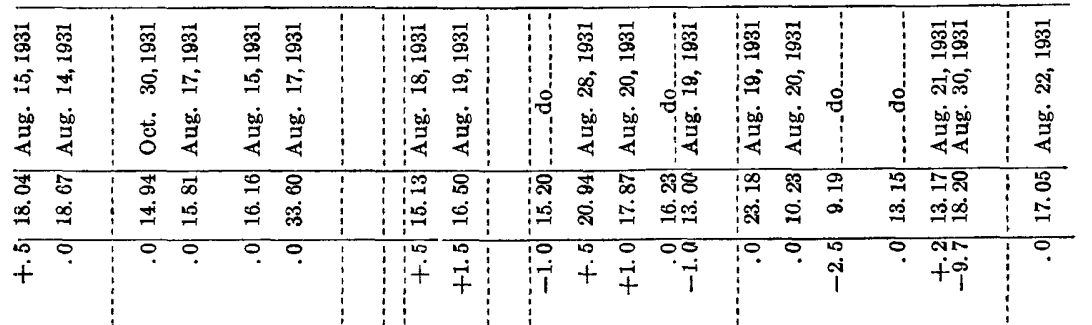

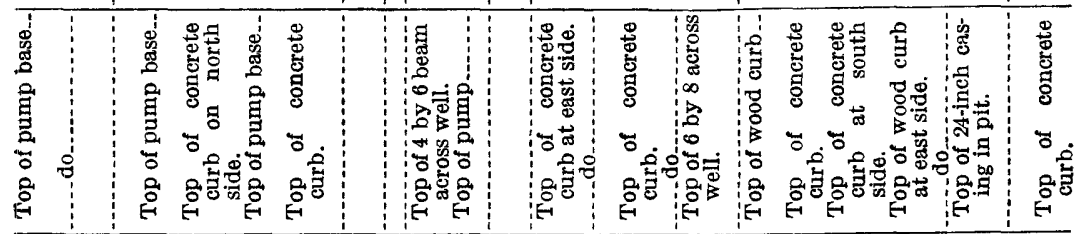

\begin{tabular}{|c|c|c|c|c|c|c|c|c|c|c|c|c|c|c|c|c|c|c|}
\hline$\mapsto$ & $m$ & $m$ & $\mapsto$ & $m$ & -1 & $m$ & $n$ & サッル & ロル & ஐே & $m$ & ロル & ロル & H & $\mapsto$ & $H$ & $\mapsto \mapsto$ & $M$ \\
\hline 5 & (9) & E & $E$ & E- & E & E- & E & EHETE & EEF & $E-$ & E- & $E \&$ & E- & $E-1$ & & $E$ & EE- & $E-1$ \\
\hline 0 & $\infty$ & $\infty$ & 0 & 0 & 0 & 0 & 0 & 000 & : & 0 & 유 & $0 *$ & : & $\infty$ & & $\infty$ & 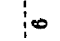 & $\infty$ \\
\hline
\end{tabular}

ส ส

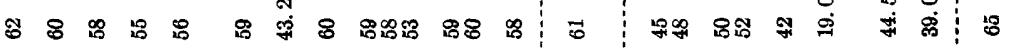

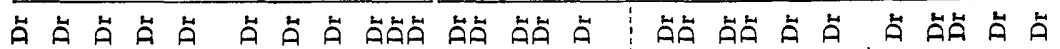

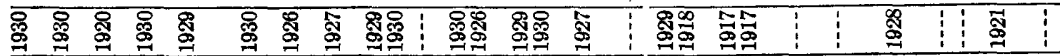

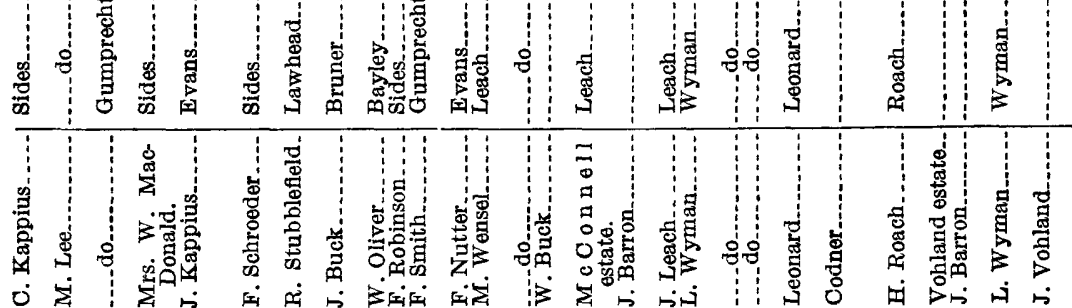

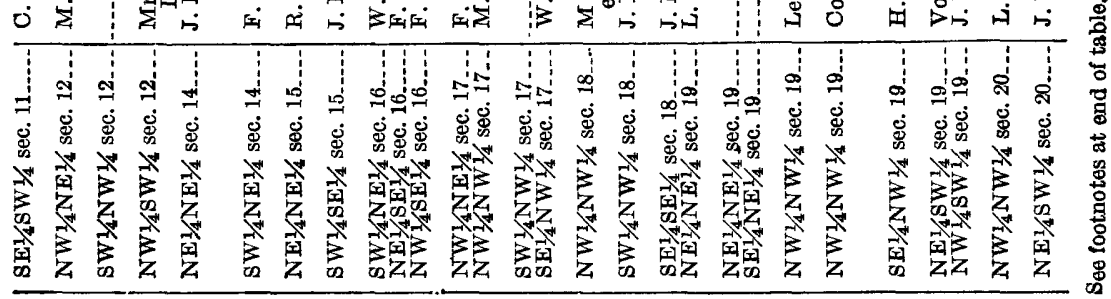

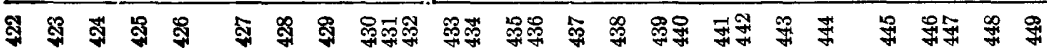




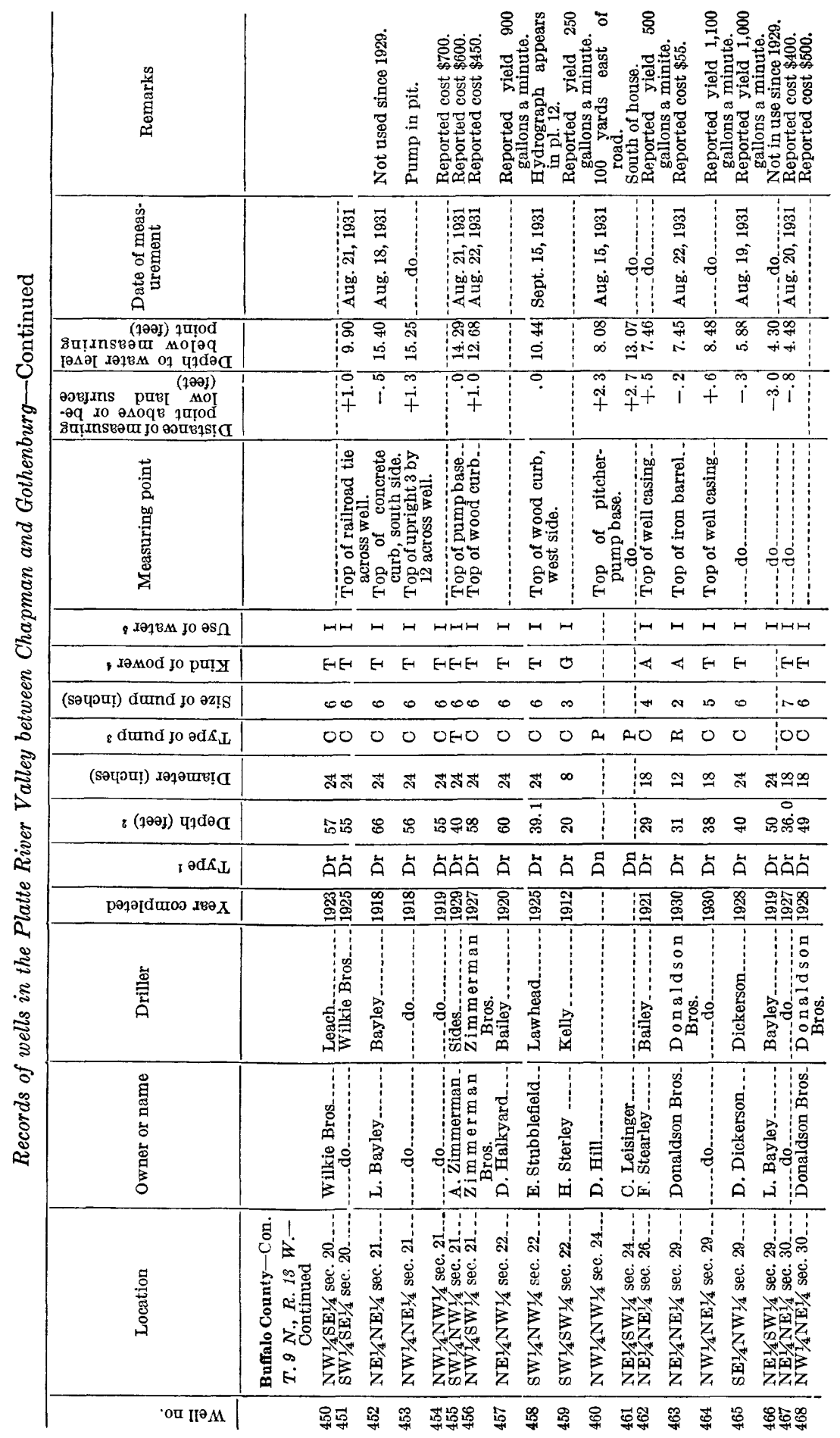




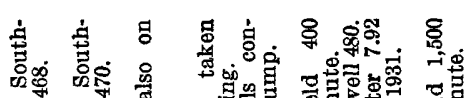

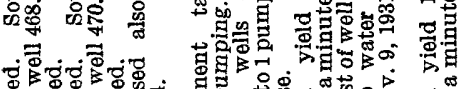

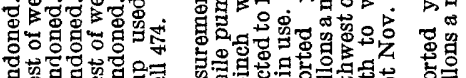

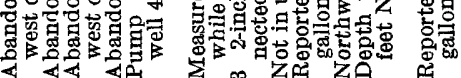

\& $8: 8$

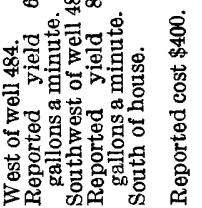

양 \& \&

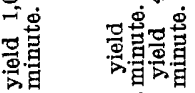

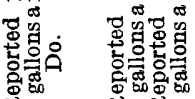
舟

\begin{tabular}{|c|c|c|c|c|c|c|c|c|c|c|c|c|c|c|c|}
\hline 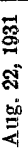 & 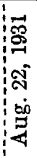 & 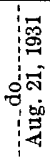 & 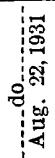 & 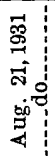 & 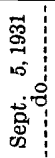 & 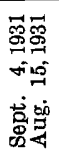 & 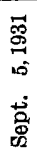 & : & 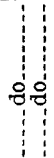 & 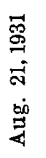 & 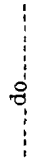 & 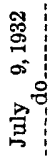 & 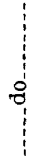 & & 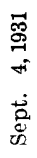 \\
\hline $\begin{array}{l}\text { ชิ } \\
\text { ง }\end{array}$ & $\begin{array}{l}10 \\
0 \\
0 \\
0\end{array}$ & 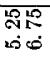 & 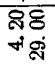 & $\begin{array}{l}\text { 요요 } \\
6 \text { in }\end{array}$ & $\begin{array}{l}\infty \% 9 \\
\infty \infty\end{array}$ & $\begin{array}{l}8 \% \\
\therefore \infty \\
\sim \infty\end{array}$ & $\begin{array}{l}P \\
9 \\
0 \\
0\end{array}$ & 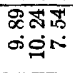 & $\begin{array}{l}\text { जै } \\
\text { के }\end{array}$ & م & $\begin{array}{l}\text { Sू } \\
0\end{array}$ & 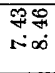 & $\vec{\infty}$ & $\underset{\infty}{-}$ & $\begin{array}{l}\infty \\
\substack{n \\
N}\end{array}$ \\
\hline i & a & \% & $\begin{array}{l}00 \\
i+i\end{array}$ & i⿱ & $\begin{array}{l}\text { के } \\
\text { iें } \\
1\end{array}$ & $\begin{array}{l}\infty N \\
+\dot{+}\end{array}$ & $\dot{+}$ & om? & क्. & $\ddot{F}$ & $\dot{8}$ & $\begin{array}{l}00 \\
\text { to } \\
++\end{array}$ & $\begin{array}{l}0 \\
+ \\
+\end{array}$ & & $?$ \\
\hline
\end{tabular}

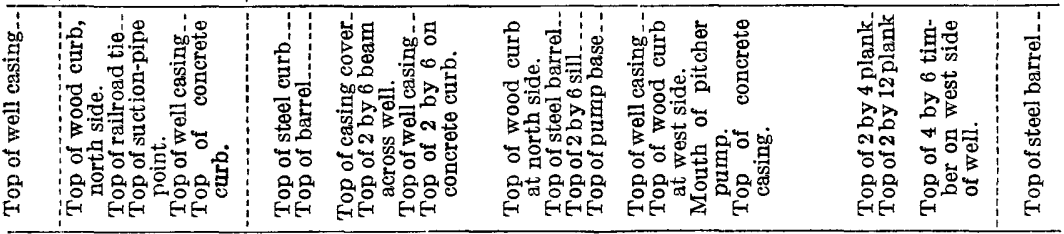

\begin{tabular}{|c|c|c|c|c|c|c|c|c|c|c|c|c|c|c|}
\hline & - & ルー & $\mapsto$ & $\mapsto \mapsto$ & $\hat{a}^{+\infty}$ & mith & $\mapsto$ & ウロロ & •ル & $\mapsto$ & ロル & $\mapsto$ & $n$ & $n$ \\
\hline & te- & IF & 4 & 4 & OE & 4 & $E$ & सहE & EE & E & E & $E$ & 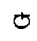 & $E$ \\
\hline
\end{tabular}

க)

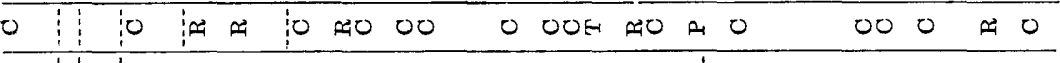

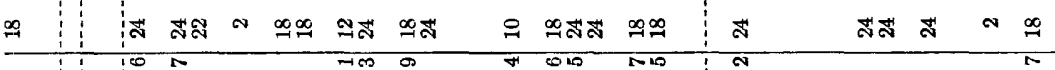

๙

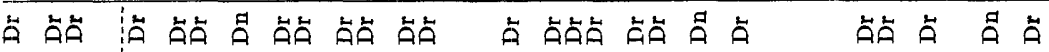

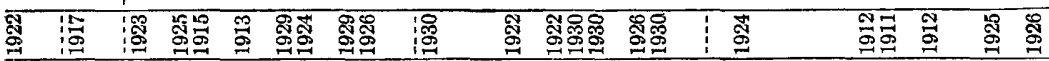

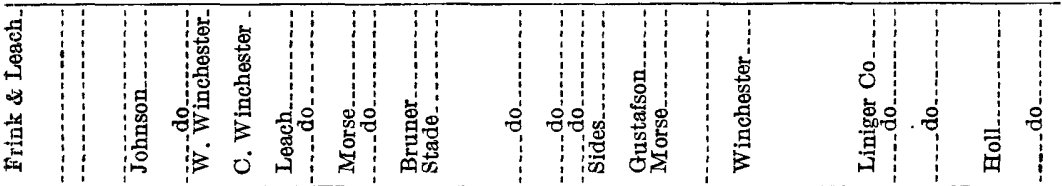

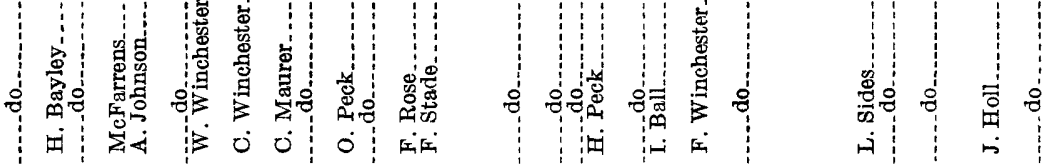

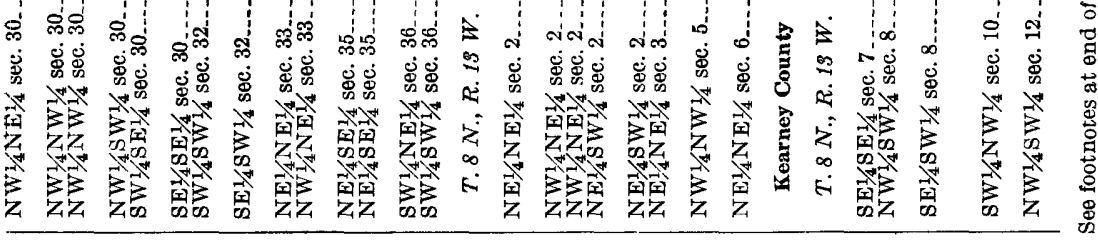

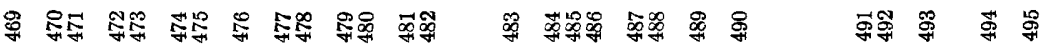




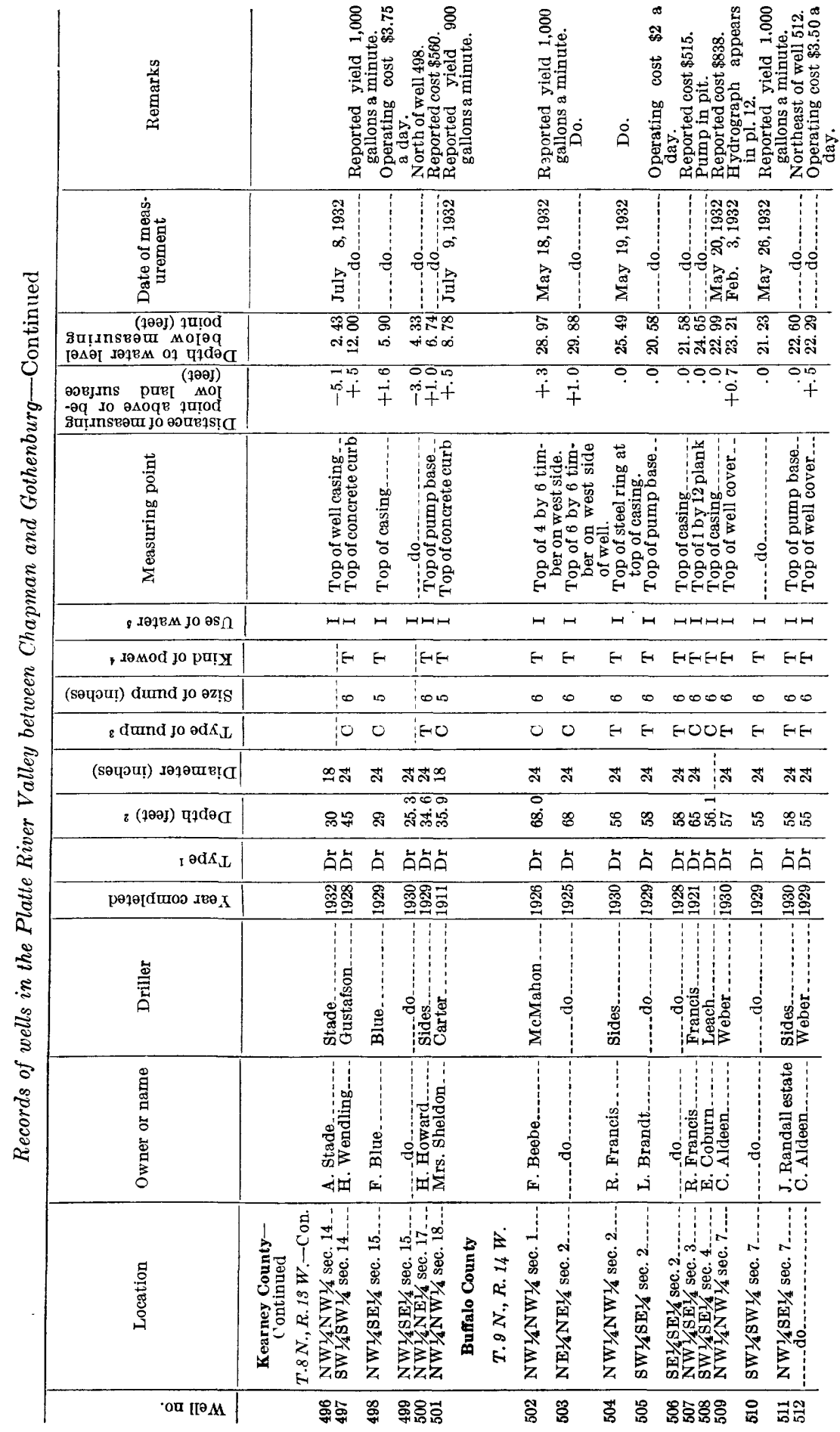




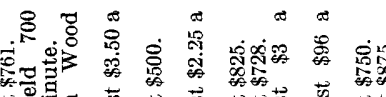

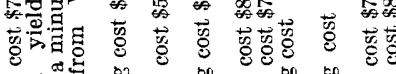

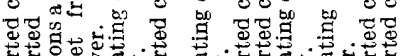

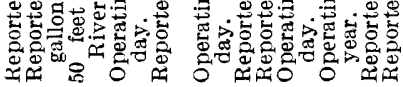

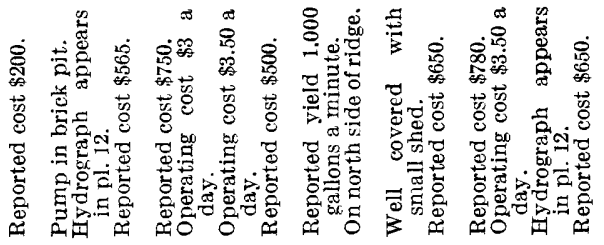

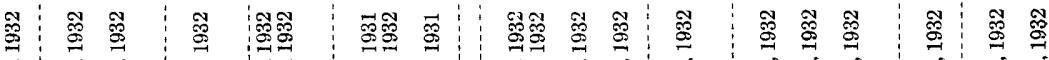

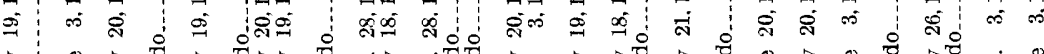

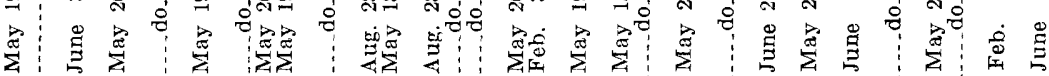
D:

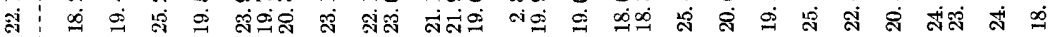

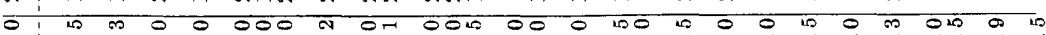
$\dot{+} \dot{+}+\dot{+}+\dot{+} \dot{+}+\dot{+}+\dot{+}+\dot{+}+\dot{+}+\dot{+}$

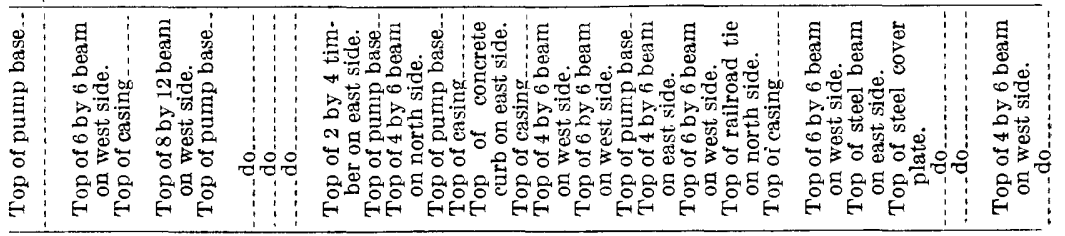

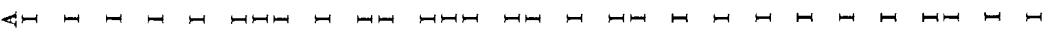

सO $F$ H

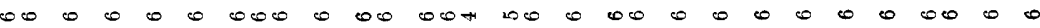

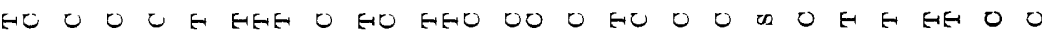

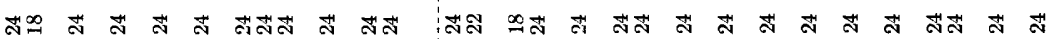

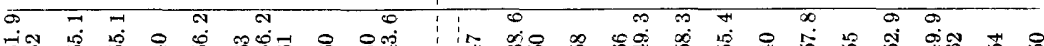
붕

翙

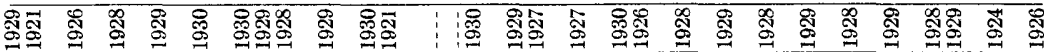

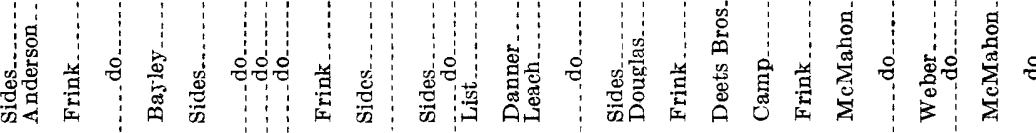

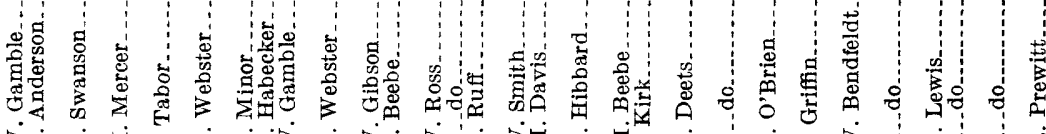

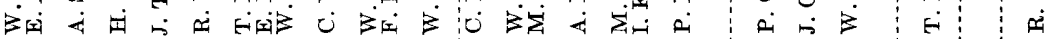
o 90 ด

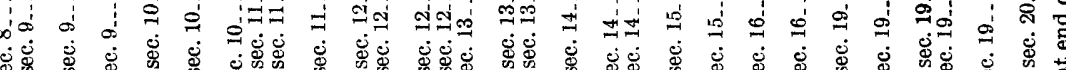
它

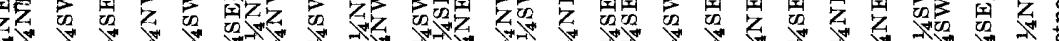

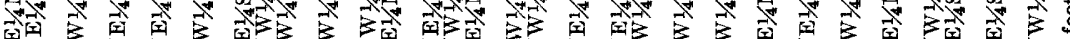

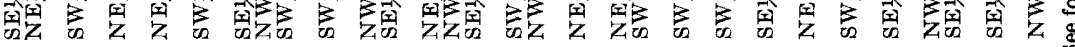

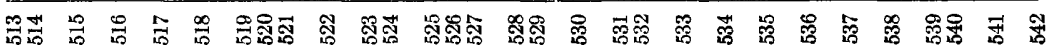




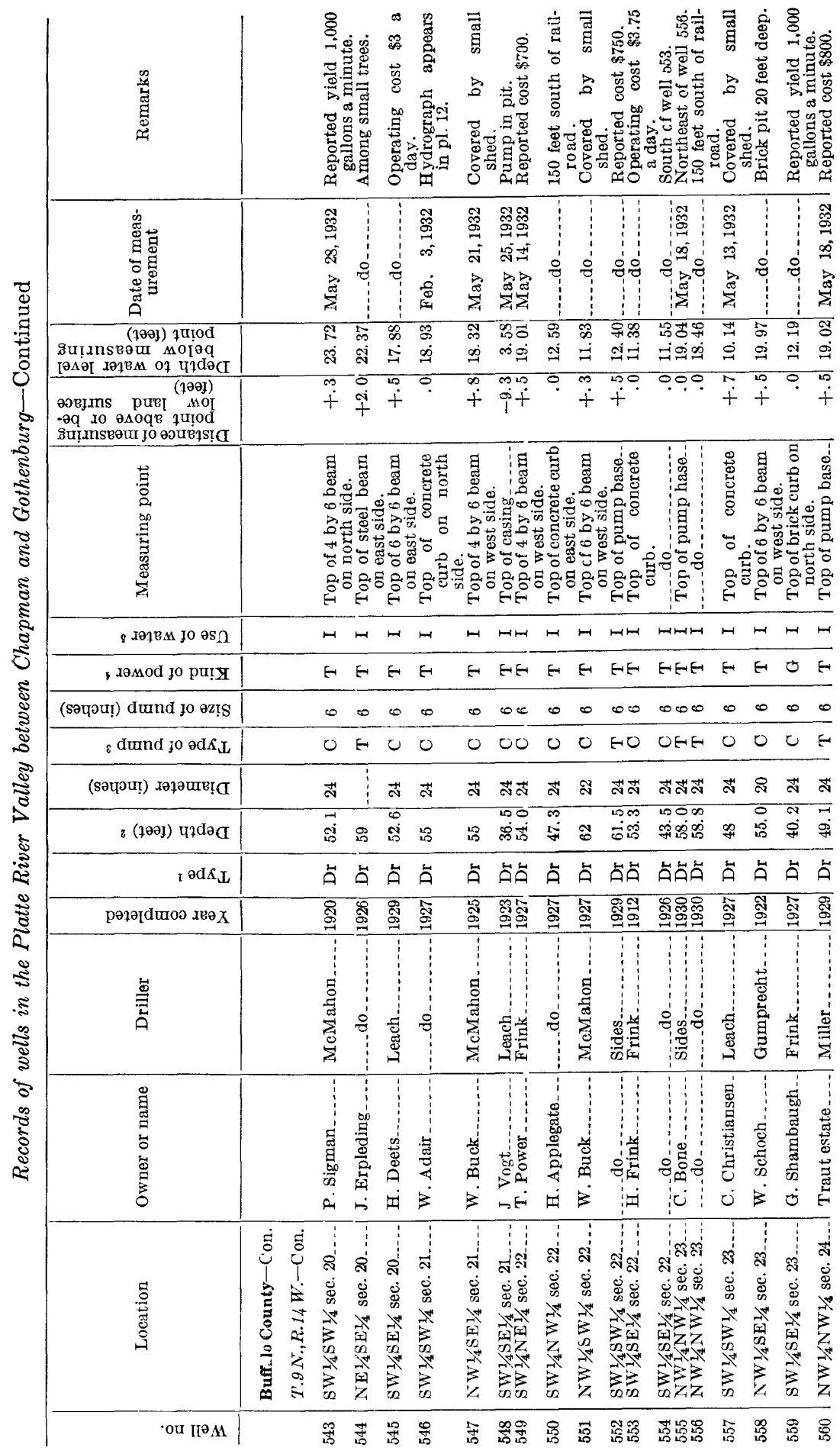




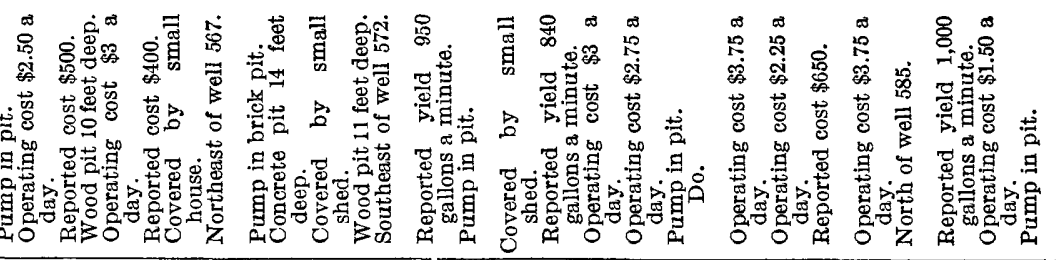

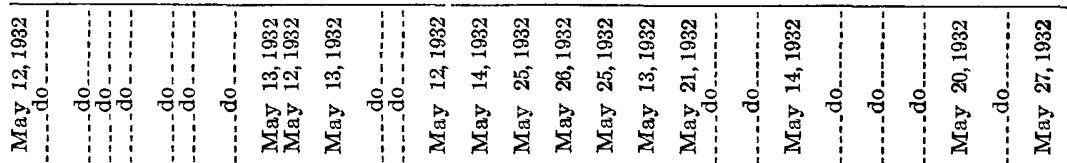

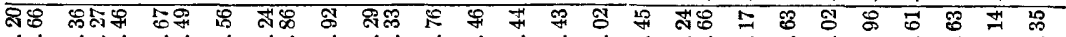
๓

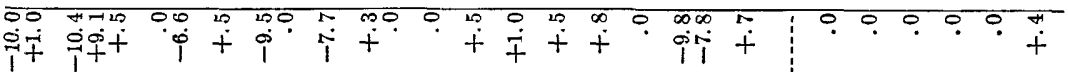

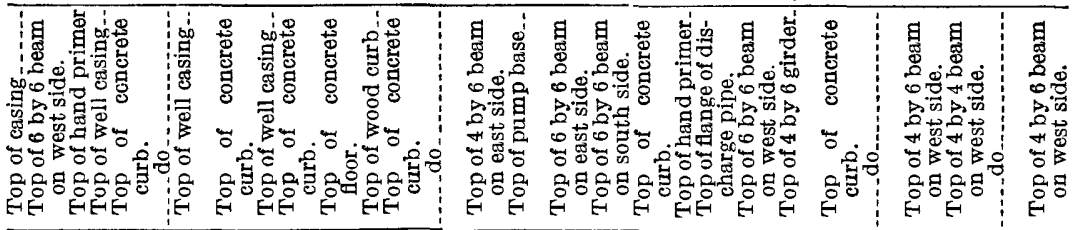

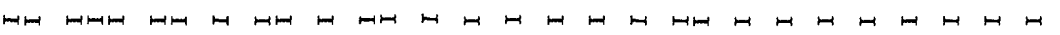

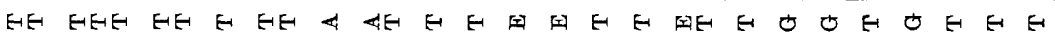

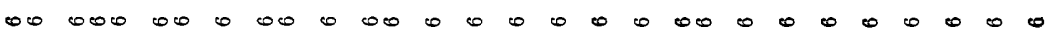

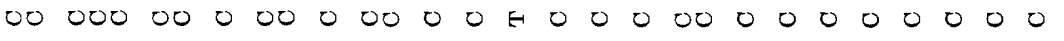

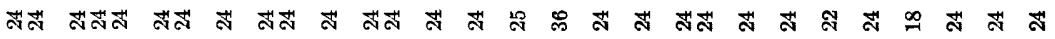
官

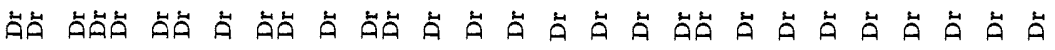

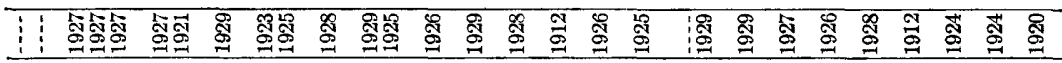

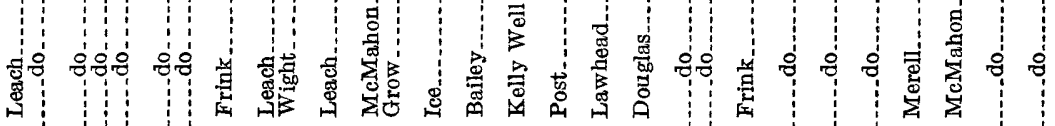

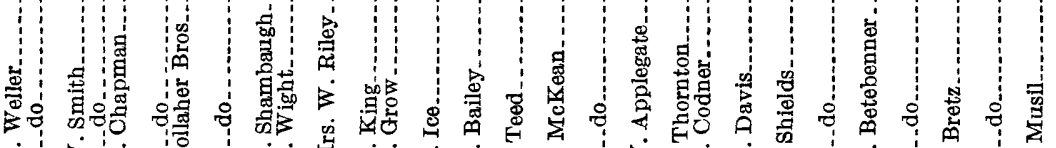
या

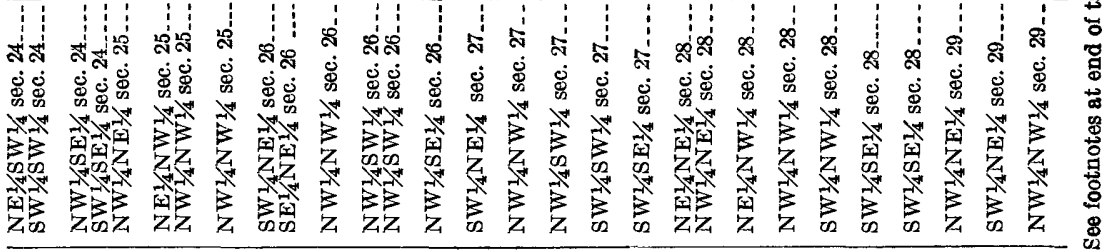

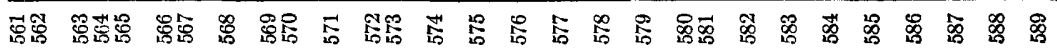
$121343-38-15$ 


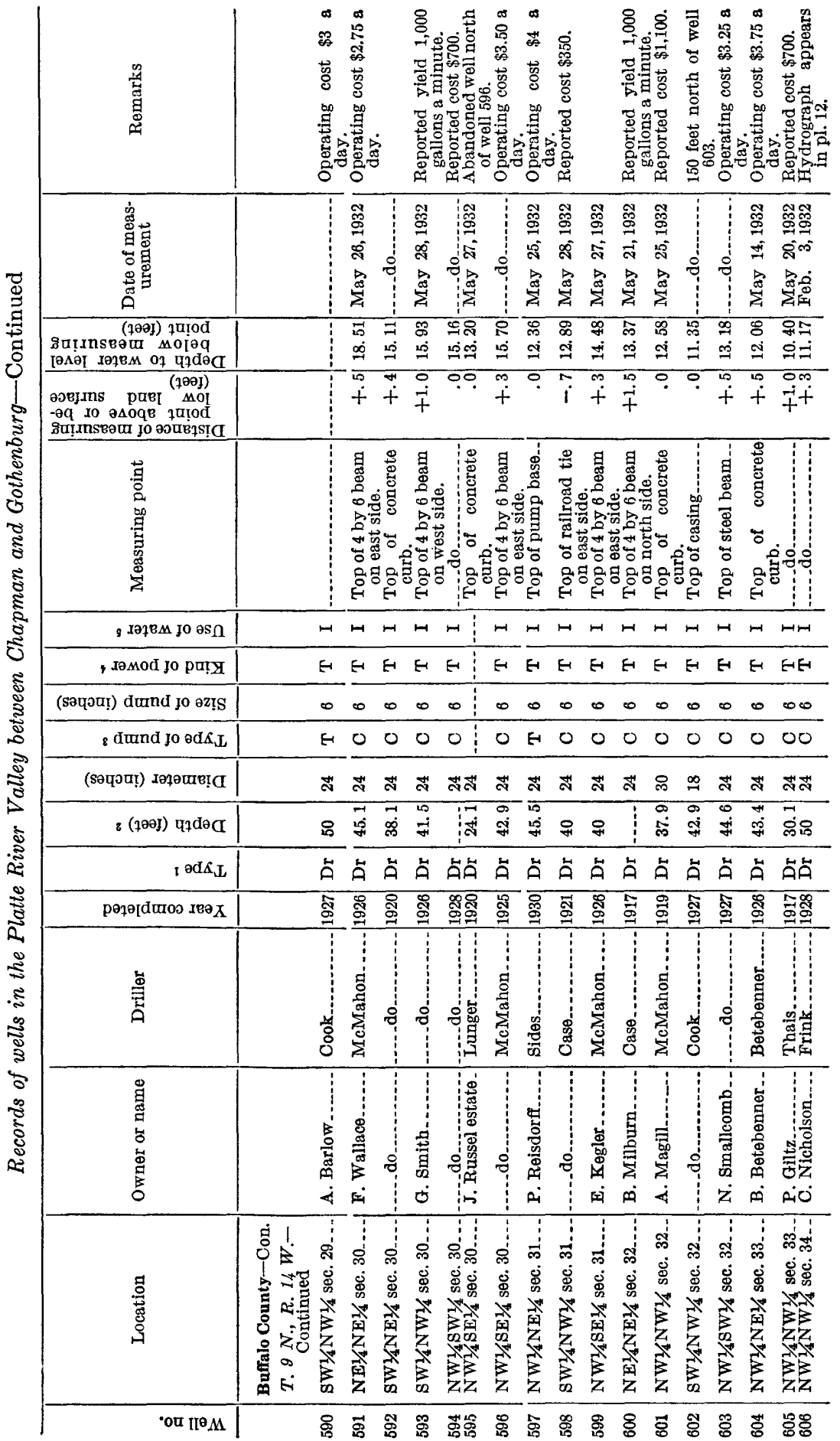




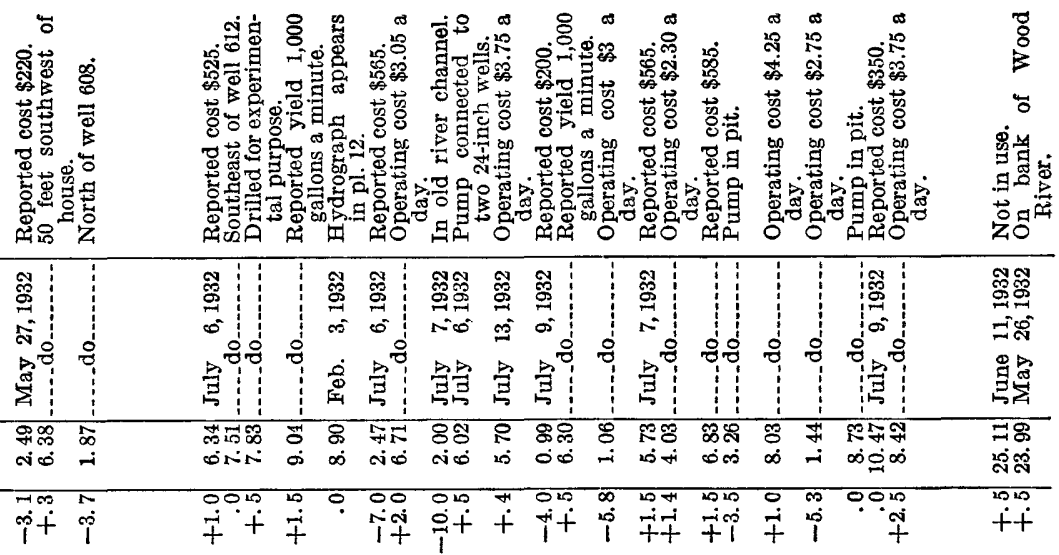

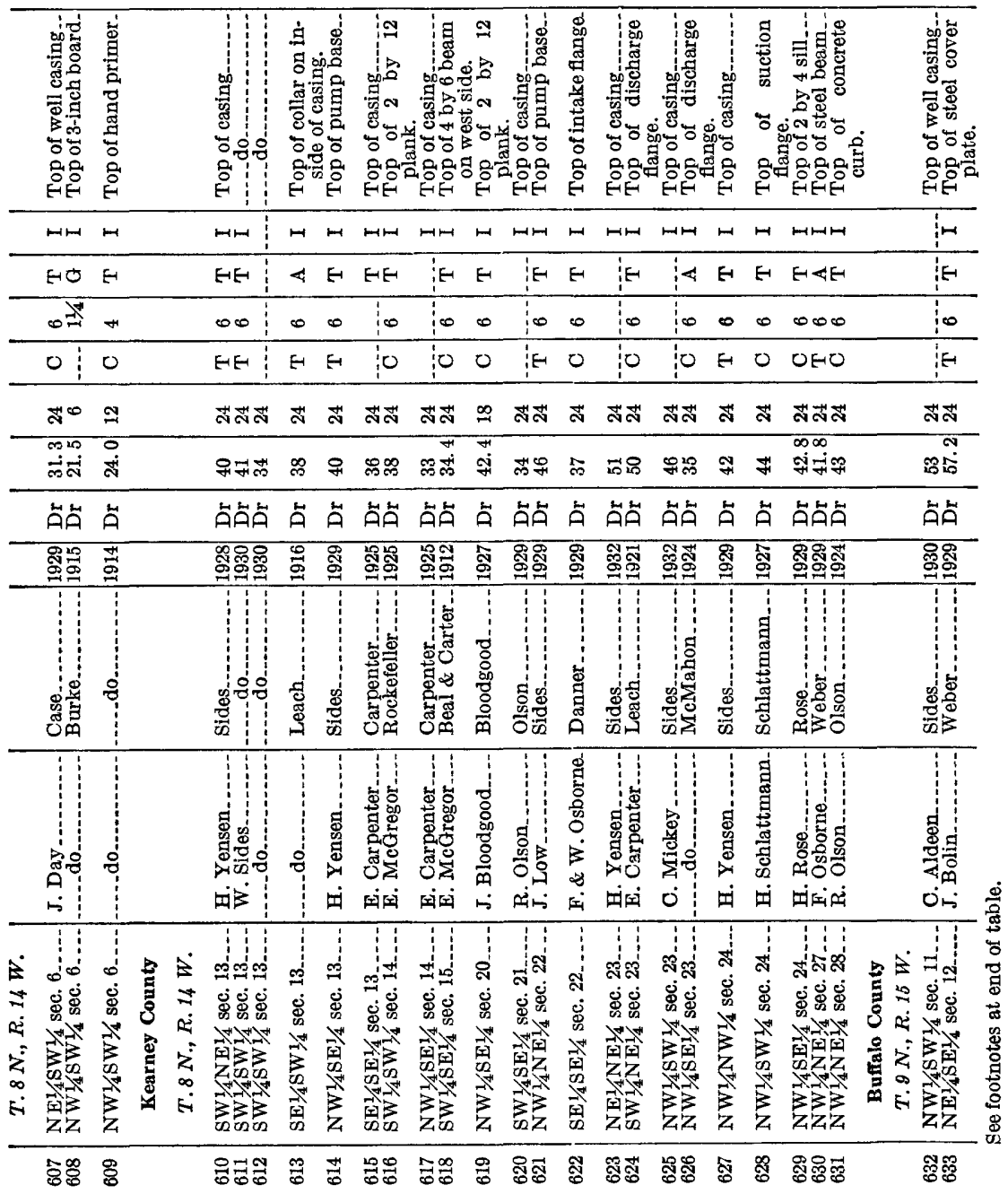




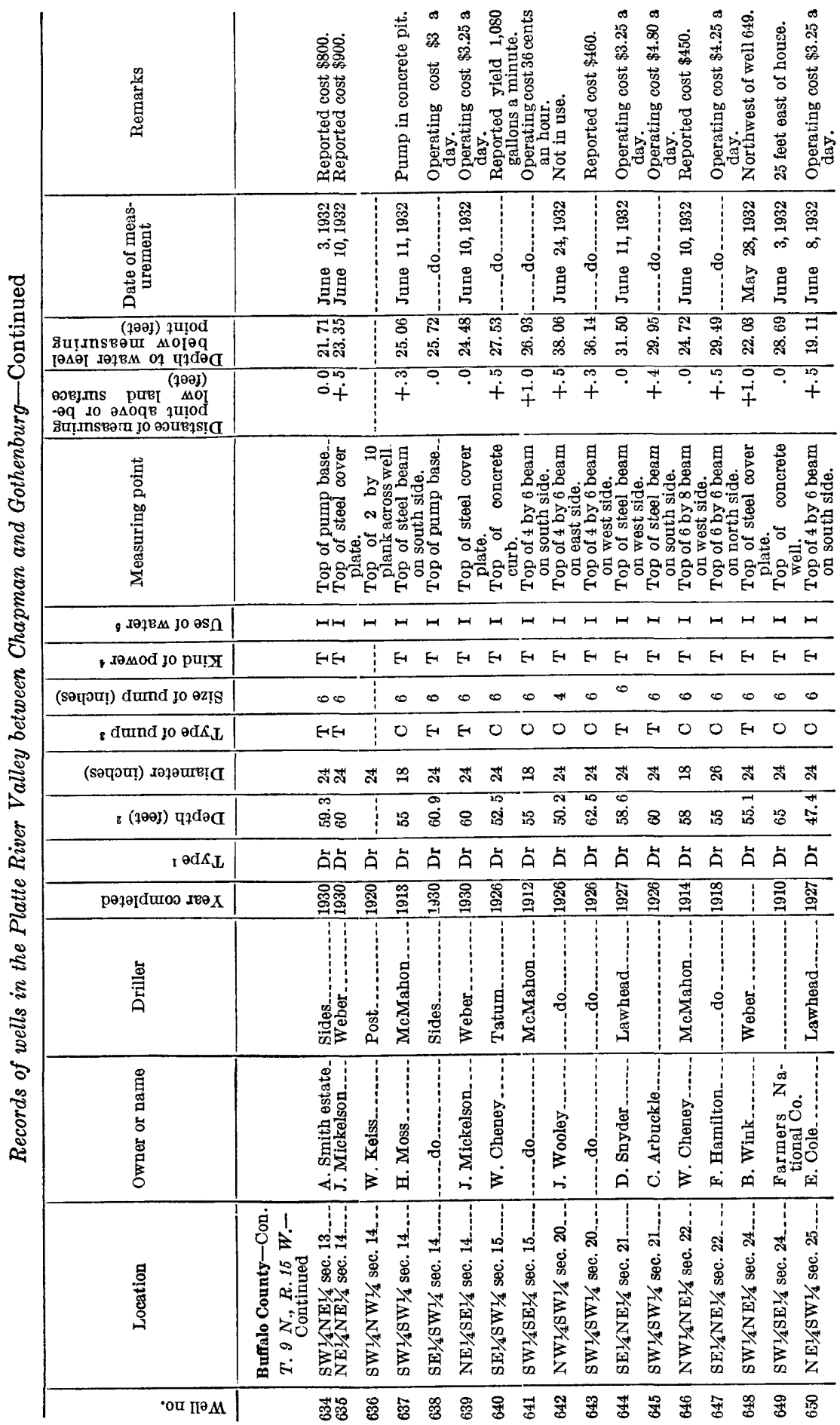




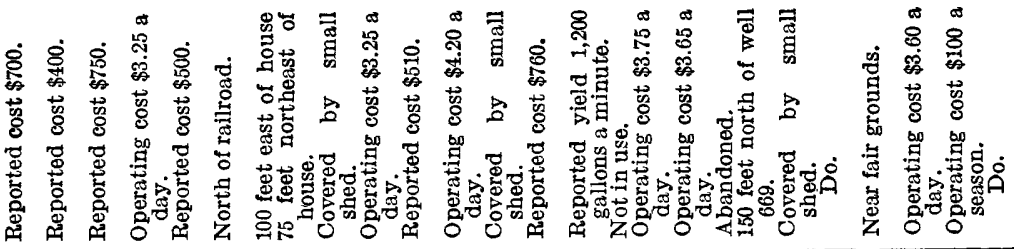

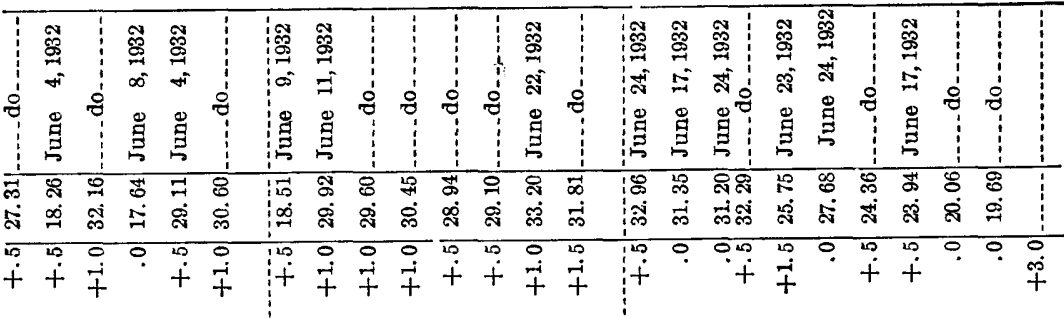

:

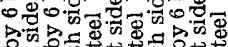

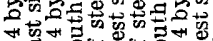

总

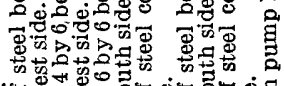

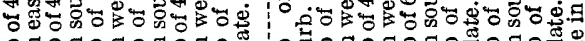

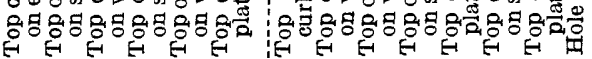

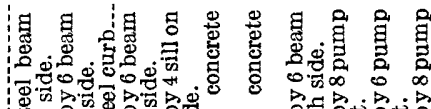

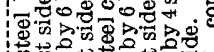
$\rightarrow \mathbb{\pi}_{\infty}^{\infty} \infty \infty_{\infty}^{\infty}$

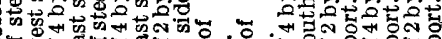

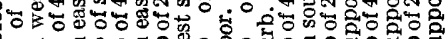
:

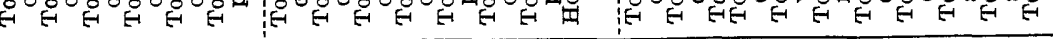

\begin{tabular}{|c|c|c|c|c|c|c|c|c|c|c|c|c|c|c|c|c|c|c|c|c|c|c|c|}
\hline$\mapsto$ & $\mapsto$ & $\mapsto$ & $\mapsto$ & $\mapsto$ & $\mapsto$ & $\mapsto \mapsto$ & $n$ & $\mapsto$ & $\mapsto$ & $\mapsto$ & $\mapsto$ & $m$ & 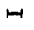 & $\mapsto \mapsto$ & 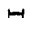 & ツル & $H$ & $\mapsto$ & $m$ & $\mapsto$ & $\mapsto$ & $M$ & $n$ \\
\hline$E$ & $E$ & $E-1$ & $E$ & E & $E$ & $E \in$ & E & E & $E$ & $E$ & $E-1$ & E & $E-1$ & EHE & $E$ & & 4 & 4 & 回 & $E-1$ & 되 & 되 & 보 \\
\hline$\infty$ & 0 & 0 & 0 & $\infty$ & 0 & $\infty \pi$ & 0 & $\infty$ & 0 & $\infty$ & $\infty$ & 0 & $\infty$ & 0 & $\infty$ & & $\#$ & $\forall$ & 200 & 0 & $\infty$ & $\infty$ & \\
\hline 0 & 0 & E & 0 & 0 & $E$ & 00 & 0 & 0 & 0 & E & 0 & $E$ & $E-1$ & $O E-1$ & 0 & & 0 & 0 & 0 & 0 & 0 & 0 & \\
\hline ¿゙ & H & స̈ & নี & 太 & ฝึ & 芯 & $\mathbb{N}$ & H & 今ं & సี & ثี & 乼 & Ë & $\stackrel{\infty}{\rightarrow}$ & त & & $\stackrel{\infty}{\sim}$ & $\stackrel{\infty}{\infty}$ & ث & H & $\ddot{N}$ & 心 & \\
\hline io & ! & लె口 & $\begin{array}{l}0 \\
\text { in }\end{array}$ & m & லి & : & $\dot{0}$ & in & $\stackrel{0}{\circ}$ & is & 10 & Di & ले & $\mathscr{7}$ & กี่ & वें & 2 & ब & व. & भु & @ & fi & \\
\hline
\end{tabular}

ล̆

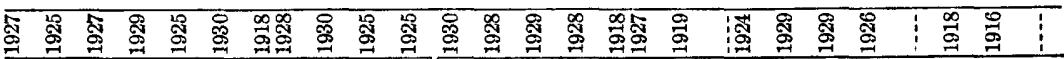

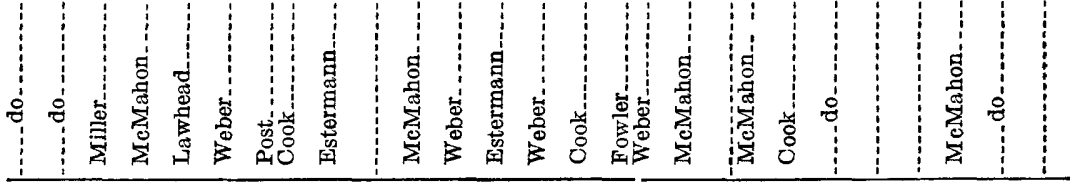

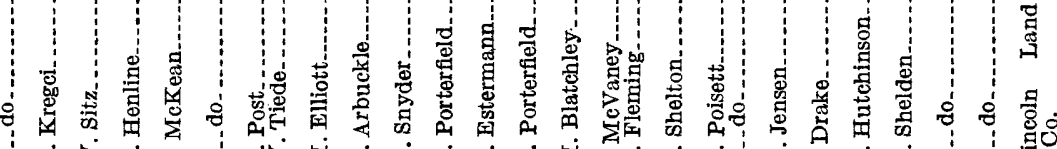

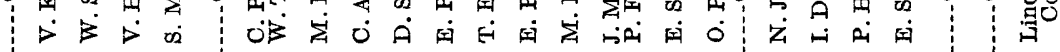
!) \&

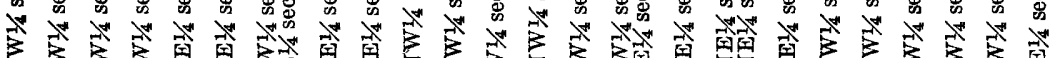

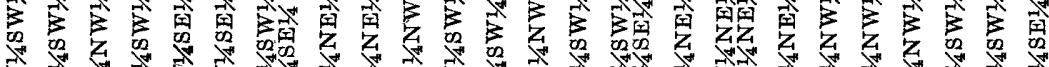
है

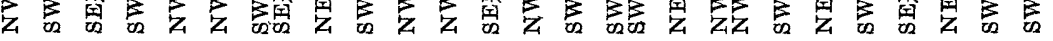

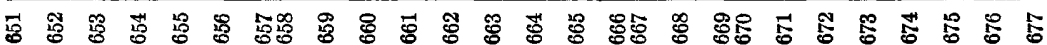




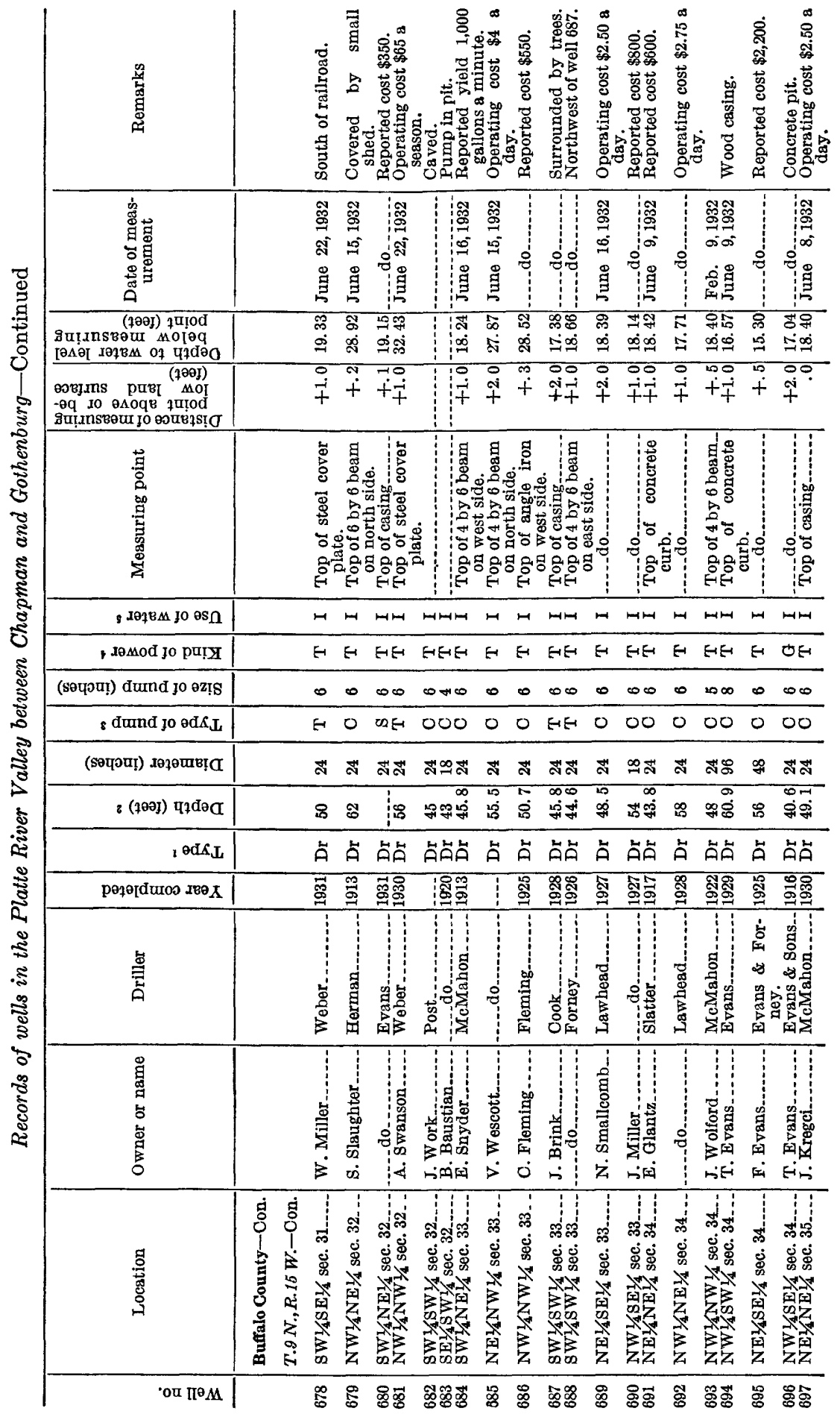




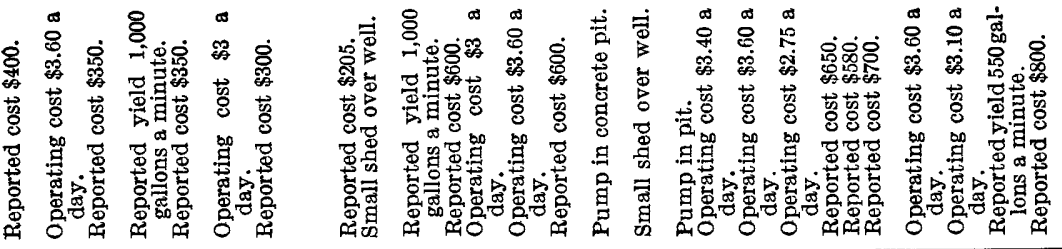

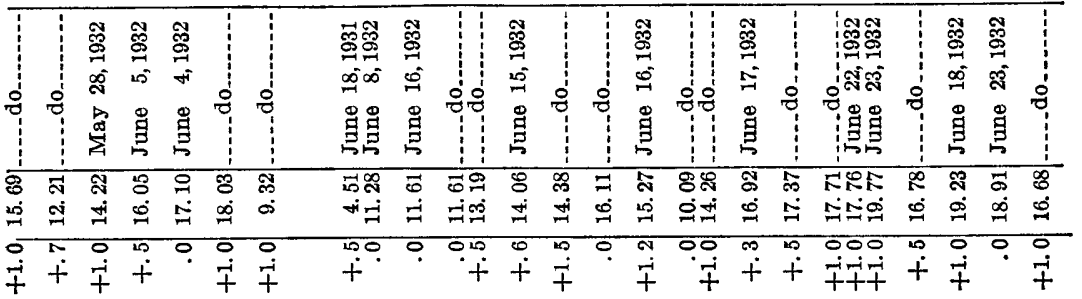

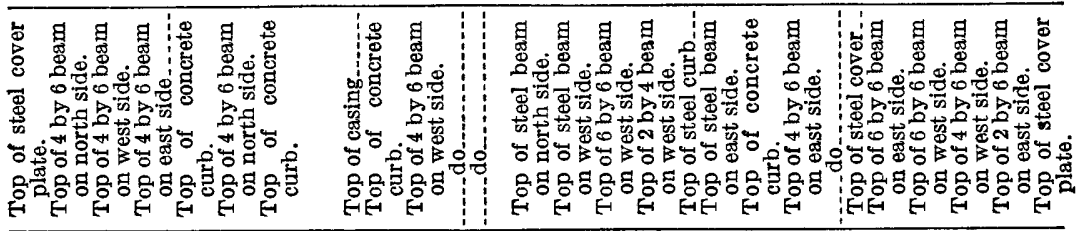

\begin{tabular}{|c|c|c|c|c|c|c|c|c|c|c|c|c|c|c|c|c|c|c|c|c|c|}
\hline$H$ & $H$ & $H$ & $\mapsto$ & $\mapsto$ & $m$ & $\mapsto$ & HII & $m$ & math & $\mapsto$ & $\mapsto$ & $\mapsto$ & $H$ & $\mapsto \mapsto$ & $M$ & $m$ & ロルル & $M$ & $m$ & $\boldsymbol{H}$ & $\mapsto$ \\
\hline E- & E- & $E-1$ & $E-1$ & $E-1$ & $E-$ & E- & 40 & E & $E-1 F$ & E- & $E$ & $E-1$ & E & $E-E-1$ & E & E- & EE-E & E & E & $E$ & $E$ \\
\hline 0 & 0 & 0 & $\infty$ & $\infty$ & 0 & $\infty$ & $+\infty$ & $\infty$ & $\infty$ & $\bullet$ & $\infty$ & $\bullet$ & 0 & $-\infty$ & + & 0 & $\infty$ & $\bullet$ & $\infty$ & $\infty$ & $\infty$ \\
\hline E & 0 & 0 & 0 & 0 & 0 & 0 & 00 & 0 & 00 & 0 & 0 & 0 & 0 & 00 & 0 & 0 & OEO & 0 & 0 & 0 & $E$ \\
\hline
\end{tabular}

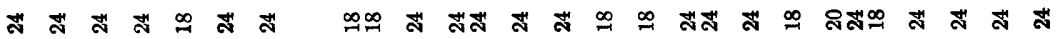
ஸ †

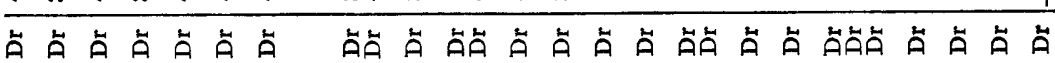

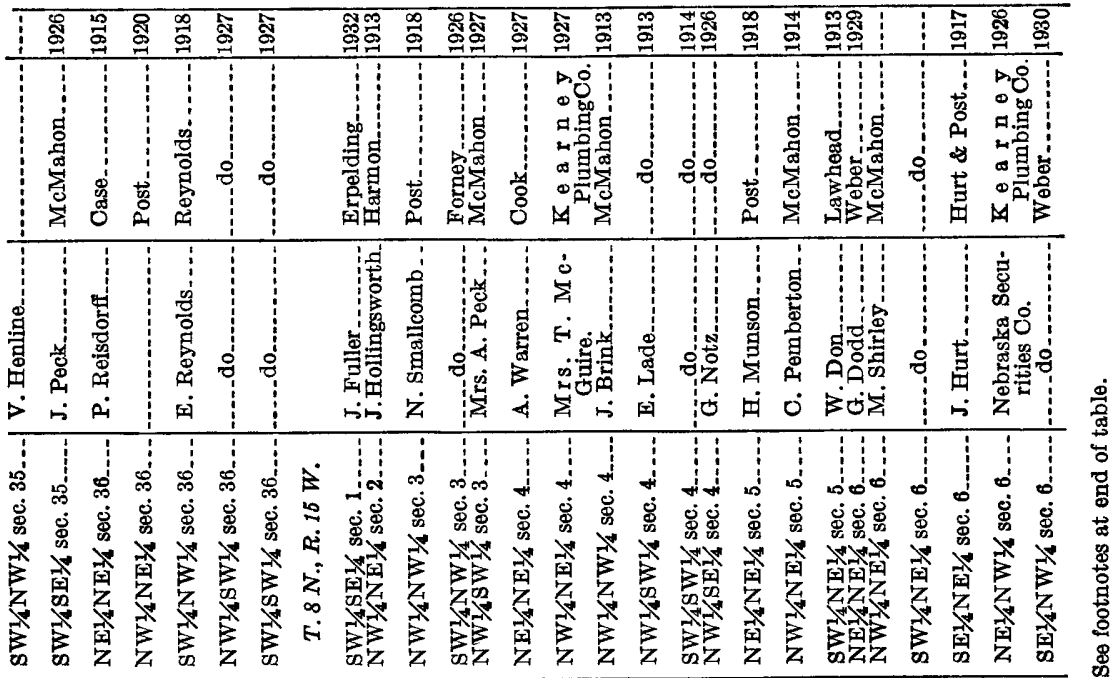

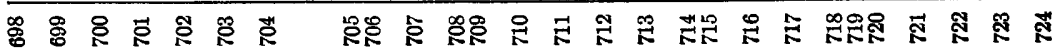




\begin{tabular}{|c|c|c|c|c|c|c|c|c|c|c|}
\hline 密 & 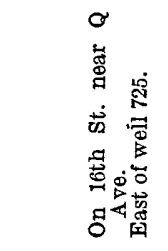 & 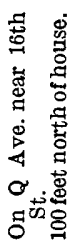 & 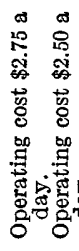 & 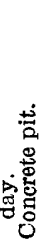 & 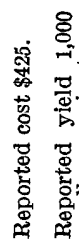 & 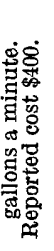 & 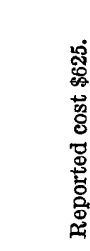 & 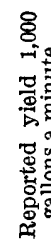 & & 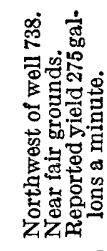 \\
\hline 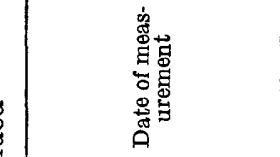 & 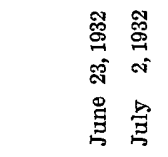 & 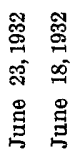 & 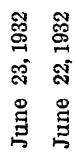 & $\begin{array}{l}\text { 怘 } \\
\text { â } \\
\text { 点 }\end{array}$ & 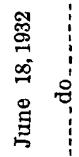 & 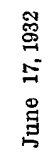 & 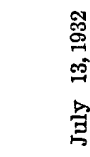 & 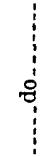 & & 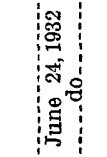 \\
\hline 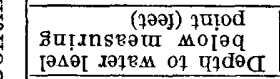 & 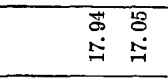 & \begin{tabular}{ll}
\multirow{2}{*}{} & $\infty$ \\
0 & 0 \\
0 & $\infty$ \\
\end{tabular} & 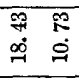 & $\begin{array}{l}5 \\
0 \\
9\end{array}$ & 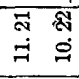 & $\begin{array}{l}\overrightarrow{0} \\
0\end{array}$ & $\underset{7}{ت}$ & i⿱ & & : \\
\hline 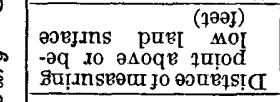 & $\begin{array}{l}\circ \\
\dot{+} \\
+\end{array}$ & $+\frac{7}{4}$ & के & 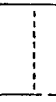 & $\stackrel{\circ}{+} \stackrel{0}{+}$ & $i$ & & & & $\begin{array}{l}100 \\
+7+7 \\
+4\end{array}$ \\
\hline 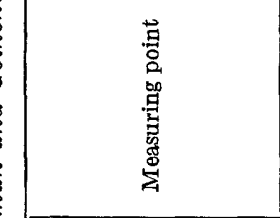 & 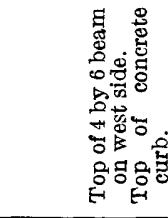 & 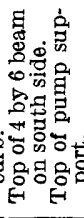 & 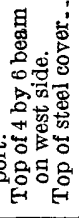 & 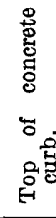 & 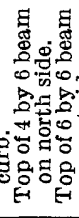 & 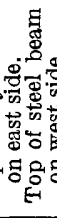 & 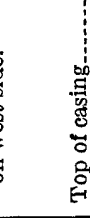 & 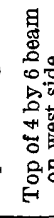 & & 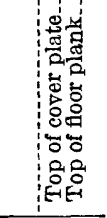 \\
\hline g JәңвM jo әS $\Omega$ & $W$ & $w W$ & $H W$ & 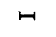 & $H-$ & $m$ & $r$ & $\omega$ & & ๒ルッ \\
\hline , дәмод уо ри! & H ठ ठ & $\Leftrightarrow \circlearrowright$ & $E E$ & $E$ & $O H$ & E & $E-1$ & E & & FEFII \\
\hline (sәपәuा) durnd jo əz!̣ & $0 \pi$ & 0 & 00 & 0 & 00 & 0 & 0 & $\circ$ & & 0000 \\
\hline${ }_{\varepsilon}$ dund jo $\theta d K_{\mathbb{L}}$ & 00 & $O \oplus$ & $O E$ & 0 & 00 & 0 & 0 & 0 & & $O E O$ \\
\hline 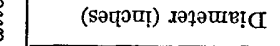 & む゙ & సే & $\stackrel{\infty}{\sim}$ & $\stackrel{\infty}{\sim}$ & ה & オ & ন & $\pi$ & & $\stackrel{\infty}{\infty} \infty$ \\
\hline 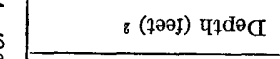 & $\begin{array}{lll}N & 1 \\
\text { gon } & 20\end{array}$ & $\stackrel{0}{\dot{*}} \stackrel{0}{\dot{H}}$ & 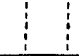 & $\overrightarrow{\mathfrak{s}}$ & 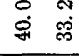 & 10 & F & $\begin{array}{l}\infty \\
\infty \\
\infty\end{array}$ & & 出宗 \\
\hline$\imath$ əब $\Lambda_{\amalg}$ & 䓃 & 㟔 & 莒 & $\dot{A}$ & 㟔 藏 & $\dot{A}$ & $\stackrel{5}{A}$ & 台 & & ค̆คัค̆ค \\
\hline 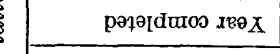 & 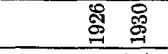 & 总 & $\begin{array}{ll}\mathscr{8} \\
\end{array}$ & 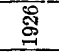 & 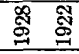 & $\$$ & $\stackrel{\mathscr{g}}{9}$ & & & 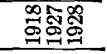 \\
\hline 总 & 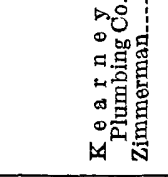 & 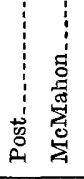 & 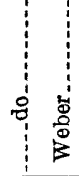 & : & 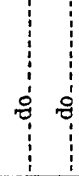 & ס̊ & 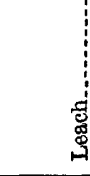 & 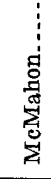 & & 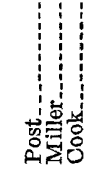 \\
\hline 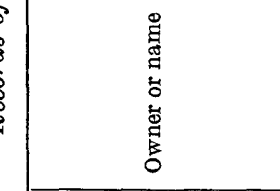 & 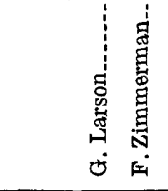 & 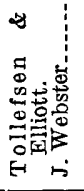 & 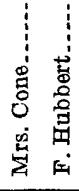 & 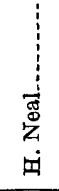 & 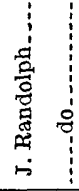 & 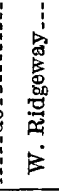 & 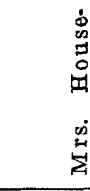 & : & & 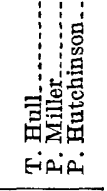 \\
\hline 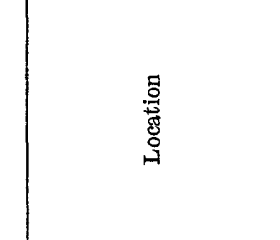 & 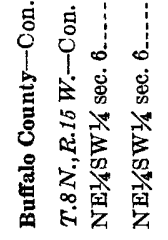 & 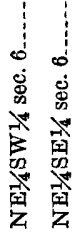 & 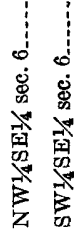 & 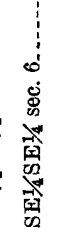 & 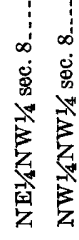 & 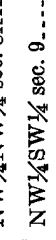 & 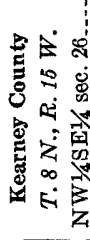 & 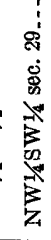 & & 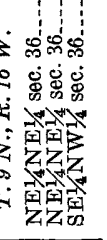 \\
\hline ० ou II⿵M & : జ & సิ ฉ & 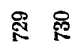 & $\overrightarrow{\mathscr{R}}$ & 承 & ? & 筑 & ஜ̊ & & 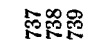 \\
\hline
\end{tabular}




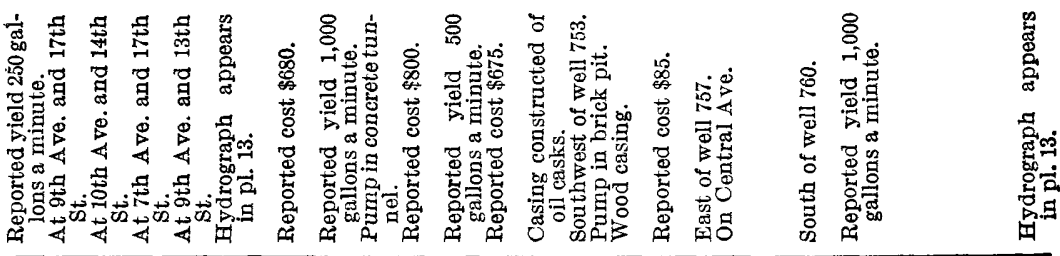

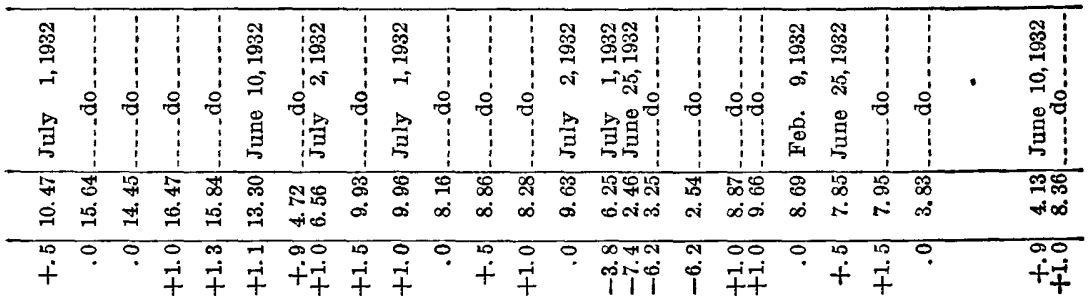

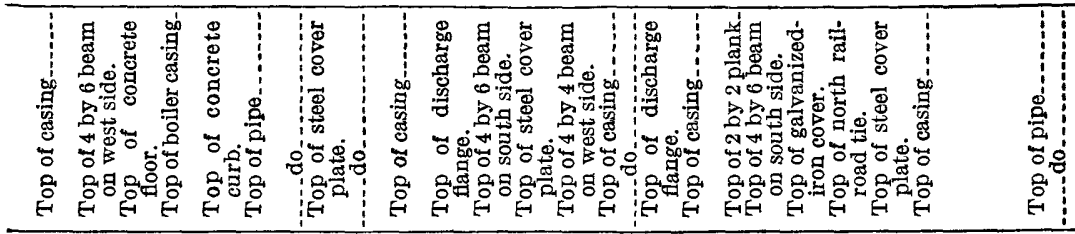

MH HWH

О О

a

O O O O O O O

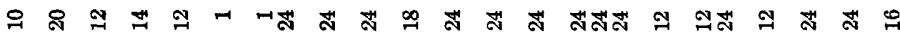

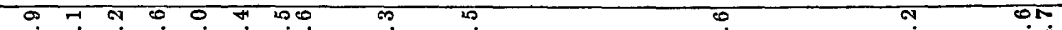

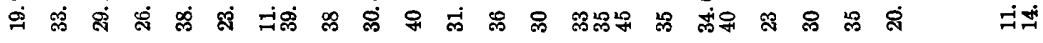

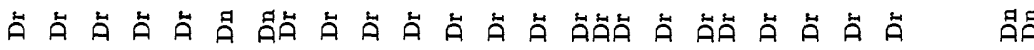

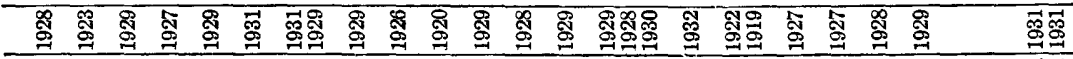

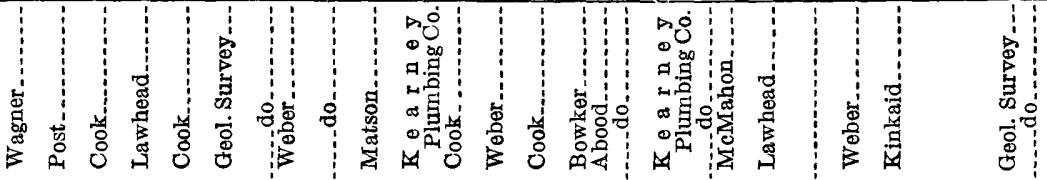

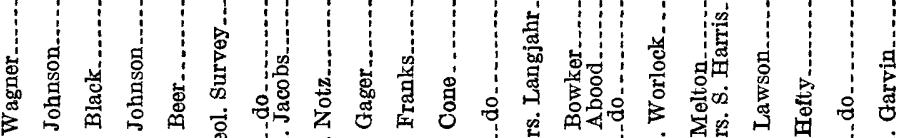

i.

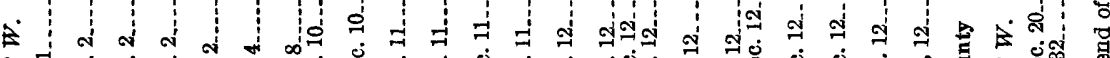

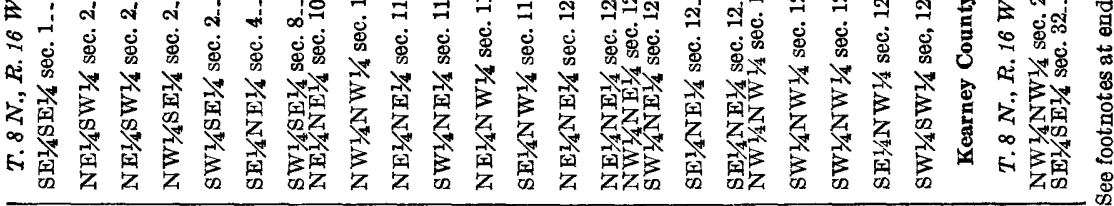

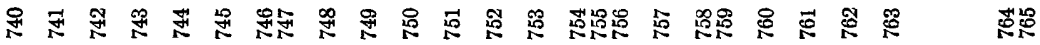




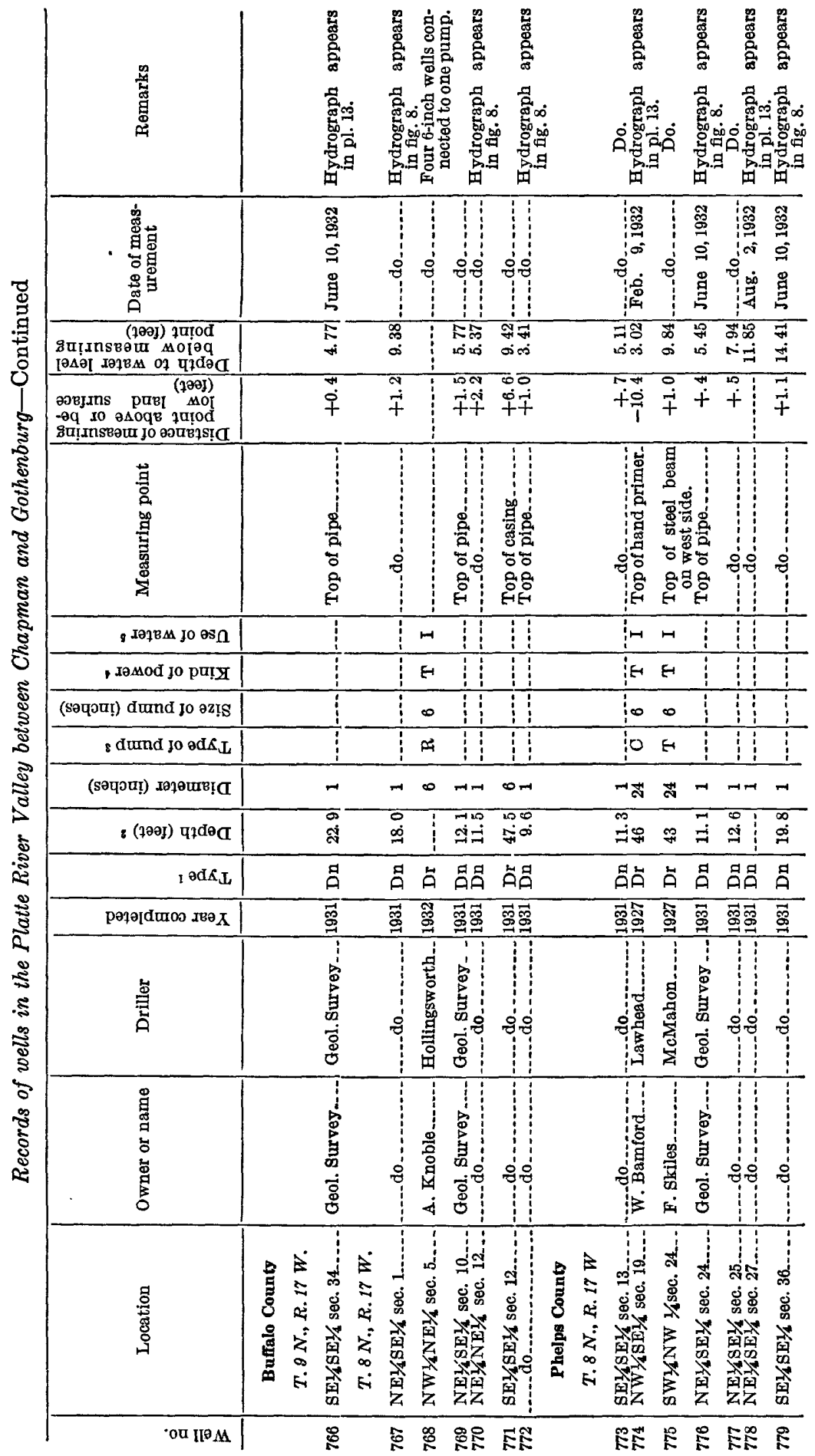




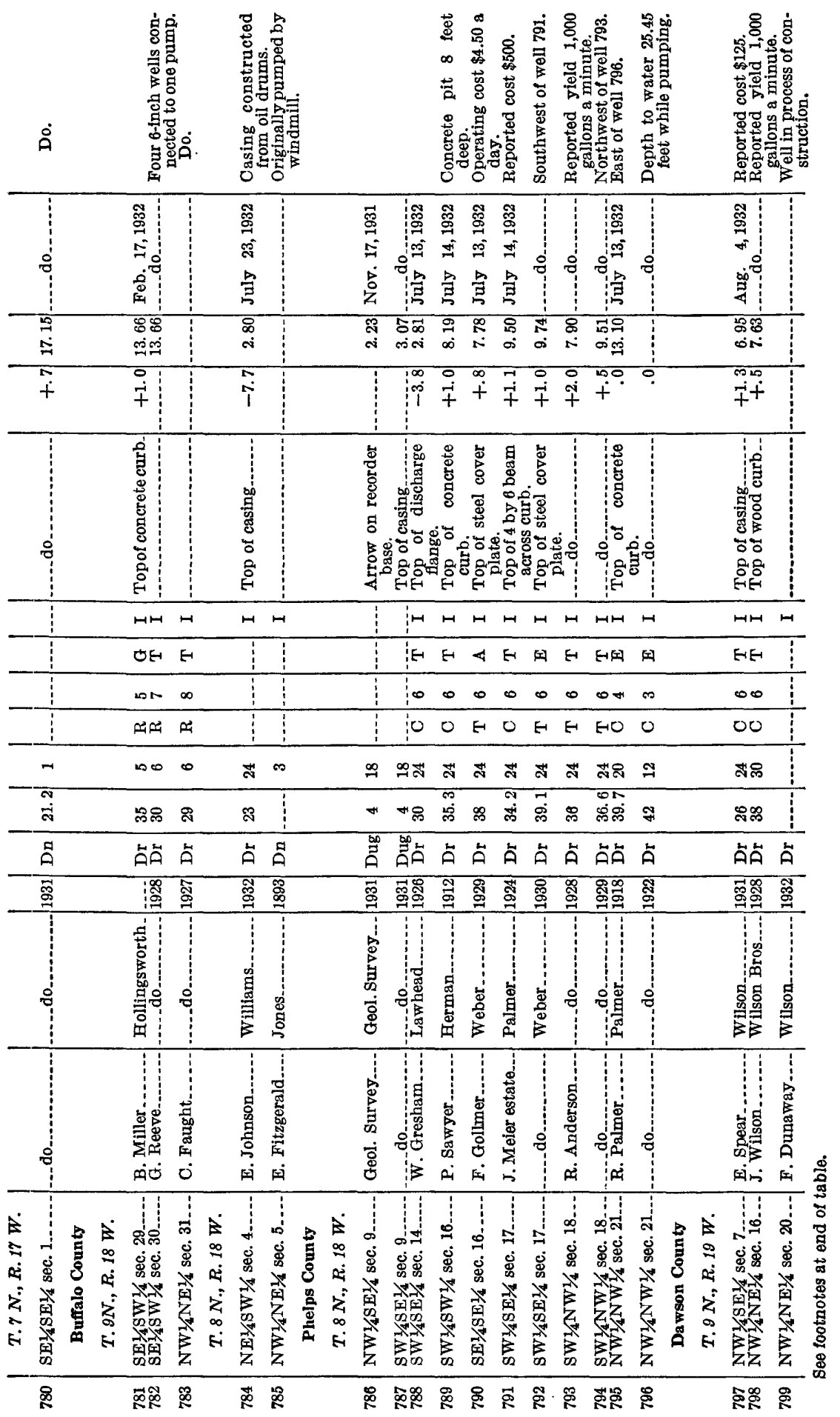




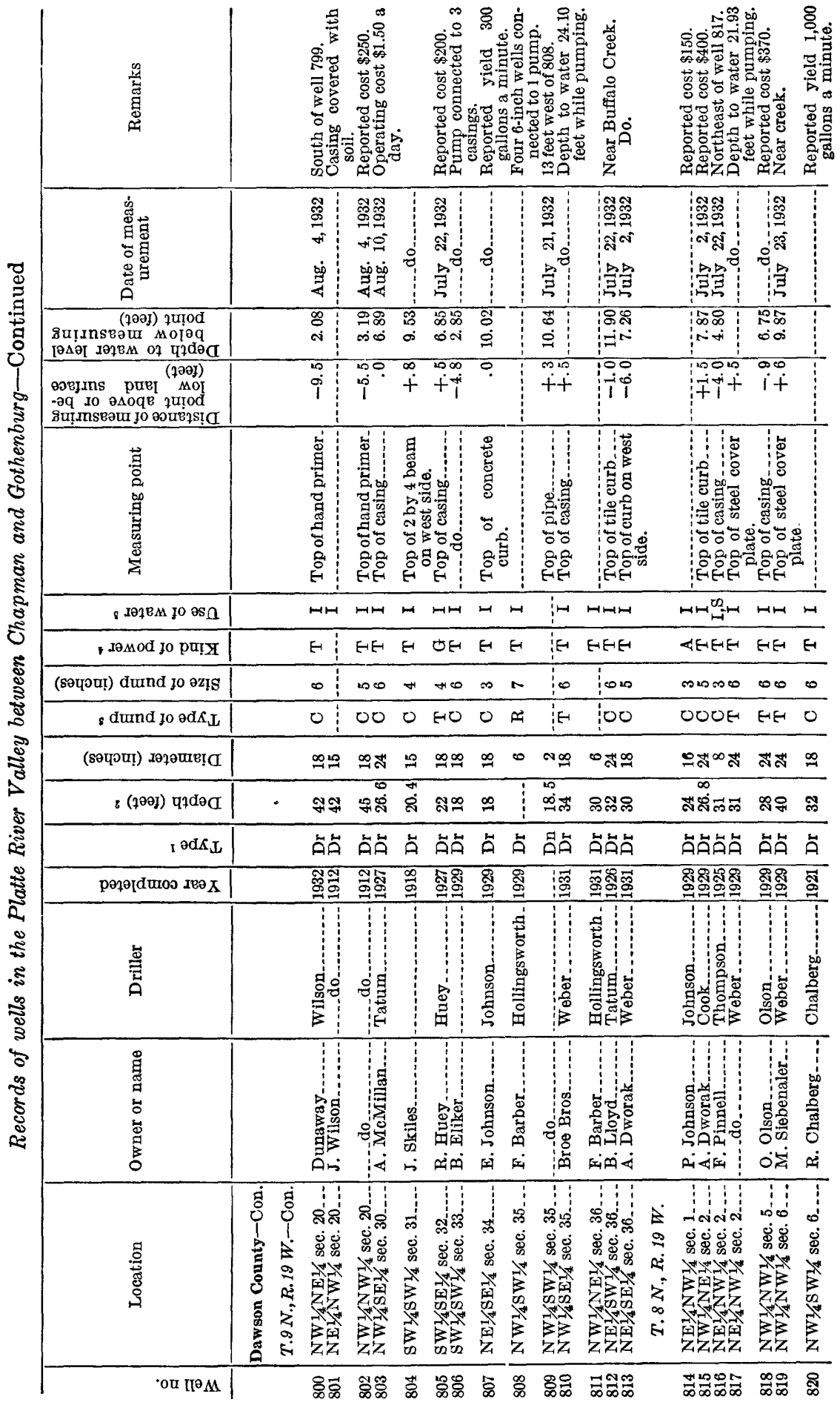



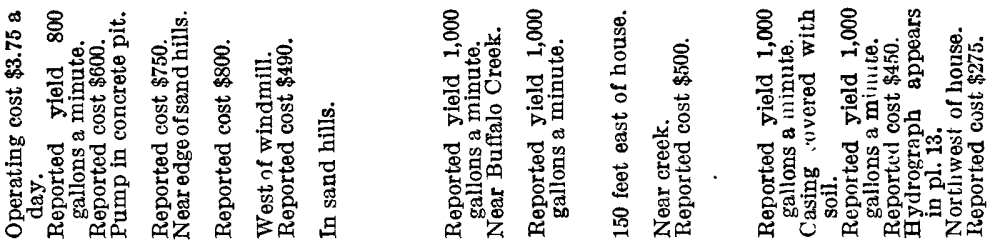

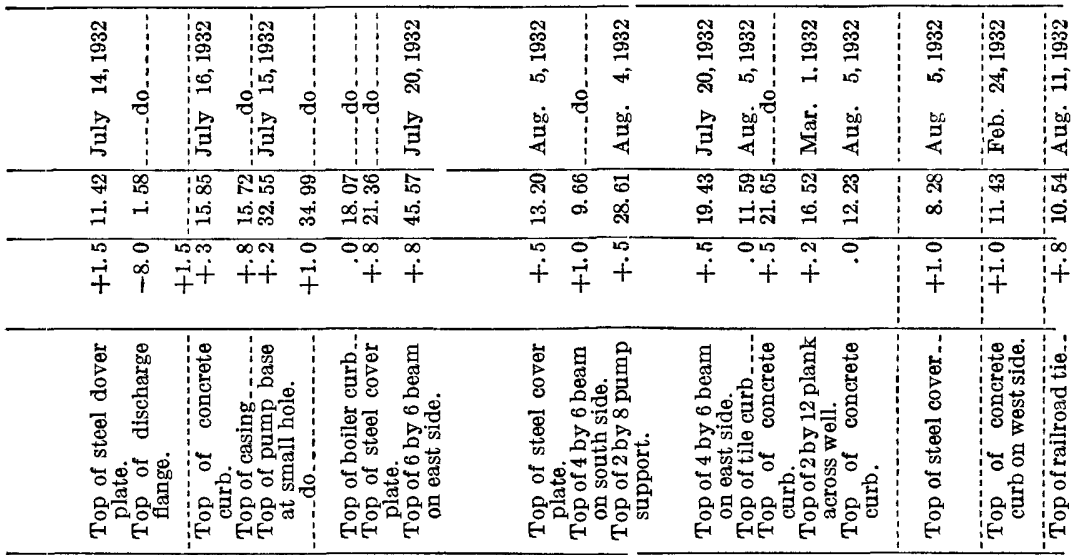

\begin{tabular}{|c|c|c|c|c|c|c|c|c|c|c|c|c|c|c|c|c|c|}
\hline$\mapsto$ & $\mapsto$ & ロル & ஈル & $m$ & ロル & $\mapsto$ & $\mapsto$ & $\mapsto$ & $\mapsto$ & $\mapsto$ & ஈル & $\mapsto$ & $\mapsto$ & $\mapsto$ & $\mapsto$ & ウル & ஈル \\
\hline E & $E$ & $E-4$ & $E-H$ & $E$ & सE & $E-1$ & E & $E$ & $E$ & $E$ & E-E & 0 & $E-$ & & $E$ & EHE & EE \\
\hline$\infty$ & مמ & $\infty 0$ & $\infty$ & $\infty$ & $\infty 0$ & هـ & $\infty$ & $\infty$ & $\infty$ & 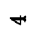 & Wo & $\infty$ & مه & & $\infty$ & $\infty$ & + \\
\hline$E$ & 0 & EOO & EE & E & EH & 0 & E & 0 & 0 & 0 & 00 & 0 & 0 & & $E$ & 00 & \\
\hline
\end{tabular}

নี

太せ

迥 ล

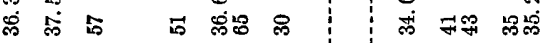

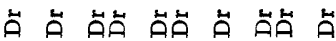

㟔 藏

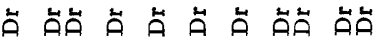

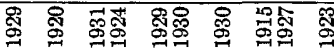

蛋 券

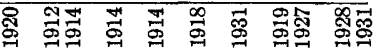

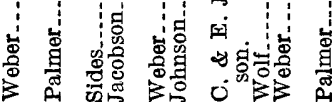

若泀

要

¿̊

要

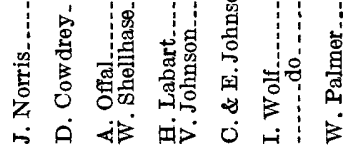

密

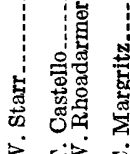

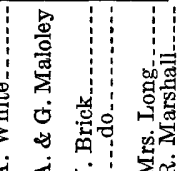

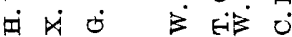

$\dot{9}$

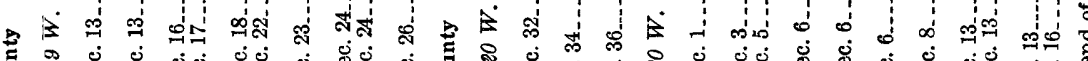

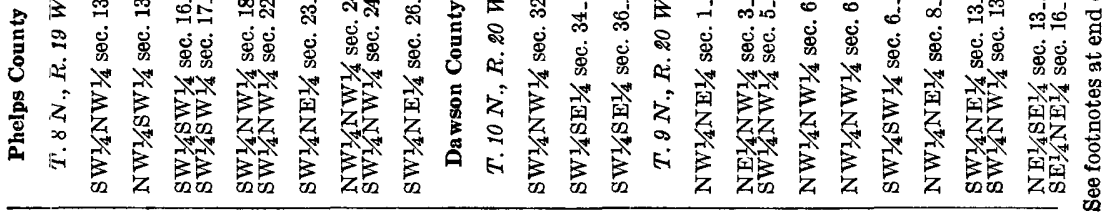

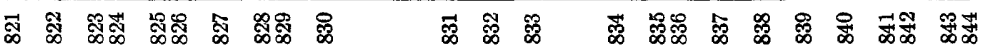




\begin{tabular}{|c|c|c|c|c|c|c|c|c|}
\hline 递 & & 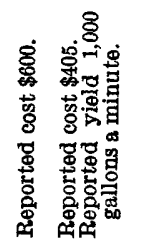 & 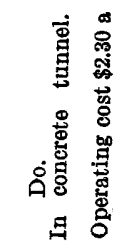 & 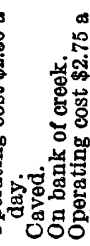 & 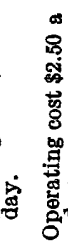 & . & & 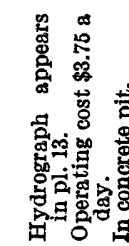 \\
\hline 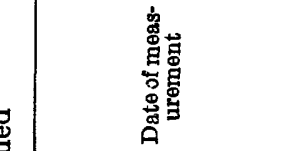 & & 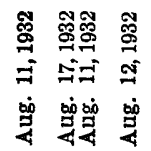 & 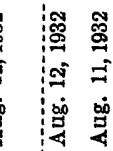 & 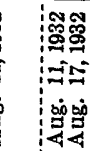 & 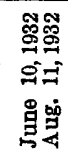 & 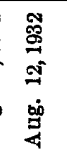 & & 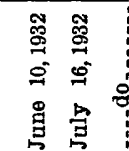 \\
\hline 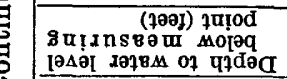 & & 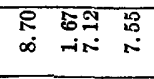 & 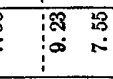 & 永右 & \&্ర & $\stackrel{\infty}{\infty}$ & & 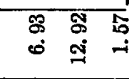 \\
\hline 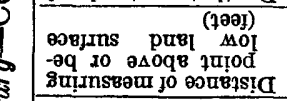 & & 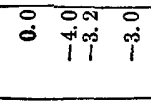 & 10 & i & $i_{+\infty}^{\infty}+i$ & & & +20 \\
\hline 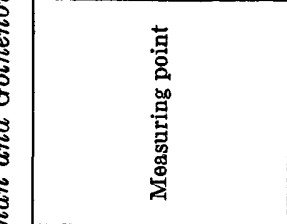 & & 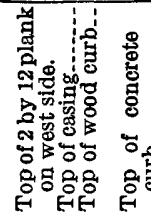 & 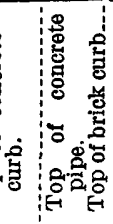 & 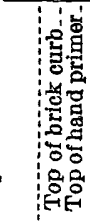 & 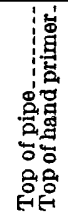 & 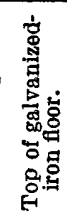 & & 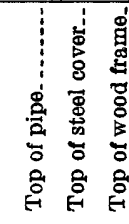 \\
\hline 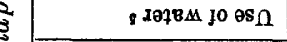 & & H HH H & HW & HயH & - & $\rightarrow$ & & $\rightarrow H$ \\
\hline , дөмод jo pu!X & & E EH & EO $E$ & EHEE & 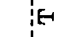 & $\mathrm{E}$ & & F $E$ \\
\hline (sөपәu!) dund jo əz!̣ & & 0 L 0 & $\infty N$ & 000 & $\infty$ & 0 & & 00 \\
\hline${ }_{\varepsilon}$ dund jo ad $s_{\mathbb{L}}$ & & 000 & 000 & 000 & 0 & 0 & & E \\
\hline (รәчәп!) дәұәшитฺ & & $\overparen{A} \stackrel{\infty}{=} \stackrel{\infty}{=}$ & 太む゙ & $\stackrel{\infty}{\sim} \underset{\sim}{\infty}$ & $-\pi$ & ה & & $\neg \stackrel{\infty}{=}$ \\
\hline 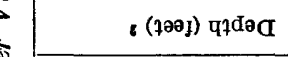 & & 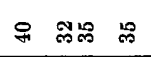 & Fॄ் & 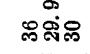 & స̊ำ & 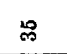 & & $\stackrel{+}{\sharp}$ 욤 \\
\hline $\boldsymbol{v} \theta \mathrm{d} K_{\mathbb{L}}$ & & 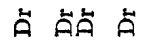 & คัด̆ คั & คืคัด้ & คีคั & Ă & & คี \\
\hline 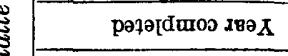 & & 离密实 & 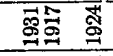 & 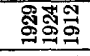 & 敬 & 药 & & 駡 惡 哥 \\
\hline 弮 & & 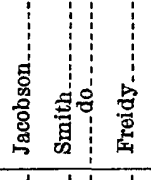 & 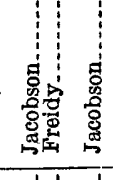 & 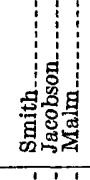 & 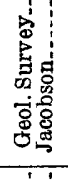 & 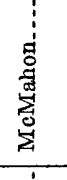 & & 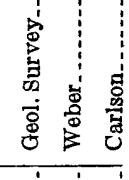 \\
\hline 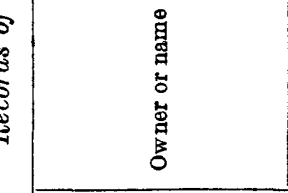 & & 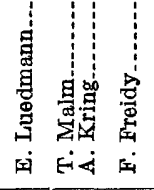 & 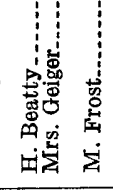 & 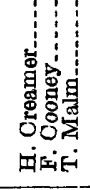 & 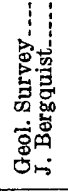 & 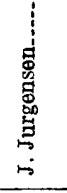 & & 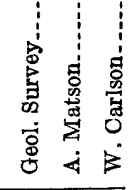 \\
\hline 芯 & 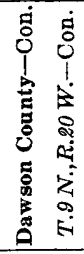 & 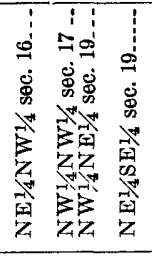 & 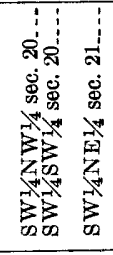 & 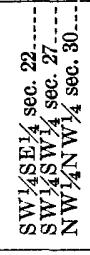 & 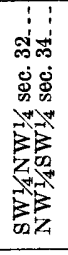 & 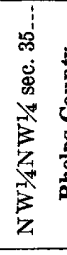 & 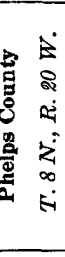 & 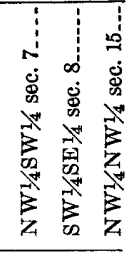 \\
\hline & & 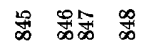 & 橎品 $\overrightarrow{0}$ & 硧落 & 迢品 & 拿 & & 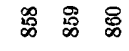 \\
\hline
\end{tabular}




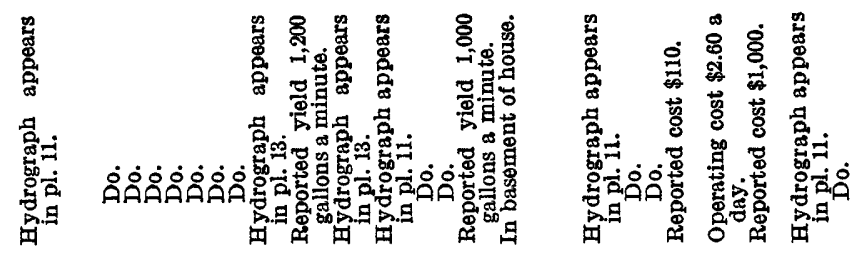

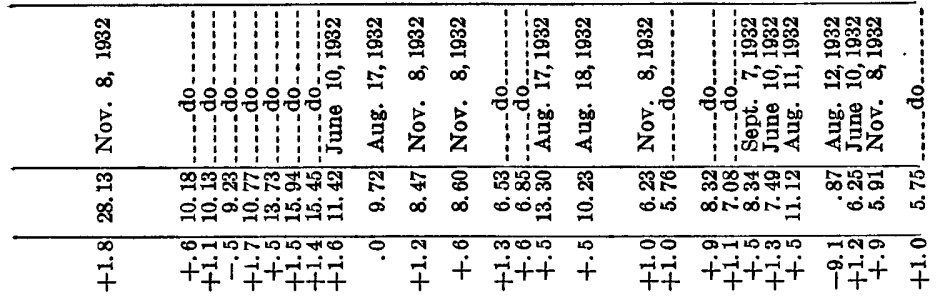

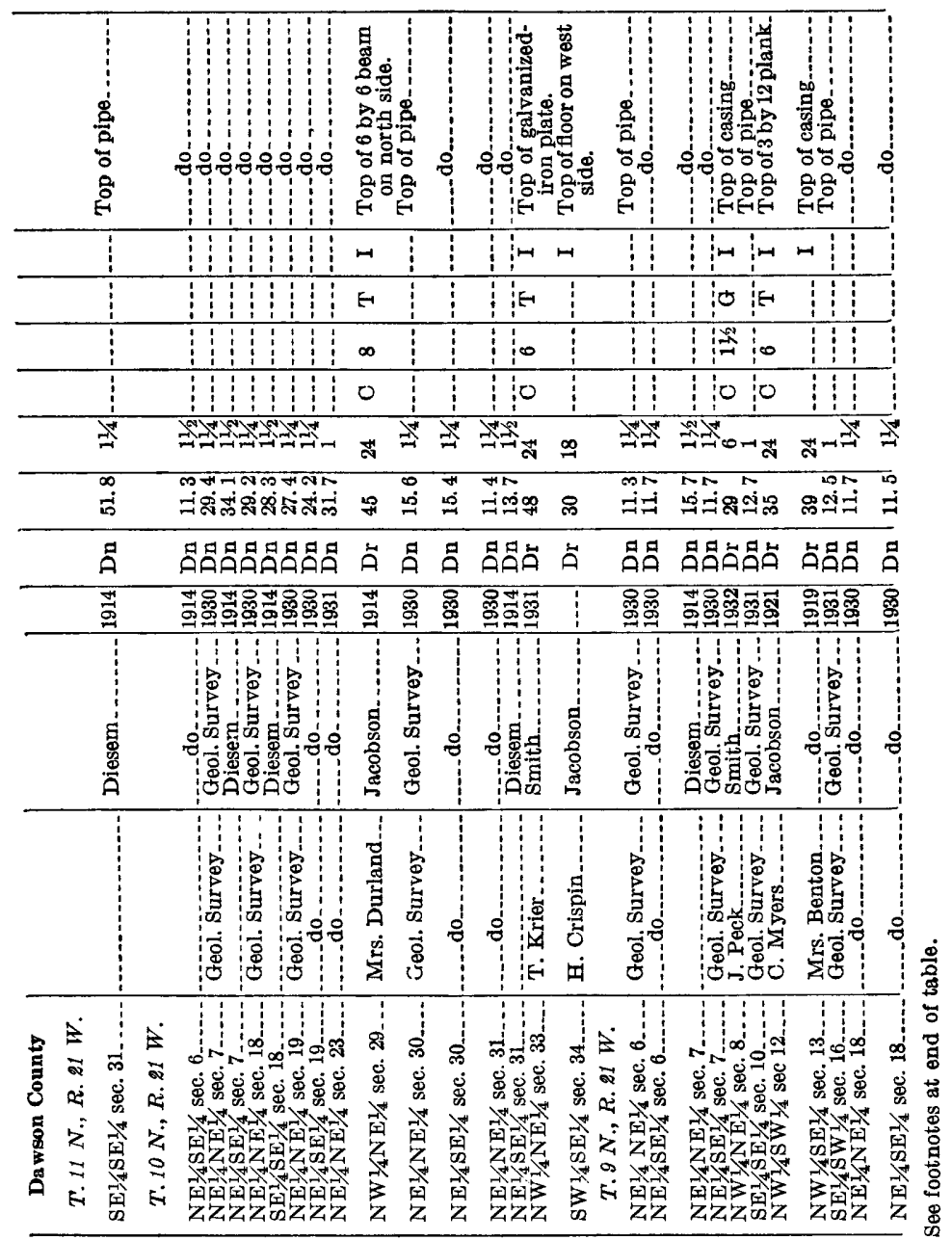

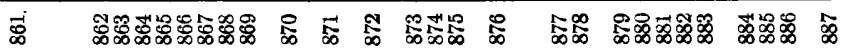




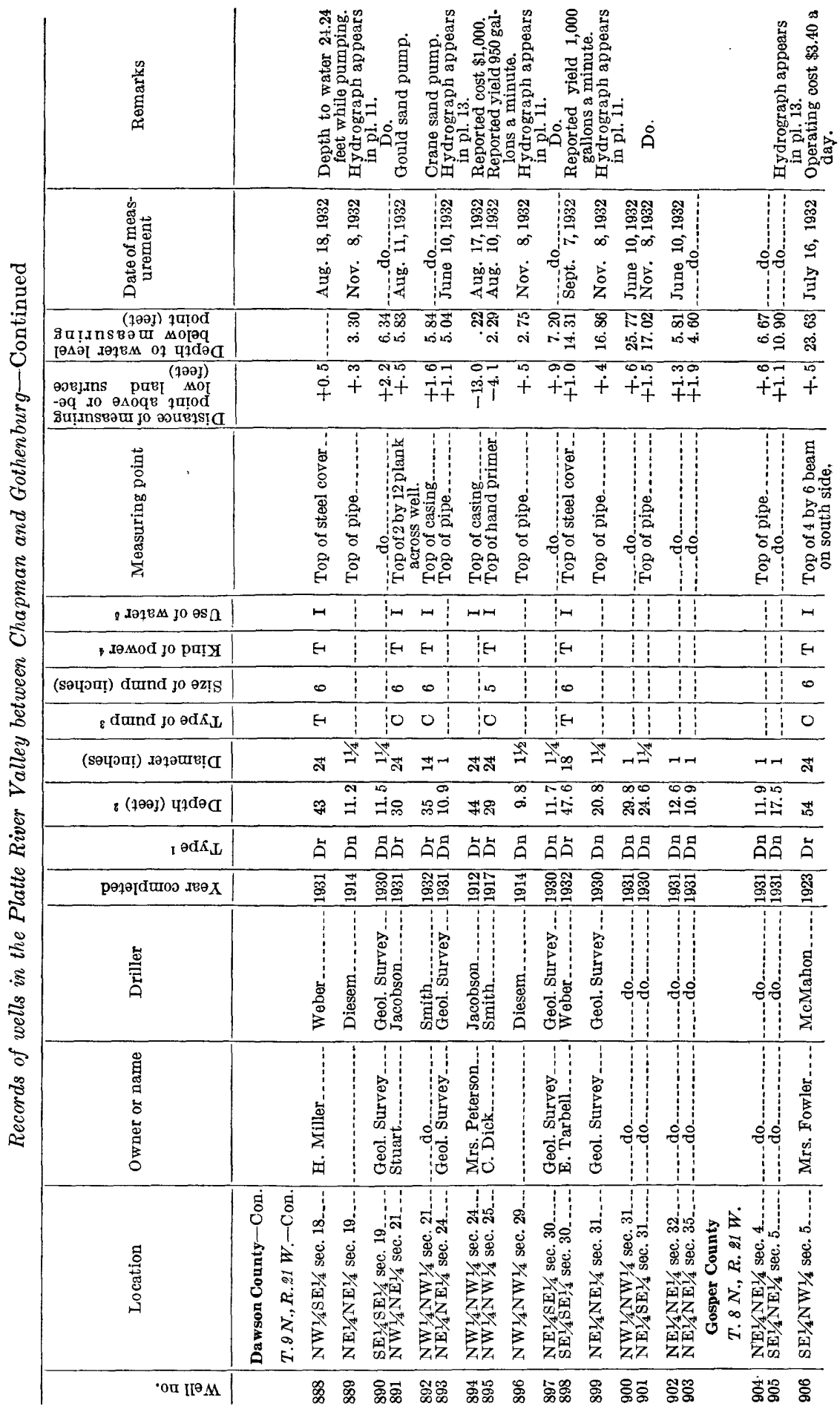




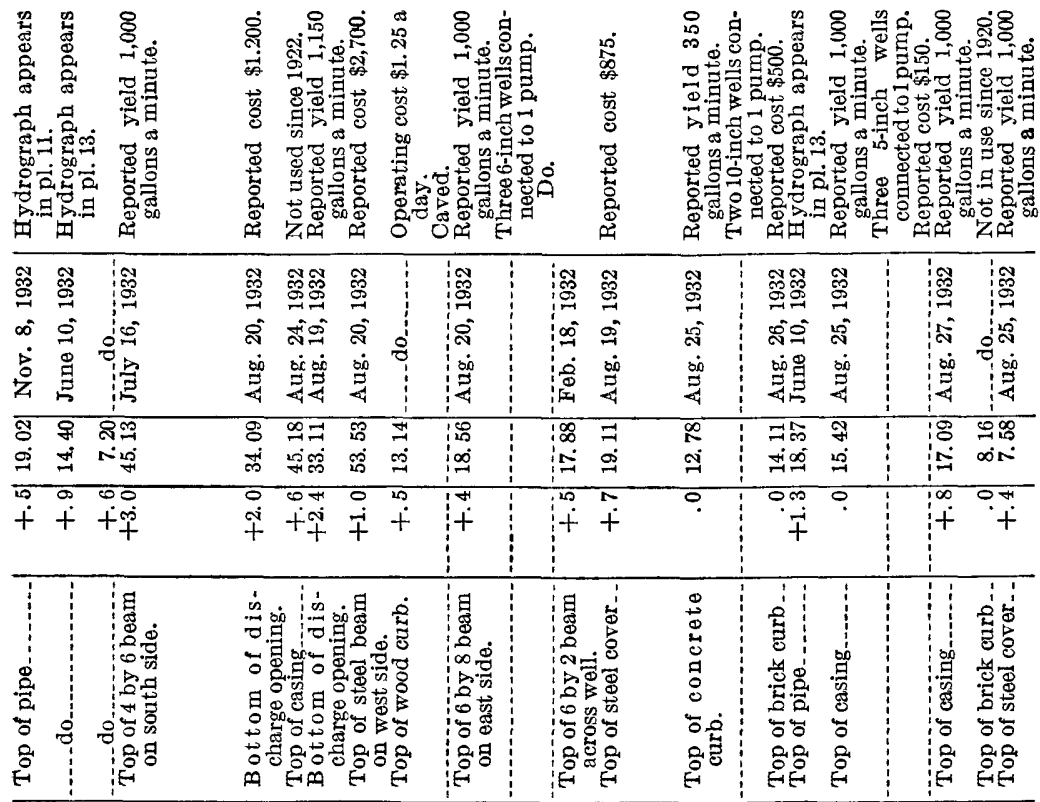

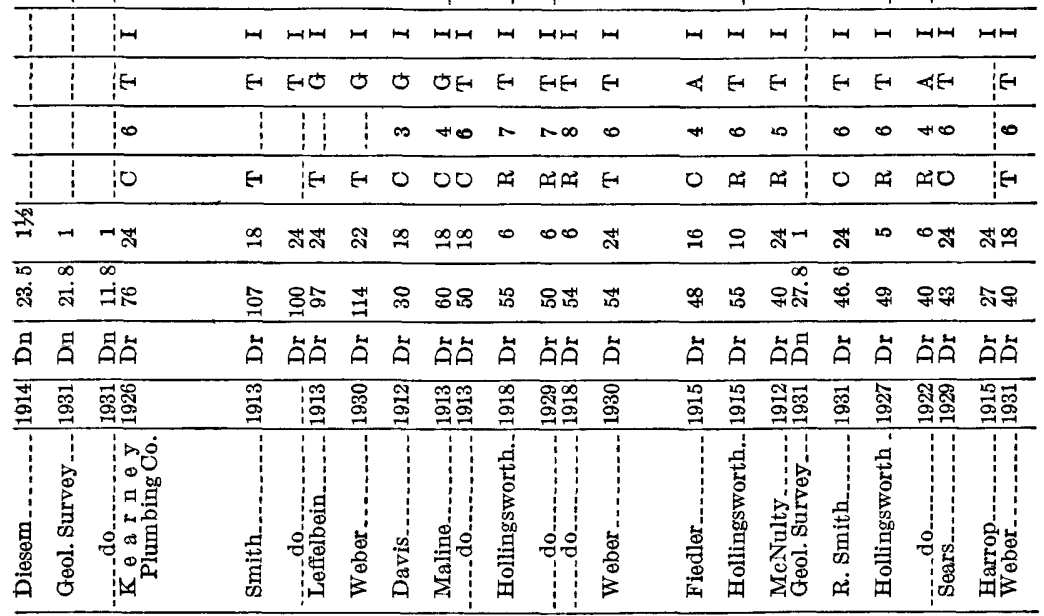

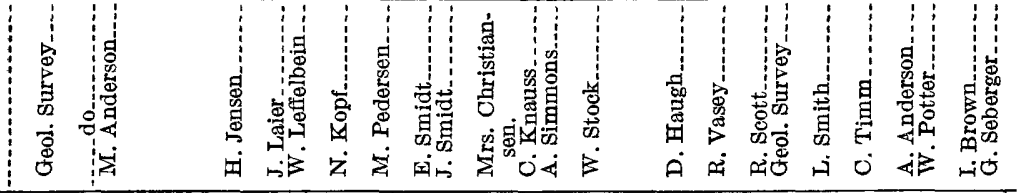

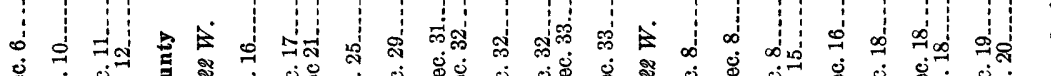

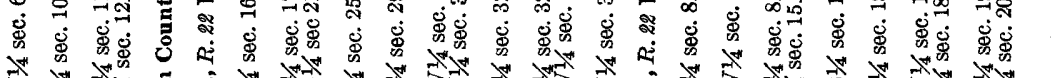

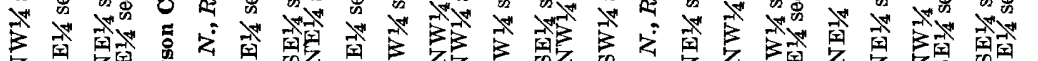

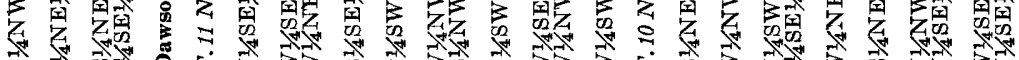

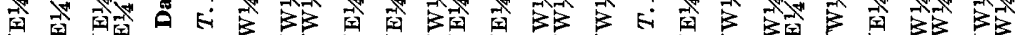

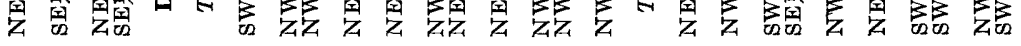

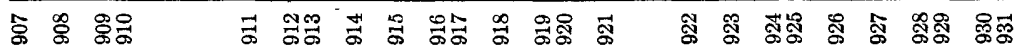




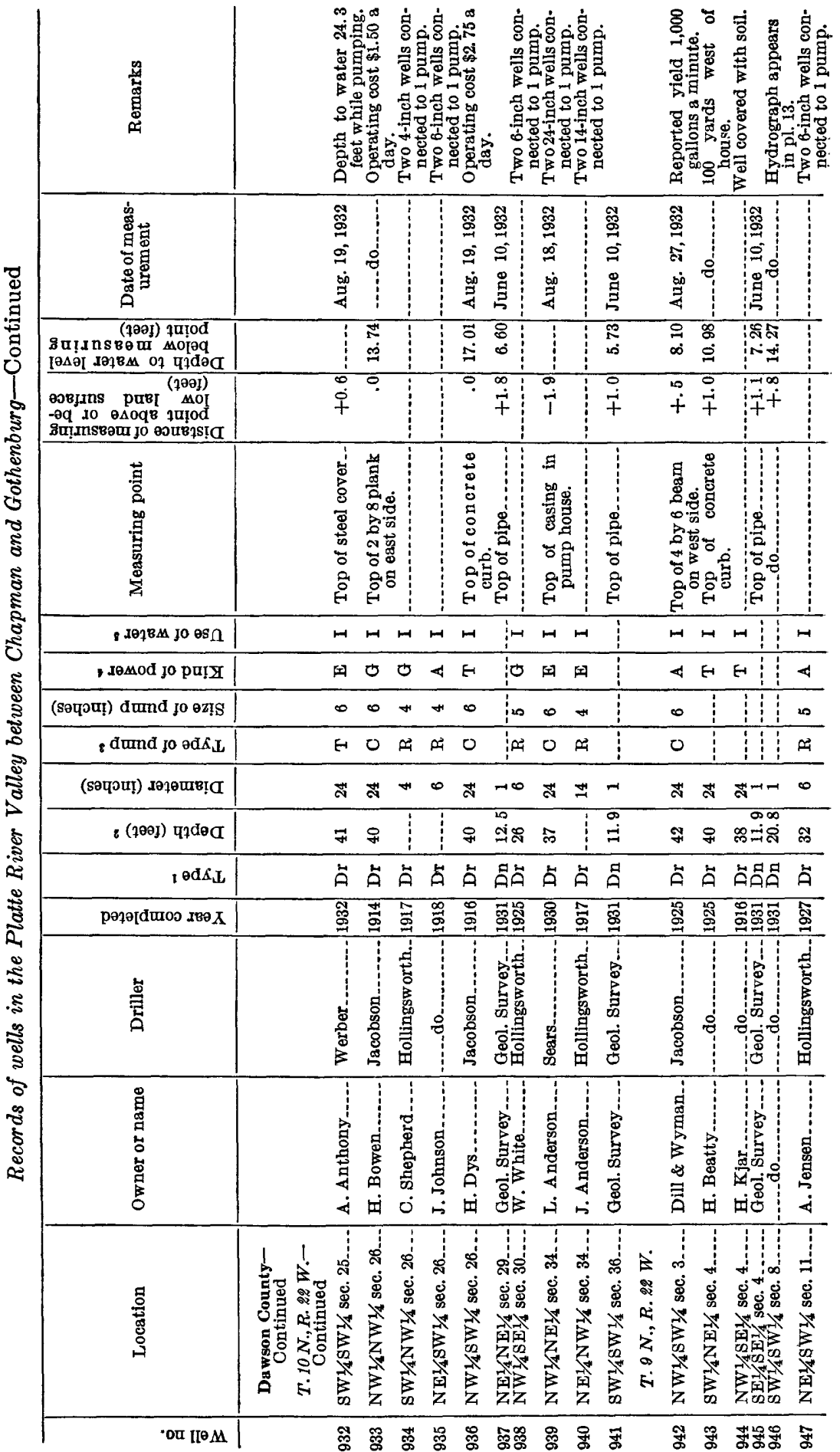




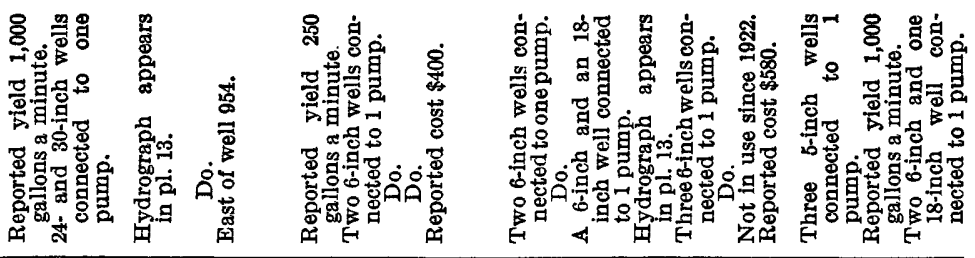

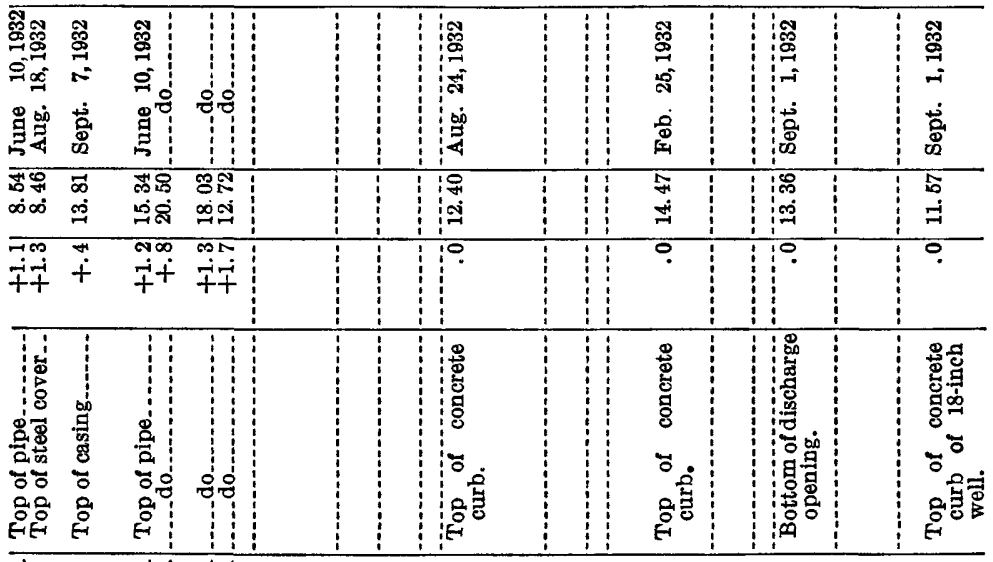

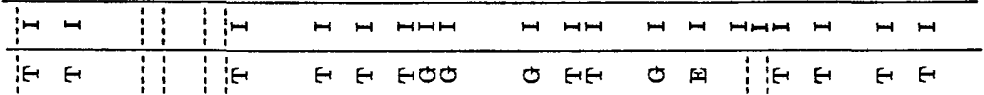

\begin{tabular}{|c|c|c|c|c|c|c|c|c|c|c|c|c|c|}
\hline $\begin{array}{ll}0 & 0 \\
0\end{array}$ & $\vdots \vdots$ & 9 & $\infty$ & + & $H$ & + & 00 & $\infty$ & $\infty$ & & $\infty$ & $\infty$ & 0 \\
\hline $\begin{array}{lll}H & 0\end{array}$ & i: & 0 & क्r & م & 뎌다 & ه्भ & 00 & مि 요 & क्ष & : & क्ष & $\mathrm{E}$ & م \\
\hline
\end{tabular}

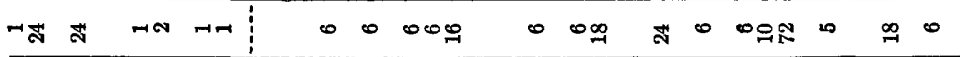

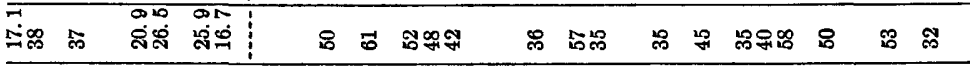

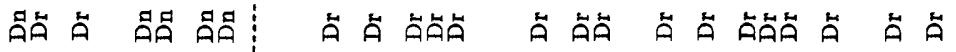

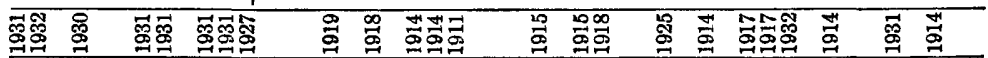

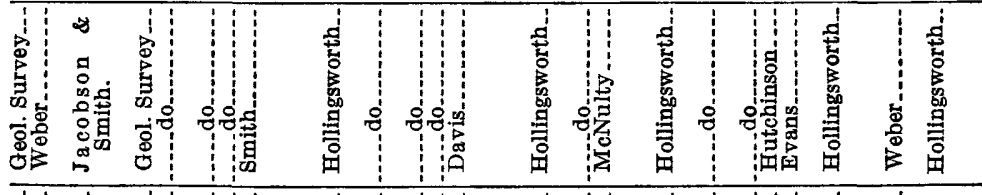

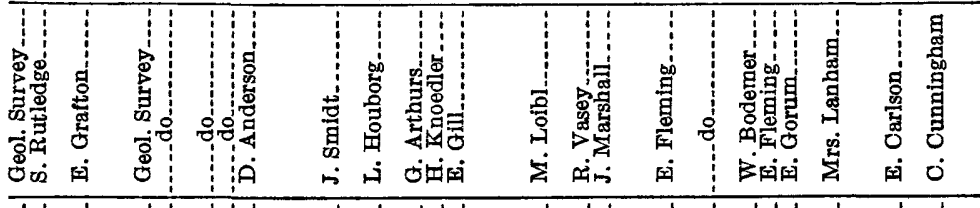

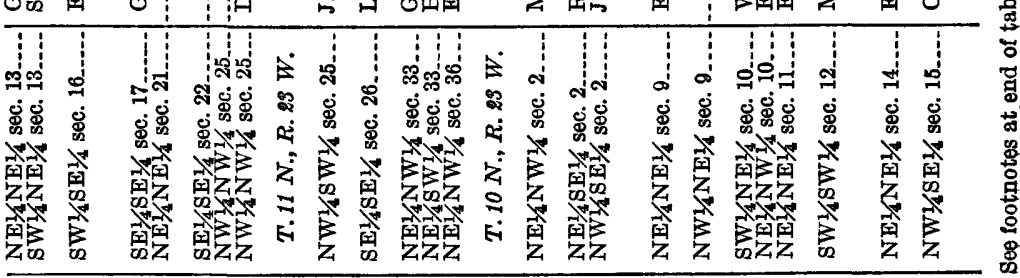

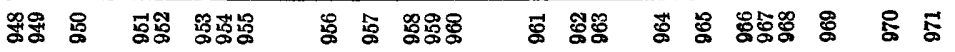




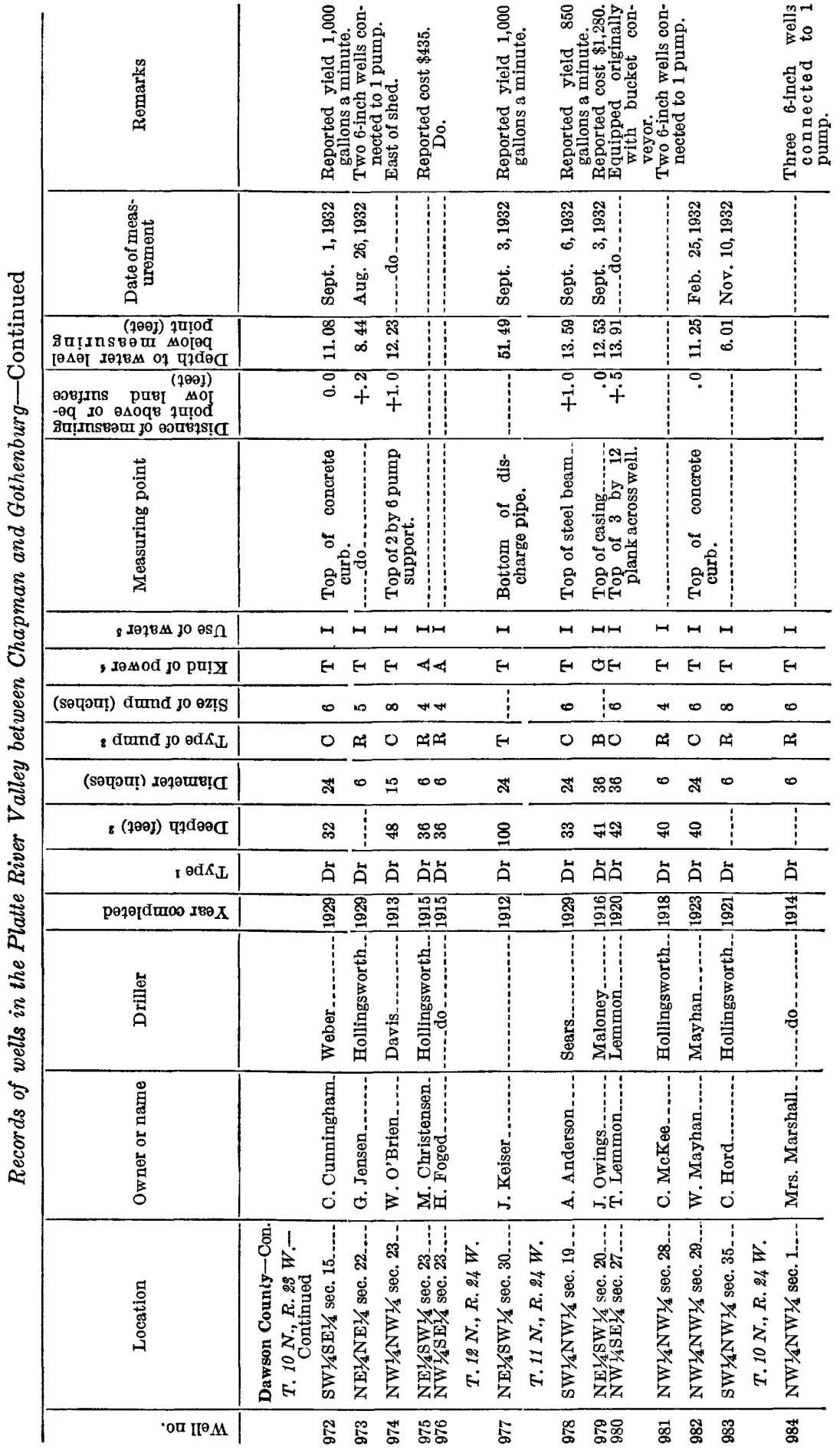




\begin{tabular}{|c|c|c|c|c|c|c|c|c|}
\hline 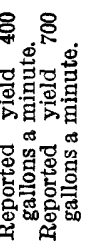 & 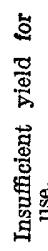 & 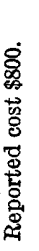 & & 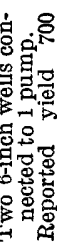 & & & 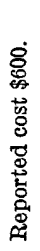 & \\
\hline 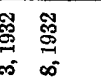 & & & & ळ్ల & 㗪 & & 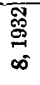 & \\
\hline 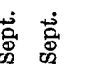 & & 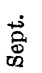 & & 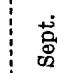 & نَّ & & 离 & \\
\hline 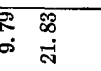 & & & & 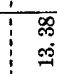 & $\begin{array}{l}1 \\
\text { ma } \\
\text { ing }\end{array}$ & & 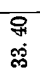 & \\
\hline & $i$ & + & & $\begin{array}{l}0 \\
+\end{array}$ & $\begin{array}{l}\infty 10 \\
i^{1+} \\
i^{-1+}\end{array}$ & & + & \\
\hline 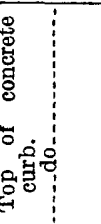 & 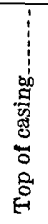 & 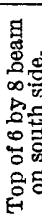 & & $\begin{array}{l}\text { : } \\
. \\
. \\
\infty \\
0 \\
0 \\
0 \\
0 \\
0 \\
0 \\
0\end{array}$ & 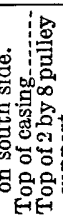 & & 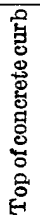 & 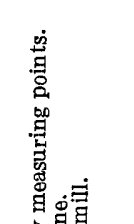 \\
\hline$H$ & $H$ & $H$ & - & $\Rightarrow H$ & HH & & $m$ & 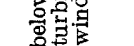 \\
\hline$E E$ & 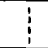 & $E$ & & II $E$ & 0 & & $E$ & 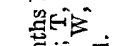 \\
\hline D & 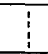 & 0 & $c$ & مו מ מ & 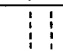 & & 0 & 苛总 \\
\hline 00 & $i$ & 0 & & 40 & 0 & & 0 & 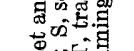 \\
\hline ন & 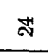 & $\Xi$ & & • & ה & & $\Delta$ & \\
\hline 太 8 & 5 & 8 & & $\leqslant \%$ & $i_{\infty}^{\infty}$ & & ఇ & \\
\hline 今̈ & $\dot{A}$ & $\ddot{A}$ & & 今̆ & ค̆م̆ & & $\ddot{A}$ & 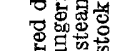 \\
\hline 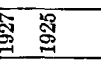 & 怘 & 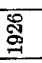 & & 跑 & 웜혐 & & 鄫 & 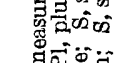 \\
\hline 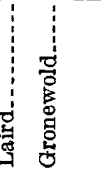 & : & 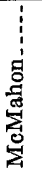 & & 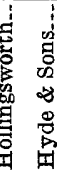 & 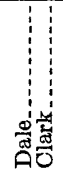 & & 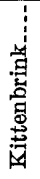 & 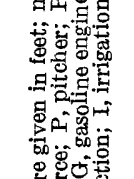 \\
\hline 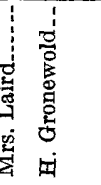 & 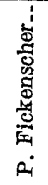 & 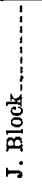 & & 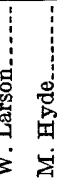 & 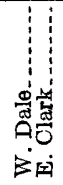 & & 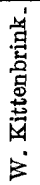 & 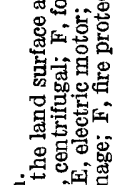 \\
\hline 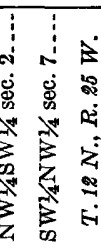 & 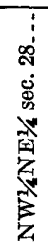 & 要 & 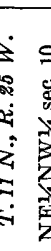 & 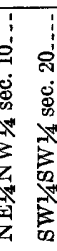 & 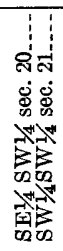 & 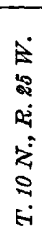 & 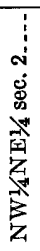 & 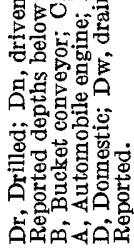 \\
\hline 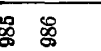 & $\stackrel{\widehat{ळ}}{\infty}$ & $\underset{\infty}{\infty}$ & & 怒 & రైల్మ & & ø & \\
\hline
\end{tabular}





\section{INDEX}

A

Abstract

Acknowledgments for aid

Adams County, log of well in

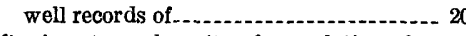

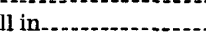
208-209

Aftonian stage, deposits of, correlation of.. 15, 18-19 deposits of, occurrence and character of. .. 23-26

Aftonian? intertill deposits, section of . ......... Agriculture in the area.

Alma, flow of tributaries between Arapahoe and.

- 173-174

flow of tributaries between Franklin and

170-173

section near

Arapahoe, flow of tributaries between Alma

and.................................. 173-174

pl. 6

Arikaree formation, correlation of............. 15

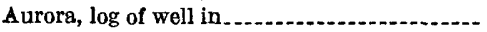

Axtell, $\log$ of well near.

B

Beaver Creek, flow of.

Bellwood, $\log$ of well near

Big Blue River, flow of - 175-176,178, 181, pl 15

West Fork of, flow of

- 177-178

Big Cottonwood Creek, discharge measurements of.

Big Sandy Creek, flow of

Blue Hill, $\log$ of well at.

Brule clay, correlation of

occurrence and character

Buffalo County, well records of

C

Cairo, water supply of

Campbell, $\log$ of well at

Carleton, $\log$ of well at

Center Creek, discharge measurements of . ... 159

Central City, Pleistocene deposits near..... 47, pl. 1

Chadron formation, correlation of. occurrence and character of

Clay Center, Pleistocene deposits near

Cooperation with University of Nebraska.... 2-4

Corn, yield of, increase of, by irrigation........ 83-84 yield of, in relation to precipitation....... 83-84

Cowles, section near........................... pl. 3

Cozad, water supply of ................. 147, 149

Cretaceous shale, correlation of............... 15

Crofton, section near. . .

Crooked Creek, discharge measurements of... $\quad 157$

Custer County, Pleistocene deposits in........ $\quad 58$

\section{D}

Dannebrog, geologic section near.

Darid City formation, correlation of
Dawson County, log of well in . ........... 58 well records of ......................... 227-237

Drainage of the area........................... 6-10

Dune sand, deposits of, correlation of......... 15

\section{$\mathbf{E}$}

Elm Creek, discharge measurements of ....... 157

Elm Creek, section near........................ pl. 6

water supply of........................ 147, 148

Elwood, $\log$ of well at..................... 58

Evaporation, features of..................... 151-153

$\mathbf{F}$

Farmers Creek, discharge measurements of... 158

Farnam, $\log$ of well at.................... 58

Fishel, V. C., analyses by ................... 90-93, 98

Flag Creek, discharge measurements of.......- 160

Franklin, flow of tributaries between Alma and. 170-173

flow of tributaries between Red Cloud and.-.............................. 167-170

Franklin County, $\log$ of well in.............. $\quad 50$

Pleistocene deposits in...................... 52

Fullerton, $\log$ of well near..................... 32

section near............................. 31

Fullerton formation, character and distribution of

correlation of ........................... 15, 18-19

occurrence of................ 36

section of

G

Geologic map of Nebraska.................... 13

Geology of the area............ 12-61

Gibbon, section near........................ pl. 7

water supply of

Glacial drift, character and extent of.......... 16-17

Gosper County, log of well in

well records of ....................... 232-233

Gothenburg, water supply of............... 147, 149

Grand Island, movement of ground water near ............................... 135

Pleistocene deposits near................. 46

water supply of

Grand Island formation, character and distribution of

correlation of .......................... 15, 18-19

ground water in . .

occurrence of . . .

section of ........................... 31, 3

Ground water, computation of percolation of, from Platte River Valley........ 181-182

discharge of, from wells................ 136-149 
Page

Ground water, general conditions of.......... levels of, in Platte Valley

levels of, investigation of.

investigation of, method of . . . . . . 105-108 movement of .......... 62-63, 128-136, pl. 8 methods of showing direction of --- 129-130 near Grand Island............... 135-136 near Kearney near Lexington..................... 130-132 net change in storage in Platte River

Valley

188-190 occurrence of, in glacial and associated deposits.

in Platte Valley 29 quantity of recharge of $84-86$, pl. 16 use of, for irrigation 183-188

Tumbotil, correlation of -64-65 occurrence and character of

H

Hall County, well records of.-

Hamilton County, $\log$ of well in 194-208 Pleistocene deposits in._... 47 well records of

Harlan County, log of well in............. 39

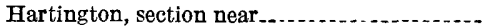

Hastings, log of well at.

Pleistocene deposits near.

Holdrege, log of well near.........................

Holdrege formation, character and distribution of ............ $36,38-43$ correlation of . . . . . . . . . . . . 15, 18-19 ground water in .......... $85-86$ section of ......... 31,32

Howard County, well records of ............ 194

\section{I}

Illinoian till, correlation of $15,18-19$

Industrial development in the area......... 11

Investigation, history of................. 2-5 purpose and need of ........ 1-2

Inwash sand and gravel, correlation of .... 15, 18-19 Iowan till, correlation of . . _ . . . . . . 15, 18-19

Irrigation, available ground water for _..... - $64-65$ depth and diameter of wells for . . . . . . 145-146 discharge from wells for................ 137-141 effect of, on water-table fluctuations... 116-117 on yield of corn................... 83-84 features of, in Platte Valley.............. 81-84 number of wells used for................. 82 types of pumps and power for . . _..... 144-145 water from, ground-water recharge by _.-_ $\quad 187$

\section{$\mathbf{K}$}

Kansan till, correlation of........... 15, 18-19, 20 occurrence and character of..._._. . . . . 26-27 section of . . . . . . . . . . 22, 24, 25, 27, 28

Kearney, $\log$ of well near. movement of ground water near ....... 133-135

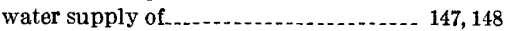

Kearney County, well records of ............. 213$214,219,224,225$

\section{$\mathbf{L}$}

Pago

Lexington, movement of ground water near_ 130-132 water supply of $\ldots \ldots \ldots$. 147,149

Lincoln, geologic section near............ pl. 2

Lincoln Creek, flow of............. 176-177, 178

Little Blue River, flow of .......... 178-181, pl. 15

Pleistocene deposits on................ 48

Little Cottonwood Creek, discharge measurements of 159

Little Sandy Oreek, flow of................ 178

Location of area................ 6-10

Loess, occurrence of ground water in......... 84 permeability of $\ldots \ldots$ physical properties of _..._..... 90

Lost Creek, discharge measurements of ..... 157

Loveland loess, character and distribution of . 53-56 correlation of . . . 15, 18-19 occurrence of . section of .

Lovely Creek, discharge measurements of _... 158

Lovers Leap, $\log$ of well near............ 32 section at............................. 31

\section{$\mathbf{M}$}

Marquette, Pleistocene deposits near........ 47

Merna, Pleistocene deposits near. ........... 58

Merrick County, well records of........... 192-194

Moisture equivalent, computation of....... 89

\section{$\mathbf{N}$}

Nebraska, University of, cooperation with...- 2-4 Nebraskan till, correlation of ......... 15, 18-19, 20 occurrence and character of

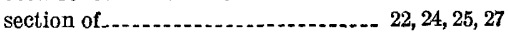

Niobrara formation, section of .

\section{0}

Ogallala formation, correlation of .......... 15 ground water in........................ 85 occurrence and character of ........... 12 permeability of . . physical properties of . . . . . . Overton, water supply of ................ 147, 148

\section{$\boldsymbol{P}$}

Peorian loess, correlation of

$15,18-19$ distribution and thickness of _... 37, 57-59, pl. 5 sections of _.......... 22, 24, 25, 27, 28, 31, 32, 35 younger loess associated with........... 57-59 Percolation, computation of, from Platte River

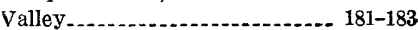
degree of, into Republican River....... 156-175 general conditions of._._. 154-156 ground-water recharge from............ 188 Permeability, computed coefficients of...... . 102-105 definition of. determination of, by ground-water velocity method.................. 99-100

by pumping-test method ......... 100-105 methods used to determine. 
Phelps County, well records of ..... 226-227, 229, 230 Pierre shale, section of Platte River, comparison of fluctuations of ... $\quad 115$ Platte River Valley, depth of water table in .-. 86-87 deviation from normal precipitation in. 128, pl. 16 ground-water areas of ground-water resources of........- 81-190, pl. 16 ground-water storage in, net change in... 188-190 irrigation in ................................ 81-84 percolation of ground water from, computation of.. $181-182$

Pleasantdale, section near

Pleistocene deposits, classification of ......... 17-19 continuity of, in Platte River Valley ..... 60-61, cross-sectional area of fluviatile, distribution of ................... 32-35 general features of relations of, to till .................... 32 ground water in ........................... 84-85 permeability of ..................... 97-98, 99-105 sections of ..................... 39-42, 46-51, 52, 58 specific yield of...................... 91-92, 94-96 volume of .................................. 66 water-bearing, character and thickness of... $65-80$, pl. 9

Polk, log of well near.

Population of the area.

Precipitation, average, and related average yield of corn. 83-84 cumulative departure from normal ......... pl. 16 effect of, on water-table fiuctuations....... 119123 , pls. 11-13 in the area 11-12 ground-water recharge by ................. 183-186

Pre-Loveland stage, erosion during .......... 28-29

Pre-Peorian erosion, extent of

Prosser, $\log$ of well at........................ 50

Pumping, determination of specific yield by _. 94-96 determination of permeability by ...... 100-105 effect of, on water-table fiuctuations.... 110-113

Pumps, irrigation, power used for............. 145 types for irrigation ...................... 144-145

\section{$\mathrm{R}$}

Ragan, log of well at

Recent loess, correlation of Red Cloud, fiow of tributaries between Franklin and........................... 167-170

flow of tributaries between Superior and

Republican River, discharge through tributaries to .......................... 156-160 map showing tributaries between Superior and Arapahoe....................... pl.14

summary of discharge through tributaries to Riverton, Pleistocene deposits near........ 49, pl. 7 Rope Creek, discharge measurement of.

\section{S}

Sacramento, $\log$ of well near.

Sand Creek, discharge measurements of

Sand-hill area, relation of, to area under inves-

tigation.................... 59-60 Sangamon stage, correlation of deposits of _. 15, 18-19
School Creok, flow of

Seepage, features of from streams, ground-water recharge by - 186-187 Shelton, water supply of.................... 146, 147 Soil, permeability of

physical properties of

Specific retention, definition of ................ 89-90

Specific yield, as computed by pumping method............................... 94-96

definition of..................... 87-88

methods used to determine.............. $\quad 89$

Stratigraphy, Pleistocene..................... 18-19

Stream flow, effect of, on water-table fiuctua. tions.............................. 113-116

Superior, flow of tributaries between Red Cloud and.......................... 161

\section{$\mathbf{T}$}

Tecumseh, section of deposits near.......... 24

Temperature in the area........................ 12

Test holes, logs of map showing location of.................. pl. 9

Thayer Connty, $\log$ of well in ............. 41

Thompson Creek, discharge measurements of. $\quad 158$ deposits exposed in........................ pl. 5

Todd Valley furmation, correlation of ........ 18-19

Topography, general, of Nebraska........... 5-10

Transpiration, effect of, on water-table fuctuations . . . . . features of................................ 149-151

Transportation, facilities for .

Trees deen-test well, $\log$ of ................... $\quad 39$

Tributary 18, discharge measurements of ...... 158

Tributary 29, discharge measurements of ...... 159

Tributary 41, discharge measurement of ..... 160

Tributary 42, discharge measurement of ...... 160

Tributary 48, discharge measurements of..... 160

Turkey Creek, discharge measurements of.... 160

$$
\text { U }
$$

University of Nebraska, cooperation with...- 2-4

Upland, Pleistocene deposits near ............ 52 Upland formation, character and distribution of ............ 51-53 correlation of $\ldots$.......................... 15, 18-19 oceurrence of ............................. 36 section of

W

Water level, factors controlling rise and decline of ............................ 109

fluctuation of................ 107-124, pls. 11-13

Water supplies, municipal................... 146-149

Water table, depth to..................... 63-64, pl. 8 depth to, in Platte Valley .............. 86-87 fluctuations of, caused by changes of atmospheric pressure............. 123-124 caused by transpiration.............. 117-119 comparison of precipitation and... 122-123, pls. $11-13$ effect of precipitation on ............ 119-123 effect of pumping on ................ 110-113 effect of stream flow and surface-water

irrigation on.................... 113-117 general conditions of..... 108-110, pls. 11-13 net rise or decline of ............. 125-128, pl. 11 


\begin{tabular}{|c|c|}
\hline Page & Page \\
\hline Water-bearing materials, hydrologic proper. & Wells, irrigation, yield of ................ 141-143 \\
\hline ties of & $\log s$ of \\
\hline methods used in determining specific & map showing location of ................ pl. 10 \\
\hline yield of & methods of construction of. .......... 143-144 \\
\hline permeability of & observation, numbers designating. ...... 106 \\
\hline specific yield of & records of, in Platte River Valley ...... 192-237 \\
\hline Webster County, log of well in........... 41 & types of \\
\hline Wells, acreage irrigated with water from.....138-139 & Wisconsin till, correlation of $\ldots \ldots$ \\
\hline $\begin{array}{l}\text { blowing } \\
\text { discharge from, for domestic and industrial }\end{array}$ & Wood River, water supply of $\ldots . . . \ldots \ldots \ldots . . .146,147$ \\
\hline uses_. & $\mathbf{Y}$ \\
\hline irrigation & \\
\hline irrigation, depth and diameter of $\ldots \ldots \ldots 145-146$ & Yarmouth stage, correlation of deposits of $-15,18-19$ \\
\hline number of & erosion during \\
\hline
\end{tabular}


The use of the subjoined mailing label to return this report will be official business, and no postage stamps will be required

\section{UNITED STATES DEPARTMENT OF THE INTERIOR \\ GEOLOGICAL SURVEY \\ OFFICIAL BUSINESS}

This label can be used only for returning official publications. The address must not be changed.

\section{GEOLOGICAL SURVEY,}


